\title{
CONTRIBUIÇÃO AO ESTUDO DAS MEDIDAS COMPENSATÓRIAS EM DIREITO AMBIENTAL
}

\begin{abstract}
Tese apresentada ao Programa de pósgraduação do Departamento de Direito Econômico e Financeiro (subárea Direito Ambiental) da Faculdade de Direito da Universidade de São Paulo, para obtenção de título de Doutora.
\end{abstract}

Orientador: Professor Fábio Nusdeo

Departamento de Direito Econômico e Financeiro

Faculdade de Direito

Universidade de São Paulo

São Paulo/2011 


\title{
TERMO DE APROVAÇÃO
}

\author{
Priscila Santos Artigas
}

\section{CONTRIBUIÇÃO AO ESTUDO DAS \\ MEDIDAS COMPENSATÓRIAS \\ EM DIREITO AMBIENTAL}

Tese apresentada ao Programa de pós-graduação do Departamento de Direito Econômico e Financeiro (subárea Direito Ambiental) da Faculdade de Direito da Universidade de São Paulo, para obtenção do título de Doutora, pela Banca Examinadora composta dos seguintes professores: 
Com amor, dedico esta tese à minha mãe, Maria Inês, eterno exemplo de força e de vida. 


\section{AGRADECIMENTOS}

Especialmente ao Professor Fábio Nusdeo, agradeço pela confiança depositada no projeto, pelos preciosos ensinamentos, pela atenciosa orientação e, sobretudo, por me permitir compartilhar da sua valiosa sabedoria. Tê-lo como professor e orientador foi um privilégio.

Uma vez mais, ao Professor Alaôr Caffé Alves, meu orientador do Mestrado, agradeço pelas sempre presentes lições, que me possibilitaram uma visão mais real do mundo e, ainda, por ter me contagiado com seu espírito crítico e insatisfeito com o status quo.

Especialmente ao Professor Édis Milaré, agradeço pela constante amizade, pelos ensinamentos diários, por compreender as ausências ao trabalho, por todo o incentivo e, sobretudo, por ter me dado a maravilhosa oportunidade de estar ao seu lado nas lides ambientais, garantindo a experiência refletida neste trabalho.

Aos Professores Ávila Coimbra e Attílio Brunacci, agradeço pela acurada revisão, pelas sugestões e pelas oportunas críticas dirigidas ao estudo.

A todos os meus colegas de trabalho, de hoje e de sempre, especialmente à Maria Clara, Victória e Fernando, agradeço pela compreensão e por todo o auxílio.

À Roberta Jardim de Morais, agradeço por compartilhar seus conhecimentos sobre o risco e por todos os livros emprestados.

A todos os meus queridos amigos e queridas amigas, agradeço pela amizade, base de apoio para o equilíbrio e a sanidade.

Ao meu saudoso avô Arnaldo Santos, agradeço por ter feito parte da minha vida por tanto tempo, e juntamente com a minha avó Yvonne Scherer dos Santos, agradeço por ter me ensinado - e ensinar - o quanto é importante a generosidade, o amor e a união familiar.

Especialmente à Maria Inês Santos Artigas, não tenho palavras para dizer o quanto é importante tê-la como mãe.

Aos meus irmãos Guilherme Santos Artigas, Gustavo Santos Artigas e Giocondo Villanova

Artigas Neto, agradeço pela união, pelo amor e por saber que os tenho sempre ao meu redor, dando-me apoio e proteção para todas as minhas jornadas.

Ao meu falecido avô Giocondo Villanova Artigas, à minha avó Maninha e ao meu pai José Luis Rocha Artigas, agradeço por sempre terem salientado a importância do conhecimento, algo extremamente valioso e que nunca se perde.

Aos meus queridos sobrinhos e queridas sobrinhas, minhas cunhadas e demais familiares, agradeço pelo amor, carinho e apoio constante. 
No limiar de um projecto que pretende reflectir sobre a protecção do meio pelo direito, importa, pois, explicar o que temos direito a esperar do jurídico.

François Ost 


\section{RESUMO}

Este trabalho estuda o instituto das medidas compensatórias como uma nova obrigação imposta pelo direito aos empreendimentos com potencial de causar impactos negativos ao meio ambiente. A pesquisa do tema se deu de forma crítica, enfrentando as contradições do sistema econômico vigente. Verificou-se que as medidas compensatórias emergiram da mais evidente crise ambiental ou à crescente escassez dos recursos naturais, buscando, ao mesmo tempo, a proteção ambiental e a manutenção do sistema de mercado. Procurando a melhor funcionalidade das medidas, pretendeu-se demonstrar que elas não se equiparam a uma forma de reparação por dano futuro, tampouco se enquadram necessariamente em uma espécie tributária; podem, como quis o Supremo Tribunal Federal, ser chamadas de compartilhamento de despesas entre o Poder Público e os empreendedores pelos custos da utilização dos recursos naturais no processo produtivo. Na verdade, em razão de serem dotadas das características da transversalidade e da interdisciplinaridade, as medidas compensatórias apresentam-se com diversas facetas, podendo mostrar características predominantes de mecanismos de comando e controle, como também de instrumentos econômicos. Assim, concluiu-se nesta tese ser um instituto híbrido, não enquadrável em uma categoria jurídica estanque. Verificou-se, ainda, ser necessária uma análise estrutural a fim de serem eficazes. Nesse sentido, propôs-se a sua instituição por normas primárias, nas quais se fixem padrões mínimos e com critérios objetivos de aplicação. Para tanto concluir, o estudo partiu dos debates já travados, tanto pela jurisprudência quanto pela doutrina, acerca da constitucionalidade, metodologia de cálculo e natureza jurídica de uma das medidas compensatórias, chamada compensação ambiental, instituída pela Lei ${ }^{\circ}$ 9.985/2000 (Lei do Sistema Nacional de Unidades de Conservação-SNUC). A partir daí, buscou-se demonstrar o processo subjacente à edição de normas ambientais, recaindo nos princípios do Direito Ambiental, dentre eles o importante princípio do poluidor-pagador, cuja premissa é internalizar os custos pela utilização dos recursos naturais no processo produtivo, para não serem assumidos pelo Poder Público e por toda a coletividade. Ainda, buscou-se diferenciar os conceitos de dano ambiental e de impacto negativo ao meio ambiente, porquanto as medidas compensatórias visam a compensar o meio ambiente pelos impactos negativos, significando uma perda aceita, prevista e gerenciada; o dano ambiental, por sua vez, é algo intolerável, indesejado e, por isso, objeto de reparação civil objetiva, de responsabilidade administrativa e, ainda, da penalização criminal.

Palavras-chave: crise ambiental - direito ambiental - princípio do poluidorpagador - dano ambiental - impacto ao meio ambiente - licenciamento ambiental - Estado - capitalismo - compensação ambiental - política ambiental - mecanismos de comando e controle - instrumentos econômicos - medidas compensatórias. 


\begin{abstract}
This paper studies the institution of compensatory measures, considered as a new obligation imposed by law for projects with the potential to cause adverse environmental impacts. The theme was investigated critically, facing the contradictions of the current economic system. In this regard, we verified compensatory measures instituted to cope with an increasingly apparent environmental crisis and the growing shortage of natural resources, while seeking environmental protection and maintenance of the market. In the search for a better functionality of the measures, we sought to demonstrate that they do not represent a form of compensation for future damages, nor do they necessarily fall within the range of any legitimate taxation. In fact, these measures were adopted by the Supreme Court more as a sharing of costs between government and entrepreneurs for the use of natural resources in the production process. Fundamentally, the compensatory measures of this instrument, equipped with characteristics of transversality and interdisciplinarity, present different aspects, which can deploy features to carry out command and control mechanisms, as well as economic instruments. Our thesis has therefore led us to the conclusion that this instrument is not readily classifiable under any isolated legal category, and should be looked upon as a hybrid mechanism. Nevertheless, we considered that a structural analysis was necessary to ensure the effectiveness of the measures. In this respect, we proposed it be instituted on primary norms, with the establishment of minimum standards and objective application criteria. This required starting with debates conducted in jurisprudence and doctrine over the constitutionality, method of calculation, and legal nature of a compensatory measure called environmental compensation, established by Law No. 9.985/2000 (Law of the National System of Conservation Units, SNUC). From there, we sought to demonstrate the process behind the issuing of environmental standards falling within the principles of environmental law; among which the important polluter pays principle, which is premised on the environmental externalities of economic activities that use natural resources, and prevents that pollution costs be borne by Government and, ultimately, by the whole community. We went on by delimiting the concepts of environmental damage and negative environmental impact, considering that compensatory measures aim at providing compensation for adverse impacts, which signify accepted, provided and managed losses. Environmental damage, in turn, is something unacceptable and undesirable, and must therefore be subject to civil liability, as well as criminal penalties.
\end{abstract}

Key-words: environmental crisis - environmental law - polluter pays principle environmental damage - environmental impact - environmental licensing Government - capitalism - environmental compensation - environmental policies - command and control mechanisms - economic instruments - compensatory measures. 


\section{RESUMÉ}

Cet article analyse des mesures compensatoires, considérées comme une nouvelle exigence imposée par le droit aux projets pouvant causer des impacts négatifs sur l'environnement. L'enquête sur la question se fait de façon critique, et en faisant face aux contradictions du système économique actuel. En ce sens, on note que les mesures compensatoires apparaissent pour faire face à la crise environnementale qui est de plus en plus évidente ou face à la rareté croissante des ressources naturelles, en recherchant d'une part la protection de l'environnement et en même temps, la perpétuation du système de marché. Cherchant une meilleure fonctionalité de ces mesures, on a cherché à démontrer qu'elles ne correspondaient pas à une forme de compensation pour des dommages futurs, ni qu'elles ne puissent être considérées comme une taxe ; Elles peuvent, comme la Cour Suprême Fédérale l'a souhaité, être appelé de partage des coûts entre les Pouvoirs Publics et les entrepreneurs pour prendre en compte les coûts d'utilisation des ressources naturelles dans le processus de production. En fait, car ils peuvent être dotés des caractéristiques de la transversalité et l'interdisciplinarité, les mesures compensatoires se présentent sous de nombreuses facettes, et peuvent présenter des caractéristiques prédominantes de mécanismes de commandement et de contrôle ainsi que d’instruments économiques. En conséquence, il a été conclu dans cette thèse qu'il s'agissait d'une institution hybride, qui n'était pas classable au sein d'une catégorie juridique hermétique. Néanmoins, il ressort qu'une analyse structurelle est nécessaire pour être efficace. En ce sens, il a été proposé de créer des normes minimales avec des critères minimums définis par le loi, avec des critères d'application objectifs. Pour conclure en ce sens, l'étude s'est basée sur les discussions antérieures sur la jurisprudence ou la doctrine en ce qui concerne la constitutionnalité, la méthodologie de calcul et la nature juridique d'une des mesures compensatoires, appelé compensation environnementale, établie par la loi $n^{\circ} 9.985 / 2000$ (Loi sur le Système Nationale des Unités de Conservation, SNUC). Ensuite nous avons cherché à démontrer le processus sous-jacent à la promulgation de normes environnementales, en revenant vers les principes du Droit de l'Environnement, en particulier l'important principe pollueur-payeur, qui est fondé sur l'internalisation des coûts relatifs à l'utilisation des ressources naturelles dans le processus de production, en évitant que ceux-ci soient assumés par les Pouvoirs Publics, et en dernière instance par toute la communauté. De plus nous avons cherché à différencier les concepts de dommages environnementaux et d'impact négatif sur l'environnement, puisque les mesures compensatoires visent à compenser les impacts environnementaux négatifs, ce qui signifie une perte acceptée, prévue et gérée ; Le dommage environnemental, de son coté est quelque chose d'intolérable, indésirable et, par conséquent, objet de dommages civils objectifs et la prise de responsabilité administrative et criminelle.

Mots-clés: crise environnementale - droit de l'environnement - principe pollueur-payeur - dommages environnementaux - impact négatif sur l'environnement - licence environnementale - Etat - capitalisme - compensation environnementale - politique environnementale - mécanismes de commandement et de contrôle - instruments économiques - mesures compensatoires. 


\section{LISTA DE SIGLAS}

ADI - Ação Direta de Inconstitucionalidade

AIA - Avaliação de Impacto Ambiental

APP - Área de Preservação Permanente

BNDES - Banco Nacional de Desenvolvimento Econômico e Social

CNI - Confederação Nacional da Indústria

CONAMA - Conselho Nacional do Meio Ambiente

CFEM - Compensação Financeira pela Exploração Mineral

CRA - Cota de Reserva Ambiental

CTN - Código Tributário Nacional

DPVAT - Danos Pessoais Causados por Veículos Automotores de Via Terrestre

EIA - Estudo de Impacto Ambiental

RIMA - Relatório de Impacto Ambiental

FLONA - Floresta Nacional

FUNAI - Fundação Nacional do Índio

GEE - Gases causadores do efeito estufa

IBAMA - Instituto Brasileiro do Meio Ambiente e dos Recursos Naturais

Renováveis

ICMBio - Instituto Chico Mendes de Conservação da Biodiversidade

ICO2 - Índice Carbono Eficiente

IFC - International Finance Corporation

IPHAN - Instituto do Patrimônio Histórico e Artístico Nacional

ISO - International Organization for Standardization

MDL - Mecanismo de Desenvolvimento Limpo

MMA - Ministério do Meio Ambiente

OCDE - Organização para a Cooperação e Desenvolvimento Econômico

OECD - Organization for Economic Co-operation and Development

PCH - Pequena Central Hidrelétrica

PPP - Princípio do Poluidor-pagador

PROINFA - Programa de Incentivo às Fontes Alternativas de Energia Elétrica PSA - Pagamento por Serviços Ambientais

Rcl - Reclamação

RFL - Reserva Florestal Legal

SAT - Seguro de Acidentes do Trabalho

SISNAMA - Sistema Nacional do Meio Ambiente

SNUC - Sistema Nacional de Unidades de Conservação

STF - Supremo Tribunal Federal

STJ - Superior Tribunal de Justiça

UHE - Usina Hidrelétrica

WWF - World Wildlife Fund 


\section{SUMÁRIO}

1.1 Premissas e objetivos do estudo

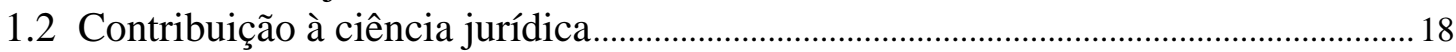

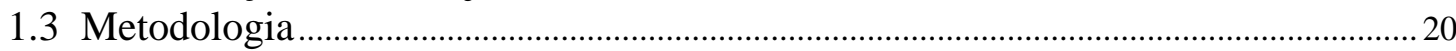

\section{O CASO DA COMPENSAÇÃO AMBIENTAL DA LEI DO SISTEMA NACIONAL DE UNIDADES DE CONSERVAÇÃO - SNUC}

2.1 Notas introdutórias.

2.2 Evolução normativa e o debate sobre a constitucionalidade da compensação ambiental

2.3 Análise crítica do julgamento do STF na ADI 3.378/DF.

2.3.1 A compensação ambiental não é o único meio eficaz de proteger o

meio ambiente

2.3.2 Os efeitos do afastamento do critério objetivo que permitia a aplicação da compensação ambiental

2.4 As controvérsias doutrinárias e jurisprudenciais sobre a natureza jurídica da compensação ambiental

2.4.1 A natureza jurídica reparatória da compensação ambiental: reparação ex ante de 'danos ambientais futuros'?

2.4.2 Críticas à corrente que concebe a natureza jurídica reparatória da compensação ambiental

2.4.3 A natureza jurídica tributária da compensação ambiental

2.4.4 Críticas à corrente que defende a compensação ambiental como uma espécie de tributo

2.4.5 A compensação ambiental como compartilhamento de despesas .. 67

2.5 Conclusões preliminares

\section{O DANO AMBIENTAL E O IMPACTO NEGATIVO AO MEIO AMBIENTE

3.1 Noções introdutórias

3.2 O desenvolvimento histórico da concepção jurídica do risco .......................................... 75

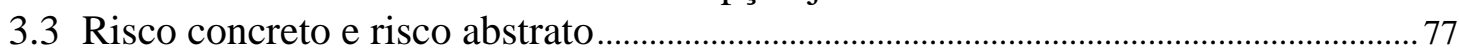

3.3.1 A teoria do risco e a responsabilidade civil objetiva por danos

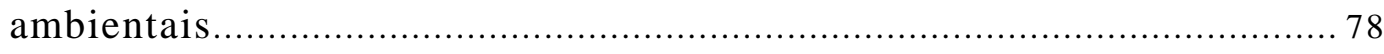

3.3.2 O risco concreto e os impactos negativos no meio ambiente......... 84

3.3.4 O risco abstrato na 'sociedade de risco' ou na 'sociedade de incertezas' 
3.3.4.1 O risco abstrato ou incerto e o princípio da precaução ...... 93

3.3.4.2 O risco abstrato ou incerto e a concepção de uma nova responsabilidade civil que prescinda da concretização do dano.... 97

3.3.4.3 O risco abstrato ou incerto e a tutela do direito das futuras

gerações

3.3.4.4 A gestão do risco abstrato pela democracia participativa 108

3.4 As diferentes concepções de dano ambiental e de impacto negativo ao meio ambiente

\section{A CRISE AMBIENTAL, O DIREITO E O PRINCÍPIO DO POLUIDOR-PAGADOR}

4.1 Escopo do capítulo.

4.2 A relação do homem com a natureza - a tomada de consciência sobre a crise ambiental

4.2.1 O confronto entre as bases do sistema de mercado e a necessária proteção ambiental

4.2.2 A crise ambiental e as necessárias alterações introduzidas no sistema econômico e no direito

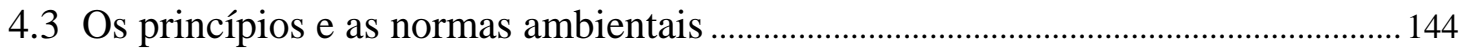

4.4 As externalidades negativas e o princípio do poluidor-pagador .................................. 148

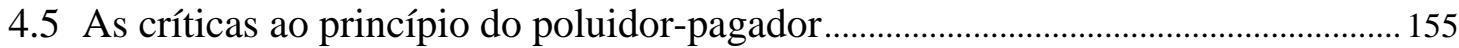

4.6 A tríplice face de aplicação do princípio do poluidor-pagador......................................158

4.6.1 O princípio do poluidor-pagador e a prevenção de danos ao meio ambiente

4.6.2 O princípio do poluidor-pagador e a responsabilidade civil

ambiental

4.6.3 O princípio do poluidor-pagador e as medidas compensatórias .. 167

4.7 Conclusões preliminares

\section{MECANISMOS E INSTRUMENTOS DAS POLÍTICAS}

5.1 Breves notas introdutórias

5.2 O Estado como regulador

5.3 Os limites para internalização dos custos pela utilização dos recursos naturais... 178

5.4 As políticas ambientais, os mecanismos de comando e controle e os instrumentos econômicos

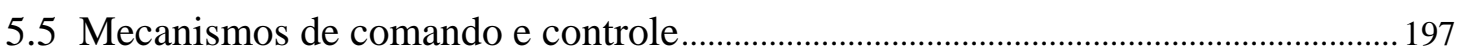

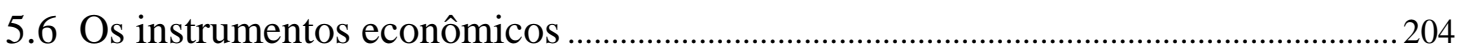

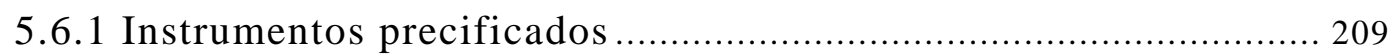

5.6.1.1 Cobrança pelo uso de um recurso natural ....................... 211

5.6.1.2 Compensações financeiras ......................................... 213

5.6.1.3 Os tributos ambientais................................................. 215

5.6.1.4 A função extrafiscal da tributação ambiental ................... 222 


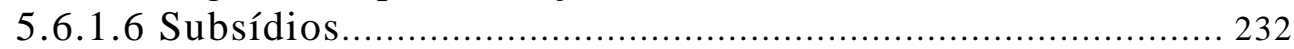

5.6.2 Instrumentos de criação de mercado ...................................... 235

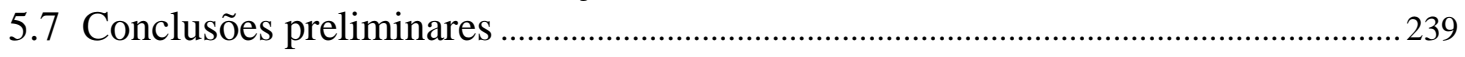

6. AS MEDIDAS COMPENSATÓRIAS …................................. 243

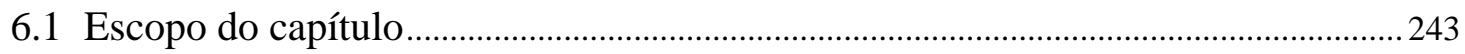

6.2 Conclusões acerca do debate em torno da natureza jurídica das medidas

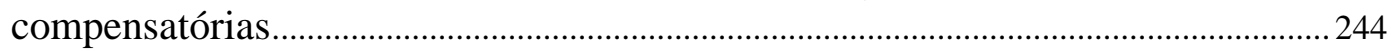

6.3 Funcionalidade e transversalidade das medidas compensatórias ...............................249

6.4 As medidas compensatórias como instrumento híbrido ................................................256

6.4.1 Medidas compensatórias como mecanismo de comando e controle ...257

6.4.2 Medidas compensatórias como instrumento econômico ............... 260

6.5 Elementos para a estruturação da regulamentação jurídica das medidas compensatórias................................................................................................................. 263

6.5.1 Medidas compensatórias impostas, sem base legal, no processo de

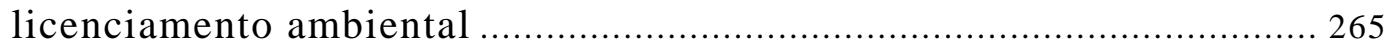

6.5.1.1 Revisitando o princípio da legalidade ............................. 265

6.5.1.2 Análise da legalidade das medidas compensatórias exigidas

sob critério exclusivo do órgão licenciador .................................... 275

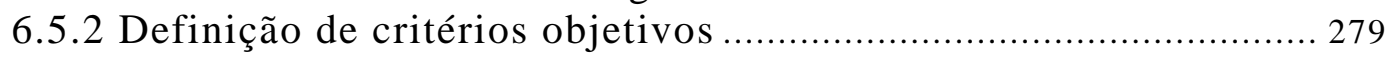

6.5.3 Competência legislativa para tratar das medidas compensatórias 280

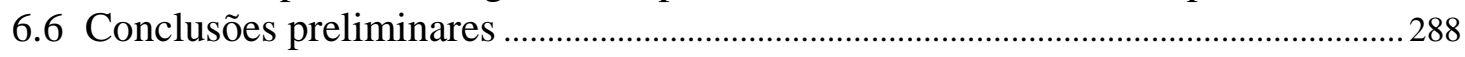

7. CONCLUSÃO GERAL ..................................................... 290

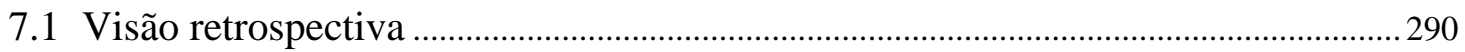

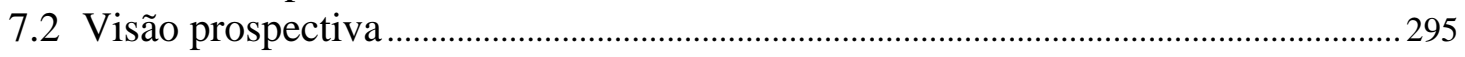

8. BIBLIOGRAFIA .................................................... 298 


\section{CONSIDERAÇÕES INICIAIS}

\subsection{Premissas e objetivos do estudo}

Sabe-se incumbir à pesquisa e ao trabalho científicos: o avanço; mas avanço com disciplina apropriada, no conhecer para operacionalizar. Com essa premissa, outro não poderia ser o escopo desta tese, ocupando-se de um tema recortado do contexto da política ambiental.

O recorte feito neste trabalho contempla as medidas compensatórias, instituto de recente origem e que, no cotidiano da sociedade, traz em seu bojo aspectos teóricos e práticos, assim como muitas lacunas a serem trabalhadas sob o foco da pesquisa acadêmica. Para desenvolvê-lo, partindo do geral para o particular, é necessário iniciar com a grande referência da Política Nacional do Meio Ambiente - Lei n ${ }^{\circ}$ 6.938, de 31 de agosto de 1981, recepcionada pela Constituição Federal.

Com o objetivo geral - expresso no caput do art. 2. ${ }^{\circ}$ - de "preservação, melhoria e recuperação da qualidade ambiental propícia à vida, visando assegurar, no País, condições ao desenvolvimento socioeconômico, aos interesses da segurança nacional e à proteção da dignidade da vida humana (...)” (art. $2^{\circ}$, caput), tal política determinou a obrigatoriedade do licenciamento ambiental de empreendimentos que têm o potencial de causar impactos no meio ambiente. A partir dessa determinação, os ditos impactos - posteriormente incorporados na terminologia técnica como 'impactos ambientais’ -, que até então não tinham relevância jurídica, passaram a ser administrados na esfera da gestão ambiental.

É cediço o fato de inúmeras atividades ou empreendimentos poderem causar impactos positivos ou negativos. Os positivos significam, por exemplo, o incremento da oferta de emprego, a geração de renda, o desenvolvimento socioeconômico. Os negativos, por sua vez, são aqueles impactos que usualmente repercutem no meio ambiente $^{1}$ e, na linguagem corrente, são entendidos como nocivos ou degradadores.

\footnotetext{
${ }^{1} \mathrm{O}$ meio ambiente impactado pode ser o natural e o artificial. Conforme Édis Milaré, o "meio ambiente natural, ou físico, [é] constituído pelo solo, pela água, pelo ar, pela energia, pela fauna e pela flora; o "meio ambiente artificial (ou humano), formado pelas edificações, equipamentos e alterações produzidos pelo homem, enfim, os assentamentos de natureza urbanística”. MILARÉ, Édis. Direito do ambiente. $7^{\text {a }}$ ed. São Paulo: RT, 2011, p. 143.
} 
Em relação a estes, é preciso frisar que por ocasião da concepção do projeto da atividade/empreendimento deve ser feita uma avaliação técnico-científica de dimensão qualiquantitativa dos impactos resultantes, tanto da implantação e execução do projeto, quanto do processo produtivo e de descarte. Essa avaliação, apreciada no decorrer do licenciamento ambiental, prevê medidas para cada impacto negativo, podendo ser elas preventivas, mitigatórias e compensatórias. Em breve síntese, as medidas preventivas, como o vocábulo permite entender, visam a evitar a ocorrência de impacto; as mitigatórias, diminuir ou minimizar a sua intensidade. E, caso os impactos não possam ser prevenidos ou mitigados, eles passam a ser compensados e, daí, as medidas compensatórias.

Como já se antevê, as medidas compensatórias, objeto desta tese, são obrigações que objetivam compensar o meio ambiente por uma determinada perda ocasionada pela implantação e/ou operação de um empreendimento, considerado necessário para o desenvolvimento socioeconômico. Significa dizer que, diferentemente dos danos ambientais, os impactos negativos são prejuízos, previsíveis, toleráveis, gerenciáveis e, ainda, aceitos pelo ser humano.

Sendo assim, diante da crise ambiental por que passa a humanidade, as medidas compensatórias vêm ganhando cada vez mais relevo, sobretudo por serem instrumentos capazes de internalizar os custos com a utilização dos recursos naturais pela cadeia produtiva.

De fato, as medidas compensatórias são consideradas um entre os meios de implementar o princípio do poluidor-pagador, buscando equacionar a falha de mercado conhecida como externalidades negativas do processo produtivo, consideradas como os custos da utilização dos recursos naturais que não são computados nesse processo, acabando, então, por ser arcados por toda a sociedade. Com efeito, o crescente desenvolvimento de novas tecnologias que aceleram o modo de produção e consumo do sistema econômico ${ }^{2}$ de mercado exige a intensa utilização dos recursos naturais que, diante disso, vão se

\footnotetext{
${ }^{2}$ Fábio Nusdeo ensina que "por sistema econômico quer-se significar um particular conjunto orgânico de instituições, através do qual a sociedade irá enfrentar ou equacionar o seu problema econômico. Este último nada mais vem a ser do que uma mera decorrência da já conhecida escassez de recursos, a exigir um processo consistente e concatenado de decisões quanto ao seu emprego. Dito de outra forma, é o conjunto de instituições destinado a permitir a qualquer grupo humano administrar seus recursos escassos com um mínimo de proficiência, evitando o quanto possível o seu desperdício ou malbaratamento. NUSDEO, Fábio. Curso de economia: introdução ao direito econômico. $6^{\mathrm{a}}$ ed. rev. e atual. São Paulo: RT, 2010, p. 97.
} 
tornando sempre mais escassos; escassez essa que exige, cada vez mais, a intervenção da economia, do Estado e do direito.

A bem ver, há um paradoxo ou uma contradição entre as bases do sistema de mercado e a crescente necessidade de se proteger o meio ambiente. Isso exige do Estado a criação de mecanismos capazes de equacionar a contradição, seja para o bem do meio ambiente, seja para o bem da manutenção e reprodução do próprio sistema econômico.

Como não podia ser diferente - ao emergirem para buscar equacionar a escassez dos recursos naturais, internalizando no processo produtivo os custos com a utilização dos bens ambientais -, as medidas compensatórias acabam por ganhar a atenção do direito, inclusive porque a obrigatoriedade de sua imposição reflete no patrimônio daqueles que pretendem desenvolver projetos empreendedores. São, portanto, obrigações legais, transmudadas na imposição de custos para o processo de implantação e de operação de inúmeros empreendimentos e atividades poluidoras e degradantes, como indústrias, rodovias, usinas hidrelétricas, atividades agropecuárias, entre muitas outras. Em outros termos, a inclusão de tais custos na cadeia de produção e consumo, ao procurar equacionar as externalidades negativas, desestimulando o uso irracional dos bens ambientais, repercute no patrimônio, ganhando a atenção, portanto, do direito.

Apesar do fundamento jurídico, esses mecanismos nem sempre são bem recebidos pela sociedade, mormente pelos empreendedores, que veem seus custos produtivos onerados por novas despesas. No entanto, isso demonstra apenas uma faceta desse mecanismo. Na verdade, ao mesmo tempo em que onera, acaba justamente por permitir que as atividades produtivas se mantenham em si mesmas e mantenham simultaneamente a qualidade essencial do meio. Vale dizer, os mecanismos equalizadores das 'falhas de mercado' - no caso, as externalidades negativas -, ao salientar a salvaguarda do meio ambiente, têm como intenção primeira a manutenção e a reprodução do próprio sistema econômico produtivo ${ }^{3}$.

\footnotetext{
${ }^{3}$ Chamaremos nesta tese o sistema econômico preponderante de 'sistema de mercado', 'sistema capitalista' e, ainda, 'sistema econômico descentralizado'.
} 
E há poucos estudos - se é que exista algum - cuidando especificamente das medidas compensatórias. Diz-se especificamente, uma vez que vários debates já foram - e vêm sendo - travados sobre uma das medidas compensatórias já positivadas, chamada de compensação ambiental, instituída pela Lei $\mathrm{n}^{\circ}$ 9.985/2000, que normatiza o Sistema Nacional de Unidades de Conservação da Natureza - SNUC. Essa compensação ambiental foi bastante perscrutada, pela doutrina e pela jurisprudência, em razão de incidir em grandes empreendimentos - aqueles que causam significativos impactos negativos no meio ambiente - e por envolver montantes financeiros razoáveis. Tais debates sobre a compensação ambiental envolveram, sobretudo, três relevantes aspectos: a constitucionalidade da norma que a instituiu, a sua metodologia de cálculo e a sua natureza jurídica.

Acerca da sua constitucionalidade e metodologia de cálculo, foi proposta uma Ação Direta de Inconstitucionalidade, cujo julgamento determinou a vigência da obrigação, mas, por entender inconstitucional, afastou a metodologia fundada em uma alíquota que incidia sobre uma base de cálculo previamente definida.

No que se refere à natureza jurídica, a doutrina vem se debruçando sobre o tema, tendo se dividido em duas principais correntes: a primeira, entendendo que a compensação ambiental é uma forma de reparação civil por danos futuros; a segunda, compreendendo a obrigação como uma espécie de tributo. O Supremo Tribunal Federal, por sua vez, ao enfrentar a questão, decidiu que a exação significa uma forma de compartilhamento de despesas entre o Poder Público e os empreendedores com as medidas necessárias à proteção ambiental.

No entanto, embora a compensação ambiental seja espécie do gênero medidas compensatórias, ela tem sido tratada como a única obrigação de tal natureza a incidir em licenciamentos ambientais de empreendimentos que causam significativos impactos negativos e não mitigáveis ao meio ambiente. De fato, existem outras medidas compensatórias não menos importantes que a dita compensação ambiental. Nesse sentido, vale citar as que preveem a compensação pela supressão de área de preservação permanente e de Mata Atlântica, dentre outras. É usual ver, ainda, medidas compensatórias sendo 
aplicadas no decorrer do licenciamento ambiental, ao exclusivo critério dos órgãos ambientais.

Sendo assim, aproveitando-nos de todas as discussões travadas especificamente acerca da compensação ambiental, faz-se necessário, então, aprofundar o estudo sobre as medidas compensatórias em geral, que é a proposta do presente estudo. É, com efeito, um pressuposto básico para todo o discurso a respeito.

Com esse entendimento, a tese procurará demonstrar por que, quando e como incidem as medidas compensatórias.

Para saber por que são, atualmente, exigidas medidas compensatórias visto a sua finalidade conformar normativamente o conteúdo da obrigação -, será preciso avaliar o processo econômico e jurídico subjacente à instituição de políticas ambientais, as quais se fundam no princípio do poluidor-pagador e, por conseguinte, são baseadas em medidas e instrumentos econômicos capazes de fazer face às externalidades negativas decorrentes da utilização dos recursos naturais no processo produtivo.

Ainda na linha do porquê, será necessário distinguir os conceitos de impacto ambiental e de dano causado ao meio ambiente. Essa distinção é importante, pois a doutrina e a jurisprudência vêm confundindo sobremaneira os institutos, o que tem implicado, a nosso ver, uma exigência errônea de compensação de impactos na forma de reparação civil, podendo significar arbitrariedades por parte dos órgãos licenciadores.

A fim de perquirir quando incidem as medidas compensatórias, é preciso expor o rito do licenciamento ambiental e a forma de imposição de medidas preventivas, mitigatórias e compensatórias para suportar os impactos negativos causados ao meio ambiente por empreendimentos que, saliente-se, são lícitos.

E, para chegar ao como serão impostas as medidas compensatórias, será absolutamente necessário averiguar se o ordenamento jurídico pátrio comporta mais uma obrigação pecuniária, se é necessário ou não estabelecê-la em lei, e por qual forma - ou 'natureza jurídica' - elas se apresentam, ou seja, se é uma espécie de reparação por dano futuro; se é uma imposição tributária; ou, ainda, se se enquadra em uma nova espécie de obrigação decorrente da evolução da sociedade e do próprio sistema econômico produtivo. 
Como se verá, tudo isso busca a funcionalidade das medidas compensatórias como meio de equacionar, ainda que parcialmente, o problema da escassez dos recursos naturais, reduzindo a sua utilização no processo produtivo e, por consequência, protegendo o meio ambiente.

\subsection{Contribuição à ciência jurídica}

Como visto, têm sido muitos os debates já travados em relação à obrigação denominada compensação ambiental. Entretanto, torna-se importante, agora, estender a análise para as medidas compensatórias em geral, pois, até o presente momento, essa abordagem ainda não havia sido devidamente realizada. Afinal, a compensação ambiental é espécie do gênero medidas compensatórias.

Ademais, o assunto é absolutamente atual, bastando ver a já comentada discussão sobre a constitucionalidade e a natureza jurídica da compensação ambiental, que culminou no julgamento pelo Supremo Tribunal Federal, em abril de 2009, da ADI 3.378/DF. Outrossim, esse julgamento pende de decisão acerca dos embargos declaratórios, o que, certamente, torna profícua a avaliação dos efeitos do julgado, inclusive de forma crítica.

A atualidade do assunto a ser apresentado decorre também das pendentes controvérsias sobre a natureza jurídica da compensação ambiental (e, em consequência, sobre todas as medidas compensatórias). De fato, vem-se analisando exclusivamente a natureza jurídica da compensação ambiental, permanecendo no esquecimento - conforme se anotou - que a correta apreensão do tema deve contemplar as medidas compensatórias como um todo. A par da natureza jurídica, é imprescindível compreender o fundamento e o objetivo das medidas compensatórias; somente assim, como referido em linhas anteriores, será possível verificar como elas se enquadram no conjunto normativo em vigor, e como devem ser instituídas e aplicadas.

A importância do tema reside, ainda, no fato de a imposição dessas obrigações ser estabelecida usualmente pelos órgãos administrativos licenciadores, no decorrer do licenciamento ambiental de empreendimentos e atividades que causem impactos ao meio ambiente. No entanto, essa imposição, 
nem sempre apresenta base legal, o que implica, por conseguinte, em uma avaliação isolada do órgão ambiental no que concerne às medidas compensatórias a serem impostas a dado impacto vislumbrado no processo de licenciamento.

Em muitas ocasiões nas quais as medidas compensatórias são impostas sem fundamento legal - e normalmente, em tais situações, com base em critérios subjetivos - podem ocorrer arbitrariedades, obstaculizar a emissão das licenças ambientais e, por vezes, servir com intuitos outros que não a compensação pelos prejuízos sentidos pelo meio ambiente. Sob outro prisma, pode-se dizer que a falta de fundamento legal e a indefinição de critérios objetivos podem levar a dificuldades em internalizar, a contento, os custos decorrentes da utilização dos recursos naturais, e a obstaculizar o avanço do desenvolvimento econômico e social.

Aliás, a imposição de medidas compensatórias excessivas ou arbitrárias, ao dificultar o processo de licenciamento ambiental (e, em algumas ocasiões, obstruir a viabilidade econômica do empreendimento), faz com que esse processo seja em muito criticado. ${ }^{4}$

Noutro giro, para boa compreensão do instituto, é necessário avaliar o fato ensejador da sua incidência, se o dano ambiental ou se o impacto negativo

\footnotetext{
${ }^{4}$ A respeito, mencione-se, por exemplo, os processos de licenciamento de grandes empreendimentos hidrelétricos, os quais vêm sendo aludidos como teimoso obstáculo à expansão da capacidade de geração de energia e, em última análise, ao crescimento do país. Quanto a isso, o escritório do Banco Mundial no Brasil concebeu estudo a título de contribuição ao debate em torno da questão. Confira-se destaque desse estudo que versa sobre o tema em análise: "O processo de licenciamento oferece poucas oportunidades para a resolução de conflitos. Como consequência, são muitos os conflitos acerca do licenciamento ambiental, os quais raramente são resolvidos, levando muitos a concluir que há excesso de regulação ambiental no país. A ausência de uma contínua atualização das normas do licenciamento ambiental contribui para o aumento de encargos e de conflitos de natureza política e social, que tornam a implantação de empreendimentos de infraestrutura cada vez mais complexa. Ademais, os conflitos de competência ambiental entre União e Estados federados, a natureza fragmentada da legislação brasileira em matéria de licenciamento ambiental, a qual não é apenas prolífica, mas desarticulada com a legislação do setor e a ausência de foco estratégico fazem com que os empreendimentos do setor de energia enfrentem incertezas e questionamentos que já deveriam ter sido respondidos antes do início dos processos de licenciamento ambiental de projetos específicos. Essa ausência de regras setoriais ou temáticas (por exemplo, sobre compensação social) resulta na obrigação de cada empreendedor de equacionar demandas não derivadas do potencial impacto social ou ambiental direto do empreendimento proposto. São exemplos deste tipo que mostram que o processo de licenciamento ambiental lida com atividades sociais que nada têm a ver com o impacto ambiental per se tais como investimentos nos municípios para construção ou asfaltamento de rodovias em áreas distantes do empreendimento e ações sociais voltadas para as populações não atingidas pelo empreendimento, como o fornecimento de cestas básicas para moradores carentes, instalação de postos de saúde e escolas, entre outros.” Banco Mundial. Licenciamento ambiental de empreendimentos hidrelétricos no Brasil: uma contribuição para o debate (em três volumes). Volume I: Relatório Síntese, 28 de março de 2008.
} 
no meio ambiente. Nesse sentido, buscou-se, de forma bastante inovadora, distinguir os seus conceitos e, ainda, mostrar serem distintas as reações jurídicas que se manifestam quando da ocorrência de cada qual.

É imperioso, por conseguinte, procurar a melhor forma de tornar funcionais as medidas compensatórias. E diz-se funcionais, uma vez que não basta serem eficazes; devem, sim, permitir a proteção ambiental e, ao mesmo tempo, a perpetuação do sistema econômico. Essa a contribuição que o presente trabalho pretende dar à ciência jurídica.

\subsection{Metodologia}

Para dar conta daquilo a que a tese se propõe, a pesquisa iniciou com a análise de normas jurídicas, dentre elas as que impõem medidas compensatórias em processos de licenciamento ambiental quando da evidência de impactos negativos não mitigáveis. Com base nas normas, prosseguiu-se, então, ao estudo de textos teóricos, nacionais e internacionais que, de uma maneira ou de outra, tratam da matéria. A prática jurídica foi de extremo auxílio, pois permitiu avaliar a exigência de medidas compensatórias em licenças ambientais, vivenciar, quando à frente de lides ambientais, os debates teóricos, refletir quando de consultas sobre o tema, e acompanhar as decisões judiciais acerca do objeto da presente tese.

Como perspectiva, buscou-se contextualizar o tema em bases históricas e filosóficas, incorporando o fundamento e a finalidade - tanto no âmbito econômico quanto na seara ambiental -, para os quais as normas e as teorias que permitiram o surgimento das medidas compensatórias não só foram e são engendradas, como também ensejaram as consequências de sua aplicação.

Oportuno frisar que foi preciso dispender um esforço para compatibilizar a doutrina estrangeira com a realidade brasileira ou a dos países em desenvolvimento. Na verdade, grande parte dos textos produzidos, por exemplo, em relação à tributação ambiental e à 'sociedade de risco', referem-se às realidades europeia e americana. E, embora se saiba da crise pela qual passam os Estados Unidos e as nações da União Europeia, não há dúvidas da larga 
diferença do seu desenvolvimento socioeconômico e ambiental frente aos países do 'Terceiro mundo', evidenciando uma preocupação muito maior, sobretudo pelos doutrinadores e cientistas europeus e americanos, com os riscos planetários. O Brasil, porém, ainda convive plenamente com os riscos da pobreza $^{5}$, da falta de saúde, da penúria da educação, da carência habitacional.

Mas, como o Brasil também é parte do planeta Terra, cujo ecossistema está absolutamente ameaçado pela forma irracional ou predatória como são explorados ou destruídos os recursos naturais, o presente estudo traz à tona igualmente os receios e riscos compartilhados por toda a humanidade, que busca soluções políticas, econômicas e jurídicas para superá-los. Nesse contexto se abrem duas perspectivas. A primeira se refere à situação do planeta; a segunda é a realidade vivida no Brasil.

Assim, quando se tratar da crise ambiental, do risco por que passa a sociedade atual de presenciar o colapso da humanidade diante das incertezas impostas pela avançada industrialização global, e respectiva economia, estaremos nos referindo a uma concepção macro, em que se considera a problemática ambiental, econômica e social em dimensão global. No entanto - é o caso da segunda perspectiva -, quando se sugerem novos conceitos para o risco, o dano ambiental e os impactos ao meio ambiente - visto que também quando se trata da evolução do instituto da responsabilidade civil ambiental e da funcionalidade das medidas compensatórias -, a referência é o contexto do sistema jurídico brasileiro, conquanto a realidade de nosso país, mormente em relação ao direito, tem peculiaridades e especificidades que não podem ser universalizadas.

Significa dizer, portanto, que não se pretende metodologicamente construir um conceito universal, mas o escopo é permitir que o Direito Ambiental brasileiro implemente e torne eficazes as medidas compensatórias que, fundamentadas no princípio do poluidor-pagador, possam internalizar,

\footnotetext{
${ }^{5}$ Nesse sentido, observe-se o fato de o censo de 2010 ter concluído que 11,4 milhões de brasileiros, o equivalente à população da Grécia, vivem em áreas ocupadas irregularmente e com carência de serviços públicos ou urbanização, como favelas, palafitas, grotas e vilas. Segundo a Folha de S. Paulo, o IBGE localizou 6.239 áreas irregulares e precárias em 323 cidades; em resumo, são 6\% dos habitantes do país vivendo em condições sub-humanas. Folha de S. Paulo, 22.12.2011.
} 
ainda que não plenamente, os custos pela utilização dos recursos naturais na cadeia produtiva, evitando as externalidades negativas.

Embora a análise estrutural seja necessária para a boa regulamentação jurídica do instituto das medidas compensatórias, permitindo sejam eficazes e efetivas e evitando sejam desvirtuadas em relação aos seus objetivos, não se deixará de incluir um viés crítico às teorias jurídicas 'clássicas' ou à dogmatização excessiva dos conceitos, pois entendemos que "a vida não está a serviço dos conceitos, mas sim estes ao serviço da vida”. ${ }^{6}$ Parafraseando Enrique Leff, consideramos que a renúncia ao fechamento dogmático, ao conformismo do pensamento e à finalização do saber é o que permite extraditar o pensado em cada momento e abrir as portas do pensamento para novos horizontes do saber, para o que ainda falta pensar em sua tarefa questionadora, sabendo que não existe retorno para o porto originário e que nunca terminará de sulcar os mares do conhecimento. ${ }^{7}$

Afinal, indivíduos podem ser profissionais do direito, mergulhados no sistema, mas não verdadeiros juristas, que devem ver o sistema à distância para julgá-lo melhor. ${ }^{8}$ Ou, como bem costuma lembrar o Prof. Fábio Nusdeo, ex facto oritur jus.

\footnotetext{
${ }^{6}$ DANZ, Erich. A interpretação dos negócios jurídicos. Trad. Fernando Miranda. São Paulo: Saraiva, 1941, p. 127.

${ }^{7}$ LEFF, Enrique. Epistemologia ambiental. Trad. Sandra Valenzuela ; rev. Técnica de Paulo Freire Vieira. $4^{\mathrm{a}}$ ed. São Paulo: Cortez, 2007, p. 11.

${ }^{8}$ CAFFÉ ALVES, Alaôr. Fundamentos do direito e meio ambiente. In: PHILIPPI JR., Arlindo; CAFFÉ ALVES, Alaôr (eds). Curso interdisciplinar de Direito Ambiental. Barueri: Manole, 2005.
} 


\section{O CASO DA COMPENSAÇÃO AMBIENTAL DA LEI DO SISTEMA NACIONAL DE UNIDADES DE CONSERVAÇÃO - SNUC}

\subsection{Notas introdutórias}

O raciocínio da presente tese parte do debate encetado acerca de uma das medidas compensatórias chamada de compensação ambiental da Lei do Sistema Nacional de Unidades de Conservação. Portanto, Este primeiro capítulo, então, serve a introduzir o tema, mostrando, ao final, caber estender às medidas compensatórias todas as discussões sobre a compensação ambiental já travadas em outras circunstâncias.

Para tanto, observe-se, de início, que diante da promulgação da Lei $\mathrm{n}^{\circ}$ 6.938, de 31 de agosto de 1981, que instituiu a Política Nacional do Meio Ambiente, passou a ser obrigatório o licenciamento ambiental de empreendimentos que têm o potencial de causar impactos no meio ambiente, licenciamento a ser obtido conforme decisão do órgão administrativo ambiental competente, sendo tal decisão orientada com base em uma avaliação dos impactos ambientais ${ }^{9}$. Isso significa que, dentre os instrumentos de gestão ambiental, a Política Nacional de Meio Ambiente elegeu como ações preventivas afetas ao Estado a avaliação de impactos ambientais e o licenciamento para a instalação de obras ou atividades potencialmente poluidoras $^{10}$.

No processo de licenciamento ambiental são averiguados, dentre outros aspectos, os impactos negativos que serão causados pela implantação e pela operação da atividade ou do empreendimento e, em função desses, estabelecidas as medidas preventivas, mitigatórias e compensatórias correspondentes. Vale dizer que, para cada impacto negativo causado no meio ambiente deverá haver

\footnotetext{
${ }^{9}$ Observe-se, desde já, que a Avaliação de Impacto Ambiental - AIA é gênero, da qual são espécies vários estudos ambientais como, por exemplo, o Estudo de Impacto Ambiental e o respectivo Relatório de Impacto Ambiental - EIA/RIMA, o Relatório Ambiental Simplificado - RAS, os Planos e Projetos de Controle Ambiental - PCA, o Relatório Ambiental Preliminar - RAP, dentre outros.

${ }^{10}$ MILARÉ, Édis. Direito do ambiente. $7^{\text {a }}$ ed. São Paulo: RT, 2011, p. 465.
} 
uma medida ou medidas administrativas correlatas, podendo ter natureza preventiva (evitando o impacto), mitigatória (diminuindo ou minimizando os efeitos do impacto) ou compensatória (compensando os efeitos do impacto). Pode-se afirmar, pois, que o impacto, não podendo ser prevenido ou evitado, deve-se procurar mitigá-lo ou minimizá-lo e, caso não possa ser prevenido nem mitigado, o mesmo deve ser compensado. Em uma palavra, as medidas compensatórias incidem quando há impactos negativos e não mitigáveis a ser causados ao meio ambiente.

Assim, hodiernamente, empreendimentos que têm o potencial de impactar impactos negativos e não mitigáveis no meio ambiente, avaliados no decorrer do processo de licenciamento ambiental, são obrigados a estabelecer medidas compensatórias a serem definidas no próprio processo, sendo muitas delas já impostas por lei, e outras, comumente exigidas mediante análise isolada do administrador público, sem qualquer embasamento normativo.

Dentre as medidas compensatórias impostas por lei, cite-se a já mencionada exação pecuniária compensação ambiental, criada pela Lei $\mathrm{n}^{\circ}$ 9.985, de 18 de julho de 2000, que instituiu o Sistema Nacional de Unidades de Conservação - SNUC ${ }^{11}$, sujeitando os empreendimentos causadores de significativos impactos ambientais apoiar a criação e a manutenção de unidades de conservação ${ }^{12}$. É o que prescrevia o seu art. $36, \S 1^{{ }^{13}}$, in verbis:

\footnotetext{
${ }^{11}$ Segundo o art. $2^{\circ}$ da Lei $n^{\circ}$ 9.985/2000, unidade de conservação é o "espaço territorial e seus recursos ambientais, incluindo as águas jurisdicionais, com características naturais relevantes, legalmente instituído pelo Poder Público, com objetivos de conservação e limites definidos, sob regime especial de administração, ao qual se aplicam garantias adequadas de proteção". As Unidades de Conservação podem ser federais, estaduais ou municipais.

${ }^{12}$ De acordo com a Lei ${ }^{\circ}$ 9.985/2000, os recursos da compensação ambiental devem ser destinados às unidades de conservação do grupo de proteção integral, sendo elas: (i) estações ecológicas; (ii) reservas biológicas; (iii) parques nacionais; (iv) monumentos naturais; e (v) refúgios da vida silvestre (art. $8^{\circ}$ ). Caso o empreendimento afete diretamente uma unidade de conservação de uso sustentável, ela também poderá ser a destinatária dos recursos (art. 36, §3º). São unidades de conservação de uso sustentável as (i) áreas de proteção ambiental; (ii) áreas de relevante interesse ecológico; (iii) florestas nacionais; (iv) reservas extrativistas; ( $v$ ) reservas de fauna; ( $v i)$ reservas de desenvolvimento sustentável; e (vi) reserva particular do patrimônio natural (art. 14).

${ }^{13}$ Diz-se prescrevia, pois, como se verá, esse dispositivo foi objeto de Ação Direta de Inconstitucionalidade - ADI $n^{\circ}$ 3.378, proposta pela Confederação Nacional da Indústria - CNI, que acabou por ser julgada parcialmente procedente. Vale destacar, desde já, a determinação do julgado de alterar a forma de cálculo do transcrito $\S 1^{\circ}$ do art. 36, a metodologia de cálculo (no mínimo 0,5\% sobre os custos totais do empreendimento).
} 
Art. 36. Nos casos de licenciamento ambiental de empreendimentos de significativo impacto ambiental, assim considerado pelo órgão ambiental competente, com fundamento em estudo de impacto ambiental e respectivo relatório EIA/RIMA, o empreendedor é obrigado a apoiar a implantação e manutenção de unidade de conservação do Grupo de Proteção Integral, de acordo com o disposto neste art. e no regulamento desta Lei.

$\S 1^{\circ} \mathrm{O}$ montante de recursos a ser destinado pelo empreendedor para esta finalidade não pode ser inferior a meio por cento dos custos totais previstos para a implantação do empreendimento, sendo o percentual fixado pelo órgão ambiental licenciador, de acordo com o grau de impacto ambiental causado pelo empreendimento.

Além da compensação ambiental contida no dispositivo acima, há outras medidas compensatórias já positivadas, como também se verificam, na prática diária dos licenciamentos ambientais, obrigações dessa natureza impostas pelos órgãos ambientais de acordo com a experiência de cada um.

Sobre as medidas compensatórias previstas em lei, vale citar, desde já, (i) as exigências de compensação por supressão de vegetação de área de preservação permanente ${ }^{14}$ e de Mata Atlântica ${ }^{15}$, e (ii) a obrigação prescrita no Estatuto da Cidade (Lei $\mathrm{n}^{\circ}$ 10.257, de 10 de julho de 2001), impondo a empreendimentos ou atividades com significativo impacto ambiental de âmbito regional ou nacional o aporte de recursos técnicos e financeiros para a elaboração do plano diretor dos municípios afetados, o que deverá ser inserido

\footnotetext{
${ }^{14}$ Art. $4^{\circ}$, §4 , da Lei ${ }^{\circ}$ 4.771, de 15.9.1965 (Código Florestal): “Art. $4^{\circ}$ A supressão de vegetação em área de preservação permanente somente poderá ser autorizada em caso de utilidade pública ou de interesse social, devidamente caracterizados e motivados em procedimento administrativo próprio, quando inexistir alternativa técnica e locacional ao empreendimento proposto. (...) $\S 4^{\circ} \mathrm{O}$ órgão ambiental competente indicará, previamente à emissão da autorização para a supressão de vegetação em área de preservação permanente, as medidas mitigadoras e compensatórias que deverão ser adotadas pelo empreendedor."

${ }^{15}$ Art. 17 e art. 32 da Lei no 11.428, de 22.12.2006 (Lei da Mata Atlântica): "Art. 17. O corte ou a supressão de vegetação primária ou secundária nos estágios médio ou avançado de regeneração do Bioma Mata Atlântica, autorizados por esta Lei, ficam condicionados à compensação ambiental, na forma da destinação de área equivalente à extensão da área desmatada, com as mesmas características ecológicas, na mesma bacia hidrográfica, sempre que possível na mesma microbacia hidrográfica, e, nos casos previstos nos arts. 30 e 31, ambos desta Lei, em áreas localizadas no mesmo Município ou região metropolitana. (...) Art. 32. A supressão de vegetação secundária em estágio avançado e médio de regeneração para fins de atividades minerárias somente será admitida mediante: I - licenciamento ambiental, condicionado à apresentação de Estudo Prévio de Impacto Ambiental/Relatório de Impacto Ambiental - EIA/RIMA, pelo empreendedor, e desde que demonstrada a inexistência de alternativa técnica e locacional ao empreendimento proposto; II adoção de medida compensatória que inclua a recuperação de área equivalente à área do empreendimento, com as mesmas características ecológicas, na mesma bacia hidrográfica e sempre que possível na mesma microbacia hidrográfica, independentemente do disposto no art. 36 da Lei no 9.985, de 18 de julho de 2000.”
} 
entre as medidas de compensação adotadas no licenciamento ambiental. ${ }^{16}$ É também usual ver normas editadas por Estados da Federação impondo medidas compensatórias específicas, a incidir no processo de licenciamento de empreendimentos que lá serão implantados e operados ${ }^{17}$.

A par das compensações previstas em lei, foi dito ser comum os órgãos ambientais licenciadores imporem exigências e/ou condições de natureza compensatória nas licenças ambientais por eles emitidas, em função da experiência concreta de cada um. Essas medidas compensatórias - que não são exigidas expressamente por lei - podem ser assim exemplificadas: a adoção de um programa de educação ambiental; o financiamento de pesquisas científicas; o replantio da mata ciliar de um rio não impactado pelo empreendimento, mas importante para o município, e outras muitas. ${ }^{18}$

Isso significa que a implantação de uma usina hidrelétrica, por exemplo, com significativos impactos ambientais, negativos e não mitigáveis, culmina no dever de arcar com a compensação ambiental da lei do SNUC, destinando recursos à(s) unidade(s) de conservação estabelecida(s) no licenciamento ambiental. Além disso, o mesmo empreendimento deverá aportar recursos técnicos e financeiros para a elaboração do plano diretor dos municípios por ele afetados. Cabe-lhe, ainda, implementar as medidas exigidas como compensação

\footnotetext{
${ }^{16}$ Art. 41, §1º da Lei ${ }^{\circ}$ 10.257, de 10.07.2001 (Estatuto da Cidade): “Art. 41. O plano diretor é obrigatório para cidades: (...) V - inseridas na área de influência de empreendimentos ou atividades com significativo impacto ambiental de âmbito regional ou nacional. $\S 1^{\circ}$ No caso da realização de empreendimentos ou atividades enquadrados no inciso $\mathrm{V}$ do caput, os recursos técnicos e financeiros para a elaboração do plano diretor estarão inseridos entre as medidas de compensação adotadas.”

${ }^{17}$ Como se verá no item 6.5.3 do Capítulo 6 desta tese, há ilustrativos exemplos de normas dessa natureza nos Estados de Goiás, do Rio Grande do Norte e Mato Grosso do Sul.

${ }^{18}$ A título de exemplo, apontem-se algumas condicionantes compensatórias, as quais não estão positivadas em lei, mas foram impostas na Licença Prévia $\mathrm{n}^{\circ}$ 342, de 1.2.2010, emitida para a conhecida Usina Hidrelétrica de Belo Monte - UHE Belo Monte, a ser implantada no rio Xingu, no Estado do Pará. Seguem: "2.8 Propor e efetivar convênios, para ações de fortalecimento, com as entidades responsáveis pela fiscalização de crimes ambientais, como o tráfico de animais silvestres e a exploração madeireira na região (IBAMA, OEMA do Pará, Polícia Ambiental, entre outros)”; "2.12 Estender aos municípios da Área de Influência Indireta - AII as ações do Plano de Articulação Institucional relativas a: i) criar mecanismos de articulação e cooperação entre entidades e instituições federais e estaduais que possibilitem o estabelecimento de parcerias para a indução do desenvolvimento regional; ii) capacitar as equipes das administrações municipais; iii) fortalecer a prática do planejamento participativo; iv) ampliar a articulação entre as diferentes áreas da administração municipal e destas com outras esferas de governo, até que o Plano de Desenvolvimento Regional Sustentável do Xingu cumpra essas funções”; e "2.37 Elaborar e implementar Programa de capacitação de comunidades para desenvolvimento de manejo de áreas de reprodução de quelônios no âmbito de suas aldeias com monitoria permanente do Projeto Quelônios da Amazônia/PQA/IBAMA”. Extraído de: <http:/www.ibama.com.br>. Acesso em: 19.10.2011.
} 
de supressão de vegetação de área de preservação permanente, de reserva legal ou de Mata Atlântica - logicamente, na medida em que tal supressão seja necessária. E, caso o licenciamento seja conduzido por um órgão estadual, haverá a possibilidade de serem impostas as medidas compensatórias instituídas no respectivo ente da Federação. Isso sem falar em outras obrigações com essa natureza, exigidas dos órgãos licenciadores, a seu exclusivo critério.

Embora existam, como se viu, outras medidas compensatórias positivadas ou não - no ordenamento jurídico nacional, todas as atenções têm se voltado para a compensação ambiental da Lei do Sistema Nacional de Unidades de Conservação. Certamente porque elas incidem em empreendimentos de vulto, impondo valores nada módicos.

Com efeito, desde a imposição da compensação ambiental, encetaram-se inúmeras discussões tanto no campo doutrinário quanto no âmbito judicial a respeito da sua constitucionalidade - inclusive com a propositura e julgamento de uma Ação Direta de Inconstitucionalidade - ADI - e da sua natureza jurídica.

Em síntese, debateu-se sobre (i) quais seriam os pressupostos caracterizadores da exação; (ii) a possibilidade de a lei ter deixado de estabelecer uma alíquota 'teto', dispondo apenas de um percentual mínimo, sem incluir qualquer critério ou parâmetro para gradação; (iii) o fato de a base de cálculo ser por demais ampla, incluindo custos, ora não relacionados com os impactos causados ao meio ambiente, ora passíveis, inclusive, de preveni-los ou mitiga-los; (iv) a constitucionalidade da norma; e (v) a natureza jurídica da exação. ${ }^{19}$

Consoante dito logo no início, esses debates permitirão aprofundar a análise das medidas compensatórias. Afinal, são várias as medidas compensatórias, podendo-se dizer que a compensação ambiental é espécie do gênero medidas compensatórias, de maneira que a análise dos fundamentos, pressupostos e modos de implementação devem ser avaliados e compreendidos em seu conjunto.

\footnotetext{
${ }^{19}$ Observe-se que também houve - e ainda há - controvérsias a respeito (i) da possibilidade de a obrigação incidir em empreendimentos já implantados antes da edição da norma, ou seja, se a obrigação poderia retroagir à empreendimentos há muito instalados e (ii) se as medidas compensatórias poderem ser cumulativas.
} 


\subsection{Evolução normativa $\mathrm{e}$ o debate sobre a constitucionalidade da compensação ambiental}

No item anterior foi destacado que toda a discussão a ser tratada neste estudo em torno das medidas compensatórias tem origem no debate travado acerca de uma delas, denominada de compensação ambiental da Lei do SNUC.

Portanto, para a boa compreensão do tema, vale expor que a cobrança da compensação ambiental em processos de licenciamento de empreendimentos de significativo impacto ambiental teve início com a Resolução do Conselho Nacional do Meio Ambiente - CONAMA $n^{0}$ 010, de 3 de dezembro de $1987^{20}$, posteriormente revogada pela Resolução CONAMA n ${ }^{\circ}$ 002, de 18 de outubro de $1996^{21}$.

A imposição da compensação ambiental por meio de resoluções do CONAMA gerou inúmeras controvérsias na esfera jurídica devido à sua duvidosa legalidade, considerando-se que violava frontalmente o princípio da legalidade, positivado no art. 5º, II, da Constituição Federal, e que dispõe -

\footnotetext{
20 “Art. $1^{\circ}$ Para fazer face à reparação dos danos ambientais causados pela destruição de florestas e outros ecossistemas, o licenciamento de obras de grande porte, assim considerado pelo órgão licenciador com fundamento no RIMA terá sempre como um dos seus pré-requisitos, a implantação de uma Estação Ecológica pela entidade ou empresa responsável pelo empreendimento, preferencialmente junto à área. Art. $2^{\circ} \mathrm{O}$ valor da área a ser utilizada e das benfeitorias a serem feitas para o fim previsto no artigo anterior, será proporcional ao dano ambiental a ressarcir e não poderá ser inferior a $0,5 \%$ (meio por cento) dos custos totais previstos para a implantação dos empreendimentos. Art. $3^{\circ}$ A extensão, os limites, as construções a serem feitas, e outras características da Estação Ecológica a implantar, serão fixados no licenciamento do empreendimento, pela entidade licenciadora. Art. $4^{\circ} \mathrm{O}$ RIMA - Re1atório de Impacto sobre o Meio Ambiente, relativo ao empreendimento, apresentará uma proposta ou projeto e indicará possíveis alternativas para o atendimento ao disposto nesta Resolução. Art. $5^{\circ} \mathrm{A}$ entidade ou empresa responsável pelo empreendimento deverá se encarregar da manutenção da Estação Ecológica diretamente ou através de convênio com entidade do Poder Público capacitada para isso. Art. $6^{\circ} \mathrm{A}$ entidade do meio ambiente, licenciadora, fiscalizará a implantação e o funcionamento das Estações Ecológicas previstas nesta Resolução.(...)” 21 “Art. $1^{\circ}$ Para fazer face à reparação dos danos ambientais causados pela destruição de florestas e outros ecossistemas, o licenciamento de empreendimentos de relevante impacto ambiental, assim considerado pelo órgão ambiental competente com fundamento do EIA/RIMA, terá como um dos requisitos a serem atendidos pela entidade licenciada, a implantação de uma unidade de conservação de domínio público e uso indireto, preferencialmente uma Estação Ecológica, a critério do órgão licenciador, ouvido o empreendedor. $\S 1^{\circ}$ - Em função das características da região ou em situações especiais, poderão ser propostos o custeio de atividades ou aquisição de bens para unidades de conservação públicas definidas na legislação, já existentes ou a serem criadas, ou a implantação de uma única unidade para atender a mais de um empreendimento na mesma área de influência. $\$ 2^{\circ}$ - As áreas beneficiadas deverão localizar-se, preferencialmente, na região do empreendimento e visar basicamente a preservação de amostras representativas dos ecossistemas afetados. Art. $2^{\circ} \mathrm{O}$ montante dos recursos a serem empregados na área a ser utilizada, bem como o valor dos serviços e das obras de infra-estrutura necessárias ao cumprimento do disposto no art. $1^{\circ}$, será proporcional à alteração e ao dano ambiental a ressarcir e não poderá ser inferior a $0,50 \%$ (meio por cento) dos custos totais previstos para implantação do empreendimento. (...) Art. $4^{\circ}$ O EIA/RIMA, relativo ao empreendimento, apresentará proposta ou projeto ou indicará possíveis alternativas para o atendimento ao disposto nesta Resolução. (...) Art. $9^{\circ}$ Revogam-se as disposições em contrário, especialmente a Resolução CONAMA n ${ }^{\circ}$ 010, de 3 de dezembro de 1987, publicada no Diário Oficial da União de 18 de março de 1988, Seção I, página 4.563.”
} 
convém lembrar - que ninguém será obrigado a fazer ou deixar de fazer alguma coisa senão em virtude de lei.

Em suma, arguia-se que a cobrança da exação, mormente por ser de ordem financeira, estaria evidentemente reservada à lei, não podendo mera resolução criar uma obrigação pecuniária.

Sendo assim, e na intenção de solucionar as controvérsias, foi editada em âmbito federal a já referida Lei $\mathrm{n}^{\circ}$ 9.985, de 18 de julho de 2000, instituindo a compensação ambiental nos termos da "liturgia” recomendada pela Lei Maior, com previsão, em seu art. 36, da obrigação ao empreendedor de, no licenciamento de empreendimentos de significativo impacto ambiental, baseados em Estudo de Impacto Ambiental e respectivo Relatório de Impacto Ambiental EIA/RIMA, apoiar a implantação e a manutenção de Unidade de Conservação, mediante a destinação de, no mínimo, 0,5\% (meio por cento) do valor total de implantação do empreendimento.

Os pressupostos para a incidência da exação, como se vê, foram bem delineados pela lei ordinária e, posteriormente, estabelecidos em definitivo pelo Decreto federal $n^{0} 5.566 / 2005^{22}$, quando, então, não restou mais dúvidas de que são três os seus requisitos ensejadores: (i) o Estudo de Impacto Ambiental e o respectivo Relatório - EIA/RIMA, demonstrando a significância do impacto ambiental; (ii) o trâmite do licenciamento ambiental; e (iii) a existência de impactos negativos e não mitigáveis ${ }^{23}$.

Em outros termos, de acordo com a Lei e o Decreto regulamentador, a obrigação da compensação ambiental apenas incidirá no decorrer do processo de licenciamento ambiental (nem depois, nem antes), em empreendimentos para os quais se exijam o Estudo de Impacto Ambiental e respectivo Relatório EIA/RIMA ${ }^{24}$, e apenas quando houver impactos negativos não mitigáveis.

\footnotetext{
${ }^{22}$ Esse decreto alterou o art. 31 do Decreto $n^{\circ}$ 4.340/2002, que passou a prescrever: “Art. 31. Para os fins de fixação da compensação ambiental de que trata o art. 36 da Lei $n^{\circ}$ 9.985, de 2000, o órgão ambiental licenciador estabelecerá o grau de impacto a partir de estudo prévio de impacto ambiental e respectivo relatório - EIA/RIMA realizados quando do processo de licenciamento ambiental, sendo considerados os impactos negativos e não mitigáveis aos recursos ambientais.”

23 Diz-se negativos e não mitigáveis, pois, em tese, é possível que um empreendimento possa causar apenas impactos positivos ou, ainda, negativos, porém mitigáveis.

${ }_{24}$ Tanto na esfera administrativa quanto na judicial foram vistas discussões sobre a possibilidade de exigência da compensação ambiental em empreendimentos licenciados com base em outros estudos, que não exatamente o EIA/RIMA, como, dentre outros, o relatório ambiental, plano e projeto de controle ambiental,
} 
Significa dizer que é a presença conjunta dos três pressupostos acima que, aproveitando o conceito tributário, caracteriza o fato gerador ou a hipótese de incidência da compensação ambiental.

A referida Lei $n^{\circ} 9.985 / 2000$, porém, gerou outras controvérsias, as quais se instalaram, de início, em razão de a lei impor como método de cálculo uma alíquota mínima (de 0,5\%), deixando de estabelecer um teto ${ }^{25}$. Além disso, para buscar o valor a ser pago a título de compensação ambiental, a norma dispunha de uma base de cálculo fulcrada nos custos totais para a implantação do empreendimento; isso foi considerado um critério muito subjetivo, pois não tinha relação estreita com os significativos impactos negativos e não mitigáveis de um dado empreendimento, podendo conter custos, inclusive com gastos para a implantação de soluções 'mais limpas' e, portanto, menos poluentes ${ }^{26}$.

relatório ambiental preliminar, diagnóstico ambiental, plano de manejo, plano de recuperação de área degradada e análise preliminar de risco (rol exemplificativo de 'estudos ambientais', constante do art. $1^{\circ}$, inciso III, da Resolução CONAMA no 237/1997). A título ilustrativo, veja-se excerto da ementa a respeito da inafastabilidade do pressuposto do EIA/RIMA, julgado do TRF da $2^{\mathrm{a}}$ Região: "PROCESSO CIVIL. AGRAVO DE INSTRUMENTO. INSTITUTO BRASILEIRO DO MEIO AMBIENTE E DOS RECURSOS NATURAIS RENOVÁVEIS - IBAMA. EXPEDIÇÃO DE LICENÇA PRÉVIA DE PRODUÇÃO PARA PESQUISA. SUBMISSÃO À EXIGÊNCIA DO ARTIGO 36 DA LEI 9.985/00. DISPOSITIVO LEGAL REFERENTE AOS EMPREENDIMENTOS DE SIGNIFICATIVO IMPACTO AMBIENTAL, COM FUNDAMENTO EM ESTUDO DE IMPACTO AMBIENTAL E RESPECTIVO RELATÓRIO EIA/RIMA. EMPREENDIMENTO DOS AUTOS FUNDADO APENAS EM ESTUDO DE VIABILIDADE AMBIENTAL - EVA, NÃO PARECENDO POSSUIR "SIGNIFICATIVO IMPACTO AMBIENTAL". AGRAVO DE INSTRUMENTO DESPROVIDO E AGRAVO INTERNO PREJUDICADO” TJ/SP Apelação no 454.590-5/6-00 - Câmara Especial de Meio Ambiente - Rel. Des. José Augusto Genofre Martins - Acórdão nº 01135250, Data de Registro 26/10/2006.

${ }^{25}$ A doutrina criticou em demasia o fato de a lei ter imposto um percentual mínimo para a obrigação, deixando de estabelecer um "teto" ou percentual máximo. A esse respeito, vide MILARÉ, Édis; ARTIGAS, Priscila Santos. Compensação Ambiental: questões controvertidas. Revista de Direito Ambiental. $n^{\circ}$ 43. Ano 11. jul-set. São Paulo: RT, 2006; OLIVEIRA, José Marcos Domingues de. A chamada compensação financeira do SNUC. Revista Dialética de Direito Tributário, $\mathrm{n}^{\circ}$ 133, out. 2006; GUERRA, Sérgio. Compensação ambiental nos empreendimentos de significativo impacto. In: WERNECK, Mário et al (coord.). Direito ambiental: visto por nós advogados. Belo Horizonte: Del Rey, 2005. Contrariamente a esse corrente, ver RODRIGUES, Marcelo Abelha. Aspectos jurídicos da compensação ambiental do art. 36, § 1. ${ }^{\circ}$ da Lei Brasileira das Unidades de Conservação (Lei no 9.985/2000). Revista de Direito Ambiental. vol. 46. São Paulo: RT, 2007.

${ }^{26}$ Sobre as críticas à base de cálculo da compensação ambiental, Marcelo Abelha Rodrigues expõe: "o critério que fixa o montante sobre o qual incidirá o percentual de $0,5 \%$ e indicará o valor mínimo a ser compensado, pode se mostrar deveras injusto. Primeiro porque muitas vezes o custo total do empreendimento pode ser indicativo de que o empreendedor teria investido em planos, bens e tecnologias limpas, que normalmente elevam o custo de um empreendimento. Segundo porque não há relação lógica entre o custo total do empreendimento e a impactação do meio ambiente. É possível que empreendimentos de custo menor sejam mais impactantes do que empreendimentos de custo maior. A relação entre impacto ambiental e custo para a implantação não é sempre um indicador seguro de que haveria razoabilidade na fixação do dever de compensar pelos prejuízos ambientais não mitigáveis. Com isso, queremos dizer que o critério eleito pelo legislador para fixar o que se denominou de "piso mínimo" da compensação ambiental é absolutamente irrazoável e inseguro para o empreendedor, além de prejudicial para o próprio meio ambiente.” 
Frente às inúmeras críticas e, certamente, procurando equacionar a falta de um limite para o percentual e a amplitude da base de cálculo, foi editada a Resolução CONAMA n ${ }^{0}$ 371, de 5 de abril de 2006, estabelecendo que o teto da compensação ambiental não poderia ultrapassar o aludido $0,5 \%$ até que os órgãos ambientais definissem e publicassem as suas metodologias de cálculo para impor a obrigação ${ }^{27}$. Ademais, o diploma limitou a base de cálculo, determinando a exclusão dos investimentos destinados à elaboração e implementação dos planos, programas e ações não exigidos pela legislação ambiental, mas estabelecidos no processo de licenciamento ambiental para mitigação e melhoria da qualidade ambiental ${ }^{28}$.

Antes disso, porém, a Confederação Nacional da Indústria - CNI já havia proposto $^{29}$ uma Ação Direta de Inconstitucionalidade (ADI 3.378/DF), a fim de impugnar a constitucionalidade do art. 36, $\S 1^{\circ}$ da Lei $n^{\circ} 9.985 / 2000$. Em 9 de abril de 2008, o STF julgou a ação, decidindo de forma parcialmente procedente pela constitucionalidade da exação, mas alterando a sua base de cálculo (0,5\% sobre os custos totais do investimento), para determinar que o montante de recursos a ser destinado como compensação ambiental devesse ser fixado de acordo com o grau de impacto ambiental, sem relação necessária com o custo do empreendimento. O julgado foi assim ementado:

Ação direta de inconstitucionalidade. Art. 36 e seus $\S \S 1 .^{\circ}, 2 .^{\circ} \mathrm{e}$ $3 .^{\circ}$ da Lei 9.985, de 18 de julho de 2000. Constitucionalidade da

RODRIGUES, Marcelo Abelha. Aspectos jurídicos da compensação ambiental do art. 36, § 1. ${ }^{\circ}$ da Lei Brasileira das Unidades de Conservação (Lei n 9.985/2000). Revista de Direito Ambiental. vol. 46. São Paulo: RT, 2007.

27 “Art. 15. O valor da compensação ambiental fica fixado em meio por cento dos custos previstos para a implantação do empreendimento até que o órgão ambiental estabeleça e publique metodologia para definição do grau de impacto ambiental.”

${ }^{28}$ Cf. art. $3^{\circ}$, §§ $1^{\circ}$ e $2^{\circ}$ da referida Resolução CONAMA n ${ }^{\circ} 371 / 2006$. Observe-se ter a Resolução CONAMA 371/2005 mantido na base de cálculo os investimentos destinados à melhoria da qualidade ambiental e à mitigação dos impactos causados pelo empreendimento, quando prescritos na legislação ambiental, o que suscitou outras críticas, as quais residiram, sobretudo, no fato de não importar se os gastos com prevenção e mitigação de impactos estavam ou não previstos em lei. Com efeito, tais investimentos, por procurarem proteger o meio ambiente definitivamente não deveriam estar incluídos na base de cálculo. Tal situação acabou por ser equacionada com a edição do Decreto $n^{0} 6.848 / 2009$, que excluiu da base de cálculo da compensação ambiental os investimentos referentes aos planos, projetos e programas exigidos no procedimento de licenciamento ambiental para mitigação de impactos, bem como os encargos e custos incidentes sobre o financiamento do empreendimento, inclusive os relativos às garantias, e os custos com apólices e prêmios de seguros pessoais e reais (cf. redação que alterou o art. 31, §3º do Decreto 4.340/2002). ${ }^{29}$ A distribuição da ADI no STF ocorreu em 16.12.2004. 
compensação devida pela implantação de empreendimentos de significativo impacto ambiental. Inconstitucionalidade parcial do $\S 1 .^{\circ}$ do art. 36. 1. O compartilhamento-compensação ambiental de que trata o art. 36 da Lei 9.985/2000 não ofende o princípio da legalidade, dado haver sido a própria lei que previu o modo de financiamento dos gastos com as unidades de conservação da natureza. De igual forma, não há violação ao princípio da separação dos Poderes, por não se tratar de delegação do Poder Legislativo para o Executivo impor deveres aos administrados. 2. Compete ao órgão licenciador fixar o quantum da compensação, de acordo com a compostura do impacto ambiental a ser dimensionado no relatório - EIA/RIMA. 3. O art. 36 da Lei 9.985/2000 densifica o princípio usuáriopagador, este a significar um mecanismo de assunção partilhada da responsabilidade social pelos custos ambientais derivados da atividade econômica. 4. Inexistente desrespeito ao postulado da razoabilidade. Compensação ambiental que se revela como instrumento adequado à defesa e preservação do meio ambiente para as presentes e futuras gerações, não havendo outro meio eficaz para atingir essa finalidade constitucional. Medida amplamente compensada pelos benefícios que sempre resultam de um meio ambiente ecologicamente garantido em sua higidez. 5. Inconstitucionalidade da expressão 'não pode ser inferior a meio por cento dos custos totais previstos para a implantação do empreendimento', no $\S 1 .^{\circ}$ do art. 36 da Lei 9.985/2000. O valor da compensação-compartilhamento é de ser fixado proporcionalmente ao impacto ambiental, após estudo em que se assegurem o contraditório e a ampla defesa. Prescindibilidade da fixação de percentual sobre os custos do empreendimento. 6. Ação parcialmente procedente. ${ }^{30}$

Diante de aventadas omissão e contradições do acórdão, a CNI e a União opuseram Embargos de Declaração que, desde 16 de setembro de 2008, encontram-se em mesa para julgamento. Segundo consta, busca-se, em suma, esclarecer se o termo “percentual” foi ou não excluído do texto da lei, como também se a decisão se aplica ex nunc, ou seja, se vigora desde a vigência da norma ou tão somente da publicação da decisão do $\mathrm{STF}^{31}$.

\footnotetext{
${ }^{30}$ DJe-112, publ. 20.06.2008, Ement. vol. 02324-02, p. 00242.

${ }^{31}$ A respeito dos Embargos de Declaração opostos pela União, o então Consultor Jurídico do Ministério do Meio Ambiente - MMA, Dr. Luiz Fernando Villares, publicou artigo no jornal Valor Econômico, de 30.06.2008, expondo que "maior insegurança pode trazer o Supremo se considerar que a decisão atinge as situações já consolidadas. Abrir-se-ia o questionamento e a revisão administrativa e judicial de todas as compensações ambientais já pactuadas e desembolsadas. O passivo administrativo ambiental exigiria imediatamente recursos materiais e servidores tão escassos. Para que isso não aconteça, a Advocacia Geral da União (AGU) demonstrou, por meio de um recurso aos ministros do Supremo, que os efeitos da decisão, se considerados retroativos, podem atingir a reavaliação de R 470 milhões só em recursos federais. Estados e municípios serão atingidos em grau mais elevado, já que a regra é o licenciamento ambiental ser por eles realizado".
} 
Não obstante a declaração de inconstitucionalidade em relação à forma de cálculo da compensação ambiental estabelecida pela Lei $n^{0}$ 9.985/2000 ${ }^{32}$, foi, todavia, posteriormente editado o Decreto Federal $n^{\circ} 6.848$, de 14 de maio de 2009, impondo uma nova metodologia de aplicação da compensação ambiental, segundo a qual o resultado dessa exação pecuniária decorrerá da aplicação do percentual máximo de $0,5 \%$ a incidir no valor do investimento do empreendimento ${ }^{33}$.

Em razão de uma aparente contradição com o julgado do STF, o Decreto $\mathrm{n}^{\circ} 6.848 / 2009$ foi contestado pelo Instituto Socioambiental - ISA, ao opor, em 18 de junho de 2009, a Reclamação (Rcl) $n^{\circ}$ 8465, pretendendo fosse “[...] suspensa a eficácia do art. $2^{\circ}$ e anexos do Decreto $n^{\circ} 6.848 / 2009$, ante o risco de aplicação imediata da norma já declarada inconstitucional aos inúmeros empreendimentos em fase de implementação no país”.

Essa Reclamação foi apreciada pelo Ministro Marco Aurélio e, em 3 de novembro de 2009, indeferiu a liminar acautelatória pretendida, entendendo que “a interposição de embargos declaratórios gera a presunção de não haver o aperfeiçoamento da prestação jurisdicional. Além disso, menciona-se o fato de o Supremo ter afastado o piso referente ao ressarcimento por possível dano ambiental quando, na verdade, o decreto envolvido na espécie versa limite”. Mediante essa decisão, o STF acabou por considerar válido o Decreto $n^{\circ}$ 6.848/2009, sobretudo em razão de não estar aperfeiçoado o julgado relativo à ADI 3.378/DF, diante da oposição dos embargos declaratórios. Por conseguinte, na prática, a metodologia de cálculo imposta por esse diploma infralegal pode e

\footnotetext{
${ }^{32}$ Observe-se que, antes do julgamento do STF, o texto do $\$ 1^{\circ}$ do art. 36 impunha, como já transcrito, que “o montante de recursos a ser destinado pelo empreendedor para esta finalidade não pode ser inferior a $0,5 \%$ (meio por cento) dos custos totais previstos para a implantação do empreendimento, sendo o percentual fixado pelo órgão ambiental licenciador, de acordo com o grau de impacto ambiental causado pelo empreendimento". Após o julgamento, esse dispositivo restou assim redigido: "o montante de recursos a ser destinado pelo empreendedor para esta finalidade, sendo [será] o percentual fixado pelo órgão ambiental licenciador, de acordo com o grau de impacto ambiental causado pelo empreendimento".

${ }^{33}$ Confira-se o art. 31-A do Decreto n ${ }^{\circ}$ 6.848/2009: "Art. 31-A. O Valor da Compensação Ambiental - CA será calculado pelo produto do Grau de Impacto - GI com o Valor de Referência - VR, de acordo com a fórmula a seguir: $\mathrm{CA}=\mathrm{VR} \times \mathrm{GI}$, onde: $\mathrm{CA}=$ Valor da Compensação Ambiental; VR = somatório dos investimentos necessários para implantação do empreendimento, não incluídos os investimentos referentes aos planos, projetos e programas exigidos no procedimento de licenciamento ambiental para mitigação de impactos causados pelo empreendimento, bem como os encargos e custos incidentes sobre o financiamento do empreendimento, inclusive os relativos às garantias, e os custos com apólices e prêmios de seguros pessoais e reais; e GI = Grau de Impacto nos ecossistemas, podendo atingir valores de 0 a 0,5\%”.
} 
deve ser aplicada pelos órgãos ambientais no licenciamento ambiental de empreendimentos que causem significativos impactos no meio ambiente.

É oportuno notar, neste ponto, em primeiro lugar, o fato de o texto legal originário ter previsto o percentual mínimo de $0,5 \%$ a ser aplicado a todos os investimentos para a implantação de empreendimentos que causem significativos impactos ambientais; em segundo lugar, esse percentual e essa base de cálculo foram julgados inconstitucionais pelo STF, ao compreender que o resultado da compensação ambiental deveria fundar-se não em um critério objetivo, mas nos significativos impactos causados pelo empreendimentos; e, em terceiro lugar, o Decreto $\mathrm{n}^{\circ} 6.848 / 2009$ acabou por introduzir uma metodologia de cálculo, a qual, ao mesmo tempo em que permitia encontrar o grau de impacto do empreendimento, reintroduziu o percentual de $0,5 \%$, dessa feita como teto máximo, a incidir sobre determinados custos do empreendimento.

Isso significa, na prática, na circunstância de a compensação ambiental vir sendo aplicada pelos órgãos licenciadores não em conformidade com o determinado pelo STF, mas de acordo com a metodologia de cálculo constante do Decreto $n^{\circ}$ 6.848/2009. Essa norma, embora tenha estabelecido uma forma de alcançar o grau de impacto de determinado empreendimento - o que seguiria o determinado pelo STF -, reintroduziu um critério objetivo para o cálculo da exação, fulcrado novamente em uma alíquota (dessa vez máxima, de 0,5\%) a incidir sobre determinados custos para a implantação do empreendimento.

Por outro prisma, tem-se que as críticas anteriores à decisão do $\mathrm{STF}^{34}$ acabaram por ser equacionadas não pelo julgamento da ADI, mas pela posterior edição daquele decreto.

Afinal, o texto legal considerado inconstitucional previa o percentual mínimo de $0,5 \%$ - nada falando sobre um teto máximo - a ser aplicado aos investimentos totais para implantar empreendimentos, o que era criticado pela doutrina. O referido decreto, por sua vez, estabeleceu o percentual máximo de

\footnotetext{
${ }^{34}$ Como já perpassado em notas acima, as críticas à Lei no 9.985/2000 residiam, basicamente, em dois pontos: o primeiro, por não ter estabelecido um teto máximo para a alíquota, mas apenas um percentual mínimo de $0,5 \%$ (meio por cento). A segunda, dizia respeito ao fato de a alíquota incidir sobre os custos totais do empreendimento, nos quais estão previstos investimentos com medidas preventivas e mitigatórias de impactos no meio ambiente, além de outros custos que a nada se referiam com estes (como tributos e contribuições).
} 
0,5\% (meio por cento), de modo que a alíquota (ou percentual) originalmente prescrita na norma primária passou de piso para teto da exação. Afora isso, em relação à base de cálculo, considerada pela lei ordinária como a totalidade dos investimentos necessários para a implantação do empreendimento, à luz do Decreto federal referidos investimentos devem ser limitados, excluindo-se os valores relativos aos “planos, projetos e programas exigidos no procedimento de licenciamento ambiental para mitigação de impactos causados pelo empreendimento, bem como os encargos e custos incidentes sobre o financiamento do empreendimento, inclusive os relativos às garantias e os custos com apólices e prêmios de seguros pessoais e reais” ${ }^{35}$.

Em verdade, a edição do Decreto $\mathrm{n}^{\circ}$ 6.848/2009 decorreu da absoluta inoperância da norma diante do julgamento da ADI 3.378/DF. De fato, o julgado do STF, ao determinar que a compensação ambiental fosse calculada com base no subjetivo critério do grau dos significativos impactos causados pelo empreendimento, tornou a obrigação de difícil aplicação. Assim, o referido decreto, ao reintroduzir um critério objetivo, embora aparentemente colida com aquela decisão, permitiu novamente a imposição da compensação ambiental no decorrer do licenciamento ambiental. ${ }^{36}$

Por essa e outras razões, vale deter-se na análise - crítica - do julgado da ADI 3.378/DF.

\footnotetext{
${ }^{35} \mathrm{O}$ art. 31-A do Decreto n ${ }^{\circ}$ 6.848/2009, ao conceituar o "Valor de Referência-VR" a ser utilizado na base de cálculo da compensação ambiental, assim dispõe: "VR = somatório dos investimentos necessários para implantação do empreendimento, não incluídos os investimentos referentes aos planos, projetos e programas exigidos no procedimento de licenciamento ambiental para mitigação de impactos causados pelo empreendimento, bem como os encargos e custos incidentes sobre o financiamento do empreendimento, inclusive os relativos às garantias, e os custos com apólices e prêmios de seguros pessoais e reais.”

${ }^{36}$ Diante do julgamento da ADI $n^{\circ}$ 3.378/DF pelo STF, como também da edição do Decreto ${ }^{\circ}$ 6.848/2009, a Procuradoria Federal Especializada do IBAMA emitiu o Parecer $n^{0}$ 027/2009-PFE/IBAMA/GABIN, em 21.12.2009, orientando a aplicação da compensação ambiental em antigos e novos processos, concluindo, dentre outras questões, que: (i) o julgamento do STF não retroage, de modo que a inconstitucionalidade ali declarada não incide em processos cujos Termos de Compromisso foram firmados; (ii) a metodologia do Decreto $n^{\circ}$ 6.848/2009 não pode ser aplicada a casos anteriores a sua publicação, em que já tenham sido estabelecidos os valores da compensação ambiental; (iii) a aplicação da nova metodologia de compensação ambiental aos casos não calculados/consumados não deve obstar a concessão de eventuais licenças e renovações; e (iv) compete ao ICMBio a assinatura de Termos de Compromisso, cabendo tão somente ao IBAMA fixar, com base no EIA/RIMA, e utilizando a metodologia constante do Decreto ${ }^{\circ}$ 6.848/2009, o valor da compensação ambiental.
} 


\subsection{Análise crítica do julgamento do STF na ADI 3.378/DF}

Neste momento, faz-se necessário analisar, de forma crítica, a base argumentativa e os efeitos do julgamento pelo STF da referida Ação Direta de Inconstitucionalidade em face do quanto disposto no art. 36, §1º , da Lei ${ }^{\circ}$ 9.985/2000. A crítica decorre principalmente do fato de o STF não ter considerado que a compensação ambiental é espécie do gênero medidas compensatórias.

Para aprofundar a avaliação do julgado da ADI 3.378/DF, observe-se, conforme se extrai da ementa do acórdão transcrita no item anterior deste estudo, ter se decidido, em suma, que (i) não há outro meio eficaz, que não seja a compensação ambiental, para alcançar o objetivo constitucional de defesa e preservação do meio ambiente para as presentes e futuras gerações; (ii) há inconstitucionalidade parcial do art. $36, \S 1^{\circ}$, da Lei $\mathrm{n}^{\circ} 9.985 / 2000$ no que se refere à expressão "não pode ser inferior a meio por cento dos custos totais previstos para a implantação do empreendimento”, devendo o valor ser fixado, pelo órgão ambiental, proporcionalmente ao impacto ambiental dimensionado no estudo respectivo; (iii) a obrigação não ofende o princípio da legalidade, dado haver sido a própria lei que previu o modo de financiamento dos gastos com as unidades de conservação da natureza; e (iv) não há violação ao princípio da separação dos poderes, por não se tratar de delegação do Poder Legislativo para o Executivo impor deveres aos administrados.

Destarte, avaliando o julgado da referida ADI, procurar-se-á demonstrar que o STF incidiu em erros, porquanto a compensação ambiental não é o único instrumento capaz de defender e proteger o meio ambiente e, ainda, o afastamento do critério objetivo da norma - forma de cálculo - gera efeitos de inoperância da obrigação, além de poder infringir os princípios da legalidade, da separação dos poderes e da segurança jurídica. Pois bem.

2.3.1 A compensação ambiental não é o único meio eficaz de proteger o meio ambiente

O primeiro ponto crítico do julgado do STF evidencia-se no posicionamento do Relator da ADI, Ministro Carlos Britto, segundo o qual "não 
há outro meio eficaz para atingir essa finalidade constitucional [de defesa e proteção ambiental] senão impondo ao empreendedor o dever de arcar, ao menos em parte, com os custos de prevenção, controle e reparação dos impactos negativos ao meio ambiente.” Em outros termos, estabeleceu o STF que não há outro instrumento, que não seja a compensação ambiental criada pela Lei $\mathrm{n}^{\circ}$ 9.985/2000, capaz de alcançar o objetivo constitucional de defesa e preservação do meio ambiente para as presentes e futuras gerações.

A esse respeito, no entanto, é oportuno repisar que a Lei $n^{\circ}$ 9.985/2000, justamente por regular o Sistema Nacional de Unidades de Conservação SNUC, instituiu a compensação ambiental com a pretensão de obrigar empreendimentos com significativos impactos ambientais, assim considerado pelo órgão ambiental competente, a apoiar a implantação e a manutenção de unidade de conservação do grupo de Proteção Integral ${ }^{37}$. E, para viabilizar essa obrigação de fazer, a norma fixava o montante de recursos a ser destinado para esse fim, calculado em percentual não inferior a 0,5\% dos custos totais previstos para a implantação do respectivo empreendimento.

Significa dizer que a Lei $n^{\circ} 9.985 / 2000$ não instituiu apenas uma exação pecuniária, mas, sobretudo, uma obrigação de fazer, a qual, para sua consecução, exigia a aplicação de um montante pré-definido. Ou seja, para fazer face a essa obrigação de fazer, impôs-se originariamente um critério objetivo, qual seja, um valor baseado em alíquota que incidiria sobre uma base de cálculo pré-definida.

Deveras, temos que a norma não pretendeu criar uma obrigação pecuniária para fazer face a todos os significativos impactos causados ao meio ambiente, mas, sim, instituir uma obrigação de fazer - apoiar a implantação e a manutenção de unidade de conservação do grupo de Proteção Integral - que serviria como uma das medidas compensatórias dos significativos impactos negativos causados por empreendimentos ou atividades ${ }^{38}$. Nesse sentido, Paulo Affonso Leme Machado sustenta que

\footnotetext{
${ }^{37}$ Art. 36, caput, Lei no $9.985 / 2000$.

${ }^{38}$ Como se verá adiante, há, todavia, doutrinadores defendendo que a Lei no 9.985/2000 objetivou criar um instrumento capaz de compensar todos os impactos negativos e não-mitigáveis causados ao meio ambiente. Nesse sentido, Erika Bechara - ao criticar o Decreto $n^{\circ}$ 6.848/2009, o qual, como aludido, impôs, após o
} 
o pagamento ou a contribuição pecuniária criada não atinge todos os campos em que possam incidir os efeitos da atividade a ser licenciada, pois a poluição das águas e da atmosfera, a poluição sonora, a poluição do solo, através de rejeitos e de agrotóxicos não estão abrangidas na compensação a ser paga. Isso porque o pagamento a ser efetuado pelo empreendedor será destinado somente às unidades de conservação. ${ }^{39}$

Ademais, diante do voto condutor do resultado do julgamento ter exposto, inúmeras vezes, a necessidade de a compensação ambiental dever ser proporcional a todos os significativos impactos negativos causados pelo empreendimento, pode-se entender, por vias oblíquas, ter o STF impossibilitado a aplicação de outras medidas compensatórias quando do licenciamento ambiental de tais empreendimentos, inclusive aquelas já prescritas em lei. Vale dizer, é possível questionar, diante do julgamento do STF, se não estão obstadas as cobranças de outras medidas compensatórias, positivadas ou não, de empreendimentos com significativos impactos no meio ambiente, sob pena de bis in idem.

Certamente, há outras medidas compensatórias capazes de fazer face aos impactos negativos e não mitigáveis causados por empreendimentos a serem implantados por meio do processo de licenciamento ambiental - conforme visto no item 2.1 do presente capítulo. No entanto, isso não foi considerado pelo STF.

2.3.2 Os efeitos do afastamento do critério objetivo que permitia a aplicação da compensação ambiental

Conforme visto, ficou excluído da norma o critério objetivo ali definido para o cálculo da compensação ambiental. A respeito, é necessário comentar as

\footnotetext{
julgamento do STF, um novo critério objetivo para a compensação ambiental, determinando, em suma, não poder a exação ser superior ao teto de $0,5 \%$ dos custos do empreendimento definidos nesse diploma legal (conforme se verá mais adiante) - assim assevera: "se de um lado, o teto satisfaz os empreendedores, de outro desatende os objetivos da compensação, que é o de contrabalançar as perdas ambientais reais, perpetradas pelos empreendimentos poluidores/degradadores. Isso porque, acuada pelo teto, a compensação não pode cobrir todos os danos ambientais do empreendimento, constatados no licenciamento ambiental. E, se não cobri-los, parte da "conta ambiental" acabará sendo paga pela coletividade." BECHARA, Erika. Licenciamento e compensação ambiental. Na Lei do Sistema Nacional das Unidades de Conservação (SNUC). São Paulo: Atlas, 2009, p. 259.

${ }^{39}$ MACHADO, Paulo Affonso Leme. Direito ambiental brasileiro. 19a ed. São Paulo: Malheiros, 2011, p. 909.
} 
dificuldades disso decorrentes, mormente quanto à eficácia do regramento após a declaração parcial de inconstitucionalidade.

Antes, porém, é necessário relembrar o fato de a Lei n ${ }^{\circ}$ 9.985/2000 ter determinado o cálculo da compensação ambiental na incidência de, no mínimo, 0,5\%, a incidir sobre os custos totais para a implantação de empreendimentos com significativos impactos ambientais. Nota-se não ter a norma definido um percentual máximo e, tampouco, critérios ou padrões para graduação de percentuais conforme o difícil conceito de grau de impacto ambiental ${ }^{40}$. Tal indefinição, aliás, permitiu aos órgãos ambientais a fixação de alíquotas bastante desarrazoadas. Ademais, a base de cálculo - custos totais para a implantação do empreendimento - era muito ampla, incluindo valores que em nada se referiam aos impactos ambientais, inclusive os gastos com tecnologias para, justamente, prevenir e mitigar os próprios impactos. Bem por isso, muito se aludiu da injustiça de tal base de cálculo, porquanto aquele que gastasse com tecnologias caras e positivas para o meio ambiente, acabava por pagar mais.

Tudo, como se vê, já indicava a duvidosa legalidade e constitucionalidade da norma e, daí, a dificuldade de sua eficácia. Conforme expõe José Marcos Domingues Oliveira:

Quanto à medida dos recursos objeto da exação em tela percebe-se o déficit de qualidade legislativa: a Lei do SNUC se valeu de conceito jurídico indeterminado ("grau de impacto ambiental" - que deve ser, repita-se à exaustão, significativo) para desta feita proceder a uma pseudo valoração da compensação. E laborou mal. Sequer listou os graus de impactos possíveis de ocorrer. E sequer correlacionou a eles diferentes alíquotas ou prestações respectivas às diversas intensidades de

\footnotetext{
${ }^{40}$ Em relação ao critério objetivo, é importante relembrar, uma vez mais, que a Lei no 9.985/2000 estabeleceu ao empreendedor a obrigação de, no licenciamento de empreendimentos de significativo impacto ambiental, apoiar a implantação e a manutenção de unidade de conservação, mediante a destinação de, no mínimo, 0,5\% (meio por cento) do valor total de implantação do empreendimento. A par disso, esse critério objetivo foi mais bem delineado pelo Decreto $\mathrm{n}^{\circ}$ 4.340, de 22 de agosto de 2002, ao dispor (antes de ser alterado pelo Decreto $\mathrm{n}^{\circ}$ 6.848, de 14 de maio de 2009) que o “órgão ambiental deveria estabelecer o grau de impacto a partir de estudo prévio de impacto ambiental e respectivo relatório - EIA/RIMA realizados quando o processo de licenciamento ambiental, sendo considerados os impactos negativos e não mitigáveis aos recursos naturais”. O mesmo diploma também prescrevia que: “Os percentuais serão fixados, gradualmente, a partir de meio por cento dos custos totais previstos para a implantação do empreendimento, considerando-se a amplitude dos impactos gerados, conforme estabelecido no caput.”
} 
comprometimento do Meio Ambiente em razão daqueles impactos variados. ${ }^{41}$

Por seu turno, o julgamento do STF acentuou as dificuldades já presentes na lei por determinar a base da exação unicamente no subjetivo critério dos significativos impactos ambientais causados pelos empreendimentos. Em uma palavra, ao afastar a forma de cálculo, retirou-se da norma legal o único parâmetro objetivo que permitia o cálculo e a aplicação da compensação ambiental.

Essa questão foi bem sentida pelo Ministro Joaquim Barbosa que, divergindo da maioria, expôs em seu voto que “a norma impugnada cuidou de fixar parâmetros claros de atuação da administração para regular a matéria, de sorte que a esta não restou campo para inovar acerca do tema, como se pode extrair do $\S 1^{\circ}$ do art. 36. O único senão que vejo na norma diz respeito ao fato de ela não ter fixado um patamar superior, ou seja, um percentual máximo a ser pago pelo empreendedor. Nesse sentido, peço vênia para discordar da solução já proposta. Eu me limitaria a dar interpretação conforme para manter a norma em vigor e o dispositivo com essa expressão; se a retirarmos removemos o parâmetro que o legislador fixou ao administrador”. Mais adiante, o mesmo Ministro afirma: “Vejo duas alternativas. Uma delas é a proposta do Ministro Menezes Direito, que implica, na verdade, retirar completamente o parâmetro mínimo fixado pela lei. Se o retira, vejo uma dificuldade enorme para o administrador criar novos parâmetros. Aí, sim, seria uma delegação em aberto”. Seu voto, todavia, foi vencido pela maioria, que considerou pertinente retirar da norma o texto que tratava do critério objetivo de cálculo da exação. ${ }^{42}$

Com o propósito de manter o critério objetivo e permitir maior segurança, o Ministro Joaquim Barbosa propôs uma interpretação conforme, segundo a qual o percentual de 0,5\% deveria servir como mínimo e máximo para o cálculo da obrigação.

\footnotetext{
${ }^{41}$ OLIVEIRA, José Marcos Domingues. O Supremo Tribunal e a compensação SNUC. A ADI 3.378-DF. Revista de Direito GV. vol. 5, nº 1. São Paulo, jan-jun 2009.

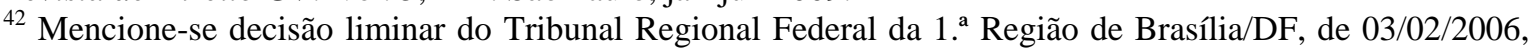
pelo Desembargador Federal Catão Alves (nos autos de Agravo de Instrumento 2005.01.00.060479-0/DF), impondo o percentual de $0,5 \%$ como o piso e o teto da obrigação, pois entendeu ser tributária a natureza jurídica da compensação ambiental.
} 
Diferentemente, o Ministro Menezes Direito, em explicações sobre o seu voto - que acabou sendo seguido pela maioria -, expôs que não seria possível a fixação de um percentual máximo para a exação, pois, no seu entender: "se não tirarmos a ideia de percentual, poderá ocorrer duas coisas: uma, não haver impacto ambiental significativo e nenhuma proporcionalidade entre o impacto ambiental e a participação do empreendedor na compensação do eventual impacto; a segunda, pode ser estabelecido outro critério que não seja o de percentual sobre empreendimento, porque esse critério, como está fixado no mínimo, pode levar ao máximo, ficando absolutamente descontrolado”.

Por conseguinte, diante do julgamento da ADI 3.378/DF pelo STF, o critério objetivo (de 0,5\% sobre os custos totais de investimento), originalmente adotado pelo legislador para o cálculo da compensação ambiental, foi considerado inconstitucional ${ }^{43}$. De fato, conforme já expendido aqui várias vezes, houve o entendimento de que a compensação ambiental deveria ser correlata aos significativos impactos causados ao meio ambiente, não devendo restringir-se a um método que fixasse uma alíquota mínima e uma base de cálculo.

De forma crítica, é importante alertar que, se já era inadmissível a ausência na lei de critérios firmes e inquestionáveis para fixar os valores exigidos a título de compensação ambiental, com o julgamento pelo STF deixouse ainda mais livre o estabelecimento de seu limite ao arbítrio do administrador

\footnotetext{
${ }^{43}$ De forma diversa, o STF, ao julgar ação que tratava da Contribuição ao Seguro de Acidentes de Trabalho SAT (RE 343.446-SC), decidiu, com bastante prudência, que cabe à norma primária fixar os padrões e critérios - ou simplesmente standards- para a gradação de uma exação tributária, o que certamente deveria ser estendido a todas as obrigações legais de cunho pecuniário. Isso permitiu que o regulamento estabelecesse uma regra que, consoante julgamento do STF, não transgride o princípio da legalidade genérico e específico (tributário). É o que ensina José Marcos Domingues Oliveira: “Nesse precedente, o STF reconheceu que a lei fixara base de cálculo conexa ao risco coberto pelo SAT (a remuneração do obreiro com fundamento na qual é ele de ser amparado em caso de sinistro); fixou também as três alíquotas da contribuição por sua vez conexas às gradações de risco por ela mesma mencionadas expressamente: $1 \%, 2 \%$ ou $3 \%$ conforme o grau de risco da atividade preponderante da empresa seja considerado leve, médio ou grave.” OLIVEIRA, José Marcos Domingues. O Supremo Tribunal e a compensação SNUC. A ADI 3.378/DF. Revista de Direito GV. vol. 5, $\mathrm{n}^{\circ}$ 1. São Paulo, jan-jun 2009. Da mesma forma, ao julgar a ADI no 2.278/DF, o STF fulminou a Taxa de Fiscalização Ambiental - TFA (instituída pela Lei $n^{\circ}$ 9.960/2000), justamente porque, entre outros motivos, "não foram definidas as respectivas alíquotas ou o critério a ser utilizado para cálculo do valor devido".
} 
público $^{44}$. Significa dizer que o montante da compensação, à luz do texto originário da Lei $\mathrm{n}^{\circ}$ 9.985/2000 e, sobretudo, da posterior decisão do STF, poderá variar de técnico para técnico, de equipe para equipe multidisciplinar, de órgão para órgão ambiental, de governo para governo etc. ${ }^{45}$

Ora, na prática, a compensação ambiental, para ser proporcional aos significativos impactos ambientais causados pelo empreendimento, deve passar primeiramente por uma avaliação de quais sejam esses impactos para, em seguida, quantificá-los de acordo com critérios que não foram parametrizados pela norma primária. Esse contexto pode ser exemplificado por um empreendimento que cause significativos impactos à fauna aquática - como é o caso de usinas hidrelétricas, cujo barramento e criação de lagos artificiais acabam impactando sobremaneira a fauna ictiológica. Nessa situação, o órgão administrativo ambiental terá que avaliar o exato impacto causado e, então,

\footnotetext{
${ }^{44}$ Temos conhecimento e experiência pessoal em processos nos quais a Administração Pública exigiu a cobrança da compensação ambiental em patamares desarrazoados, os quais chegavam, por vezes, a mais de $5 \%$ (cinco por cento); e, uma vez que a lei não fixava um limite, podiam tender ao infinito.

${ }^{45}$ A esse respeito, é oportuno observar que, antes do julgamento do STF, o IBAMA criou uma Câmara de Compensação Ambiental, instituída pela Portaria $\mathrm{n}^{\circ}$ 7, de 19 de janeiro de 2004 (Regimento Interno estabelecido pela Portaria 44, de 22 de abril de 2004), com o objetivo de adotar as decisões necessárias à aplicação e ao uso dos recursos financeiros oriundos do processo de licenciamento ambiental sob a forma de compensação, sendo suas atribuições, conforme prescreviam os incisos de seu art. $3^{\circ}$, dentre outras, (i) a de decidir sobre os critérios de gradação de impactos ambientais, bem como procedimentos administrativos e financeiros para execução da compensação ambiental, e propor ao Conselho Gestor uma normatização necessária a esse fim, bem como (ii) examinar e decidir sobre os recursos administrativos de revisão de gradação de impactos ambientais. Em suma, aquela Câmara elaborou Metodologias de Cálculo, as quais foram utilizadas para a fixação do percentual da compensação ambiental, sem que se respaldassem, no entanto, por atos formalizados legalmente. E pior, foram constantemente aplicados pelo IBAMA, por vezes de forma pouco razoável e desproporcional. Afinal, como já se viu nesta tese, as normas que criaram e regulamentaram a compensação ambiental, além de não imporem um teto, não definiram se o percentual devido pelo empreendedor deveria incidir sobre o total dos custos diretos ou também sobre o total dos custos indiretos despendidos no empreendimento. Mais recentemente, após o julgamento da ADI pelo STF e a edição do Decreto ${ }^{\circ}$ 6.848/2009, foi editada a Portaria Conjunta MMA-IBAMA 225, de 30 de junho de 2011, criando, no âmbito do Instituto Brasileiro do Meio Ambiente e dos Recursos Naturais Renováveis IBAMA, o Comitê de Compensação Ambiental Federal - CCAF, integrado por entidades daquele Instituto, do Meio Ministério do Meio Ambiente e do Instituto Chico Mendes de Conservação da Biodiversidade ICMBio. O comitê tem como atribuições, em suma, deliberar sobre a divisão e a finalidade dos recursos oriundos da compensação ambiental; manter os registros dos Termos de Compromisso firmados, dos relatórios de execução dos recursos e dos relatórios relacionados com a auditoria, monitoria e avaliação dos recursos aplicados; verificar o atestado de cumprimento das obrigações do órgão gestor; consolidar os documentos que demonstram a quitação da obrigação pelo empreendedor. Também recentemente foi editada a Instrução Normativa IBAMA n ${ }^{\circ}$ 8, de 14 de julho de 2011, que regulamenta, no âmbito da Autarquia, o procedimento para o cálculo e a indicação da proposta de Unidades de Conservação a serem beneficiadas pelos recursos da Compensação Ambiental.
} 
partir para a difícil tarefa de valorar monetariamente esse impacto ${ }^{46}$. É bastante intuitiva a enorme dificuldade dessa equação. Bem por isso - acredita-se - a norma primária introduziu, originalmente, um critério objetivo para o cálculo da obrigação.

Assim, por um lado, a Lei do SNUC, embora tenha introduzido um critério objetivo de cálculo, não indiciou parâmetros e padrões para graduação de alíquotas, deixando a interpretação do grau do impacto ao juízo técnico da Administração Pública, a qual já ficava completamente livre, isto é, insuscetível de ser controlada, para fixar o valor de uma exação pecuniária de acordo com a sua compreensão.

Por outro lado, a situação não melhorou com o julgamento da ADI 3.378/DF pelo STF. Ao contrário, com o julgamento dessa demanda, a obrigação acabou por ficar inoperante. Afinal, determinar que a exação se baseie no significativo impacto ambiental, sem qualquer critério objetivo a orientar a atuação da Administração Pública, é o mesmo que não dizer nada ou, ainda, vincular uma obrigação pecuniária a um aspecto absolutamente subjetivo. Basta ver que inexiste no ordenamento jurídico pátrio o conceito de significativo impacto ambiental ${ }^{47}$.

Deveras, tem-se que nem a lei nem o STF definiram - em respeito aos princípios da segurança jurídica e da separação dos poderes - quais os graus de impacto e os demais critérios e parâmetros necessários para a aplicação da regra, e, tampouco, o conceito de significativo impacto ambiental. E não há dúvidas de que, em se tratando de prestação pecuniária, minimamente, a lei deve conter os critérios objetivos da medida do ônus que pretenda impor: causa e

\footnotetext{
${ }^{46}$ É oportuno aqui destacar de antemão que há inúmeros debates e controvérsias sobre os métodos de valoração de danos e, por consequência, de impactos ambientais. Isso será mais bem detalhado no item 5.3 do Capítulo 5 desta tese, podendo-se aqui adiantar, apenas, que a quantificação de um impacto ambiental, significativo ou não, tem encontrado as mesmas e já verificadas dificuldades para quantificar monetariamente danos ambientais.

${ }^{47}$ Acerca da dificuldade de definição do termo significativo, José Marcos Domingues de Oliveira assim expõe: "desenganadamente, significativo é vocábulo volátil, de conteúdo rarefeito, difuso, impregnado que é de um sentimento subjetivo de percepção da realidade.” OLIVEIRA, José Marcos Domingues de. Direito tributário e meio ambiente. $3^{\text {a }}$ ed. rev. e ampl. Rio de Janeiro: Forense, 2007, p. 201. Não obstante, é a própria Constituição Federal brasileira que introduziu o termo significativa degradação do meio ambiente (art. 225, §1º IV), como pressuposto para impor a obrigação de apresentar o Estudo de Impacto Ambiental.
} 
momento lícitos da exigência, ordem de grandeza legítima e parcela desta que corresponda ao objeto da providência que determinar.

Observe-se: não se quer dizer que a norma primária devia conter todos os dados necessários para a aplicação da compensação ambiental; trata-se, sim, de estabelecer, no mínimo, os graus de gradação e o método de cálculo a incidir para cada qual (ou seja, por exemplo, para cada grau de impacto incide uma determinada alíquota). Logicamente, que é a partir desses critérios ou padrões genéricos que o agente regulamentador pode definir os critérios de enquadramento na norma.

A par disso, vale ressaltar, a falta de critérios e parâmetros no texto originário da lei pode dar margem a uma indesejável espécie de negociação, não contemplada pela lei, entre o empreendedor e o órgão técnico, a depender das informações prestadas e dos critérios utilizados para o seu cálculo. Isso implica, como é intuitivo, a ofensa aos princípios da legalidade, da segurança jurídica e da separação dos poderes.

Portanto, a decisão do STF, em uma análise crítica, encaminhou mal a questão. Com efeito, além de tornar a compensação ambiental da Lei do SNUC a única medida compensatória passível de ser exigida no decorrer do licenciamento ambiental de empreendimentos ou atividades a ela sujeitos, também extraiu o único critério objetivo contido na lei, tornando a obrigação de difícil aplicabilidade.

Dessa feita, abriu-se um leque infindável de opções para a definição do quantum da exação pela Administração Pública, o que certamente contraria os ditos princípio da legalidade, o princípio da segurança jurídica e o princípio da separação dos poderes.

\subsection{As controvérsias doutrinárias e jurisprudenciais sobre a natureza jurídica da compensação ambiental}

Neste ponto, importante aludir, ainda, à discussão doutrinária que vem sendo travada acerca da correta natureza jurídica da espécie compensação 
ambiental, o que permitirá avaliar posteriormente a natureza jurídica do gênero medidas compensatórias.

Antes, é oportuno observar, lançando mão dos ensinamentos do Prof. Fábio Nusdeo, que a busca pela natureza jurídica das medidas compensatórias não pretende encontrar um conceito estanque para esse instituto. Na verdade, grande parte das discussões sobre a natureza jurídica perdeu sua justificativa maior com a crescente presença do Estado na vida econômica, ou seja, com a superação do liberalismo. Isso porque essas categorias, tais como a de natureza jurídica, foram basicamente elaboradas para um sistema baseado no direito privado e com mínima intervenção do Estado. Sendo assim, quando se suscita neste estudo a natureza jurídica da compensação ambiental e das medidas compensatórias, intenta-se enquadrar os institutos no arcabouço normativo brasileiro, objetivando viabilizar uma boa forma de implementação e aplicação prática; ou seja, para permitir a validade e a eficácia da obrigação.

Os debates travados para procurar a correta natureza jurídica da compensação ambiental dividiram os doutrinadores em três correntes. A primeira, defendendo a compensação ambiental com natureza jurídica reparatória; a segunda, sustentando que o instituto nada mais é do que um tributo; e, a terceira, arguindo ser a obrigação uma forma de compartilhamento de despesas entre o Poder Público e os entes empreendedores privados quando se lançam em atividade potencialmente impactante ou com amplas externalidades negativas.

Desde a instituição da compensação ambiental por Resoluções editadas pelo Conselho Nacional de Meio Ambiente - CONAMA, e mesmo com o advento da Lei $n^{\circ}$ 9.985/00 e após o julgamento da ADI 3.378/DF pelo STF, não se conseguiu definir qual a correta natureza jurídica da exação.

Em que pese o debate, merece relevo o fato de nenhuma das correntes citadas - da mesma forma como o STF, no referido julgado da ADI 3.378/DF ter levado seriamente em consideração que a obrigação da compensação ambiental é uma das medidas compensatórias - e não a única - exigidas das atividades ou empreendimentos causadores de impactos negativos e não mitigáveis ao meio ambiente. Senão, vejamos. 
2.4.1 A natureza jurídica reparatória da compensação ambiental: reparação ex ante de 'danos ambientais futuros'?

Como já aludido, há uma corrente ${ }^{48}$ que sustenta ser reparatória de danos ambientais a natureza jurídica do instituto da compensação ambiental da Lei do SNUC.

Para seus integrantes, a Constituição Federal, ao positivar o princípio do poluidor-pagador, o fez com objetivo eminentemente reparatório, pois o art. 225, §3 $3^{\circ}$, dispõe que: “As condutas e atividades consideradas lesivas ao meio ambiente sujeitarão os infratores pessoas físicas ou jurídicas, a sanções penais e administrativas, independentemente da obrigação de reparar os danos causados”.

A linha de raciocínio dessa corrente se apoia ainda na Lei federal $\mathrm{n}^{\circ}$ 6.938/1981, especificamente no inciso VII do seu art. $4^{\circ}$, o qual determina que a Política Nacional do Meio Ambiente visará “à imposição ao poluidor e ao predador, da obrigação de recuperar e/ou indenizar os danos causados e, ao usuário, da contribuição pela utilização de recursos ambientais com fins econômicos”. Essa lei também determina, no $\S 1^{\circ}$ do seu art. $14^{49}$, a responsabilidade objetiva pela reparação de danos ao meio ambiente.

Partindo, portanto, dessas proposições normativas é que segue o argumento de a compensação ambiental ter natureza jurídica subsumida ao instituto de reparação civil, sendo uma forma de indenização pelos danos que serão ocasionados ao meio ambiente.

\footnotetext{
${ }^{48}$ Nessa linha, Paulo Affonso Leme Machado. Direito ambiental brasileiro. $18^{\mathrm{a}}$ ed. São Paulo: Malheiros, 2010, p. 865; Erika Bechara. Licenciamento e compensação ambiental - na lei do Sistema Nacional das Unidades de Conservação (SNUC). São Paulo: Atlas, 2009, p. 194-205; Marcelo Abelha Rodrigues. Aspectos jurídicos da compensação ambiental do art. 36, § 1. ${ }^{\circ}$ da Lei Brasileira das Unidades de Conservação (Lei no 9.985/2000). Revista de Direito Ambiental. vol. 46. São Paulo: RT, 2007; e Sandra Clice de Aquino. A compensação ambiental na legislação brasileira sob o foco do desenvolvimento sustentável das cidades. In: SILVA, Bruno Campos (org.). Direito ambiental: enfoques variados. São Paulo: Lemos \& Cruz, 2004, p. 144.

49 “Art. 14 - Sem prejuízo das penalidades definidas pela legislação federal, estadual e municipal, o não cumprimento das medidas necessárias à preservação ou correção dos inconvenientes e danos causados pela degradação da qualidade ambiental sujeitará os transgressores: (...) $\S 1^{\circ}$ - Sem obstar a aplicação das penalidades previstas neste artigo, é o poluidor obrigado, independentemente da existência de culpa, a indenizar ou reparar os danos causados ao meio ambiente e a terceiros, afetados por sua atividade. $\mathrm{O}$ Ministério Público da União e dos Estados terá legitimidade para propor ação de responsabilidade civil e criminal, por danos causados ao meio ambiente.”
} 
Liderando essa corrente, Paulo Affonso Leme Machado sustenta: “a compensação ambiental é uma das formas de se implementar o princípio usuário-pagador, antecipando possíveis cobranças por danos ambientais”. 50 E, ainda, argumenta, “o dever legal do empreendedor de efetuar o pagamento da contribuição monetária ambiental surge do fato de seu empreendimento ter a potencialidade de causar impacto significativo ao meio ambiente, independentemente de lhe ser atribuída qualquer culpa, pois se aplica a responsabilidade objetiva prevista no art. 14 , $\S 1^{\circ}$, da Lei $n^{\circ} 6.938 / 81$ ”. ${ }^{51}$

Erika Bechara assegura que a compensação ambiental é “uma reparação por danos ambientais futuros, ou seja, uma reparação antecipada ou ex ante, devida em virtude de danos não mitigáveis, identificados antes mesmo da sua ocorrência concreta, quando do licenciamento ambiental da atividade”. ${ }^{52} \mathrm{~A}$ autora assim explica o raciocínio que permitiu chegar à afirmação acima:

Quando, em Direito Ambiental, fala-se em compensação de danos, vem à mente, de imediato, a ocorrência de uma lesão irreversível ao meio ambiente, que não permitirá a reparação in natura ou o retorno ao status quo ante e que, por isso mesmo, dará lugar à reparação por equivalente, mediante o oferecimento de bens e/ou serviços que representem algum benefício ao entorno, ou à reparação pecuniária, mediante o pagamento de valor em dinheiro (ao Fundo Federal e aos fundos estaduais de defesa dos direitos difusos).

A compensação ambiental prevista na Lei do SNUC não está tão distante desta compensação de danos, já que, igualmente, tem por escopo minorar os efeitos de uma perda ecossistêmica importante com um ganho ecossistêmico diverso (já que o que foi "perdido" não será mais "reconquistado"), mas nem por isso menos relevante.

A mais sensível diferença entre estas duas “compensações” é temporal: a compensação de danos "clássica” é exigida do poluidor ou degradador quando o meio ambiente já sofreu um impacto irreversível - ela se dá, por conseguinte, posteriormente ao dano - e a compensação ambiental da Lei 9.985/2000 é exigida do empreendedor quando ele estiver prestes a causar um impacto irreversível e inevitável, verificando-se, dessa forma, anteriormente ao dano. Em suma, uma é exigida quando o ambiente já foi impactado, a outra

\footnotetext{
${ }^{50}$ MACHADO, Paulo Affonso Leme. Direito ambiental brasileiro. 19a ed. São Paulo: Malheiros, 2011, p. 73.

${ }^{51}$ Idem, p. 909.

52 BECHARA, Erika. Licenciamento e compensação ambiental - na lei do Sistema Nacional das Unidades de Conservação (SNUC). São Paulo: Atlas, 2009, p. 194-195.
} 
quando ele estiver prestes a sê-lo. No primeiro caso, a compensação sucede o dano ambiental e, no segundo, a compensação o precede. ${ }^{53}$

Com vistas a sustentar a compensação ambiental como uma forma de reparação de danos futuros, a mesma autora lembra que, para superar “alguns dogmas do sistema da responsabilidade civil, está em gestação um movimento doutrinário em defesa da responsabilidade civil preventiva, que atue antes da ocorrência do dano, diante da simples colocação do meio ambiente em risco". ${ }^{4}$

$\mathrm{Na}$ mesma linha, Annelise Monteiro Steigleder defende que “o fundamento, seja para a compensação ambiental a que se refere a Lei $n^{0}$ 9.985/00, seja para as demais formas de compensação ecológica contempladas na Lei $\mathrm{n}^{\circ} 4.771 / 65$ e na Lei $\mathrm{n}^{\circ}$ 11.428/06, é a incidência do princípio da responsabilização civil por danos ambientais futuros, considerados não mitigáveis, identificados antes mesmo de sua ocorrência concreta, quando do licenciamento ambiental, embora os critérios para fixação da compensação sejam diferenciados”. 55

Para Marcelo Abelha Rodrigues “o instituto do art. 36 da Lei do SNUC tem o seu embrião na finalidade reparatória dos impactos não mitigáveis gerados pelos empreendimentos de grande porte”. E, na mesma linha de Erika Bechara, crê que a obrigação se funda na possibilidade de reparação dos danos futuros, como se vê:

Ora, é superada a discussão sobre o dever de ressarcimento de danos futuros, e, os lucros cessantes são a prova cabal desta superação. O que importa para existir o dever de ressarcir é que o dano seja certo, podendo ser atual ou futuro. Dano certo é o dano ocorrido ou o que é seguro e evidente que ocorrerá. A certeza do dano permite que danos que ainda não ocorreram, mas que têm a ocorrência prevista com razoável grau de probabilidade, também devem ser objeto de reparação. Observe-se, ainda, que a certeza do dano advém de estudo completo, baseado em dados técnicos fornecidos por equipe multidisciplinar e contrastados com análises do órgão ambiental no procedimento de EIA-RIMA. Portanto, existe base

\footnotetext{
${ }^{53}$ Idem, p. 194-195.

${ }^{54}$ Idem, p. 200.

55 STEIGLEDER, Annelise Monteiro. Responsabilidade civil ambiental: as dimensões do dano ambiental no direito brasileiro. $2^{\mathrm{a}}$ ed. Porto Alegre: Livraria do Advogado, 2011, p. 229.
} 
técnica sólida que permite afirmar que os danos ambientais ocorrerão com aquela obra ou atividade. ${ }^{56}$

Para essa corrente, há três espécies de danos ambientais: (i) o dano concreto (já ocorrido); (ii) o dano futuro, porém concreto, sendo considerado aquele que ainda não se concretizou, mas sabe-se que certamente ocorrerá em um futuro próximo (impactos avaliados no licenciamento ambiental); e, também, (iii) os danos ambientais futuros, impostos pela 'sociedade de risco' e cujos efeitos são desconhecidos (mudança climática, energia nuclear etc.). Com essa classificação, tal linha doutrinária argumenta que a compensação ambiental se enquadraria no dano futuro, porém concreto, que, certamente, ocorrerá em um futuro próximo ${ }^{57}$. Ou, nas próprias palavras de Erika Bechara, “somos da opinião de que o sistema da responsabilização civil comporta a reparação de danos futuros, ainda não causados, porém de ocorrência certa, devidamente antevista. Danos futuros não são meros riscos, que podem ou não concretizar-se. São danos certos, porém ainda não concretizados”. 58

Nessa linha argumentativa, o instituto da responsabilidade civil, baseado no princípio do poluidor-pagador, poderia objetivar medidas preventivas, precaucionais e compensatórias. Assim, a responsabilidade civil, visto como mecanismo preventivo de danos ao meio ambiente, transforma-se em um instrumento econômico capaz de corrigir as externalidades negativas. Nessa linha é o ensinamento de Délton Winter de Carvalho:

O entendimento da responsabilidade civil por danos ambientais como manifestação direta do princípio do poluidorpagador, a partir da constatação de que "quem contamina, paga”, impõe ao instituto a existência de uma função dupla (repressiva e preventiva), em semelhança ao próprio princípio. Nesse sentido, a responsabilidade civil objetiva representa de forma imediata a função repressiva "quem contaminar, deve pagar” pelos danos, atribuindo os custos da contaminação

\footnotetext{
${ }^{56}$ RODRIGUES, Marcelo Abelha. Aspectos jurídicos da compensação ambiental do art. 36, § $1 .^{\circ}$ da Lei Brasileira das Unidades de Conservação (Lei no 9.985/2000). Revista de Direito Ambiental. vol. 46. São Paulo: RT, 2007.

${ }^{57}$ Como se verá no item 3.3.1 do Capítulo 3 desta tese, para o considerado dano futuro, porém concreto, há medidas processuais para evitar a sua ocorrência.

58 BECHARA, Erika. Licenciamento e compensação ambiental - na lei do Sistema Nacional das Unidades de Conservação (SNUC). São Paulo: Atlas, 2009, p. 201-202.
} 
àquele que, em qualquer momento de sua produção, transporte, uso ou disposição final, tenha repercutido em dano ambiental. A partir dessa constatação, a responsabilidade civil passa a ter não apenas um sentido jurídico (reparação de danos), mas um sentido econômico (ajuste de atividades), em uma demonstração de seu potencial policontextual (integração intersistência entre direito e economia).

Em uma análise das ressonâncias econômicas da responsabilidade civil por danos ambientais, tem-se que esse mecanismo atua na correção das "falhas de mercado" (Market failure), uma vez que a incidência da responsabilidade civil nas condutas que ocasionem danos ambientais terá o efeito de internalização dos custos ambientais (externalidades negativas). ${ }^{59}$

Como se vê, há bastante lógica no raciocínio que sustenta ser indenizatória a natureza jurídica da compensação ambiental. Não deve haver dúvidas quanto a isso. Há, no entanto, percalços, por vezes intransponíveis, a enfrentar. Existem, também, desvantagens em relação à aplicação prática do instituto, como uma forma de reparação civil, que não se pode deixar de apontar.

\subsubsection{Críticas à corrente que concebe a natureza jurídica reparatória da compensação ambiental}

Como dito, não obstante a lógica e a coerência da doutrina que defende ser a compensação ambiental uma espécie de reparação por danos futuros, não há como esquecer os óbices impostos pelo ordenamento jurídico. De fato, observe-se que o instituto da responsabilidade civil pressupõe - de acordo com o art. 927 do Código Civil de 2002 - além do ato infracional ou ilícito, a existência concreta de danos ao meio ambiente. No caso da responsabilidade ambiental, não há necessidade de comprovação da culpa (e, portanto, da ilicitude da conduta), posto ser objetiva. Não obstante, para se determinar uma reparação, não se pode prescindir do pressuposto do efetivo dano ao meio

\footnotetext{
${ }^{59}$ CARVALHO, Délton Winter de. Dano ambiental futuro - a responsabilização civil pelo risco ambiental. Rio de Janeiro: Forense Universitária, 2008, p. 76-77.
} 
ambiente e do nexo de causalidade. Em outros termos, é impossível determinar a reparação de algo que não ainda não ocorreu.

A esse respeito, o Ministro Marco Aurélio, no multirreferido julgamento da ADI 3.378/DF, divergindo inicialmente da maioria, asseverou que a compensação ambiental confrontava a premissa “inafastável” de prévio dano ao meio ambiente. De fato, afirmou que “a compensação financeira em questão, assim como a recuperação do meio ambiente, depende de que este tenha sido degradado ( $\S 2^{\circ}$ do art. 225 da CF), “premissa inafastável” que não se configura, ainda, no momento da análise do pedido prévio de licença ambiental”, e que, de todo modo, pelo $\S 3^{\circ}$ do art. 225 da CF, somente infratores à legislação ambiental estariam sujeitos a sanções administrativas correlatas, a par da préfalada obrigação de indenizar danos; haveria conflito entre o $\S 1^{\circ}$ do art. 36 Lei do SNUC e os citados dispositivos da Carta, que pressuporiam a pré-existência de dano ambiental para que se pudesse cogitar quer de indenização, quer de sancionamento, havendo "imposição de desembolso para obter-se a licença, sem mesmo saber-se a extensão de danos causados".

A par disso, a reparação de um “dano futuro” também prescinde do pressuposto do nexo de causalidade, visto que não há um ato que implique dano efetivo ao meio ambiente. Novamente o Ministro Marco Aurélio, percebendo a incongruência da subsunção da compensação ambiental a uma espécie de indenização por danos ambientais, expôs que "salta aos olhos a inexistência do nexo de causalidade. O desembolso não corresponde, como disposto na Constituição Federal, a danos efetivamente causados, mas ao vulto do empreendimento".

Outro tanto, em que pese ser objetiva a responsabilidade civil ambiental, não há dúvidas de os danos ambientais originarem-se em uma atividade ou ato ilícitos ou, ao menos, indesejados. A respeito, pondera Sérgio Guerra:

no processo de licenciamento ambiental, por óbvio, inexiste ato ilícito capaz de ensejar a caracterização de uma indenização. Com efeito, o particular que executa pesquisa, lavra ou extração de recursos minerais, ou que constrói, reforma, amplia, instala ou faz funcionar, em qualquer parte do território nacional, estabelecimentos, obras ou serviços potencialmente poluidores com a devida licença ou autorização do órgão ambiental 
competente, e de acordo com as normas legais e regulamentares pertinentes, não é um infrator, eis que não se enquadra na tipificação dos arts. 55 e 60 da Lei de Crimes Ambientais. ${ }^{60}$

Nesse mesmo sentido, José Marcos Domingues salienta:

a obrigação de pagar tal prestação compulsória, imposta por lei, não deriva de uma ilicitude praticada pelo empreendedorcontribuinte: age ele na chamada 'zona de tolerância', que se situa a meio caminho da 'zona livre' e da 'zona proibida' de utilização da natureza. Aliás, a Lei do SNUC invoca como seus fundamentos os incisos I, II, III e VII do art. 225, parágrafo $1^{\circ}$, da Constituição Federal, e não o parágrafo $3^{\circ}$ desse dispositivo, que é aquele que funda o combate à ilicitude ambiental por meio de sanções e reparações de danos causados. ${ }^{61}$

O tema merece mais um questionamento, o qual reside na eficácia do argumento que defende ser a compensação ambiental uma espécie de reparação civil por danos ambientais futuros. Afinal, ao considerar as verbas decorrentes da obrigação como 'indenizatórias', surge a dúvida de como elas serão fixadas no decorrer do licenciamento ambiental, por um órgão administrativo, de forma, inclusive, a condicionar a emissão da licença ambiental. De fato, de acordo com as normas que regem a matéria, a compensação ambiental deve ser estabelecida - e o Termo de Compromisso celebrado - antes da emissão da Licença de Instalação ${ }^{62}$; isso implica que o empreendedor acaba concordando - ou tendo que concordar - com o valor definido pelo órgão licenciador para poder, dentro do seu cronograma e planejamento, iniciar a implantação física do projeto.

Assim, não há dúvidas, ao compreender a compensação ambiental como uma forma de ‘indenização’ por danos futuros, deixar-se-á inevitavelmente nas mãos e ao exclusivo critério do órgão licenciador a fixação do seu valor, abrindo-se espaços para inevitáveis oportunismos e abusos de poder.

\footnotetext{
${ }^{60}$ GUERRA, Sérgio. Compensação ambiental nos empreendimentos de significativo impacto. In: Direito ambiental: visto por nós advogados. Coord. Mário Werneck et.al. Belo Horizonte: Del Rey, 2005, p. 137.

${ }^{61}$ OLIVEIRA, José Marcos Domingues de. A chamada 'Compensação Financeira SNUC'. Revista Dialética de Direito Tributário, $\mathrm{n}^{\circ}$ 133, out. 2006, p. 51.

62 Conforme impõe a Resolução CONAMA n ${ }^{\circ}$ 371/2006, art. 5º §2: “A fixação do montante da compensação ambiental e a celebração do termo de compromisso correspondente deverão ocorrer no momento da emissão da Licença de Instalação”. Da mesma forma, o Decreto $\mathrm{n}^{0}$ 6.848/2009, ao alterar o Decreto $\mathrm{n}^{\circ}$ 4.340/2002, impôs que: Art. 31-A, § 3: “As informações necessárias ao calculo do VR deverão ser apresentadas peloempreendedor ao órgão licenciador antes da emissão da licença de instalação.”
} 
Além disso, a compensação ambiental será a única medida compensatória capaz de ser cobrada em empreendimentos com significativos impactos ambientais. Poder-se-á, inclusive, questionar a possibilidade de cumulação de outras medidas compensatórias fixadas em lei, como as já referidas medidas compensatórias por supressão de área de preservação permanente ou de Mata Atlântica. Na verdade, se a intenção da instituição da compensação ambiental era reparatória de eventual dano ao meio ambiente, o cálculo da exação deve ser conforme a regra do art. 944 do Código Civil de 2002, o qual impõe que a indenização seja medida pela extensão do dano.

Lembre-se, ainda, o fato de a destinação dos recursos da compensação ambiental se dar unicamente para o apoio e a manutenção de unidades de conservação, significando dizer que a 'reparação' pelos ‘danos futuros' a serem causados por um determinado empreendimento não necessariamente serão direcionados para o local que sofrerá com os prejuízos enfrentados pelo meio socioambiental. A esse respeito, Erika Bechara, embora defenda a compensação ambiental como reparação de um dano futuro, critica a norma instituidora da exação ao expor: "se a compensação ambiental englobar os impactos ambientais de todas as naturezas, um dano ao patrimônio cultural, por exemplo, acabará sendo compensado com um benefício ao patrimônio natural (já que a atenção da lei ficou toda para as unidades de conservação), em uma clara e indesejável assimetria entre dano e reparação.”63

Por conseguinte, para a corrente que defende ser a compensação ambiental uma forma de responsabilidade civil por danos futuros, haveria uma contradição na norma primária (Lei nº 9.985/2000), porquanto, ao fim e ao cabo, a indenização em si não é utilizada para a recomposição efetiva do dano a ser causado.

Erika Bechara, uma vez mais, ao enfrentar esse problema, propõe:

que a lei institua, clara e explicitamente, uma distinção, seja para esclarecer que eles não devem ser considerados no cálculo da compensação ambiental, abrindo assim a possibilidade de serem objeto de medidas compensatórias específicas,

\footnotetext{
63 BECHARA, Erika. Licenciamento e compensação ambiental - na lei do Sistema Nacional das Unidades de Conservação (SNUC). São Paulo: Atlas, 2009, p. 266.
} 
determinadas no mesmo procedimento de licenciamento ambiental, seja para mantê-los incluídos neste cálculo mas prevendo a destinação de parte dos recursos da compensação para ações específicas em prol do patrimônio cultural ou artificial (respeitando, sempre, os demais critérios de aplicação, como a localização na área de influência do projeto e a equivalência entre o bem beneficiado e o bem prejudicado). ${ }^{64}$

Essa mesma autora ainda recomenda, mediante uma adequação da norma, a divisão dos recursos da compensação ambiental, fazendo com que sejam direcionados proporcionalmente ao patrimônio impactado. Ou seja, se houve impacto ao patrimônio natural, parte deve ser dirigida a outro patrimônio natural; se houve impacto ao patrimônio cultural e artificial, parte dos recursos deve ser destinado a outro local em que haja patrimônio cultural e artificial.

Em uma palavra, para a compensação ambiental se enquadrar em uma espécie de dano futuro, seria necessária uma readequação total da norma instituidora da compensação ambiental, tratando-a, a bem ver, como a única medida compensatória do ordenamento jurídico ${ }^{65}$. Em verdade, a intenção é boa; difícil é concretizá-la.

Finalmente, não vemos razão ou vantagens em considerar a compensação ambiental como uma espécie de reparação civil por danos futuros. Afinal, os meios reparatórios e compensatórios têm pressupostos e momento de concretização absolutamente distintos, bastando verificar, utilizando-se da compensação ambiental, os seus requisitos ensejadores: Estudo de Impacto Ambiental e respectivo Relatório de Impacto Ambiental - EIA/RIMA, licenciamento ambiental, e a verificação de significativos impactos negativos e não mitigáveis. Por sua vez, a reparação civil do dano ambiental exige a presença de um dano concreto, cuja ocorrência por certo não foi desejada.

\footnotetext{
${ }^{64}$ Idem, p. 266.

65 Isso significa, ainda, a necessidade de revogar outras normas que impõem medidas compensatórias a impactos específicos. Afinal, existem, consoante já aludido aqui tantas vezes, outras medidas compensatórias positivadas na legislação brasileira, como é o caso, por exemplo, da já citada Lei $n^{\circ}$ 10.257/2001 (Estatuto da Cidade), que visa a compensar os significativos impactos causados ao meio ambiente artificial ao impor a obrigação de aportar recursos técnicos e financeiros para a elaboração de planos diretores de municípios inseridos na área de influência de empreendimentos ou atividades com significativo impacto de âmbito regional ou nacional (art. 41, inciso $\mathrm{V}, \S 1^{\circ}$ ).
} 
Aliás, mais adiante ${ }^{66}$ será analisada a diferença entre os conceitos de dano ambiental e de impacto negativo no meio ambiente. Por ora, é suficiente verificar que o dano ambiental determina a reparação civil, enquanto o impacto negativo no meio ambiente exige a implementação de medidas compensatórias. E, embora ambos causem modificações no meio ambiente, o conceito de dano ambiental distingue-se sobremaneira da definição de impacto ambiental, sendo suficiente verificar que qualquer dano ao meio ambiente é também um impacto; no entanto, nem todo impacto pode ser considerado danoso. Basta ver que qualquer atividade humana implica impactos no meio ambiente, sem que isso configure, necessariamente, um dano ambiental - no sentido jurídico, ou seja, a ensejar a incidência das responsabilidades civil, administrativa e criminal. Em outros termos, a atividade humana significativamente impactante - entendida como o empreendimento devidamente licenciado pelo órgão ambiental - não pode ser considerada como a destruição da propriedade alheia para a qual se exige a devida reparação/indenização.

Assim, incluídos em um único conceito lato, poder-se-iam confundir seus pressupostos e respectivos meios de implementação dos instrumentos, gerando, sobretudo, a ineficácia das medidas compensatórias como forma de equacionar as externalidades negativas. Em síntese, entendemos que a eficácia e a efetividade desses institutos reparatórios e das medidas compensatórias, em que pesem estar ambos fundados no mesmo princípio do poluidor-pagador, dependem da separação da sua análise, compreensão, implementação e prática.

À derradeira, vale mencionar que o STF, no julgamento da multicitada ADI 3.378/DF, além de modificar substancialmente a forma de cálculo da compensação ambiental, concluiu não ser reparatória a natureza jurídica da obrigação. ${ }^{67}$

Sobre o tema, o Ministro Carlos Britto expôs: “não posso, por mais que me esforce, por mais que seja tentado a votar no sentido da preservação do meio ambiente, imaginar indenização sem dano. Não posso inverter a ordem natural das coisas, que tem força maior, e placitar a criação de verba indenizatória sem

\footnotetext{
${ }^{66}$ Ver item 3.4 do Capítulo 3 desta tese.

${ }^{67}$ Sobre o assunto, vide OLIVEIRA, José Marcos Domingues de. O Supremo Tribunal e a compensação SNUC. A ADI 3.378-DF. Revista Direito GV. São Paulo, vol. 5, nº 1, jan/jun 2009.
} 
a verificação do dano, impondo o ônus dessa verba àquele que é simplesmente requerente da licença para instalar o empreendimento.” Em outra passagem, o Ministro Relator assevera: "não é indenização, é um compartilhamento de despesas”.

No mesmo sentido, o Ministro Menezes Direito, no voto que acabou sendo acatado pela maioria, assim se pronunciou acerca da natureza jurídica da compensação ambiental: “Não entendo que essa verba seja indenizatória. Ao contrário, é uma verba de natureza compensatória porque visa preservar o meio ambiente e eventual empreendimento que possa causar o significativo impacto ambiental”.

Nessa mesma linha, o Ministro Celso de Mello, embora inicialmente tenha exposto que “o que se discute é a responsabilidade daquele que deseja, responsabilidade prévia sob o ângulo da indenização, implantar um empreendimento que possa degradar o meio ambiente”, mais adiante pontuou que "a definição de um montante de recursos, como disse o eminente Ministro Carlos Alberto Menezes Direito, tem uma função nitidamente compensatória”. Em seguida, discorreu: “o custo a ser imputado ao poluidor não está exclusivamente vinculado à imediata reparação do dano, mas, na verdade, a uma atuação preventiva.” 68

Como se vê, ao se defender a compensação ambiental como uma forma de reparação por danos futuros (ex ante) encontram-se diversos percalços, seja porque no licenciamento ambiental não se verificam os requisitos da concretização do dano e do nexo de causalidade para incidência da responsabilidade civil; seja porque será considerada como a única medida compensatória que pode ser exigida no decorrer do licenciamento ambiental de empreendimentos que causem significativos impactos ao meio ambiente, sob pena de bis in idem; seja porquanto a indenização será calculada e cobrada unicamente pelo órgão ambiental licenciador, em momento anterior à emissão

\footnotetext{
${ }^{68}$ Diferentemente, o Superior Tribunal de Justiça considerou o instituto da compensação ambiental com características de reparação civil, não coincidente, todavia, com outros danos ambientais causados pelo empreendimento, os quais devem ser indenizados pela responsabilidade civil clássica. No acórdão, o Relator, Ministro Castro Meira, pontua que, embora a compensação ambiental tenha conteúdo reparatório, não há equiparação entre ela e a responsabilidade civil ambiental. Vide STJ - Resp 896863 - Ministro CASTRO MEIRA - 2 ${ }^{\mathrm{a}}$ Turma - DJe 02.06.2011.
} 
da licença de instalação, podendo gerar oportunismos e abuso de poder; seja em razão de a compensação ambiental não servir para reequilibrar o local impactado, na medida em que sua norma prevê destinação específica para unidades de conservação não necessariamente localizadas na mesma área impactada; e seja em razão de os pressupostos da compensação ambiental serem absolutamente distintos daqueles exigidos para emergir o dever de responsabilização civil.

Na verdade, considerar a compensação ambiental como uma forma de reparação por danos futuros, é tornar a obrigação inoperante, de difícil aplicação, tal como ocorreu com o julgado do STF ao vincular a exação ao difícil conceito de significativos impactos ambientais.

\subsubsection{A natureza jurídica tributária da compensação ambiental}

A corrente que defende ser a compensação ambiental um tributo ${ }^{69}$, parte da premissa de que o princípio do poluidor-pagador não implica apenas ações reparatórias. De fato, conforme será minuciado no item 4.6 do Capítulo 4 desta tese, o referido princípio, ao objetivar a internalização das externalidades negativas, pode ser aplicado como fundamento para, por exemplo, instituir uma política pública extrafiscal ou, ainda, exigir medidas mitigadoras e compensatórias no decorrer do processo de licenciamento ambiental.

\footnotetext{
${ }^{69}$ Nesse sentido, vide DOMINGUES, José Marcos. A chamada 'compensação financeira SNUC'. Revista Dialética de Direito Tributário, $\mathrm{n}^{\circ}$ 133, out. 2006; GUERRA, Sérgio. Compensação ambiental nos empreendimentos de significativo impacto. In: Direito ambiental: visto por nós advogados. Coord. Mário Werneck et al. Belo Horizonte: Del Rey, 2005; MILARÉ, Édis. Direito do ambiente. $7^{a}$ ed. São Paulo: RT, 2011. A propósito, vale mencionar decisão do Tribunal Regional Federal da $1^{\mathrm{a}}$ Região de Brasília/DF que, através de liminar concedida pelo Desembargador Federal Catão Alves (nos autos de Agravo de Instrumento $n^{\circ}$ 2005.01.00.060479-0/DF), limitou em 0,5\% a aplicação do percentual referente à compensação ambiental, instituída pela Lei $n^{\circ}$ 9.985/2000. O Desembargador Catão Alves abriu importante precedente ao conceder a liminar, considerando, em síntese, que, a natureza jurídica da compensação ambiental é tributária, de modo que a Lei ${ }^{\circ} 9.985 / 2000$, ao estabelecer que o seu percentual será definido pelo órgão ambiental licenciador, sem limitá-lo ou delinear como será feita a sua gradação, fere o art. 97, inciso IV do Código Tributário Nacional, como também o Princípio da Legalidade, que impõem que apenas lei em sentido estrito pode fixar as alíquotas de tributos, "não sendo possível sua imposição ao alvedrio da autoridade administrativa". A referida decisão foi suspensa por força de pedido de Suspensão de Segurança $n^{0} 2.875$, proposto pelo IBAMA perante o e. Supremo Tribunal Federal.
} 
Nessa linha ${ }^{70}$, José Marcos Domingues frisa: “juridicamente, o princípio do poluidor-pagador pode realizar-se tanto através do licenciamento, da imposição de multas, da determinação de recuperação ambiental ou de medidas compensatórias, como pela cobrança de tributos, enquanto fontes de recursos para custeio da proteção ambiental”. ${ }^{71}$

Em síntese, o princípio do poluidor-pagador é a base irrefutável para a responsabilização civil ambiental. Porém, o mesmo princípio ainda pode embasar outros meios (políticas públicas, políticas extrafiscais, instituição de tributos ambientais etc.), os quais não têm natureza jurídica reparatória, mas são capazes de fazer com que os custos da utilização dos recursos ambientais sejam internalizados na cadeia produtiva. Ou seja, o princípio do poluidor-pagador é fundamento das medidas reparatórias de danos ambientais; mas é também o pilar de medidas preventivas, repressivas e compensatórias de danos e impactos no meio ambiente.

Por outro lado, essa linha doutrinária demonstra a compensação ambiental subsumindo-se perfeitamente ao conceito de tributo do art. $3^{0}$ do Código Tributário Nacional - CTN, na medida em que é obrigação (i) compulsória; (ii) pecuniária, com valor expresso em moeda; (iii) não constitui sanção de ato ilícito, mas, ao contrário, o fato gerador é atividade empresarial lícita; (iv) foi instituída em lei; e (v) far-se-á por atividade administrativa vinculada. A respeito, José Marcos Domingues sustenta:

Interessante notar a identidade de circunstâncias em que a Compensação SNUC se vê preconizada no Direito Positivo pátrio, substituindo por pecúnia o dever material (prestação in natura) de criação e manutenção de uma unidade de conservação, a imprimir-lhe no nascedouro, filosófica e etiologicamente, a natureza jurídica essencialmente tributária.

Mesmo que se admita por amor à argumentação que a exigência de apoio não seria necessariamente de aporte

\footnotetext{
${ }^{70}$ Junto com Édis Milaré, filiamo-nos inicialmente a esse corrente que defende a compensação ambiental com natureza jurídica tributária. Nesse entendimento, vide MILARÉ, Édis; ARTIGAS, Priscila Santos. Compensação Ambiental: questões controvertidas. Revista de Direito Ambiental. $n^{\circ}$ 43. Ano 11. jul-set. São Paulo: RT, 2006. No entanto, aprofundando-me no tema, percebi que o tratamento da natureza jurídica não pode restringir-se ao instituto da compensação ambiental, mas, sim, a todas as medidas compensatórias, que são aplicadas no momento em que se verifica a ocorrência de impacto negativo e não mitigável.

${ }^{71}$ OLIVEIRA, José Marcos Domingues. A chamada 'compensação financeira SNUC'. Revista Dialética de Direito Tributário, $\mathrm{n}^{\circ}$ 133, out. 2006, p. 45.
} 
financeiro direto ao Tesouro, mas de bens entregues ou de serviços custeados pelo empreendedor, ainda assim a Compensação SNUC (valorada em no mínimo 0,5\% do custo do empreendimento) recai na definição de tributo do CTN (...), onde precisamente a lei complementar tributária contempla como tributo valor exigido do administrado em troca de bens ou serviços que, com o seu dinheiro, o Estado adquiriria ou contrataria. Tomar compulsoriamente dinheiro do particular, ou tomar-lhe compulsoriamente bens ou serviços de valor equivalente sem indenização, estranha doação obrigatória, configura exatamente o mesmo: transferência (ou 'desembolso', como afinal confessa o parágrafo $1^{\circ}$ do art. $5^{\circ}$ da Resolução CONAMA n $\left.{ }^{\circ} 371 / 2006\right)$ compulsória de patrimônio privado ao setor público, isto é, tributo. ${ }^{72}$

Além disso, esse mesmo autor argui que a compensação ambiental da Lei do SNUC, ao incorporar como obrigação principal uma obrigação de fazer (apoiar a implantação e a manutenção de uma unidade de conservação), é uma prestação ou tributo in natura (ou facere). Domingues recorda que, no âmbito do Direito Tributário, praticam-se historicamente exigências de comportamentos materiais e não apenas as cobranças de prestações em prol do custeio da despesa pública. ${ }^{73} \mathrm{O}$ tributarista cita Aliomar Baleeiro, ao anotar que, pelo menos excepcionalmente, ainda hoje se verifica a requisição pura e simples das 'coisas e serviços súditos’. Lembra, de igual modo, Ulhôa Canto, ao também entender que, 'embora excepcional a arrecadação em espécie, não é elemento definicional da obrigação tributária que assim não possa ser'. ${ }^{74}$

\footnotetext{
${ }^{72}$ OLIVEIRA, José Marcos Domingues. Ob. cit., p. 49.

${ }^{73}$ OLIVEIRA, José Marcos Domingues. A chamada 'compensação financeira SNUC'. Revista Dialética de Direito Tributário, $\mathrm{n}^{\circ}$ 133, out. 2006, p.47. Acerca dos tributos in natura (facere) esse autor expõe, exemplificativamente, que: "Alberto Xavier entende que o requisito da patrimonialidade da prestação tributária não exige que esta se traduza em pecúnia, podendo apresentar-se uma prestação de facere, como o imposto municipal português de prestação de trabalho 'em um dia de cada ano', suscetível de remição obrigatória por deliberação legislativa, ou seja, substituição por pecúnia, salvo em relação aos desempregados; mais recentemente, Soares Martínez - informando do vetusto "tributo de sangue", isto é, a prestação do serviço militar como condição de isenções de imposto", e mencionando autores que depois integraram o serviço militar na categoria de imposto - alude à possibilidade de configurar-se este, hoje, como uma 'prestação de caráter tributário, embora consistindo num serviço pessoal, mas de conteúdo econômico. Assim, também Giuliani Fonrouge expõe que, embora comumente em dinheiro, 'não é forçoso que assim ocorra', já que 'o caráter pecuniário não constitui a essência da obrigação tributária', e cita, entre outros, impostos argentinos 'em espécie', com fins de regulação econômica (grãos, erva mate, vinhos). E Antonio Berliri leciona, quanto ao recrutamento militar, 'que o estado se assegura de um meio econômico - a mão-deobra - necessário à própria defesa', sendo evidente 'a analogia entre aquele e o imposto (...). O Direito Tributário deveria deste modo enquadrar-se em uma disciplina mais ampla que abarcasse todas as prestações coativas de fazer' e também 'todas as prestações de dar'.”

${ }^{74}$ OLIVEIRA, José Marcos Domingues. Ob. cit., p. 48.
} 
Mas foi Alfredo Becker, de igual modo citado por José Marcos Domingues, quem fez a defesa teórica da pertinência da inserção das prestações in natura no âmbito da obrigação tributária ${ }^{75}$. Segundo Becker, já foi muito utilizada e é uma tipificação que hoje se justifica diante da maior crise socioeconômica possível, não sendo “estranhável, nem teratológico, que modernamente haja uma expansão, em variedade e importância, dos tributos in natura e in labore. Esta expansão não será alternativa aos tributos pecuniários, porém integrativa”76. E continua esse autor: “Os tributos pecuniários continuarão sempre a ter importância muito maior que os tributos in natura ou in labore; entretanto, o que se observa é que estes últimos sairão do estado embrionário e perderão a aparência de confisco ou de entidade jurídica rara e enigmática ou de instrumental jurídico tributário que deveria ser arquivado em museus." 77

Esse mesmo doutrinador, ao sustentar a pertinência da inserção de prestações in natura no âmbito da obrigação tributária, assim discorre: "as regras jurídicas fundamentais que os devem reger e disciplinar, conferindo-lhes segurança e certeza às suas órbitas jurídicas, estão no Direito Tributário”, porque, entre outras razões, e no ponto de interesse:

O dever jurídico de prestação em dinheiro é dever de dar determinada quantidade de unidade ideal de valor conduzida (ou incorporada) pelo dinheiro. Por sua vez, este dever jurídico de prestação em dinheiro pode não ser originário, mas derivado da transformação de um dever, originariamente in natura ou in labore (...) o conteúdo jurídico da prestação será sempre o mesmo: um prestar, isto é, um ato positivo (facere) ou um ato negativo (non facere) do sujeito passivo da relação jurídica. (...) O objeto da prestação é que poderá variar segundo o critério da Política Fiscal; esta poderá escolher (mediante criação de regra jurídica.) em lugar do dinheiro, um outro bem (ex.: imóvel) ou um serviço pessoal. Aliás, (...), a prestação em dinheiro não deixa de ser também uma prestação in natura: unidade ideal de valor. ${ }^{78}$

\footnotetext{
${ }^{75}$ Idem, p. 48.

${ }^{76}$ BECKER, Alfredo Augusto. Teoria geral do Direito Tributário. 4ª ed. São Paulo: Noeses, 2007, p. 655.

${ }^{77}$ Idem, p. 655.

${ }^{78}$ BECKER, Alfredo Augusto. Ob. cit., p. 670-671.
} 
Com base nessa doutrina, seria possível deduzir que a compensação ambiental (e as medidas compensatórias em geral) é um tributo in natura, o qual pode ser exigido in pecunia, mas não apenas nela.

Em termos ambientais, José Marcos Domingues de Oliveira recorda que "Wilfried Kluth relata, a propósito, que certa lei da Renânia do Norte-Westfalia prevê que o causador de degradação ambiental realiza em outro lugar medidas compensatórias de proteção da natureza ou tratamento paisagístico, como a plantação de sebes e árvores. Se isso não é possível ou resulta insuficiente, prevê o pagamento de prestações pecuniárias que se designam como tributos compensatórios por danos à natureza. Segundo o autor, o Tribunal Federal do Contencioso Administrativo alemão 'qualifica o tributo compensatório de 'tributo especial com características próprias", como no caso da Lei de Baden Wurtemberg." Para esse autor, a semelhança desse instrumento germânico com a compensação SNUC salta aos olhos e corrobora a afirmação de que se trata de vero tributo ${ }^{79}$.

Por esse prisma, poder-se-ia sustentar, inclusive, ser o Direito Ambiental como um determinador de uma regressão do direito tributário ao exigir novas obrigações na forma de tributos in natura, fazendo face aos direitos difusos e coletivos, como os ambientais. Isso significa que tais obrigações tributárias, seriam primeiramente exigidas como obrigações de fazer para, após, serem traduzidas em obrigações de pagar.

Embora também bastante lógica e coerente, as dificuldades dessa corrente residem no rígido sistema tributário nacional. De fato, embora existam inúmeros exemplos internacionais de tributos ambientais, é dificultoso encontrar uma espécie tributária, no ordenamento jurídico brasileiro, em que seria possível encaixar a compensação ambiental. Vejamos.

\footnotetext{
79 OLIVEIRA, José Marcos Domingues de. A chamada 'compensação financeira SNUC'. Revista Dialética de Direito Tributário, no 133 , out. 2006, p. 48-49.
} 
2.4.4 Críticas à corrente que defende a compensação ambiental como uma espécie de tributo

Como se viu, a linha de pensamento que defende ser tributária a natureza jurídica da compensação ambiental é bastante lógica e coerente; porém, as dificuldades encontradas não têm calão menor do que as avaliadas em relação à natureza jurídica reparatória da exação.

A bem ver, semelhante ao que ocorre com a defesa da natureza jurídica reparatória, as dificuldades verificadas para subsumir a compensação ambiental a uma espécie tributária parecem decorrer ora de uma falha da lei que a instituiu ou um déficit de qualidade legislativa, ora da transgressão de diversos princípios e normas que regem a ordem normativa. Senão, vejamos.

Argumenta-se, por exemplo, a compensação ambiental como um preço público $^{80}$ ou como uma taxa. No entanto, a nenhuma dessas espécies poderia subsumir-se a referida exação. Basta ver, em suma, que o preço público pressupõe a cobrança pelo uso de um bem público, e não a tentativa de compensar um impacto ambiental não mitigável. Por outro lado, a taxa, nos termos do disposto no art. 145, inciso II, da Constituição Federal, e do art. 77 do Código Tributário Nacional, é espécie de tributo cujo fato gerador é o exercício do poder de polícia ou a utilização efetiva ou potencial de serviços públicos específicos ou divisíveis, prestados ao contribuinte ou postos sob a sua disposição; essa situação não se apresenta quando da concreção de significativos impactos no meio ambiente avaliados no processo de licenciamento ambiental. ${ }^{81}$

Sobre o assunto, Erika Bechara assim discorre: “a compensação ambiental não é taxa de serviço, afinal, não se vislumbra, nem no licenciamento ambiental (em que é exigida a compensação ambiental) tampouco no ato da exigência da

\footnotetext{
${ }^{80}$ Para Sérgio Guerra, a compensação ambiental poderia ser considerada um preço público, "na medida em que o empreendedor estaria remunerando a União Federal pela exploração ou pelo uso de um bem a ela pertencente.” GUERRA, Sérgio. Compensação ambiental nos empreendimentos de significativo impacto. In: WERNECK, Mário et al. (coord.). Direito ambiental: visto por nós advogados. Belo Horizonte: Del Rey, 2005, p. 137.

${ }^{81}$ GUERRA, Sérgio. Compensação ambiental nos empreendimentos de significativo impacto. In: WERNECK, Mário et al. (coord.). Direito ambiental: visto por nós advogados. Belo Horizonte: Del Rey, 2005, p. 138.
} 
compensação ambiental e muito menos ainda na implantação de unidades de conservação, um serviço público (geral ou singular, divisível ou indivisível) prestado pelo Estado.” Em relação ao preço público, afirma a autora: “a compensação ambiental não se reveste da natureza jurídica de preço público, tampouco encontra abrigo no princípio do usuário-pagador, porque sua finalidade não é pagar ao Estado uma contraprestação pelo uso ou exploração de um bem público ou difuso; é compensar os prejuízos a serem causados ao meio ambiente, por determinados empreendimentos, que o estado-da-arte não consegue afastar.”82

Ainda, sustenta-se ser a Contribuição de Intervenção no Domínio Econômico - CIDE a melhor forma tributária a se subsumir a compensação ambiental. Afinal, o art. 149 da Constituição autoriza a União Federal a editar leis criando programas de estímulo ao desenvolvimento de setores da economia nos quais a intervenção estatal seja necessária; e nesses programas se enquadra a defesa ao meio ambiente, vislumbrada como princípio da ordem econômica constitucional (art. 170, inciso VI). A esse respeito, Sérgio Guerra expõe:

a União Federal está autorizada a editar leis que criem programas de estímulo ao desenvolvimento de setores da economia nos quais a intervenção estatal seja necessária, como poderia ser o caso da preservação ambiental, instituída como sub-princípio de temperamento da ordem econômica constitucional (art. 170, VI), nos casos de licenciamentos de empreendimentos de significativo impacto ambiental. Cumpre asseverar que o antes mencionado art. 149 da Constituição Federal revela os três elementos básicos necessários à instituição da CIDE, quais sejam: (a) a utilização desse instrumento como meio de intervenção e regulação da livre iniciativa; (b) a limitação do grupo atingido pela exação; e (c) os princípios constitucionais a que está submetida. Como visto anteriormente, o art. 36 da Lei $\mathrm{n}^{\circ}$ 9.985/2000 institui uma compensação ambiental a ser realizada nos casos de licenciamento ambiental de empreendimentos de significativo impacto ambiental, em montante não inferior a meio por cento dos custos totais previstos para a implantação do empreendimento a depender do grau de impacto ambiental por este causado. Como se vê, a denominada compensação ambiental não está vinculada ao suposto dano ambiental a ser reparado, e, sim, ao montante despendido pelo empreendedor na

\footnotetext{
82 BECHARA, Erika. Licenciamento e compensação ambiental - na lei do Sistema Nacional das Unidades de Conservação (SNUC). São Paulo: Atlas, 2009, p. 189, 194.
} 
instalação do negócio. Nessa ordem de considerações, é justo destacar que no plano constitucional, a instituição de uma contribuição de intervenção no domínio econômico propriamente dita deve ter como base um setor econômico que esteja, de algum modo, em desconformidade com os princípios da ordem econômica prevista no art. 170 da Constituição Federal. (...) A bem da verdade, a denominada compensação ambiental instituída pelo art. 36 da Lei ${ }^{\circ}$ 9.985/2000, tem por objetivo principal estimular comportamentos compatíveis com a preservação do meio ambiente, o que deveria ser efetivado através da cobrança de espécie de tributo que se ajuste à atividade econômica em questão. ${ }^{83}$

De fato, se uma categoria de empreendimentos, cujo conjunto se integra por causarem significativos impactos no meio ambiente, formando por isso um setor econômico específico capaz de afrontar o princípio da ordem econômica acima apontado, legitima-se a intervenção do Estado a exigir a contribuição estampada no referido dispositivo constitucional.

Essa situação, aliás, enquadrar-se-ia perfeitamente no princípio do poluidor-pagador (que será mais bem analisado no item 5.6.1.4 do Capítulo 5 deste estudo), ao definir determinado setor econômico arcando com a CIDE e, assim, internalizando em sua cadeia produtiva os custos dos impactos causados ao meio ambiente.

No entanto, mesmo considerando a compensação ambiental em análise como uma espécie da CIDE, a sua instituição, pela Lei n ${ }^{\circ}$ 9.985/2000, certamente prescindiu de pressupostos constitucionais, como, por exemplo, a reserva a lei complementar ${ }^{84}$, conforme prescreve o art. 146, III, ‘a', da Constituição Federal ${ }^{85}$.

83 GUERRA, Sérgio. Compensação ambiental nos empreendimentos de significativo impacto.In: WERNECK, Mário et al. (coord.). Direito ambiental: visto por nós advogados. Belo Horizonte: Del Rey, 2005, p. 137. Também nessa linha, ver ARTIGAS, Priscila Santos; MILARÉ, Édis. Compensação Ambiental: questões controvertidas. Revista de Direito Ambiental. no 43. Ano 11. jul-set. São Paulo: RT, 2006.

${ }^{84}$ É oportuno destacar que há os que defendem ser prescindível a 'lei complementar' para a instituição de CIDEs. A esse respeito, vide TÔRRES, Heleno Taveira. Da relação entre competências constitucionais tributária e ambiental - os limites dos chamados 'tributos ambientais'. In: TÔRRES, Heleno Taveira (org.). Direito Tributário Ambiental. São Paulo: Malheiros, 2005, p. 139.

${ }^{85}$ A bem ver, quer como imposto residual, quer como contribuição econômica interventiva, a compensação ambiental deveria ter sido prescrita por meio de uma "lei complementar", como determinado no art. 154, I, da Lei Maior, ou precedida, como dito acima, de lei complementar de normas gerais específicas (art. 146, III). OLIVEIRA, José Marcos Domingues de. A chamada 'compensação financeira SNUC'. Revista Dialética de Direito Tributário, no 133, out. 2006, p. 63. 
Com efeito, ao ser considerada uma tentativa oblíqua para a instituição de uma CIDE (ou contribuição de intervenção ambiental), sua criação deveria estar prevista na Carta da República e, ainda, respeitar a todos os princípios constitucionais tributários, o que não ocorre na hipótese. ${ }^{86}$

Acerca do tema do enquadramento da compensação ambiental em uma espécie de impostos afetados com uma finalidade (como a CIDE), Erika Bechara assevera que, além de não visar a um incentivo à ordem econômica, “somos obrigados a concluir que a compensação ambiental, embora afetada a uma finalidade específica - a receita derivada da compensação será inteiramente aplicada nas unidades de conservação -, não deve ser considerada um imposto especial ou finalístico porque não foi instituída com vistas ao financiamento da saúde, educação e seguridade social ou à intervenção no domínio econômico, muito menos ao atendimento de categoria profissional ou econômica”. ${ }^{87}$

Em relação a outras espécies tributárias, novamente lançamos mão dos ensinamentos de Erika Bechara, ao chamar a atenção para o fato de a compensação não se enquadrar nas figuras de imposto, empréstimo compulsório, e de contribuições sociais. Em síntese, sobre o imposto (em geral), a autora menciona: “diferentemente dos impostos gerais, a receita da compensação ambiental tem aplicação vinculada e, além disso, não é arrecadada pelo Poder Público - este apenas determina e conduz sua aplicação - e nem sempre consiste em pagamento em dinheiro.” Em relação ao empréstimo compulsório, ela expõe: “a diferenciar os empréstimos compulsórios da compensação ambiental, temos que os recursos destinados pelo empreendedor às unidades de conservação, a título de compensação ambiental, não lhe são restituídos; além disso, a compensação ambiental não foi criada para auxiliar a União a lidar com situação de calamidade pública ou guerra, tampouco por motivo de urgência e de relevante interesse nacional ambiental." Quanto às contribuições sociais, Bechara afirma: “a compensação ambiental não tem natureza jurídica de contribuição social geral, haja vista que, de acordo com a melhor doutrina, não

${ }^{86}$ GUERRA, Sérgio. Compensação ambiental nos empreendimentos de significativo impacto. In: WERNECK, Mário et al. (coord.). Direito ambiental: visto por nós advogados. Belo Horizonte: Del Rey, 2005, p. 142.

${ }^{87}$ BECHARA, Erika. Licenciamento e compensação ambiental - na lei do Sistema Nacional das Unidades de Conservação (SNUC). São Paulo: Atlas, 2009, p. 177. 
se podem criar outras contribuições gerais que não as previstas na própria Constituição Federal.”88

Poder-se-ia considerar a compensação ambiental como uma espécie de Contribuição Negativa ${ }^{89}$ (reverso da Contribuição de Melhoria), na medida em que a Constituição Federal de 1988 abriu a possibilidade, vinculada a obras públicas, de, por lei complementar ou por lei ordinária, estabelecer-se critérios desvinculados da clássica dicotomia: custo da obra e valorização do imóvel. ${ }^{90}$ No entanto, isso exigiria uma emenda constitucional, permitindo a exação não apenas em obras públicas, mas em todos os empreendimentos capazes de causar externalidades negativas. ${ }^{91}$

Não há dúvidas de que, na forma como foi instituída a compensação ambiental pela Lei do SNUC, a obrigação não consegue encaixar-se em qualquer espécie tributária e tampouco respeitar o rigor das regras de instituição de tributos.

Ademais, sob os aspectos materiais, o viés da natureza jurídica tributária da compensação ambiental exigiria ter a norma fixado critérios objetivos para a sua incidência; o que, como já visto tantas vezes, deixou de fazer. De efeito, embora nada impeça a criação de impostos progressivos, as faixas de incidência devem vir discriminadas na lei, sendo inconcebível deixar umas e outras ao talante do agente lançador, tendo, para o caso da compensação ambiental, como único parâmetro a apreciação subjetiva da importância do impacto ambiental causado pelo empreendimento. Ora, a falta de fixação, na lei, de critérios e parâmetros objetivos para a gradação de tributos infringe o art. 150, I, da Constituição Federal e o art. 97 do Código Tributário Nacional ${ }^{92}$.

\footnotetext{
${ }^{88}$ BECHARA, Erika. Ob. cit., p. 174, 175, 185, 188.

${ }^{89}$ OLIVEIRA, José Marcos Domingues de. Direito tributário e meio ambiente. $3^{\mathrm{a}}$ ed. rev. e ampl. Rio de Janeiro: Forense, 2007, p. 96.

${ }^{90}$ NUSDEO, Fábio. A contribuição de melhoria revisitada: uma revisão e uma proposta. In: SCHOUERI, Luís Eduardo (org.). Direito tributário: homenagem a Alcides Jorge Costa. São Paulo: Quartier Latin, 2003.

${ }^{91}$ NUSDEO, Fábio. Curso de economia - Introdução ao Direito Econômico. 6 a ed. rev. e atual. São Paulo: RT, 2010, p. 379-380.

92 Sob um viés tributário, defendendo a compensação ambiental como uma espécie de tributo, José Marcos Domingues salienta que o conceito de significativo impacto ambiental não seria uma tipicidade aberta, mas uma verdadeira tipicidade escancarada, ou uma atipicidade, arbitrária, aleatória, sem limites nem critérios que permitam a sua compreensão.” OLIVEIRA, José Marcos Domingues. A chamada 'compensação financeira SNUC’. Revista Dialética de Direito Tributário, nº 133, out. 2006, p. 52.
} 
Deveras, a Lei $n^{\circ} 9.985 / 2000$ sequer listou os graus de impactos possíveis de ocorrer e tampouco correlacionou a eles diferentes alíquotas ou prestações relativas às diversas intensidades de comprometimento do meio ambiente em razão daqueles impactos variados. ${ }^{93}$

Observe-se, ainda, o princípio da segurança jurídica da tributação, objetivando impedir o confisco da propriedade produtiva, o que certamente ocorre quando se deixa ao livre arbítrio do Administrador Público a fixação das alíquotas que, aliás, não têm sequer um limite máximo.

Ao se defender a natureza jurídica tributária da compensação ambiental, pretende-se, em verdade, adequar a norma para que a obrigação seja considerada um tributo ambiental. No entanto, esse tributo ambiental acabaria por desvirtuar a intenção primeira da concepção da compensação ambiental, qual seja, propiciar efetividade ao Sistema Nacional de Unidades de Conservação SNUC, ao permitir a arrecadação de verbas pecuniárias aportadas por empreendimentos capazes de causar significativos impactos ambientais. Assim, além de sua norma instituidora não ter respeitado o rígido sistema tributário, salvo na espécie de CIDE (que, no caso, não poderia ser temporária) ou como uma Contribuição Negativa (que exigiria uma emenda constitucional), a compensação ambiental, de fato, não se enquadra em uma espécie tributária.

2.4.5 A compensação ambiental como compartilhamento de despesas

O Supremo Tribunal Federal, ao julgar a ADI 3.378/DF, afastou a natureza jurídica reparatória da compensação ambiental. Além disso, ao considerar o especial trato conferido pela Constituição Federal ao meio ambiente, sustentou ser esse instituto uma forma de compartilhamento de despesas com as medidas oficiais de específica prevenção em face de empreendimentos com significativos impactos ambientais.

O relator, Ministro Carlos Ayres Britto, decidiu, em suma, ter a Lei $n^{\circ}$ 9.985/2000 criado uma forma de compartilhamento das despesas em razão de a

\footnotetext{
${ }^{93}$ OLIVEIRA, José Marcos Domingues de. A chamada 'compensação financeira SNUC'. Revista Dialética de Direito Tributário, no 133, out. 2006, p. 54.
} 
Carta Federal ter imposto, em seu art. 225, “ao Poder Público e à coletividade o dever de defender e preservar o meio ambiente para as presentes e futuras gerações”. Segundo ele, esse diploma legal criou tal obrigação, densificada no “princípio usuário-pagador, este a significar um mecanismo de assunção da responsabilidade social (partilhada, insista-se) pelos custos ambientais derivados da atividade econômica". ${ }^{94}$

A bem ver, a decisão do STF segue a linha com a qual se defende que, ao tratar do meio ambiente, a tarefa de atuar, preventivamente, deve ser vista como uma responsabilidade compartilhada, exigindo uma atuação de todos os setores da sociedade, cabendo ao Estado criar instrumentos normativos e política ambiental preventiva. Outrossim, cabe a todos os cidadãos o dever de participar, influir nas políticas ambientais, evitar comportamentos nocivos ao meio ambiente saudável ${ }^{95}$.

Ter-se-ia, assim, uma obrigação pecuniária cunhada na responsabilidade compartilhada de todos na defesa do meio ambiente. Essa obrigação não se equipara ao instituto da reparação civil, tampouco se encaixa necessariamente em uma espécie tributária, embora essas duas espécies, ao procurarem a proteção ambiental, possam ser consideradas uma obrigação compartilhada.

Até há pouco tempo, o uso dos recursos naturais não era considerado ameaçador, pois as riquezas do planeta eram tidas infindáveis. Com a mudança dessa concepção - decorrente de um ganho de consciência sobre a crise ambiental, consoante se exporá no Capítulo 4 deste estudo -, verificou-se a finitude e, por consequência, a escassez dos bens ambientais. É uma constatação determinante para emergir normas que visam a proteção do meio ambiente, dentre elas a obrigação compartilhada de todos pela prevenção, reparação ou compensação dos danos e impactos causados aos recursos naturais. Isso faz com que não só o Estado (e, portanto, toda a sociedade), mas todos aqueles que utilizam com proveito econômico os recursos da natureza arquem

\footnotetext{
${ }^{94}$ Ao final do seu voto, o relator assim sustentou: "nessa ampla moldura, é de se inferir que o fato de, aqui e ali, inexistir efetivo dano ambiental não significa isenção do empreendedor de partilhar os custos de medidas preventivas. Isto porque uma das vertentes do princípio usuário-pagador é a que impõe ao empreendedor o dever de também responder pelas medidas de prevenção de impactos ambientais que possam decorrer, significativamente, da implementação de sua empírica empreitada econômica.”

${ }^{95}$ LEITE, José Rubens Morato. AYALA, Patryck de Araújo. Dano ambiental: do patrimonial ao coletivo extrapatrimonial: teoria e prática. $4^{\text {a }}$ ed. rev. atual. ampl. São Paulo: RT, 2011, p. 56-57.
} 
financeiramente com as medidas preventivas e com os efeitos da poluição e com a degradação ambiental.

Saliente-se: a compensação ambiental não decorre de uma perda de algo que não deveria ter ocorrido ${ }^{96}$, como se fosse um dano ilícito e indesejado, o qual, como perpassado, faria emergir a responsabilidade civil; trata-se, sim, de prejuízos socioambientais inerentes a uma atividade lícita e devidamente licenciada. Essa perda - que é, frise-se, lícita e desejada - até pouco tempo atrás não era sentida, acabando por ser absorvida pela sociedade, seja porque havia uma compatibilidade entre a utilização dos recursos naturais e a capacidade do meio ambiente em disponibilizá-los e renová-los, seja porque a perda não era tão significativa quanto os ganhos. Hoje, verifica-se a intensa exploração dos recursos da natureza impondo uma nova consciência sobre a sua forma de exploração e utilização, de consumo e descarte; é uma nova consciência a

96 Observe-se que o STF, quando do julgamento do Recurso Extraordinário - RE 228.800, que tratava da participação dos entes federados no produto ou compensação financeira pela exploração de recursos minerais ou potenciais hidrelétricos (CF, art. 20, $\S 1^{\circ}$ ), especificamente as Leis $n^{\circ} 7.990 / 1989$, arts. $1^{\circ}$ e $6^{\circ}$, e Lei $n^{\circ}$ 8.001/1990, além de afastar a natureza jurídica tributária da exação, entendeu-a como uma forma de recomposição de uma perda sofrida pela atividade econômica. A respeito, verifique-se excerto bastante elucidativo do voto condutor: "Por outro lado, diferentemente do que ocorre em relação aos impostos espécie tributária não-vinculada a qualquer contraprestação estatal -, tanto a participação nos resultados como a CFEM têm a sua causa - direta ou indireta, como se verá - na exploração de recursos hídricos, para fins de geração de energia elétrica e minerais - bens integrantes do patrimônio da União (CF, art. 20, VIII e IX). Com razão, desse modo, a decisão recorrida e o parecer do Ministério Público, ao afirmarem o caráter não tributário das receitas previstas no art. 20, $\S 1^{\circ}$, da Constituição. Tenho, no entanto, que a obrigação instituída pela L. 7990/89 não corresponde ao modelo constitucional. Essa compensação financeira há de ser entendida em seu sentido vulgar de mecanismo destinado a recompor uma perda, sendo, pois essa perda, o pressuposto e a medida da obrigação do explorador. A que espécie de perda, porém, se refere implicitamente a Constituição? Não, certamente, à perda dos recursos minerais em favor do explorador, pois, nesse caso, a compensação financeira, para compensá-la efetivamente, haveria de corresponder à totalidade dos recursos minerais explorados - o que inviabilizaria a sua exploração econômica privada. Nem corresponde, muito menos, à 'perda' dos potenciais de energia elétrica, que, sendo inesgotáveis, não sofrem qualquer diminuição ao serem explorados. Em todo caso, não seria lógico compensar os Estados, o Distrito Federal e os Municípios pela perda de bens que não lhes pertencem, mas exclusivamente à União. A compensação financeira se vincula, a meu ver, não à exploração em si, mas aos problemas que gera. Com efeito, a exploração de recursos minerais e de potenciais de energia elétrica é atividade potencialmente geradora de um sem número de problemas para os entes públicos, especialmente para os municípios onde se situam as minas e as represas. Problemas ambientais - como a remoção da cobertura vegetal do solo, poluição, inundação de extensas áreas, comprometimento da paisagem e que tais -, sociais e econômicos, advindos do crescimento da população e da demanda dos serviços públicos. Além disso, a concessão de uma lavra e a implantação de uma represa inviabilizam o desenvolvimento de atividades produtivas na superfície, privando Estados e Municípios das vantagens delas decorrentes. Pois bem. Dos recursos despendidos com esses e outros efeitos da exploração é que devem ser compensadas as pessoas referidas no dispositivo. (...).”A bem ver, a decisão do STF sobre a compensação financeira, introduziu uma nova medida compensatória ao ordenamento jurídico nacional, imposta pela exploração de recursos minerais e potenciais hidrelétricos, os quais devem repassar percentual de seu faturamento aos entes por eles afetados. 
assegurar a proteção do meio ambiente para a própria manutenção e reprodução do sistema econômico vigente e, ao mesmo tempo, a sobrevida da espécie humana na Terra.

Esse contexto de um sistema de desenvolvimento econômico e social exploração e utilização dos recursos naturais, consumo dos produtos deles advindos e descarte dos seus resíduos - impõe perdas que não têm condições de ser absorvidas pela sociedade, porquanto seus efeitos geram toda a ordem de prejuízos pessoais e coletivos. Um exemplo desse cenário é a quantidade de veículos nos grandes centros urbanos, onde, até há pouco tempo, seu reduzido número viabilizava uma eficaz utilização e usufruto desse bem. Todavia, a crescente demanda por veículos automotores sem a contrapartida de um racional e humano planejamento territorial, vem causando cada vez mais congestionamentos e perda de tempo no trânsito. À evidência, essas circunstâncias impõem prejuízos pessoais - tempo no trajeto, gasto excessivo com combustível, estresse, agressividade etc. - e coletivos, ou seja, o aumento de gastos públicos para ampliar a estrutura viária. Sem incluir a emissão de gás carbônico e material particulado, implicando danos à saúde de toda a população e, com isso, sobrecarregando o sistema público de saúde.

Tal modelo de crescimento exige, assim, uma adequação das normas legais de modo que, àquele que provoca a perda da qualidade ambiental seja determinado que arque, ainda que parcialmente, com os custos - antes custeados por todos - dela decorrentes. Ou, como frisou o STF no julgamento da ADI 3.378/DF, uma obrigação compartilhada por todos - Estado e empreendedor. Daí toda e qualquer medida que vise a internalizar os custos pela utilização dos recursos ambientais. E, como se verá no Capítulo 5 deste estudo, são inúmeros os instrumentos e medidas capazes de alcançar esse objetivo, dentre eles a compensação ambiental da Lei $n^{\circ} 9.985 / 2000$ e todas as outras medidas compensatórias.

Em outros termos, o compartilhamento de despesas não se refere exatamente a uma natureza jurídica, mas ao próprio objetivo - ou, como se verá no item 6.3 do Capítulo 6 desta tese, a funcionalidade - da obrigação. 


\subsection{Conclusões preliminares}

A compensação ambiental, imposta pelo art. 36, §1 ${ }^{\circ}$, da Lei ${ }^{\circ}$ 9.985/2000 (SNUC), é espécie do gênero medidas compensatórias, nas quais se incluem outras obrigações já positivadas em lei (como a compensação por supressão de área de preservação permanente e de Mata Atlântica, a medida compensatória prevista no Estatuto da Cidade) e, ainda, outras comumente impostas ao exclusivo critério dos órgãos licenciadores.

Todavia, provavelmente em razão de recair em grandes empreendimentos e de abranger vultosos valores pecuniários, as atenções se concentraram na compensação ambiental. Assim, toda a discussão - doutrinária e jurisprudencial - que girou em torno dela não considerou detidamente, de fato, ser a compensação ambiental apenas uma das medidas compensatórias a incidir na hipótese de impactos, significativos ou não, negativos e não mitigáveis ao meio ambiente, a ser causados por empreendimentos lícitos e desejados pela sociedade.

Não obstante, são dos debates travados sobre a compensação ambiental que permitirão aprofundar, a partir do próximo capítulo, o tema deste trabalho, qual seja, as medidas compensatórias.

Sobre a compensação ambiental, verificou-se no decorrer deste capítulo o seu histórico, as discussões sobre a sua constitucionalidade e as controvérsias a respeito da sua natureza jurídica. ${ }^{97}$

\footnotetext{
${ }^{97}$ É oportuno anotar haver discussões a respeito, também, da (i) possibilidade de a compensação ambiental ser aplicada retroativamente, em empreendimentos já implantados; e (ii) se o EIA/RIMA é um requisito imprescindível para a incidência da compensação ambiental, ou se ela poderia concretizar-se em processos de licenciamento ambiental fundados em estudos menos complexos, como é o caso, por exemplo, do RAP Relatório Ambiental Preliminar e o do RAS - Relatório Ambiental Simplificado. Sobre a retroatividade da norma, há decisão do Tribunal de Justiça de São Paulo, no seguinte sentido: “Apelação - Ação civil pública Meio ambiente - Licenciamento ambiental - Represa de Jurumirim, compensação ambiental - Sentença improcedente - Cabimento da compensação prevista no art. 36 da Lei 9.985/00 somente com EIA/RIMA (licenciamento de empreendimentos de significativo impacto ambiental) - Legislação precária de proteção ao meio ambiente à época da construção que não exigia a realização de estudos de impactos ambientais e de relatórios - Lei 9.985/00 não tem efeito retroativo, ação proposta após 40 anos da construção da usina Aventura judicial por parte do Município - Resolução CONAMA 06/87 (art. 12, §5.․) - Recurso improvido” (TJSP, Apelação 454.590-5/6-00, Câmara Especial de Meio Ambiente, rel. Des. José Augusto Genofre Martins, Acórdão 01135250, Registro 26.10.2006)”. No que se refere à inafastabilidade do EIA/RIMA para a concretização da compensação ambiental, cite-se julgado do TRF $2^{\mathrm{a}}$ Região, que seguiu assim ementado: "Processo civil. Agravo de Instrumento. Instituto Brasileiro do Meio Ambiente e dos Recursos Naturais Renováveis - IBAMA. Expedição de licença prévia de produção para pesquisa. Submissão à exigência do art.
} 
Em relação ao tema da constitucionalidade, foi possível criticar o julgamento, pelo STF, da ADI 3.378/DF, mormente por ter afastado a forma de cálculo da obrigação, determinando o seu cálculo de forma proporcional ao subjetivo conceito dos significativos impactos a ser causados ao meio ambiente.

Em relação às controvérsias acerca da correta natureza jurídica da compensação ambiental da Lei do SNUC, verificou-se haver três principais correntes: a primeira, defendendo a compensação ambiental com natureza jurídica reparatória; a segunda, sustentando ser o instituto um tributo; e, a terceira, defendendo a obrigação como uma forma de compartilhamento de despesas. Essas correntes, à similaridade do que ocorreu no julgado do STF, também deixaram de considerar a compensação ambiental como apenas uma espécie do gênero medidas compensatórias, o que certamente empobreceu os debates.

À derradeira, repise-se: partir-se-á de toda a discussão que circunscreveu (e circunscreve) o instituto da compensação ambiental, instituído pela Lei $n^{\circ}$ 9.985/2000, para aprofundar a análise das medidas compensatórias em geral, mormente para a compreensão dos seus pressupostos e, ainda, propor uma forma de aplicação prática e eficaz ao instituto.

36 da Lei n. ${ }^{\circ}$ 9.985/2000. Dispositivo legal referente aos empreendimentos de significativo impacto ambiental, com fundamento em Estudo de Impacto Ambiental e respectivo Relatório - EIA/RIMA. Empreendimento dos autos fundado apenas em Estudo de Viabilidade Ambiental - EVA, não parecendo possuir "significativo impacto ambiental". Agravo de instrumento desprovido e agravo interno prejudicado. (...) TRF $2^{\mathrm{a}}$ Região - Agravo de Instrumento ${ }^{\circ}$ 2005.02.01.010349.6 - $5^{\mathrm{a}}$ Turma - Rel. Des. Vera Lucia Lima - DJU 24.05.2006, FLS. 147/153.” 


\section{O DANO AMBIENTAL E O IMPACTO NEGATIVO AO MEIO AMBIENTE}

\subsection{Noções introdutórias}

Para a boa implementação e aplicação das medidas compensatórias, faz-se necessário, antes, que se compreenda a diferenciação entre os conceitos de dano ambiental e de impacto negativo no meio ambiente. Como já pontuado no capítulo anterior, as medidas compensatórias são aplicadas para compensar os estragos ao meio ambiente causados pelos impactos negativos de atividades ou de empreendimentos lícitos, desejados e devidamente licenciados. Significa dizer serem medidas que não emergem quando da ocorrência de um dano ambiental, decorrente de um ato ou de uma omissão ilícitos, e que causa efeitos nunca desejados e, por conseguinte, determina a incidência das responsabilidades civil objetiva, administrativa e criminal.

Embora nos pareça muito clara a diferença entre esses dois conceitos, é bastante usual verificar o dano ambiental e o impacto negativo no meio ambiente não serem distinguidos pela doutrina, pela jurisprudência e no âmbito do processo administrativo de licenciamento ambiental. Ao contrário, não é raro ver o termo dano sendo utilizado para designar um impacto negativo avaliado no decorrer do processo de licenciamento ambiental e, por outras, aponta-se como impacto um dano ilícito cuja reparação civil se impõe.

Certamente, a olhos menos avisados, poderia parecer pouco producente distinguir o dano do impacto negativo, porquanto, ao fim e ao cabo, ambos causam um efeito adverso e prejudicial ao meio ambiente. No entanto, para ser bem conduzida a reação jurídica - que deve emergir para equacionar o problema causado por um e por outro -, é absolutamente necessário, como se verá, distinguir o correto significado de cada um.

A confusão que se faz em relação ao entendimento dos termos dano ambiental e impacto negativo no meio ambiente e das suas distintas reações jurídicas decorre, ao que parece, de um lado, da má compreensão e da má 
utilização do termo risco e, de outro lado, do intento consciente de os enquadrar na mesma categoria jurídica de dano. ${ }^{98}$ De fato, consoante já foi perpassado no capítulo anterior, há os que defendem ser o impacto negativo, apreciado no processo de licenciamento ambiental, um dano futuro, o qual deve ser solucionado por meio da reparação civil objetiva.

No entanto, uma detida análise desses conceitos permitirá verificar serem distintos os pressupostos do dano ambiental e do impacto negativo no meio ambiente, como também são diversas as reações jurídicas quando da concretização de cada um deles. Basta ver, desde já, o dano ambiental impondo, no âmbito civil, a reparação, cujo arcabouço jurídico já está devidamente construído, baseando-se na responsabilidade civil objetiva, fulcrada na teoria do risco. Já o impacto negativo no meio ambiente, por sua vez, é apreciado no âmbito do processo de licenciamento ambiental, manejado na esfera da Administração Pública, onde se cominam medidas preventivas, mitigatórias e compensatórias. $^{99}$

Portanto, a seguir far-se-á uma breve digressão acerca da acepção jurídica do conceito de risco, e como ele evoluiu para o que hoje se conhece como sociedade do risco ou sociedade das incertezas. Nesse caminho, ver-se-á a teoria do risco, fundamentadora da responsabilidade civil ambiental objetiva. Será, de igual modo, analisada a vinculação do risco concreto com os impactos negativos a serem causados ao meio ambiente por atividades lícitas e aceitas. A par disso, será avaliado o risco abstrato ou incerto tendo relação específica com o dano futuro e a forma como pode ser gerenciado e evitado.

\footnotetext{
${ }^{98}$ Há autores defendendo a identidade de todos os efeitos adversos causados ao meio ambiente com o conceito de dano. Em uma compreensão técnica do assunto, vale transcrever a lição de Luiz Enrique Sanchéz, onde o autor não diferencia o conceito de dano e impacto. Senão, vejamos: que "deve-se distinguir entre o dano programado, planejado e devidamente autorizado pelo Poder Público (na forma de licença ambiental, por exemplo) e o dano não autorizado previamente, seja ele voluntário ou involuntário. Mediante decisões de natureza às vezes mais política do que técnica, que estabelecem o grau de perturbação ambiental aceitável em troca de bem-estar, distingue-se um do outro. SÁNCHEZ, Luiz Enrique. Danos e passivo ambiental. In: PHILIPPI JR., Arlindo; CAFFÉ ALVES, Alaôr (eds.). Curso interdisciplinar de Direito Ambiental. Barueri: Manole, 2005.

${ }_{99}$ A decisão sobre quais as medidas a serem aplicadas à frente de um determinado impacto negativo cabe a um órgão público administrativo que, como se sabe, tem suas ações prefixadas (ou vinculadas) ao que está estabelecido no ordenamento jurídico vigente. Ou seja, consoante será detidamente apreciado no item 6.5.1.1 do Capítulo 6 desta tese, a Administração Pública deve respeitar o princípio da legalidade - ainda que considerado em uma acepção mais flexível - quando da imposição de condicionantes ambientais, inclusive as medidas compensatórias.
} 
Tudo para concluir, por fim, serem diferentes os conceitos de dano ambiental e de impacto negativo no meio ambiente, o que, como dito, considerase absolutamente necessário para encontrar os corretos e efetivos mecanismos de reação jurídica para cada situação empírica deles decorrente.

\subsection{O desenvolvimento histórico da concepção jurídica do risco}

O entendimento do risco ${ }^{100}$ permaneceu, durante muito tempo, vinculado ao comércio marítimo. Alcançou um estágio evolutivo mais avançado nos séculos XIV, XV e XVI com a chegada e o aprimoramento dos contratos de seguro marítimo, os quais permitiram aos seus subscritores a transferência do risco. Nesses casos, em geral, apenas os riscos decorrentes dos infortúnios do mar, das fatalidades e dos eventos fortuitos poderiam ser garantidos, ou seja, garantidos em circunstâncias que estavam completamente fora do controle humano. Nessa época, o conceito de risco construído pelo direito referia-se a um acontecimento futuro, casual e capaz de ocasionar um dano, parecendo haver sido inteiramente influenciado pelo seu significado epistemológico da época que, então, remetia à ideia de eventos danosos (tempestades, ataques de piratas etc.) causados pelo mar aos navegadores.

A concepção do risco alterou-se substancialmente do século XVI até o século XIX, quando passou a contemplar eventos não apenas imprevisíveis, mas passíveis de ocorrer também em terra firme. De fato, com o advento da era industrial e do aumento gradativo dos acidentes de trabalho, seguiram-se novas ideias sobre responsabilidade civil e os seguros de acidente de trabalho. Significa dizer que os avanços apresentados pela revolução industrial passaram a desencadear novos riscos, principalmente para os trabalhadores das fábricas (riscos individuais). Daí a materialização do direito de indenização por um dano - consequência negativa do risco.

\footnotetext{
${ }^{100}$ O histórico do conceito de risco no direito aqui introduzido baseou-se, em grande parte, no capítulo "As relações entre o direito e o risco: uma perspectiva histórico-metodológica”. In: MORAIS, Roberta Jardim de. O princípio da precaução (re)visitado - um olhar jurídico-econômico sobre o comércio internacional dos organismos geneticamente modificados. Tese de Doutorado, Universidade de Coimbra, 2008.
} 
A partir desse momento, o risco passou a ser calculável, coletivo e capitalizado, e o Estado assumiu o papel protetor dos riscos criados pela própria sociedade, os chamados “riscos sociais", propondo a ela uma seguridade generalizada. E daí, em síntese, o Estado Providência.

A teoria das probabilidades e a estatística, e as técnicas bastante utilizadas no contexto dos seguros, tornaram possível demonstrar a regularidade com que ocorriam os acidentes laborais. Com isso, o risco poderia ser objeto de medidas de prevenção com o escopo de impedir sua realização ou sua repetição. $\mathrm{O}$ acidente não poderia mais ser vinculado a uma fatalidade, mas a uma lógica causal e, de certo modo, determinista, como algo inerente ao próprio exercício da atividade.

Ainda no século XIX houve iniciativas de ações preventivas contra o risco, principalmente relacionados com patologias infecciosas, sendo a base para o aprimoramento da ação preventiva e para a edificação de toda a moderna evolução do direito para o enfrentamento do risco.

Essa concepção de "risco certo", ligado a uma estatística comprovada e alta probabilidade de repetição, implicou, como se verá, a atual concepção da responsabilidade civil objetiva por danos ambientais baseada na teoria do risco; como também implicou a avaliação de impactos ambientais, gerenciados por meio do processo de licenciamento ambiental.

Nos tempos presentes, o termo risco é ainda utilizado para designar a probabilidade de ocorrência de um evento cujas consequências, em geral coletivas e de grande magnitude, não são de possível previsão ou estimativa. Seus efeitos não são sentidos apenas quando de sua ocorrência, mas a longo prazo, como no tristemente célebre caso da Baía de Minamata no Japão ${ }^{101}$.

O momento atual (tida como modernidade tardia, sociedade pós-moderna, sociedade pós-industrial, sociedade de risco, sociedade das incertezas etc.), como se verá mais detalhadamente no item 3.3.4 abaixo, é a terceira fase da evolução conceitual do risco, etapa na qual a capacidade da sociedade de preveni-lo e mensurá-lo pode ser frustrada, porquanto a incerteza quanto à sua existência e seus efeitos passa a ocupar um papel central.

${ }^{101}$ Onde, em 1956, várias pessoas morreram por envenenamento por mercúrio contido no pescado. 


\subsection{Risco concreto e risco abstrato}

Neste ponto, importante diferenciar o risco concreto e o risco abstrato, eis que de ambos decorrem diferentes consequências e, bem por isso, diversas reações jurídicas.

O risco concreto traz em si um conhecimento sobre a probabilidade da sua ocorrência e a magnitude dos seus efeitos. Assim, o risco concreto pode implicar tanto danos ambientais como impactos negativos ao meio ambiente cujas reações jurídicas, no entanto, e como se concluirá mais adiante, são distintas.

Já o risco abstrato está ladeado de incertezas, seja quanto a sua probabilidade, seja quanto a sua magnitude. A bem ver, o risco abstrato é invisível à percepção humana, só transparecendo quando se concretiza em um dano ambiental, em geral de dimensões catastróficas e efeitos imensuráveis (vide Chernobyl, Bhopal, Fukushima ${ }^{102}$, além de tantos outros). Em relação a eles, o que se conhece é a sua possibilidade de concretização, causando danos incalculáveis à espécie humana, senão a sua extinção, como no caso dos arsenais atômicos.

Em suma, as diferentes acepções do risco têm características singulares que os diferenciam sobremaneira. Os riscos concretos ou certos do processo industrial, como o conhecemos, são singulares e de conhecidas probabilidade e magnitude. Os riscos abstratos ou incertos, fundadores de uma nova 'sociedade de risco' ou 'sociedade de incertezas', são absolutamente incertos, indeterminados, invisíveis, de probabilidade e magnitude desconhecidas. Senão, vejamos.

\footnotetext{
${ }^{102}$ Chernobyl, cidade na Ucrânia, antiga URSS, que, em abril de 1986, sofreu um acidente nuclear liberando imensa nuvem radioativa. Bhopal, na Îndia, que, também na década de 80, sofreu grave acidente tóxico em uma indústria química. Fukushima, no Japão, que, em março de 2011, foi atingida por um terremoto seguido de um tsunami, destruindo parte de uma central nuclear.
} 
3.3.1 A teoria do risco e a responsabilidade civil objetiva por danos ambientais

O dano ambiental já não é mais um risco; é, sim, um fato concreto que, em um determinado momento, pode ou não ter sido apreciado como um risco. De efeito, para o dano ambiental, na acepção jurídica atual e usualmente empregada, o dano é algo passado, ou uma situação concretizada, podendo ser verificada sensitivamente pelo homem e, diante disso, deve ser equacionada por meio dos mecanismos das responsabilidades civil ambiental objetiva, administrativa e criminal. Frise-se, desde já, tratar-se de um fato jurídico ilícito e indesejado.

Portanto, quando se fala de um dano ambiental, da forma como conhecemos, inexiste a preocupação com o gerenciamento do risco. Logicamente, em um momento anterior, pode-se ter avaliado uma determinada atividade com potencial de causar um dano, razão pela qual se buscariam medidas para evitá-lo; nessa hipótese, a situação é enfrentada como um risco concreto, ou seja, passível de ser previsto, estimado e gerenciado. É o que ocorre em relação aos acidentes de trânsito, cuja estimativa e probabilidade permitem elaborar os cálculos de valores para os seguros dos automóveis, inclusive os obrigatórios. Na seara ambiental, pode-se citar a Lei $\mathrm{n}^{\circ} 13.577$, de 8 de julho de 2009, do Estado de São Paulo, tratando das áreas contaminadas e, assim, estabelecendo a forma de gerenciamento tanto dos passivos ambientais já existentes quanto das atividades com potencial de contaminação, consideradas, assim, um risco concreto, que pode se concretizar ou não em um dano.

E, quando ocorre o dano ambiental, não há dúvidas, incide a responsabilidade civil objetiva, além de ser possível a aplicação das responsabilidades administrativa e criminal ${ }^{103}$.

\footnotetext{
${ }^{103}$ Como ensina Édis Milaré, a "danosidade ambiental, potencial ou efetiva, pode gerar uma tríplice reação do ordenamento jurídico, ou seja, um único ato pode detonar a imposição de sanções administrativas, penais e civis. Assim, por exemplo, o carreamento de efluentes para um manancial, comprometendo a fauna ictiológica e as condições sanitárias do meio ambiente, pode ensejar: (i) pagamento de multa de R \$ 5.000,00 (cinco mil reais) a R \$50.000.000,00 (cinquenta milhões de reais), com base no art. 62, VIII, do Dec. 6.514/2008; (ii) condenação à pena de detenção, de 1 a 3 anos, ou multa, ou ambas cumulativamente, com base no art. 33 da Lei 9.605/1998; (iii) pagamento de indenização ou cumprimento de obrigação de fazer ou de não fazer, com base no art. 14, § $1 .^{\circ}$, da Lei 6.938/1981”. MILARÉ, Édis. Direito do ambiente. $7^{\text {a }}$ ed. São Paulo: RT, 2011, p. 214.
} 
Sobre o instituto da responsabilidade civil por danos ambientais, vale recordar, inicialmente de caráter subjetivo - exigindo-se a comprovação da culpa -, com o desenvolvimento das relações sociais, máxime com a chegada da era industrial e a evolução do processo de industrialização, passou se caracterizar como responsabilidade objetiva, prescindindo da comprovação da culpa, e bastando a presença do dano e do nexo de causalidade. ${ }^{104}$

Em verdade, o avanço da industrialização determinou a ocorrência de danos ambientais, trazendo consigo uma profunda dificuldade para a constatação da culpa, do agente causador e da sua extensão. Daí a necessidade de incorporar ao instituto da responsabilidade civil a teoria do risco, segundo a qual, quem assume, direta ou indiretamente, o risco de desenvolver uma determinada atividade, deve responsabilizar-se pelos efeitos dela decorrentes, independentemente da licitude da conduta. Nesse sentido, aliás, a lição de Alvino Ferreira Lima em seu clássico Culpa e risco $^{105}$.

Essa evolução da responsabilidade civil foi incorporada no ordenamento jurídico nacional pela Lei $\mathrm{n}^{\circ}$ 6.453/1977, estabelecendo a responsabilização civil para a atividade nuclear, e imputou ao seu operador o dever de indenizar os danos provocados sem a necessidade de comprovação de culpa. ${ }^{106}$

Posteriormente, a Política Nacional de Meio Ambiente (Lei $\mathrm{n}^{\circ}$ $6.938 / 1981$ ), de forma a contemplar todas as atividades poluidoras, determinou

\footnotetext{
${ }^{104}$ Acerca da evolução da responsabilidade civil subjetiva para a responsabilidade civil ambiental objetiva, Fabio Dutra Lucarelli bem expõe: "O princípio básico da responsabilidade civil consistia no da responsabilidade subjetiva, baseado na teoria da culpa, originada, sobretudo, da Lex Aquilia romana. Por essa corrente, o dever de indenizar só se verificaria quando aferida culpa da pessoa pelo evento danoso, ou seja, se fosse demonstrado que esta agiu em conformidade com uma das modalidades de culpa (negligência, imperícia ou imprudência). Este é o princípio básico de nosso Código Civil, consubstanciado no seu art. 159. Porém, inobstante a vital importância da teoria subjetiva, verificou-se, com a evolução dos fatos, que ela não era bastante para os casos específicos de danos ecológicos, os quais, dadas suas peculiaridades de difícil e custosa comprovação, aliadas à extrema gravidade e extensão dos prejuízos causados, não poderia ficar restrita a tal modalidade de responsabilidade. A teoria subjetiva representava um limite à tutela ambiental, sobretudo pela dificuldade de produzir-se a prova da culpabilidade, a qual dependia dos resultados de complexas perícias, além do fato de que é habitual que o dano se concretize no futuro ou seja causado por diversos fatores. Passou-se então à idéia de adoção da teoria objetiva, atribuindo-se a responsabilidade sem que, no nexo causal, fosse preciso aferir-se a existência de ato ou omissão culposa”. LUCARELLI, Fabio Dutra. Responsabilidade civil por dano ecológico. Revista dos Tribunais. vol. 700, p. 7, Fev / 1994, DTR $\backslash 1994 \backslash 114$.

${ }^{105}$ LIMA, Alvino Ferreira. Culpa e risco. atual. por Ovídio Rocha Barros Sandoval. São Paulo: RT, 1998.

106 A norma prescreveu excludentes de responsabilidade em caso de acidentes que decorressem de insurreições, conflitos armados e 'por excepcional fato da natureza'. Também delimitou o custo monetário para a indenização em um milhão e quinhentas mil ORTNs.
} 
ao poluidor e ao predador a obrigação de reparar e/ou indenizar os danos causados, não levando em conta a existência de culpa (art. 14, §1 ${ }^{\circ}$ ). Confira-se:

Art. 14 - Sem prejuízo das penalidades definidas pela legislação federal, estadual e municipal, o não cumprimento das medidas necessárias à preservação ou correção dos inconvenientes e danos causados pela degradação da qualidade ambiental sujeitará os transgressores:

(...)

$\S 1^{\circ}$ - Sem obstar a aplicação das penalidades previstas neste artigo, é o poluidor obrigado, independentemente da existência de culpa, a indenizar ou reparar os danos causados ao meio ambiente e a terceiros, afetados por sua atividade. O Ministério Público da União e dos Estados terá legitimidade para propor ação de responsabilidade civil e criminal, por danos causados ao meio ambiente.

A mesma Lei $n^{\circ}$ 6.938/1981 determinou ser o poluidor “a pessoa física ou jurídica, de direito público ou privado, responsável, direta ou indiretamente, por atividade causadora de degradação ambiental” (art. 3º, IV), sendo corolário dessa proposição normativa a presença do nexo de causalidade entre o dano e a atividade e, ainda, a solidariedade entre todos aqueles que contribuíram, de alguma forma, para que a concretização do dano.

O Código Civil de 2002 acompanhou a tendência da responsabilidade objetiva diante do risco, ao dispor, em seu art. 927, que "haverá obrigação de reparar o dano, independentemente de culpa, nos casos especificados em lei, ou quando a atividade normalmente desenvolvida pelo autor do dano implicar, por sua natureza, risco para os direitos de outrem”.

Está, portanto, bem evidenciada a responsabilidade civil objetiva por danos causados ao meio ambiente, prescindindo da verificação da culpa. A isso chamou-se teoria do risco, pela qual é o risco da atividade o desencadeador da responsabilidade por eventuais danos ambientais dela decorrentes. Ou seja, se o empreendedor assume o risco de um empreendimento ou atividade, ele também assume o risco pelos danos por ele ocasionados ao meio ambiente, independentemente da comprovação da culpa. 
O debate ${ }^{107}$ hoje está centrado na extensão da teoria do risco. Ou seja, discute-se se a responsabilidade civil ambiental, em que pese ser objetiva, baseia-se na teoria do risco criado $^{108}$, permitindo suscitar as excludentes de responsabilidade, ou na teoria do risco integral ${ }^{109}$, no âmbito da qual o caso fortuito, a força maior e o fato de terceiro não podem ser ventilados para afastar a responsabilização.

Ademais, não se pode olvidar o fato de a responsabilidade civil por danos ambientais abarcar, além da função repressiva/reparatória, também uma categoria preventiva, na qual, verificada a potencialidade concreta de um dano, ele pode ser evitado.

É o que ocorreria, em âmbito civil, caso se evidenciasse o muro do vizinho prestes a desabar sobre uma residência, quando, então, seus moradores obrigariam aquele a corrigir o problema, evitando um dano. Analogamente, no Direito Ambiental, isso se evidenciaria no fato de uma represa apresentar rachaduras em sua barragem e, vendo-se a iminência de rompimento, o empreendedor seria obrigado a, preventivamente, fazer o esvaziamento pouco a pouco do lago a montante, pelo vertedouro, evitando danos ambientais imensuráveis.

Observe-se, entre parênteses, o fato de a responsabilização civil ambiental, seja reparatória, seja preventiva, a nosso ver, só ser possível frente a riscos concretos, vale dizer, os previsíveis e estimáveis. Tal observação é oportuna, pois, como se verá, há os que defendem a incidência da responsabilidade civil para os riscos abstratos, sendo eles os invisíveis, incertos, imprevisíveis e inestimáveis, ou seja, os danos futuros. Para essa

\footnotetext{
107 Sobre o assunto Jorge Alex Nunes Athias discorre: "Estava definitivamente caracterizada a responsabilidade objetiva em termos de dano ambiental. Sucede que isso não é suficiente para definir-se de forma induvidosa os limites dessa responsabilização, pelo fato de existirem inúmeras correntes doutrinárias acerca da responsabilidade objetiva. Dizer que ela se dá independentemente de culpa é um grande avanço. Porém dentro de qual dessas correntes doutrinárias incluir essa responsabilização? Dependendo da corrente doutrinária dar-se-ia um ou outro tratamento, inclusive no que respeita a questão de excludentes de responsabilidade. ATHIAS, Jorge Alex Nunes. Responsabilidade civil e meio ambiente - breve panorama do direito brasileiro. In: BENJAMIN, Antonio Herman V. (coord.). Dano ambiental: prevenção, reparação $e$ repressão. São Paulo: RT, 1993, p. 242.

${ }^{108}$ Délton Winter de Carvalho defende a teoria do risco criado.

${ }^{109}$ Édis Milaré, Nelson Nery e Sérgio Ferraz advogam ser mais correto aplicar, em relação ao meio ambiente, a teoria do risco integral, a qual, aliás, vem sendo usada como base para diversas condenações judiciais por danos ambientais.
} 
corrente há a necessidade de uma adequação do instituto da responsabilidade civil para gestão dos riscos abstratos, tornando possível a tutela judicial, inclusive dos danos ambientais futuros imprevisíveis e incertos. No entanto, parece-nos equivocada essa corrente, na medida em que o risco abstrato implica, consoante se verá, a manifestação do princípio da precaução, evidenciando-se em uma decisão política e governamental sobre a forma de desenvolvimento econômico de uma determinada sociedade.

Para o risco concreto, a responsabilidade civil preventiva não reside na ampliação do conceito de dano, nem na internalização do risco abstrato no sistema da responsabilidade objetiva, cuja finalidade é apenas reparatória (de ressarcimento); reside, sim, na aplicação de um sistema extraído do dever de preventividade objetiva do art. 225, caput, da Constituição Federal de 1988, capaz de inibir ou remover o ilícito (tutela inibitória ou tutela de remoção do ilícito), independentemente da ocorrência ou não do dano, que pode ser uma consequência eventual do ilícito.

Nessa linha, Luiz Guilherme Marinoni propõe a adoção das demandas inibitória e de remoção de ilícito para, preventivamente, evitar a concreção de um dano ambiental, cuja ocorrência é previsível e consequências estimáveis. Para tanto, apresenta uma diferenciação do dano e do ilícito ambiental, considerando que o “dano é uma consequência eventual do ilícito e, além disto, (....) não há cabimento em ter que esperar pelo dano para evocar a tutela jurisdicional”. ${ }^{110}$ Como exemplos, nos quais seria possível utilizar dessas espécies de medidas processuais, esse autor expõe as seguintes situações:

Para que o direito fundamental ao meio ambiente e as normas que lhe conferem proteção possam ser efetivamente respeitados, é necessária uma ação que i) ordene um não fazer ao particular para impedir a violação da norma de proteção e o direito fundamental ambiental; ii) ordene um fazer ao particular quando a norma de proteção lhe exige uma conduta positiva; iii) ordene um fazer ao Poder Público quando a norma de proteção dirigida contra o particular requer uma ação concreta (por exemplo, fiscalização de área de preservação permanente); iv) ordene um fazer ao Poder Público para que a prestação que lhe

\footnotetext{
${ }^{110}$ MARINONI, Luiz Guilherme. Técnica processual e tutela dos direitos. $3^{\mathrm{a}}$ ed. rev. e atual. São Paulo: Editora dos Tribunais, 2010, p. 276.
} 
foi imposta pela norma seja cumprida (por exemplo, tratar da canalização de um rio); v) ordene ao particular um não fazer quando o estudo de impacto ambiental, apesar de necessário, não foi exigido; vi) ordene ao particular um não fazer quando o licenciamento contraria o estudo de impacto ambiental sem a devida fundamentação, ressentindo-se de vício de desvio de poder; vii) ordene ao particular um não fazer quando o licenciamento se fundou em estudo de impacto ambiental incompleto, contraditório ou ancorado em informações ou fatos falsos ou inadequadamente explicitados. ${ }^{111}$

Como se vê da listagem acima, são casos de riscos concretos, em que é possível prever e estimar os efeitos danosos de uma determinada ação ou omissão. Dessa forma, a tutela inibitória ou de remoção de ilícito se impõem, de forma preventiva, a fim de que aqueles efeitos nefastos não se concretizem.

Assim sendo, é desnecessário adequar o instituto da responsabilidade civil para enfrentar riscos concretos ou possíveis e previsíveis danos ambientais, porquanto o direito brasileiro já comporta os mecanismos processuais necessários para tanto. ${ }^{112}$

De fato, sobre os mecanismos processuais antecipatórios ou inibitórios, novamente Marinoni discorre:

a ação adequada, em todos esses casos, é a inibitória, pois voltada, mediante um não fazer, a impedir a prática ou a continuação do ilícito, ou dirigida, por meio de um fazer, a realizar o desejo preventivo da norma de proteção. Contudo, no caso de ilícito de eficácia continuada - ou seja, na hipótese de

\footnotetext{
${ }^{111}$ MARINONI, Luiz Guilherme. Ob. cit., p. 276-277.

${ }^{112}$ Cite-se o caso da biotecnologia, cujo debate sobre a pesquisa com células-tronco embrionárias foi levado ao Supremo Tribunal Federal, por força da ADI 3510. Nesse feito, acabou se decidindo, com base em extensa prova técnica (que contou, inclusive, com a presença de cientistas em uma audiência realizada naquele Tribunal), não terem as pesquisas o condão de violar o direito à vida, tampouco a dignidade da pessoa humana. Vide a ementa do julgado: “CONSTITUCIONAL. AÇÃO DIRETA DE INCONSTITUCIONALIDADE. LEI DE BIOSSEGURANÇA. IMPUGNAÇÃO EM BLOCO DO ART. $5^{\circ}$ DA LEI N ${ }^{\circ}$ 11.105, DE 24 DE MARÇO DE 2005 (LEI DE BIOSSEGURANÇA). PESQUISAS COM CÉLULAS-TRONCO EMBRIONÁRIAS. INEXISTÊNCIA DE VIOLAÇÃO DO DIREITO À VIDA. CONSTITUCIONALIDADE DO USO DE CÉLULAS-TRONCO EMBRIONÁRIAS EM PESQUISAS CIENTÍFICAS PARA FINS TERAPÊUTICOS. DESCARACTERIZAÇÃO DO ABORTO. NORMAS CONSTITUCIONAIS CONFORMADORAS DO DIREITO FUNDAMENTAL A UMA VIDA DIGNA, QUE PASSA PELO DIREITO À SAÚDE E AO PLANEJAMENTO FAMILIAR. DESCABIMENTO DE UTILIZAÇÃO DA TÉCNICA DE INTERPRETAÇÃO CONFORME PARA ADITAR À LEI DE BIOSSEGURANÇA CONTROLES DESNECESSÁRIOS QUE IMPLICAM RESTRIÇÕES ÀS PESQUISAS E TERAPIAS POR ELA VISADAS. IMPROCEDÊNCIA TOTAL DA AÇÃO”. STF - ADI 3510 - Min. Relator Carlos Ayres Britto - Publ. DJE 28.5.2010 - Ata no 16/2010. DJE no 96, divulgado em 27.5.2010.
} 
um agir já exaurido, mas cujos efeitos ilícitos ainda se propagam, abrindo oportunidade a danos - é necessária apenas a remoção do ilícito, vale dizer, a ação de remoção do ilícito. Essas duas ações - a inibitória e a de remoção de ilícito - têm base, em termos de instrumental processual, no art. 84 do CDC. Esse artigo permite que o juiz ordene um não fazer ou um fazer sob pena de multa, na sentença ou em sede de tutela antecipatória. Além disso, o $\S 5^{\circ}$ do art. 84 do CDC exemplifica as medidas executivas que podem ser requeridas pelo autor, incluindo entre elas a busca e apreensão. Tal artigo, apesar de inserido no CDC, abre oportunidade para proteção de qualquer espécie de direito difuso, como deixa claro o art. 21 da Lei da Ação Civil Pública. Assim, os legitimados à ação coletiva, previstos no art. $5^{\circ}$ da Lei da Ação Civil Pública, podem propor ação coletiva inibitória e ação coletiva de remoção do ilícito, conforme o caso. ${ }^{113}$

Por conseguinte, é da teoria do risco que se concretiza a presença do elemento risco, como de interesse jurídico, na atual concepção da responsabilidade civil ambiental. Ainda que preventivamente, o instituto da responsabilidade civil emerge em um comando antecipatório ou cautelar para evitar a concretização de um dano ambiental, cuja ocorrência era previsível e estimável.

Em outros termos, o dano ambiental, na forma hoje vislumbrada, era um risco que se consumou de forma indesejada e, bem por isso, determinou a incidência da responsabilidade civil objetiva baseada na teoria do risco, impondo, independentemente da constatação de culpa, a obrigação de reparar o dano àquele que o causou - ou causará.

\subsubsection{O risco concreto e os impactos negativos no meio ambiente}

Os riscos usuais da implantação e operação de uma determinada atividade, considerados os inerentes impactos negativos, são avaliados no decorrer do processo de licenciamento ambiental. São riscos concretos, significando ser possível a sua previsão e, ainda, a estimativa dos seus efeitos, os quais são conhecidos cientificamente. Assim, o licenciamento ambiental

${ }^{113}$ MARINONI, Luiz Guilherme. Ob. cit., p. 276-277. 
permite realizar uma apreciação técnica e de controle de atividades ou de empreendimentos a serem implantados e operados para o bem do desenvolvimento econômico, fazendo com que seus impactos adversos sejam administrados e, dessa maneira, possa-se preservar o quanto possível o meio ambiente.

Conforme o art. 10 da Lei $\mathrm{n}^{0}$ 6.938/1981, os empreendimentos e as atividades considerados efetiva ou potencialmente degradadoras do meio ambiente (em verdade, impactantes, conforme terminologia considerada mais adequada e utilizada nesta tese) dependem de prévio licenciamento ambiental ${ }^{114}$. Vale dizer, o licenciamento ambiental procura estimar e avaliar o risco concreto ou o impacto a ser ocasionado ao meio ambiente por determinada obra ou atividade, sopesando as suas repercussões nos ecossistemas, no acervo dos recursos naturais e no meio socioeconômico. Trata-se de um processo a partir do qual se estabelecem, mediante uma avaliação de impacto, os fatores limitantes e fixam-se as condicionantes preventivas, mitigatórias e compensatórias para o seu desenvolvimento ou implantação.

Com efeito, tudo o que limita ou direciona uma licença ambiental, por exemplo, pode ser tomado como condicionante. E, quando se trata de gestão ambiental, as condicionantes, tomadas no sentido lato, abrangem três espécies de medidas, as quais se inter-relacionam. Tais medidas são as já mencionadas medidas de prevenção, de mitigação e de compensação.

Embora se trate de espécies diferentes de um mesmo gênero, as preventivas e as mitigadoras podem, para fins didáticos, ser tratadas conjuntamente, pois se caracterizam como medidas de controle ambiental, de caráter eminentemente técnico, identificadas por meio de estudos ambientais e fixadas na licença ambiental. Bem por isso, tais medidas são cabíveis à luz do princípio da prevenção, o qual se preocupa, consoante será demonstrado no item

\footnotetext{
${ }^{114}$ Licenciamento ambiental, segundo definição da Resolução CONAMA n ${ }^{\circ}$ 237/1997, art. $1^{\circ}$, I, é o "procedimento administrativo pelo qual o órgão ambiental competente licencia a localização, instalação, ampliação e a operação de empreendimentos e atividades utilizadoras de recursos ambientais, consideradas efetiva ou potencialmente poluidoras ou daquelas que, sob qualquer forma, possam causar degradação ambiental, considerando as disposições legais e regulamentares e as normas aplicáveis ao caso.”
} 
4.6.1 do Capítulo 4 desta tese, com o “agir antecipadamente” mediante a implementação de ações que evitem ou minimizem a ocorrência dos impactos ambientais.

As medidas preventivas visam a evitar a ocorrência de impactos negativos no meio ambiente, pela supressão das ações que tenham esse potencial, o que se faz mediante o estudo de alternativas locacionais e/ou tecnológicas. Sempre que possível, o órgão licenciador deve impor medidas destinadas à não agressão ao meio ambiente.

No entanto, se o procedimento invasivo, modificador ou impactante se fizer indispensável, em contrapartida, pode ser igualmente indispensável tornálo mais brando e suave. Em outros termos, para os casos em que o impacto é inevitável, o órgão licenciador deve lançar mão de condicionantes/exigências necessárias para atenuar os seus efeitos negativos. Para tanto, são impostas as medidas mitigadoras.

Além dos dois grupos: medidas preventivas e mitigadoras, há uma terceira espécie de exigência destinada a compensar os impactos negativos que não puderam ser prevenidos ou mitigados. Tratam-se das medidas compensatórias - tema deste estudo -, incidentes em situações distintas das medidas preventivas e mitigadoras, pois não guardam relação direta com os aspectos técnicos do empreendimento.

As formas de criação e implementação das medidas compensatórias serão detalhadas no Capítulo 6 desta tese.

Por ora, basta notar ser o risco concreto relacionado com os impactos negativos causados por atividades lícitas, licenciadas e, portanto, desejadas, equacionado por meio do processo de licenciamento ambiental, que impõe, em âmbito administrativo, medidas preventivas, mitigatórias e compensatórias.

3.3.4 O risco abstrato na 'sociedade de risco' ou na 'sociedade de incertezas'

Aos riscos concretos (previsíveis) da sociedade industrial são incorporados e acrescidos os riscos abstratos (invisíveis, imprevisíveis e 
incertos) característicos da sociedade hodierna, ${ }^{115}$ impondo uma nova significação da concepção de risco. Os riscos abstratos podem ser exemplificados nos processos que levam às mudanças climáticas, na geração de energia nuclear, no uso da biotecnologia etc.; atividades essas gerenciadas pelo Direito Ambiental em um âmbito diverso dos riscos concretos. De fato, como considerado por Canotilho, esses riscos (abstratos) estão em uma segunda geração de problemas ecológicos, em que o sujeito relevante já não é apenas a pessoa ou grupos de pessoas, mas também o ‘sujeito geração' ou ‘futuras gerações'. 116

Nessa nova concepção, o termo risco é utilizado para caracterizar uma fase da sociedade em que o homem lida com invisibilidades e incertezas sobre os eventos futuros, notadamente acerca das consequências decorrentes da forma irracional e intensa de exploração dos recursos naturais, como também a destinação dos resíduos provenientes da atividade industrial e do próprio consumo. Em síntese, tem-se, hoje, uma sociedade de risco distribuidora de riscos abstratos, invisíveis e incertos; esses riscos abstratos ou incertos não se confundem com risco concreto (passível de demonstração causal e previsão baseada na estatística e na probabilidade), visto na primeira e segunda fase da sociedade industrial como embasador ora da responsabilidade civil objetiva por danos ambientais, ora do necessário gerenciamento dos impactos negativos causados ao meio ambiente por meio do licenciamento ambiental. Nas palavras de Délton Winter de Carvalho:

A passagem de uma teoria do risco concreto (ou dogmático) para uma teoria do risco abstrato (proveniente das teorias sociais dos autores como Niklas Luhmann, Raffaele De Giorgi, Ulrich Beck) decorre da própria mutação da sociedade, ou seja, da transição de uma sociedade industrial para uma sociedade de risco, na qual as indústrias química e atômica demarcam uma produção de riscos globais, invisíveis e de consequências ambientais imprevisíveis.

... A sociedade de risco demarca a passagem de uma primeira modernidade (modernidade simples) para uma

\footnotetext{
${ }^{115}$ CARVALHO, Délton Winter de. Dano ambiental futuro - a responsabilização civil pelo risco ambiental. Rio de Janeiro: Forense Universitária, 2008, p. 14.

${ }^{116}$ CANOTILHO, José Joaquim Gomes. Estudos sobre direitos fundamentais. Coimbra: Coimbra Editora, 2004, p. 177.
} 
modernidade reflexiva, ou seja, a passagem de uma modernidade fundada em uma racionalidade cientificista, no Estado-nação, na previsibilidade e calculabilidade dos riscos e perigos da técnica, na luta de classes e na segurança, para uma modernidade em que o êxito do capitalismo industrial gera uma autoconfrontação da sociedade industrial com suas próprias consequências: o surgimento de riscos globais, imprevisíveis, incalculáveis, invisíveis, transtemporais, transnacionais, como foi o caso paradigmático de Chernobyl. ${ }^{117}$

Em outros termos, significa dizer não ter o risco abstrato vinculação com a teoria do risco, analisada frente à concepção atual de responsabilidade civil objetiva, e tampouco com o risco concreto, evidenciado quando da iminência de impactos negativos gerenciados por meio do licenciamento ambiental. Em verdade, o risco abstrato se impõe em uma nova fase da sociedade, considerada uma sociedade de risco ou, como preferimos, uma sociedade de incertezas.

O termo 'sociedade do risco' foi cunhado em meados dos anos 80 do século passado pelo sociólogo alemão Ulrich Beck. Segundo Beck, os riscos, aos quais a sociedade contemporânea está exposta, resultam do desenvolvimento tecnológico e científico e apresentam três características básicas: não podem ser limitados quanto ao tempo e espaço, não se enquadram nas regras tradicionais de responsabilidade e são dificilmente indenizáveis. ${ }^{118}$

Não há dúvidas de que os avanços científicos e tecnológicos experimentados, principalmente a partir do advento da chamada modernidade, a par de terem proporcionado mais conforto, comodidade e bem-estar aos indivíduos, fizeram com que os efeitos das ações humanas ganhassem formas e dimensões, temporais e espaciais, imensuráveis, passando a representar constantes riscos à incolumidade ambiental e, por igual, à própria vida do homem. ${ }^{119}$

\footnotetext{
${ }^{117}$ CARVALHO, Délton Winter de. Ob. cit., p. 59.

118 Anthony Giddens também adotou esse conceito ao sustentar o dever de os diferentes atores mobilizaremse para minimizar os possíveis impactos negativos de novos riscos. Por outro lado, Luhmann vislumbra-os como fruto de um processo decisório e afirma que não existe decisão isenta de risco, ou seja, qualquer escolha - inclusive a própria opção por não decidir - implica riscos. Vai além Raffaele De Giorgi, que prega a impossibilidade ou não necessidade de iniciativas precaucionárias, porque a geração de novos riscos faz parte da evolução social e novas tecnologias oferecerão alternativas suficientes. SETZER, Joana. Panorama do princípio da precaução: o direito do ambiente face aos novos riscos e incertezas. Dissertação (mestrado). Programa de Ciência Ambiental. Universidade de São Paulo-USP, São Paulo, 2007, p. 13.

119 ARRUDA, Domingos Sávio de Barros. A categoria acautelatória da responsabilidade ambiental. Revista de Direito Ambiental. vol. 42, p. 25, abr /2006.
} 
Segundo Raffaele De Giorgi, no passado ocorria certa regularidade na estrutura seletiva dos acontecimentos e isso fornecia uma relativa segurança à ação e, ao mesmo tempo, possibilitava o tratamento do desvio, ou seja, tornava possível a normalização. A regularidade, então, permitia construir conexões entre os acontecimentos, imputar causalidade e elaborar descrições que tornavam manifesta a rede de conexões entre os acontecimentos. A calculabilidade das imputações na construção de conexões conferia a esta caráter de razoabilidade. Assim, era possível harmonizar a dimensão temporal do agir com a dimensão social em acontecimentos e a sua calculabilidade. Contudo, esse jurista italiano alerta para o fato de as indeterminações terem passado a constituir a normalidade do mundo contemporâneo de modo que o que nunca se verificou, pode acontecer de forma imprevista, razão pela qual as eventuais decisões relativas ao comportamento devem levar em consideração essa possibilidade. Significa dizer que o modelo de sociedade industrial, que tinha como pressuposto a estabilidade da relação entre racionalidade e tempo, fragmentou-se e o potencial descritivo das distinções que a viabilizou esgotouse, a ponto de aquele modelo, paulatinamente, ver-se substituído por uma sociedade caracterizada pela perda de qualquer padrão de normalidade, sujeita, portanto, de modo permanente, ao imprevisto. ${ }^{120}$

Assim, tem-se indubitavelmente que, nessa época de riscos abstratos ou incertezas, vemos a ponta de um iceberg, cuja profundidade e tamanho não somos sequer capazes de imaginar. Basta ver, por exemplo, o terremoto seguido de um tsunami que atingiram a costa do Japão em março de 2011, promovendo quase trinta mil mortes e desaparecimentos ${ }^{121}$ e inúmeros prejuízos materiais ${ }^{122}$.

\footnotetext{
${ }^{120}$ Apud ARRUDA, Domingos Sávio de Barros. A categoria acautelatória da responsabilidade ambiental. Revista de Direito Ambiental. vol. 42, p. 25, Abr /2006. Mencione-se que Raffaele De Giorgi não concorda com a concepção de que o risco é um fato, um dado. Para ele, o risco não é algo real, não é um dado. É, ao contrário, a possibilidade de um evento danoso que uma outra decisão poderia ter evitado. Antes de se saber que o contágio da AIDS ocorre por via sexual, as relações sexuais não eram consideradas relações de risco ou, como uma vez afirmou Luhmann, antes da invenção do guarda-chuva, não existia o risco de se molhar quando chovia. A respeito, vide GIORGI, Raffale De. O risco na sociedade contemporânea. Revista de Direito Sanitário. São Paulo, v. 9, n.1, p.37-49, mar/jun. 2008.

${ }^{121}$ Conforme o Wikipedia. Disponível em: <http: pt.wikipedia.org/wiki/Sismo_e_tsunami_de_Tohoku_de_2011>. Acesso em: 14.11.2011.

${ }_{122}$ De acordo com as informações do Wikipedia (vide nota acima), o sismo causou danos substanciais no Japão, incluindo a destruição de rodovias e linhas ferroviárias, assim como incêndios em várias regiões, e o rompimento de uma barragem. Aproximadamente 4,4 milhões de habitantes no nordeste do Japão ficaram
} 
Mas o que chamou mais a atenção foram os danos causados à Usina Nuclear de Fukushima, causando um temor de efeitos de magnitude catastrófica ao meio ambiente, àquele país e a toda a humanidade. De fato, os riscos impostos pelas avarias aos reatores nucleares da usina foram imensuráveis e incertos, e seguramente geraram um sentimento de temor que não encontrou fronteiras.

A respeito da dimensão do risco das usinas nucleares, Ulrich Beck já salientava, em momento que seguiu o acidente de Chernobyl:

Os estudos de segurança de reatores [nucleares] limitamse à estimativa de determinados riscos quantificáveis em razão de acidentes prováveis. A dimensionalidade do risco é, portanto, de saída reduzida à manuseabilidade técnica. Para amplos setores da população e para os opositores da energia nuclear, é, ao contrário, precisamente o potencial catastrófico da energia nuclear que está no centro da questão. Mesmo uma probabilidade de acidentes tão reduzida é alta demais quando um acidente significa extermínio. ${ }^{123}$

Em verdade, mesmo após o acidente de Chernobyl, a sociedade assumiu o risco de continuar instalando usinas nucleares. De fato, mesmo sendo de natureza catastrófica, o ser humano compreendeu necessária a geração de energia nuclear ${ }^{124}$, aceitando os riscos incertos dela decorrentes, certamente por ser considerar necessária ao desenvolvimento econômico nos moldes hoje presenciados.

No que se refere ao acidente do Japão, verificou-se a incerteza da cumulação dos riscos operacionais de uma usina nuclear com a ocorrência de um evento natural de dimensões catastróficas. Essa situação é paradigmática dessa sociedade de risco ou sociedade de incertezas. Para tanto demonstrar, bastaria perguntar: Quantas pessoas, até aquele momento, conheciam a Usina de

sem energia elétrica, e 1,4 milhão sem água. Muitos geradores deixaram de funcionar e, como se sabe, uma Usina Nuclear foi atingida. Estima-se que foi o maior sismo a atingir o Japão e o quinto maior do mundo desde que os registros modernos começaram a ser compilados.

${ }^{123}$ BECK, Ulrich. Sociedade de risco: rumo a uma outra modernidade. Trad. Sebastião Nascimento. São Paulo: Ed.34, 2010, p. 35.

${ }^{124}$ Há, inclusive, aqueles que pregam a viabilidade das usinas nucleares. Para Décio Michellis, "O fato do meu ou do seu casamento ter terminado em divórcio não significa que a instituição casamento esteja falida. Igualmente com a energia termonuclear: acidentes e incidentes nucleares não são razões necessariamente suficientes para o abandono desta tecnologia como uma alternativa de suprimento energético. Exigirá novos esforços tecnológicos para aumentar a segurança das instalações frente às catástrofes naturais de maior severidade como as de Honshu no Japão”. Disponível em: http://www.canalenergia.com.br/zpublisher/ materias/Artigos_e_Entrevistas.asp?id=82282. Acesso em 21.3.2011. 
Fukushima? Quem poderia imaginar que ela seria atingida por um terremoto e um tsunami de rara magnitude, os quais poderiam causar efeitos catastróficos? Quem melhor do que os estudiosos e minuciosos japoneses poderia prever uma situação parecida, os quais, no entanto, não conseguiram imaginar o evento a ponto de conter previamente os riscos de um desastre nuclear? Frente a esses questionamentos, não restam dúvidas de que a instalação da Usina Nuclear de Fukushima no Japão, após o terremoto e tsunami de 2011, trouxe consigo uma percepção de ameaça de dimensão planetária, que, para a maioria da população mundial, por muito tempo, não podia sequer ser imaginada, muito menos administrada. ${ }^{125}$

Ademais, veja-se o exemplo da aviação civil, em que se conhecem os riscos ou os impactos causados por apenas um avião, mas, cumulativamente, a operação de milhares de aviões mundo afora, crescendo de modo exponencial, pode representar danos incertos, imprevisíveis e, ainda, de dificílima - senão impossível - mensuração.

Sem dúvida, estamos claramente diante de uma época de incertezas, usualmente chamada de sociedade de risco, em que se lidam com situações absolutamente incertas e não quantificáveis. Cremos que, bem por isso, o mais correto seria empregar o termo incerteza ao invés de risco. ${ }^{126}$

\footnotetext{
${ }^{125}$ Sabe-se ter ocorrido, após o acidente no Japão, envolvendo a Usina Nuclear de Fukushima, em 2011, inúmeras manifestações na Alemanha e na França, conhecidas geradoras de energia nuclear, contra a instalação e manutenção de usinas dessa natureza.

${ }^{126}$ O Dicionário Aurélio da Língua Portuguesa define risco como "perigo, possibilidade de perigo ou situação em que há probabilidades mais ou menos previsíveis de perda ou ganho"; incerteza como "falta de certeza, hesitação, indecisão, perplexidade, dúvida.” A respeito do melhor vocábulo para caracterizar a era pela qual passamos, se risco ou incerteza, valemo-nos da concepção de Frank Knight. Segundo ele, existe o risco quando não se sabe exatamente o que irá acontecer, mas conhecem-se as chances do que pode acontecer; incerteza é quando não se conhecem nem mesmo as chances do que poderá acontecer. Daniel Farber, também se socorrendo de Knight, diferencia riscos e incertezas da seguinte forma: “'uncertainty' (where the likelihood of the peril is non-quantifiable) and 'risk' (where the likelihood is quantifiable)." Para Farber, as incertezas residem, por exemplo, nas formas de controle e nos possíveis danos gerados pelos gases de efeito estufa; nos meios de adaptação para a inevitável mudança climática; nas dúvidas quanto à regulação da nanotecnologia; nos métodos para administrar seguramente a longa vida do lixo nuclear; e, ainda, nas possibilidades de controle da instabilidade financeira mundial. FARBER, Daniel. Uncertainty. The Georgetown Law Jornal. Vol. 99, p. 901, 2011; UC Berkeley Public Law Research Paper No. 1555343. Disponível em: http://ssrn.com/abstract=1555343, extraído em 13.10.2011. Vale mencionar que o autor alerta que as incertezas não significam completa ignorância. De fato, para ele "Large bodies of data and theory bear on climate change and financial markets, so it is not as if we were operating completely in the dark. The trouble is that, as the quoted statements indicate, our knowledge about potential catastrophic outcomes is much more limited. As to those extreme outcomes, we confront grave uncertainty".
} 
Em outros termos, o risco apresenta-se em uma situação onde é possível verificar, com base em estatística e probabilidade, a possibilidade da ocorrência de determinado evento. Na incerteza, não há cálculos para avaliar seguramente as probabilidades e possibilidades a ser enfrentadas, vez que é absoluto o desconhecimento das consequências de uma determinada situação. Sendo assim, o termo incerteza parece estar mais relacionado com a nossa compreensão atual do risco abstrato. Afinal, nos tempos que passam, considerados a terceira fase da história do risco, há, em verdade, um momento de absoluta incerteza em relação ao porvir. De fato, vê-se uma etapa em que a capacidade da sociedade de prevenir e mensurar os riscos para o meio ambiente em escala planetária parece estar frustrada, de modo que a incerteza em relação ao futuro passa a ocupar um papel central. Em uma palavra, "true uncertainty involves risks that are not well understood, where the range of outcomes is potentially very large, and where probabilities cannot be assigned with confidence”. ${ }^{127}$

Sendo assim, o risco abstrato ou a incerteza não pode ser externalizado, já que ele supera as bases e as categorias do risco concreto, com o qual se tem pensado e atuado até o presente, seja por meio de instrumentos preventivos, mitigatórios ou compensatórios, seja por meio do instituto da responsabilização civil. Em outro dizer, não é possível criar mecanismos de internalização dos custos para arcar com riscos abstratos ou incertos, vez que eles não são sequer perceptíveis.

A bem ver, quando se fala em riscos abstratos ou incertezas, está se querendo referir a eventos como a mudança climática; os riscos da produção nuclear de energia elétrica, notadamente em relação ao destino, perigo e longa duração do lixo nuclear; a cumulatividade de certos impactos (como o caso da aviação civil) e crises financeiras em dimensões globais, como a que se viu em 2008. Ou seja, o risco abstrato ou incerto tem uma estrita relação com a catástrofe e, desse modo, sua gestão deve ser realizada em um âmbito político e

\footnotetext{
${ }^{127}$ FARBER, Daniel. Uncertainty. The Georgetown Law Jornal. Vol. 99, p. 901, 2011; UC Berkeley Public Law Research Paper No. 1555343. Disponível em: http://ssrn.com/abstract=1555343, extraído em 13.10.2011. Para uma apurada análise das diferenças entre as concepções dos termos 'risco' e 'incerteza', vide SETZER, Joana. Panorama do princípio da precaução: o direito do ambiente face aos novos riscos $e$ incertezas. Dissertação (mestrado). Programa de Ciência Ambiental. Universidade de São Paulo-USP, São Paulo, 2007.
} 
governamental, por meio do princípio da precaução e legitimação pela democracia participativa.

\subsubsection{O risco abstrato ou incerto e o princípio da precaução}

Raffaele De Giorgi chama de risco a probabilidade de se poder verificar um dano futuro que a tomada de uma outra decisão teria podido evitar. O risco, para o doutrinador, descreve uma condição estrutural da ação dos sistemas da sociedade moderna. Diz, ainda, que a observação do risco permite ver como os sistemas sociais constroem suas estratégias de absorção da incerteza e, ao mesmo tempo, ver igualmente como a impossibilidade de juridicizar o risco abstrato constitui o atual limite do direito. ${ }^{128}$

De fato, diante das absolutas dificuldades do direito de lidar com riscos abstratos ou incertos, a ordem jurídica internacional cria o princípio da precaução; isso significa a lógica segundo a qual a falta de certezas científicas sobre um determinado risco 'sério', imprevisível e incerto, mas de possíveis dimensões catastróficas, não poderá retardar a adoção de medidas com o escopo de evita-lo ou mesmo minimizá-lo. ${ }^{129}$ Nessa mesma visão Michel Prieur salienta:

Face à l'irréversibilité de certaines atteintes à l'environnement et à l'incertitude scientifique qui affecte des dossiers complexes (diminution de la couche d'ozone, centrales nucléaires et déchets radioactifs, utilisation d'organismes génétiquement modifiés), une nouvelle forme de prévention a été imaginée pour proteger la société contre des risques encore inconnus ou incertains. L'ignorance quant aux conséquences exactes à court ou à long terme de certaines actions ne doit pas servir de prétexte pour remettre à plus tard l'adoption de mesures visant à prévenir la dégradation de l'environnement. Autrement dit, face à l'incertitude ou à la controverse scientifique actuelle, il vaut mieux prendre des mesures de protection sévères à titre de précaution que de ne rien faire. $C^{\prime}$ est en réalité mettre concrètement en oeuvre le droit à l'environnement des générations futures. ${ }^{130}$

\footnotetext{
${ }^{128}$ GIORGI, Raffaele De. Direito, democracia e risco: vínculos com o futuro. Porto Alegre: Sergio Antonio Fabris Editor, 1998, p. 14.

${ }^{129}$ GIORGI, Raffaele De. Ob. cit., p. 56.

${ }^{130}$ PRIEUR, Michel. Droit de l'environnement. 5a ed. Paris: Dalloz, 2004, p. 154.
} 
Neste ponto, é oportuno destacar que o princípio da precaução não se confunde com o princípio da prevenção, este também objeto de análise no item 4.6.1 do Capítulo 4 da presente tese. O primeiro aplica-se ao risco abstrato ou às incertezas, e busca evitar que uma atividade cujo efeito, potencialmente arriscado e que não tenha sido objeto de análise científica conclusiva, venha a ocorrer; o segundo, por seu turno, incide nas situações de risco concreto, em que seus efeitos são conhecidos - inclusive pela ciência -, sendo passíveis de estimativa e mensuração, razão pela qual a eles se aplicam as medidas preventivas, mitigatórias ou compensatórias avaliadas em processos administrativos ou judiciais.

A esse respeito, expõem José Rubens Morato Leite e Patryck de Araújo que, “comparando-se o princípio da precaução com o da atuação preventiva, observa-se que o segundo exige que os perigos comprovados sejam eliminados. Já o princípio da precaução determina que a ação para eliminar possíveis impactos danosos ao ambiente seja tomada antes de um nexo causal ter sido estabelecido com evidência científica absoluta.”131

Acerca da distinção dos princípios, registre-se o fato de terem sido mencionados de forma apartada no Tratado da União Europeia (acrescido pelo Tratado de Maastrich), art. 130, R/2, que assim dispõe: “A política da Comunidade de Domínio do ambiente visará a um nível de proteção elevado, tendo em conta a diversidade das situações existentes nas diferentes regiões da Comunidade. Basear-se-á nos princípios da precaução e da ação preventiva, da correção, prioritariamente na fonte, dos danos causados ao meio ambiente, e do poluidor pagador. As exigências em matéria de proteção do ambiente devem ser integradas na definição e aplicação das demais políticas comunitárias.”

No direito brasileiro, a prevenção está estabelecida no art. 225, §1 ${ }^{\circ}$, inciso V, da Constituição Federal, ${ }^{132}$ e no art. 54, §3º, da Lei $n^{\circ}$

\footnotetext{
${ }^{131}$ LEITE, José Rubens Morato. AYALA, Patryck de Araújo. Dano ambiental: do patrimonial ao coletivo extrapatrimonial: teoria e prática. $4^{\mathrm{a}}$ ed. rev. atual. ampl. São Paulo: RT, 2011, p. 53.

132 "Art. 225. Todos têm direito ao meio ambiente ecologicamente equilibrado, bem de uso comum do povo e essencial à sadia qualidade de vida, impondo-se ao Poder Público e à coletividade o dever de defendê-lo e preservá-lo para as presentes e futuras gerações. $\S 1^{\circ}$ - Para assegurar a efetividade desse direito, incumbe ao Poder Público: (...) V - controlar a produção, a comercialização e o emprego de técnicas, métodos e substâncias que comportem risco para a vida, a qualidade de vida e o meio ambiente”.
} 
9.605/1998, ${ }^{133}$ que penaliza criminalmente quem deixar de adotar medidas preventivas exigidas pelo Poder Público. O princípio da precaução encontra-se consagrado na Lei da Biossegurança, no seu art. $1^{\circ}$ da Lei ${ }^{\circ} 11.105 / 2005 .{ }^{134}$

Poder-se-ia dizer que a precaução se aplica a atividades cujos efeitos são incertos, não havendo avaliação científica suficiente para embasar uma decisão sobre a possibilidade de sua implementação ou não; por sua vez, a prevenção recai quando, sabendo-se quais são os efeitos do projeto ou atividade a ser instalada, exigem-se medidas preventivas para evitar ou mitigar as suas usuais consequências deletérias.

Exemplos típicos da atuação preventiva, conforme será analisado no item 4.6.1 Capítulo 4 desta tese, são os instrumentos do Estudo de Impacto Ambiental e o licenciamento ambiental, tendo ambos como objetivo avaliar e administrar os impactos a serem causados por um empreendimento ou atividade potencialmente poluidora. De igual modo, podem ser citados (i) as medidas preventivas e mitigadoras impostas no decorrer do licenciamento ambiental que, observe-se desde já, também causam repercussões econômicas; (ii) os instrumentos econômicos, visando compor fundos para a proteção ambiental ou, ainda, incentivar condutas 'mais limpas'; e (iii) as referidas medidas processuais preventivas de danos ambientais já apontadas em linhas anteriores. Dessa forma, a prevenção, necessariamente, implica um mecanismo antecipatório do modo de desenvolvimento da atividade econômica, mitigando, avaliando e procurando impedir os seus efeitos ambientais negativos. ${ }^{135}$

\footnotetext{
133 “Art. 54. Causar poluição de qualquer natureza em níveis tais que resultem ou possam resultar em danos à saúde humana, ou que provoquem a mortandade de animais ou a destruição significativa da flora: (...) $\S 3^{\circ}$ Incorre nas mesmas penas previstas no parágrafo anterior quem deixar de adotar, quando assim o exigir a autoridade competente, medidas de precaução em caso de risco de dano ambiental grave ou irreversível”. Observe-se que, embora o dispositivo prescreva medidas de precaução, utiliza erroneamente o termo, pois é a prevenção, como visto, que está ligada a riscos previsíveis, ainda que graves e irreversíveis.

134 "Art. $1^{\circ}$ Esta Lei estabelece normas de segurança e mecanismos de fiscalização sobre a construção, o cultivo, a produção, a manipulação, o transporte, a transferência, a importação, a exportação, o armazenamento, a pesquisa, a comercialização, o consumo, a liberação no meio ambiente e o descarte de organismos geneticamente modificados - OGM e seus derivados, tendo como diretrizes o estímulo ao avanço científico na área de biossegurança e biotecnologia, a proteção à vida e à saúde humana, animal e vegetal, e a observância do princípio da precaução para a proteção do meio ambiente”.

135 LEITE, José Rubens Morato. AYALA, Patryck de Araújo. Ob. cit., p. 56.
} 
Não há dúvidas, pois, quanto ao princípio da prevenção incidir em situações de risco concreto, onde há a possibilidade de a atividade humana causar um impacto ou um dano - conhecidos, diga-se de passagem - ao meio ambiente; isto é, a intervenção a ser causada ao meio ambiente, seja ela danosa, seja ela impactante, tem repercussão conhecida pela ciência.

Já quanto ao princípio da precaução, ele não se dirige às atividades de risco concreto, potencialmente impactantes ou danosas; antes, aplica-se a todas as atividades humanas que geram risco abstrato ou incerto à biodiversidade global e, em última instância, a própria vida no planeta Terra, sobretudo quando não se tem conhecimento científico sobre os seus efeitos adversos. A definição da precaução importa uma moral de ação que leva a tomar decisões para o futuro.

É certo que na aplicação do princípio da precaução, há vinculação à permanência da insuficiência, imprecisão e inconclusão dos dados científicos ou, ainda, ao julgamento de convicção do acentuado potencial de perigo, que impeça a tomada de decisão no sentido de permitir que a sociedade o suporte. ${ }^{136}$ Será sempre, portanto, uma decisão política baseada no fato de inexistir conhecimento científico acerca de uma determinada atividade. Quando houver o conhecimento científico, o risco passa a ser gerenciado pelo princípio da prevenção.

Em suma, o princípio da prevenção é uma conduta racional diante de um mal que a ciência pode objetivar e mensurar, movendo-se no campo das certezas científicas. A precaução ${ }^{137}$, pelo contrário, enfrenta

\footnotetext{
${ }^{136}$ HAMMERSCHMIDT, Denise. O risco na sociedade contemporânea e o princípio da precaução no Direito Ambiental. Revista dos Tribunais. Ano 92. v. 808. Fev. 2003, p. 39-56.

137 Observe-se o fato de o princípio da precaução sofrer diversas críticas, as quais residem sobretudo na circunstância de representar uma moratória indeterminada no tempo ou à interdição de realizar um projeto ou lançar no mercado um produto. Segundo essa órbita, pode-se vincular a precaução a uma inação e dar força argumentativa a quem sustenta que a aplicação do princípio contraria a ideia de progresso, que ela limita ou trava a investigação científica. Os Estados Unidos, por exemplo, sempre foram bastante críticos acerca do princípio da precaução, bastando ver que ele nunca foi de fato adotado de maneira efetiva nesse país, seja legalmente, seja em decisões administrativas ou judiciais. E embora o Governo americano tenha determinado que as agências avaliem as incertas catástrofes discutindo "worst case scenarios", ${ }^{137}$ a base das decisões administrativas que envolvem 'riscos concretos' e/ou 'riscos abstratos' concentra-se na confiança que o país mantém nos tradicionais instrumentos de avaliação de riscos ("risk assessments"). Conforme expõe Daniel A. Farber, "the worst case scenario is a relevant consideration - although not usually decisive - in certain models of decision making under uncertainty". FARBER, Daniel. Uncertainty. The Georgetown Law Jornal. Vol. 99, p. 901, 2011; UC Berkeley Public Law Research Paper No. 1555343. Disponível em: http://ssrn.com/abstract=1555343, extraído em 13.10.2011.
} 
a outra natureza da incerteza: a incerteza do saber científico em si mesmo. $^{138}$

Tendo claras as distinções entre a prevenção e a precaução ${ }^{139}$, fica intuitivo perceber o princípio da precaução sendo invocado em questões bastante controvertidas, que envolvem, por exemplo, a liberação de organismos geneticamente modificados, a radiação nuclear, o buraco na camada de ozônio ou o efeito estufa. ${ }^{140}$ Ainda, a precaução incide quando, do fenômeno da cumulatividade de impactos de determinadas atividades, se evidencia o absoluto desconhecimento dos seus efeitos - como é a situação da aviação civil, citada em linhas acima, ou, ainda, o tráfego intenso por uma hidrovia. Nessas situações, o melhor seria uma decisão em nível global ${ }^{141}$ ou coletiva, que leve em conta o desconhecimento do tema e a vontade da população.

\subsubsection{O risco abstrato ou incerto e a concepção de uma nova responsabilidade civil que prescinda da concretização do dano}

Como se viu, os perigos e as incertezas gerados pela 'sociedade de risco' implicam dúvidas em relação ao futuro. Tal realidade exige a reestruturação do Estado para fazer face às novas demandas criadas por essa nova fase da humanidade, mormente diante da necessidade de uma proteção efetiva ao meio ambiente, a qual não só hospede as futuras gerações, como também permita a manutenção e a reprodução do sistema econômico de mercado.

\footnotetext{
${ }^{138}$ HAMMERSCHMIDT, Denise. O risco na sociedade contemporânea e o princípio da precaução no Direito Ambiental. Revista dos Tribunais. Ano 92. v. 808. Fev. 2003.

${ }^{139}$ É sempre bom anotar que decisões envolvendo o princípio da precaução ou o princípio da prevenção, ou qualquer outra base capaz de conferir dados à tomada de decisão, além dos efeitos ambientais, deve apreciar os efeitos econômicos dali decorrentes. Ou, como aduz Daniel A. Farber, "in making policy decisions, we care not only about physical impacts but also about their economic effects, the cost of mitigating climate change, and the cost of tempering impacts on humans through adaptation measures.” In: FARBER, Daniel. Uncertainty.The Georgetown Law Jornal. Vol. 99, p. 901, 2011; UC Berkeley Public Law Research Paper No. 1555343. Disponível em: <http://ssrn.com/abstract=1555343>. Acesso em: 13.10.2011.

${ }^{140}$ Saliente-se o fato de o princípio da precaução, erroneamente, mas de forma bastante usual, ser suscitado em decisões judiciais para evitar a implantação de empreendimentos, cujos impactos são conhecidos. Há circunstâncias, inclusive, nas quais o princípio da precaução fundamenta decisões que impedem a implantação de empreendimentos em virtude de incompletude de estudos, omissão de informações etc.

${ }^{141}$ Conforme exposto pelo sociólogo Michael Burawoy, em entrevista dada à Folha de S. Paulo, e divulgada na edição de 09.10.2011, “a crise ambiental vai forçar uma resposta em nível global”.
} 
Para alcançar esses objetivos, a atual concepção da responsabilidade civil pouco auxilia. Era isso, aliás, o que discorria Ulrich Beck, quando mencionava não ser possível na sociedade de risco gerenciar as incertezas com base na responsabilidade civil. Ou, conforme Rafaelle De Giorgi, como já exposto, ao alertar que o limite do direito era a incerteza. Nesse sentido, José Rubens Morato Leite e Patryck de Araújo Ayala defendem que “o direito ambiental, especialmente o sistema jurídico da responsabilidade civil, acaba por exercer uma função meramente figurativa na sociedade de risco, operando de forma simbólica diante da necessidade de uma efetiva proteção do meio ambiente.” ${ }^{42}$

No entanto, essa posição não é unânime, bastando ver que parte dos juristas que estudam as formas de reação jurídica aos efeitos da 'sociedade de risco' defende uma revisão da teoria da responsabilidade civil ambiental - hoje prescindindo de culpa, mas exigindo a presença do nexo de causalidade e da concretização do dano - voltada para um sistema onde se passa a não mais exigir o pressuposto da concretização do dano.

Diante dessa concepção, os riscos abstratos e as incertezas, ao serem transpostos para o direito, recebem a denominação de “danos ambientais futuros”; e, segundo seus defensores, ${ }^{143}$ geram uma responsabilidade intergeracional (responsabilidade das gerações atuais para com as gerações futuras), fazendo com que a humanidade passe a gerenciar, por meio da responsabilidade civil, as suas atividades lidando com situações hipotéticas, imprevisíveis e incertas. Nesse sentido, Délton Winter de Carvalho, um desses defensores, ensina: “a partir das mudanças nas estruturas sociais desencadeadas pela utilização massificada da ciência e da técnica para a produção industrial, tem-se a exposição dos processos de tomada de decisão jurídica às situações de risco e perigo, sem a necessidade de concretização de um dano.” ${ }^{44}$

\footnotetext{
${ }^{142}$ LEITE, José Rubens Morato. AYALA, Patryck de Araújo. Dano ambiental: do patrimonial ao coletivo extrapatrimonial: teoria e prática. $4^{\mathrm{a}}$ ed. rev. atual. ampl. São Paulo: RT, 2011, p. 119.

${ }^{143}$ Dentre eles, Délton Winter de Carvalho e Annelise Monteiro Steigleder.

${ }^{144}$ CARVALHO, Délton Winter de. Dano ambiental futuro - a responsabilização civil pelo risco ambiental. Rio de Janeiro: Forense Universitária, 2008, p. 14. Segundo Winter, "o direito passa por enormes dificuldades em responder aos problemas referentes aos 'novos direitos', por deter uma estrutura baseada no individualismo, conflituosidade, na programação condicional (voltada para o passado), em um antropocentrismo restritivo, quando, na verdade, o direito ambiental requer uma teoria do direito epistemologicamente fundamentada no transindividualismo, na solidariedade intergeracional, na
} 
Carvalho, todavia, ao mesmo tempo em que demonstra que a base legal da existência do dano ambiental futuro no direito brasileiro encontra-se no texto do art. 225 da Constituição Federal - cujos termos preveem tanto as presentes quanto as futuras gerações como titulares de direito ao meio ambiente ecologicamente equilibrado - afirma que o sistema jurídico não é capaz de cuidar dessa fase evolutiva da sociedade de risco e do dano ambiental futuro, havendo um verdadeiro “abismo epistemológico entre questões ecológicas e teoria do direito vigente”. Sendo assim, esse autor frisa:

O paradoxo fundamental do direito ambiental consiste exatamente em sua principal função, ou seja, se antecipar aos danos futuros utilizando-se dos instrumentos principiológicos e processuais vigentes. Contudo, em muitos casos que envolvem questões de risco, perigo, ou mesmo de dano ambiental, não há conhecimento científico, nem experiência jurídica anterior para ser tomada em consideração como precedente. Para tanto, o direito ambiental deve criar um instrumental jurídico, suficientemente complexo para lidar com a incerteza das consequências futuras de determinadas atividades, com a complexidade das reações ambientais de danos presentes ou futuros e com o controle e a regulação das inovações tecnológicas. Portanto, pode-se constatar a formação de uma justiça intertemporal, fundada em direitos e obrigações intergeracionais. ${ }^{145}$

Conforme já verificado no item 3.3.1 acima, não há dúvida em relação à evolução do instituto da responsabilidade civil; evolução essa que iniciou com a constatação da ocorrência de danos ambientais e, posteriormente, com as dificuldades de se identificar os seus responsáveis e a sua extensão. E, daí, a teoria do risco - ou a responsabilidade civil objetiva - e a solidariedade.

Essa mesma linha evolutiva permite, hoje, sustentar a necessidade de superação da concepção vigente da responsabilidade civil ambiental objetiva, pois ela não mais estaria dando conta dos danos ambientais futuros, incertos e abstratos decorrentes da atual sociedade de risco. É uma realidade que vem exigindo, segundo seus defensores, uma nova maneira de conceber a responsabilidade civil ambiental, passando os seus pressupostos a ser, unicamente, a ilicitude da conduta e o nexo de causalidade, não havendo mais a

transdisciplinaridade, em um alargamento do antropocentrismo e, acima de tudo, na necessidade de controle e programação do futuro (programação finalística).” CARVALHO, Délton Winter de. Ob. cit., p. 24.

${ }^{145}$ CARVALHO, Délton Winter. Ob. cit., p. 46. 
necessidade de comprovação do dano. Para aqueles que abraçam essa tese, o fundamento jurídico para a aplicação prática desta nova teoria da responsabilidade civil encontraria fulcro no art. 187 do Código Civil de 2002. ${ }^{146}$ A esse respeito, lança-se mão novamente dos ensinamentos de Délton Winter de Carvalho:

Diante da nova estrutura da ilicitude civil, pode ser visto que a probabilidade determinante de um dano ambiental futuro (dano às futuras gerações) desvela-se como ilícito passível de sanção civil, imprimindo a possibilidade de imposição de restrições em razão dos seus custos sociais (Paollo Gallo). Considerando a existência de um "dever de preventividade objetiva” imposto pelo art. 225 da CF, sua violação a partir da produção de riscos ambientais intoleráveis acarreta a configuração de um ilícito ambiental em razão dos custos sociais decorrentes da generalização destes na sociedade (pós-) industrial. Tendo como sustentação normativa os termos do art. 225 da Constituição Federal e a abertura no sentido atribuído à ilicitude civil apresentada pelo art. 187 do Código Civil de 2002 (desnecessidade de comprovação de culpa e dano), o dano ambiental futuro é verdadeira fonte de obrigação civil, que resulta em tutela diversa da mera indenização ou reparação, atuando por meio da imposição de medidas preventivas (de caráter inibitório ou mesmo mandamental). ${ }^{147}$

Para aqueles que seguem a tese da nova concepção da ilicitude do risco abstrato, advogando a sua incorporação por uma nova roupagem da responsabilidade civil, essa concepção decorre do sopesamento de sua probabilidade, irreversibilidade e grau de tolerabilidade (gravidade das possíveis lesões) à qualidade ambiental. Os riscos ilícitos serão aqueles cuja avaliação quanto à sua probabilidade e magnitude lhe conferir a condição de riscos intoleráveis. ${ }^{148}$ Para os seus defensores, os danos ambientais futuros, portanto, são riscos ilícitos, que impõem a adoção de medidas atreladas à responsabilização civil. ${ }^{149}$

\footnotetext{
146 "Art. 187. Também comete ato ilícito o titular de um direito que, ao exercê-lo, excede manifestamente os limites impostos pelo seu fim econômico ou social, pela boa-fé ou pelos bons costumes.”

${ }^{147}$ CARVALHO, Délton Winter de. Ob. cit., p. 150.

${ }^{148}$ Idem, p. 154.

${ }^{149}$ No entanto, como visto no item 3.3.1 acima, essa concepção do caráter preventivo da responsabilidade civil aplica-se, segundo entendemos, aos riscos concretos ou certos e, assim, previsíveis e estimáveis, e não aos riscos abstratos e incertos, tidos aqui como danos ambientais futuros.
} 
Ora, é bastante eloquente sustentar a incidência de um novo princípio da responsabilidade para tutelar os direitos das futuras gerações - ou a ética intergeracional -, sendo ele determinante para adequar o instituto da responsabilidade civil, passando a ser desnecessária a presença efetiva do dano. Ou seja, o risco abstrato ou o dano futuro seriam capazes de acionar os mecanismos da responsabilização civil, cominando ao possível transgressor as sanções decorrentes. A bem ver, vem se considerando que o 'principio da responsabilidade' amplia a função da responsabilidade civil que deve responder satisfatoriamente à necessidade de reparar os danos ambientais futuros a fim de que as gerações que ainda virão possam usufruir da mesma quantidade de recursos naturais, do mesmo bem-estar e igual qualidade de vida de que dispomos hoje. ${ }^{150}$

Tendemos, no entanto, a discordar dessa posição, pois o direito, como já nos disse Beck e De Giorgi, encontra seus limites quando se depara com o risco abstrato ou incerto. De fato, a 'sociedade de risco' ou a 'era das incertezas' impõem uma nova responsabilidade, mas não no sentido de reparação por um dano que não ocorreu, e, sim, uma responsabilidade ética da humanidade pelos riscos abstratos que o desenvolvimento econômico vigente, no modo de produção e consumo impostos, vem causando aos recursos naturais e ao meio ambiente como um todo.

Com efeito, o 'princípio da responsabilidade', introduzido em 1979 por Hans Jonas, é um princípio ético de obrigação moral, que propõe não só uma responsabilidade alargada e estendida no tempo, como também uma responsabilidade elástica, com atuação mais a priori do que a posteriori. Para Jonas, nada se equivale no passado ao que o homem é capaz de fazer no presente e ver-se-á impulsionado a seguir fazendo no exercício irresistível desse seu poder. Em face de novas modalidades de poder, a ética tradicional é incapaz de mostrar o que é bom e mau. “O novo continente da práxis coletiva que adentramos com a alta tecnologia ainda constitui, para a teoria ética, uma terra

\footnotetext{
150 STEIGLEDER, Annelise Monteiro. Responsabilidade civil ambiental: as dimensões do dano ambiental no direito brasileiro. $2^{\mathrm{a}}$ ed. Porto Alegre: Livraria do Advogado, 2011, p. 160.
} 
de ninguém." 151 Por isso, o objetivo do autor é compor uma nova ética, "um tractatus technologicus”. Essa ética, contrariando as tendências filosóficas atuais, conduz à metafísica: se a tecnologia nos traz riscos radicais, é preciso ter coragem para refletir radicalmente; se a ética clássica sempre foi uma "ética de simultaneidade”, necessitamos hoje de uma ética para o futuro, e um futuro que não se aproxime da utopia. ${ }^{152}$

Para Jonas, essa nova ética exige novos imperativos. O imperativo categórico de Kant: “Aja de modo que tu também possas querer que tua máxima se torne lei geral” - valia para o presente. O imperativo proposto por Jonas, adequado ao novo tipo de agir humano e voltado para o novo tipo de sujeito atuante, projeta-se para o futuro: “Aja de modo a que os efeitos de tua ação sejam compatíveis com a permanência de uma autêntica vida humana sobre a Terra”. Quanto à sua implementação, Hans Jonas reconhece que o "princípio da responsabilidade” exigiria mais esforço da esfera pública.

Diferentemente, sob o aspecto jurídico, a ideia de responsabilidade relaciona-se somente com o ato de imputar uma obrigação de fazer ou não fazer, ou uma sanção pecuniária ao causador de um dano. Considerando as regras de responsabilidade civil e os mecanismos legais para exigi-la, percebe-se que a responsabilização pensada pelo direito tem uma finalidade claramente indenizatória, contrapondo-se, portanto, à finalidade antecipatória do princípio responsabilidade (de Hans Jonas), que tem uma relação muito mais ligada ao princípio da precaução. ${ }^{153}$

Sendo assim, temos que o risco abstrato ou incerto não pode ser administrado pelo instituto da responsabilidade civil, uma vez que ele significa eventos invisíveis, incertos, de dimensões inestimáveis - normalmente catastróficas. Portanto, a sua gestão cabe a uma esfera superior, onde se deve decidir em que mundo e em qual sistema econômico as futuras gerações viverão.

\footnotetext{
151 JONAS, HANS. O princípio responsabilidade: ensaio de uma ética para a civilização tecnológica. Trad. Marijane Lisboa e Luiz Barros Montez. Rio de Janeiro: Contraponto: Ed. PUC-Rio, 2006, p. 21.

152 SETZER, Joana. Panorama do princípio da precaução: o direito do ambiente face aos novos riscos e incertezas. Dissertação (mestrado). Programa de Ciência Ambiental. Universidade de São Paulo-USP, São Paulo, 2007, p. 72.

153 SETZER, Joana. Ob. cit., p. 76.
} 
3.3.4.3 O risco abstrato ou incerto e a tutela do direito das futuras gerações

Conforme será pontuado no item 4.2.1 do Capítulo 4 desta tese, o discurso do desenvolvimento sustentável evoluiu para o que se chama hoje de direito das futuras gerações ou ética da equidade intergeracional. ${ }^{154}$

Esse discurso usualmente aparece frente às obras de grande porte (como a Usina Hidrelétrica de Belo Monte), que causam inevitáveis e significativos impactos negativos ao meio socioambiental, os quais, como visto, devem ser caracterizados como risco concreto, porquanto os seus impactos são conhecidos, mensuráveis e estimáveis, sendo possível administrá-los com fulcro no princípio da prevenção. Nessas situações, verificam-se, na prática, argumentos tendentes a impedir a concretização dos impactos com base no direito das futuras gerações de desfrutarem da mesma qualidade ambiental oferecida às presentes gerações.

O argumento quanto à violação do direito das futuras gerações (ou ética da equidade intergeracional) também se fulcra na nova definição de risco abstrato (trazida, conforme já visto neste estudo, por Ulrich Beck em seu conceito de 'sociedade de risco'), que exige a imposição de limites aos avanços do desenvolvimento econômico, sob pena de fazer perecer, em um futuro próximo, a própria humanidade. Para Raffaele De Giorgi, o risco é um paradoxo constitutivo da modernidade da sociedade contemporânea, como um vínculo com o futuro que possibilita o agir em condições de desconhecimento em que são feitas escolhas no presente. ${ }^{155}$

Em suma, pretende-se introduzir a ética da equidade intergeracional em cada decisão do presente, inclusive em relação aos impactos conhecidos, previstos e mensuráveis, levando em consideração seus possíveis efeitos sobre as gerações futuras. Não vemos, todavia, possibilidade na lógica desse pensar.

\footnotetext{
${ }^{154}$ A ética da equidade intergeracional já foi incorporada pelo ordenamento jurídico pela Constituição Federal (art. 225), ao determinar a obrigação de defender e preservar o meio ambiente 'para as presentes e futuras gerações'.

${ }^{155}$ GIORGI, Raffale De. O risco na sociedade contemporânea. Revista de Direito Sanitário. São Paulo, v. 9, n.1, p. 37-49, mar/jun. 2008.
} 
Para tanto demonstrar, evidencie-se não haver realmente dúvidas de que a sociedade pós-moderna (ou a 'sociedade de risco') exige uma avaliação a mais diante do irracional modelo de desenvolvimento econômico, que vem impondo, em âmbito global, o risco de impossibilitar a manutenção de um meio ambiente sadio e capaz de comportar a vida para as futuras gerações. Ou, em outros termos, é irrefutável que a intensa, irracional e insustentável exploração dos recursos naturais, necessários para a manutenção e evolução do sistema econômico vigente, confronta com a obrigação de preservar o meio ambiente, podendo, caso contrário, levar à destruição da própria vida na Terra.

Tem-se, na verdade, que a ponderação do risco abstrato, juntamente com o 'princípio da responsabilidade' e com a ética da equidade intergeracional, exige que o homem pense ou reflita a respeito das próprias bases do sistema econômico de produção e consumo implantado na maior parte dos países ocidentais ${ }^{156}$. De fato, as dúvidas relativas ao “como faremos daqui em diante?” ou, “é possível permanecer explorando os recursos naturais como fazemos, máxime pelo evidente exaurimento de fontes absolutamente necessárias para manter a saúde e a vida das futuras gerações?”, pertencem a uma opção muito maior do que evidenciar os impactos - conhecidos - de obras necessárias para o sistema econômico vigente se manter e se reproduzir.

Em razão do propalado risco abstrato ou incerto decorrente da intensa e irracional exploração dos recursos naturais para manter e se reproduzir o sistema de produção e consumo vigentes, gerando dúvidas - para alguns, certeza - sobre a possibilidade de vida para as futuras gerações, o homem hodierno deve decidir se quer manter seu estilo egoístico e individualista, se quer continuar a usufruir do conforto da luz elétrica, do ar condicionado, do uso do carro, do lucro etc; tudo isso em detrimento da qualidade ambiental das gerações futuras.

Em verdade, a compreensão do risco abstrato e o advento da ética da equidade intergeracional impõem ao ser humano a avaliação quanto à viabilidade da manutenção do crescimento econômico nos moldes atuais, ou

\footnotetext{
${ }^{156}$ Mencione-se, por oportuno, não ser apenas o sistema de mercado capaz de levar ao exaurimento dos recursos naturais. De fato, isso pode ocorrer em qualquer espécie de sistema econômico - inclusive nos centralizados - caso se evidencie uma irracional utilização do meio ambiente.
} 
seja, um desenvolvimento inserido num veloz sistema de produção e consumo numa sociedade mercantilista em escala mundial. Essa avaliação, no entanto, encontra-se em um momento anterior e em uma esfera superior, não condizente com a avaliação do risco concreto verificado em projetos e atividades com impactos conhecidos e estimados, e cujo comando fica ao encargo de órgãos públicos, administrativos. Em verdade, o risco abstrato e a ética intergeracional exigem da presente geração uma decisão sobre se quer manter o modelo de produção e consumo vigentes, sobretudo face ao evidente exaurimento dos recursos naturais. Isso significa não ser cabível impor ao administrador público, no decorrer do licenciamento ambiental, e com base no princípio da precaução ou na ética da equidade intergeracional, a apreciação da viabilidade ambiental ou não de um determinado empreendimento em razão dos possíveis riscos abstratos capazes de ser causados, inclusive com prejuízos para as futuras gerações. Afinal, como dito, essa decisão é anterior, e deve permear o debate político e governamental, preferencialmente baseado no princípio da precaução e centrado na participação pública.

Em outros termos, não compete às agências e aos órgãos administrativos de controle definir, por conta própria, se o empreendimento e/ou atividade que se pretende implantar ou operar cumprem preceitos morais, como aqueles vinculados à ética da equidade intergeracional. A esse respeito, Eric Posner discorre:

How can this be? The answer is that agencies act within a thick institutional and political environment that bars them from directly implementing moral precepts - or that would result in perverse outcomes if agencies did try to directly implement moral precepts. The discount rate that agencies should use is not the theoretically ideal discount rate but the discount rate that generates the best outcomes in a world in which agencies do not have complete freedom of action.

This argument rests on the basic distinction between moral goals and decision procedures, a distinction from which all of the authors under consideration abstract. ${ }^{157}$

\footnotetext{
${ }^{157}$ POSNER, Eric. Agencies should ignore distant-future generations. The University of Chicago law review. 74:139, 2007.
} 
Desse modo, é bastante claro serem morais os preceitos do direito das futuras gerações ou da ética da equidade intergeracional. Não há como impor normas que tutelem o direito do futuro, salvo por meio de princípios - muito mais morais do que jurídicos -, os quais devem permear as decisões governamentais e políticas. Pode-se, inclusive, sustentar serem preceitos, visando, mais uma vez, escamotear o paradoxo entre as bases do sistema econômico de mercado e as determinações cada vez mais emergentes de proteção dos recursos naturais. De fato, como se verá no próximo capítulo, iniciando com o desenvolvimento sustentável e, hoje, no direito das futuras gerações, vê-se um discurso absolutamente desconectado da realidade em que vivemos.

Acerca dessa inafastável realidade, vale questionar: É possível imaginar as presentes gerações abrindo mão dos bens que usufruem, da sua propriedade, do seu direito de consumo, em prol de gerações futuras, para legitimar decisões governamentais nesse sentido? É possível observar a sociedade atual, que não tem sequer ética com a própria geração, lutar pelos direitos das futuras gerações? Pode-se imaginar pessoas que não se indignam com a dimensão da miséria, da violência, da fome, ou com crianças dormindo na rua, dignando-se a defender os direitos básicos das futuras gerações? É crível supor uma pessoa que passa desapercebidamente por uma criança dormindo na rua, preocupandose com os direitos de uma criança que ainda não nasceu?

Aliás, é válido ainda perguntar: Qual qualidade ambiental se quer proteger para as futuras gerações? A qualidade que usufruem as camadas mais abastadas ou aquela em que são obrigados a viver as populações mais pobres, geralmente as que sofrem com a injustiça ambiental?

Assim, se as atuais gerações, que votam, que consomem, que legitimam decisões governamentais, não se preocupam com as futuras gerações, como, então, pretender legitimar decisões governamentais que defendam os direitos das que virão? Justamente sobre esse ponto Eric Posner frisa: “intertemporal egalitarianism is possible only if voting members of the current generation weight the interests of future persons to the same extent as they weight their own interests."

\footnotetext{
${ }^{158}$ POSNER, Eric. Ob. cit. Sobre as dificuldades constatadas para a tutela dos direitos das futuras gerações, esse autor frisa: "suppose, for sake of argument, that the government's proper goal is maximization of social
} 
Exemplificativamente, vale citar o conhecido e recente caso envolvendo a presença e liberação de gás metano no Shopping Center Norte, amplamente divulgado em meados de setembro e final de outubro de 2011 pela mídia paulistana. Houve notícias claras de que os lojistas não estavam preocupados com os riscos de explosão, e manifestaram-se de forma indignada e contrários ao fechamento desse centro comercial. E não podia ser diferente, pois os custos das suas lojas, as já efetuadas aquisições de produtos para comercialização, o vencimento do salário de seus funcionários e dos tributos ligados à atividade permaneciam inalterados, sendo eles então que se sentiam onerados por uma ventilada omissão ou negligência dos proprietários ou administradores do Shopping Center. O mesmo sucede quando as atuais gerações são postas à frente das futuras gerações: Quem arcará com custos ou prejuízos atuais para beneficiar gerações futuras? Será que o governo - atual - tomará decisões que contrariem interesses das gerações atuais em prol das gerações futuras? Sobretudo ao considerar que os governantes são eleitos pelas gerações atuais?

Por conseguinte, o risco abstrato ou as incertezas, o direito das futuras gerações ou a ética intergeracional estão em um campo onde todos os seres humanos irão enfrentar-se para uma decisão que culminará em um divisor de águas, qual seja, manter o atual sistema econômico vigente ou partir para outra opção social - se é que essa decisão seja possível.

welfare, where the social welfare function includes future generations as well as the current generation and weights the utility of all individuals equally, regardless of when they live. It follows from the arguments discussed by Kaplow and others that the government should use a discount rate based on the opportunity cost of capital. This ensures that the marginal utility of individuals will be equalized regardless of when they live. A benevolent dictator - that is, a government that acts in the morally perfect way - would do just this. But the real government is not a benevolent dictator. It is constrained by numerous factors, of which I emphasize two. First, because officials with political power are elected, they must choose policies that at least toughly please the public of important constituents. They cannot choose morally ideal policies unless the public seeks morally ideal outcomes. The 'public' here will be taken to consist of people who have the vote and thus can affect the electoral success of current government officials. Thus, the public excludes future generations. Second, because governance is complex, the government must divide itself into multiple institutions, each of which has jurisdiction over a different set of problems". 


\subsubsection{A gestão do risco abstrato pela democracia participativa}

Como resposta para os problemas e obstáculos que se apresentam à concretização do ideal de proteger o ambiente, todos direta ou indiretamente relacionados com o reconhecimento dos efeitos da irresponsabilidade organizada, José Rubens Morato Leite e Patryck de Araújo Ayala sugerem uma proposta tendente a superar as dificuldades decorrentes da reprodução dos riscos. Para os autores, essa sugestão concentra-se

[no] desenvolvimento acentuado e progressivo de cada vez mais espaços, procedimentos, instrumentos e comportamentos relacionados à dimensão participativa no espaço público de tomada de decisões.

A proposta insere-se em um esquema de indução e provação de ações estaduais e privadas, no sentido de redefinição do modelo de cidadania, seja numericamente, na extensão de seu conteúdo em sua qualidade, para um modelo de participação, que implica a superação do projeto da representação, próprio da modernidade liberal, para corrigi-la e conforma-la ao novo Estado de Direito Ambiental, que exige uma cidadania autenticamente ambiental, cidadania esta que só se realiza se organizada em torno da necessária realização de um complexo e multifacetado feixe de espécies de direitos, que com ele se relacionam de modo interdependente.

Esse modelo específico de cidadania tensiona o poder de modo a exigir seu deslocamento para as instâncias e espaços onde se verificam as situações de criação de riscos e exposição a ameaças, proporcionando o desenvolvimento de faces de responsabilidade mais poderosas a essa proposta cidadã de participação. ${ }^{159}$

A respeito da participação democrática ou democracia participativa, tivemos, em outro estudo, a oportunidade de avaliar os seus limites e possibilidades como mecanismo de proteção ambiental. ${ }^{160}$ Sobre o assunto, portanto, verificamos, em síntese, que as mazelas decorrentes da exploração irracional dos recursos naturais transcendem a perda de rentabilidade do processo econômico e atingem toda a sociedade, mormente as classes menos

\footnotetext{
${ }^{159}$ LEITE, José Rubens Morato. AYALA, Patryck de Araújo. Direito ambiental na sociedade de risco. Rio de Janeiro: Forense Universitária, 2002, p. 108.

160 ARTIGAS, Priscila Santos. Os limites da democracia participativa na defesa do meio ambiente. Dissertação de Mestrado, Departamento de Filosofia e Teoria Geral do Direito. Faculdade de Direito da Universidade de São Paulo - USP. Maio/2008.
} 
privilegiadas (o que se chama de injustiça ambiental). Isso implica o surgimento de novas demandas, tidas como coletivas ou difusas, consideradas como direitos de terceira geração, em que não mais se protege o indivíduo isolado, mas um grupo, como o povo, a nação, as coletividades étnicas, com desdobramento nas futuras gerações etc.

Diante desse amplo contexto, emergem as normas do Direito Ambiental, dentre elas a que garante a democracia participativa na gestão e na proteção dos recursos naturais. A democracia participativa incide em razão de a democracia representativa encontrar limites para legitimar decisões que envolvem direitos difusos e coletivos.

Com efeito, verifica-se ser a democracia liberal caracterizada, em síntese, por um corpo restrito de representantes eleitos por cidadãos a quem são reconhecidos direitos universais de cunho político, social, civil e, mais recentemente, ambiental. O sistema representativo, no entanto, está absolutamente limitado devido às novas demandas, onde estão incluídos os direitos ao meio ambiente em condições de garantir uma sadia qualidade de vida às presentes e futuras gerações.

Basta ver, exemplificativamente, as novas demandas ambientais não possibilitando mais decisões homogêneas, mas, sim, soluções isoladas e específicas para cada caso. Além disso, essas demandas exigem um conhecimento técnico e social específico, não apropriável pelos representantes eleitos e que atuam de forma centralizada, em função de uma dada dinâmica política.

Assim sendo, a democracia participativa manifesta-se como um mecanismo realmente valioso, em condições de dar voz às forças capazes de se contraporem aos interesses predominantes, conscientizando no sentido de mobilizar e unir a maioria desprivilegiada e, consequentemente, trazendo-lhe mais benefícios e esperanças. Desse modo, então, a democracia participativa, no contexto de uma globalização econômica e cultural, é tida como um mecanismo que pode proporcionar a defesa ambiental, inclusive para as futuras gerações; além do que, permite oferecer alento e esperança para os menos favorecidos - usualmente os que mais sofrem com a exploração irracional dos 
recursos naturais - que, por vezes, podem ter suas demandas atendidas de forma mais direta. Quanto a isso, Enrique Leff expõe:

\begin{abstract}
os princípios de gestão ambiental e de democracia participativa propõem a necessária transformação dos Estados nacionais e da ordem internacional para uma convergência dos interesses em conflito e dos objetivos comuns dos diferentes grupos e classes sociais em torno do desenvolvimento sustentável e da apropriação da natureza. ... A gestão ambiental participativa está propondo, além da oportunidade de reverter os custos ecológicos e sociais da crise econômica, a possibilidade de integrar a população marginalizada num processo de produção para satisfazer suas necessidades fundamentais, aproveitando o potencial ecológico de seus recursos ambientais e respeitando suas identidades coletivas. ${ }^{161}$
\end{abstract}

Por conseguinte, são claras as vantagens da democracia participativa, mormente ao possibilitar a conscientização, a mobilização, a informação e a educação de todos, sobretudo das classes menos privilegiadas - as mais atingidas pela injustiça ambiental -, fazendo com que, por vezes, vejam seus interesses tutelados.

Ao conscientizar, mobilizar, informar e educar, a prática da democracia participativa tem a força modificadora do ser humano e, por isso, de modificar a maneira como se relaciona com o meio ambiente. Ao participar, o homem tem condições de se educar, de se informar e, mais, de aprender a se mobilizar para buscar melhores condições socioambientais para si e para a sociedade.

Por certo, há inúmeras dificuldades à prática da democracia participativa. ${ }^{162}$ Dentre tais dificuldades, vale citar a própria inércia do cidadão que, preocupado com seus interesses pessoais, não tem vontade - nem tempo para procurar discutir assuntos que dizem respeito à coletividade. Além disso, como se pode supor educar ambientalmente pessoas que sequer têm educação básica? Ainda, constata-se o desestímulo do próprio poder econômico em

\footnotetext{
${ }^{161}$ LEFF, Enrique. Saber ambiental. Trad. Lúcia Mathilde Endlich Orth. $5^{\text {a }}$ ed. Petrópolis: Vozes, 2001, p. $62-63$.

${ }^{162}$ Uma análise ampla de tais dificuldades para a democracia participativa foi feita em nossa dissertação de Mestrado: ARTIGAS, Priscila Santos. Os limites da democracia participativa na defesa do meio ambiente. Dissertação de Mestrado, Departamento de Filosofia e Teoria Geral do Direito. Faculdade de Direito da Universidade de São Paulo - USP. Maio/2008.
} 
proporcionar a abertura de espaços para a efetiva participação popular, uma vez que, isso pode levar, eventualmente, à legitimação de decisões estatais que contrariem os seus interesses. Outrossim, há obstáculos mais técnicos, conforme suscitado por Dahl, os quais impõem sérias dificuldades a qualquer modelo mais participativo de democracia, como (i) a dificuldade de implementar assembleias diretas em democracias de larga escala diante do tempo que cada membro terá para expressar suas posições ou pela ascensão natural de lideranças não eleitas e (ii) a complexidade das sociedades modernas, que exigem a otimização do tempo para a tomada de decisões eficientes. ${ }^{163}$

Uma forma de contornar - ainda que parcialmente - tais dificuldades, se dá por meio do estabelecimento de regras objetivas a respeito dos mecanismos de implementação da participação, abrindo, por meio de normas jurídicas ${ }^{164}$, espaços participativos. Vale dizer, para que a democracia participativa tenha um viés prático, torna-se necessário instituir um procedimento geral para fixar quem poderá participar e de que forma será a participação. A esse respeito, Norberto Bobbio, ao ensaiar uma definição para a democracia, propõe-na como sendo um conjunto de regras (primárias ou fundamentais) que estabelecem quem está autorizado a tomar as decisões coletivas e quais procedimentos a serem seguidos. ${ }^{165}$ Nesse mesmo caminho, Habermas assim expõe: “o desabrochar da política deliberativa não depende de uma cidadania capaz de agir coletivamente e sim da institucionalização dos correspondentes processos e pressupostos

\footnotetext{
${ }^{163}$ DAHL, Robert. On democracy. New Haven: Yale University Press, 1998.

${ }^{164}$ Cumpre sublinhar, então, o fato de o ordenamento jurídico brasileiro já dispor de espaços instituídos para a participação popular voltada especificamente para a gestão de recursos ambientais. Segundo Álvaro Valery Mirra, esses espaços se apresentam de três formas. A primeira é a própria existência da legislação ambiental, derivada da possibilidade da iniciativa popular (art. 61, caput e $\S 2^{\circ}, \mathrm{CF} / 88$ ), da realização de referendo sobre as leis (art. 14, II, CF/88) e da atuação de representantes da sociedade civil em órgãos colegiados com poderes normativos. A segunda é mediada pelo Poder Judiciário, que pode assegurar in concreto o equilíbrio de um ecossistema, nos casos em que este for ameaçado ou danificado. Na terceira, temos que os cidadãos podem participar da construção e execução de políticas ambientais. Isto é feito por intermédio da representação em órgãos colegiados relacionados com tais objetivos; por outra parte, através da co-atuação junto a instituições públicas e privadas nos diversos procedimentos deliberativos sobre questões ambientais. MIRRA, Álvaro. Princípios Fundamentais do Direito Ambiental. In: OLIVEIRA Jr., José Alcebíades, LEITE, José Rubens Morato (orgs.). Cidadania coletiva. Florianópolis: Paralelo, 27, 1996.

165 BOBBIO, Norberto. O futuro da democracia. Trad. Marco Aurélio Nogueira. $8^{\text {a }}$ ed. São Paulo: Editora Paz e Terra, 2002, p. 30.
} 
comunicacionais, como também do jogo entre deliberações institucionalizadas e opiniões públicas que se formaram de modo informal”. ${ }^{166}$

Mencione-se, ainda, um instrumento amplamente utilizado na gestão ambiental, denominado audiência pública ${ }^{167}$, considerada o foro adequado criado pelas normas ambientais. Aos afetados por uma determinada atividade econômica ou empreendimento que ser quer implantar, seja no meio rural, seja em âmbito urbano, tal instrumento proporciona a oportunidade de se informarem, questionar, criticar, condenar, apoiar, adotando, enfim, a posição que julgar oportuna ${ }^{168}$ e conveniente.

A bem ver, a audiência pública é considerada (e efetivamente é) um importantíssimo instrumento de gestão do meio ambiente. É suficiente observar como ela visa considerar o empreendimento sob a ótica direta e final do respeito à comunidade e ao meio ambiente. Nesse sentido, ela deve contribuir para os necessários ajustes do projeto e dos possíveis impactos positivos e negativos ao meio ambiente. De igual modo, ela deve proporcionar, então, ideias, argumentos e sugestões ditadas pelo interesse da população. ${ }^{169}$

\footnotetext{
${ }^{166}$ HABERMAS, Jurgen. Direito e democracia: entre facticidade e validade, vol. II. Trad. Flávio Beno Siebeneichler. Rio de Janeiro: Tempo Brasileiro, 1997, p. 21.

${ }^{167}$ A audiência pública está regulamentada na Resolução CONAMA n ${ }^{0}$ 009, de 3.12.1987, que disciplinou sua finalidade, sua iniciativa, os prazos e procedimento em matéria ambiental, prescrevendo ainda que a sua intenção maior era "expor aos interessados o conteúdo do produto em análise e do seu referido RIMA, dirimindo dúvidas e recolhendo dos presentes críticas e sugestões a respeito" (art. 1). Observe-se que a audiência pública também é um dos instrumentos da gestão democrática da cidade, conforme estabelecido na Lei $\mathrm{n}^{0}$ 10.257/2001 (Estatuto da Cidade). Esse diploma legal determina a obrigatoriedade da realização de audiência pública do Poder Público municipal e da população interessada nos processos de implantação de empreendimentos ou atividades com efeitos potencialmente negativos sobre o meio ambiente natural ou construído, o conforto e a segurança da população.

${ }^{168}$ É na audiência pública que se tem a oportunidade de convergir diversas percepções e opiniões sobre os impactos que estão sendo causados. A respeito, Luiz Roberto Tommasi expõe que "a primeira e mais importante preocupação de uma comunidade conscientizada é quanto aos efeitos sobre sua saúde e segurança. Outra preocupação que poderá atingir especialmente os ambientalistas, é quanto à perda de espécies raras, em risco de extinção. Para outros, serão as espécies de interesse comercial e recreacional (pesca esportiva, por exemplo). Os ecologistas se preocuparão (e com muita razão) por perdas de habitats! A percepção do ambiente por uma comunidade é frequentemente diferente daquela que autoridades locais ou nacionais.” TOMMASI, Luiz Roberto. Estudo de impacto ambiental. São Paulo: CETESB: Terragraph Artes e Informática, 1993, p. 17.

${ }^{169}$ A audiência pública é defendida como o instrumento de garantia para o efetivo exercício dos princípios da publicidade e da participação comunitária, na linha do comando estabelecido pela Constituição Federal. Nesse sentido, MILARÉ, Édis. Direito do ambiente. $7^{\text {a }}$ ed. São Paulo: RT, 2011.
} 
Não obstante as dificuldades citadas, é certo dizer que a prática da democracia participativa pode gerar as condições necessárias para uma apropriação mais equitativa dos recursos ambientais e para uma gestão mais participativa dos povos no aproveitamento dos recursos naturais e produtivos ${ }^{170}$, inclusive no que concerne aos riscos abstratos ou as incertezas e ao futuro da humanidade.

\subsection{As diferentes concepções de dano ambiental e de impacto negativo ao meio ambiente}

Como visto acima, as concepções de dano ambiental e de impacto no meio ambiente encontram-se na fase do risco concreto, em que é possível, hoje, averiguar, no campo da estatística e da probabilidade, o grau de possibilidade da sua ocorrência e os efeitos deles decorrentes. Por conseguinte, quando se fala nesta tese de dano ambiental e impacto negativo no meio ambiente, quer-se referir ao campo das certezas e probabilidades, estando absolutamente dissociado da concepção de risco e incerteza trazidos pela nova fase pela qual passa a humanidade, conhecida, como se viu, como 'sociedade do risco' ou ‘sociedade das incertezas'. Assim, a partir de agora, o risco abstrato ou incerto será deixado de lado neste estudo.

Outro tanto, também se aludiu terem as medidas compensatórias o objetivo de compensar as perdas ambientais pelos impactos negativos e não mitigados a ser provocados por empreendimentos ou atividades lícitos e devidamente licenciados.

Assim, para bem apreender a forma como devem ser instituídas e aplicadas as regras que fundamentam as medidas compensatórias, faz-se necessário, antes, precisar o conceito de impacto no meio ambiente, a fim de não confundi-lo com danos, poluição e degradação, cujos efeitos requerem uma reação jurídica absolutamente diversa.

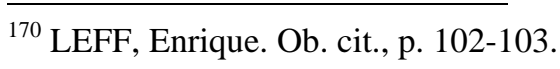


Na verdade, como já mencionado, tem sido encontrada uma enorme dificuldade em estabelecer os conceitos - e a diferenciação entre eles - dos termos impacto, dano, poluição e degradação. Nesse sentido, Luiz Enrique Sánchez expõe que “a locução 'impacto ambiental' é encontrada com frequência na imprensa e no dia-a-dia. No sentido comum, ela é, na maioria das vezes, associada a algum dano à natureza”. ${ }^{171}$ Além disso, também é normal verificar textos doutrinários que confundem sobremaneira os conceitos de impacto e dano com as definições de degradação e de poluição.

Buscando, portanto, estabelecer uma distinção epistemológica e com fins didáticos dos conceitos de impacto, dano, poluição e degradação, vale lembrar, de início, o fato de qualquer atividade do homem (ação antrópica ${ }^{172}$ ) ser capaz de alterar, de alguma maneira, o meio ambiente. São alterações desejadas ou não, significantes ou insignificantes, positivas ou negativas. Afastando-se os aspectos positivos, é certo dizer serem o impacto ou o dano as mudanças provocadas no meio ambiente, ambos podendo causar poluição ou degradação.

De efeito, é possível definir, até por intuição, serem o impacto negativo ou o dano os fatos, enquanto que a poluição ou a degradação são as suas consequências. Ou seja, um impacto negativo pode ser poluidor ou degradador, como também o dano pode ser poluidor ou degradador. Didaticamente, no entanto, compreendemos o dano e o impacto como os fatos, enquanto a poluição e a degradação são suas consequências negativas, sendo profícuo estabelecer a consequência degradação ligada ao impacto negativo no meio ambiente, enquanto o efeito poluição deve ser relacionado com o dano ambiental.

A legislação brasileira, notadamente a Resolução CONAMA nº 001/1986, que estabeleceu o procedimento do Estudo de Impacto Ambiental - EIA, não é clara em relação às noções de impacto ambiental e de dano ambiental. De fato,

\footnotetext{
${ }^{171}$ SÁNCHEZ, Luiz Henrique. Avaliação de impacto ambiental: conceitos e métodos. São Paulo: Oficina de Textos, 2008, p. 28.

${ }^{172}$ Ação antrópica: "uma forma de presença ativa do ser humano junto aos demais seres que o cercam e nos quais imprima a sua característica." COIMBRA, José de Ávila Aguiar. O outro lado do meio ambiente. Campinas: Millenium, 2002, p. 281. Neste ponto, vale recordar, conforme nos ensina Luiz Roberto Tommasi, o fato de os recursos naturais sofrerem efeitos não apenas da mão do homem, mas também da própria natureza, a qual pode, inclusive, impor paroxismos extremamente calamitosos aos próprios ecossistemas. TOMASSI, Luiz Roberto. Estudo de impacto ambiental. São Paulo: CETESB: Terragraph Artes e Informática, 1993, p. 13.
} 
esse diploma reza ser o impacto ambiental "qualquer alteração das propriedades físicas, químicas ou biológicas do meio ambiente, causada por qualquer forma de matéria ou energia resultante das atividades humanas, que direta ou indiretamente afetem: I - a saúde, a segurança e o bem-estar da população; II as atividades sociais e econômicas; III - as condições estéticas e sanitárias do meio ambiente; IV - a qualidade dos recursos ambientais”.

Vale notar, ainda, a similaridade do conceito acima de impacto ambiental, introduzido pela Resolução CONAMA nº 001/1986, com a definição de poluição estabelecida na Política Nacional de Meio Ambiente (Lei $\mathrm{n}^{\circ}$ 6.938/1981), segundo a qual esse termo significa “a degradação da qualidade ambiental resultante de atividades que direta ou indiretamente: a) prejudiquem a saúde, a segurança e o bem-estar da população; b) criem condições adversas às atividades sociais e econômicas; c) afetem desfavoravelmente a biota; d) afetem as condições estéticas ou sanitárias do meio ambiente; e) lancem matérias ou energia em desacordo com os padrões ambientais estabelecidos”. ${ }^{173}$

A respeito do conceito de impacto ambiental prescrito na referida Resolução CONAMA n 001/1986 e da sua aparente relação com a definição de poluição da Política Nacional de Meio Ambiente, Luiz Enrique Sánchez assim se manifesta:

salta aos olhos, no caso brasileiro, a impropriedade dessa definição, que felizmente não é levada ao pé da letra na prática da avaliação de impacto ambiental nem é tomada em seu sentido estrito na interpretação dos tribunais. Trata-se de uma definição de poluição, como se observa pela menção a 'qualquer forma de matéria ou energia' como fator responsável pela 'alteração das propriedades físicas, químicas ou biológicas’ do ambiente. Paradoxalmente, a definição de poluição dada pela Lei da Política Nacional do Meio Ambiente reflete melhor o conceito de impacto ambiental, embora somente no que se refere a impacto negativo. Como se sabe, o impacto ambiental também pode ser positivo. ${ }^{174}$

Evidentemente, as então incipientes noções de poluição e impacto, introduzidas pela Política Nacional de Meio Ambiente (Lei n ${ }^{\circ}$ 6.938/1981) e

\footnotetext{
${ }^{173}$ Art. $3^{\circ}$, III.

${ }^{174}$ SANCHEZ, Luiz Henrique. Ob.cit., p. 30-31.
} 
pela Resolução CONAMA n 001/1986, devem ser interpretadas em consonância com a nova moldura estabelecida pela Constituição Federal de 1988, a qual tratou o impacto ambiental como a degradação ao meio ambiente, determinando, ainda, que, quando essa degradação for significativa, a instalação da obra ou da atividade a ela correlata deverá ser precedida de estudo prévio de impacto ambiental. É o que dispõe o art. 225, §1 ${ }^{\circ}$, inciso IV, da Lei Maior, in verbis:

Art. 225. Todos têm direito ao meio ambiente ecologicamente equilibrado, bem de uso comum do povo e essencial à sadia qualidade de vida, impondo-se ao Poder Público e à coletividade o dever de defendê-lo e preservá-lo para as presentes e futuras gerações.

$\S 1^{\circ}$ Para assegurar a efetividade desse direito, incumbe ao Poder Público:

(...)

IV - exigir, na forma da lei, para instalação de obra ou atividade potencialmente causadora de significativa degradação do meio ambiente, estudo prévio de impacto ambiental, a que se dará publicidade.

Como se vê, a Constituição Federal fala em degradação ambiental, o que já era tratado pela mencionada Política Nacional de Meio Ambiente (Lei $\mathrm{n}^{\circ}$ 6.938/1981) como a “alteração adversa das características do meio ambiente”. Assim, considerando, de um lado, a Carta Maior entendendo o impacto ambiental como a degradação ao meio ambiente e, de outro lado, a Lei $\mathrm{n}^{\circ}$ 6.938/1981 conceituando degradação como a alteração adversa das características do meio ambiente, é possível concluir ser impacto negativo qualquer alteração adversa, significativa ou não, das características do meio ambiente, por atividades ou empreendimentos lícitos. ${ }^{175}$

\footnotetext{
${ }^{175}$ Conforme nos ensina Luiz Roberto Tommasi, “o 'Glossário de Ecologia' da ACIESP (1987) define impacto ambiental como ...'toda ação ou atividade, natural ou antrópica, que produz alterações bruscas em todo meio ambiente ou apenas em alguns de seus componentes. De acordo com o tipo de alteração, pode ser ecológico, social ou econômico." O mesmo autor ensina que "segundo o ‘Federal Environmental Assessment Review Office' (FEARO, 1979), impacto ambiental são processos que perturbam, descaracterizam, destroem características, condições ou processos no ambiente natural; ou que causam modificações nos usos instalados, tradicionais, históricos, do solo e nos modos de vida ou na saúde de segmentos da população humana; ou que modifiquem de forma significativa, opções ambientais.” TOMMASI, Luiz Roberto. Estudo de impacto ambiental. São Paulo: CETESB: Terragraph Artes e Informática, 1993, p. 14.
} 
O dano, por sua vez, é a lesão ilícita e indesejada nos recursos ambientais, com consequente poluição prejudicial ao equilíbrio ecológico e à qualidade de vida. Nesse sentido, José Rubens Morato Leite e Patryck Araújo Ayala ensinam que “dano ambiental significa, em uma primeira acepção, uma alteração indesejável ao conjunto de elementos chamados meio ambiente, como, por exemplo, a poluição atmosférica; seria, assim, a lesão ao direito fundamental que todos têm de gozar e aproveitar do meio ambiente apropriado.”176

Nesse ritmo, já se pode concluir ser o impacto negativo ao meio ambiente, além de uma 'alteração adversa' ou degradadora, algo previsto e avaliado - e, portanto, aceito - no processo de licenciamento ambiental, podendo ele ser significativo ou não. Por outro lado, o dano ambiental representa um indesejado prejuízo ou uma perda a um indivíduo ou à coletividade, resultante de uma conduta ilícita.

A diferenciação dos conceitos repercute na distinta reação jurídica para cada um dos eventos. De fato, o impacto negativo no meio ambiente exige um sistema de comando e controle, consubstanciado no multirreferido processo administrativo de licenciamento ambiental, e no qual incidem medidas preventivas, mitigadoras e compensatórias. O dano ambiental, por sua vez, determina a incidência da tríplice responsabilidade: administrativa, criminal e civil.

Neste ponto, é oportuno observar ser comum a propositura de demandas reparatórias no decorrer de processos de licenciamento ambiental, em que ainda estão sendo avaliados os impactos negativos e sendo discutidas ou implementadas as respectivas medidas preventivas, mitigatórias ou compensatórias respectivas. É normal ocorrer, com efeito, ações indenizatórias,

\footnotetext{
${ }^{176}$ MORATO LEITE, José Rubens; AYALA, Patryck de Araújo. Dano ambiental: do individual ao coletivo extrapatrimonial: teoria e prática. $4^{\mathrm{a}}$ ed. São Paulo: RT, 2011, p. 94. Esses autores lembram que há uma segunda conceituação para o dano ambiental, ao englobar os efeitos à saúde das pessoas e em seus interesses. De fato, o dano ambiental também engloba os efeitos aos interesses individuais e patrimoniais. É o que se usou chamar de efeito ricochete ou reflexo, uma vez que um dano ao meio ambiente normalmente ainda causa danos ao patrimônio e à saúde das pessoas. Temos, todavia, que o efeito ricochete ou reflexo não é uma segunda conceituação do dano ambiental, mas faz parte do seu primeiro conceito, sendo uma consequência que, de igual modo, deve ser reparada. Nessa toada, acerca dos efeitos ricochetes causados pelo dano ambiental, Édis Milaré leciona: “o dano ambiental, embora sempre recaia diretamente sobre o ambiente e os recursos e elementos que o compõem, em prejuízo da coletividade, pode, em certos casos, refletir-se, material ou moralmente, sobre o patrimônio, os interesses ou a saúde de uma certa pessoa ou de um grupo de pessoas determinadas ou determináveis.” MILARÉ, Édis. Direito do ambiente. $7^{\mathrm{a}}$ ed. São Paulo: RT, p. 1120.
} 
por exemplo, em processos de licenciamento de obras de grande porte, como são as grande usinas hidrelétricas, em que alguns dos atingidos (pescadores, proprietários que serão desapropriados etc.) receiam, já no início da concepção do empreendimento, sofrer perdas materiais e pessoais e, antes mesmo de concluídas as medidas determinadas em âmbito administrativo, intentam receber parcelas indenizatórias, normalmente atribuídas em pecúnia.

Nessa situação, em que há ainda a avaliação e o gerenciamento do impacto negativo, inexiste um dano ambiental a ser reparado. É realmente uma típica manifestação do equívoco entre a concepção do impacto negativo e do dano ambiental. De fato, apenas ocorrerá o dano caso as medidas preventivas, mitigatórias e compensatórias - que, como visto, incidem para equacionar o impacto negativo - não sejam devidamente implementadas ou, se, no futuro, elas se mostrarem inadequadas ou insuficientes - mas isso também não precisa ser necessariamente indenizado, pois pode ser corrigido de igual modo no âmbito do licenciamento ambiental.

Cite-se a situação de pescadores atingidos por usinas hidrelétricas. Usualmente a implantação desses empreendimentos causa impactos negativos a essa atividade, os quais são devidamente estudados por meio de uma avaliação de impacto ambiental (p.ex.: o EIA/RIMA) ${ }^{177}$. Após a avaliação dos impactos, passa-se a exigir, tanto na fase de implantação, quanto na fase de operação do empreendimento, diversas medidas preventivas - para evitar, o quanto possível o impacto, como é a situação de mudança estratégia de local de canteiro de obras, evitando a proximidade com os locais de pesca -, medidas mitigadoras que visam a atenuar o impacto, como é a racionalização dos horários de explosão, implantação de escada de peixes na barragem, medidas alternativas para a navegabilidade, educação etc. -, e medidas compensatórias - impostas para as situações em que não é possível prevenir ou mitigar o impacto negativo, como são os projetos de pesca em cativeiro (ou pesca sustentável).

Por conseguinte, é na condução do processo de licenciamento que se dá a verificação da efetividade das medidas preventivas, mitigatórias e

\footnotetext{
${ }^{177}$ Nessa fase, procura-se levantar dados sobre a atividade pesqueira, como análise dos padrões de pesca, como a navegabilidade, os recursos pesqueiros, o comércio de peixes etc.
} 
compensatórias dos impactos negativos. Ademais, é sempre possível, avaliando a inadequação ou insuficiência da medida, que o órgão administrativo ambiental imponha medidas complementares para o equacionamento de um determinado impacto. Nessa situação, em empreendimentos ou atividades lícitos e licenciados é muito difícil falar em dano no decorrer da sua implantação ou da sua operação, salvo se decorrer ou algum fato não previsto no processo de licenciamento, ou desídia do órgão ambiental, ou mesmo omissão do empreendedor em implantar as medidas exigidas.

Daí se vê, nitidamente, não se poder falar em dano no decorrer do processo de licenciamento ambiental de atividades lícitas e licenciadas, no qual estão sendo avaliados os impactos negativos e sendo prevenidos, mitigados e compensados os seus efeitos.

Volvendo à diferenciação dos termos dano e impacto, saliente-se que, ao mesmo tempo em que inexiste sinonímia entre eles, não vemos razão para haver uma relação indissociável entre o termo impacto e o seu eventual adjetivo significativo.

Na verdade, para alguns autores, como Álvaro Luiz Valery Mirra, o 'impacto ambiental' é toda 'significativa degradação ambiental', havendo assim uma relação umbilical entre o substantivo ‘impacto' e o adjetivo 'significativo'. De fato, ensina o autor, “nos termos da Constituição Federal, 'impacto ambiental’ não é qualquer alteração do meio ambiente, mas uma degradação significativa do ambiente”. Mais adiante, reafirma que “a Constituição de 1988 impõe - isto é, obriga - a realização do estudo de impacto ambiental para toda e qualquer obra ou atividade potencialmente causadora de "significativa degradação ambiental”, expressão que o constituinte utilizou para definir o “impacto ambiental”. ${ }^{178}$

Não concordamos, no entanto, com esses ensinamentos. Basta ver, de um lado, a obrigação de licenciamento ambiental impondo-se para atividades causadoras de 'impacto ao meio ambiente' (impacto esse que não precisa ser necessariamente significativo), conforme imposto pela Resolução CONAMA n ${ }^{\circ}$

\footnotetext{
${ }^{178}$ MIRRA, Álvaro Luiz Valery. Impacto ambiental - aspectos da legislação brasileira. $4^{\mathrm{a}}$ ed. São Paulo: Juarez de Oliveira, 2008, p. 36 e 156.
} 
237/1997, dispondo serem obrigados ao licenciamento ambiental os “empreendimentos e atividades utilizadoras de recursos ambientais consideradas efetiva ou potencialmente poluidoras, bem como os empreendimentos capazes, sob qualquer forma, de causar degradação ambiental”. ${ }^{179}$ Por outro lado, a Resolução CONAMA $n^{0}$ 001/1986, ao considerar significativo o impacto, determina a sua avaliação mediante a apresentação de Estudo de Impacto Ambiental - EIA, da mesma forma como o faz a Constituição Federal (art. 225, $\S 1^{\circ}$, inciso IV).

Significa dizer que um empreendimento, por ser impactante, de acordo com o estabelecido pela Resolução CONAMA n ${ }^{\circ}$ 237/1997, exige prévio licenciamento ambiental, com base em uma Avaliação de Impacto Ambiental AIA $^{180}$, a qual não precisa ser necessariamente o Estudo de Impacto Ambiental EIA. No entanto, caso o órgão ambiental verifique tratar-se de empreendimento ou atividade causador de significativo impacto, ele deve ser licenciado com base em Estudo de Impacto Ambiental - EIA, consoante impõe a listagem exemplificativa ${ }^{181}$ da Resolução CONAMA nº 001/1986 ${ }^{182}$.

\footnotetext{
179 O mesmo diploma ainda lista, em seu Anexo 1, os empreendimentos e as atividades sujeitas ao prévio licenciamento ambiental, aos quais podem ser acrescidos outros, conforme definição dos órgãos ambientais competentes.

${ }^{180}$ Avaliação de Impactos Ambientais - AIA é gênero, do qual o Estudo de Impacto Ambiental - EIA é espécie. De fato, todo licenciamento ambiental deve ser precedido de uma das espécies de uma AIA, que, quando o impacto for significativo, deve ser o EIA. Édis Milaré bem explica que a Resolução CONAMA n ${ }^{\circ}$ 237/1997 dispõe que “a Avaliação de Impacto Ambiental, que ela chama de "Estudos Ambientais”, é gênero, de que são espécies todos e quaisquer estudos relativos aos aspectos ambientais apresentados como subsídio para a análise da Licença Ambiental, tais como: relatório ambiental, plano e projeto de controle ambiental, relatório ambiental preliminar, diagnóstico ambiental, plano de manejo, plano de recuperação de área degradada e análise preliminar de risco.” MILARÉ, Édis. Direito do ambiente. $7^{\mathrm{a}}$ ed. São Paulo: RT, 2011, p. 472.

${ }^{181}$ Diz-se 'listagem exemplificativa', pois, conforme ensina Álvaro Luiz Valery Mirra "esse rol de atividades previstas na Resolução n. 001/1986 é meramente indicativo, de maneira que outras atividades nele não incluídas poderão também ter de se sujeitar ao EIA, se forem potencialmente causadoras de significativa degradação ambiental. Consequentemente, ainda assim, competirá ao órgão público ambiental, em muitas hipóteses, a determinação desse conceito indeterminado de "significativa” degradação ambiental". MIRRA, Álvaro Luiz Valery. Ob. cit., p. 38.

182 "Art. $2^{\circ}$ - Dependerá de elaboração de estudo de impacto ambiental e respectivo relatório de impacto ambiental - RIMA, a serem submetidos à aprovação do órgão estadual competente, e do IBAMA em caráter supletivo, o licenciamento de atividades modificadoras do meio ambiente, tais como: I - Estradas de rodagem com duas ou mais faixas de rolamento; II - Ferrovias; III - Portos e terminais de minério, petróleo e produtos químicos; IV - Aeroportos, conforme definidos pelo inciso 1, art. 48, do Decreto-Lei no 32, de 18.11.66; V Oleodutos, gasodutos, minerodutos, troncos coletores e emissários de esgotos sanitários; VI - Linhas de transmissão de energia elétrica, acima de 230KV; VII - Obras hidráulicas para exploração de recursos hídricos, tais como: barragem para fins hidrelétricos, acima de 10MW, de saneamento ou de irrigação, abertura de canais para navegação, drenagem e irrigação, retificação de cursos d'água, abertura de barras e embocaduras, transposição de bacias, diques; VIII - Extração de combustível fóssil (petróleo, xisto, carvão);
} 
Voltando, uma vez mais, à diferenciação de impacto negativo ao meio ambiente e dano ambiental, em que pese as suas consequências práticas serem bastante similares, verifica-se serem absolutamente diversos os seus pressupostos de incidência e os efeitos jurídicos deles decorrentes, mormente quanto à gestão administrativa e jurídica a ser operacionalizada em cada caso.

Sendo assim, tornar-se-á possível, mediante a diferenciação da definição de impacto negativo ao meio ambiente e de dano ambiental, alcançar a correta natureza jurídica e a funcionalidade das medidas compensatórias, porquanto elas têm em vista compensar um impacto negativo e não mitigável causado ao meio ambiente, e não reparar um dano ambiental. ${ }^{183}$ Em uma palavra, o impacto negativo ao meio ambiente e não mitigável deve ser compensado, enquanto que o dano ambiental exige ser reparado.

\subsection{Conclusões preliminares}

O presente capítulo procurou mostrar a diferença entre os conceitos de dano ambiental e de impacto negativo no meio ambiente, diferença absolutamente necessária para contextualizar e melhor entender as medidas compensatórias. Afinal, consoante vem se afirmando, as medidas compensatórias, impostas no decorrer do processo de licenciamento ambiental, são aplicadas para compensar o meio ambiente pelos impactos negativos

IX - Extração de minério, inclusive os da classe II, definidas no Código de Mineração; X - Aterros sanitários, processamento e destino final de resíduos tóxicos ou perigosos; XI - Usinas de geração de eletricidade, qualquer que seja a fonte de energia primária, acima de 10MW; XII - Complexo e unidades industriais e agro-industriais, petroquímicos, siderúrgicos, cloroquímicos, destilarias de álcool, hulha, extração e cultivo de recursos hídróbios; XIII - Distritos industriais e zonas estritamente industriais - ZEI; XIV - Exploração econômica de madeira ou de lenha, em áreas acima de 100 hectares ou menores, quando atingir áreas significativas em termos percentuais ou de importância do ponto de vista ambiental; XV - Projetos urbanísticos, acima de 100ha. ou em áreas consideradas de relevante interesse ambiental a critério da SEMA e dos órgãos estaduais ou municipais; XVI - Qualquer atividade que utilizar carvão vegetal, derivados ou produtos similares, em quantidade superior à dez toneladas por dia; XVII - projetos agropecuários que contemplem áreas acima de 1.000 há, ou menores, neste caso, quando se tratar de áreas significativas em termos percentuais ou de importância do ponto de vista ambiental, inclusive nas áreas de proteção ambiental; XVIII - nos casos de empreendimentos potencialmente lesivos ao patrimônio espeleológico nacional.”

183 Justamente por isso é que consideramos, em princípio, incorreta a doutrina que advoga ser reparatória a natureza jurídica das medidas compensatórias. 
resultantes dos empreendimentos lícitos e desejados, e não pelos danos ambientais decorrentes de eventos ilícitos e, portanto, não desejados.

Como visto, esses conceitos não são usualmente distinguidos pela doutrina e pela jurisprudência; daí resultando sérios equívocos quando empregados nessas searas, como também no decorrer dos processos administrativos de licenciamento ambiental, não sendo raro verificar o termo dano utilizado para designar um impacto, e vice-versa.

Foi demonstrado que a falta de distinção quanto à definição correta dos termos dano ambiental e impacto negativo no meio ambiente decorre, ao que parece, de duas razões: a má compreensão e da errônea utilização do termo risco, de um lado, e o intento consciente de enquadrá-los na mesma categoria jurídica de dano, de outro. Daí, fez-se necessário ingressar na análise do risco e, ainda, avaliar os argumentos pelos quais se defende ser o impacto ambiental um dano futuro por um imperativo de precisão científica, inclusive para o fim de determinar as searas próprias da prevenção e da precaução.

Em relação ao entendimento de risco, verificou-se que, hodiernamente, a sua compreensão divide-se na teoria do risco, no risco concreto e no risco abstrato. O dano ambiental, por exemplo, é um risco consumado, cuja reparação se dá por meio da responsabilidade civil objetiva, fundada na aludida teoria do risco. O risco concreto propriamente dito é o provável impacto negativo a ser causado ao meio ambiente, apreciado, avaliado e gerenciado no decorrer do processo de licenciamento ambiental, por meio do qual se impõem medidas preventivas, mitigadoras e compensatórias, com fulcro no princípio da prevenção. Já o conceito de risco abstrato vem sendo usado para designar a possibilidade de um dano ambiental futuro, cujos efeitos são desconhecidos, incertos e imprevisíveis. Ao risco abstrato incide o princípio da precaução contemplado em uma decisão política ou governamental - preferencialmente legitimada pela democracia participativa - sobre a segurança e a necessidade de uma determinada atividade cujos efeitos não são conhecidos cientificamente.

De fato, os riscos abstratos ou danos futuros - que se diferenciam em absoluto dos riscos concretos - estão umbilicalmente ligados à sociedade de risco caracterizada por absoluta complexidade e que deve buscar a equidade 
intergeracional; passam, assim, por investigação, avaliação e gestão, baseandose no princípio da precaução.

Viu-se, ainda, ser o instituto da responsabilidade civil de pouca ajuda frente aos riscos abstratos ou incertos, ou aos 'danos futuros' e à ética da equidade intergeracional. Embora esse ponto de vista seja uma premissa ainda bastante controvertida, tendemos a demonstrar a 'sociedade de risco' ou a 'era das incertezas' impondo uma nova responsabilidade; não, porém, no sentido de reparação por um dano que não ocorreu, e, sim, uma responsabilidade ética da humanidade pelos riscos abstratos decorrentes do modelo de desenvolvimento econômico vigente. Nesse sentido, procurou-se demonstrar a democracia participativa como um caminho possível e viável para discutir os riscos abstratos, sobretudo para reavaliar o caminho pelo qual a humanidade está trilhando.

Noutro giro, toda a análise do risco permitiu concluir estarem as concepções de dano ambiental e de impacto no meio ambiente na fase do risco concreto, sendo possível averiguar, na atualidade, no campo da estatística e da probabilidade, o grau de possibilidade da sua ocorrência e os efeitos deles decorrentes. Por conseguinte, quando se fala, nesta tese, de dano e impacto ambiental, quer-se referir ao campo das certezas e probabilidades, estando absolutamente dissociado da concepção de risco e incerteza trazidos pela nova fase pela qual passa a humanidade, conhecida, como se viu, como 'sociedade do risco' ou 'sociedade das incertezas'.

A partir dessas premissas, foi possível constatar o conceito de impacto no meio ambiente não podendo ser confundido com os termos dano, poluição e degradação. De fato, perseguindo um bom e correto emprego desses termos, propusemos, inicialmente, serem o dano e o impacto considerados os fatos, enquanto a poluição e a degradação serem as suas consequências negativas. Ademais, para melhor entendimento, demonstramos estar a consequência degradação mais bem vinculada ao impacto ambiental, enquanto o efeito poluição relaciona-se com o dano.

Nesse contexto, e considerando que, de um lado, a Carta Maior estabeleceu o impacto ambiental como a degradação ao meio ambiente e, de outro lado, a Lei $\mathrm{n}^{\circ}$ 6.938/1981 conceituando degradação como a alteração adversa das características do meio ambiente, foi possível concluir ser o 
impacto negativo qualquer alteração adversa, significativa ou não, das características do meio ambiente, por atividades ou empreendimentos lícitos.

O dano ambiental, por sua vez, é a lesão ilícita aos recursos ambientais, causando um indesejado prejuízo - ou poluição - ao meio ambiente e/ou a terceiros (conhecido este último efeito como efeito ricochete ou reflexo). Em outro modo de dizer, o dano ambiental, além de ser sempre negativo em razão de representar um prejuízo ou uma perda a um indivíduo ou à coletividade, não é jamais desejado.

Outrossim, o impacto negativo no meio ambiente exige um sistema de comando e controle, consubstanciado no multirreferido processo administrativo de licenciamento ambiental. O dano ambiental, por sua vez, determina a reação da responsabilidade administrativa, criminal e civil.

Em síntese, e para bem visualizar o quanto se pretendeu demonstrar no presente capítulo, segue quadro demonstrativo:

\begin{tabular}{|c|c|c|c|}
\hline ESPÉCIE DE RISCO & FATO & EFEITO & REAÇÃO JURÍDICA \\
\hline TEORIA DO RISCO & $\begin{array}{c}\text { DANO } \\
\text { AMBIENTAL }\end{array}$ & POLUIÇÃO & $\begin{array}{l}\text { RESPONSABILIDADE CIVIL } \\
\text { - tutela preventiva, inibitória ou } \\
\text { remoção de ilícito } \\
\text { - tutela reparatória, com condenação } \\
\text { em obrigações de fazer, não fazer ou } \\
\text { pagar. } \\
\text { RESPONSABILIDADE } \\
\text { ADMINISTRATIVA } \\
\text { RESPONSABILIDADE CRIMINAL }\end{array}$ \\
\hline RISCO CONCRETO & $\begin{array}{c}\text { IMPACTO } \\
\text { NEGATIVO NO } \\
\text { MEIO } \\
\text { AMBIENTE }\end{array}$ & DEGRADAÇÃO & $\begin{array}{l}\text { PRINCÍPIO DA PREVENÇÃO } \\
\text { LICENCIAMENTO AMBIENTAL } \\
\text { - medidas preventivas, mitigatórias e } \\
\text { compensatórias }\end{array}$ \\
\hline RISCOS ABSTRATOS & $\begin{array}{l}\text { DANO } \\
\text { FUTURO }\end{array}$ & $\begin{array}{l}\text { IMPREVISÍVEL, } \\
\text { IMENSURÁVEL E } \\
\text { DE DIMENSÕES } \\
\text { CATASTRÓFICAS }\end{array}$ & $\begin{array}{l}\text { PRINCÍPIO DA PRECAUÇÃO } \\
\text { DEMOCRACIA PARTICIPATIVA }\end{array}$ \\
\hline
\end{tabular}


Com essas premissas bem consolidadas, passa a ser possível demonstrar a correta natureza jurídica e a funcionalidade das medidas compensatórias, porquanto elas têm em vista compensar um impacto negativo e não mitigável causado ao meio ambiente, e não reparar um dano ambiental. 


\section{A CRISE AMBIENTAL, O DIREITO E O PRINCÍPIO DO POLUIDOR-PAGADOR}

\subsection{Escopo do capítulo}

A racionalidade jurídica na esfera do meio ambiente ultrapassa um olhar técnico, dogmático e monodisciplinar, havendo a necessidade de compreender a atual crise ambiental por uma visão interdisciplinar que inclui um enfoque mais sociológico do risco, ${ }^{184}$ e ainda leva em consideração a sua vinculação com a economia. Vale dizer, para bem apreender um instituto jurídico específico permeado pela variável ambiental - como é o caso das medidas compensatórias, objeto deste estudo - é necessário, antes, discorrer acerca do seu subjacente processo político, social, cultural e econômico.

De fato, há um processo que conduz à formulação de princípios e à positivação de normas pelo direito; em relação ao Direito Ambiental, são princípios e normas que compõem um conjunto de regras, objetivando, de um lado, preservar e conservar os recursos naturais do nosso planeta e, de outro lado, permitir a renovação e a manutenção do sistema de desenvolvimento econômico vigente.

No contexto desse processo, verifica-se o conjunto normativo do Direito Ambiental decorrer da atual e notória crise ambiental pela qual passa a humanidade, chegando-se ao ponto de aludir vivermos em uma sociedade de riscos ou de incertezas. Acerca dessa crise ambiental, no entanto, apenas se tomou consciência nos últimos decênios.

Com efeito, não há dúvidas do quanto está em voga o tema 'crise ambiental', sendo notícia constante nos dias atuais. A mídia vem se encarregando de divulgá-la, quer pela apreensão que gera (e com isso, obtém um grande Ibope), quer pelo fato irrefutável de tal notícia corresponder a um problema real, o qual vem causando efeitos drásticos na vida do planeta e dos

\footnotetext{
${ }^{184}$ MORATO LEITE, José Rubens; AYALA, Patryck de Araújo. Dano ambiental: do individual ao coletivo extrapatrimonial: teoria e prática. $4^{\mathrm{a}}$ ed. São Paulo: RT, 2011, p. 115.
} 
seres que o habitam. A esse respeito, notam-se, por exemplo, o crescente número de furacões, a incontestável alteração do clima, o prognóstico de aumento do nível do mar, os deslizamentos de terra, as inundações, os perigos da radiação nuclear, as dúvidas concernentes ao uso da biotecnologia.

A bem ver, a experiência pessoal de cada ser humano, juntamente com as análises científicas, ${ }^{185}$ não mais permitem esconder o fato de a intensa utilização dos recursos naturais ter colocado o planeta em crise. Ou, como bem aponta Fábio Nusdeo: "um processo de degradação dos bens integrantes da biosfera: as águas; o ar; o solo; as ondas sonoras; o visual ou a paisagem de sítios, quer naturais, quer criados pelo homem; a cobertura vegetal; as reservas minerais; as espécies animais e outros bens que tais, prestadores de serviços úteis aos homens e às sociedades, serviços esses não remunerados ou não compensados adequadamente, donde a sua deterioração, poluição ou exaustão.”186

Não há, com efeito, mais dúvidas quanto aos significativos e negativos impactos que as atividades humanas vêm causando na natureza. Em outras palavras, a humanidade chegou a uma encruzilhada: ou se alteram os modos de produzir e de consumir impostos pelo modelo capitalista de desenvolvimento econômico, ou ela assume o risco de sua própria extinção. A propósito, Norberto Bobbio pontua: “o momento chegou, de tal forma que o que até este momento parecia impossível tornou-se agora necessário.”187

Nesse cenário, para apreender devidamente o Direito Ambiental e os mecanismos de efetividade, é imprescindível, antes, partir dos fatores sociológicos subjacentes à positivação de regras e princípios que visam

\footnotetext{
${ }^{185}$ Estimativas atuais demonstram estar em queda livre o número de populações de espécies tropicais, enquanto a demanda humana por recursos naturais sobe vertiginosamente e chega a $50 \%$ a mais do que o planeta pode suportar. Isto é o que revela a edição de 2010 do Relatório Planeta Vivo, da rede WWF, publicação que representa a principal pesquisa sobre a saúde do planeta. Um dos indicadores utilizados no Relatório demonstra ter duplicado a demanda por recursos naturais desde 1966 e, ainda, o fato de utilizarmos o equivalente a um planeta e meio para sustentar nossas atividades. Significa, assim, que se continuarmos a viver além da sua capacidade, até 2030 precisaremos de uma capacidade produtiva equivalente a dois planetas para satisfazer os níveis anuais da nossa demanda.

Fonte: http://www.wwf.org.br/informacoes/noticias_meio_ambiente_e_natureza/?uNewsID=26164> Acesso em 30.10.2011.

${ }^{186}$ NUSDEO, Fábio. Economia do Meio Ambiente. In: PHILIPPI JR., Arlindo; CAFFÉ ALVES, Alaôr (eds.). Curso interdisciplinar de Direito Ambiental. Barueri: Manole, 2005, p. 194.

${ }^{187}$ BOBBIO, Norberto. As ideologias e o poder em crise. Trad. João Ferreira; rev. téc. Gilson César Cardoso. $4^{a}$ ed. Brasília: UNB, 1999, p. 72.
} 
propiciar a solução da crise ambiental, ou proteger o meio ambiente para que a crise seja, pelo menos, atenuada.

Pois bem.

\subsection{A relação do homem com a natureza - a tomada de consciência sobre a crise ambiental}

Perscrutando, como dito, o processo subjacente à positivação de regras e princípios destinados a proteger o meio ambiente, é preciso, de início, demonstrar como evoluiu a relação do homem com a natureza.

Nesse sentido, e fazendo um corte histórico, mencione-se ter a humanidade, em um momento não bem definido, levada pela irrupção do monoteísmo hebraico, dado o passo inicial para a atual acepção da dessacralização da natureza ao colocar o homem entre Deus e a Natureza, tornando-os, ao mesmo tempo, realidades distintas e separadas. De fato, em breves termos, foi a partir desse momento histórico que se lançaram as raízes do teocentrismo e do antropocentrismo ${ }^{188}$ na trajetória da humanidade. ${ }^{189}$ E é sobre o substrato do paradigma teocêntrico-antropocêntrico “que vai se desenvolver, na Europa Ocidental, entre 1550 e 1700 a chamada revolução científica, que constrói uma concepção racionalista, mecanicista e utilitarista do mundo. A ciência moderna dedicou-se predominantemente a conhecer as “leis” da natureza para dominá-la, sujeitá-la, controlá-la, para colocá-la a seu serviço. ${ }^{190}$

O Iluminismo, movimento intelectual europeu da segunda metade do século XVIII, enfatizando a supremacia da razão e da ciência como formas de explicar o Universo, pode ser considerado o grande divisor de águas do progresso civilizatório. A equação fundamental do Iluminismo pressupõe a existência de harmonia entre o processo civilizatório ocidental e o aumento da

\footnotetext{
${ }^{188}$ Quanto à visão antropocentrista em contraposição ao ecocentrismo, vide MILARÉ, Édis; COIMBRA, José de Ávila Aguiar. Antropocentrismo x Ecocentrismo na ciência jurídica. In: Revista de Direito Ambiental. no 36. Ano 9. out/dez. São Paulo: RT, 2004, p. 9-41.

${ }^{189}$ SOFFIATI, Arthur. A natureza no pensamento liberal clássico. Revista de Direito Ambiental. $\mathrm{n}^{\circ}$ 21. Ano 6. jan-mar. São Paulo: RT, 2001, p. 159-176.

${ }^{190}$ Idem, p. 161.
} 
felicidade. A partir desse pressuposto, então, o elemento principal para a construção de um novo mundo decorria da combinação de vetores de mudança alimentados e fortalecidos mutuamente. Tais vetores eram: o aumento do saber científico; o domínio crescente da natureza pela tecnologia; o aumento exponencial da produtividade e da riqueza material; a emancipação das mentes após séculos de opressão religiosa, de superstição e de servilismo; a transformação das instituições políticas com bases racionais; e o aprimoramento intelectual e moral do ser humano por meio da ação conjunta da educação e das leis. $^{191}$

Do contexto desse novo modo de pensar o mundo decorreu a ideia de a natureza poder ser dominada e, ao dominá-la, ser possível vencer a escassez e submeter o mundo às vontades e aos caprichos dos seres humanos. ${ }^{192}$ Aliás, Giordano Bruno (1540-1600) vira exatamente nesse contexto o modo pelo qual poderíamos recriar um paraíso tecnológico, em que o homem faria de si um deus sobre a terra. Na mesma linha, Francis Bacon (1561-1626) defendera o conhecimento científico como capaz de reduzir o sofrimento e aumentar o bemestar. Isto quando, pouco antes, no seio do cristianismo medieval o iluminismo era uma heresia por afirmar ser o paraíso aqui-e-agora.

Foi assim, sob o efeito da tripla revolução ocorrida nesse período (científica, industrial e política), que o conceito iluminista de progresso, e tudo o que implicava em termos de otimismo quanto ao futuro terreno da espécie humana, assinalou uma clara ruptura em relação às ideias dominantes do mundo antigo, medieval e renascentista. ${ }^{193}$

\footnotetext{
${ }^{191}$ SETZER, Joana. Panorama do princípio da precaução: o direito do ambiente face aos novos riscos $e$ incertezas. Dissertação (mestrado). Programa de Ciência Ambiental. Universidade de São Paulo-USP, São Paulo, 2007, p. 20.

${ }^{192}$ É verdade que, já nos séculos XVIII e XIX, havia uma certa percepção de que os recursos naturais eram findáveis. A esse propósito, mencione-se a conhecida teoria de Thomas Robert Malthus (1766-1834), demonstrando, no final do século XVIII e início do século XIX, o fato de as populações humanas (e as suas demandas) crescerem em progressão geométrica, enquanto os meios de subsistência (e os recursos naturais) apenas poderem crescer em progressão aritmética. A esse respeito, aliás, é oportuno ressaltar a notícia amplamente divulgada no final de outubro/2011 sobre o fato de a humanidade ter chegado aos 7 bilhões de habitantes, significando, em menos de um século, ter praticamente duplicado a população (em 1930, éramos 2 bilhões). Por outro lado, sabe-se estarem os recursos naturais cada vez mais escassos, seja pelo aumento da demanda decorrente do crescimento populacional, seja pela irracional forma com que são utilizados, seja por serem normalmente não-renováveis ou, ainda, por dependerem de um longo período para serem renovados.

${ }^{193}$ SETZER, Joana. Ob.cit., p. 20-21.
} 
A partir dessa conjuntura - notadamente com as filosofias defensoras do contrato social e, sobretudo, depois das revoluções política e industrial - os humanos destacaram-se racionalmente dos outros seres da natureza, passando a pensar e a agir como se os recursos naturais, além de estarem sob o seu domínio, fossem infindáveis e, assim, capazes de proporcionar uma ilimitada oferta para a produção e exploração do planeta. Em suma, a oposição entre natureza e sociedade é uma construção do século XIX, a qual serviu ao duplo propósito: controlar a natureza nos seus resultados mas ignorá-la no seu funcionamento. 194

Até o fim do século XIX, como bem expõe Fábio Nusdeo, a percepção do homem estava voltada para "um sistema produtivo, de proporções reduzidas, abarcado por uma esfera imensa representada pelo meio ambiente natural, não afetado pelas relações processadas dentro da esfera menor nele contida, seja pelo saque de seus bens - matérias primas -, seja pelos resíduos devolvidos para serem por ela reciclados”. Era, como lembra o referido mestre, a percepção do cowboy, em que se vislumbrava “a vastidão dos campos e a inexistência de limites [que] impunham a ideia de ser ilimitada a fronteira do homem, pois passível de ser levada sempre para diante, indefinidamente, indeterminadamente”. 195

Essa compreensão do mundo permaneceu até o final da Idade Moderna, quando se iniciou um avanço exponencial da tecnologia e do conhecimento relacionados com a transformação dos recursos extraídos da natureza.

Foi apenas na segunda metade do século XX (a partir da década de 60) que os alarmes dados foram efetivamente ouvidos, quando ecossistemas inteiros começaram a entrar em colapso, o clima planetário a mudar de forma drástica, e se descobriu um imenso buraco na camada de ozônio. ${ }^{196}$ Nessa circunstância, a sociedade passou a tomar consciência da limitação dos recursos naturais. Para Enrique Leff, “a consciência ambiental surgiu nos anos 60 com a Primavera

\footnotetext{
${ }^{194}$ BECK, Ulrich. Sociedade de risco: rumo a uma outra modernidade. Trad. Sebastião Nascimento. São Paulo: Ed. 34, 2010, p. 9.

${ }^{195}$ NUSDEO, Fábio. Curso de Economia - Introdução ao Direito Econômico. 6a ed. São Paulo: RT, 2010, p. 370-374.

${ }^{196}$ MILARÉ, Édis. Direito do ambiente. $7^{\mathrm{a}}$ ed. São Paulo: RT, 2011, p. 381.
} 
Silenciosa de Rachel Carson ${ }^{197}$, e se expandiu durante os anos $70,{ }^{198}$ depois da Conferência das Nações Unidas sobre o Meio Ambiente Humano, celebrada em Estocolmo, em 1972. ${ }^{199}$ Naquele momento, foram assinalados os limites da racionalidade econômica e os desafios da degradação ambiental ao projeto civilizatório da humanidade". ${ }^{200}$ Ainda em 1960, não se pode deixar de mencionar o seminal artigo de Ronald Coase no Journal of Law and Economics, com o sugestivo título “The problem of social cost”. 201

${ }^{197}$ Rachel Carson (1907-1964) era uma bióloga e escritora americana que, em 1951, escreveu seu mais famoso best seller chamado Silent Spring ('Primavera Silenciosa' em português), no qual apontou os problemas ambientais causados pelos pesticidas sintéticos.

${ }^{198}$ Vale notar que a crise que se revela a partir da década de 1970 não é apenas ambiental, mas também social, decorrente de os extraordinários avanços tecnológicos e científicos terem imposto, de forma praticamente definitiva, o afastamento do homem do setor produtivo. A esse respeito, João S. Whitaker Ferreira afirma que "[A crise] que se torna visível na década de 70 é causada por uma tendência inegável: por um lado o surgimento de novos padrões tecnológicos e organizacionais - impulsionados também pelo surgimento e concorrência do modelo japonês de produção, o chamado toyotismo- que romperam a lógica de produção fordista-taylorista e exacerbaram os níveis de produtividade e, por outro, a desindustrialização que esses mesmos padrões provocaram, gerando a terceirização e, em função da generalização de políticas neoliberais, o desemprego. (...) Nesse quadro já difícil, a informatização elevou a produção a níveis nunca vistos, ao mesmo tempo que instaurou um processo de substituição da mão-de-obra viva pela máquina, fazendo com que o sistema capitalista mundial estivesse - e ainda esteja - produzindo cada vez mais, empregando cada vez menos e, conseqüentemente, não tendo a quem vender.” FERREIRA, João S. Whitaker. O mito da cidade-global: o papel da ideologia na produção do espaço urbano. Petrópolis, RJ: Vozes, 2007, p. 95.

${ }^{199}$ Importa observar o fato de, nessa Conferência de Estocolmo, em 1972, o Brasil de então expressou a oposição entre o Hemisfério Norte, rico e já preocupado com a proteção ambiental, e o Hemisfério Sul, pobre e preocupado com seu desenvolvimento econômico. Defendeu, assim, o desenvolvimento econômico a qualquer preço, o que causou grande mal-estar e controvérsia. Daí a frase que marcou a conferência: "O Brasil está pronto para importar a poluição." O momento era de "um regime que promovia um desenvolvimento acelerado por meio do Estado centralizador e quase onipresente em todos os setores da economia. Entre 1968 e 1973, o país viveu o período batizado de 'milagre' econômico. Em 1973, o crescimento do Produto Interno Bruto (PIB) foi de 11,4\%, um número recorde.” CABRAL, Ligia Maria Martins (coord.). O meio ambiente e o setor de energia elétrica brasileiro. Rio de Janeiro: Centro de Memória da Eletricidade no Brasil, 2009, p. 47. Saliente-se que, ainda na década de 70, foi editado o livro Desenvolvimento e ecologia, de Fábio Nusdeo, que mostra a doutrina nacional partindo para uma análise jurídica da crise ambiental. NUSDEO, Fábio. Desenvolvimento e ecologia. São Paulo: Saraiva, 1975.

${ }^{200}$ LEFF, Enrique. Saber ambiental. Trad. Lúcia Mathilde Endlich Orth. $5^{\mathrm{a}}$ ed. Petrópolis: Vozes, 2001, p. 16-17.

${ }^{201}$ Em 1960, em artigo que ficou famoso, Ronaldo Coase contrapôs-se à ideia de que as externalidades deviam invariavelmente ser objeto de intervenção do Estado no sentido de impor sua internalização, como se defendia desde o trabalho de Pigou. Sua proposta foi no sentido de que na ausência de custos de transação as partes poderiam chegar a um resultado mais eficiente - vale dizer, que aumenta o valor da produção - do que aquele propiciado pela intervenção do Estado. NUSDEO, Ana Maria de Oliveira. O uso dos instrumentos econômicos nas normas de proteção ambiental. Revista da Faculdade de Direito da Universidade de São Paulo, v. 101, jan/dez 2006. Vale observar que Coase desenvolveu uma teoria segundo a qual é possível eliminar, pela negociação, a divergência entre os custos privados e os custos sociais, que decorre da não valorização do bem diante da inexistência de propriedade. O autor propõe, em suma, um sistema de negociação direta, entre o lesado e o lesante, como forma de equacionar as externalidades negativas impostas pelo sistema de mercado em situações de custo de transação próximo a zero. Maria Alexandra de Sousa Aragão informa que essa posição já foi muito criticada, não sendo hoje em muito considerada, pois “... Só nos casos de o número de partes em cada lado ser suficientemente pequeno para tornar a negociação possível, 
Para François Ost, esse momento de tomada de consciência se intensificou no início dos anos 70 do século $\mathrm{XX}$, quando “a questão dos desequilíbrios ecológicos iria conhecer uma transformação desta ordem: de tema de preocupação científica ela iria muito rapidamente transformar-se, ao ritmo dos acidentes e dos gritos de alarme que se multiplicavam, numa prioridade para a opinião pública, numa questão de mobilização política, em que atestava, na mesma altura, o nascimento dos primeiros partidos 'verdes', e de uma nova geração, bastante mais combativa, de associações de defesa do ambiente (Os amigos da Terra, o Greenpeace...), e, finalmente, num objecto de consideração administrativa sob a forma de regulamentações e instituições específicas”. ${ }^{202}$

A partir de então - novamente nas palavras de Fábio Nusdeo - o homem começou a se perceber como um tripulante de espaçonave, o qual "deve se ajustar à ideia do nada fora da nave e modular com prudência a sua atividade de molde a ajustá-la ao sistema cíclico de caráter físico-biológico, onde o que sai por um lado deve entrar pelo outro, e onde não mais existem reservatórios livres, seja de novos materiais, seja para a disposição dos já utilizados”. ${ }^{203}$

Fica claro, assim, ter emergido apenas recentemente a consciência em relação à crise ambiental, na forma como a vislumbramos hoje. Essa consciência é coletiva, porquanto a maior parte da população já tem ciência dos prejuízos e riscos ocasionados ao meio ambiente pela atividade humana.

\footnotetext{
é que as partes afectadas, deixadas a si próprias, vão negociar, através de pagamento, o reajuste de comportamentos até o nível óptimo, reduzindo a poluição existente. À medida que o número de partes de qualquer dos lados se torna criticamente elevado, a negociação, pelos custos administrativos que implica, torna-se proibitiva.” ARAGÃO, Maria Alexandra de Sousa. O princípio do poluidor pagador: pedra angular da política comunitária do ambiente. Coimbra: Coimbra Editora, 1997, p. 40. Nesse mesmo entendimento, Ronaldo Seroa da Motta expõe que "devido ao caráter difuso do problema ambiental, observa-se um número elevado de partes afetadas e geradoras de externalidades. Não somente é difícil avaliar a causalidade entre cada fonte de degradação com o efeito ambiental geral, como também o valor econômico dos recursos ambientais (...) não se resume somente a valores de uso, mas inclui igualmente valores de não-uso que afetam a sociedade como um todo. Assim, soluções coasianas acabam gerando altos custos de transação que podem resultar em pontos de equilíbrio muito próximos à total degradação ou exaustão.” SEROA DA MOTTA, Ronaldo. Economia ambiental. Rio de Janeiro: Editora FGV, 2006, p. 185. No entanto, o chamado Teorema de Coase teve a finalidade de chamar a atenção para a possibilidade e consequências de arranjos institucionais melhores do que a simples proibição de determinada atividade.

${ }^{202}$ OST, François. A natureza à margem da lei - A ecologia à prova do direito. Trad. Joana Chaves. Lisboa: Instituto Piaget, 1997, p. 121.

${ }^{203}$ LEFF, Enrique. Ob. cit., p. 374.
} 
4.2.1 O confronto entre as bases do sistema de mercado e a necessária proteção ambiental

A recente consciência da crise ambiental permitiu descortinar não apenas a limitação dos recursos naturais, mas também o fato de a produção nos moldes do sistema econômico de mercado estar em absoluto conflito com a restrita disponibilidade dos recursos do planeta.

Observe-se, entre parênteses, o fato de a contradição também poder estar presente em outras espécies de sistemas econômicos, bastando que não se atente para uma necessária utilização racional do meio ambiente. A esse respeito, Fábio Nusdeo ensina:

\begin{abstract}
“a degradação ambiental é comum, tanto aos sistemas centralizados de índole coletivista, como aos regimes de mercado, de cunho capitalista. A esse respeito, o Mar Báltico fornece um exemplo eloquente: banhando sete países de diversa formação histórica, diferentes sistemas econômicos e constituídos por povos de variada origem étnica, com as duas Alemanhas, a Suécia, a Noruega, a Dinamarca, a Rússia, a Polônia e a Finlândia, suas águas recebem detritos de toda ordem provenientes de todos eles. A contaminação das mesmas atinge tais índices a ponto de praticamente não ser possível a pesca, bem como quaisquer atividades de lazer ou recreio, inclusive com prejuízo de algumas célebres estações balneárias. Devido à peculiar conformação geográfica que dificulta a oxigenação de suas águas, o Báltico é hoje considerado um mar em decomposição, de longe o mais poluído do mundo, a ponto de os sete países que o margeiam terem vencido barreiras ideológicas, políticas e econômicas para constituírem um órgão destinado a enfrentar o desafio comum. ${ }^{204}$
\end{abstract}

No entanto, é certo dizer, em relação ao sistema de mercado em que vivemos, haver uma dicotomia inescapável: por um lado, necessidades ilimitadas; por outro, recursos limitados ou finitos. ${ }^{205} \mathrm{E}$ é esse fenômeno, aliás, tão singelo quanto importante - bens finitos versus necessidades infinitas - que

\footnotetext{
${ }^{204}$ NUSDEO, Fábio. Desenvolvimento e ecologia. São Paulo: Saraiva, 1975, p. 22.

205 NUSDEO, Fábio. Economia do Meio Ambiente. In: PHILIPPI JR., Arlindo; CAFFÉ ALVES, Alaôr (eds.). Curso interdisciplinar de Direito Ambiental. Barueri: Manole, 2005, p. 197.
} 
está na raiz de grande parte dos conflitos que se estabelecem no seio da comunidade mundial. ${ }^{206}$

Para bem compreender essa dicotomia com sabor de paradoxo, é importante lembrar o fato de a lei da acumulação nos padrões capitalistas ${ }^{207}$ impor competitividade, exigindo a diminuição dos custos produtivos, a criação de necessidades ilimitadas e, com a globalização ${ }^{208}$, a crescente velocidade de produção, de consumo e de descarte.

De efeito, o sistema de mercado, para sua manutenção e renovação, impõe vivermos em uma sociedade valorizadora da aparência e da posse, o que significa forjar necessidades infinitas; essas, por sua vez, demandam a criação de produtos novos, atraentes, às vezes inúteis e de rápido descarte; e exigem, por inevitável consequência, rápidas inovações tecnológicas e uma incomensurável utilização dos recursos naturais disponíveis.

Grosso modo, ao basear-se na apropriação da riqueza (visando ao lucro), o sistema impõe uma ampla competitividade entre os produtores para verem seus produtos consumidos, exigindo deles não somente rapidez na produção e no consumo, como também diminuição dos custos. Toda essa agilidade de produção e consumo, com a diminuição de custos, são propiciados pelo avanço científico e tecnológico (leia-se: máquinas que produzem mais rápido, com maior tecnologia e eficiência, a baixo custo). Mas, não é suficiente a criação célere de novos produtos com baixo custo; é preciso, além disso, ser o consumo incentivado pela criação constante de novas necessidades que levam ao desejo

\footnotetext{
${ }^{206}$ MILARÉ, Édis. Direito do ambiente. $7^{\mathrm{a}}$ ed., São Paulo: RT, 2011, p. 1035. O autor lembra que a corrida armamentista e as guerras, em regra, não passam de dissensões entre países que buscam a conquista da hegemonia sobre os bens essenciais e estratégicos da natureza. A questão ideológica nada mais é do que um biombo a esconder essa verdade. De fato, a possibilidade de conflitos tende a aumentar, já que o mundo, depois de ter enfrentado a crise do petróleo na segunda metade do século XX, prepara-se agora para enfrentar a crise da água. Lembre-se, por exemplo, que a paz no Oriente Médio estará sempre em risco pela ameaça de uma bomba-d'água. Aliás, um dos motivos da guerra entre Israel e seus vizinhos (a Guerra dos Seis Dias), em 1967, foi justamente a ameaça, por parte dos árabes, de desviar o fluxo do rio Jordão, que, juntamente com seus afluentes, fornece $60 \%$ da água consumida em Israel.

${ }^{207}$ Como salientado em notas acima, isso não significa, todavia, que outros sistemas econômicos fossem capazes de manter incólume ou mais saudável o meio ambiente. O que se diz aqui, é que os pressupostos do modo de produção e consumo capitalistas se contrapõem frontalmente com a necessidade da proteção ambiental. Aliás, quando se fala em "leis", quer se referir justamente aos pressupostos de certo modelo de desenvolvimento econômico.

${ }^{208}$ A respeito dos impactos que a globalização gera no meio ambiente, vide VIEIRA, Liszt. Cidadania e Globalização. 8a ed. Rio de Janeiro: Record, 2005, p. 92-97.
} 
(e daí a publicidade e o marketing) e, por decorrência, à 'pseudo-obrigação' dos homens (sobretudo os que habitam os meios urbanos) de consumir itens, os quais, aparentemente, irão suprir tais necessidades. A economia de mercado, portanto, cria a cada dia necessidades sociais e culturais (como, por exemplo, a adoração ou culto do mito da juventude eterna) a fim de que os homens, inconscientemente, sejam levados a consumir os produtos que lançados pelos mercado.

Surge uma competitividade que implica acelerar o processo de produzir e de consumir, encurtando o tempo normalmente exigido para satisfazer novas carências. Vale dizer, quando se ‘cria' uma nova necessidade, é preciso acelerar o processo de comercialização do bem de consumo capaz de supri-la, porque, de imediato, surgirão produtos similares, de outras marcas, os quais também suprirão aquela mesma necessidade. ${ }^{209} \mathrm{E}$, a partir do momento em que se dá conta de determinado produto - por ter sido copiado, ou por ter sido superado pelo feito de tecnologia - não ser mais consumido em número suficiente para atender as expectativas de lucro, é necessário, então, fabricar também rapidamente outro produto e, por consequência, gerar uma nova necessidade.

Num cenário da sociedade globalizada, intensifica-se a cada dia esse processo produtivo, porquanto o incremento científico e tecnológico (para propiciar uma rápida comercialização, e daí o lucro) permite uma célere criação de bens de consumo. De fato, o modo de produção de mercado amplia-se progressivamente em âmbito mundial, bastando considerar não haver mais apenas produtores competindo dentro de cada região ou no âmbito de um determinado país; na verdade, os produtores estão localizados no mundo inteiro,

\footnotetext{
${ }^{209}$ Isso se evidencia claramente com o proliferado lançamento de 'smartphones', como o 'Iphone', da conhecida Apple, lançado em janeiro de 2007, o qual, em quatro anos, já se encontra indo para a sua quinta geração (o site Wikipedia nos dá conta de que a quinta geração, o IPhone 4S foi anunciado em 4 de outubro de 2011). Tal aparelho foi, como é notório, extremamente copiado por empresas concorrentes. Isso sem falar na velocidade com que foi lançado o 'tablet' conhecido como 'iPad', também da Apple, e que em menos de um ano, já lançou uma segunda geração, chamado de iPad 2 (sobre este aparelho, o referido site Wikipedia expõe que o primeiro iPad foi lançado em abril de 2010, tendo sido vendidos três milhões de equipamentos em oitenta dias. Durante 2010 foram vendidos quatorze milhões e oitocentos mil aparelhos. Já em março de 2011, ou seja, em menos de um ano, a Apple lançou a segunda versão do 'tablet', conhecido como iPad 2). Sabe-se que o iPad vem sendo em muito copiado por empresas concorrentes, como o 'tablet' da Samsung Galaxy, lançado em setembro de 2010 (e cujas vendas, segundo anunciado na mídia, ultrapassaram o iPad 2 no terceiro trimestre de 2011).
} 
independentemente da sua nacionalidade. Da mesma forma, pulverizam-se mundo afora os riscos com a descomedida utilização dos recursos naturais, não se podendo, então, apontar causas e causadores específicos para muitos dos danos ambientais e, tampouco, responsabilidades identificáveis.

Por esse prisma, fica claro que a competitividade e o tempo necessário para produzir e consumir bens geram uma racionalidade apenas econômica com base em um tipo de exploração da natureza, fonte de matéria-prima ou depositária de rejeitos, absolutamente incompatível com a atual exigência de sua preservação. Em outros termos, o ciclo de produção, consumo e descarte não se compatibiliza com a limitação dos recursos naturais, e com a capacidade de o planeta absorver os resíduos gerados; daí a absoluta contradição das leis do desenvolvimento econômico do sistema de mercado com as leis de proteção do meio ambiente. Nas palavras de Édis Milaré:

o processo de desenvolvimento dos países se realiza, basicamente, à custa dos recursos naturais vitais, provocando a deterioração das condições ambientais em ritmo e escala até então ainda desconhecidos. A paisagem natural da Terra está cada vez mais ameaçada pelos riscos nucleares, pelo lixo atômico, pelos dejetos orgânicos, pela "chuva ácida”, pelas indústrias e pelo lixo químico.

Por conta disso, em todo o mundo - e o Brasil não é nenhuma exceção -, o lençol freático se abaixa e se contamina, a água escasseia, a área florestal diminui, o clima sofre profundas e quiçá irreversíveis alterações, o ar se torna irrespirável, o patrimônio genético se desgasta, abreviando os anos que o homem tem para viver sobre o Planeta. Isto é, "do ponto de vista ambiental o planeta chegou quase ao ponto de não retorno. Se fosse uma empresa estaria à beira da falência, pois dilapida seu capital, que são os recursos naturais, como se eles fossem eternos. O poder de autopurificação do meio ambiente está chegando ao limite. ${ }^{210}$

Aliás, esse paradoxo entre o processo produtivo e a limitação dos recursos naturais, no estágio de globalização e ampliação da degradação ambiental, sobretudo frente à cumulatividade de impactos, vem sendo considerado como uma nova fase pela qual passa a humanidade, considerada,

${ }^{210}$ MILARÉ, Édis. Direito do ambiente. $7^{\mathrm{a}}$ ed. São Paulo: RT, 2011, p. 66. 
conforme analisado no item 3.3.4 Capítulo 3 deste estudo, uma 'sociedade de risco' ou, como preferimos, uma 'sociedade das incertezas'.

Em uma palavra: não há mais dúvidas da limitação ou escassez dos recursos naturais - inclusive os renováveis: flora, fauna, água, solo, ar -, os quais, bem por isso, não podem ser explorados de modo ilimitado.

Assim, infere-se desse paradoxo o fato de a saída para a crise ser de dificílima - senão impossível - solução, pois qualquer alternativa tende a levar à inevitável ruptura do sistema de mercado vigente. Ou seja, na hipótese de se decidir por continuar explorando os recursos da natureza nos moldes atuais, será inevitável a destruição do meio ambiente, o que também significará a destruição do sistema econômico. Caso se persiga uma radical conservação dos recursos naturais, para o bem da qualidade de vida das presentes e futuras gerações, também haverá uma ruptura das bases do sistema econômico, vez que a intensa utilização daqueles é absolutamente necessária para a sua manutenção e reprodução, sobretudo no planeta globalizado em que vivemos. ${ }^{211}$

Portanto, por um lado, é bastante ingênuo advogar a resolução da crise ou do problema ambiental vivenciado neste século XXI, pois isso só será possível com a transposição das bases do sistema econômico ocidental. Por outro lado, embora não seja factível transpô-lo, é necessário defender a atenuação ou acomodação dessa situação de impasse ou de contradição - como se fez com as contradições $^{212}$, ou falhas de

${ }^{211}$ A esse respeito, o sociólogo Michael Burawoy, em entrevista divulgada na Folha de São Paulo de 09.10.2011, expõe que 'a grande crise do capitalismo virá com a catástrofe ambiental' e, ainda, que 'a crise de fundo do capitalismo: [será] destruir as condições de sua própria existência, destruindo o ambiente.'

${ }^{212}$ Vale mencionar que outras contradições já se revelaram no sistema econômico. A respeito, cite-se a crise da década de 1930, quando houve o conhecido crack na economia americana, situação que foi acomodada ou atenuada pela estruturação do Estado de Bem-Estar Social. Nesse sentido, lança-se mão novamente dos ensinamentos de João Sette Whitaker Ferreira, que expõe com clareza que "embora a economia dos países em desenvolvimento já contasse, desde o século XIX, com forte protecionismo estatal, o liberalismo econômico e em especial o período liberal da economia norte-americana entre 1913 e 1929 levariam a economia capitalista à crise de 1930, conhecida dos economistas como uma crise 'de subconsumo', que se sobrepôs aos aspectos de cunho apenas territorial e espacial. De forma muito resumida, a situação era a de que, ao explorar exaustivamente a força de trabalho e rebaixar constantemente os salários, o antagonismo já apontado por Marx chegaria a seu ponto extremo: o capitalismo industrial, que além do mais se financeirizava rapidamente, produzia sem parar, porém não tinha mais a quem vender. A saída para tal impasse teria uma lógica clara: promover, por meio da intervenção do Estado, agora no âmbito da regulação econômica keynesiana, a elevação generalizada dos padrões de consumo da população - e portanto da força de trabalho - para garantir a expansão do mercado de consumo de massa e o escoamento da produção, viabilizando o ciclo de produção do capital. Marcada por forte intervencionismo estatal, a estruturação do chamado Estado do Bem-Estar Social deu-se baseada em políticas de proteção tarifária, subvenções às 
mercado ${ }^{213}$, já evidenciadas no interior do sistema econômico de mercado -, seja por meio de decisões políticas, seja mediante a irrupção de normas e regras jurídicas limitadoras da utilização dos recursos naturais ou indutoras de condutas 'mais limpas', seja pela constante busca por uma maior justiça ambiental. É preciso, em suma, encontrar meios para manter a qualidade ambiental, propiciadora de uma saudável condição de sobrevida para o ser humano e, ao mesmo tempo, capaz de permitir a renovação e a manutenção do sistema econômico vigente.

4.2.2 A crise ambiental e as necessárias alterações introduzidas no sistema econômico e no direito

A partir da conscientização quanto à realidade da crise ambiental e do paradoxo existente entre as bases do sistema econômico vigente e o crescente esgotamento dos recursos naturais, foi possível verificar profundas alterações no campo da economia e do direito, como forma de atenuar a crise, por meio de mecanismos políticos, econômicos e jurídicos.

Diante desse cenário de crise ambiental, em um primeiro momento a economia passa a exigir inovações tecnológicas para o desenvolvimento de técnicas de produção “mais limpas”, capazes de atender às demandas do mercado e, ao mesmo tempo, preservar os recursos naturais. Por conseguinte, a inicial positivação de normas ambientais teve por escopo justamente impor a obrigação de empregar novas técnicas de produção - mantendo, no entanto, seus

exportações, créditos públicos, oferta de monopólios, apoio à pesquisa e desenvolvimento, criação de frentes de trabalho, autorização à criação de sindicatos, e assim por diante. A mobilização e luta do proletariado, que no bojo dessa conjuntura foi garantindo vitórias trabalhistas fundamentais, permitiu a regulamentação de seus direitos, como o limite à jornada de trabalho, as férias, o salário mínimo, a assistência médica e educacional, o que na prática contribuiu para a consolidação do bem-estar social.” FERREIRA, João S. Whitaker, Ob.cit., p. 41-42.

${ }^{213}$ Fábio Nusdeo cita seis falhas, imperfeições ou inoperacionalidades do mercado. O autor define as falhas de mercado como as 'situações nas quais os seus pressupostos de funcionamento não se fazem presentes, tornando-o inoperacional. Essas falhas seriam ‘1) quanto à mobilidade de fatores - é uma falha de origem física ou cultural; 2) quanto à transparência ou acesso à informação - é uma falha de origem legal; 3) quanto à concentração da economia - é uma falha de estrutura; 4) quanto aos efeitos externos ou externalidades - é uma falha de sinal; 5) quanto ao suprimento de bens coletivos - é uma falha de incentivo; 6) a falha analítica quando os custos de transação são desconsiderados.'. A respeito, vide NUSDEO, Fábio. Curso de economia: introdução ao Direito Econômico. 6a ed. rev. atual. São Paulo: RT, 2008, p. 138-170. 
níveis - como também adotar instrumentos específicos para, do mesmo modo, prevenir ou mitigar, compensar ou reparar danos ambientais.

A esse respeito, vale observar, exemplificativamente, o fato de os Estados de São Paulo e do Rio de Janeiro, na década de 1970, terem enfrentado uma crise decorrente de um notável processo de industrialização e, por decorrência, um nível alto de degradação ambiental. Por esses motivos, editaram leis e instituíram órgãos para controlar a poluição, notadamente das águas e do ar. Essas leis levaram à interdição de algumas fábricas importantes, e o Governo Federal, em pleno regime de ditadura militar, respondeu de modo autoritário com um decreto-lei, proibindo estados e municípios de interditar indústrias, reservando esse ato ao Presidente da República. Posteriormente, no início da década de 1980, e últimos anos da ditadura, a Lei Federal n 6.938, de 31 de agosto 1981, dispôs sobre a Política Nacional do Meio Ambiente, seus fins e mecanismos de formulação e aplicação. Essa lei incorporou e aperfeiçoou normas estaduais já vigentes e instituiu o Sistema Nacional do Meio Ambiente SISNAMA, integrado pela União, por Estados e Municípios, e atribuiu aos Estados a responsabilidade maior na execução das normas protetoras do meio ambiente. $^{214}$

A Lei Federal no 6.938/1981 tornou-se um marco no Direito Ambiental ${ }^{215}$, e adveio com o justo propósito de disponibilizar instrumentos para viabilizar a proteção e a conservação da natureza, procurando harmonizá-las com o considerado necessário desenvolvimento econômico. Com efeito, esse diploma incluiu como seu primeiro objetivo a “preservação, melhoria e recuperação da qualidade ambiental propícia à vida, visando assegurar no País condições ao desenvolvimento socioeconômico, aos interesses da segurança nacional e à proteção da dignidade da vida humana ...” (art. $\left.2^{\circ}\right){ }^{216} \mathrm{O}$ mesmo diploma legal ainda busca a “compatilização do desenvolvimento econômico-social com a

\footnotetext{
${ }^{214}$ MILARÉ, Édis. Direito do ambiente. $7^{\mathrm{a}}$ ed. São Paulo: RT, 2011, p. 407.

${ }^{215}$ O Direito Ambiental tem entre suas bases a identificação das situações que conduzem as comunidades naturais a uma maior ou menor instabilidade, e é também sua função apresentar regras que possam prevenir, evitar e/ou reparar esse desiquilíbrio. MACHADO, Paulo Affonso Leme. Direito ambiental brasileiro. 19a ed. São Paulo: Malheiros, 2011, p. 63.

${ }^{216}$ A referência à 'segurança nacional' é um reflexo do regime de governo que, no tempo da ditadura militar (1981) pautou-se pelos princípios da chamada Doutrina da Segurança Nacional, cujo slogan era 'Segurança e Desenvolvimento'.
} 
preservação da qualidade do meio ambiente e do equilíbrio ecológico" (art. $4^{\circ}$, I), do que é possível inferir, o fato de os legisladores possivelmente estarem mais preocupados com as ameaças ao desenvolvimento econômico de mercado devido ao discurso da proteção ambiental daquela época - do que com a defesa do meio ambiente propriamente dita.

Posteriormente, promulgou-se a Constituição Federal de 1988, contemplando um verdadeiro capítulo de proteção ambiental ${ }^{217}$, evidenciado pelo seu art. 225, in verbis: “Todos têm direito ao meio ambiente ecologicamente equilibrado, bem de uso comum do povo e essencial à sadia qualidade de vida, impondo-se ao Poder Público e à coletividade o dever de defendê-lo e preservá-lo para as presentes e futuras gerações.” Mas não é só. Seu art. 170, ao tratar da ordem econômica, impõe o dever de a economia ser “fundada na valorização do trabalho humano e na livre iniciativa, tem por fim assegurar a todos existência digna, conforme os ditames da justiça social, observados os seguintes princípios: (...) VI - defesa do meio ambiente, inclusive mediante tratamento diferenciado conforme o impacto ambiental dos produtos e serviços e de seus processos de elaboração e prestação.”

Diante da conciliação necessária entre o direito ao desenvolvimento e o direito a uma vida saudável, José Afonso da Silva expõe decorrer, daí, “como consequência, que os Estados, por terem que satisfazer a esses dois direitos humanos dos respectivos povos, 'têm o direito soberano de explorar seus próprios recursos segundo suas próprias Políticas de Meio Ambiente e Desenvolvimento, e a responsabilidade de assegurar que atividades sob sua jurisdição ou controle não causem danos ao meio ambiente de outros Estados ou de áreas além dos limites da jurisdição nacional’”. ${ }^{218}$

A bem ver, o referido art. 170 da Lei Maior mostra a necessidade de preservação do meio ambiente não só pelo fato de ser direito de todos a um

\footnotetext{
${ }^{217}$ Conforme Paulo Affonso Leme Machado, “a Constituição de 1988 pela primeira vez no Brasil insere o tema 'meio ambiente' em sua concepção unitária. Não foi a primeira Constituição da América Latina a fazêlo, tendo sido precedida pelas Constituições do Equador e do Peru de 1979, Chile e Guiana de 1980, Honduras de 1982, Panamá de 1983, Guatemala de 1985, Haiti e Nicarágua de 1987. Nossos ancestrais na Europa - Portugal e Espanha - inovaram em 1976 e 1978 - introduzindo o tema nas Constituições.” MACHADO, Paulo Affonso Leme. Direito ambiental brasileiro. 19a ed. São Paulo: Malheiros, 2011, p. 121. ${ }^{218}$ SILVA, José Afonso da. Direito ambiental constitucional. 9a ed. São Paulo: Malheiros, 2011, p. 66.
} 
ambiente saudável, mas também para viabilizar a renovação do sistema econômico vigente.

As disposições dos arts. 225 e 170, inciso VI, da Constituição Federal densificam o princípio do desenvolvimento sustentável, cunhado no final da década de 1980 e amplamente utilizado a partir da década de 1990. Tal conceito tem como princípio a possibilidade de conciliar o crescimento econômico com a preservação da natureza. A expressão desenvolvimento sustentável tornou-se famosa após haver sido definida no documento chamado 'Nosso Futuro Comum' (ONU, 1987), também conhecido como Relatório Bruntland ${ }^{219}$, em homenagem à primeira ministra norueguesa, a quem se deve a sua elaboração; nesse documento sustentou-se a máxima de que “todos nós neste planeta compartilhamos um futuro comum: morreremos ou sobreviveremos juntos”.

Em 1992, a Conferência das Nações Unidas sobre Meio Ambiente e Desenvolvimento - CNUMAD, mais conhecida como Rio 92 ou Eco 92, adotou, na Declaração do Rio e na Agenda 21, o conceito do desenvolvimento sustentável como meta a ser buscada e respeitada por todos os países. Nesse sentido, o Princípio 4 desse documento estabelece: "Para alcançar o desenvolvimento sustentável, a proteção ambiental constituirá parte integrante do processo de desenvolvimento e não pode ser considerada isoladamente deste.”

Não há dúvidas de que o conceito de desenvolvimento sustentável denunciou, de forma implícita, como inviáveis os atuais modelos de desenvolvimento, tanto no Hemisfério Norte como no Hemisfério Sul, onde se seguem padrões de crescimento econômico não sustentáveis. O conceito põe em mira a discussão de um novo padrão até mesmo por razões de ordem ética: não se aceita que a geração atual, para sobreviver, destrua as condições de sobrevivência das gerações vindouras. ${ }^{220}$

\footnotetext{
${ }^{219}$ Em breve síntese, as Nações Unidas criaram a Comissão Mundial de Meio Ambiente e Desenvolvimento, em 1983, de modo que esta, presidida por Gro Bruntland, na ocasião, primeira-ministra da Noruega, concluiu que, para satisfazer as necessidades do presente sem comprometer a capacidade das futuras gerações de satisfazer suas necessidades, a proteção ao meio ambiente e o crescimento econômico deveriam ser abordados como uma única questão. Como resultado do Relatório Bruntland, a Assembléia Geral das Nações Unidas convocou a Conferência das Nações Unidas sobre Meio Ambiente e Desenvolvimento (CNUMAD). Essa conferência, conhecida como Eco 92, ou Cúpula da Terra, aconteceu no Rio de Janeiro de 3 a 14 de junho de 1992. Foi um marco decisivo nas negociações internacionais sobre as questões de meio ambiente e desenvolvimento.

${ }^{220}$ VIEIRA, Lizst. Cidadania e globalização. 8a ed. Rio de Janeiro: Record, 2005, p. 130.
} 
O conceito de desenvolvimento sustentável foi - e é - difundido como um “projeto social e político que aponta para o ordenamento ecológico e a descentralização territorial da produção, assim como para a diversificação dos tipos de desenvolvimento e dos modos de vida das populações que habitam o planeta”.221

Em suma, é inquestionável que esse entendimento ensejou uma nova visão da crise ambiental e do futuro, e exigiu um repensar o caminho que a humanidade está trilhando.

No entanto, por outro prisma, e levantando a cortina da aparência, que enaltece a importância da proteção ambiental, percebe-se, no sistema econômico vigente, o discurso da sustentabilidade montando um simulacro a fim de negar os limites do crescimento, e, com isso, acelerar a corrida desenfreada do processo econômico para a morte entrópica. ${ }^{222}$

Com efeito, ao se deparar com a necessidade de, ao mesmo tempo, proteger os recursos naturais como maneira de se manter um meio ambiente ecologicamente equilibrado e, ainda, propiciar a utilização desses mesmos recursos para o desenvolvimento econômico, emprega-se - discursivamente, no caso - o conceito ou o princípio do desenvolvimento sustentável. ${ }^{223}$

Isso significa ter o entendimento do desenvolvimento sustentável aparentemente resolvido a dicotomia entre o avanço do crescimento econômico nos moldes do sistema de mercado e a obrigatória proteção do meio ambiente. De fato, a partir desse conceito ou princípio 'convencionou-se' que os recursos naturais não deverão ser explorados a um ponto em que eles não mais possam ser renovados a médio ou a longo prazo.

${ }^{221}$ LEFF, Enrique. Saber ambiental: sustentabilidade, racionalidade, complexidade, poder. Trad. Lúcia Mathilde Endlich Orth. $5^{\mathrm{a}}$ ed. Petrópolis: Vozes, 2001, p. 57.

${ }^{222}$ Idem, p. 23.

${ }^{223}$ É oportuno expor que a Constituição Federal, em verdade, parece ter conformado a contradição existente entre a preservação dos recursos econômicos e a necessidade de o sistema econômico utilizá-los cada vez de forma mais intensa. Em outras palavras, o desenvolvimento sustentável relativiza ou coloca no mesmo plano os direitos fundamentais, de um lado, do desenvolvimento econômico e da livre iniciativa e, de outro lado, a garantia do meio ambiente ecologicamente equilibrado. Sempre haverá, no entanto, a necessidade de manter um equilíbrio (ou, como usamos dizer, o marco de elasticidade) do sistema econômico vigente. Isso significa, por vezes, que o interesse por um meio ambiente equilibrado se sobreporá ao interesse econômico e, por outras, a economia se sobreporá ao meio ambiente, uma vez que, consoante lembra o Prof. Fábio Nusdeo, tratam-se de princípios e não de regras jurídicas, donde à inevitável e mesmo necessária ponderação 
Assim, o ideal do desenvolvimento sustentável, ao defender a inclusão da variável ambiental no processo de produção do modelo de mercado, propicia a reprodução do atual sistema mediante a manutenção dos hodiernos índices de crescimento econômico. Com a inclusão da variável ambiental, esse ideal, a curto prazo, promove uma suave mitigação para a crise ambiental; a longo prazo, porém, não conseguirá reverter o possível esgotamento dos recursos da natureza, utilizados de forma exponencial pelas forças produtivas de mercado.

Por conseguinte, não desconsiderando a importância do discurso do desenvolvimento sustentável - que enseja efetivamente um ganho de consciência por parte da sociedade em geral, e implica, ainda, a criação e a implementação de medidas absolutamente necessárias para a proteção do meio ambiente -, dificilmente esse discurso favorecerá o fim maior de preservação ambiental e a garantia de qualidade de vida para as atuais e futuras gerações. Para tanto, como visto, seria necessário alterar o modo de produção capitalista, implementando-se, por exemplo, sociedades sustentáveis, nas quais se asseguraria a utilização de instrumentos capazes de propiciar a subsistência de uma determinada comunidade de acordo com os seus próprios recursos. ${ }^{224}$

Sintetizando este raciocínio, Liszt Vieira pontua:

não resta dúvida de que o conceito de desenvolvimento sustentável pode ser usado como instrumento para denunciar e tentar resolver os conflitos entre crescimento econômico, desigualdade social e conservação ambiental. Inegavelmente, porém, ele possui um lado ingênuo, ao ignorar a correlação de forças no plano internacional em favor dos países

em torno desses princípios, na esteira de Dworkin e, entre nós, Humberto Ávila e Virgílio Lopes da Silva e demais autores sobre o tema.

${ }^{224}$ Um exemplo de sociedade sustentável são as reservas extrativistas que foram instituídas como Unidades de Conservação de uso sustentável. Segundo a Lei Federal nº 9.985, de 18 de julho de 2000, são áreas utilizadas por populações extrativistas tradicionais, cuja subsistência baseia-se no extrativismo e, complementarmente, na agricultura de subsistência e na criação de animais de pequeno porte, e tem como objetivos básicos proteger os meios de vida e a cultura dessas populações, e assegurar o uso sustentável dos recursos naturais da unidade (art. 18). Até 2008, e segundo o Instituto Brasileiro de Meio Ambiente e dos Recursos Naturais Renováveis (Disponível em: <www.ibama.gov.br>), haviam sido criadas trinta e nove reservas extrativistas em âmbito nacional, não havendo, na época, aprovação para qualquer delas do respectivo plano de manejo, instrumento essencial para a gestão dessas áreas. A respeito das reservas extrativistas, ver SANTILLI, Juliana. Socioambientalismo e novos direitos. São Paulo: Peirópolis, 2005, p. 141-147. 
industrializados, as relações desiguais no comércio internacional, o poder das multinacionais etc. ${ }^{225}$

As inúmeras críticas ao conceito de desenvolvimento sustentável vêm tornando obsoleto o seu emprego apenas discursivo ou retórico. Hoje, o discurso funda-se mais nos já analisados ${ }^{226}$ conceitos dos direitos das futuras gerações ou da ética da equidade intergeracional, como também nos alardes frente à 'sociedade de risco, 227 .

Por ora, é suficiente notar como são alarmantes os prognósticos em relação à espoliação irracional dos recursos naturais, particularmente os não renováveis e os essenciais à sobrevivência planetária. Como não há a perspectiva - ou vontade? - para se reformular o comportamento da sociedade humana, ou promover uma verdadeira mudança quanto à forma de produção e consumo atuais, buscam-se respostas e fórmulas para equacionar ou atenuar a crise ambiental.

Diante desses alardes, essas respostas e soluções, seja para resolver a crise ambiental, seja para escamoteá-la, são buscadas na formalização de equações econômicas, políticas e jurídicas.

\subsection{Os princípios e as normas ambientais}

A permanente e cada vez mais assustadora crise ambiental, ou a crescente escassez dos recursos naturais, exige intervenções econômicas pelo Estado, determinando, pois, a imposição de estratégias de preservação ambiental ${ }^{228}$. Nesse contexto, estabelece-se a necessidade de introduzir reformas democráticas no Estado, de incorporar normas ecológicas ao processo econômico e de criar

\footnotetext{
${ }^{225}$ VIEIRA, Lizst. Ob. cit., p. 131.

${ }^{226}$ Vide item 3.34 do Capítulo 3 desta tese.

${ }^{227}$ Como visto no item 3.3.4 do Capítulo 3 desta tese, a sociedade de risco está fundamentada no fato de a contradição entre as leis do sistema econômico capitalista e as leis da proteção ambiental terem evoluído ao ponto de colocar a humanidade, enfim, no tão temido momento de incertezas quanto ao futuro. Ou seja, chegou-se ao estágio, sem retorno, que tanto preocupava aqueles defensores do desenvolvimento sustentável nas décadas de 80 e 90 do século passado.

${ }^{228}$ CAFFÉ ALVES, Alaôr. Fundamentos dos direito e meio ambiente. In: PHILIPPI JR., Arlindo; CAFFÉ ALVES, Alaôr (eds.). Curso interdisciplinar de Direito Ambiental. Barueri: Manole, 2005, p. 318.
} 
novas técnicas para controlar os efeitos contaminantes e dissolver as externalidades socioambientais geradas pela lógica do capital. ${ }^{229}$

Essas estratégias podem ser vistas como um impulso ideológico, pois permitem manter o modo irracional do sistema de mercado, não pela força, mas pelo convencimento social de que não há razões para alardes e revoltas. Significa dizer que a manifestação representativa do sistema jurídico-ambiental cria uma falsa impressão de que existe uma ativa e completa assistência ecológica por parte do Estado, o que produz uma realidade fictícia, na qual a sociedade é mantida confiante e tranquila em relação aos padrões de segurança existentes. $^{230}$

Diante desse cenário, a crise ambiental é resolvida na sua aparência, mediante a imposição de regras que contemplem saídas formais para o problema. Vale observar, no entanto, não ter a normatização do problema o condão de pôr o acento no principal, ou seja, nas contradições entre a forma adotada para produção e consumo e a limitação dos recursos naturais.

O Protocolo de Kyoto, por exemplo, é uma alternativa formal para o problema das mudanças climáticas; cria-se um sistema que, virtualmente, será capaz de reduzir as emissões de carbono de um determinado país, mediante a compensação pela sua redução por parte de outro país. Assim, permite-se uma postergação ou uma melhora no problema das mudanças climáticas, mas, todavia, não necessariamente o resolve. Com efeito, em síntese, para tanto seria necessário, a uma, adotar de imediato estratégias de alteração substancial nos modos de produção e consumo atuais e, a duas, encontrar outras formas de energia mais limpas de modo a cessar, ou ao menos diminuir, a utilização do combustível fóssil ${ }^{231}$.

\footnotetext{
${ }^{229}$ LEFF, Enrique. Saber Ambiental. Trad. Lúcia Mathilde Endlich Orth. 5a ed. Petrópolis: Vozes, 2001, p. 133.

${ }^{230}$ LEITE, José Rubens Morato; AYALA, Patryck de Araújo. Dano ambiental: do patrimonial ao coletivo extrapatrimonial: teoria e prática. $4^{\mathrm{a}}$ ed. rev. atual. ampl. São Paulo: RT, 2011, p. 119.

${ }^{231}$ Já em 1975, Fábio Nusdeo, sustentava que “... deve ter ficado clara a idéia de que o crescimento econômico de duração indefinida somente poderá conviver com a necessária preservação do meio ambiente e da manutenção de razoáveis fontes de abastecimento de matéria-prima, desde que ele, como processo, passe a incorporar nova tecnologia voltada a esses objetivos”. NUSDEO, Fábio. Desenvolvimento e ecologia. São Paulo: Saraiva, 1975, p. 20-21.
} 
Por conseguinte, por qualquer ângulo que se observe a crise ambiental, vê-se a estruturação de todo um arcabouço de normas nacionais e internacionais pretendendo racionalizar a crise ao incluir, em suma, a variável ambiental no processo econômico. ${ }^{232}$ Daí, o Direito Ambiental.

O Direito Ambiental, portanto, ao mesmo tempo em que garante a manutenção e a reprodução do atual sistema econômico, vem dar esperanças à continuação da própria existência da espécie humana, que está ameaçada pelos nefastos efeitos já visíveis do processo produtivo hodierno.

A respeito, Alaôr Caffé Alves sustenta:

o capitalismo, especialmente em sua fase avançada ou tardia, abre possibilidades científico tecnológicas infinitas para os homens, mas tais possibilidades logo se mostram limitadas pela necessidade de preservação das condições naturais do planeta que não suportam as pressões degradadoras decorrentes dos anseios para a acumulação acelerada do capital. Progressiva e rapidamente, vai se formando a consciência coletiva dessa limitação, particularmente a respeito dos grandes riscos e perigos para todos os povos do mundo, especialmente em razão da exploração irracional e globalizada dos recursos naturais de todo o planeta. Dessa consciência, formada a partir das condições estruturais da sociedade, surgem os movimentos sociais e políticos de defesa do meio ambiente, exigindo controles cada vez mais aprimorados e eficazes, dentre os quais avulta a criação, aperfeiçoamento e ampliação acelerados das normas jurídicas, nacionais e internacionais. ${ }^{233}$

Na mesma linha, Édis Milaré acrescenta ser lei uma terapia para a superação da crise ambiental, porquanto

entre as várias terapias ecológicas sugeridas para a prevenção e a cura da doença, ressalta-se o recurso ao Direito como elemento essencial para coibir, com regras coercitivas, penalidades e imposições oficiais, a desordem e a prepotência dos poderosos (poluidores, no caso). É que, como dissemos, dado que o embate de interesses para a apropriação dos bens da

\footnotetext{
${ }^{232}$ Forte nessa realidade, e tendo em vista o caráter global e a dimensão planetária que assumem as graves e crescentes perturbações do equilíbrio ecológico, é que, na Declaração do Rio de Janeiro sobre Meio Ambiente e Desenvolvimento (1992), se inseriu, no Princípio 11, recomendação segundo a qual "os Estados adotarão legislação ambiental eficaz (...)”. Na mesma linha, aliás, a Agenda 21, no seu Capítulo 39, buscou incentivar a formulação de propostas para o aperfeiçoamento da capacidade legislativa dos países em desenvolvimento. MILARÉ, Édis. Direito do ambiente. $7^{\mathrm{a}}$ ed. São Paulo: RT, 2011, p. 1037.

${ }^{233}$ CAFFÉ ALVES, Alaôr. Ob.cit., p. 318.
} 
natureza se processa em autêntico clima de guerra - de prepotentes Golias contra indefesos Davis -, a ausência de postulados reguladores de conduta poderia redundar numa luta permanente e desigual, com o mais forte sempre impondo-se ao mais fraco. E é evidente que esse estado de beligerância não convém para a tranquilidade social, já que o homem não pode estar em paz consigo mesmo enquanto estiver em guerra com a natureza. Daí a necessidade de um regramento jurídico, para que esse jogo de interesses possa estabelecer-se com um mínimo de equilíbrio, pois é sabido que, 'onde há fortes e fracos, a liberdade escraviza, a lei é que liberta`. Começou, então, o legislador a transfundir em normas os valores da convivência harmoniosa do homem com a natureza, ensejando o aparecimento de uma nova disciplina jurídica - o Direito Ambiental -, nascida do inquestionável direito subjetivo a um ambiente ecologicamente equilibrado e de um direito objetivo cujos passos, ainda titubeantes, urge afirmar e acelerar. ${ }^{234}$

Tendo claras, pois, a crise ambiental e, por decorrência, as circunstâncias das quais emergiu o ordenamento jurídico ambiental em âmbito nacional e internacional, é importante atentar que o Direito Ambiental (denominado também Direito do Ambiente) está organizado em princípios dogmáticos estruturadores, sólidos e juridicamente bem desenvolvidos. Segundo Michel Prieur, são grandes princípios que “resultént soit du droit international conventionnel ou coutumier, soit du droit national à travers les constitutions ou les lois cadre sur l'environnement." ${ }^{235}$ Embora esses grandes princípios possam subdividir-se em outros, não havendo consenso na doutrina ${ }^{236}$ sobre a quantidade

\footnotetext{
${ }^{234}$ MILARÉ, Édis. Ob. cit., p. 1036.

${ }^{235}$ Para esse mesmo autor, “depuis Stockholm (1972), l'Acte unique européen (1985), le traité de Maastricht et Rio (1992), on assiste à une extension de ce que Kant appelait le droit cosmopolitique. Il y a désormais des príncipes comuns aux peuples de la planète, expression d'une solidarité mondiale due à la globalité des problèmes d'environnement. Cela conduit, selon le préambule de la Déclaration de Rio, à instaurer 'un partenariat mondial sur une base nouvelle' en reconnaissant que 'la terre, foyer de l'humanité, constitue un tout marqué par l'interdépendance'.” PRIEUR, Michel. Droit de l'environnement. $5^{\mathrm{a}}$ ed. Paris: Dalloz, 2004, p. 49.

${ }^{236}$ Édis Milaré expõe serem os princípios fundamentais do Direito do Ambiente: (i) princípio do ambiente ecologicamente equilibrado como direito fundamental da pessoa humana; (ii) princípio da solidariedade intergeracional; (iii) princípio da natureza pública da proteção ambiental; (iv) princípios da prevenção e da precaução; (v) princípio da consideração da variável ambiental no processo decisório de políticas de desenvolvimento; (vi) princípio do controle do poluidor pelo poder público; (vii) princípio do poluidorpagador (polluter pays principle); (viii) princípio do usuário-pagador; (ix) princípio da função socioambiental da propriedade; (x) princípio da participação comunitária; (xi) princípio da cooperação entre os povos. In: Direito do Ambiente. $7^{\text {a }}$ ed. São Paulo: RT, 2011, p. 1064-1081. Por sua vez, Paulo Affonso Leme Machado elenca como princípios gerais do direito ambiental os que seguem: (i) princípio do direito ao meio ambiente equilibrado; (ii) princípio do direito à sadia qualidade de vida; (iii) princípio do acesso equitativo aos recursos naturais; (iv) princípios usuário-pagador e poluidor-pagador; (v) princípio da precaução; (vi) princípio da prevenção; (vii) princípio da reparação; (viii) princípio da informação; (ix) princípio da
} 
exata de princípios e subprincípios norteadores do Direito Ambiental, e tampouco unanimidade quanto à sua nomenclatura, pode-se dizer serem eles os: (i) princípio da informação; (ii) princípio da participação; (iii) princípio da prevenção; (iv) princípio da precaução; e (v) princípio do poluidor-pagador.

Todos eles se entrelaçam, são do mesmo quilate e guiam conjuntamente as regras positivadas do Direito Ambiental. Todavia, o tema deste estudo concentrar-se-á, sobretudo, no princípio do poluidor-pagador.

\subsection{As externalidades negativas e o princípio do poluidor-pagador}

Como visto, dentre os princípios do Direito Ambiental, o princípio do poluidor-pagador ${ }^{237}$ tem merecido um incremento teórico e grande aplicação prática na sociedade contemporânea caracterizada economicamente pela produção e consumo de bens; dele vêm se erigindo inúmeras normas capazes de lhe prestar eficácia.

A seu respeito, vale observar de início, entre parênteses, que se usa falar também em princípio do usuário-pagador. Por vezes, o usuário é distinguido frontalmente do princípio do poluidor-pagador, por outras, são considerados complementares e, ainda, há oportunidades onde se sustenta que o princípio do poluidor-pagador é um subprincípio do usuário-pagador. De fato, para alguns autores, como Paulo Affonso Leme Machado, um princípio complementa o outro e, para outros, como Édis Milaré, os princípios são diversos e não tem qualquer intuito de complementação ou hierarquia. De fato, Leme Machado ensina que “o princípio usuário-pagador contém o princípio poluidor-pagador, isto é, aquele que obriga o poluidor a pagar a poluição que pode ser causada ou que já foi causada”. ${ }^{238}$ Milaré, por sua vez, sustenta que “o princípio do usuário-pagador

participação; (x) princípio da obrigatoriedade da intervenção do Poder Público. In: Direito ambiental brasileiro. $19^{\mathrm{a}}$ ed. São Paulo: Malheiros, 2011, p. 61-118.

${ }^{237}$ Observe-se, por oportuno, que ao se referir ao poluidor, este estudo quer caracterizar tanto aquele que produz bens ou exerce atividades poluentes, como também aquele que os consome.

${ }^{238}$ MACHADO, Paulo Affonso. Direito ambiental brasileiro. 19a ed. São Paulo: Malheiros, 2011, p. 71 
pode parecer uma reduplicação do seu congênere, o princípio do poluidorpagador. Na realidade são diferentes e, de algum modo, complementares.”239

No entanto, não vemos razões para diferenciar o princípio do usuáriopagador do princípio do poluidor-pagador. Temos ambos como variações em torno do mesmo tema, modificando-se apenas a nomenclatura. Vale dizer, o termo usuário adveio como um 'amenizador' do adjetivo poluidor, ou seja, em substituição da malvista palavra poluidor. De fato, parece serem ambos os princípios sinônimos, bastando considerar ser o usuário de recursos naturais inevitavelmente um poluidor, na medida em que suprime e modifica o meio ambiente; da mesma forma, o poluidor, ao utilizar-se de recursos naturais, causando uma degradação, é certamente um usuário de recursos naturais.

Volvendo ao princípio do poluidor-pagador, observe-se ser ele oriundo, em 1972, das instruções da Organização para a Cooperação e Desenvolvimento Econômico - OCDE ${ }^{240}$, que o apresentou como princípio econômico. Posteriormente, foi recepcionado pelo Ato Único Europeu, quando encontrou pioneiramente nas obrigações convencionais internacionais o espaço para o desenvolvimento dogmático do seu conteúdo. ${ }^{241}$ Mais adiante, foi previsto expressamente na forma do Princípio 16 da Declaração sobre Meio Ambiente e Desenvolvimento, aprovada, em 1992, por ocasião da Conferência do Rio de Janeiro: “As autoridades nacionais devem procurar promover a internalização dos custos ambientais e o uso de instrumentos econômicos, tendo em vista a abordagem segundo a qual o poluidor deve, em princípio, arcar com o custo da poluição, com a devida atenção ao interesse público e sem provocar distorções no comércio e nos investimentos internacionais.”

Como se vê, o princípio do poluidor-pagador deflui da economia que, ao constatar a escassez dos recursos naturais, exige a internalização dos seus custos no processo de produção e de consumo, deixando de ser ignorados como o foram por séculos; isso significa impor aos agentes econômicos a elaboração da conta dos custos de sua produção com a inclusão daqueles custos relativos à utilização

\footnotetext{
${ }^{239}$ MILARÉ, Édis. Direito do ambiente. $7^{\mathrm{a}}$ ed. São Paulo: RT, p. 1076.

${ }^{240}$ A respeito, vide OECD. The polluter pays principle: definition, analysis, implementation, 1975.

${ }^{241}$ LEITE, José Rubens Morato; AYALA, Patryck de Araújo. Direito ambiental na sociedade de risco. Rio de Janeiro: Forense Universitária, 2002, p. 76.
} 
dos recursos naturais. Ou seja, o princípio visa a evitar a falha de mercado conhecida como externalidade negativa ${ }^{242}$.

O conceito de externalidade foi de início citado por Marshall ${ }^{243}$, em 1890, ao constatar o fato de o preço de mercado dos bens não refletir fielmente os verdadeiros custos ou benefícios resultantes da sua produção ou do seu consumo. Mais tarde, o conceito foi estudado por Pigou, em $1920^{244}$, no contexto da economia do bem-estar, e posteriormente criticado, em 1960, por Coase. ${ }^{245}$

As externalidades negativas ${ }^{246}$, conforme Fábio Nusdeo,

correspondem, pois, a custos ou benefícios circulando externamente ao mercado, vale dizer, que se quedam incompensados, pois, para eles, o mercado, por limitações institucionais, não consegue imputar um preço. E, assim, o nome externalidade ou efeito externo não quer significar fatos ocorridos ou efeitos ocorridos fora das unidades econômicas, mas sim fatos ou efeitos ocorridos fora do mercado, externos ou paralelos a ele, podendo ser vistos como efeitos parasitas. ${ }^{247}$

Para o Direito Ambiental, o exemplo clássico dessa falha de mercado é a poluição. ${ }^{248}$ Pode-se visualizar o problema imaginando-se uma indústria que lança efluentes num rio, afetando a comunidade localizada à jusante, onde os

\footnotetext{
${ }^{242}$ É bom mencionar o fato de a utilização dos recursos naturais não geram apenas externalidades negativas, mas também externalidades positivas. Como exemplo, cite-se uma empresa que desenvolve um método de produção ou administração de baixo custo que é absorvido por outra empresa. Ou quando um fazendeiro preserva uma área florestal que favorece gratuitamente a proteção de outros fazendeiros. SEROA DA MOTTA, Ronaldo. Economia ambiental. Rio de Janeiro: Editora FGV, 2006, p. 183.

${ }^{243}$ MARSHALL, Alfred. Principles of economics. 8th ed. London: Macmillian, 1920.

${ }^{244}$ Como nos explica Ana Maria de Oliveira Nusdeo, "no tocante à falha da externalidades foi bastante influente o trabalho do economista Pigou, no seu 'The Economics of Welfare', na década de 20 do século passado. O autor propunha que o Estado taxasse a fonte geradora da externalidade quando essa fosse negativa, e subsidiasse-a quando positiva, forçando as unidades, assim, a internalizá-las.” In: O uso dos instrumentos econômicos nas normas de proteção ambiental. Revista da Faculdade de Direito da Universidade de São Paulo. v. 101, jan/dez 2006.

${ }^{245}$ ARAGÃO, Maria Alexandra de Sousa. O princípio do poluidor pagador: pedra angular da política comunitária do ambiente. Coimbra: Coimbra Editora, 1997, p. 31-32.

${ }^{246}$ Importante frisar que as externalidades negativas não decorrem necessariamente de uma ação delituosa ou ilegal por parte dos causadores dos custos, mas constituem um dado ou um resultado 'normal' de atividade econômica, a ser, evidentemente atenuado na legislação.

${ }^{247}$ NUSDEO, Fábio. Curso de economia-Introdução ao Direito Econômico. 6 ${ }^{\text {a }}$ ed. São Paulo: RT, 2010, p. 153.

${ }^{248}$ Edward Nevin expõe alguns interessantes exemplos de externalidades negativas em geral: "loud music may give much pleasure to one person but cause considerable annoyance to his neighbor; each new car purchased adds to congestion and thus reduces the utility of a car to all exiting others; a new house to one is a loss of view to another, and so on.” NEVIN, Edward. The economics of Europe. Macmillan, 1990, p. 82.
} 
resíduos são responsáveis pela redução das atividades pesqueiras e requerem maiores custos de tratamento da água pela municipalidade. Esses custos não são compensados pela indústria, isto é, circulam externamente ao mercado, não sendo internalizados no preço de seus produtos. ${ }^{249}$

A bem ver, o uso dos recursos ambientais na cadeia produtiva ${ }^{250}$ gera custos e benefícios não captados no sistema de mercado. Embora esses recursos tenham valor econômico, não lhes são atribuídos preços adequados. Assim, o custo ou benefício privado desse recurso não reflete o seu custo ou benefício econômico (ou social). ${ }^{251}$ As externalidades são, assim, manifestações de preços ineficientes. E essas manifestações são, em geral, decorrentes de direitos de propriedade não bem definidos.

De fato, as externalidades negativas existem porque o sistema de mercado, baseado no direito de propriedade, paradoxalmente permite a apropriação dos recursos naturais dando-se indistintamente por todos. Dessa forma, o problema da degradação ambiental resolver-se-ia pela permissão de apropriação privada dos bens ambientais ${ }^{252}$. A esse respeito, François Ost sustenta que, no âmbito do sistema de mercado, na perspectiva do direito da

\footnotetext{
${ }^{249}$ NUSDEO, Ana Maria de Oliveira. O uso dos instrumentos econômicos nas normas de proteção ambiental. In: Revista da Faculdade de Direito da Universidade de São Paulo, v. 101, jan/dez 2006, p. 357-378.

${ }^{250}$ Frise-se que, quando nos referimos à utilização dos recursos naturais no ciclo econômico, estamos querendo dizer toda a cadeia que envolve a sua utilização, ou seja, a produção, a distribuição, o consumo e o descarte dos resíduos (estes contemplam tanto os produzidos pela indústria e por outras atividades produtoras de bens e serviços, quanto àqueles decorrentes do pós-consumo). Aliás, a Política Nacional de Resíduos Sólidos - PNRS, instituída pela Lei $\mathrm{n}^{\circ} 12.305$, de 2 de agosto de 2010, conceitua resíduos sólidos como "material, substância, objeto ou bem descartado resultante de atividades humanas em sociedade, a cuja destinação final se procede, se propõe proceder ou se está obrigado a proceder, nos estados sólido ou semissólido, bem como gases contidos em recipientes e líquidos cujas particularidades tornem inviável o seu lançamento na rede pública de esgotos ou em corpos d'água, ou exijam para isso soluções técnica ou economicamente inviáveis em face da melhor tecnologia disponível.” (art. $3^{\circ}$, inc. XVI) Sobre a Política Nacional de Resíduos Sólidos, ver LEMOS, Patricia Faga Iglecias. Resíduos sólidos e responsabilidade civil pós-consumo. São Paulo: RT, 2011.

${ }^{251}$ SEROA DA MOTTA, Ronaldo. Economia ambiental. Rio de Janeiro: Editora FGV, 2006, p. 180.

${ }^{252}$ Quando se fala de bens ambientais nesta tese, quer-se referir tanto aos bens de produção quanto aos bens de consumo. Conforme nos ensina Fábio Nusdeo, os bens de consumo "atendem de forma direta e imediata a uma dada necessidade". Os bens de produção "atendem-na de forma indireta ou mediata, pois são empregados para, em imensa cadeia técnica, gerarem os bens de consumo. São exemplos dos primeiros: alimentos, vestuário, canetas, concertos musicais, serviços diretos e tantos outros. São bens de produção: máquinas, matérias-primas, ferramentas, a terra, o tijolo, os serviços dos operários nas fábricas, e assim por diante”. NUSDEO, Fábio. Curso de economia: introdução ao direito econômico. $6^{\mathrm{a}}$ ed. rev. e atual. São Paulo: RT, 2010, p. 37. O autor, todavia, alerta que essa classificação não é absoluta, podendo um determinado bem de consumo (carro) servir como bem de produção, e vice-versa. É sempre importante, portanto, observar a situação concreta.
} 
propriedade, o bem comum não permite a proteção do meio ambiente, pois, em tese, todos podem utilizá-lo livremente. A saída, portanto, para a proteção ambiental seria permitir a apropriação privada dos recursos naturais. ${ }^{253}$

Nesse mesmo sentido, Ronaldo Seroa da Motta, após lecionar sobre a definição dos direitos de propriedade e seu vínculo inexorável - como papelchave, inclusive - no sistema de preços, salienta: “muitos economistas consideram a poluição um problema que poderia ser resolvido se todos os recursos naturais fossem propriedade privada (individual ou coletiva), de modo que os proprietários tivessem incentivos para administrar esses recursos ambientais adequadamente." Segundo esse autor, “é difícil coletar um preço pelo uso do recurso quando não há exclusividade de direitos de uso ou de propriedade. Assim, os preços não servem para racionar o uso e gerar receitas para sua conservação resultando em exaustão ou degradação.”254

Ainda nessa linha, Fábio Nusdeo ensina:

Quando os bens vão se tornando escassos é necessário que alguém assuma a sua propriedade para ordenar a sua utilização; evitar o perecimento ou a exaustão e ainda prover uma racional reprodução no caso de recursos renováveis, como, por exemplo, as florestas.

É conhecido o caso dos pastos de utilização comum, encontrados na Idade Média em toda a Europa anglo-saxã, e que eram conhecidos pelo nome de 'commons'. Com o crescimento dos rebanhos e sua utilização cada vez mais intensiva eles foram desativados e passaram a ser apropriados privadamente, como forma de reposição e conservação das pastagens que de outra maneira acabariam por se extinguir ineroxavelmente.

Em síntese, quando um bem passa a ser útil e escasso (bem econômico) a sua apropriação individualizada passa a ser condição para a sua racional utilização e, portanto, preservação. Esse o motivo pelo qual os animais domésticos não se extinguem, enquanto os animais bravios constituem, em sua maioria, espécies em extinção. ${ }^{255}$

\footnotetext{
${ }^{253}$ OST, François. A natureza à margem da lei - A ecologia à prova do direito. Trad. Joana Chaves. Lisboa: Ed. Instituto Piaget, 1995, p. 155 e segs.

${ }^{254}$ SEROA DA MOTTA, Ronaldo. Ob. cit., p. 181.

${ }^{255}$ NUSDEO, Fábio. Desenvolvimento e ecologia. Revista Justitia, São Paulo, 47(128): 52-59, jan/mar 1995, p. 55.
} 
Embora a ideia de propriedade dos recursos naturais pareça desarrazoada, ela não destoa do sistema econômico de mercado, em que apenas se valora e se protege o que é passível de apropriação privada. Assim, dentro desse contexto, talvez fosse realmente mais razoável - embora não seja possível -, entregar a propriedade dos recursos naturais e, consequentemente, a sua proteção, a proprietários particulares com o intuito de proteger o meio ambiente no sistema econômico em que vivemos,

Frente a essa realidade, e enquanto não se resolver o paradoxo do usufruto do meio ambiente por todos, em um sistema econômico baseado na propriedade privada, cabe procurar meios de equacionar as externalidades negativas, seja para o bem da manutenção e reprodução do sistema econômico, seja para a proteção do meio ambiente, seja para que não sejam injustamente assumidas por toda a sociedade; tarefas essas cujo alcance deve ser perseguido mediante a implementação de mecanismos e instrumentos baseados no princípio do poluidor-pagador.

Fábio Nusdeo, já em 1975, chamava a atenção para a necessidade de “definir com precisão as relações de intercâmbio entre os ganhos a serem obtidos em termos de ar mais puro, de paisagens preservadas e de água mais límpida com os custos envolvidos, representados sobretudo por restrições a alguns tipos de atividade, preços mais altos para certos produtos e, sobretudo, impostos mais elevados”. ${ }^{256}$ Daí, inclusive, o seu conceito de tarifação ambiental, introduzindo na doutrina jurídica nacional uma primeira análise do que hoje se conhece como o princípio do poluidor-pagador.

O hoje Ministro do Superior Tribunal de Justiça Antonio Herman V. Benjamin, em 1993, sustentava: “todo o Direito Ambiental, queiramos ou não, gira em torno do princípio do poluidor-pagador, já que é este que orienta - ou deve orientar - sua vocação redistributiva, ou seja, sua função de enfrentamento das deficiências do sistema de preços.”257

\footnotetext{
${ }^{256}$ NUSDEO, Fábio. Desenvolvimento e ecologia. São Paulo: Saraiva, 1975, p. 65.

${ }^{257}$ BENJAMIN, Antonio Herman V. O princípio do poluidor pagador e a reparação do dano ambiental. In: BENJAMIN, Antonio Herman V. (coord.). Dano ambiental: prevenção, reparação e repressão. São Paulo: RT, 1993, p. 227.
} 
De fato, há muito vem se destacando a importância do princípio do poluidor-pagador ${ }^{258}$. E sua relevância persiste até os dias atuais, acreditando-se que preponderará igualmente frente aos novos conceitos e princípios decorrentes de uma postulada “segunda fase” ou "segunda geração” do Direito Ambiental ou dos problemas ecológicos. ${ }^{259}$

Para Édis Milaré, o princípio assenta-se “na vocação redistributiva do Direito Ambiental e se inspira na teoria econômica de que os custos sociais externos que acompanham o processo produtivo (...) precisam ser internalizados, vale dizer, que os agentes econômicos devem leva-los em conta ao elaborar os custos de produção e, consequentemente, assumi-los”. 260

Paulo de Bessa Antunes, por sua vez, expõe que tal princípio "parte da constatação de que os recursos ambientais são escassos e que o seu uso na produção e no consumo acarretam a sua redução e degradação”. Continua o autor, frisando que "se o custo da redução dos recursos naturais não for considerado no sistema de preços, o mercado não será capaz de refletir a escassez”. E conclui: “são necessárias políticas públicas capazes de eliminar a falha de mercado, de forma a assegurar que os preços dos produtos reflitam os custos ambientais." 261

Ou, conforme salienta novamente Fábio Nusdeo, "tal princípio significa nada mais do que promover a internalização do custo ambiental, transmudandoo de uma externalidade negativa, ou custo social, num custo privado.”262

A Organização para a Cooperação e Desenvolvimento Econômico OCDE, em sua "Recomendação do conselho sobre princípios orientadores

\footnotetext{
${ }^{258}$ Uma análise detida do princípio do poluidor-pagador pode ser encontrada em ARAGÃO, Maria Alexandra de Sousa. O princípio do poluidor pagador: pedra angular da política comunitária do ambiente. Coimbra: Coimbra Editora, 1997, p. 51-52.

${ }^{259}$ Conforme nos ensina Canotilho, "os problemas de primeira geração incidem fundamentalmente na proteção do ambiente tendo em conta os elementos constitutivos (poluição, água, ar, solo). Hoje, a segunda geração de problemas ecológicos relaciona-se com efeitos que extravasam da consideração isolada dos elementos constitutivos do ambiente e com as implicações dos mesmos (camada de ozônio, efeito estufa, mudanças climáticas).” CANOTILHO, José Joaquim Gomes. Estudos sobre direitos fundamentais. Coimbra: Coimbra Editora, 2004, p. 177.

${ }^{260}$ MILARÉ, Édis. Direito do ambiente. $7^{\text {a }}$ ed. São Paulo: RT, 2011, p. 1074.

${ }^{261}$ ANTUNES, Paulo de Bessa. Direito ambiental. $11^{\text {a }}$ ed. amplamente reformulada. Rio de Janeiro: Lumen Juris, 2008, p. 48-49.

${ }^{262}$ NUSDEO, Fábio. Direito Econômico Ambiental. In: PHILIPI JR., Arlindo; CAFFÉ ALVES, Alaôr (eds.). Curso Interdisciplinar de Direito Ambiental. Barueri: Manole, 2005, p. 731.
} 
relativos aos aspectos econômicos internacionais das políticas ambientais”, assim define o princípio do poluidor-pagador: “O princípio que se usa para afetar os custos das medidas de prevenção e controle da poluição, para estimular a utilização racional dos recursos ambientais escassos e para evitar distorções ao comércio e ao investimento internacionais, é o designado 'princípio do poluidor-pagador'. Este princípio significa que o poluidor deve suportar os custos do desenvolvimento das medidas acima mencionadas decididas pelas autoridades públicas para assegurar que o ambiente esteja num estado aceitável. Por outras palavras, o custo destas medidas deveria refletir-se no preço dos bens e serviços que causam poluição na produção ou no consumo."263

Sendo assim, o princípio do poluidor-pagador visa a imputar ao poluidor o custo social - externalidade negativa - da degradação ou poluição por ele gerada, criando um mecanismo de responsabilidade pelos impactos negativos ou danos causados ao meio ambiente.

\subsection{As críticas ao princípio do poluidor-pagador}

Inúmeros foram os debates fundamentados na alegação de que o princípio do poluidor-pagador oferecia uma carta em branco ao direito de poluir. De fato, muito se sustentou que o princípio do poluidor-pagador iria permitir a poluição mediante um 'preço', baseando-se na máxima segundo a qual 'se pagar, pode poluir’. A esse respeito, Édis Milaré esclarece:

O princípio não objetiva, por certo, tolerar a poluição mediante um preço, nem se limita apenas a compensar os danos causados, mas sim, precisamente, evitar o dano ao ambiente. Nesta linha, o pagamento pelo lançamento de efluentes, por exemplo, não alforria condutas inconsequentes, de modo a ensejar o descarte de resíduos fora dos padrões e das normas ambientais. A cobrança só pode ser efetuada sobre o que tenha respaldo na lei, pena de se admitir o direito de poluir. Trata-se do princípio poluidor-pagador (poluiu, paga os danos), e não pagador-poluidor (pagou, então pode poluir). Esta colocação

\footnotetext{
${ }^{263}$ Recomendação OCDE C(72)128, de 26 de Maio de 1972, “Guiding Princíples Concerning International Economic Aspects of Environmental Policies.”
} 
gramatical não deixa margem a equívocos ou ambiguidades na interpretação do princípio. ${ }^{264}$

Em breve síntese, em que pese à discussão, tem-se hoje o entendimento preponderante de que o pagamento efetuado pelo poluidor ou predador não lhes confere qualquer direito a poluir. ${ }^{265}$

Critica-se, ainda, o principio do poluidor-pagador, partindo-se da premissa de que a inclusão dos custos da utilização dos recursos naturais na cadeia produtiva acabam, em última instância, sendo assumidos pelos consumidores dos bens dali derivados. Sobre o assunto, a Organização para a Cooperação e Desenvolvimento Econômico - OCDE tem uma posição de neutralidade face à transferência dos custos dos poluidores para terceiros, considerando que, do "ponto de vista da conformidade com o princípio do poluidor-pagador, não interessa se o poluidor transfere para os seus preços parte ou todos os custos ambientais ou se os absorve.”266

Ademais, é certo sustentar o fato de o mercado, mediante a lógica da competitividade, encarregar-se de fazer com que os custos com a utilização dos recursos naturais não sejam transferidos para terceiros. Segundo essa lógica, caso haja um aumento significativo do preço final do produto, o seu consumo deixará de ser incentivado, podendo, inclusive, ser inviabilizado comercialmente, forçando o consumidor a procurar outro com preço mais acessível. Significa dizer que a lógica do mercado impõe ao empreendedor/poluidor arcar - ainda que em parte - com os custos da utilização dos recursos naturais; isso não significa, logicamente, que não vá repassar esses custos para o produto final, como faz com todos os seus outros custos.

Ademais, conforme Fábio Nusdeo, o fato de a inclusão dos custos pela utilização dos recursos naturais encarecer os produtos finais redunda em grande vantagem. Afinal, a ideia é exatamente essa, pois os maiores preços levarão a uma diminuição do seu consumo, reduzindo, assim, a utilização do meio

\footnotetext{
${ }^{264}$ MILARÉ, Édis. Direito do ambiente. $7^{\mathrm{a}}$ ed. São Paulo: RT, 1075.

265 MACHADO, Paulo Affonso Leme. Direito ambiental brasileiro. 19a ed. São Paulo: Malheiros, 2011, p. 72.

${ }^{266}$ Note on the implementation of the polluter pays principle. OCDE, 1975. In: The polluter pays principle: definition, analysis, implementation. Organisation for Economic Co-operation and Development, 1975.
} 
ambiente. Por outro lado, estimulará a conversão da tecnologia para fins de controle de tais externalidades pela introdução de produtos e meios de produção de menor agressividade ambiental. ${ }^{267}$

O que importa, segundo a OCDE, é a utilização dos recursos naturais ser computada na cadeia de produção e de consumo, de modo a internalizar as externalidades negativas decorrentes, que envolvem o consumo do que foi produzido e o descarte dos seus resíduos.

Aliás, existem avançados estudos indicando que a restrição ao uso dos recursos naturais por medidas de comando e controle preventivas e mitigatórias - as quais também representam a inclusão de custos na cadeia produtiva - não implicam efeitos adversos no crescimento da economia ou na competitividade do mercado. Conforme Richard Revesz e Robert Stavins, “recent studies have reinforced this conclusion, finding that environmental regulation does not reduce labor demand, and dos not impair productivity. Such findings are not surprising, given that for all but the most heavily pollution industries, the costs of complying with environmental regulation area a small share of the total costs of production - an average of about 2 percent". ${ }^{268}$

Outra crítica dirigida ao princípio do poluidor-pagador consiste em não permitir equacionar ou atenuar a injustiça ambiental; ao contrário, pode de fato piorá-la, porque, ao impor ao poluidor um preço pela degradação ambiental, ele pode procurar implementar sua atividade em locais onde esse custo não é tão alto, indo, por consequência, instalar-se em países pobres ou subdesenvolvidos. Nesse sentido, não restam dúvidas de que os maiores sofredores com as mazelas ambientais são os pobres, desassistidos ou excluídos da sociedade em que vivem nesses países.

Em suma, as mazelas criadas pelo aproveitamento irracional dos recursos naturais transcendem a perda de rentabilidade do processo de acumulação capitalista e atingem classes menos privilegiadas. Fácil, assim, verificar que a

\footnotetext{
${ }^{267}$ NUSDEO, Fábio. Curso de economia - Introdução ao Direito Econômico. $6^{\mathrm{a}}$ ed. rev. e atual. São Paulo: RT, 2010, p. 380.

${ }^{268}$ REVESZ, Richard L. STAVINS, Robert N. Environmental Law and Policy. NYU Public Law Research Paper 82; NYU Law \& Econ Research Paper 04-015; Harvard Public Law Working Paper No. 102; KSG Working Paper No. RWP04-023. Setembro/2004. Disponível em: <http://ssrn.com/abstract=552043>. Acesso em: 03.10.2011.
} 
exploração dos recursos do meio ambiente se dá por poucos, enquanto que as externalidades negativas ${ }^{269}$ dessa exploração são, em geral, sentidas por uma maioria desprotegida.

Ulrich Beck frisa: “a história da distribuição de riscos mostra que estes se atêm, assim como as riquezas, ao esquema de classe - mas de modo inverso: as riquezas acumulam-se em cima, os riscos em baixo. Assim, os riscos parecem reforçar, e não revogar, a sociedade de classes”. E pontua: “são principalmente as vizinhanças mais acessíveis aos grupos de menor renda da população, nas redondezas de centros de produção industrial, que são oneradas no longo prazo por conta de diversos poluentes no ar, na água e no solo.”270

Não obstante as críticas, não há como duvidar da suma importância do princípio do poluidor-pagador, mormente por ser o fundamento de criação de inúmeros mecanismos e instrumentos capazes de internalizar os custos da utilização dos recursos naturais, equacionando - ainda que apenas em parte - a sua escassez e, também, evitando a assunção das externalidades negativas pela sociedade em geral. O princípio do poluidor-pagador permite racionalizar o processo, fazendo os exploradores - os que auferem lucros - dos recursos naturais, assumirem os custos daí decorrentes. Esses mecanismos e instrumentos, por sua vez, podem ter cunho reparatório, preventivo e, ainda, compensatório.

\subsection{A tríplice face de aplicação do princípio do poluidor-pagador}

O princípio do poluidor-pagador, considerado um dos princípios basilares do Direito Ambiental, dá ensejo a outras normas instituidoras de mecanismos e instrumentos capazes de conduzir à internalização dos custos decorrentes da utilização de recursos naturais na cadeia produtiva. Nesse

\footnotetext{
${ }^{269}$ Segundo Fábio Nusdeo, as externalidades negativas são também chamadas de "custo externo" e "custo social” e, então, deseconomias externas. NUSDEO, Fábio. Curso de economia: introdução ao direito econômico. $6^{\mathrm{a}}$ ed. rev. e atual. São Paulo: RT, 2010.

${ }^{270}$ BECK, Ulrich. Sociedade de risco: rumo a uma outra modernidade. Trad. Sebastião Nascimento. São Paulo: Ed. 34, 2010, p. 41-42.
} 
sentido, ao buscar equacionar as externalidades negativas ambientais, podem ser impostos mecanismos e instrumentos de diversas naturezas, visando ora a prevenir e a mitigar os impactos negativos, ora a compensá-los, ora a reparar os danos indesejadamente causados ao meio ambiente.

Para bem situar a presente análise, é importante ter claro que do princípio do poluidor-pagador não decorre unicamente o fundamento para a reparação civil de danos ambientais. Ou seja, o princípio do poluidor-pagador pode servir de apoio para a implementação de um mecanismo que anteceda o impacto e o dano ambiental, servindo para preveni-lo ou mitigá-lo.

A observação é necessária, pois, correntemente depara-se com proposições dogmáticas, sustentando, em síntese, ser o princípio do poluidorpagador fundamento apenas de medidas reparatórias. ${ }^{271}$

Sendo assim, é preciso enfatizar, com forte tinta, o fato de o princípio do poluidor-pagador não implicar apenas ações reparatórias. Basta ver o referido princípio podendo ser aplicado como fundamento, por exemplo, para a instituição de um tributo ambiental, uma política extrafiscal, instrumentos econômicos ou, ainda, para a exigência de medidas de comando e controle no decorrer do processo de licenciamento ambiental. Sim, porque todos os custos com medidas e instrumentos que visem prevenir, mitigar, compensar impactos negativos ou reparar danos ambientais encarecem o preço dos bens decorrentes da cadeia produtiva, significando, assim, justamente internalizar os custos pela utilização dos recursos naturais. Nesse sentido, aliás, é o ensinamento de Édis Milaré: “a reparação civil do dano ambiental é a manifestação mais evidente do princípio do poluidor-pagador, embora este também alcance medidas de cunho preventivo e repressivo, assim como os custos correspondentes à própria utilização dos recursos naturais”. 272

Nessa mesma direção, salienta Maria Alexandra Aragão não ser apenas reparatório o objetivo do princípio do poluidor-pagador. De fato, para a autora

\footnotetext{
${ }^{271}$ Nessa linha, aliás, segue o próprio Ministério do Meio Ambiente - MMA, valendo verificar seus argumentos contra os termos da Ação Direta de Inconstitucionalidade - ADI 3.378/DF, de que tratamos no Capítulo 2 desta tese. Com efeito, tentando demonstrar ter o instituto da compensação ambiental natureza jurídica de reparação civil, alegou o MMA ter o princípio do poluidor-pagador encarnado em seu escopo tão somente o viés reparatório.

${ }^{272}$ MILARÉ, Édis. Direito do Ambiente. $6^{a}$ ed. São Paulo: RT, 2009, p. 881-882.
} 
portuguesa, “apesar de a formulação do princípio recordar efectivamente o princípio jurídico segundo o qual quem causa um dano é responsável e deve suportar as medidas adequadas à reparação do dano causado, pensamos, com o apoio de uma grande parte da doutrina (entre outros, Jean-Philippe Barde, Emilio Gerelli, Allonso Garcia, Eckard Rehbinder, e Ludwig Kramer; ao nível nacional, Gomes Canotilho e Souza Franco), que o PPP não se reconduz, de todo, a um simples princípio de responsabilidade civil”. ${ }^{273}$

Nessa mesma corrente segue José Gomes Canotilho, ${ }^{274}$ sustentando que “o princípio do poluidor-pagador não se identifica com o princípio da responsabilidade, pois abrange, ou, pelo menos foca outras dimensões não enquadráveis neste último.”275

O princípio do poluidor-pagador, portanto, é eminentemente econômico e visa a corrigir as externalidades negativas causadas pela utilização dos recursos naturais na atividade econômica, sem a devida inclusão dos custos correspondentes na cadeia de produção, consumo e descarte. Essa correção se dá por meio de diversos instrumentos e medidas, dentre eles o instituto da responsabilização civil por danos ambientais, mecanismos de comando e controle e instrumentos econômicos, dentre outros.

Consoante José Marcos Domingues de Oliveira, “juridicamente o princípio do poluidor-pagador pode realizar-se tanto através do licenciamento administrativo, da imposição de multas, da determinação de limpeza ou recuperação ambiental, como pela cobrança de tributos, enquanto fonte de recursos para custeio da proteção ambiental”. ${ }^{276}$ Nessa mesma direção, ensinam José Rubens Morato Leite e Patryck Araújo Ayala:

\footnotetext{
${ }^{273}$ ARAGÃO, Maria Alexandra de Sousa. O princípio do poluidor-pagador: pedra angular da política comunitária do meio ambiente. Coimbra: Coimbra Editora, 1997, p. 111.

${ }^{274}$ Conforme expõem José Rubens Morato Leite e Patryck de Araújo Ayala, Canotilho concebe o princípio do poluidor-pagador como multifuncional, no sentido de que "1) é uma diretiva da política de prevenção, evitando que as externalidades sejam cobertas por subsídios do Estado; 2) é um princípio da tributação; 3) é um princípio tendencialmente conformador do instituto da responsabilidade.” LEITE, José Rubens Morato; AYALA, Patryck de Araújo. Dano ambiental: do patrimonial ao coletivo extrapatrimonial: teoria e prática. $4^{\mathrm{a}}$ ed. rev. atual. ampl. São Paulo: RT, 2011.

${ }^{275}$ Apud: LEITE, José Rubens Morato; AYALA, Patryck de Araújo. Dano ambiental: do patrimonial ao coletivo extrapatrimonial: teoria e prática. $4^{\mathrm{a}}$ ed. rev. atual. ampl. São Paulo: RT, 2011, p. 60.

${ }^{276}$ OLIVEIRA, José Marcos Domingues de. Direito tributário e meio ambiente. $3^{\mathrm{a}}$ ed. rev. e ampl. Rio de Janeiro: Forense, 2007, p. 31.
} 
O princípio do poluidor pagador tem reflexos na economia ambiental, na ética ambiental, na administração pública ambiental e no direito ambiental, pois tenta imputar na economia de mercado e no poluidor custos ambientais e, com isso, visa a combater a crise em suas origens ou na fonte. Como diz Mateo: "O princípio do poluidor pagador constitui uma autêntica pedra angular no direito ambiental: sua efetividade pretende eliminar as motivações econômicas da contaminação ambiental, aplicando-se imperativos da ética distributiva. ${ }^{277}$

Aliás, observe-se que ditos mecanismos e instrumentos, ao serem utilizados conjuntamente, permitem uma proteção mais eficaz para o meio ambiente. Ou, nas palavras de Michel Prieur

Pour que le polluer assure une véritable depollution permettant à la collectivité des habitants e au milieu naturel d'être dans un environnement satisfaisant, le pouvoirs publics qui veulent faire supporter la charge de la dépollution au pollueur peuvent recourir à plusieurs instruments qui, pris isolément, n'ont sûrement pas la même efficacité mais qui sont généralement utilisés conjointement. Il s'agit de la taxation des pollutions, de l'imposition de normes et de la mise en place de mécanismes divers de compensation. Le príncipe doit également se traduire juridiquement par l'abolition des droit acquis em matière de pollution. ${ }^{278}$

Significa dizer, portanto, e mais uma vez, ser o princípio do poluidorpagador indutor da implementação de medidas e instrumentos capazes de incluir na cadeia produtiva os custos sociais externos ou as externalidades negativas; implementação essa a ser realizada mediante instrumentos e mecanismos de prevenção, compensação e/ou reparação tanto dos impactos negativos no meio ambiente quanto dos danos ambientais.

Nessa esteira desse entendimento, o princípio do poluidor-pagador articula-se com outros princípios do direito ambiental para apresentar suas faces preventiva e compensatória. Cristiane Derani expõe que o "princípio do poluidor-pagador se revelaria, portanto, destinado a atuar como uma espécie de

\footnotetext{
${ }^{277}$ LEITE, José Rubens Morato. AYALA, Patryck de Araújo. Dano ambiental: do patrimonial ao coletivo extrapatrimonial: teoria e prática. $4^{\mathrm{a}}$ ed. rev. atual. ampl. São Paulo: RT, 2011, p. 62.

${ }^{278}$ PRIEUR, Michel. Droit de l'environnement. $5^{\text {a }}$ ed. Paris: Dalloz, 2004, p. 147.
} 
'princípio ponte’ ao indispensável diálogo interdisciplinar para a proteção ambiental.,279

4.6.1 O princípio do poluidor-pagador e a prevenção de danos ao meio ambiente

Em relação à face preventiva do princípio do poluidor-pagador, tal princípio serve como uma alavanca efetiva de prevenção do dano ambiental e dos impactos negativos ao meio ambiente, fazendo com que a atividade de preservação e conservação dos recursos naturais custe menos que a devastação. ${ }^{280}$ Em outros termos, o princípio da prevenção pode reconduzir-se à fórmula do poluidor-pagador, já que é o poluidor que está em condições de, com a máxima eficácia econômica e ecológica e com a máxima equidade, proceder à internalização dos custos de prevenção e controle da poluição. ${ }^{281}$

Para Maria Alexandra de Sousa Aragão, o primeiro objetivo do princípio do poluidor-pagador é prevenir a poluição, realçando, ainda, que a doutrina dedicada ao estudo do princípio do poluidor-pagador converge para mesmo entendimento. De fato, não há dúvida de que o custo das necessárias medidas para prevenir a ocorrência da poluição é, em geral, muito inferior aos custos das medidas de despoluição após a ocorrência do dano ${ }^{282}$ e do impacto.

Como já dito, o princípio do poluidor-pagador pode efetivamente embasar de maneira bastante eficaz medidas preventivas de danos ambientais e de impactos negativos no meio ambiente, quer, por exemplo, mediante a imposição de medidas de comando e controle no decorrer do licenciamento ambiental, quer pela a cobrança pelo uso de um recurso natural, quer pela utilização dos tributos na forma extrafiscal, incentivando ou induzindo condutas ‘mais limpas', e prevenindo ações poluidoras e degradadoras. Ao arcar com medidas de comando e controle, o poluidor é, antes de poluir, pagador dos

\footnotetext{
${ }^{279}$ DERANI, Cristiane. Direito ambiental econômico. $3^{\text {a }}$ ed. São Paulo: Saraiva, 2008, p. 144.

${ }^{280}$ BENJAMIN, Antonio Herman V. O princípio do poluidor pagador e a reparação do dano ambiental. In: BENJAMIN, Antonio Herman V. (coord.). Dano ambiental: prevenção, reparação e repressão. São Paulo: RT, 1993, p. 236.

${ }^{281}$ ARAG ̃̃O, Maria Alexandra de Sousa. Ob. cit., p. 70.

${ }^{282}$ Idem, p. 116-177.
} 
custos relativos às medidas preventivas - nas quais se incluem as mitigadoras -, destinadas a evitar a produção do resultado proibido ou não pretendido, ou seja, é primeiro pagador, porque paga não porque poluiu, mas paga justamente para que não polua. ${ }^{283}$

Como visto, o princípio do poluidor-pagador também pode embasar instrumentos que induzam - por meio de incentivos econômicos - a implementação de condutas preventivas. Nessa linha, José Rubens Morato Leite e Patryck de Araújo Ayala discorrem sobre a possibilidade indutora do princípio do poluidor-pagador objetivando a prevenção, expõem ser um “procedimento [que] se desenvolve mediante técnicas de indução, oferecendo ao poluidor acesso democrático a condições abertas de escolha pela conduta que lhe for menos onerosa, que será necessariamente pagar para não poluir e que será preferida à opção de poluir e pagar.”284

Embora já tenhamos passado pelo princípio da prevenção ${ }^{285}$ no item 3.3.4.1 do Capítulo 3 desta tese, quando o contrapusemos ao princípio da precaução, é oportuno, agora, novamente destacar que esse princípio significa o “agir antecipadamente” mediante a implementação de ações de prevenção, dentre elas, o planejamento ambiental e econômico integrados. Cristiane Derani, aliás, coloca esse princípio como a essência do direito ambiental, asseverando que ele "se resume na busca do afastamento, no tempo e no espaço, do perigo; na busca também da proteção contra o próprio risco e na análise do potencial danoso oriundo do conjunto de atividades. Sua atuação se faz sentir, mais apropriadamente, na formação de políticas públicas ambientais, onde a exigência de utilização da melhor tecnologia disponível é necessariamente um corolário.”286

É oportuno registrar, como ensina Michel Prieur, que a prevenção $a$ priori é complementar à repreensão a posteriori, na medida em que não é

\footnotetext{
${ }^{283}$ LEITE, José Rubens Morato. AYALA, Patryck de Araújo. Direito ambiental na sociedade de risco. Rio de Janeiro: Forense Universitária, 2002, p. 78.

${ }^{284}$ Idem, p. 79.

${ }^{285}$ O princípio da prevenção encontra-se estampado na Declaração do Rio de Janeiro de 1992, cujo Princípio 8 assim impõe: “A fim de conseguir-se um desenvolvimento sustentado e uma qualidade de vida mais elevada para todos os povos, os Estados devem reduzir e eliminar os modos de produção e de consumo não viáveis e promover políticas demográficas apropriadas.”

${ }^{286}$ DERANI, Cristiane. Direito Econômico Ambiental. $3^{\mathrm{a}}$ ed. São Paulo: Saraiva, 2008, p. 151.
} 
possível prevenir ou prever todos os males que podem ocorrer no meio ambiente. Ou, como bem ensina o autor francês a respeito do princípio da prevenção:

La prévention consiste à empêcher la survenance d'atteintes à l'environnement par des mesures appropriées dites préventives avant l'élaboration d'un plan ou la réalisation d'un ouvrage ou d'une activité. L'action préventive est une action anticipatrice et a priori qui, depuis fort longtemps, est préférée aux mesures a posteriori du type réparation, restauration ou répression qui interveniennent après une atteinte avérée à l'environnement. On a parfois opposé les deux types de mesures. En réalité elles ne sont pas exclusives mais complémentaires car il n'est pas toujours possible de tout prévoir. ${ }^{287}$

Sendo assim, a instituição de mecanismos e instrumentos de prevenção tende a fugir do espírito sancionatório do Direito, buscando aplicá-lo de forma a promover condutas específicas tendentes a evitar a ocorrência do impacto negativo e, ainda, do indesejado dano ambiental. Vale dizer, o princípio do poluidor-pagador, no sentido de buscar a concretização do princípio da prevenção, permite adotar estratégias vinculadas aos custos da produção, majorando ou diminuindo-as, de modo a agir antecipadamente ao impacto negativo ou ao dano ambiental. Essas estratégias, como será aprofundado no item 6.3 do Capítulo 6 deste estudo, perpassam várias áreas do Direito.

\subsubsection{O princípio do poluidor-pagador e a responsabilidade civil ambiental}

No item anterior, procurou-se demonstrar o fracasso do argumento sustentador de uma visão exclusivamente reparatória do princípio do poluidorpagador $^{288}$; mesmo assim, porém, não deve haver dúvidas, como bem leciona Édis Milaré, que “o princípio do poluidor-pagador constitui o fundamento

\footnotetext{
${ }^{287}$ PRIEUR, Michel. Ob. cit., p. 71.

${ }^{288}$ BENJAMIN, Antonio Herman V. O princípio do poluidor pagador e a reparação do dano ambiental. In BENJAMIN, Antonio Herman V. (coord.). Dano ambiental: prevenção, reparação e repressão. São Paulo: RT, 1993, p. 235.
} 
primário da responsabilidade civil em matéria ambiental. Sua origem nada mais é que um princípio de equidade, existente desde o Direito Romano: aquele que lucra com uma atividade deve responder pelo risco ou pelas vantagens dela resultantes”. 289

Desse modo, o princípio do poluidor-pagador comporta uma outra vertente, complementar à preventiva (e, como se verá, à compensatória), e vinculada à responsabilidade civil por danos ambientais; ou, apenas, um viés reparatório. Significa dizer que o custo pela reparação do meio ambiente lesado de modo indevido - ou indesejado - deve ser arcado pelo responsável, independentemente da remuneração devida pela utilização normal de um bem ambiental.

Já dissemos no item 3.3.1 do Capítulo 3 desta tese ter sido o regime da responsabilidade civil, em matéria ambiental, positivado no nosso ordenamento jurídico pela Lei $n^{\circ} 6.938 / 1981$, cujo art. 14 , $\S 1^{\circ}$, dispõe ser o poluidor obrigado, independentemente da existência de culpa, a reparar os danos causados ao meio ambiente e a terceiros afetados por sua atividade. Em reforço, a Constituição Federal, em perfeita consonância com o princípio do poluidorpagador, determinou, em seu art. 225, $\S 3^{\circ}$, que “as condutas e atividades consideradas lesivas ao meio ambiente sujeitarão os infratores, pessoas físicas ou jurídicas, a sanções penais e administrativas, independentemente da obrigação de reparar os danos causados”.

Trata-se, como já dito, do regime da responsabilidade civil objetiva, em que ao direito não interessa perquirir a respeito: (i) do elemento subjetivo (negligência, imperícia ou imprudência = culpa; vontade consciente $=$ dolo) da pessoa física ou jurídica, de direito público ou privado, responsável, direta ou indiretamente, por atividade causadora de degradação ambiental; (ii) da legalidade de empreendimento que venha a provar-se lesivo ao meio; e, se adotada a teoria do risco integral ${ }^{290}$, (iii) nem mesmo das chamadas

\footnotetext{
${ }^{289}$ MILARÉ, Édis. Direito do ambiente. $7^{\mathrm{a}}$ ed. São Paulo: RT, 2011, p. 1251.

${ }^{290}$ Foi pontuado no item 3.3.1 do Capítulo 3 o debate da doutrina e da jurisprudência acerca da adoção, pela responsabilidade civil ambiental objetiva, da teoria do risco integral, em que não se admite suscitar as excludentes de responsabilidade, ou da teoria do risco criado, pela qual é possível afastar a responsabilização pelo dano causado na hipótese de se comprovar ter ele decorrido de caso fortuito, força maior ou fato de terceiro.
} 
excludentes, tais como o caso fortuito ou a força maior. Bastam, assim, para a incidência do dever de reparar, a configuração do dano ambiental e o estabelecimento do nexo de causalidade entre ele e o suposto poluidor. A respeito, Paulo Affonso de Leme Machado sustenta:

a responsabilidade objetiva ambiental significa que quem danificar o ambiente tem o dever jurídico de repará-lo. Presente, pois, o binômio dano/recuperação. Não se pergunta a razão da degradação para que haja o dever de indenizar e/ou reparar. A responsabilidade sem culpa tem incidência na indenização ou na reparação dos 'danos causados ao meio ambiente e aos terceiros afetados por sua atividade' (art. $14, \S 1^{\circ}$, da Lei $\mathrm{n}^{\circ} 6.938 / 81$ ). Não interessa que tipo de obra ou atividade seja exercida pelo que degrada, pois não há necessidade de que ela apresente risco ou seja perigosa. Procura-se quem foi atingido e, se for o meio ambiente e o homem, inicia-se o processo lógico-jurídico da imputação civil objetiva ambiental. Só depois é que se entrará na fase do estabelecimento do nexo de causalidade entre a ação ou omissão e o dano. É contra o Direito enriquecer-se ou ter lucro à custa da degradação do meio ambiente. ${ }^{291}$

É relevante registrar que a reparação do dano ambiental pode ocorrer na forma de (i) restauração no local; (ii) obrigação de não fazer $^{292}$; (iii) obrigação de fazer $^{293}$ mediante a substituição por equivalente in situ, ou substituição por equivalente em outro local; e (iv) indenização pecuniária.

${ }^{291}$ MACHADO, Paulo Affonso Leme. Direito ambiental brasileiro. $19^{a}$ ed. São Paulo: Malheiros, 2011,
p. 369.
Nesse sentido, vale colacionar acórdão do Tribunal de Justiça do Estado do Paraná (Apelação Cível no
$125619-7-1^{a}$ CC, Rel. Des. Dilmari Helena Kessler, j. 15.02.2005), assim ementado: MEIO AMBIENTE.
(...) OBRIGAÇÃO DE NÃO FAZER. PRIMAZIA DO INTERESSE PÚBLICO EM DETRIMENTO DO
PARTICULAR. PRINCÍPIO DA ISONOMIA. NÂO CONFIGURADO. OFENSA AO PRINCÍPIO DO
DESENVOLVIMENTO SUSTENTÁVEL. CARACTERIZADA. CÓDIGO FLORESTAL.
PRESERVAÇÃO PERMANENTE. DIREITO ADQUIRIDO. NÃO CONFIGURADO EM RAZÃO DA
NECESSIDADE DE FISCALIZAÇÃO CONTÍNUA. HONORÁRIOS ADVOCATÍCIOS.
SUCUMBENCIA. APELO DESPROVIDO. MANUTENÇÃO "IN TOTUM" DA SENTENÇA. 1. (..) 2. Em
matéria ambiental, não cabe invocar direito adquirido, que é de natureza particular, quando ocorre prejuízo ao
interesse coletivo. 3. O princípio da prevalência do meio ambiente deve ser observado em face de outros,
porque matéria de ordem pública. 4. Comprovado o dano ambiental em área de preservação permanente,
obriga-se o proprietário a compô-lo, minimizando seus efeitos e abstendo-se da prática de atos lesivos ao
meio ambiente; 5 . Diante da caracterização de dano ambiental, resultado das agressões decorrentes do uso
nocivo da propriedade e pelas condutas ou atividades poluidoras que degradam o meio ambiente, afetando,
necessariamente, uma pluralidade difusa de vítimas ou mesmo quando atinja individualmente algum grupo
ou sujeito, o poluidor será instado a uma obrigação de fazer, consistente na abstenção de sua atividade ou
transferir-se para local adequado.
293 É oportuno aqui pontuar, novamente, o fato de a responsabilização civil imposta mediante uma obrigação
de fazer não ter relação com as medidas compensatórias cominadas antes de o empreendimento ter causado
qualquer dano ao meio ambiente. Com efeito, a reparação decorre de um ato causador de um dano concreto e 
Em uma palavra: quem colhe benefícios com determinada atividade responde pelos riscos daí decorrentes, impondo-se-lhe, assim e com fulcro no princípio do poluidor-pagador, a obrigação de reparar, independentemente da culpa, os danos ambientais, causados durante atividades realizadas no interesse ou sob o domínio de uma atividade econômica.

\subsubsection{O princípio do poluidor-pagador e as medidas compensatórias}

Dentre os mecanismos decorrentes do princípio do poluidor-pagador, há os compensatórios, os quais, sendo bem instituídos e aplicados, ajustam-se perfeitamente à concepção de que os custos pela utilização dos recursos naturais devem ser internalizados na cadeia produtiva.

De fato, compensar, em termos etimológicos, significa colocar um peso ou valor para suprir um outro peso ou valor que tenha sido danificado, tirado, lesado, subtraído. A esse respeito, Paulo Affonso Leme Machado ensina que, “em diversas línguas - inclusive na portuguesa - a compensação visa a contrabalançar uma perda ou um inconveniente presente ou futuro. A compensação não é um presente que se dá a alguém, pois se compensa por algo que representa um desequilíbrio, isto é, tenta-se o restabelecimento do equilíbrio." 294

$\mathrm{Na}$ gestão ambiental, compensar equivale a reequilibrar um estrago infligido por um impacto negativo causado a um recurso natural ou a um bem ambiental em razão da implantação e da operação de um empreendimento necessário ao desenvolvimento econômico - e, bem por isso, lícito e desejado.

As medidas compensatórias incidem quando da implantação de uma atividade ou empreendimento lícito e devidamente licenciado pelo órgão ambiental competente, constituindo uma forma de o empreendedor contrabalançar ou compensar os impactos negativos ou prejuízos (no sentido

indesejável ao meio ambiente; a compensação, pelos impactos negativos causados ao meio ambiente por uma atividade lícita e desejada, antes da sua implantação, ou seja, da concreção de qualquer impacto ou dano ambiental. Em suma, conforme será mais bem detalhado no item 6.2 do Capítulo 6 deste estudo, as medidas compensatórias não se equiparam à reparação pelos danos causados ao meio ambiente.

${ }^{294}$ MACHADO, Paulo Afonso Leme. Ob. cit., p. 73. 
positivo da palavra) causados ao meio ambiente. Em outros termos, como não se pode recuperar o meio ambiente impactado negativamente em função de um determinado empreendimento a ser implantado para assegurar o desenvolvimento social e econômico, a legislação prevê a compensação desses impactos com obrigações de fazer ${ }^{295}$ ou mediante o pagamento de determinada exação pecuniária.

Conforme será detalhado no item 5.3 do Capítulo 5, embora sejam de difícil valoração, os impactos negativos devem ser "pesados”, ou seja, ponderados no sentido de os ecossistemas ou o meio ambiente no seu conjunto não sofrerem diminuição quantitativa ou qualitativa dos seus componentes e atributos sem que algo se lhes dê em retribuição.

A bem ver, tais medidas visam a compensar a coletividade pela utilização dos recursos naturais, evitando que todos arquem com as mazelas causadas pela implantação de empreendimentos com impactos negativos ao meio ambiente, o que faz mediante a internalização do seu custo com fundamento no princípio do poluidor-pagador.

\subsection{Conclusões preliminares}

Nos dias que correm, é raro passarem despercebidos a drástica mudança nas condições climáticas, o grau de desequilíbrio da biodiversidade, os desastres ecológicos, os riscos da atividade nuclear, os controvertidos impactos causados por grandes empreendimentos. De fato, não há dúvidas em relação à existência

\footnotetext{
${ }^{295}$ No direito francês, as obrigações de fazer que visam a recompor o meio ambiente em equivalente - como é o caso do replantio de uma área desmatada - chamam-se remise en état, as quais podem ser cominadas em decorrência da obtenção de licenças ou autorizações administrativas que permitem impactar negativamente os recursos naturais. A esse respeito, Michel Prieur ensina que "la remise en état est ici imposée à un administre titulaire d'une autorisation administrative et préalablement à la survenance d'une atteinte à l'environnement. C'est une règle de police prescrite par un acte administratif, qui constitue le plus souvent une mesure de compensation à l'atteinte prévisible à l'environnement.. Il s'agira par exemple de l'autorisation de coupe ou d'abattage d'arbres dans les espaces boisés classes, accompagnée de l'obligation de proceder à des reboisements ou à des plantations de remplacement ou bien de l'autorisation de coupes extraordinaires dans les forêts privées subordonnées à des travaux de repeuplement." PRIEUR, Michel. Droit de l'environnement. $5^{\mathrm{a}}$ ed. Paris: Dalloz, 2004.
} 
de uma consciência coletiva quanto à crise ambiental por que passa a humanidade.

Tal crise decorre, em suma, da acelerada e irracional utilização dos recursos naturais. Com efeito, o fenômeno da industrialização e o sistema de produção em série, típicos da sociedade de consumo, gerou - e gera - um processo de degradação ambiental sem precedentes.

Como visto, embora contradições possam ocorrer em qualquer espécie de sistema econômico, o modelo de mercado, ao impor viver em uma sociedade de valorização da aparência e do ter, demanda a criação de novos produtos, atraentes e de rápido descarte, exigindo, por conseguinte, rápidas inovações tecnológicas e uma incomensurável e contínua utilização dos recursos naturais ainda disponíveis. Esse modelo implica, ainda, competitividade, que tem o lucro como parâmetro; dele decorre a diminuição dos custos produtivos, a criação de necessidades ilimitadas e, com a globalização, a crescente velocidade de produção e de consumo.

Sendo assim, fica claro que o processo em torno desse modelo não se compatibiliza com a limitação dos recursos naturais, e daí a inevitável contradição entre as leis do sistema capitalista e as leis de proteção do meio ambiente.

Como dito, esse sistema chegou ao ponto de provocar uma crise ambiental sem precedentes. Além de agredir a qualidade de vida do planeta e comprometer a capacidade de sobrevivência das futuras gerações, tem causado efeitos negativos e drásticos ao próprio sistema econômico, sobretudo frente à perspectiva de uma rápida - e, por isso, aparentemente próxima - exaustão daqueles recursos que são necessários para manter o atual modo de produção industrial.

Esse cenário exige uma mobilização social, econômica, política e jurídica em condições de equacionar a crise ou, ao menos, atenuá-la. Vale dizer, da crise ambiental e da mobilização social, política, econômica e jurídica, emergem institutos jurídicos para proteger o meio ambiente e, ao mesmo tempo, viabilizar a renovação e a manutenção do sistema econômico vigente dentro de padrões da racionalidade. 
É nessa ritmo, portanto, que vão sendo editados princípios e normas jurídicos nacionais e internacionais de proteção aos recursos naturais. Em outros termos, a crise ambiental preconiza a estruturação de todo um arcabouço normativo capaz de racionalizar a crise ao incluir, em suma, a variável ambiental no processo econômico. Daí o Direito Ambiental e seus mais conhecidos princípios estruturadores, sendo eles: (i) o princípio da informação; (ii) o princípio da participação; (iii) o princípio da prevenção; (iv) o princípio da precaução; e (v) o princípio do poluidor-pagador. Como referido em páginas anteriores, esses princípios se entrelaçam, são todos do mesmo quilate e guiam conjuntamente as regras positivadas do Direito Ambiental. O tema deste estudo, porém, concentra-se, sobretudo, no princípio do poluidor-pagador.

Conforme visto, o princípio do poluidor-pagador se inspira, em síntese, na teoria econômica segundo a qual os custos sociais externos que acompanham o processo de produção e de consumo não podem ser ignorados. Eles devem, sim, ser internalizados, impondo aos agentes econômicos, quando da elaboração da conta dos custos das atividades produtivas, a inclusão daqueles relativos à utilização dos recursos naturais. Ou seja, o princípio visa a evitar externalidades negativas.

Claramente, o princípio do poluidor-pagador, em suas diversas facetas, faz com que os custos da utilização dos recursos naturais sejam assumidos por aquele que efetivamente os explora e os utiliza em seu processo econômico, evitando que a sociedade tenha que arcar, injustamente, com tais custos.

A referência às diversas facetas do princípio do poluidor-pagador decorre do fato desse princípio ser fundamentador de vários mecanismos e instrumentos capazes de equacionar - como se verá no Capítulo 5, ainda que não plenamente - a falha de mercado denominada externalidade negativa. Para tanto, com efeito, podem ser criados e impostos mecanismos e instrumentos com o objetivo de prevenir, mitigar, compensar e, ainda, reparar os impactos negativos ou os danos ambientais.

O princípio do poluidor-pagador, assim, pode ser o fundamento das medidas de comando e controle impostas no decorrer do licenciamento ambiental; de condenações reparatórias; da instituição de tributos ambientais; da implementação de uma política extrafiscal; da imposição de instrumentos 
econômicos indutores de condutas mais limpas ou capazes de formar fundos para a proteção ambiental; etc.

Em sua face preventiva, o princípio do poluidor-pagador articula-se com o princípio da prevenção, baseando medidas em condições de impedir a ocorrência do impacto ou do dano ambiental, seja incluindo medidas de controle para o processo produtivo, seja permitindo incentivos econômicos para induzir condutas 'mais limpas'. Esses mecanismos e instrumentos serão mais bem detalhados no próximo capítulo. Por ora, basta ter claro que a atividade de preservação e conservação dos recursos naturais é mais barata que a devastação. Em outros termos, o princípio da prevenção pode reconduzir-se à fórmula do poluidor-pagador, pelo fato de o 'poluidor' estar em condições de proceder à internalização dos custos de prevenção e controle da poluição, com a máxima eficácia econômica e ecológica e com maior equidade.

Noutro giro, também não restam dúvidas de que o princípio do poluidorpagador constitui o fundamento primário da responsabilidade civil objetiva em matéria ambiental. À evidência, quem colhe benefícios com determinada atividade responde pelos riscos daí decorrentes, impondo-se lhe, assim, e com fulcro no princípio do poluidor-pagador, a obrigação de reparar, independentemente da comprovação da culpa, os indesejados danos ambientais, causados durante o desenvolvimento de atividades de interesse econômico.

Ademais, o princípio do poluidor-pagador é o fundamento das medidas compensatórias, objeto do presente estudo; sendo bem instituídas e aplicadas, essas medidas, a nosso ver, são as que melhor se ajustam à concepção de que os custos pela utilização dos recursos naturais devem ser internalizados na cadeia produtiva. Afinal, tais medidas visam a compensar a coletividade pela utilização dos recursos naturais, evitando que todos arquem pelas mazelas causadas pela implantação de empreendimentos causadores de impactos ambientais, evidentemente necessários para o desenvolvimento socioeconômico. É, pois, o justo modo de internalizar o custo da utilização dos recursos do meio ambiente com fundamento no princípio do poluidor-pagador. 


\section{MECANISMOS E INSTRUMENTOS DAS POLÍTICAS AMBIENTAIS}

\subsection{Breves notas introdutórias}

A intenção do presente capítulo é demonstrar o porquê e como o Estado regula práticas visando à preservação ambiental.

O porquê complementará as análises já expostas no capítulo anterior, quando se verificou que o processo subjacente às regras jurídicas protetoras dos recursos naturais é, em suma, a crescente crise ambiental, que permitiu a recente tomada de consciência quanto à escassez dos bens da natureza e, daí, a necessidade de equacionar o fato pela economia e pelo direito. Neste momento, o porquê se mostra nas razões pelas quais o Estado, destacando-se da sociedade civil e da economia como um ente autônomo, surge como regulador e, no campo ambiental, impõe regras e limites quanto ao uso dos recursos naturais, seja para evitar que o poder econômico ${ }^{296}$ determine uma cada vez maior utilização desses bens da natureza, seja para manter uma qualidade razoável do meio ambiente. Tudo, como se verá, permitindo a sobrevivência e a renovação do sistema de mercado em que vivemos.

Aliás, frente à globalização - e a intensa velocidade com que se compete no mercado econômico e como se produzem e distribuem bens de consumo -, exporemos que o Estado acaba por se fortalecer e reestruturar, justamente para garantir que as forças do mercado sejam contidas, evitando, ao fim e ao cabo, a sua autodestruição.

E, fala-se em como o Estado vem instituindo e implementando medidas tendentes à proteção ambiental (inclusive por políticas ambientais), porquanto é

\footnotetext{
${ }^{296}$ A propósito do conceito de poder econômico, utilizaremos as palavras de Tércio Sampaio Ferraz Jr., para quem, visto na sociedade de consumo, o poder econômico tem o "sentido nítido de organização e de gestão orgânica. Não mais pertence à pessoa física, a alguém que o exerça, é um modo eficiente de organização nesse grande círculo do consumo.” FERRAZ JR., Tércio Sampaio. Poder econômico e gestão orgânica. In: FERRAZ JR., Tércio Sampaio; SALOMÃO FILHO, Calixto; NUSDEO, Fábio (orgs.). Poder econômico: direito, pobreza, violência, corrupção. Barueri: Manole, 2009, p. 24.
} 
preciso mostrar com quais instrumentos será ele capaz de alcançar as metas e os objetivos fixados em tais medidas, que funcionam, como se verá, de diversa natureza. Esta tese, todavia, focará precipuamente os mecanismos de comando e controle e os instrumentos econômicos. O foco nesses meios das políticas ambientais decorre da análise, no capítulo seguinte, onde será possível verificar que o objeto deste estudo - qual seja: as medidas compensatórias - é, a bem ver, um mecanismo ou um instrumento híbrido, significando que comporta características tanto dos mecanismos de comando e controle, quanto dos instrumentos econômicos, podendo emergir em diversas facetas - tal como ocorre com o princípio do poluidor-pagador.

Neste ponto, uma observação ainda se faz necessária: com vistas a demonstrar quais são os instrumentos econômicos, não nos furtaremos a expender considerações acerca dos tributos ambientais, inclusive quanto a um novel tributo ambiental, e do mecanismo da extrafiscalidade tributária. No entanto, é preciso anotar, desde já, que o objetivo deste estudo não é realizar uma análise completa e minuciosa do tema tributação ambiental, pois isso certamente se prestaria a uma tese específica. Pretende-se, apenas, explorar o tema, demonstrando - ainda que superficialmente - como o Direito Tributário, tanto no campo fiscal, quanto no extrafiscal, pode ser utilizado para alcançar a almejada proteção ambiental.

\subsection{O Estado como regulador}

De início, vale concentrar esforços para demonstrar como o Estado, destacando-se da sociedade civil e da economia, condiciona um mecanismo de estabilidade do vigente sistema social, político e econômico. Essa demonstração é necessária para que se possa verificar como e por que emergem medidas e regras de proteção ambiental (sejam interventivos, sejam de controle, sejam econômicos, sejam repressivos) no conhecido processo de produção e consumo de mercado.

Para tanto, cabe salientar que o Estado não protege de modo exclusivo os grandes ou pequenos empreendedores, e tampouco especificamente as classes 
menos privilegiadas, ou mesmo só o meio ambiente; protege, sim, o sistema político, social e econômico com um todo.

Nessa linha, o Estado conforma os conflitos ou as “falhas de mercado" que são inerentes ao sistema econômico vigente. Para tanto, esse ente sobrepõese à sociedade civil e à economia, aparecendo como uma instituição destacada e independente destas duas. Ou, como bem expõe Alaôr Caffé Alves,

a condição de possibilidade da relação social de produção
mercantil é representada pela organização política estatal, que
a um só tempo manifesta a garantia de reprodução daquela
relação antagônica por essência, sob a forma de capital, e a
dissimula sob a forma de 'interesse geral', destacado dos
interesses específicos e concretos dos sujeitos sociais por ela
mesma constituídos. Por esse modo, o Estado aparece como um
terceiro sujeito, por força mesma do caráter antagônico das
relações sociais básicas da sociedade mercantil-industrial,
qualificado como forma essencial e inafastável da organização
política desta sociedade, sem que isso signifique que seja um
instrumento utilizado intencionalmente para favorecer esta ou
aquela classe social. ${ }^{297}$

Em suma, é destacando-se da sociedade civil e da economia que o Estado acaba por justamente conformar os conflitos sociais e equacionar as falhas de mercado ou as contradições do sistema econômico. Afinal, a força coativa não pode advir da sociedade em si ou do próprio mercado, mas, sim, de um ente externo dito “neutro”, capaz de "pacificar” legitimamente os conflitos, a saber: o Estado (através do direito). Sendo assim, o ente estatal aparece como uma força independente, pairando sobre a sociedade civil e o mercado para a defesa de valores teóricos e aparentemente consensuais como "liberdade”, “igualdade”, “bem comum”, “legitimidade”, “segurança jurídica”, “bem-estar social”, “meio ambiente equilibrado" etc.

E, para conformar os conflitos, o Estado deve atender ora aos interesses do mercado, ora a interesses a eles contrapostos - como o são os interesses sociais ou ambientais -, mantendo o equilíbrio ou um marco de elasticidade do sistema. Na verdade, se não houver um contraponto - por meio do poder estatal

${ }^{297}$ CAFFÉ ALVES, Alaôr. Estado e ideologia - aparência e realidade. São Paulo: Brasiliense, 1987, p. 275-276. 
- capaz de conter as forças cegas do mercado, estas, abandonadas a si mesmas, se autodestruiriam.

Esse entendimento, aplicado aos aspectos ambientais, significa que o Estado coloca limites no uso dos bens ambientais pelo processo produtivo, porquanto o mercado, sem uma devida contenção, certamente prosseguiria com a utilização máxima dos recursos naturais e, ao mesmo tempo, buscaria um custo mínimo (ou zero) em relação a tais recursos, numa atitude tipicamente hedonista, considera aqui uma atitude pela qual o homem visa sempre a maximizar os resultados de suas ações e iniciativas ${ }^{298}$. Isso, por certo, levaria à destruição, a um só tempo, do meio ambiente e do próprio processo produtivo. Entretanto, ao Estado cabe garantir que esses limites não sejam extremos, devendo propiciar que as forças do mercado continuem com a utilização dos recursos naturais para produzir os bens necessários, e, com isso, mantenham girando o sistema econômico baseado no lucro e na apropriação da riqueza.

Em suma, o Estado, permite utilizar os recursos naturais, mas impõe limites para tanto, sempre com o intuito de manter um equilíbrio (ou marco de elasticidade) entre as atividades econômicas e os recursos naturais capaz de perpetuar o sistema capitalista em que vivemos. Esse processo, a bem ver, revela a hegemonia do sistema, caracterizada aqui, conforme o entendimento de Gramsci, para quem, em síntese,

uma classe mantém seu domínio não simplesmente através de uma organização específica da força, mas por ser capaz de ir além de seus interesses corporativos estreitos, exercendo uma liderança moral e intelectual e fazendo concessões, dentro de certos limites, a uma variedade de aliados unificados num bloco social de forças a que se chama de bloco histórico ${ }^{299}$.

Este bloco representa uma base de consentimento para uma certa ordem social, na qual a hegemonia de uma classe

\footnotetext{
${ }^{298}$ NUSDEO, Fábio. Curso de economia: introdução ao direito econômico. $6^{\text {a }}$ ed. rev. e atual. São Paulo: RT, 2010, p. 114.

${ }^{299}$ Para maior clareza do conceito de hegemonia e bloco histórico, vale lançar mão das palavras de Luciano Gruppi que, ao analisar Gramsci, expõe "a hegemonia tende a construir um bloco histórico, ou seja, a realizar uma unidade de forças sociais e políticas diferentes; e tende a conservá-las juntas através da concepção do mundo que ela traçou e difundiu. (...). 'A estrutura e a superestruturas - diz ele [Gramsci] - formam um bloco histórico'. A luta pela hegemonia deve envolver todos os níveis da sociedade: a base econômica, a superestrutura política e a superestrutura ideológica.” GRUPPI, Luciano. O conceito de hegemonia em Gramsci. Rio de Janeiro: Graal, 1978, p. 78.
} 
dominante é criada e recriada numa teia de instituições, relações sociais e idéias. ${ }^{300}$

Por conseguinte, a limitação do uso do meio ambiente - ou a contenção da utilização dos escassos bens ambientais - no processo produtivo acaba por não beneficiar o meio ambiente em si, mas, sim, o modo de produção e consumo vigente.

Essa premissa é bastante importante para que, de um lado, não se caia na ingenuidade de defender uma internalização 'perfeita' dos custos pela utilização dos recursos naturais ou, ainda, advogar a necessidade de uma exata valoração dos danos ambientais ou dos impactos negativos causados no meio ambiente; de outro lado, a premissa serve para demonstrar o dever do Estado de conformar as 'falhas de mercado', dentre elas, as externalidades negativas, o que faz impondo e implementando regras e limites para a utilização dos recursos naturais, seja para o proveito da coletividade, seja para o bem do próprio mercado.

Aliás, justamente por serem cada vez mais escassos os recursos naturais, é também cada vez mais constante e consistente a imposição e a implementação de políticas ambientais ${ }^{301}$ pelo Estado. Basta ver como vêm proliferando nos últimos anos normas de cunho ambiental, dentre elas a implantação de importantes políticas públicas. ${ }^{302}$

Isso mostra, outrossim, que o Estado não se enfraquece diante do avanço do sistema econômico em níveis globalizados, mas se reestrutura para proteger o mercado local e, ainda, manter e reproduzir o sistema econômico vigente. Em outros termos, há uma reestruturação da força estatal, da qual o sistema econômico descentralizado não pode prescindir.

\footnotetext{
${ }^{300}$ BOTTOMORE, Tom (ed.). Dicionário do pensamento marxista. Trad. Waltensir Dutra. Rio de Janeiro: Jorge Zahar Ed., 2001, p. 177.

${ }^{301}$ Sobre a estrutura jurídica das políticas ambientais, vide NUSDEO, Ana Maria de Oliveira. Pagamento por serviços ambientais no Brasil: elementos para uma regulamentação ambientalmente íntegra e socialmente justa. Tese apresentada à Faculdade de Direito da Universidade de São Paulo para obtenção do título de Livre-Docente. São Paulo/2010, p. 205-219 e BUCCI, Maria Paula Dallari, Políticas públicas: reflexões sobre o conceito jurídico. São Paulo: Saraiva, 2006.

${ }^{302}$ Em 2009, a Política Nacional de Mudanças Climáticas; em 2010, a Política Nacional de Resíduos Sólidos, sem falar nas importantes Lei da Mata Atlântica, editada em 2006; e, em dezembro de 2011, aprovado pelo Senado Federal o Projeto de Lei do novo Código Florestal.
} 
Assim, apesar das tendências à constituição de uma função pública transnacional, e da emergência de movimentos sociais (organizações não governamentais, fortalecimento da sociedade civil etc.), o Estado nacional/territorial continua sendo a instância central de legitimação do poder. Em certa medida, portanto, o que está ocorrendo é um movimento de adaptação no qual o Estado se reestrutura para enfrentar a globalização e a ilimitada utilização dos recursos naturais. ${ }^{303}$

A propósito, é bastante ilustrativo demonstrar que o Estado tem hoje um papel fundamental na política financeira ${ }^{304}$, na qual, aliás, se fundamenta todo o sistema produtivo. Basta ver, de fato, que “o capitalismo se sustenta graças à intervenção direta e cotidiana dos Estados nos mercados monetário e financeiro, cujo desabamento implicaria no desabamento ulterior do comércio e da indústria”. ${ }^{305}$ Ou, em outro dizer, o papel do Estado está restrito ao “ajuste da economia no plano nacional, com o objetivo de ganhar competitividade no mercado global e assegurar o clima de confiabilidade capaz de atrair investidores". 306

Nesse ritmo, não deve haver dúvidas de que o Estado também é um ator protagonista na política ambiental e, para tanto, fortalece-se e se reestrutura para fazer face à cada vez mais assustadora crise ambiental, controlando as forças hegemônicas ao exigir uma maior proteção dos recursos naturais.

Em síntese, cabe ao Estado, ao se deparar com a escassez dos recursos da natureza, institucionalizar meios para internalizar os custos da utilização desses recursos, fazendo com que as externalidades negativas (a que nos referimos no

\footnotetext{
${ }^{303}$ Quanto a isso, Osvaldo Coggiola pondera que, na verdade, “estamos diante de uma violenta reação antiliberal (se é que o termo "liberalismo" conserva algum sentido econômico) que concretiza a mais violenta intervenção estatal na economia de que se tem memória na história do capitalismo”. COGGIOLA, Osvaldo. Neoliberalismo, futuro do capitalismo? In: KATZ, Claudio. COGGIOLA, Osvaldo. Neoliberalismo ou crise do capital? São Paulo: Xamã, 1996. cit., p. 197. Aliás, o precedente vem desde 1933, com o New Deal do Presidente Roosevelt.

${ }^{304}$ A título ilustrativo do intuito protecionista do Estado, evitando que as forças do mercado se autodestruam, vale mencionar a intervenção do governo americano na queda das bolsas em decorrência da crise do sistema imobiliário nos EUA, em 2008. Da mesma forma vem ocorrendo na crise financeira de 2011, quando ficou bastante evidente a intervenção do Estado na Economia pelas medidas tomadas pelo presidente americano Barack Obama, que interveio fortemente para elevar o piso da dívida internacional daquele país, permitindo maiores investimentos para implementar os índices de emprego.

${ }^{305}$ COGGIOLA, Osvaldo. Ob. cit, p. 197.

${ }^{306}$ VIEIRA, Liszt. Os argonautas da cidadania - A sociedade civil na globalização. Rio de Janeiro: Record, 2001, p. 94.
} 
item 4.4 do Capítulo 4) sejam arcadas por aqueles que obtêm lucro com as atividades produtivas e, ao mesmo tempo, evitar que a sociedade arque com o custo da poluição e da degradação ambiental.

Para tanto, institucionalizam-se políticas ambientais, com base em uma diversidade de mecanismos e instrumentos, dentre eles os importantes mecanismos de comando e controle e os instrumentos econômicos, que passarão a ser analisados a seguir.

Antes, porém, será preciso demonstrar as razões pelas quais não é possível internalizar plenamente a utilização dos recursos naturais no processo produtivo. Senão, vejamos.

\subsection{Os limites para internalização dos custos pela utilização dos recursos naturais}

O ponto a ser enfrentado neste momento da tese já foi ilustrado no Capítulo 2, onde se demonstrou que a compensação ambiental foi instituída pela Lei federal $n^{\circ}$ 9.985/200, com o objetivo de financiar o Sistema Nacional de Unidades de Conservação - SNUC, mediante o apoio e a manutenção dessas áreas protegidas. Para tanto, impôs originalmente o pagamento da exação com base em um critério objetivo, qual seja: no mínimo, 0,5\% sobre os custos totais do investimento de projetos licenciados, que causassem significativo impacto ambiental, avaliados por meio de EIA/RIMA. Sim, como também já aludido naquele momento, era um critério objetivo que acabou sendo excluído pelo STF por meio do julgamento da $\mathrm{ADI} 3.378 / \mathrm{DF}$, no qual se decidiu, em suma, que a obrigação deveria basear-se unicamente no quantum atribuído em conformidade com a valoração dos significativos impactos ambientais.

A bem ver, se já era difícil trabalhar com a falta de uma alíquota limite e com a generalidade da base de cálculo, a situação piorou diante daquele julgamento; a partir daí, verificou-se a total inoperância da norma.

A necessidade do critério objetivo evidencia, a bem ver, e consoante também já perpassado no item 2.3.2 do Capítulo 2, a enorme dificuldade de quantificar em pecúnia o dano ambiental e o impacto ao meio ambiente, e, bem 
por isso, quão necessários são critérios e parâmetros objetivos na criação e implementação de mecanismos e instrumentos econômicos em políticas ambientais. ${ }^{307}$ Afinal, as dificuldades de valorar os recursos ambientais repercute logicamente na valoração das externalidades negativas. Nesse sentido, José Rubens Morato Leite e Patryck de Araújo Ayala expõem que, "na verdade, o princípio do poluidor-pagador é uma solução parcial aos problemas econômicos ambientais, pois existem sérios obstáculos em avaliar os custos das externalidades, que devem ser internalizados pelos poluidores, e não existe implementação generalizada deste modelo" ${ }^{308}$

Sobre a dificuldade de valoração dos bens ambientais, Édis Milaré expõe:

o meio ambiente, além de ser um bem essencialmente difuso, possui em si valores intangíveis e imponderáveis que escapam às valorações correntes (principalmente econômicas e financeiras), revestindo-se de uma dimensão simbólica e quase sacral, visto que obedece a leis naturais anteriores e superiores à lei dos homens. É o que, com eloquência, retratou a carta do cacique Seattle, em 1852, ao presidente Millard Fillmore, dos Estados Unidos, que desejava adquirir as suas terras para colonizá-las: 'O presidente, em Washington, informa que deseja comprar a nossa terra. Mas como é possível comprar ou vender o céu ou a terra? A ideia nos é estranha. Se não possuímos o frescor do ar e a vivacidade da água, como vocês poderão comprá-los? Cada parte dessa terra é sagrada para o meu povo. Cada arbusto brilhante do pinheiro, cada porção de praia, cada bruma na floresta escura, cada inseto que zune, todos são sagrados na memória e na experiência do meu povo.'. Nessa linha, aproveitando o exemplo antes referido, cabe perguntar: quanto vale, em parâmetros econômicos, uma espécie que desapareceu? Qual o montante necessário para a remediação de um sítio inquinado por organoclorados? Assim, mesmo que levado avante o esforço reparatório, nem sempre é possível, no estágio atual do conhecimento, o cálculo da totalidade do dano ambiental. ${ }^{309}$

A par das dificuldades impostas pela própria natureza, o mercado é o dificultador maior da tal valoração dos bens ambientais, significando dizer,

\footnotetext{
307 Sobre a valoração do bem econômico (e, por consequência do bem ambiental), vide NUSDEO, Fábio. Curso de economia: introdução ao direito econômico. $6^{\text {a }}$ ed. rev. e atual. São Paulo: RT, 2010, p. 43-61.

${ }^{308}$ LEITE, José Rubens Morato; AYALA, Patryck de Araújo. Dano ambiental: do patrimonial ao coletivo extrapatrimonial: teoria e prática. $4^{\mathrm{a}}$ ed. rev. atual. ampl. São Paulo: RT, 2011, p. 63.

${ }^{309}$ MILARÉ, Édis. Direito do ambiente. $7^{\text {a }}$ ed. São Paulo: RT, 2011, p. 1124.
} 
inclusive, usando do ensinamento de Rehbinder, que no sistema econômico vigente “não há intenção de uma completa internalização do custo" ${ }^{310}$ A esse respeito, Cristiane Derani frisa:

A dificuldade, ou mesmo a impossibilidade, de atribuirse uma medida monetária ao recurso natural está sobretudo no fato de que lhe falta a soma de fatores inerentes à produção. Isto é, ele vale pela sua simples requisição para continuidade do processo produtivo. Sua valoração dispensa o fator custo de produção, estando sujeita teoricamente à quantidade ou escassez. Esta valoração é constituída por um raciocínio simplificado de preço, o qual partiria do zero - caso o recurso fosse abundante, por exemplo, o ar - atingindo valores diversos na medida de sua escassez no mercado.

No entanto, é importante frisar que escassez, como elemento regulador de preço, significa escassez no interior de determinadas relações de mercado, dependente da quantidade do bem apresentado para comércio, bem como da relativização da sua finalidade, e não da sua existência em termos absolutos. Exemplificando, o valor de uma seringueira numa colônia de seringueiros não é o mesmo valor de uma seringueira que enfeita um jardim em São Paulo. Embora se possa determinar um valor monetário para ambas, jamais ele será um valor monetário intrínseco a cada árvore, simplesmente porque elas existem. Natureza 'humanizada', em relação com o homem, é uma categoria social. Seu conteúdo e valor é-lhe socialmente atribuído. ${ }^{311}$

Mas não é só na natureza e no mercado que se dificultam a valoração dos bens ambientais. De fato, a estrutura jurídica também torna infactível a efetiva quantificação financeira dos recursos naturais, ao caracterizá-los como bens públicos, isto é, que não têm proprietários exclusivos e, daí, também não têm quem lhes atribua um 'preço' para uso ou troca ${ }^{312}$; bem por isso, aliás, o 'bem público’ é considerar também uma ‘falha de mercado’. Sobre o assunto, Fábio Nusdeo ensina:

Sempre que um bem não livre, isto é, um bem econômico não tiver essa sua qualidade assinalada por um preço que

\footnotetext{
${ }^{310}$ Apud: LEITE, José Rubens Morato; AYALA, Patryck de Araújo. Dano ambiental: do patrimonial ao coletivo extrapatrimonial: teoria e prática. $4^{\mathrm{a}}$ ed. rev. atual. ampl. São Paulo: RT, 2011, p. 63.

${ }^{311}$ DERANI, Cristiane. Direito ambiental econômico. $3^{\mathrm{a}}$ ed. São Paulo: Saraiva, 2008, p. 96.

312 Bem por isso, como visto no item 4.4 do Capítulo 4 desta tese, a resolução do problema residiria em permitir a apropriação privada dos recursos naturais, se é que isso fosse possível.
} 
traduza o seu grau de escassez, estar-se-á em presença de uma falha de sinalização do mercado, induzindo-o a um comportamento incompatível com a realidade dos fatos. Em outras palavras, um bem de suprimento restrito estará sendo superutilizado como se plenamente abundante fora. ${ }^{313}$

A respeito, vale lembrar, a literatura econômica chama de bens públicos aqueles cujos direitos de propriedade não estão completamente definidos e, portanto, suas trocas com outros bens acabam não se realizando eficientemente pelo mercado. Dessa forma, o sistema de preços é incapaz de valorá-los adequadamente. Isso se dá em decorrência de duas características: a nãoexclusividade e a não-rivalidade. Ana Maria de Oliveira Nusdeo enfatiza que, "em função dessas características, o mercado não gera estímulos suficientes para a oferta desses bens, pois os indivíduos, dentro do padrão hedonista de comportamento no mercado, não tendem a pagar um preço por algo que não possuirão ou usufruirão com exclusividade”. ${ }^{314}$

Sendo assim, seja por motivos inerentes à própria natureza, seja pelas razões impostas pelo mercado, seja diante das regras jurídicas, os bens ambientais são de dificílima valoração.

Precisamente por isso é que os danos ambientais vêm sendo reparados ou indenizados com base em critérios ditos objetivos e que nem sempre têm a efetiva relação com o prejuízo de fato causado. Ora, caso os danos ambientais fossem totalmente reparados, sem dúvida que isso conduziria, em muitos casos, à inviabilização de continuidade da atividade empresarial.

Aliás, os pesquisadores debatem para apresentar uma metodologia de cálculo que alcance, o máximo possível, a valoração dos bens ambientais. Até hoje, porém, esse intento não conseguiu realizar-se a contento. Por conseguinte,

\footnotetext{
${ }^{313}$ NUSDEO, Fábio. Desenvolvimento e ecologia. São Paulo: Saraiva, 1975, p. 57.

${ }^{314}$ NUSDEO, Ana Maria de Oliveira. O uso dos instrumentos econômicos nas normas de proteção ambiental. Revista da Faculdade de Direito da Universidade de São Paulo, v. 101, jan/dez 2006, p. 362. A autora, nessa mesma obra, discorre que "a não-exclusividade do direito de uso ou de propriedade de um determinado bem se refere ao fato de que seu uso por um indivíduo não impede o uso concomitante por outros, contrariamente aos bens exclusivos. $\mathrm{O}$ ar, as reservas florestas e a biodiversidade podem ser considerados bens públicos ou coletivos. As transações de mercado dão-se com relação aos bens de uso e propriedade exclusiva. Relativamente ao bem público, faltando-lhe o atributo da exclusividade, não é possível atribuir-lhe um preço". Ainda, expõe que "a não-rivalidade do bem diz respeito ao seu uso, que pode ser feito por um indivíduo sem necessidade de reduzir-se a quantidade disponível a outro indivíduo. O prazer de desfrutar de um parque ou de admirar uma paisagem, por exemplo".
} 
de igual modo não há previsão legal de metodologias para quantificação econômica dos danos ambientais; então, em ações civis públicas, em geral, o juiz se socorre do perito designado para elaborar o laudo pericial; de modo costumeiro, o perito indica os danos irreversíveis e fixa um valor que lhes é correspondente, elaborado com base em parâmetros da Associação Brasileira de Normas Técnicas ou da literatura especializada em economia do ambiente. ${ }^{315}$

De fato, verifica-se, por vezes, que os danos ambientais são indenizados com base na avaliação dos custos totais das obras e trabalhos necessários à recuperação do meio ambiente, condenando-se o responsável ao pagamento do valor correspondente. Em outras palavras, pode ocorrer a fixação de determinada soma em dinheiro, como aconteceu, por exemplo, em caso no qual foram abatidas aproximadamente cinco mil aves de várias espécies silvestres, entre rolinhas, sabiás e tico-ticos ${ }^{316}$. Nessa situação específica, o réu foi condenado ao pagamento de determinada quantia em dinheiro, calculada com base no número de aves abatidas, multiplicado pelo valor unitário de mercado do exemplar da espécie correspondente. Um outro critério pode ser baseado na aferição monetária da perda do bem, como ocorreu em um caso de queima de palha de cana-de-açúcar. Naquela circunstância, buscou-se multiplicar a quantidade de litros de álcool produzidos pela cana pelos hectares necessários para o seu cultivo, chegando-se à soma em dinheiro a ser paga pela empresa poluidora. Um último parâmetro, também muito comum, é a substituição do bem danificado por outro equivalente ou que possa substituir a função daquele. ${ }^{317}$

Os danos ambientais costumam, ainda, ser indenizados com base na capacidade financeira do réu, ao se considerar, em síntese, o fato de não adiantar impor uma determinada quantia a uma empresa que, além de não ter condições de pagá-la, ao adimpli-la pode significar a sua morte financeira.

Há muitos que se indignam frente a situações dessa natureza, quando, por exemplo, não é possível reparar plenamente um dano ambiental em ações civis

\footnotetext{
${ }^{315}$ STEIGLEDER, Annelise Monteiro. Responsabilidade civil ambiental: as dimensões do dano ambiental no direito brasileiro. $2^{\mathrm{a}}$ ed. Porto Alegre: Livraria do Advogado, 2011, p. 235.

${ }^{316}$ Caso conhecido como a "Passarinhada do Embu", em que um Prefeito Municipal, pretendendo reelegerse, abateu as referidas aves para um 'churrasco' oferecido aos seus eleitores.

${ }^{317}$ MORATO LEITE, José Rubens; AYALA, Patryck de Araújo. Dano ambiental: do individual ao coletivo extrapatrimonial: teoria e prática. $4^{\mathrm{a}}$ ed. São Paulo: RT, 2011, p. 218-219.
} 
públicas, mediante a condenação em indenização pecuniária aparentemente equivalente, em razão da insuficiente condição financeira do réu. É o que expõe Annelise Monteiro Steigleder:

\begin{abstract}
existe uma tendência do Poder Judiciário, no sentido de reduzir as indenizações por dano material, considerando a condição financeira do poluidor, aspecto este que, em um sistema de responsabilização objetivo por danos ambientais, deveria ser irrelevante para efeitos de definição do valor indenizatório do dano material. Ou seja, a incapacidade econômica é um dado da realidade que afetará o cumprimento da sentença, não há dúvidas. No entanto, não é um aspecto que mereça ser computado no momento da quantificação do dano material, que deve ser apurado a partir de dados objetivos sobre a gravidade, extensão e irreversibilidade dos impactos negativos. ${ }^{318}$
\end{abstract}

Não obstante as críticas, diante das dificuldades para a valoração dos danos ambientais e dos impactos negativos ao meio ambiente, vêm sendo construídos inúmeros critérios objetivos - ou o mais objetivo possível - para valorar os recursos da natureza. De modo usual, são metodologias de cálculo não têm uma relação direta e exata com o dano ou o prejuízo ambiental causado. De fato, a quantificação da indenização das cinco mil aves sacrificadas, como acima aludido, não necessariamente retribui ao meio ambiente o prejuízo ambiental ocasionado por sua perda, bastando considerar que ali não foram incluídos os efeitos que essa perda gerou para a cadeia reprodutiva, produtiva e alimentar. Os passarinhos, como se sabe, além de serem importantes para a cadeia alimentar, são absolutamente necessários para garantir a diversidade da flora, como também a sua expansão.

Com o fito de buscar a internalização da utilização dos recursos naturais, o direito norte-americano introduziu três elementos básicos a serem considerados para definir os métodos de avaliação: 1. Custo da restauração, reabilitação, recomposição de recursos naturais ou aquisição deles; 2. Redução do valor desses recursos naturais, considerando a recuperação do recurso para a

\footnotetext{
318 STEIGLEDER, Annelise Monteiro. Responsabilidade civil ambiental: as dimensões do dano ambiental no direito brasileiro. $2^{\mathrm{a}}$ ed. Porto Alegre: Livraria do Advogado, 2011, p. 235.
} 
linha-base, se o dano não tivesse ocorrido; e 3. Custo razoável da avaliação desses danos. $^{319}$

Por sua vez, a União Europeia implementou o “Environmental Liability Directive (EDL)”, por meio do qual estabeleceu métodos para alcançar a valoração dos recursos ambientais, a fim de que "environmental damage be remediated (restored) so that the affected environment returns to (or toward) its baseline condition and the public is compensated for the initial damage and the losses during the time it takes for the environment to recover (interim losses)." 320

No direito brasileiro, a Lei nº 7.347/1985 (Lei da Ação Civil Pública) dispôs que a ação civil pública “poderá ter por objeto a condenação em dinheiro ou o cumprimento de obrigação de fazer ou não fazer” (art. $3^{\circ}$ ). Assim, a reparação in natura (por meio da obrigação de fazer ou não fazer) ou, quando esta não for factível, a indenização em espécie, são as formas possíveis para internalizar, ainda que parcialmente, as externalidades negativas decorrentes dos danos causados ao meio ambiente.

Há, ademais, parâmetros estabelecidos no Decreto federal n ${ }^{\circ}$ 6.514/2009 para o cálculo de multas ambientais. Segundo esse diploma, essas penalidades administrativas podem ter por base "a unidade, hectare, metro cúbico, quilograma, metro de carvão-mdc, estéreo, metro quadrado, dúzia, estipe, cento, milheiros ou outra medida pertinente, de acordo com o objeto jurídico lesado” $\left(\right.$ art. $\left.8^{\circ}\right)$.

Mas, usualmente, o critério seguido para a condenação in pecúnia tem sido a medida do que custaria para reparar integralmente o dano causado - caso fosse possível -, considerando evidentemente os limites para tanto e a condição financeira do réu.

Por outro lado, para os impactos negativos e não mitigáveis, avaliados e gerenciados no decorrer do licenciamento ambiental, há, como visto, medidas compensatórias positivadas (vide item 2.1 do Capítulo 2), cujo cálculo se baseia

\footnotetext{
${ }^{319}$ Idem, p. 224.

${ }^{320}$ COLE, Scott G. Environmental compensation using Resource Equivalency Analysis (REA) and Habitat Equivalency Analysis (HEA): Is it just for the birds? Licentiate Thesis. Swedish University of Agricultural Sciences, Umeå, 2010, p. 10.
} 
em critérios objetivos - como é o multicitado caso da compensação ambiental, em que se atribuiu, originalmente, o critério do $0,5 \%$ sobre os custos totais do empreendimento.

Sendo assim, da mesma forma como os danos, os impactos negativos acabam por não ser plenamente internalizados, o que implica, mais uma vez, um resíduo de custos não computados no processo produtivo e que acabam sendo assumidos por toda a coletividade.

À evidência, os custos sem condições de serem internalizados são assumidos por toda a coletividade, seja na forma de oneração para os cofres do Poder Público que deverá procurar corrigi-los, seja na forma de poluição do ar, do solo e da água que são suportados pela população em geral. A parte que não é internalizada representa, a bem ver, um déficit necessário para a manutenção e a reprodução do sistema econômico vigente. De fato, caso fosse possível internalizar todos os custos da utilização dos recursos naturais, seriam possivelmente inviáveis a sua assimilação pelo mercado, o que consistiria em uma ruptura desse modo de produção e consumo. Assim, cabe ao Estado prover esse déficit necessário com os valores arrecadados dos contribuintes e, em parte, cobrando-se uma reparação, uma compensação, um preço ou um tributo dos poluidores, quando possível.

Em outros termos, tem-se que a valoração dos bens ambientais é pragmática, e não precisa ou intrínseca. Portanto, o custo que será embutido na cadeia de produção e consumo, com intento de internalizar as externalidades negativas, será o compatível em termos econômicos para o momento. Ou o economicamente viável (ou o grau ou nível ótimo ${ }^{321}$ ), que permita continuar a

\footnotetext{
${ }^{321}$ Nas palavras de Ronaldo Seroa da Motta, "o principal objetivo da cobrança pelo uso dos recursos ambientais é o de alterar o custo de oportunidade do recurso de forma que seu uso atinja um nível ótimo. Ou seja, fixar um nível de atividade socialmente ótimo onde o benefício marginal privado líquido se iguale ao custo marginal causado pelas externalidades. Este tipo de cobrança é denominada de 'taxas pigouvianas'. Essas 'taxas pigouvianas' encontram inúmeros obstáculos de aplicação, sobretudo em razão das amplas dificuldades de valoração econômica dos danos e impactos ambientais. Assim, em razão de estas taxas não serem aplicadas, tenta-se alcançar níveis 'aceitáveis' de degradação por meio de cobranças de uso que induzem os usuários a atendê-los”. O autor explica que, teoricamente, a 'taxa pigouviana', já apontada em páginas anteriores, seria o dano ambiental no ótimo econômico da poluição (denominação dada por Arthur Cecil Pigou, que a formulou pela primeira vez na década de 1920). SEROA DA MOTTA, Ronaldo. Economia ambiental. Rio de Janeiro: Editora FGV, 2006, p. 81. Por sua vez, Robert Stavins discorre sobre as dificuldades em identificar o grau ótimo de poluição de um determinado recurso natural (água, solo ou ar): "One important characteristic of individual pollution problems that will affect the identification of the
} 
atividade econômica e, ao mesmo tempo, equacionar, ainda que apenas em parte, a falha de mercado ou as externalidades negativas. Salvo, é claro, se for uma atividade absolutamente indesejada - como é o caso das ilícitas ou meramente predatórias -, quando, então, é melhor que deixe de ser exercida. De fato, em casos extremos, a inviabilidade de produção e de consumo pode se revelar desejável quando confrontada com os malefícios causados pela atividade agressora. É o caso ocorrido com um projeto de construção de uma megausina sucroalcooleira, cuja consequência seria a contaminação permanente de toda uma bacia hidrográfica, inviabilizando qualquer outra atividade agrícola ou pecuária; o projeto, assim, não foi adiante.

Mais uma vez o ensinamento de Cristiane Derani nos auxilia, quando discorre que “a imposição de um custo ao causador do dano não significa necessariamente que o dano será eliminado. O princípio do poluidor-pagador não está em eliminar o efeito negativo, ele está inscrito na lógica do Ótimo de Pareto $^{322}$, exigindo uma ponderação, uma espécie de avaliação de custobenefício econômico (financeiro)”. E continua a autora, expondo que "dentro dessa perspectiva, a economia de mercado atinge seu grau ótimo quando realiza uma satisfatória relação entre o uso de um recurso natural e sua conservação, encontrando um preço que permita a utilização do bem ao mesmo tempo que o conserva. Em outras palavras, a relação uso e não uso deve atingir um estágio

optimal point of regulatory intervention is the degree of mixing of the pollutant in the receiving body (airshed, watershed, or ground). At one extreme, uniformly mixed pollution problems (in their purest form, global commons problems such as stratospheric ozone depletion and global climate change) can be efficiently addressed through input or emissions interventions. At the other extreme, it would be problematic to address a highly non-uniformly mixed pollution problem through such an approach; instead, an intervention that focused on ambient concentrations, at a minimum, would be preferable". STAVINS, Robert N. Experience with market-based environmental policy instruments. Fondazione Eni Enrico Mattei - FEEM, Working Paper $n^{\circ}$ 52/2002; Kennedy School of Government - KSG/Harvard University, Working Paper $n^{\circ}$ 00/2004. Disponível em <http://ssrn.com/abstract=199848>. Acesso em: 3.10.2011.

${ }^{322} \mathrm{O}$ conceito de Pareto considera uma medida eficiente se ela acarretar uma mudança vantajosa para um indivíduo, sem causar desvantagem alguma a qualquer outro. Uma situação econômica é considerada ótima, nesses termos, se não houver outro cenário que lhe seja mais eficiente no sentido paretiano. Dada sua dificuldade de operacionalização, pois poucas modificações passariam por esse teste, o conceito de Pareto foi adaptado por Kaldor-Hicks, que descreve como eficientes alterações cujos benefícios sejam superiores às perdas, de modo a ser possível, em tese, compensar prejuízos sofridos por terceiros, ainda que essa compensação não se efetive na prática. NUSDEO, Ana Maria de Oliveira. Pagamento por serviços ambientais no Brasil: elementos para uma regulamentação ambientalmente íntegra e socialmente justa. Tese apresentada à Faculdade de Direito da Universidade de São Paulo para obtenção do título de Livre-Docente. São Paulo/2010, p. 35. 
ótimo, que permita a continuação desta prática econômica, ou seja, a sustentabilidade do desenvolvimento". 323

Sobre o custo-benefício ${ }^{324}$, Fábio Nusdeo há muito já ensina:

Como se trata de sopesar ganhos e ônus vinculados a determinados cursos alternativos de ação, os economistas acenam, desse logo, com um instrumento útil em vários setores: a análise de custo-benefício. Cálculos bastante diferenciados permitem, com efeito, estimar acuradamente os benefícios líquidos trazidos por diversos projetos alternativos, mediante a mensuração de sua taxa de retorno não apenas privada, mas social. É mediante o emprego dessa técnica que se selecionam os projetos a serem contemplados com investimentos diretos ou com financiamentos de origem oficial, atribuindo-lhes graus de prioridade, precisamente em função de seu maior ou menor quociente benefício-custo. ${ }^{325}$

No entanto, observa Nusdeo que, nos casos “poluição e da degradação ambiental, as coisas se passam de maneira um tanto diversa, uma vez que os custos desses fenômenos são dificilmente avaliáveis, por se referirem a aspectos pouco quantificáveis do bem-estar dos indivíduos e da sociedade”. ${ }^{326}$ A bem ver, para o cálculo do custo da utilização dos recursos da natureza no processo produtivo, só se considera a maior parte dos recursos do ponto de vista de funções de produção e, ainda, de forma restritiva porque os fatores fora de mercado (capacidade de autodepuração de um curso de água, trabalho da microfauna e da microflora, do solo, por exemplo) são também ignorados. ${ }^{327}$

Tudo isso significa, embora de ajuda a análise do custo-benefício, a inviabilização de um cálculo perfeito dos custos pelo uso dos recursos naturais no processo produtivo, sejam as matérias-primas, sejam os decorrentes dos impactos negativos, sejam em virtude de danos ambientais. Essa inviabilização

\footnotetext{
${ }^{323}$ DERANI, Cristiane. Direito ambiental econômico. $3^{\text {a }}$ ed. São Paulo: Saraiva, 2008, p. 115.

${ }^{324}$ No Direito, também vem se chamando de "princípio da proporcionalidade”, baseando-se nele a forma de limitar as medidas de reparação dos danos ambientais (ou a compensação de impactos negativos) àquelas medidas ótimas, fruto da comparação entre o seu custo e a vantagem a ser obtida. STEIGLEDER, Annelise Monteiro. Responsabilidade civil ambiental: as dimensões do dano ambiental no direito brasileiro. $2^{\mathrm{a}}$ ed. Porto Alegre: Livraria do Advogado, 2011, p. 225.

${ }^{325}$ NUSDEO, Fábio. Desenvolvimento e ecologia. São Paulo: Saraiva, 1975, p. 66.

${ }^{326}$ Idem, p. 67.

327 GERENT, Juliana. Internalização das externalidades negativas ambientais - uma breve análise da relação jurídico-econômica. Revista de Direito Ambiental. nº 44. Ano 11. out-dez. São Paulo: RT, 2006.
} 
é, sem dúvida, uma regra imposta pelo próprio sistema econômico vigente. Sim, pois caso fosse efetivamente possível calcular o exato preço dos recursos naturais, o custo respectivo seria altíssimo, o que, por certo, faria o mercado sucumbir, ora pela impraticabilidade do lucro, ora por não ser mais factível o consumo de produtos demasiadamente caros. Bem por isso, como dito em linhas acima, diz-se que a valoração dos bens ambientais é pragmática.

Logo, não há efetivamente como questionar que não basta exigir o pagamento pelo custo da utilização dos recursos da natureza; é também necessário que aquele de quem seja cobrado esse custo tenha disponibilidade para o seu pagamento. Ademais, a própria internalização dos custos pela utilização dos recursos naturais, caso não seja devidamente regulada e controlada, pode distorcer o mecanismo e permitir uma desleal concorrência ao afastar do mercado aqueles que não têm condições de pagar pelo preço, permitindo um monopólio dos economicamente mais fortes. De novo nas palavras de Cristiane Derani:

Quanto maior o preço da mercadoria (recursos naturais), menor a quantidade de sujeitos que têm acesso a ela. Por causa do aumento da dificuldade de acesso a estes 'bens', surge uma forma nova de exclusão da concorrência no mercado. O aumento do custo da produção permite maior concentração de capital, numa clara tendência monopolista. A concorrência é paulatinamente reduzida e o mercado torna-se um oligopólio de grandes grupos, que estão dispostos não somente a pagar, como também a diminuir a incômoda concorrência. O pagamento e a disposição a pagar são movimentos decorrentes da produção. Paga-se à medida que se detém o poder de compra. No desenvolvimento desta prática, não se alcança efetivamente o objetivo de conservação dos recursos naturais. O que ocorre é a sumária transferência de uso da natureza para faixas cada vez mais estreitas da sociedade. Um instrumento que seria para afastar a poluição, afasta a concorrência e concede privilégios de poluir. ${ }^{328}$

Não obstante as dificuldades, e justamente para evitar que o mercado se aproveite desse déficit necessário - pois, como visto, as forças hegemônicas, deixadas livres, têm a capacidade de procurar um lucro máximo e, com isso, se autodestruir e destruir o próprio sistema econômico -, o Estado, impondo uma

${ }^{328}$ DERANI, Cristiane. Direito ambiental econômico. $3^{\text {a }}$ ed. São Paulo: Saraiva, 2008, p. 95. 
contraprestação, deve definir critérios objetivos de cálculo para propiciar, o quão possível, uma efetiva internalização dos custos pela utilização dos recursos naturais, ainda que isso não signifique equacionar plenamente as externalidades negativas.

Com o intuito de melhor internalizar os custos com a utilização dos recursos naturais, os critérios objetivos de cálculo devem ser preferencialmente definidos em lei e com metodologias factíveis, simples e transparentes. Sim, porque, caso não se imponham, de forma positivada, critérios objetivos e factíveis, com toda a certeza se perderá em um universo infindável de discussões sobre o devido quantum necessário para reparar o dano ou compensar o impacto negativo a ser causado ${ }^{329}$. Deve ser, também, simples e transparente a fim de evitar a contestação e a manipulação de dados. E, ainda, critérios pragmáticos para impedir o uso excessivo do bem ambiental, independentemente do seu custo, que é zero.

Sendo assim, é uma ingenuidade imaginar que todos os custos com a utilização dos recursos naturais podem ser internalizados. Ou, melhor dizendo, é sem dúvida frágil o discurso que defende a possibilidade de equacionar perfeitamente as externalidades negativas. Nas palavras de Edward Nevin: “in the textbook world this would be the end of the matter but in the world of reality the first-best solution may not be costless or even feasible."330

Alerte-se: essa é uma lógica do mercado em que vivemos, que impõe, como se viu, um pragmatismo da valoração dos bens ambientais e, com isso, um déficit necessário em relação aos custos da exploração da natureza; tal déficit serve para permitir a reprodução e a manutenção do sistema econômico de mercado. Portanto, não há nessa lógica um aspecto malévolo, predatório ou destruidor; trata-se apenas de uma regra imposta pelo próprio sistema econômico de mercado. ${ }^{331}$

\footnotetext{
${ }^{329}$ As discussões sobre o quantum do dano ou do impacto normalmente variam, em síntese, ora no valor efetivo do dano ou do impacto, ora no valor para a sua recuperação ou compensação, ora no valor possível para o empreendedor.

${ }^{330}$ NEVIN, Edward. The economics of Europe. Macmillan, 1990, p. 84.

331 Da mesma forma com que ocorre com a lógica segundo a qual não é possível pagar ao empregado o que efetivamente vale o seu trabalho, pois isso impediria o lucro e, assim, a manutenção e a reprodução do sistema.
} 


\subsection{As políticas ambientais, os mecanismos de comando e controle e os instrumentos econômicos}

Diante das premissas acima colocadas, fica fácil defender que o Estado, ao impor a internalização dos custos pela uso dos recursos naturais, o faz com a tarefa de manter o equilíbrio ou o marco de elasticidade do sistema econômico. $\mathrm{Na}$ verdade, o mercado, sem imposição de limites - consoante dito em linhas anteriores -, certamente prosseguiria aproveitando-se ao máximo dos recursos da natureza e, ao mesmo tempo, procurando um custo mínimo, em uma atitude tipicamente hedonista; tudo, como já se expôs no item 4.2.1 do Capítulo 4 desta tese, para alcançar suas metas de lucro, o que exige demasiada competitividade e, sobretudo, diante da economia globalizada, cada vez com mais rapidez no processo produtivo e mercantil.

Portanto, para bem utilizar os instrumentos capazes de internalizar os custos pela utilização dos recursos naturais sem criar outras falhas de mercado ou aspectos indesejados (monopólios, desemprego etc.), é preciso que o Estado implemente políticas ambientais. ${ }^{332}$ Sim, como jamais será possível internalizar totalmente o custo dos recursos naturais, será sempre necessário regular, conforme já dissemos, como e onde se quer chegar, contemplando os recursos da natureza em políticas ambientais que se utilizem de diversas gamas de processos, como econômicos, bancários, de mercado, judiciais, tributários, administrativos etc. É preciso, porém, uma vez mais, ter em mente a impossibilidade de valorar os bens ambientais, quer pelos obstáculos impostos pelo mercado, quer porque, de fato, não é possível encontrar um preço que lhes seja efetivamente compatível.

Esse cenário exige a implementação de uma política ambiental realista, com mecanismos e instrumentos devidamente organizados e que visam a um determinado objetivo ou meta. Ou, nas palavras de Robert Stavins, "environmental policies typically combine the identification of a goal (either

\footnotetext{
${ }^{332}$ Efeitos indesejados podem emergir quando da instituição de mecanismos e instrumentos econômicos que são criados sem estarem vinculados a uma política ambiental e tampouco têm base legal. A esse respeito, citem-se os efeitos da Instrução Normativa ICMBio 09, de 28 de abril de 2010, acerca dos quais se tratará no item 6.5.1 do Capítulo 6 deste estudo.
} 
general or specific) with some means to achieve that goal. In practice, these two components are often linked within the political process". 333

Para ser efetivo o alcance dos ditos objetivos e metas, as políticas ambientais vêm introduzindo mecanismos e instrumentos cada vez mais consistentes - e, por vezes, cada vez mais complexos ${ }^{334}$ - para a proteção dos recursos naturais, internalizando o quão possível os custos pelo seu emprego no processo produtivo industrial.

O emprego desses mecanismos e instrumentos, diante das peculiaridades da política e dos objetivos e metas que se quer alcançar, é avaliado consoante diversos critérios. No tema sobre as questões que usualmente emergem da discussão do melhor instrumento - ou dos melhores - a utilizar em determinada política ambiental, a doutrina estrangeira considera, usualmente, que (i) no single instrument is clearly superior along all the dimensions relevant to policy choice; even the ranking along a single dimension often depends on the circumstances involved; (ii) significant trade-offs arise in the choice of instrument. In particular, assuring a reasonable degree of fairness in the distribution of impacts, or ensuring political feasibility, often will require a sacrifice of cost-effectiveness, (iii) it is sometimes desirable to design hybrid instruments that combine features of various instruments in their "pure" form; (iv) for many pollution problems, more than one market failure may be involved, which may justify (on efficiency grounds, at least) employing more than one instrument; (v) potential interactions among environmental policy instruments are a matter of concern, as are possible adverse interactions between policies simultaneously pursued by separate jurisdictions. ${ }^{335}$

\footnotetext{
${ }^{333}$ STAVINS, Robert N. Experience with market-based environmental policy instruments. Fondazione Eni Enrico Mattei - FEEM, Working Paper $n^{\circ}$ 52/2002; Kennedy School of Government - KSG/Harvard University, Working Paper $n^{\circ}$ 00/2004. Disponível em <http://ssrn.com/abstract=199848>. Acesso em: 3.10.2011.

${ }^{334}$ A complexidade pode significar que os bens da natureza vêm ficando cada vez mais escassos. De fato, como nos ensina Fábio Nusdeo, "quanto mais escassos os bens e aguçados os interesses sobre eles, maior quantidade e diversidade de normas se fazem necessárias para o equilíbrio de tais interesses". NUSDEO, Fábio. Curso de economia: introdução ao direito econômico. 6a ed. rev. e atual. São Paulo: RT, 2010, p. 29. ${ }^{335}$ GOULDER, Lawrence H. PARRY, Ian W. H. Instrument Choice in Environmental Policy. Resources for the future - RFF Discussion Paper No. 08-07. April/2008. Disponível em: $<$ http://ssrn.com/abstract=1117566>. Acesso em: 3.10.2011.
} 
Importante frisar que a análise econômica ${ }^{336}$ pode trazer valiosos subsídios para a melhor avaliação e formulação dos mecanismos e instrumentos a serem utilizados em determinada política ambiental. A esse respeito, Richard Revesz e Robert Stavins descrevem importantes critérios a serem considerados quando da avaliação e formulação de políticas ambientais, mormente em relação aos instrumentos que conduzirão ao alcance de seus objetivos e metas:

A variety of criteria have been posited as relevant for choosing environmental policy instruments, including: (1) will the policy instrument achieve the stated goal or standard; (2) will it do so at the lowest possible cost, including both privatesector compliance and public-sector monitoring and enforcement; (3) will it provide government with the information it needs to implement the policy; (4) will the instrument be flexible in the face of changes in tastes and technology; (5) will the instrument provide dynamic incentives for research, development, and adoption of better pollutionabatement technologies; (6) will the implementation of the policy instrument result in an equitable distribution of the benefits and costs of environmental protection; and (7) will the policy be politically feasible in terms of enactment and implementation ? $^{337}$

Ademais, diante das peculiaridades já citadas - dificuldade de valoração dos bens e obstáculos impostos pelo mercado para efetiva internalização dos custos pela utilização dos recursos naturais -, é importante utilizar-se da maior gama possível de mecanismos e instrumentos para alcançar os objetivos e metas da política ambiental. ${ }^{338}$

\footnotetext{
${ }^{336}$ Ana Maria de Oliveira Nusdeo pontua que “a preservação ambiental [...] pode ser analisada sob a perspectiva econômica, análise que tem o mérito de mostrar a insuficiência do mercado para garanti-la e a necessidade da atuação do Estado para esse fim.”. NUSDEO, Ana Maria de Oliveira. Ob. cit., p. 362.

${ }^{337}$ REVESZ, Richard L. STAVINS, Robert N. Environmental Law and Policy. NYU Public Law Research Paper 82; NYU Law \& Econ Research Paper 04-015; Harvard Public Law Working Paper No. 102; KSG Working Paper No. RWP04-023, September, 2004. Disponível em: <http://ssrn.com/abstract=552043>. Acesso em: 3.10.2011.

${ }^{338}$ A esse respeito, Goulder e Parry, a propósito da política de redução de gases de efeito estufa, defendem que a política ambiental alcançará uma melhor eficácia nos seus objetivos e metas quando houver a aplicação de mais de um instrumento. Senão vejamos: "There is a theoretical and empirical literature comparing the efficiency of alternative environmental policy instruments in promoting the development of cleaner technologies (e.g., Jaffe et al. 2003; Jung et al. 1996; Fischer et al. 2003; Milliman and Prince1989). No single instrument can effectively correct market failures from both emissions externalities and the knowledge appropriability problem, however. Indeed, as Fischer and Newell (2007) and Goulder and Schneider (1997) indicate in the climate policy context, achieving a given emissions reduction through one instrument alone involves considerably higher costs than employing two instruments. GOULDER, Lawrence H. PARRY, Ian
} 
Significa dizer que, para administrar da forma mais eficaz possível a política ambiental, procurando equacionar ao máximo a falha de mercado denominada externalidades negativas, é preciso ter em mãos um conjunto de medidas e instrumentos, baseadas no princípio do poluidor-pagador, e que visam tanto prevenir, mitigar ou compensar os impactos negativos, quanto reparar os danos ambientais - o que foi devidamente detalhado no item 4.6 do Capítulo 4 deste estudo. Esse conjunto de instrumentos e de medidas podem e devem ser impostos por meio de instrumentos de comando e controle incorporados em processos administrativos (licenciamento ambiental), por condenações judiciais (reparação civil), por instrumentos econômicos etc. Sobre o assunto, Ana Maria Nusdeo expõe:

Dessa forma, a solução que se apresenta possível para lidar com a falha de mercado da externalidade é a regulação estatal, seja para impor a cobrança pelo uso do recurso natural ou pela recuperação de sua qualidade, seja para simplesmente restringir o seu uso, através, por exemplo, de normas de controle de emissão e de obrigação de tratamento de efluentes. ${ }^{339}$

No Brasil, a Política Nacional do Meio Ambiente, positivada por meio da multicitada Lei $n^{\circ}$ 6.938/1981, arrola os instrumentos para a proteção ambiental de forma geral $^{340}$, quais sejam: (i) o estabelecimento de padrões de qualidade

W. H. Instrument Choice in Environmental Policy. Resources for the future - RFF Discussion Paper No. 0807. April/2008. Disponível em: <http://ssrn.com/abstract=1117566>. Acesso em: 3.10.2011.

${ }^{339}$ NUSDEO, Ana Maria de Oliveira. O uso dos instrumentos econômicos nas normas de proteção ambiental. Revista da Faculdade de Direito da Universidade de São Paulo, v. 101, jan/dez 2006, p. 361-363.

${ }^{340}$ Diz-se de forma geral ou genericamente, pois há políticas específicas, federais e estaduais, e que definem seus próprios instrumentos, além daqueles já impostos pela Política Nacional do Meio Ambiente. Cite-se, por exemplo, a Política Nacional de Recursos Hídricos - PNRH (Lei federal no 9.433, de 8 de janeiro de 1997), que dispôs os seguintes instrumentos (i) os Planos de Recursos Hídricos; (ii) o enquadramento dos corpos de água em classes, segundo os usos preponderantes da água; (iii) a outorga dos direitos de uso de recursos hídricos; (iv) a cobrança pelo uso de recursos hídricos; (v) a compensação a municípios; e (vi) o Sistema de Informações sobre Recursos Hídricos (art. $5^{\circ}$ e incisos). Vale pontuar, ainda, os inúmeros instrumentos da recente Política Nacional de Resíduos Sólidos (Lei federal $n^{\circ}$ 12.305, de 2 de agosto de 2010) - cuja quantidade, aliás, bem demonstra a evolução da preocupação ambiental -, quais sejam: (i) os planos de resíduos sólidos; (ii) os inventários e o sistema declaratório anual de resíduos sólidos; (iii) a coleta seletiva, os sistemas de logística reversa e outras ferramentas relacionadas à implementação da responsabilidade compartilhada pelo ciclo de vida dos produtos; (iv) o incentivo à criação e ao desenvolvimento de cooperativas ou de outras formas de associação de catadores de materiais reutilizáveis e recicláveis; (v) o monitoramento e a fiscalização ambiental, sanitária e agropecuária; (vi) a cooperação técnica e financeira entre os setores público e privado para o desenvolvimento de pesquisas de novos produtos, métodos, processos e tecnologias de gestão, reciclagem, reutilização, tratamento de resíduos e disposição final 
ambiental; (ii) o zoneamento ambiental; (iii) a avaliação de impactos ambientais; (iv) o licenciamento e a revisão de atividades efetiva ou potencialmente poluidoras; (v) os incentivos à produção e instalação de equipamentos e a criação ou absorção de tecnologia, voltados para a melhoria da qualidade ambiental; (vi) a criação de espaços territoriais especialmente protegidos pelo Poder Público federal, estadual e municipal, tais como áreas de proteção ambiental, de relevante interesse ecológico e reservas extrativistas; (vii) o sistema nacional de informações sobre o meio ambiente; (viii) o Cadastro Técnico Federal de Atividades e Instrumento de Defesa Ambiental; (ix) as penalidades disciplinares ou compensatórias ao não cumprimento das medidas necessárias à preservação ou correção da degradação ambiental; (x) a instituição do Relatório de Qualidade do Meio Ambiente, a ser divulgado anualmente pelo Instituto Brasileiro do Meio Ambiente e Recursos Naturais Renováveis - IBAMA; (xi) a garantia da prestação de informações relativas ao Meio Ambiente, obrigandose o Poder Público a produzi-las, quando inexistentes; (xii) o Cadastro Técnico Federal de atividades potencialmente poluidoras e/ou utilizadoras dos recursos ambientais; e (xiii) instrumentos econômicos, como concessão florestal, servidão ambiental, seguro ambiental e outros (art. $9^{\circ}$ e incisos).

Conforme ensina José Afonso da Silva, os instrumentos da Política Nacional de Meio Ambiente são medidas, meios e procedimentos com os quais o Poder Público executa a Política Ambiental, tendo em vista a realização concreta de seu objeto, ou seja, a preservação, melhoria e recuperação do meio

ambientalmente adequada de rejeitos; (vii) a pesquisa científica e tecnológica; (viii) a educação ambiental; (ix) os incentivos fiscais, financeiros e creditícios; (x) o Fundo Nacional do Meio Ambiente e o Fundo Nacional de Desenvolvimento Científico e Tecnológico; (xi) o Sistema Nacional de Informações sobre a Gestão dos Resíduos Sólidos (Sinir); (xii) o Sistema Nacional de Informações em Saneamento Básico (Sinisa); (xiii) os conselhos de meio ambiente e, no que couber, os de saúde; (xiv) os órgãos colegiados municipais destinados ao controle social dos serviços de resíduos sólidos urbanos; (xv) o Cadastro Nacional de Operadores de Resíduos Perigosos; (xvi) os acordos setoriais; (xvii) no que couber, os instrumentos da Política Nacional de Meio Ambiente, entre eles: a) os padrões de qualidade ambiental; o Cadastro Técnico Federal de Atividades Potencialmente Poluidoras ou Utilizadoras de Recursos Ambientais; o Cadastro Técnico Federal de Atividades e Instrumentos de Defesa Ambiental; d) a avaliação de impactos ambientais; e) o Sistema Nacional de Informação sobre Meio Ambiente (Sinima); f) o licenciamento e a revisão de atividades efetiva ou potencialmente poluidoras; (xviii) os termos de compromisso e os termos de ajustamento de conduta; (xix) o incentivo à adoção de consórcios ou de outras formas de cooperação entre os entes federados, com vistas à elevação das escalas de aproveitamento e à redução dos custos envolvidos (art. $8^{\circ}$ e incisos). Sobre a Política Nacional de Resíduos Sólidos ver LEMOS, Patricia Faga Iglecias. Resíduos sólidos e responsabilidade civil pós-consumo. São Paulo: RT, 2011. 
ambiente e do equilíbrio ecológico. Para esse autor, as medidas são de variada natureza, podendo ser agrupados em instrumentos de intervenção ambiental, instrumentos ou mecanismos de comando e controle ambiental e instrumentos de controle repressivo. ${ }^{341}$ Haveria a necessidade, ainda, que acrescer a esse rol os instrumentos econômicos. ${ }^{342}$

Em nosso modo de ver, e aproveitando a terminologia citada pelo autor acima, temos que os instrumentos de intervenção ambiental são aqueles positivados e que protegem o ambiente a priori, definindo, por exemplo, as áreas protegidas (áreas de proteção permanente, unidades de conservação, limites para implantação de empreendimentos, definição de percentual de reserva legal etc.), ou seja, independem da existência ou do planejamento de qualquer empreendimento ou atividade econômica. Os instrumentos ou mecanismos de comando e controle são (i) as medidas impostas legalmente considerando uma determinada atividade ou um específico segmento econômico (como ocorre com as regras exigidas dos postos de gasolina, os limites de emissão de poluentes para veículos automotores etc.) ou (ii) os limites preventivos, mitigatórios e compensatórios - exigidos pelas autoridades administrativas no decorrer do processo de licenciamento ambiental de determinado empreendimento. Os instrumentos de controle repressivo são aqueles que emergem quando da concretização de um dano ambiental, podendo acarretar penalidades administrativas, civis e criminais. Os instrumentos econômicos, por sua vez, tratam de medidas que visam a efetivamente incluir o custo da utilização do recurso natural no processo decisório de produção ou oferecer incentivos ou subsídios para evitar que esse recurso seja ali utilizado. ${ }^{343}$

\footnotetext{
${ }^{341}$ SILVA, José Afonso da. Direito ambiental constitucional. $9^{a}$ ed. São Paulo: Malheiros, 2011, p. 224. Para esse autor, os instrumentos de intervenção ambiental são mecanismos normativos com base nos quais o Poder Público intervém no meio ambiente para condicionar a atividade particular ou pública ao fim da Política Nacional do Meio Ambiente. Já os instrumentos de controle ambiental são todos aqueles atos e medidas destinados a verificar a observância das normas e planos que visem à defesa e recuperação da qualidade do meio ambiente e do equilíbrio ecológico.

${ }^{342}$ Saliente-se, uma vez mais, que os instrumentos econômicos foram incluídos na Política Nacional do Meio Ambiente apenas em 2006, pela Lei federal $n^{\circ}$ 11.284, de 2 de março daquele ano, a Lei da Gestão de Florestas Públicas.

${ }^{343}$ Usando-se a Política Nacional de Recursos Hídricos (Lei no 9.433/1997), cujos instrumentos foram listados em nota 340 anterior, tem-se que a cobrança pelo uso da água é instrumento econômico, enquanto que a outorga do direito de uso da água e o licenciamento ambiental são instrumentos de comando e controle.
} 
Importa observar serem todos instrumentos que, ao fim e ao cabo, têm repercussões econômicas, pois mesmo os interventivos ou os mecanismos de comando e controle acabam por imputar - ainda que por vias oblíquas - um custo para a atividade ou para o empreendimento. Basta ver, de fato, que uma multa administrativa, o embargo de uma obra, a obrigação de cumprir certos parâmetros de emissão de efluentes gasosos, dentre tantos outros exemplos, certamente impõem custos para a cadeia produtiva, às vezes, inclusive, bastante representativos, significando que também equacionam as externalidades negativas. Por conseguinte, em última instância, são todos instrumentos econômicos, tendo por base o princípio do poluidor-pagador.

Ao tema de interesse para este estudo, fixaremos o foco nos mecanismos de comando e controle e nos instrumentos econômicos propriamente ditos. Afinal, ainda que se entenda que as políticas ambientais devam ir muito além da solução de problemas definidos como externalidades e precisem, sobretudo, projetar-se no futuro para indicar os caminhos para o desenvolvimento e crescimento econômicos em padrões sustentáveis, ambiental e socialmente ${ }^{344}$, é fundamental o emprego dos chamados instrumentos econômicos, ao lado dos instrumentos conhecidos como de controle.

São eles, ademais, os principais instrumentos das políticas voltadas à proteção ambiental, classificados pela literatura econômica e também jurídica como as medidas de comando e controle e os instrumentos econômicos. Essas medidas e instrumentos devem ser edificados e implementados em políticas públicas, nas quais é possível comparar e avaliar a relação dos meios econômicos com aquelas medidas de controle. ${ }^{345}$

Por fim, observe-se: no que concerne às vantagens da aplicação dos mecanismos de comando e controle prioritariamente aos instrumentos econômicos, ou vice-versa, vai depender da política ambiental a ser formulada. Essas questões exigem uma análise econômica e ambiental caso a caso, sendo impossível estabelecer, de antemão, quais os instrumentos que devem ser

\footnotetext{
${ }^{344}$ NUSDEO, Ana Maria de Oliveira. O uso dos instrumentos econômicos nas normas de proteção ambiental. Revista da Faculdade de Direito da Universidade de São Paulo, v. 101, jan/dez 2006, p. 363.

${ }^{345}$ NUSDEO, Ana Maria de Oliveira. Ob. cit., p. 363.
} 
priorizados. ${ }^{346}$ Não obstante, é oportuno deter-se em cada um desses meios de alcançar os objetivos das políticas ambientais, pois, como se verá mais adiante, as medidas compensatórias, objeto deste estudo, podem apresentar características predominantes tanto de mecanismos de comando e controle, quanto de instrumentos econômicos (conforme defenderemos mais a frente, trata-se, então, de um instrumento híbrido).

\subsection{Mecanismos de comando e controle}

Os mecanismos de controle, ou de comando e controle, são, na maioria das vezes, orientados por relações tecnológicas, padrões e processos, e impostos normativamente - portanto, de forma pouco flexível - a todos os usuários, por vezes, sem diferenciação espacial. Ou seja, os mecanismos de comando e controle não consideram, explicitamente, os custos individuais de cada usuário. Esse tipo de instrumento em geral impõe níveis máximos de poluentes ou de utilização a serem atingidos, penalizando quem os ultrapassa. ${ }^{347}$

Vale dizer, tais mecanismos fixam normas, regras, procedimentos e padrões determinados para as atividades econômicas a fim de assegurar o cumprimento dos objetivos da política em questão, como, por exemplo, reduzir a poluição do ar ou da água. ${ }^{348}$ Esses repousam fundamentalmente em prescrições de cunho administrativo, cujo descumprimento envolve a aplicação de sanções de caráter administrativo, tais como multas, interdições, fechamento de unidades etc. ${ }^{349}$ Os exemplos mais típicos são as normas de controle da poluição

\footnotetext{
${ }^{346}$ A esse respeito, Lawrence Goulder e Ian Parry salientam: "the cost advantage [de um mecanismo de commando e controle] will be modest if there is little heterogeneity among firms so that a single technology mandate can bring marginal abatement costs close to equality. Similarly, if incentive-based instruments only have a small effect on product prices, then the failure to optimally exploit the output reduction channel under direct regulatory approaches will not matter much in practice." GOULDER, Lawrence H. PARRY, Ian W. H. Instrument Choice in Environmental Policy. Resources for the future - RFF Discussion Paper No. 08-07. April/2008. Disponível em: <http://ssrn.com/abstract=1117566>. Acesso em: 3.10.2011.

${ }^{347}$ SEROA DA MOTTA, Ronaldo. Economia ambiental. Rio de Janeiro: Editora FGV, 2006, p. 76.

348 SEROA DA MOTTA, Ronaldo. Instrumentos econômicos e política ambiental. Revista de Direito Ambiental, n. 20, out/dez, 2000.

${ }^{349}$ NUSDEO, Fábio. Desenvolvimento e ecologia. São Paulo: Saraiva, 1975, p. 78. Consoante já apontamos mais acima, Nusdeo chama o que consideramos 'mecanismos de comando e controle' como 'medidas de controle direto'.
} 
atmosférica ou da água que fixam padrões determinados ${ }^{350}$; são, ainda, as normas de zoneamento, estabelecendo restrições para a utilização de áreas protegidas e alguns procedimentos específicos como o licenciamento ambiental. $^{351}$

A fixação de padrões pode dar-se por meio de diversos critérios, sendo eles padrões de emissão de poluentes (na atmosfera e na água), como também fixação de padrões tecnológicos, cujo critério é a melhor tecnologia prática disponível. Podem ser padrões definidos legalmente, ou a priori, independentemente de um empreendimento ou atividade específicos. Ou podem ser regras e limites de controle impostos a posteriori, ou particularmente no decorrer do processo de licenciamento ambiental, em que se avaliam as características e as peculiaridades do projeto e do ambiente onde deverá ser desenvolvido e, daí, as medidas preventivas, mitigatórias e compensatórias.

Os mecanismos de comando e controle são objeto de diversas críticas. Uma das mais usuais refere-se à exigência de uma pesada estrutura de fiscalização ${ }^{352}$. Mas podem-se apontar outras, como a sua inflexibilidade ${ }^{353}$, decorrente da imposição dos mesmos parâmetros para diferentes plantas industriais, cujos padrões, por exemplo, de emissão são praticamente incomparáveis. Inclusive, haveria uma tendência das normas a exigir padrões tecnológicos e de emissão mais rígidos das plantas novas quando do seu

\footnotetext{
${ }^{350}$ Como é o caso da Resolução CONAMA n ${ }^{\circ}$ 357, de 17 de março de 2005, que, além de dispor da classificação dos corpos de água e diretrizes ambientais para o seu enquadramento, estabelece as condições e padrões de lançamento de efluentes.

${ }^{351}$ NUSDEO, Ana Maria de Oliveira. O uso dos instrumentos econômicos nas normas de proteção ambiental. Revista da Faculdade de Direito da Universidade de São Paulo, v. 101, jan/dez 2006, p. 364.

352 Já em 1975, Fábio Nusdeo chamava a atenção para esse fato crítico das medidas de controle, bradando que "essas medidas pressupõem todo um aparato técnico, administrativo e fiscalizador para que possam ser efetivamente aplicadas e impostas. É inócuo, quando não ridículo e desmoralizador, promulgar-se leis e regulamentos inaplicáveis, seja por estarem tecnicamente divorciados da realidade, seja por não dispor o órgão encarregado de um eficiente aparelho de fiscalização e de atuação das normas expendidas”. NUSDEO, Fábio. Desenvolvimento e ecologia. São Paulo: Saraiva, 1975, p. 78.

${ }^{353}$ Sobre a inflexibilidade dos mecanismos de comando e controle, Richard Revesz e Robert Stavins expõem: "conventional approaches to regulating the environment - frequently characterized as command-andcontrol - allow relatively little flexibility in the means of achieving goals. Such policy instruments tend to force firms to take on similar shares of the pollution-control burden, regardless of the cost, sometimes by setting uniform standards for firms, the most prevalent of which are technology - and performance-based standards". REVESZ, Richard L. STAVINS, Robert N. Environmental Law and Policy. NYU Public Law Research Paper 82; NYU Law \& Econ Research Paper 04-015; Harvard Public Law Working Paper No. 102; KSG Working Paper No. RWP04-023, September, 2004. Disponível em: $<$ http://ssrn.com/abstract=552043>. Acesso em: 3.10.2011.
} 
licenciamento, tornando a entrada nos mercados mais difícil. Outra importante crítica relaciona-se com a dependência do governo em relação ao setor empresarial para a obtenção das informações relativas aos níveis de emissão e às possibilidades de sua redução. Isto é, os empresários não são incentivados a fornecer as informações capazes de levar a autoridade pública a fixar padrões mais restritivos. Assim, o sistema não cria incentivos para que o agente capaz de reduzir suas emissões, além do exigido pela legislação, o faça. ${ }^{354}$

A bem ver, os mecanismos de comando e controle não são flexíveis a ponto de se adequar às diversas peculiaridades, seja das plantas industriais, seja do ambiente em que elas estão instaladas e operando. Basta considerar, em um país de dimensões continentais como o Brasil, e com tão diferentes características ambientais (vale mencionar: floresta amazônica, cerrado, Mata Atlântica, semiárido, pampa etc.), o quão injusta e excludente pode ser a aplicação do mesmo padrão de emissão de poluentes para uma planta industrial na cidade de São Paulo e para outra localizada no interior do Piauí. Além de poder ser injusta, a fixação dos mesmos padrões e a imposição de novas - e usualmente caras - tecnologias pode significar ainda um nicho de mercado, porquanto às grandes empresas será fácil atendê-lo; o que também será benéfico às grandes empresas, na medida em que é possível excluir do mercado as menores, e, com isso, a incômoda concorrência. Afinal, é bastante claro que aplicar os mesmos padrões pode significar a impossibilidade do atendimento diante das diversas características ambientais, como também a imposição de novas tecnologias pode implicar a inviabilização econômica de pequenas ou médias empresas.

Não obstante as críticas, não há dúvidas quanto à importância dos mecanismos de comando e controle na medida em que eles fixam padrões a todos aqueles que exerçam atividades poluidoras ou desenvolvam projetos que implicam impactos negativos, determinando a adoção de comportamentos absolutamente necessários frente à cada vez mais assustadora crise ambiental. Ademais, ao fixar os mesmos padrões e parâmetros para uma mesma cadeia de atividades impactantes, certamente eles equacionam - ainda que parcialmente -

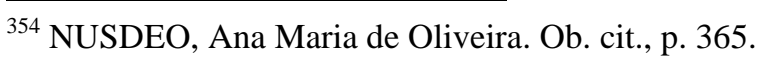


o grande problema da cumulatividade de impactos. Afinal, a emissão de apenas um veículo automotor pode não ser representativa, mas o acúmulo de emissões de todos os veículos da cidade de São Paulo é certamente preocupante. Bem por isso, o controle de emissões gasosas dos veículos automotores não distingue o seu ano de produção, o modelo ou a marca.

Outro tanto, é oportuno destacar que o licenciamento ambiental funciona como um típico mecanismo de comando e controle, podendo, ainda, ser o processo capaz de realizar uma eficaz gestão do meio ambiente. Dessa forma, é meio para serem aplicadas outras medidas de comando e controle (como a fixação de padrões de emissão de poluentes líquidos ou gasosos, a implantação de novas tecnologias, as restrições de edificação etc), permitindo a sua fiscalização.

De fato, as políticas ambientais, por vezes citam o licenciamento ambiental como um mecanismo de comando e controle; por outras, é através desse processo que se implementam e são fiscalizados outros mecanismos de controle. Significa dizer que o licenciamento ambiental é a seara mais adequada para serem impostos e fiscalizados tanto os padrões definidos a priori, quanto os limites específicos a serem aplicados em razão das particularidades do projeto ou, como já dissemos, a posteriori.

O processo de licenciamento ambiental já foi destacado no item 3.3.2 do Capítulo 3 desta tese. Neste momento, vale ressaltar que ele incide justamente nas situações em que se vislumbram impactos negativos ${ }^{355}$, os quais podem ser estimados, avaliados e gerenciados pela Administração Pública em razão da implantação e da operação de determinada atividade ou empreendimento. É, com efeito, por meio do licenciamento ambiental que se impõem as regras limitadoras dessa atividade ou desse empreendimento - controle de poluição do ar, obrigação de tratamento de efluentes e lançamento em corpos hídricos de acordo com determinados parâmetros, limitações de implantação em respeito às

\footnotetext{
${ }^{355}$ De fato, já dissemos que o art. 10 da Lei no 6.938/1981 determinou que os empreendimentos e atividades considerados efetiva ou potencialmente poluidores (em verdade, impactantes, conforme terminologia considerada mais adequada e utilizada nesta tese), ou capazes de causar degradação ao ambiente, dependerão de prévio licenciamento ambiental.
} 
áreas protegidas etc. -, como também é no seu âmbito que se exigem condições para prevenir, mitigar e/ou compensar os impactos negativos. ${ }^{356}$

Vale notar que a Política Nacional de Meio Ambiente (Lei nº 6.938/1981) elege como mecanismo de comando e controle, com ação preventiva afeta ao Poder Público, o licenciamento ambiental, ${ }^{357}$ para a instalação e o funcionamento de empreendimentos potencialmente impactantes.

O licenciamento ambiental ${ }^{358}$ é um procedimento complexo que se desdobra em fases, iniciando-se com uma solicitação do interessado, passando por etapas de análise de estudos ambientais, de audiências públicas, se necessárias, de posteriores complementações técnicas, até chegar ao ato final visado pelo procedimento, qual seja, a expedição da licença ambiental.

O licenciamento visa a antever, identificar e gerenciar o impacto que dada atividade econômica ou empreendimento possa ocasionar ao meio ambiente, ponderando as suas repercussões nos ecossistemas e no acervo dos recursos naturais e, a partir disso, fixando as condicionantes para o seu desenvolvimento. Essas condicionantes, conforme já especificado no item 5.5 do Capítulo 5 deste estudo, podem ser de natureza preventiva, mitigatória e compensatória.

\footnotetext{
${ }^{356}$ Oportuno frisar, uma vez mais, que os impactos negativos tendem a ser prevenidos para que não ocorram, e mitigados para que haja a sua concreção seja minimizada ao máximo. Caso, no entanto, não possam ser prevenidos ou mitigados, passam a ser compensados.

${ }^{357}$ Sobre o licenciamento ambiental, Édis Milaré expõe: "Segundo a lei brasileira, o meio ambiente é qualificado como patrimônio público a ser necessariamente assegurado e protegido para uso da coletividade ou, na linguagem do constituinte, bem de uso comum do povo, essencial à sadia qualidade de vida. Por ser de todos em geral e de ninguém em particular, inexiste direito subjetivo à sua utilização, que, à evidência, só pode legitimar-se mediante ato próprio de seu direto guardião - o Poder Público. Para tanto, arma-o a lei de uma série de instrumentos de controle - prévios, concomitantes e sucessivos -, por meio dos quais possa ser verificada a possibilidade e regularidade de toda e qualquer intervenção projetada sobre o ambiente considerado. Assim, por exemplo, as permissões, autorizações e licenças pertencem à família dos atos administrativos de controle prévio; a fiscalização é meio de controle concomitante; e o habite-se é forma de controle sucessivo. MILARÉ, Édis. Direito do ambiente. $7^{\mathrm{a}}$ ed. São Paulo: RT, 2011, p. 509-510.

${ }^{358}$ O licenciamento ambiental, segundo definição constante da Resolução CONAMA nº 237/1997, art. $1^{\circ}$, I, é o "procedimento administrativo pelo qual o órgão ambiental competente licencia a localização, instalação, ampliação e a operação de empreendimentos e atividades utilizadoras de recursos ambientais, consideradas efetiva ou potencialmente poluidoras ou daquelas que, sob qualquer forma, possam causar degradação ambiental, considerando as disposições legais e regulamentares e as normas aplicáveis ao caso.”
} 
A bem ver, como ação típica e indelegável do Poder Executivo, ${ }^{359}$ o licenciamento constitui importante instrumento de gestão do ambiente, na medida em que, por meio dele, a Administração Pública busca exercer o necessário controle sobre as atividades humanas que interferem nas condições ambientais, de forma a compatibilizar o desenvolvimento econômico com a preservação do equilíbrio ecológico. ${ }^{360}$

Conforme já dito, e segundo entendemos, além de ser um típico mecanismo de comando e controle, é preponderantemente no licenciamento ambiental que se permite a imposição de outras medidas com essa natureza, seja antes da implantação, seja durante, seja depois de se permitir a operação do empreendimento. A esse respeito, José Afonso da Silva discorre:

Esse controle é exercido sempre pelo Poder Público, mas pode ser de iniciativa dele ou de interessados particulares. Ocorrerá em três momentos:

a) antes da ação suscetível de dano ao meio ambiente, dito controle prévio, que se realiza pelo Estudo e Avaliação de Impacto Ambiental e Licenciamento Prévio de obras ou atividades efetiva ou potencialmente poluidoras;

b) durante a ação potencialmente danosa ao meio ambiente, dito controle concomitante, que se efetiva pelas inspeções, fiscalizações, produção de Relatório de Qualidade do Meio Ambiente, a ser divulgado anualmente pelo IBAMA, a garantia de prestação de informações relativas ao meio ambiente; o Cadastro Técnico Federal de Atividades e Instrumentos de Defesa do Meio Ambiente e o Cadastro Técnico Federal de Atividades Potencialmente Poluidoras ou Utilizadoras dos Recursos Ambientais;

c) depois da ação potencialmente prejudicial ao meio ambiente, dito controle sucessivo ou 'a posteriori', mediante vistoria e exames, a fim de verificar se a ação se ateve aos ditames legais de proteção ambiental. ${ }^{361}$

As etapas descritas acima, por José Afonso da Silva, como medidas de controle impostas antes, durante e depois, na verdade se equiparam às etapas do

\footnotetext{
${ }^{359}$ Vale observar que, no dia 9 de dezembro de 2011, foi publicada a Lei Complementar $\mathrm{n}^{\circ}$ 140, que fixa, dentre outras questões, as competências para o licenciamento ambiental em âmbito federal, estadual e municipal.

${ }^{360}$ MILARÉ, Édis. Direito do ambiente. $7^{\mathrm{a}}$ ed. São Paulo: RT, 2011, p. 511.

${ }^{361}$ SILVA, José Afonso da. Direito ambiental constitucional. 9ª ed. São Paulo: Malheiros, 2011, p. 225.
} 
licenciamento ambiental, quais sejam: o licenciamento prévio, o licenciamento de instalação e o licenciamento de operação, em que são emitidas as respectivas licenças ambientais.

A Licença Prévia é o ato pelo qual o administrador aprova a localização e a concepção do empreendimento ou atividade, atestando a sua viabilidade ambiental e estabelecendo os requisitos básicos e condicionantes a serem atendidos nos próximos passos de sua implementação; a Licença de Instalação expressa consentimento para o início da implementação do empreendimento ou atividade, de acordo com as especificações constantes dos planos, programas e projetos aprovados, incluindo as medidas de controle ambiental e demais condicionantes. Por sua vez, a Licença de Operação manifesta concordância com a operação da atividade ou empreendimento, após a verificação do efetivo cumprimento do que consta nas licenças anteriores, com as medidas de controle ambiental e condicionantes então determinadas. ${ }^{362}$

Atente-se que o processo de licenciamento não finda com a emissão da Licença de Operação, que deve ter prazo de validade, sendo que, para a sua renovação ${ }^{363}$ há que ser comprovado o cumprimento de todas as medidas de comando e controle ali estabelecidas, quer tenham cunho preventivo, quer mitigatório, quer compensatório.

À derradeira, e conforme já mencionamos, observe-se serem os mecanismos de comando e controle também uma atuação por meio do princípio do poluidor-pagador, pois representam sem dúvidas a incorporação de custos de produção e de consumo dos agentes. Afinal, (i) normas fixando padrões de emissão que exijam a substituição de equipamentos pelas unidades de produção; (ii) regras que determinem adoção de filtros ou outras soluções inseridas no espectro da melhor tecnologia disponível; (iii) medidas preventivas, mitigatórias ou compensatórias impostas ao longo do processo de licenciamento, representam, todas, custos de grande magnitude em determinadas atividades ou projetos e, ao mesmo tempo em que resultam em melhor desempenho ambiental

\footnotetext{
${ }^{362}$ Decreto federal nº 99.274/1990, art. 19, e Resolução CONAMA nº 237/1997, art. 8. ․

363 Aliás, todas as licenças ambientais (prévia, de instalação e de operação) podem ser renovadas, bastando que isso seja pleiteado com 120 dias antes do vencimento do seu prazo de validade. É o que dispõe o art. 14, $\S 4^{\circ}$, da novel Lei Complementar n ${ }^{\circ} 140 / 2011$.
} 
das unidades de produção, acabam por promover a internalização de custos ambientais. $^{364}$

\subsection{Os instrumentos econômicos}

Os instrumentos econômicos propriamente ditos são aqueles que atuam de modo direto nos custos de produção dos agentes cujas atividades econômicas estejam inseridas nos objetivos da política ambiental. ${ }^{365}$ Esses instrumentos incidem justamente no sentido de alterar o preço (custo) de utilização de um recurso, internalizando as externalidades negativas e, portanto, afetando seu nível de utilização (demanda). ${ }^{366}$ Podem ser, prioritariamente, indutores de comportamento, encorajando empresas e indivíduos a empreender esforços de controle de poluição para atender seus próprios interesses, mas que acabam, ao mesmo tempo, permitindo atingir as metas da política ambiental. ${ }^{367}$ De igual modo, podem visar a formação de fundos, cujos recursos serão oportunamente destinados a projetos cujo objetivo é a proteção ambiental. Sobre os instrumentos econômicos, citamos novamente Richard Revesz e Robert Stavins:

market-based instruments encourage behavior through market signals, rather than through explicit directives regarding pollution control levels or methods. These policy instruments can reasonably be described as 'harnessing market forces', because if they are well designed and properly implemented, they encourage firms or individuals to undertake pollution control efforts that are in their own interests and that collectively meet policy goals. Market-based instruments fall within four categories: pollution charges, tradeable permits, market-friction reductions, and government subsidy reductions. Liability rules can also be thought of as a market-based instrument, because they provide incentives for firms to take

\footnotetext{
${ }^{364}$ NUSDEO, Ana Maria de Oliveira. O uso dos instrumentos econômicos nas normas de proteção ambiental. Revista da Faculdade de Direito da Universidade de São Paulo, v. 101, jan/dez 2006, p. 366.

365 SEROA DA MOTTA, Ronaldo. Instrumentos econômicos e política ambiental. Revista de Direito Ambiental, n. 20, out/dez, 2000.

${ }^{366}$ SEROA DA MOTTA, Ronaldo. Economia ambiental. Rio de Janeiro: Editora FGV, 2006, p. 76.

${ }^{367}$ REVESZ, Richard L. STAVINS, Robert N. Environmental Law and Policy. NYU Public Law Research Paper 82; NYU Law \& Econ Research Paper 04-015; Harvard Public Law Working Paper No. 102; KSG Working Paper No. RWP04-023, September, 2004. Disponível em: <http://ssrn.com/abstract=552043>. Acesso em: 3.10.2011.
} 
into account the potential environmental damages of their decisions, allowing full flexibility in technology and control practices. $^{368}$

É importante ter claro que, embora se tenha experimentado inúmeras iniciativas de criação e implementação de instrumentos econômicos como meio de buscar a proteção do meio ambiente, esses instrumentos não vêm substituindo os mecanismos de comando e controle nessa importante tarefa. A bem ver, os instrumentos econômicos acabam por seguir ao lado - ou ser-lhes complementares - dos insuperáveis mecanismos de comando e controle.

Os instrumentos econômicos diferem dos mecanismos de comando e controle por não serem coercitivos e nem por pressuporem o estabelecimento de restrições. A lógica subjacente à sua utilização admite que, a partir de incentivos econômicos corretamente dimensionados - usualmente por meio de sistema de preços -, agentes privados reagirão, na margem, modificando suas atitudes para interiorizarem aqueles incentivos e continuarem maximizando seus lucros ou sua utilidade. ${ }^{369}$

Sim, além de buscar a internalização desses custos, para que não precisem ser totalmente assumidos por toda a sociedade, os instrumentos econômicos podem e devem enfatizar o caráter indutor ${ }^{370}$ dos comportamentos desejados pela política ambiental, por oposição aos instrumentos de controle.

\footnotetext{
${ }^{368}$ REVESZ, Richard L. STAVINS, Robert N. Ob. cit.

${ }^{369}$ RIVA, Ana Luisa M.; FONSECA, Luis Fernando Laranja da; HASENCLEVER, Leonardo. Instrumentos econômicos e financeiros para a conservação ambiental no Brasil: uma análise do estado da arte no Brasil e no Mato Grosso: Desafios e Perspectivas. Instituto Socioambiental - ISA. Disponível em: $<$ http://www.socioambiental.org/banco_imagens/pdfs/InstEconomicos.pdf >. Acesso em: 1º.12.2011.

370 Sobre o caráter indutor dos instrumentos econômicos, Robert Stavins expõe que "Market-based instruments are regulations that encourage behavior through market signals rather than through explicit directives regarding pollution control levels or methods. These policy instruments, such as tradable permits or pollution charges, are often described as "harnessing market forces" because if they are well designed and implemented, they encourage firms (and/or individuals) to undertake pollution control efforts that are in their own interests and that collectively meet policy goals". Mais adiante, pontua ainda que "In contrast to command-and-control regulations, market-based instruments have the potential to provide powerful incentives for companies to adopt cheaper and better pollution-control technologies. This is because with market-based instruments, particularly emission taxes, it always pays firms to clean up a bit more if a sufficiently low-cost method (technology or process) of doing so can be identified and adopted (Downing and White 1986; Malueg 1989; Milliman and Prince 1989; Jaffe and Stavins 1995; and Jung, Krutilla, and Boyd 1996)". STAVINS, Robert N. Experience with market-based environmental policy instruments. Fondazione Eni Enrico Mattei - FEEM, Working Paper $n^{\circ}$ 52/2002; Kennedy School of Government - KSG/Harvard University, Working Paper $n^{\circ}$ 00/2004. Disponível em <http://ssrn.com/abstract=199848>. Acesso em: 3.10.2011.
} 
Esse caráter indutor - já perpassado ao tratar-se nesta tese do caráter preventivo do princípio do poluidor-pagador - se dá a partir de imposição de tributos e preços públicos, da criação de subsídios ou, ainda, da possibilidade de transação sobre direitos de poluir ou créditos de não poluição. ${ }^{371}$

É o que vem se chamando de função promocional do direito, a qual, a par das sanções negativas, estabelecem-se sanções positivas com a intenção de promover, induzir ou incentivar condutas afeiçoadas aos objetivos que se quer alcançar, em uma ótica funcionalista do direito. Ou, no dizer de Norberto Bobbio, “a ação que o direito desenvolve pelo instrumento das sanções positivas, isto é, por mecanismos genericamente compreendidos pelo nome de 'incentivos', os quais visam não a impedir atos socialmente indesejáveis, fim precípuo das penas, multas, indenizações, reparações, restituições, ressarcimentos etc., mas sim, a 'promover' a realização de atos socialmente desejáveis.” 372

Além disso, pode-se buscar, por meio dos instrumentos econômicos, a formação de fundos que permitem implementar medidas de proteção ambiental.

Conforme já ventilado, a Lei $n^{\circ}$ 6.938/1981, que instituiu a Política Nacional do Meio Ambiente, contempla, por força da alteração da Lei federal $n^{\circ}$ $11.284 / 2006$, os instrumentos econômicos como meio para alcançar os seus objetivos. Arrola esse diploma legal, como exemplos, dentre outros, de instrumentos econômicos possíveis de ser implementados: a concessão florestal, a servidão ambiental e o seguro ambiental.

A concessão florestal, segundo a referida Lei $\mathrm{n}^{0} 11.284 / 2006$, é, em suma, uma delegação onerosa, feita pelo poder concedente, do direito de praticar manejo florestal sustentável para explorar produtos e serviços em uma unidade de manejo. Mediante licitação, a delegação é concedida à pessoa jurídica, em consórcio ou não, que atenda às exigências do respectivo edital de licitação e demonstre capacidade para seu desempenho, por sua conta e risco e por prazo determinado. A bem da verdade, a intenção maior da concessão florestal, segundo o Ministério do Meio Ambiente, é transformar a

${ }^{371}$ NUSDEO, Ana Maria de Oliveira. Ob. cit., p. 366. 
biodiversidade em ativo real e, com isso, promover o uso sustentável da floresta, auxiliando no combate ao desmatamento ilegal e também à grilagem de terras em florestas importantes, como a Amazônia.

O mecanismo da servidão ambiental, observados certos requisitos impostos pela lei, trata de renúncia voluntária do proprietário rural, em caráter temporário ou permanente, total ou parcialmente, do direito de uso, exploração ou supressão de recursos naturais existentes na propriedade, mediante a anuência do órgão ambiental competente.

O seguro ambiental, por sua vez, é um importante instrumento de implementação do princípio da reparação integral do dano ambiental, pois garante a disponibilidade dos recursos financeiros necessários à repristinação total do dano. Vale citar que a Lei $n^{0} 13.577$, de 8 de julho de 2009, do Estado de São Paulo, ao dispor sobre diretrizes e procedimentos para a proteção da qualidade do solo e gerenciamento de áreas contaminadas, estabelece, dentre os seus instrumentos, ${ }^{373}$ o seguro ambiental.

Além desses, inúmeros outros instrumentos econômicos podem ser instituídos com base na Lei $n^{\circ}$ 6.938/1981. É o que ensina Édis Milaré, ao expor que os “instrumentos previstos pela Lei [6.938/1981], por não terem natureza de numerus clausus, possibilitam a abertura para a criação de outros mecanismos capazes de incentivar a adoção de práticas ambientalmente corretas, buscando uma melhor conciliação entre o desenvolvimento econômico e a necessária preservação do meio ambiente”. Segue o mestre, trazendo como exemplo “a Lei 11.428/2006, conhecida como Lei da Mata Atlântica, [que] previu a adoção de incentivos econômicos ${ }^{374}$ para a proteção e o uso sustentável do referido bioma,

\footnotetext{
${ }^{372}$ BOBBIO, Norberto. Da estrutura à função, novos estudos de teoria do direito. Barueri: Manole, 2007, p. XII

${ }^{373}$ Os instrumentos dessa norma, para a implantação do sistema de proteção da qualidade do solo e para o gerenciamento de áreas contaminadas no Estado de São Paulo, são: (i) Cadastro de Áreas Contaminadas; (ii) disponibilização de informações; (iii) declaração de informação voluntária; (iv) licenciamento e fiscalização; (v) Plano de Desativação do Empreendimento; (vi) Plano Diretor e legislação de uso e ocupação do solo; (vii) Plano de Remediação; (viii) incentivos fiscais, tributários e creditícios; (ix) garantias bancárias; (x) seguro ambiental; (xi) auditorias ambientais; (xii) critérios de qualidade para solo e águas subterrâneas; (xiii) compensação ambiental; (xiv) fundos financeiros; e (xv) educação ambiental (art. $4^{\circ}$ e incisos).

${ }^{374}$ Vide Título IV, arts. 33 a 35.
} 
entre os quais um Fundo de Restauração destinado ao financiamento de projetos de recuperação ambiental e de pesquisa científica”. ${ }^{375}$

Mas não só. Para ilustrar a importância que vêm ganhando os instrumentos econômicos no cenário nacional, cite-se novamente a Lei $\mathrm{n}^{\circ}$ 13.577/2009, que trata da gestão de áreas contaminadas no Estado de São Paulo, e introduziu, de forma bastante inovadora, um capítulo exclusivo para tratar de instrumentos econômicos, ${ }^{376}$ arrolando, dentre eles, as compensações ambientais $^{377}$.

${ }^{375}$ MILARÉ, Édis. Direito do ambiente. $7^{\mathrm{a}}$ ed. São Paulo: RT, p. 583.

376 "CAPÍTULO IV - INSTRUMENTOS ECONÔMICOS: Artigo 30 - Fica criado o Fundo Estadual para Prevenção e Remediação de Áreas Contaminadas - FEPRAC, fundo de investimento vinculado à Secretaria do Meio Ambiente e destinado à proteção do solo contra alterações prejudiciais às suas funções, bem como à identificação e à remediação de áreas contaminadas. Artigo 31 - Constituem receitas do FEPRAC: I dotações ou créditos específicos, consignados no orçamento do Estado; II - transferências de outros fundos estaduais ou de suas subcontas, cujos recursos se destinem à execução de projetos, planos, programas, atividades e ações relacionados com a prevenção e o controle da poluição, de interesse comum; III transferência da União, dos Estados e dos Municípios para a execução de planos, programas, atividades e ações de interesse do controle, preservação e melhoria das condições do meio ambiente do Estado; IV recursos provenientes de ajuda e cooperação internacional e de acordos intergovernamentais; $\mathrm{V}$ - retorno de operações de crédito contratadas com órgãos ou entidades da administração direta ou indireta, consórcios intermunicipais, concessionários de serviços públicos e empresas privadas; VI - produto de operações de crédito e rendas provenientes da aplicação de seus recursos; VII - doações de pessoas naturais ou jurídicas, públicas ou privadas, nacionais, estrangeiras ou multinacionais; VIII - compensações ambientais provenientes de atividades potencialmente causadoras de contaminação; $\mathrm{X}$ - recursos provenientes do ressarcimento de despesas efetuadas nos termos dos $\S \S 1^{\circ}$ e $2^{\circ}$ do artigo 32 desta lei. Artigo 32 - Os recursos de que trata o artigo 31, serão aplicados em operações financeiras destinadas a apoiar e a incentivar a execução de ações relacionadas com a identificação e remediação de áreas contaminadas. $\S 1^{\circ}$ - Os recursos do FEPRAC poderão ser aplicados a fundo perdido, quando o tomador for o Estado e os recursos forem utilizados visando à intervenção em área contaminada, para remoção de perigo iminente à saúde pública. $\S 2^{\circ}$ - O Estado deverá ser ressarcido, pelo responsável legal pela área contaminada das despesas decorrentes da identificação e remediação de áreas contaminadas de acordo com o estabelecido no $\S 1^{\circ}$ deste artigo. $\S 3^{\circ}$ - O Estado, uma vez ressarcido das despesas previstas nos $\S \S 1^{\circ}$ e $2^{\circ}$ deste artigo, destinará o montante recebido diretamente ao FEPRAC. Artigo 33 - O FEPRAC terá Conselho de Orientação composto paritariamente por representantes do Estado, Municípios e Sociedade Civil, com 8 (oito) membros titulares e 8 (oito) membros suplentes de cada um dos segmentos. $\S 1^{\circ}$ - As funções de Conselheiro não serão remuneradas, devendo ser consideradas de interesse público relevante. $\S 2^{\circ}$ - O Conselho poderá solicitar a órgãos e entidades públicos e privados pareceres de mérito sobre a viabilidade técnica dos planos, programas e projetos apresentados. Artigo 34 - Compete ao Conselho de Orientação do FEPRAC: I - orientar e aprovar a captação e a aplicação dos recursos do Fundo; II - aprovar normas, critérios, prioridades e programas para a aplicação dos recursos do Fundo, fixando seus respectivos limites; III - aprovar os critérios para verificação da viabilidade técnica, econômica e financeira dos projetos; IV - aprovar o orçamento de aplicação dos recursos do Fundo; V elaborar o seu regimento interno; VI - exercer outras atribuições que lhe forem conferidas por regulamento; VII - aprovar programas, ações e medidas preventivas à geração de áreas contaminadas, bem como de garantia à informação e à participação da população afetada nas decisões relacionadas com as áreas contaminadas. Artigo 35 - A CETESB - Companhia Ambiental do Estado de São Paulo exercerá as funções de agente técnico e de secretaria executiva do FEPRAC, disponibilizando todo o suporte técnicoadministrativo necessário ao seu funcionamento, mediante solicitação do Conselho de Orientação, sem prejuízo do exercício das demais atribuições previstas em lei. Artigo 36 - O Banco Nossa Caixa S.A. será o Agente Financeiro do FEPRAC e atuará como mandatário do Estado, em conformidade com o estabelecido nas normas legais e nas deliberações do Conselho de Orientação. Artigo 37 - O FEPRAC reger-se-á pelas 
Buscando uma classificação para os instrumentos econômicos, Ronaldo Seroa da Motta $^{378}$, da mesma forma como Ana Maria Nusdeo, frisa que eles podem ser separados como instrumentos precificados e instrumentos de criação do mercado ${ }^{379}$ ou, conforme Fábio Nusdeo, medidas de finanças públicas e medidas com base no mercado. ${ }^{380}$ Richard Revesz e Robert Stavins elencam os seguintes instrumentos econômicos: "pollution charges, tradeable permits, market-friction reductions, and government subsidy reductions”. ${ }^{381}$

Nesta tese, de forma didática e adaptada à realidade brasileira, entendemos melhor dividir os instrumentos econômicos em (i) instrumentos precificados e (ii) instrumentos de criação de mercado.

\subsubsection{Instrumentos precificados}

Os instrumentos precificados têm como característica a alteração dos preços dos bens e serviços da economia, para cima ou para baixo, como parte da política pública em questão. ${ }^{382}$ Podem incidir direta ou indiretamente numa

normas do Decreto-lei Complementar n ${ }^{\circ}$ 18, de 17 de abril de 1970, e alterações posteriores. Artigo 38 - O dirigente da Unidade de Despesa à qual se encontra vinculado o Fundo submeterá, anualmente, à apreciação do Secretário do Meio Ambiente e do CONSEMA, o relatório das atividades desenvolvidas. Parágrafo único - O relatório das atividades de que trata este artigo deverá ser encaminhado às Comissões de Fiscalização e Controle e de Defesa do Meio Ambiente da Assembléia Legislativa do Estado. Artigo 39 - Deverá ser publicado, trimestralmente, no Diário Oficial do Estado, o relatório financeiro do Fundo. Artigo 40 - Para atender às despesas decorrentes da aplicação desta lei, fica o Poder Executivo autorizado a: I - efetuar as transferências a que se refere o artigo 31, inciso II, desta lei; II - abrir créditos adicionais especiais até o limite de R \$100,00 (cem reais), incluindo as classificações orçamentárias que se fizerem necessárias."

377 Daí, aliás, já se antevê que as compensações ambientais, ou, como preferimos, as medidas compensatórias, além de serem típicos mecanismos de comando e controle aplicados no decorrer do licenciamento ambiental, podem também ser consideradas instrumentos econômicos, pois permitem internalizar na cadeia de produção e consumo os custos pela utilização dos recursos naturais. Bem por isso, como se verá no próximo capítulo desta tese, são instrumentos híbridos.

${ }^{378}$ SEROA DA MOTTA, Ronaldo. Instrumentos econômicos e política ambiental. Revista de Direito Ambiental, $\mathrm{n}^{\circ}$ 20, out/dez, 2000.

${ }^{379}$ NUSDEO, Ana Maria de Oliveira. Ob. cit., p. 366.

${ }^{380}$ NUSDEO, Fábio. Desenvolvimento e ecologia. São Paulo: Saraiva, 1975, p. 81-92.

${ }^{381}$ REVESZ, Richard L. STAVINS, Robert N. Environmental Law and Policy. NYU Public Law Research Paper 82; NYU Law \& Econ Research Paper 04-015; Harvard Public Law Working Paper No. 102; KSG Working Paper No. RWP04-023,Setembro, 2004. Disponível em: <http://ssrn.com/abstract=552043>. Acesso em: 3.10.2011. Os autores ainda indicam as 'normas de responsabilidade' como possíveis instrumentos econômicos, pois elas incentivam as empresas a terem em consideração em suas decisões os efeitos financeiros dos potenciais danos ambientais.

${ }^{382}$ NUSDEO, Ana Maria de Oliveira. Ob. cit., p. 366. 
atividade relacionada com o objetivo da política e ser superavitário ou deficitário. ${ }^{383}$

Para Ronaldo Seroa da Motta, o instrumento é superavitário como, por exemplo, um tributo que aumenta o preço de um bem ou serviço que é o objetivo da política e, portanto, não exige um aumento na carga fiscal dos outros bens e serviços fora do escopo da política. Por sua vez, é deficitário como os subsídios, financiando a diminuição do preço ou um bem ou serviço que é o objetivo da política, mas requer, em contrapartida, um aumento na carga fiscal dos outros bens e serviços fora do escopo da política. ${ }^{384}$

Seroa da Motta ainda aponta três metas dos instrumentos econômicos: (i) maximizar o bem-estar social (evitando que a sociedade assuma os custos pela utilização dos recursos naturais); (ii) financiar uma atividade social; e (iii) induzir um comportamento social. Para a maximização do bem-estar social, corrige-se um preço de mercado de um bem ou serviço de tal forma que ele se torne equivalente ao seu valor social. É o que se chama de taxa pigouviana que, no entanto, inexiste na sua forma pura devido justamente à dificuldade de atender aos requisitos de conhecer os custos e benefícios associados ao valor social. Buscando o financiamento de uma atividade social, corrige-se o preço de mercado de um bem ou serviço para financiar um nível de receita para cobrir custos de provisão ou investimentos. Os exemplos típicos são os tributos, as taxas e os preços públicos. A alteração no padrão de uso do bem ou serviço pela internalização dos seus custos sociais não é uma tarefa prioritária. Para induzir um comportamento social, corrige-se um preço de mercado de um bem ou serviço para induzir uma mudança no comportamento do agente econômico, significando que a receita gerada não é o objetivo principal do instrumento. É a situação da tributação extrafiscal, em que se impõem, por exemplo, alíquotas diferenciadas de determinado tributo para induzir condutas 'mais limpas'. ${ }^{385}$

Tem-se no presente estudo que, para alcançar as metas acima expendidas, os instrumentos econômicos precificados têm como exemplos (além da

\footnotetext{
383 SEROA DA MOTTA, Ronaldo. Instrumentos econômicos e política ambiental. Revista de Direito Ambiental, $\mathrm{n}^{\circ}$. 20, out/dez, 2000.

${ }^{384}$ Idem, ibidem.

385 SEROA DA MOTTA, Ronaldo. Ob. cit.
} 
concessão florestal, da servidão ambiental e do seguro ambiental já citados): (i) cobranças pelo uso de um recurso natural, (ii) compensações financeiras; (iii) tributos ambientais; (iv) extrafiscalidade do Direito Tributário; (v) Pagamento por Serviços Ambientais - PSA e ( $v$ ) subsídios. Observe-se que esta não é uma classificação inflexível e tampouco a mais correta. De fato, ela serve aqui apenas para organizar, nesta tese, os meios econômicos aplicados nas políticas ambientais, podendo, no entanto, ser incluídos outros instrumentos econômicos ou elencados em diferentes categorias.

\subsubsection{Cobrança pelo uso de um recurso natural}

Conforme já explicado nesta tese, os conflitos de interesses imanentes ao uso dos bens ambientais, em razão do risco de escassez e da crescente demanda, tornam-nos bens de valor econômico, cuja utilização enseja uma contraprestação pecuniária. Assim, a Lei 6.938/1981, ao definir os objetivos da Política Nacional do Meio Ambiente, incluiu, entre eles, a imposição ao usuário da obrigação de contribuir pela utilização de recursos ambientais com fins econômicos, o que, no nosso modo de ver, não deixa de ser uma imposição vinculada ao princípio do poluidor-pagador. ${ }^{386}$

Aliás, o direito brasileiro já previa a cobrança pela utilização de bens públicos, de forma genérica. O Código Civil de 1916, em seu art. 68, estabelecia que o uso comum podia ser gratuito ou retribuído, conforme leis da União, dos Estados ou Municípios, a cuja administração pertencessem. ${ }^{387}$

Sobre a retribuição pelo uso de bens coletivos (ou públicos) ambientais, é bastante paradigmático o instrumento chamado cobrança pelo uso da água, instituído pela Lei $n^{\circ}$ 9.433, de 8 de janeiro de 1997 (Política Nacional de

\footnotetext{
${ }^{386}$ A cobrança pelo uso de um recurso natural (ou de um bem público) pode ser exemplificada no sistema paulistano da "Zona Azul”, pelo qual se utiliza uma parte da via pública por determinado período, pagando por isso. O efeito dessa utilização é que, nesse interregno, o espaço da via pública, bem de uso comum, destina-se exclusivamente ao usuário, em detrimento dos demais. GRANZIERA, Maria Luiza Machado. Direito das águas: disciplina jurídica das águas doces. São Paulo: Atlas, 2001, p. 224.

${ }^{387}$ Essa disposição foi repetida no Código Civil de 2002, em seu art. 103, que dispõe: “O uso comum dos bens públicos pode ser gratuito ou retribuído, conforme for estabelecido legalmente pela entidade a cuja administração pertencerem”.
} 
Recursos Hídricos). ${ }^{388}$ Ao lado dos instrumentos: (i) Planos de Recursos Hídricos; (ii) enquadramento dos corpos de água em classes, segundo os usos preponderantes da água; (iii) outorga dos direitos de uso de recursos hídricos; (iv) a compensação a municípios; e (vi) Sistema de Informações sobre Recursos Hídricos (art. $5^{\circ}$ e incisos), a cobrança pelo uso da água ${ }^{389}$ é instrumento econômico que confere a possibilidade de exigir retribuição financeira pelo uso de recursos hídricos, tendo por objetivo (i) reconhecer a água como bem econômico e dar ao usuário uma indicação de seu real valor; (ii) incentivar a racionalização do uso da água; (iii) obter recursos financeiros para o financiamento dos programas e intervenções contemplados nos Planos de Recursos Hídricos (art. 19).

A cobrança pelo uso da água consiste no instrumento econômico da política de recursos hídricos ${ }^{390}$. É econômico em dois sentidos: o primeiro, relativo ao financiamento de obras contidas no plano de recursos hídricos; o segundo, no que tange ao entendimento da água como bem de valor econômico, cuja utilização deve ser cobrada. ${ }^{391}$

Assim, não há dúvidas de que a cobrança pelo uso de recursos hídricos é importante instrumento econômico, que permite alcançar objetivos relacionados com a proteção ambiental e, dentro dos limites já expostos anteriormente, pode efetivar a internalização dos custos pela utilização dos recursos naturais na cadeia produtiva. ${ }^{392}$

\footnotetext{
388 Observe-se que o Código de Águas, de 1934, já estabelecia a possibilidade da cobrança por seu uso. Em seu art. 36, prescreve: "É permitido a todos usar de quaisquer águas públicas, conformando-se com os regulamentos administrativos". E acrescenta: “O uso comum das águas pode ser gratuito ou retribuído, conforme as leis e regulamentos administrativos da circunscrição administrativa a que pertencem”.

389 Sobre a natureza jurídica do instrumento econômico cobrança pelo uso da água, vide OLIVEIRA, José Marcos Domingues de. Direito tributário e meio ambiente. $3^{\text {a }}$ ed. ver. e ampl. Rio de Janeiro: Forense, p. 263-267. MACHADO, Paulo Affonso Leme. Recursos hídricos: direito brasileiro e internacional. São Paulo: Malheiros, 2002, p. 87-88. GRANZIERA, Maria Luiza Machado. Direito das águas: disciplina jurídica das águas doces. São Paulo: Atlas, 2001, p. 222-224. MILARÉ, Édis. Direito do ambiente. $7^{\mathrm{a}}$ ed. São Paulo: RT, 2011, p. 614. O primeiro, o terceiro e o quarto autores são explícitos ao apontar a natureza de preço público do instituto.

390 É válido anotar que, no caso do uso de recursos hídricos para fins de geração hidráulica de energia elétrica (por UHEs e PCHs), a Lei $n^{\circ} 9.648$, de 27.5.1998, em seu art. 17, $\S 1^{\circ}$, inciso II, e $\S 2^{\circ}$, incluiu a cobrança do uso da água no cômputo do percentual da compensação financeira (essa, por sua vez, decorrente do art. 20, $\S 1^{\circ}$, da CF).

${ }^{391}$ GRANZIERA, Maria Luiza Machado. Direito das águas: disciplina jurídica das águas doces. São Paulo: Atlas, 2001, p. 220.

${ }^{392}$ Ainda a título exemplificativo, é válido citar a cobrança americana para financiar a coleta de lixo, onde famílias e empresas são cobrados pelo incremento de resíduos gerados, que devem ser recolhidos e
} 


\subsubsection{Compensações financeiras}

A Constituição Federal, em seu art. 20, $\S 1^{\circ},{ }^{393}$ determina que as atividades de exploração dos recursos minerais e dos aproveitamentos dos recursos hídricos para fins de exploração energética possui um regime particular no que tange à compensação pecuniária.

A Lei ${ }^{\circ}$ 7.990, de 28 de dezembro de 1989 e a Lei $n^{\circ} 8.001$, de 13 de março de 1990, ao regularem a previsão constitucional de contrapartida pela exploração de bem público de domínio da União (minério) estabelecida no art. 20, IX, e o acima transcrito $\S 1^{\circ}$ da Constituição Federal, instituíram a Compensação Financeira pela Exploração Mineral - CFEM, veiculando normas sobre a indenização a ser paga por todo aquele que exerce referida atividade. ${ }^{394}$

Na Exposição de Motivos da Lei no 8.001/1990, encontram-se nítidas as razões para a instituição da CFEM, entre elas a preservação do meio ambiente, através de verba provinda da exploração de recursos minerais, haja vista a utilização destes, bem como os impactos ambientais decorrentes da referida atividade econômica. Confira-se:

A nova Constituição, como não poderia deixar de fazê-lo, estendeu aos Estados e Municípios o direito a uma compensação pela exploração de recursos hídricos e minerais (art. $20, \S 1^{\circ}$ ). Além do mais, o novo texto constitucional caracterizou-se e notabilizou-se por uma elevada preocupação com a preservação do meio ambiente, explicitada nos termos do seu art. 225,

devidamente destinados. Chamados "pay-as-you-throw”, significando que os usuários pagam proporcionalmente pelo volume de lixo que geram. REVESZ, Richard L. STAVINS, Robert N. Environmental Law and Policy. NYU Public Law Research Paper 82; NYU Law \& Econ Research Paper 04015; Harvard Public Law Working Paper No. 102; KSG Working Paper No. RWP04-023, September/2004. Disponível em: <http://ssrn.com/abstract=552043>. Acesso em: 3.10.2011. Em relação às taxas do lixo, os autores ressaltam que se evidenciou uma redução do volume de geração de resíduo familiar.

393 “Art. 20. (...). §1 $1^{\circ}$ É assegurada, nos termos da lei, aos Estados, ao Distrito Federal e aos Municípios, bem como a órgãos da administração direta da União, participação no resultado da exploração de petróleo ou gás natural, de recursos hídricos para fins de geração de energia elétrica e de outros recursos minerais no respectivo território, plataforma continental, mar territorial ou zona econômica exclusiva, ou compensação financeira por essa exploração.”

${ }^{394}$ O Ministro Sepúlveda Pertence afirma, em voto proferido no julgamento do RE 228800-5/DF, que “a compensação financeira (...) não tem natureza tributária, constituindo, sim, receita patrimonial do Estado, cuja origem se encontra na exploração do patrimônio público”. E aduz que “a compensação (...) se situa na órbita das receitas patrimoniais e não tributárias...Essa compensação financeira há de ser entendida em seu sentido vulgar de mecanismo efetuado a recompor uma perda, sendo, pois, essa perda, o pressuposto e a medida da obrigação do explorador”. 
preocupação essa que de certa maneira justifica e confirma a necessidade de provimento de recursos específicos para esse fim, oriundos do aproveitamento econômico dos recursos explorados nos territórios estaduais e municipais.

Neste ponto, oportuno expor que o STF compreendeu a vinculação da compensação financeira à preservação ambiental, descartando a sua eventual natureza jurídica tributária por estabelecê-la como receita patrimonial do Estado. É o que constou no acórdão do julgamento relativo ao Recurso Extraordinário $\mathrm{n}^{\circ}$ 228.800-5/DF, cujo relator, o Ministro Sepúlveda Pertence, asseverou que "A compensação financeira se vincula, a meu ver, não à exploração em si, mas aos problemas que gera (...) Com efeito, a exploração de recursos minerais e de potenciais de energia elétrica é atividade potencialmente geradora de um sem número de problemas para os entes públicos, especialmente para os municípios onde se situam as minas e as represas. Problemas ambientais - como a remoção da cobertura vegetal do solo, poluição, inundação de extensas áreas, comprometimento da paisagem e que tais -, sociais e econômicos, advindos do crescimento da população e da demanda por serviços públicos.”

Heleno Taveira Tôrres propõe que “a compensação financeira, prevista no art. $20, \S 1^{\circ}$, da CF, apesar de não se definir como receita 'tributária', poderia prestar-se como excelente instrumento de controle ambiental, com majorações de alíquotas, formações de fundos e outras determinações cabíveis”. E continua: “... esses pagamentos de compensações financeiras poderiam perfeitamente ensejar a formação de fundos especiais, voltados à proteção do ambiente natural, sua preservação e até mesmo recomposição, sem prejuízo das obrigações contratuais assumidas pelas partes contratantes para esse fim”. ${ }^{395}$

Portanto, o aporte de recursos financeiros às políticas de preservação do meio ambiente, em caso de exploração minerária e de recursos hídricos, se faz pelo pagamento de um quantum calculado a partir da verba obtida com a exploração dos recursos minerais (bens da União). ${ }^{396}$

395 TÔRRES, Heleno Taveira. Da relação entre competências constitucionais tributária e ambiental - os limites dos chamados 'tributos ambientais'. In: TÔRRES, Heleno Taveira (org.). Direito Tributário Ambiental. São Paulo: Malheiros, 2005, p. 108 e 113.

396 Sobre a natureza jurídica das compensações financeiras instituídas por força do art. $20, \S 1^{\circ}$, da Constituição Federal, vide PETRY, Rodrigo Caramori. Compensações financeiras, participações e outras 


\subsubsection{Os tributos ambientais}

Conforme será mais bem explorado no Capítulo 6 desta tese, a preocupação com a defesa do meio ambiente tem caráter interdisciplinar e se apresenta como um tema transversal, encontrando-se, por esse motivo, em inúmeros campos da ciência e, da mesma forma, se envolve com vários ramos do direito. ${ }^{397}$

Com efeito, não deve haver dúvidas de que a crise ambiental, para ser equacionada, incide inevitavelmente na economia, na administração (pública e privada), na engenharia, na educação, na arquitetura, na biologia, no direito etc.; especificamente na ciência do direito, a preocupação ambiental segue como uma linha transversal que corta vários ramos do direito, como o constitucional, o econômico, o penal, o civil, o administrativo e, ainda, o tributário ${ }^{398}$.

Claramente, a tributação pode ser um instrumento econômico com grande potencial apropriado para a proteção ambiental. Afinal, não basta que o poluidor arque com os custos da utilização dos recursos naturais no processo produtivo; é também necessário que pague pelas despesas administrativas decorrentes do desenvolvimento (custos de planejamento, execução e controle de medidas de proteção) de uma política do ambiente. A respeito, Maria Alexandra de Sousa Aragão sustenta que “é, com efeito, mais justo que sejam os 'geradores' ou beneficiários da poluição a suportar os custos administrativos da proteção do

cobranças estatais sobre empresas dos setores de mineração, energia, petróleo e gás. Revista Tributária e de Finanças Públicas. vol. 89. Nov/2009. E, especificamente sobre a natureza jurídica da CFEM (Compensação Financeira pela Exploração Mineral), vide OLIVEIRA, José Marcos Domingues de. Direito tributário e meio ambiente. $3^{\text {a }}$ ed. rev. e ampl. Rio de Janeiro: Forense, 2007, p. 233-250. Embora o assunto seja bastante controverso, ambos os autores, socorrendo-se inclusive de julgados do STF, compreendem que a natureza jurídica das compensações financeiras, em geral, não é tributária, mas, sim, receita patrimonial originária.

397 Na esteira desse entendimento e estando no âmbito da administração da escassez, os recursos naturais devem ser vistos também pelas lentes da economia. A economia e o direito, por sua vez, conforme nos ensina Fábio Nusdeo, "são um todo indiviso, uma espécie e de verso e reverso da mesma moeda, sendo difícil dizerse até que ponto o Direito determina a Economia, ou pelo contrário, esta influi no Direito". Outro tanto, conforme continua o mestre, não há dúvidas de que a "imbricação Economia-Direito (...) manifesta-se em virtualmente todos os ramos da árvore jurídica”. NUSDEO, Fábio. Curso de economia: introdução ao direito econômico. $6^{\mathrm{a}}$ ed. rev. e atual. São Paulo: RT, 2010, p. 30 e 31.

${ }^{398}$ Sobre a incidência da preocupação ambiental no direito tributário, ver NABAIS, José Casalta. Tributos com fins ambientais. Revista Tributária e de Finanças Públicas. vol. 80. Mai/2008. 
ambiente, do que sejam os contribuintes, muitas vezes, eles próprios vítimas inocentes da poluição, a suportar, através de impostos, mais esse encargo". 399

Para essa autora, os impostos e as taxas são os instrumentos econômicos mais difundidos para esse intento, sendo que os impostos, tal como foram propostos por Pigou, ${ }^{400}$ consistem em fazer o poluidor pagar ao Estado um valor proporcional à poluição pela qual ele é responsável. ${ }^{401}$

Sobre os impostos, eles têm, no Brasil, difícil aplicação quando se trata de proteger o meio ambiente (salvo, como se verá, se utilizados com intuitos extrafiscais), porquanto sua natureza é eminentemente fiscal.

Já as taxas, como é cediço, são cobradas pela prestação de serviços públicos, ${ }^{402}$ o que pode ser estendido para os serviços de despoluição ou de proteção ambiental.

José Marcos de Oliveira Domingues expõe que, “no direito brasileiro, à luz do artigo 77 do CTN, parecem admissíveis como fatos geradores [das taxas] o licenciamento, a fiscalização e a limpeza ou recuperação ambiental, guardando uma razoável equivalência com o custo dos serviços públicos de licenciamento e fiscalização, e da limpeza ou recuperação ambiental correlacionáveis, exemplificativamente, a situações individuais dos contribuintes (tipo de estabelecimento/instalações/atividades, área fiscalizada etc.) e aos volumes de emissões, despejos ou produção de resíduos poluidores”. 403

Sobre o assunto, Heleno Taveira Tôrres enfatiza que “a majoração de taxas de poder de polícia, como as que são cobradas em licenciamentos

\footnotetext{
399 ARAGÃO, Maria Alexandra de Sousa. O princípio do poluidor pagador: pedra angular da política comunitária do ambiente. Coimbra: Coimbra Editora, 1997, p. 159-161.

${ }_{400}$ Conforme já visto, Alfred Pigou foi o primeiro a defender o mecanismo da fiscalidade para a internalização das deseconomias externas. Fábio Nusdeo ensina que a recomendação clássica de Pigou é: "uma vez que o mercado se revela inoperante para captar o efeito externo, caberia ao Estado, identificando-o, tributar a fonte geradora do mesmo quando negativo e subsidiá-la quando positivo. Seria uma forma de fazer com que os agentes econômicos tivessem diante de si uma constelação de preços que lhes indicassem pelo menos aproximadamente os custos sociais de suas ações. A mencionada taxa deveria corresponder ao montante dos custos adicionais impostos pela atividade geradora do efeito, no caso de ele ser negativo." NUSDEO, Fábio. Desenvolvimento e ecologia. São Paulo: Saraiva, 1975, p. 81.

${ }^{401}$ ARAGÃO, Maria Alexandra de Sousa. Ob. cit., p. 179.

${ }^{402}$ As taxas cobradas "em razão do exercício do poder de polícia402 ou pela utilização, efetiva ou potencial, de serviços públicos específicos e divisíveis, prestados ao contribuinte ou postos a sua disposição” (art. 145, II, CF).

${ }_{403}$ OLIVEIRA, José Marcos Domingues de. Direito tributário e meio ambiente. $3^{\text {a }}$ ed. rev. e ampl. Rio de Janeiro: Forense, 2007, p. 83.
} 
periódicos, de acordo com o índice de atendimento ou não dos deveres concernentes aos domínios ambientais de atividade, também poderia ser uma solução de natureza tributária sobremodo oportuna e plenamente autorizada pela Constituição, para o descumprimento de normas ambientais”. 404

Em âmbito federal, a principal taxa ambiental é a TCFA - Taxa de Controle e Fiscalização Ambiental, instituída pela Lei 10.165 de 27.12.2000 (alterando a Lei 6.938/81), ${ }^{405}$ cobrada pelo IBAMA e com o fim de controlar e fiscalizar atividades potencialmente poluidoras e utilizadoras de recursos ambientais.

Cite-se, ainda como exemplo de taxa ambiental, a taxa de preservação ambiental exigida no Arquipélago de Fernando de Noronha, Distrito de Pernambuco, nos termos da Lei $n^{\circ} 10.403$, de 29.12.1989, e alterada pela Lei $\mathrm{n}^{\circ}$ 11.305, de 28.12.1995, cujo fato gerador é “a utilização, efetiva ou potencial, por parte das pessoas visitantes, da infra-estrutura física implantada no Distrito Estadual e do acesso e fruição ao patrimônio natural e histórico do Arquipélago de Fernando de Noronha” (art.84).

\footnotetext{
${ }^{404}$ TÔRRES, Heleno Taveira. Da relação entre competências constitucionais tributária e ambiental - os limites dos chamados 'tributos ambientais'. In: TÔRRES, Heleno Taveira (org.). Direito Tributário Ambiental. São Paulo: Malheiros, 2005, p. 110-111. Salienta o jurista, porém, que "a majoração de taxas de poder de polícia, nessas hipóteses, estariam vinculadas à espécie não como sanções ao ilícito cometido, mas exclusivamente como condição para a continuidade da exploração, nas condições presentes, sem prejuízo da aplicação de multas e outros instrumentos pertinentes à apuração dos danos causados.”

${ }^{405}$ Inicialmente foi instituída a TFA - Taxa de Fiscalização Ambiental, pela Lei no 9.960/2000, que, por força da ADI n ${ }^{\circ}$ 2178, teve sua eficácia suspensa pelo Supremo Tribunal Federal, que acabou por julgar que os dispositivos desse diploma, ao tratar da referida taxa, são insuscetíveis de instituir, validamente, o tributo, porque (a) o fato gerador não era o serviço prestado ou posto à disposição do contribuinte, mas a atividade por esses exercida; (b) não definiu quais exatamente eram as atividades potencialmente poluidoras ou utilizadoras de recursos ambientais; e (c) não indicou as respectivas alíquotas ou o critério a ser utilizado para o cálculo do valor devido, tendo-se limitado a estipular valores uniformes por classe de contribuintes, com flagrante desobediência ao princípio da isonomia. A fim de reverter os equívocos da Lei no 9.960/2000, foi promulgada a Lei $\mathrm{n}^{\circ} 10.165$, de 27.12.2000, instituindo nova taxa com o fim de controle e fiscalização de atividades potencialmente poluidoras e utilizadoras de recursos ambientais, que acabou sendo denominada TCFA. Muitos doutrinadores alegaram que a referida taxa também estava eivada de inconstitucionalidades e ilegalidades, sob os fundamentos, dentre outros, de que (a) a norma prevê a cobrança de valores de forma indiscriminada, ferindo o princípio da isonomia; (b) fere, também, a capacidade contributiva diante da onerosidade de sua cobrança anual; (c) além disso, a TCFA seria inconstitucional porquanto incide de maneira genérica sobre todos os que exercem atividades potencialmente poluidoras e que utilizem de recursos ambientais, não considerando os critérios territoriais e as competências constitucionais; (d) e ainda a TCFA representa bitributação, ou seja, incide sobre o mesmo fato gerador exercido pelo órgão ambiental competente (normalmente estadual) para o licenciamento ambiental e, como tal, igualmente competente para o exercício fiscalizatório. Muito se discutiu judicialmente sobre a constitucionalidade e legalidade da TCFA, que, no entanto, foi ao fim considerada constitucional pelo STF, conforme se vislumbra na decisão relativa ao RE $n^{\circ}$ 416.601/DF (julgado pelo Pleno, rel. Ministro Carlos Velloso, em 10.8.2005, DJ 30.9.2005).
} 
Como se vê, são restritas as possibilidades de utilizar tributos considerados em seu fim fiscal - para a proteção ambiental. Bem por isso, aliás, é que vários autores vêm defendendo a necessidade de instituir um tributo exclusivamente ambiental, ou um “imposto ecológico” ou “tributo verde”, que objetive internalizar na cadeia produtiva os custos da utilização dos recursos naturais.

A respeito, Roberto Ferraz discorre: "como a maioria dos danos causados à natureza não é reparável, ao tributo ambiental caberia a função de aproximar, decisivamente, o custo do produto nocivo em termos ambientais ao seu custo real”. E continua, expondo “que a experiência internacional tem apontado a adequação da adoção de práticas tributárias que - ao invés de simplesmente incentivar atividades benéficas, como a substituição de equipamentos, ou, ainda, apenas aumentar o peso tributário de determinados produtos cujo consumo se deseja diminuir, como os combustíveis ou a energia elétrica - busquem, de fato, demonstrar o custo ambiental dos produtos, colocando em seu preço tributos mais destinados à restauração dos prejuízos ambientais que causam”. Ferraz conclui, ressaltando que “a melhor opção para uma política fiscal ambientalmente orientada é adotar tributos que internalizem o custo ambiental dos produtos, com necessária vinculação do produto de arrecadação a essa tarefa". 406

Nessa mesma linha, Omara Oliveira de Gusmão, após sustentar não ser a carga tributária brasileira a razão para deixar de instituir um tributo ambiental, expende que "se os caminhos trilhados pelo Estado na proteção ambiental não têm sido eficazes, a tributação apresenta-se, inicialmente, como coadjuvante nesse processo de busca da realização do princípio da proteção e defesa do meio ambiente". Essa mesma autora ainda aduz que "na medida em que a consciência ambiental for se cristalizando, e passar a ser prioridade estatal, há possibilidade, mediante as necessárias alterações constitucionais na competência impositiva dos entes federativos, conjugada com a inclusão de ressalva ao art. $167, \mathrm{IV},{ }^{407}$

\footnotetext{
${ }^{406}$ FERRAZ, Roberto. Tributação e meio ambiente: O green tax no Brasil (a contribuição da Emenda 33/2001). Revista de Direito Ambiental. n 31. Ano 8. jul-set. São Paulo: RT, 2003, p. 167-172.

${ }^{407} \mathrm{O}$ art. 167, IV, da Constituição Federal, prescreve: “Art. 167. São vedados: (...) IV - a vinculação de receita de impostos a órgão, fundo ou despesa, ressalvadas a repartição do produto da arrecadação dos
} 
da Constituição, de se efetuar uma imposição específica visando atingir as atividades nocivas ao meio ambiente, vinculando a arrecadação a fundo destinado à proteção ambiental”. ${ }^{408}$

Entretanto, da mesma maneira como se defende a instituição de um tributo estritamente ambiental, também vem se alertando quanto aos aspectos dificultosos ou negativos dessa proposta.

Com efeito, não há como escapar da inflexibilidade do sistema tributário nacional no sentido de criar novos tributos. Basta ver que a instituição de um tributo ambiental implicaria, antes de mais nada, a necessidade de uma emenda constitucional, ${ }^{409}$ permitindo que a União, Estados e Municípios instituíssem exações cuja base de cálculo seria a extensão do impacto negativo causado à natureza (jamais um dano, pois o tributo não pode estar vinculado a um ato ilícito - art. $\left.3^{\circ}, \mathrm{CTN}\right){ }^{410}$

De fato, o Direito Tributário brasileiro é caracteristicamente rígido, tal qual imposto pela Lei Maior, sendo, bem por isso, apenas relativamente capaz de abarcar a criação de tributos propriamente ditos (tributos ambientais) com intuito de proteção ambiental, como é usual ocorrer em outros países. ${ }^{411}$ A bem

impostos a que se referem os arts. 158 e 159, a destinação de recursos para as ações e serviços públicos de saúde, para manutenção e desenvolvimento do ensino e para realização de atividades da administração tributária, como determinado, respectivamente, pelos arts. 198, § 2º, 212 e 37, XXII, e a prestação de garantias às operações de crédito por antecipação de receita, previstas no art. 165, § $8^{\circ}$, bem como o disposto no $\S 4^{\circ}$ deste artigo.”

408 GUSMÃO, Omara Oliveira de. Proteção ambiental e tributação: o tributo como coadjuvante na concretização do valor constitucional “meio ambiente”. Revista Tributária e de Finanças Públicas. vol. 66. Jan/2006.

${ }^{409}$ Sobre a proposta do Ministério do Meio Ambiente - MMA ao relator da reforma tributária, vide SEROA DA MOTTA, Ronaldo; OLIVEIRA, José Marcos Domingues de; MARGULIS, Sergio. Proposta de tributação ambiental na atual reforma tributária brasileira. IPEA. Texto para discussão $n^{\circ} 738.2000$. Disponível em: < http://www.ipea.gov.br/pub/td/td_2000/td0738.pdf>. Acesso em: 3.12.2011.

410 Sobre o fato gerador, Marcelo Abelha Rodrigues expõe: "o momento social, político, histórico e econômico da realidade brasileira não justifica a criação de um novo imposto ecológico, mas que, caso isso venha a se desenvolver, é melhor que não se utilize a poluição como fato gerador”. Para o autor, seria melhor que recaísse sobre o conceito de contribuinte-usuário, eis que é no sentido de usuário (contribuinte) pagador - tendo por base o aproveitamento ou benefício do bem que é de uso comum do povo - que se deve fincar a noção de imposto ambiental.” RODRIGUES, Marcelo Abelha. Aspectos jurídicos da compensação ambiental e do art. 36, $\S 1^{\circ}$ da Lei brasileira das Unidades de Conservação (Lei $n^{\circ}$ 9.985/2000). Revista de Direito Ambiental. no 46. Ano 12. abr-jun. São Paulo: RT, 2007, p. 236.

${ }^{411}$ Alertando para a impropriedade da comparação com o sistema tributário de outros países, nos quais se vêm criando e impondo inúmeros tributos com vistas à proteção ambiental, vale o alerta de Heleno Taveira Torres, para quem é preciso ter cuidado ao importar para a realidade brasileira as discussões sobre tributação ambiental, as quais se encontram em estágio muito mais avançado no exterior. TÔRRES, Heleno Taveira. Da relação entre competências constitucionais tributária e ambiental - os limites dos chamados 'tributos ambientais’. In: TÔRRES, Heleno Taveira (org.). Direito Tributário Ambiental. São Paulo: Malheiros, 2005, 
ver, essa rigidez implica, de um lado, o fato de a Constituição brasileira contemplar um processo especial para ser modificada; mais complexo, por sinal, do que aquele previsto para a elaboração de uma lei ordinária, o que se transmite ao Sistema Tributário Nacional, somente podendo ser modificado, em sua estrutura básica, por meio de emenda constitucional. Por outro lado, toda modificação a ser implementada no plano infraconstitucional deverá atentar às balizas pré-estabelecidas na Lei Maior, o que resulta na restrita liberdade outorgada aos legisladores ordinário e complementar para dispor sobre tributação - e, obviamente, que resulta na nenhuma liberdade outorgada ao administrador fiscal. ${ }^{412}$

Sobre o assunto, Heleno Taveira Tôrres é peremptório ao afirmar que “não encontramos, à luz da nossa Constituição, espaço para a criação de alguma espécie de ‘imposto’ ecológico, salvo eventual exercício da competência residual da União (art. 154, I), nos limites dessa hipótese, tampouco a criação de fundos a partir dos impostos já existentes, haja vista a limitação do art. 167, IV, da CF”. O referido mestre ainda expõe que “a criação de impostos, no Brasil, de início, deveria ser não-cumulativo e não ter fato jurídico tributário ou base de cálculo idênticos aos dos já existentes. Atendidos a esses requisitos, dever-se-ia observar restrições à sua translação, para evitar que, ao final, fossem os consumidores dos produtos os efetivos contribuintes.”413

A par do engessamento imposto pela Constituição Federal, há que se observar o perigo desse 'tributo ambiental' ter tão somente uma intenção arrecadatória, ou seja, tornar-se uma fonte perversa de arrecadação de receitas para o governo. Mais uma vez nas palavras de Heleno Taveira Tôrres, “faz-se necessário, pois, resguardar a sociedade de investidas legislativas do poder de tributar, a pretexto de medidas preservacionistas, para criar tributo que, ao fim e

p. 102. A respeito das experiências internacionais acerca da tributação orientada para fins de proteção ambiental, vide OLIVEIRA, José Marcos Domingues de. Direito tributário e meio ambiente. $3^{\mathrm{a}}$ ed. rev. e ampl. Rio de Janeiro: Forense, 2007, p.59-62, e GUSMÃO, Omara Oliveira de. Proteção ambiental e tributação: o tributo como coadjuvante na concretização do valor constitucional "meio ambiente". Revista Tributária e de Finanças Públicas. vol. 66. Jan/2006.

412 COSTA, Regina Helena. Apontamentos sobre a tributação ambiental no Brasil. In: TÔRRES, Heleno Taveira (org.). Direito Tributário Ambiental. São Paulo: Malheiros, 2005, p. 319.

413 TÔRRES, Heleno Taveira. Da relação entre competências constitucionais tributária e ambiental - os limites dos chamados 'tributos ambientais'. In: TÔRRES, Heleno Taveira (org.). Direito Tributário Ambiental. São Paulo: Malheiros, 2005, p. 109. 
ao cabo, não mais permitam do que ampliar a carga tributária geral, desprovido de qualquer vínculo com a atividade estatal de proteção ao meio ambiente”. ${ }^{414}$

Não obstante os alertas críticos, tem se defendido - conforme já perpassado no item 2.4.3 do Capítulo 2 deste trabalho - que, caso seja criado um novo tributo ambiental, que ele venha na forma de Contribuição de Intervenção no Domínio Econômico - CIDE. Heleno Taveira Tôrres expende que “o domínio ambiental parece ser, assim, campo muito propício para o emprego da Contribuição de Intervenção no Domínio Econômico - CIDE, como instrumento da ordem econômica, ao exigir: 'VI - defesa do meio ambiente, inclusive mediante tratamento diferenciado conforme o impacto ambiental dos produtos e serviços e de seus processos de elaboração e prestação' (redação dada pela Emenda Constitucional n ${ }^{\circ}$ 42, de 19.12.2003)."415 Uma contribuição de intervenção ambiental poderia ter fatos geradores, alíquotas e bases de cálculo diferenciados em razão do grau de utilização repercutida na degradação dos recursos ambientais ou da capacidade de assimilação do meio ambiente. Sua eventual introdução no sistema constitucional do país introduziria efetivamente o princípio do poluidor-pagador no Sistema Tributário brasileiro. ${ }^{416}$

Deveras, não há dúvidas de que a CIDE é um importante instrumento tributário, já existente no ordenamento jurídico, que poderia ser utilizado como meio de proteção ao meio ambiente, pois tem sua finalidade constitucionalmente definida. Tanto é assim que, à vista do sistema atual, podem ser instituídas uma ou várias contribuições de intervenção no domínio econômico com propósito ambiental. Com efeito, sendo a defesa do meio ambiente um princípio geral da atividade econômica (art. 170, inciso VI), nada impede que sejam $\operatorname{criadas}^{417}$ as

\footnotetext{
${ }^{414}$ Idem, p. 101.

${ }^{415}$ Idem, p. 101.

${ }^{416}$ NUSDEO, Ana Maria de Oliveira. O uso dos instrumentos econômicos nas normas de proteção ambiental. Revista da Faculdade de Direito da Universidade de São Paulo. v. 101. jan/dez, 2006, p. 372. A autora lembra que a proposta da Contribuição de Intervenção Ambiental foi formulada especificamente pelo Ministério do Meio Ambiente para incorporação no projeto de reforma tributária, há muito em discussão no Congresso Nacional. Sobre a proposta de tributação ambiental, vide SEROA DA MOTTA, Ronaldo; OLIVEIRA, José Marcos Domingues de; MARGULIS, Sergio. proposta de tributação ambiental na atual reforma tributária brasileira. IPEA. Texto para discussão $\mathrm{n}^{0}$ 738, 2000. Disponível em: < http://www.ipea.gov.br/pub/td/td_2000/td0738.pdf>. Acesso em: 3.12.2011.

${ }^{417}$ Há os que, frente ao comando do art. 149 da Constituição Federal, defendem que a CIDE apenas pode ser criada por lei complementar. Heleno Taveira Tôrres rechaça essa premissa, sustentando que: “ao que nos afigura, a Constituição reserva a exigência de lei complementar, salvo algumas exceções (150, VIII), para
} 
contribuições para custear a ação da União em determinados setores econômicos, visando justamente à proteção ambiental.

Aliás, a Constituição Federal já contempla para a CIDE formas de destinação do produto da arrecadação, dentre eles o "financiamento de projetos ambientais relacionados com a indústria de petróleo e gás.” 418

A CIDE, portanto, é indubitavelmente um bom instrumento tributário para ser utilizado na busca da proteção ambiental, pois a sua cobrança se dará a uma determinada categoria de empresas que tenham como atividade uma potencialidade lesiva ao meio ambiente, sendo o fundo arrecadado com essa contribuição vinculado a um órgão representativo dessa categoria; isso, então, possibilita instituir programas de prevenção de eventuais danos, cursos para os empregados e ainda outros mecanismos de proteção ambiental que visem a contribuir e beneficiar as empresas associadas a esse órgão.

\subsubsection{A função extrafiscal da tributação ambiental}

Diante da inflexibilidade constitucional do Direito Tributário para abarcar um tributo ambiental como instrumento econômico para a internalização dos custos com a utilização dos recursos naturais, evidencia-se a possibilidade de uma via alternativa no Direito Tributário, mediante o uso da extrafiscalidade. ${ }^{419}$

todos os casos em que não se tenha a definição da materialidade do tributo previamente determinada, como no caso do art. 148 - empréstimo compulsório; ou do art. 154, I, no exercício da competência residual para impostos ou contribuições sociais (art. 195, §4 $4^{\circ}$ ). Como reconhecimentos que o art. 149 faz referência à materialidade pressuposta, com fatos determináveis a partir da intervenção do Estado na ordem econômica ou de associação em entidades corporativas, não nos parece que seja exigível o procedimento de lei complementar para a respectiva instituição dessas contribuições. Basta-se com lei ordinária”. TÔRRES, Heleno Taveira. Da relação entre competências constitucionais tributária e ambiental - os limites dos chamados 'tributos ambientais'. In: TÔRRES, Heleno Taveira (org.). Direito Tributário Ambiental. São Paulo: Malheiros, 2005, p. 139.

${ }^{418}$ Exemplo do emprego da CIDE com finalidade ambiental foi introduzido no art. 177, da Lei Maior, mediante a Emenda Constitucional n ${ }^{\circ} 33$, de 11.12.2001, cujo $§ 4^{\circ}$ dispõe: "A lei que instituir contribuição de intervenção no domínio econômico relativa às atividades de importação ou comercialização de petróleo e seus derivados, gás natural e seus derivados e álcool combustível deverá atender aos seguintes requisitos: (...) II - os recursos arrecadados serão destinados: (...) b) ao financiamento de projetos ambientais relacionados com a indústria do petróleo e do gás.”

${ }^{419}$ Sabe-se que um dos critérios para a definição dos tributos é a finalidade. Por ela, distinguem-se os tributos fiscais (que têm finalidade de arrecadação de recursos financeiros), parafiscais (que se destinam ao custeio de 
Com a extrafiscalidade, ${ }^{420}$ o Direito Tributário pode ser utilizado como instrumento ao alcance de objetivos e metas de políticas ambientais; ou seja, utilizada sem exigir a específica criação de tributos ambientais ou "impostos ecológicos” ou "tributos verdes” para fazer face às externalidades negativas. A bem ver, a extrafiscalidade tem sido vista por muitos como o verdadeiro entroncamento do Direito Tributário com a preservação ambiental. ${ }^{421}$

A extrafiscalidade é a possibilidade de intermediação de regras tributárias com as quais o Estado pode intervir diretamente na economia de mercado, regulando condutas, condicionando e incentivando comportamentos afeiçoados aos objetivos do princípio do poluidor-pagador, seja no seu viés de buscar alternativas para a internalização dos custos pela utilização dos recursos naturais, seja no seu âmbito preventivo, em que busca medidas que evitem a utilização destes recursos, sob pena de pagamento de um preço. Nesse sentido, José Marcos de Oliveira Domingues acentua que, ao encontrar-se com o Direito Tributário, o princípio do poluidor-pagador tem um sentido seletivo, por meio do qual “o princípio determina prioritariamente ao Poder Público que gradue a tributação de forma a incentivar atividades, processos produtivos ou consumos 'ecologicamente corretos', ou environmentally friendly (literalmente, amistosos, adequados sob a ótica ambientalista, numa palavra, não-poluidores), e desestimular o emprego de tecnologias defasadas, a produção e o consumo de bens 'ecologicamente incorretos', ou not environmentally friendly (isto é, nefastos à preservação ambiental)”. ${ }^{422}$

atividades paralelas à da administração pública direta, como a seguridade social - art. 195 da Constituição) e extrafiscais (que atendem a fins outros que não a arrecadação, mas, geralmente, à correção de situações sociais indesejadas e à condução da economia - estímulo ou desestímulo de certas atividades) nos termos da

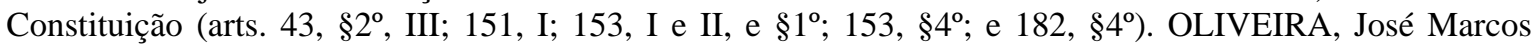
Domingues de. Direito tributário e meio ambiente. $3^{\mathrm{a}}$ ed. rev. e ampl. Rio de Janeiro: Forense, 2007, p. 38.

${ }^{420}$ Para Alfredo Becker, a tributação sob o caráter da extrafiscalidade é a moldura que vem se desenhando na contemporaneidade. “A principal finalidade de muitos tributos (que continuarão a surgir em volume e variedade sempre maiores pela progressiva transfiguração dos tributos de finalismo clássico ou tradicional) não será a de um instrumento de arrecadação de recursos para o custeio das despesas públicas, mas a de um instrumento de intervenção estatal no meio social e na economia privada. Na construção de cada tributo não mais será ignorado o finalismo extrafiscal, nem será esquecido o fiscal. Ambos coexistirão, agora de um modo consciente e desejado; apenas haverá maior ou menor prevalência deste ou daquele finalismo”. BECKER, Alfredo Augusto. Teoria geral do Direito Tributário. $4^{\text {a }}$ ed. São Paulo: Noeses, 2007, p. 624-625.

421 COSTA, Regina Helena. Apontamentos sobre a tributação ambiental no Brasil. In: TÔRRES, Heleno Taveira (org.). Direito Tributário Ambiental. São Paulo: Malheiros, 2005, p. 321.

422 OLIVEIRA, José Marcos Domingues de. Direito tributário e meio ambiente. $3^{\mathrm{a}}$ ed. rev. e ampl. Rio de Janeiro: Forense, 2007, p. 57. 
Observe-se, como é sabido, que a extrafiscalidade não objetiva punir ou reprimir certas atividades, ${ }^{423}$ mas, sim, orientar 0 agente econômico (contribuinte) a planejar seu negócio lícito de acordo com uma política pública legitimada pela Constituição. ${ }^{424}$ Tampouco se poderá tomar as atividades do homem em relação ao seu meio ambiente como hipótese de incidência de norma tributária, $^{425}$ porque isso não se apresenta como forma de manifestação de capacidade produtiva, para os fins de instituição ou majoração de 'impostos'. O tributo ambiental seria aquele afetado pela finalidade, em sua latente extrafiscalidade, portanto. ${ }^{426}$

Sendo assim, a extrafiscalidade da tributação ambiental é aquela orientada para fins outros que não a captação de dinheiro para o erário, praticando-se, basicamente, por meio de incentivos ou desestímulos fiscais, induzindo ${ }^{427}$ o comportamento dos contribuintes. Dessa forma, a extrafiscalidade é, realmente, a melhor forma de conciliar o Direito Tributário com as prementes necessidades de internalização dos custos derivados da utilização dos recursos naturais e, ainda, como forma de incentivar condutas 'mais limpas'. ${ }^{428}$ Tudo,

\footnotetext{
${ }^{423}$ E nem poderia, pois o tributo não emerge em atos ilícitos.

${ }^{424}$ OLIVEIRA, José Marcos Domingues de. Ob. cit., p. 50.

${ }^{425}$ Conforme expõe Claudia Alexandra Dias Soares, "é a finalidade que preside à sua criação, e não o seu facto gerador, que permite qualificá-lo como ambiental. Pois, de outro modo, ou a sua classificação como instrumento de defesa do ambiente estaria comprometida, devido à semente de potencial ineficácia que uma definição fundada nesse outro critério depositaria no seu seio, por ser perturbada a ideia de prevenção que deve presidir à abordagem ambiental, ou, in extremis, todos os impostos seriam ambientais, já que viver é poluir". Apud TÔRRES, Heleno Taveira. Da relação entre competências constitucionais tributária e ambiental - os limites dos chamados 'tributos ambientais'. In: TÔRRES, Heleno Taveira (org.). Direito Tributário Ambiental. São Paulo: Malheiros, 2005, p. 100.

${ }^{426}$ TÔRRES, Heleno Taveira. Da relação entre competências constitucionais tributária e ambiental - os limites dos chamados 'tributos ambientais'. In: TÔRRES, Heleno Taveira (org.). Direito Tributário Ambiental. São Paulo: Malheiros, 2005, p. 100-101.

${ }^{427}$ Sobre o emprego de normas tributárias indutoras em matéria ambiental, vide SCHOUERI, Luís Eduardo. Contribuição ao estudo das normas tributárias indutoras como instrumento de intervenção sobre o domínio econômico. São Paulo: USP, 2002, e SCHOUERI, Luís Eduardo. Normas tributárias indutoras em matéria ambiental. In: TÔRRES, Heleno Taveira (org.). Direito Tributário Ambiental. São Paulo: Malheiros, 2005, p. 235-256.

${ }^{428}$ José Casalta Nabais traz exemplos de extrafiscalidade aplicados em Portugal: “... em Portugal estão previstas a isenção do imposto sobre produtos petrolíferos dos biocombustíveis, a isenção no imposto sobre as sociedades das entidades gestoras de sistemas de embalagens e resíduos de embalagens, a isenção desse mesmo imposto dos fundos de investimento imobiliário em recursos florestais e a redução da taxa ou alíquota a $10 \%$ dos rendimentos das correspondentes unidades de participação, a aceitação de provisões para a recuperação paisagística de terrenos, a dedução à colecta de encargos com equipamentos novos de energias renováveis etc”. NABAIS, José Casalta. Tributos com fins ambientais. Revista Tributária e de Finanças Públicas. vol. 80. Mai/2008.
} 
ressalte-se, visando a alcançar metas e objetivos de uma determinada política ambiental.

A extrafiscalidade pode ser implementada mediante a instituição e a graduação de tributos, a concessão de isenções e de outros incentivos fiscais, como a possibilidade de deduzir de despesas efetuadas pelos contribuintes referentes aos recursos empregados na preservação do meio ambiente. ${ }^{429}$

Na linha da extrafiscalidade tributária, iniciamos lançando o exemplo da Contribuição de Melhoria, que, conforme nos ensina Fábio Nusdeo ${ }^{430}$, a Constituição Federal de 1988, ao "laconicamente fala[r] em 'contribuição de melhoria decorrente de obras públicas"”, deixou “aberta a possibilidade de, ou por lei complementar ou por lei ordinária, conforme as diferentes interpretações, vir o legislador a estabelecer critérios outros para a respectiva exação”. ${ }^{431}$ Sendo assim, expõe o mestre que, com a vigente Lei Maior:

fica clara a abertura para um tipo diferenciado de exação, desvinculada da clássica dicotomia: custo da obra - valorização (ou benefício), permitindo ao legislador infraconstitucional ir além, para cobrar a contribuição não apenas do proprietário do imóvel beneficiado, mas de quem, por qualquer outra forma, auferiu uma dada vantagem decorrente de obra pública. ${ }^{432}$

Aliás, essa noção elástica da Contribuição de Melhoria, contemplando também as externalidades negativas (e não apenas a valorização mobiliária) já havia sido suscitada por Fábio Nusdeo desde $1975 .{ }^{433}$ E, em seu Curso de Economia, o mestre salienta a referida Contribuição (disposta no art. 81, CTN que tem por fato gerador a valorização imobiliária decorrente de obra pública,

\footnotetext{
${ }^{429}$ COSTA, Regina Helena. Apontamentos sobre a tributação ambiental no Brasil. In: TÔRRES, Heleno Taveira (org.). Direito Tributário Ambiental. São Paulo: Malheiros, 2005, p. 322.

${ }^{430}$ NUSDEO, Fábio. A contribuição de melhoria revisitada: uma revisão e uma proposta. In: SCHOUERI, Luís Eduardo (org.). Direito tributário: homenagem a Alcides Jorge Costa. São Paulo: Quartier Latin, 2003, p. 680-681.

${ }^{431}$ NUSDEO, Fábio. Desenvolvimento e ecologia. São Paulo: Saraiva, 1975, p. 682. Antes, porém, o mestre aduziu importante lição trazida no histórico do tributo no direito nacional, segundo o qual "nos dizeres do art. 124 [da Constituição de 1934] era-lhe atribuída a natureza de uma compensação a ser paga pelos proprietários de imóveis valorizados por motivo de obras públicas”. Continua, expondo que a visão daquela constituição "estava bastante acurada por ferir um dos pontos nevrálgicos do funcionamento do sistema econômico: as discrepâncias existentes entre custos privados e custos sociais ou entre benefícios privados e benefícios sociais a demandarem alguma forma de correção”. NUSDEO, Fábio. Ob. cit., p. 680-681.

${ }^{432}$ NUSDEO, Fábio. Desenvolvimento e ecologia. São Paulo: Saraiva, 1975, p. 683.

${ }^{433}$ Vide NUSDEO, Fábio. Desenvolvimento e ecologia. São Paulo: Saraiva, 1975.
} 
tendo como limite total a despesa realizada e, como limite individual, o acréscimo de valor que da obra resulta para cada imóvel beneficiado), muito embora tenha por finalidade a captura de externalidades positivas geradas por uma iniciativa custeada por recursos de toda a sociedade, a incidir como compensação financeira ou ressarcimento pelos danos ambientais, externalidades negativas causadas pela atividade econômica, com o fim de melhorar o meio ambiente inquinado. ${ }^{434}$

Avançando no estudo do tema, Nusdeo advoga que a Contribuição de Melhoria - após, por certo, passar por emenda constitucional, desvinculando-a da área exclusiva das obras públicas ${ }^{435}$ - pode ser aplicada em duas mãos de direção, quais sejam:

a primeira de setores ou grupos da sociedade que aufiram benefícios decorrentes de obras, iniciativas ou permissões, inclusive ambientais, do poder público e a segunda, de setores ou grupos da sociedade que gerem custos externos, incompensados, de qualquer natureza, inclusive não diretamente quantificáveis, quando incidentes sobre a sociedade como um todo ou parte dela, conforme definido em leis específicas emanadas dos poderes tributantes, com lei complementar delimitando-lhes as bases diretrizes e condições de cobrança. ${ }^{436}$

Como se vê, a Contribuição pode ser empregada como uma boa solução para as externalidades negativas, incidente na forma de uma medida compensatória capaz de equacioná-las, ainda que parcialmente. Nesse viés, o

\footnotetext{
${ }^{434}$ NUSDEO, Fábio. Curso de economia - Introdução ao Direito Econômico. $6^{\text {a }}$ ed. rev. e atual. São Paulo: RT, 2010, p. 379-380. Sobre o assunto, vide, ainda, NUSDEO, Fábio. A contribuição de melhoria revisitada: uma revisão e uma proposta. In: SCHOUERI, Luís Eduardo (org.). Direito tributário: homenagem a Alcides Jorge Costa. São Paulo: Quartier Latin, 2003.

${ }^{435}$ A esse respeito, Fábio Nusdeo destaca que "haveria uma emenda constitucional destinada a desvincular a contribuição de melhoria da área exclusiva das obras públicas, para ampliá-la no sentido de a tornar cabível em duas mãos de direção: a primeira de atores ou grupos da sociedade que aufiram benefícios decorrentes de obras, iniciativas ou permissões, inclusive ambientais, do poder público e a segunda, de setores ou grupos da sociedade que gerem custos externos, incompensados, de qualquer natureza, inclusive não diretamente quantificáveis, quando incidentes sobre a sociedade como um todo ou parte dela, conforme definido em leis específicas emanadas dos poderes tributantes, com lei complementar delimitando-lhes as bases, diretrizes e condições para a cobrança”. NUSDEO, Fábio. A contribuição de melhoria revisitada: uma revisão e uma proposta. In: SCHOUERI, Luís Eduardo (org.). Direito tributário: homenagem a Alcides Jorge Costa. São Paulo: Quartier Latin, 2003, p. 685.

${ }^{436}$ NUSDEO, Fábio. . A contribuição de melhoria revisitada: uma revisão e uma proposta. In: SCHOUERI, Luís Eduardo (org.). Direito tributário: homenagem a Alcides Jorge Costa. São Paulo: Quartier Latin, 2003, p. 685.
} 
produto da arrecadação, em uma concepção extrafiscal, seria canalizado para um fundo especial, com três destinações básicas: a) fornecer ao poder público ou a organizações de caráter público recursos para a recuperação de bens atingidos pelas externalidades negativas de qualquer espécie; b) servir de fonte para subsídios necessários àqueles setores da sociedade que produzem externalidades positivas, sobretudo ambientais, como por exemplo, o reflorestamento, segundo exigências técnico-científicas e c) o financiamento, inclusive a fundo perdido, de pesquisas e estudos voltados ao desenvolvimento de novas tecnologias que, ao invés de consumir ou destruir bens coletivos, como os componentes do meio ambiente, poupem-nos, preservem-nos e os recuperem. ${ }^{437}$

Essa concepção da Contribuição de Melhoria também foi tratada por José Marcos Domingues, para quem: “é um tributo que, a par de seu potencial arrecadador (fiscal), pode transformar-se num elemento estimulador de grandes obras de profundo sentido ambiental (extrafiscal)". ${ }^{438}$ Como uma imagem no espelho, pode se vislumbrar uma Contribuição Negativa que, segundo esse mesmo autor, seria imposta no caso em que o Estado permite instalar uma fábrica geradora de resíduos, ou autoriza a construção de um aterro sanitário ou outra obra pública, oportunidade em que se verifica uma desvalorização de propriedade particular ${ }^{439}$.

Outrossim, tratando dos impostos, mencione-se que a extrafiscalidade está claramente estampada no Imposto sobre Produtos Industrializados - IPI, que se baseia no princípio da seletividade em função da essencialidade do produto art. 153, $\S 3^{\circ}$ da Constituição Federal - e, assim, pode ser facilmente aplicado para fins ambientais. Aliás, o IPI já foi utilizado dessa forma, o que se denota do Decreto Federal $\mathrm{n}^{\circ}$ 755, de 19.2.1993, que estabeleceu diferentes alíquotas para veículos movidos a gasolina e para veículos movidos a álcool. A ideia era incentivar a aquisição de carros a álcool, mas acabou, por via oblíqua,

\footnotetext{
${ }^{437}$ Idem, p. 685.

438 OLIVEIRA, José Marcos Domingues de. Direito tributário e meio ambiente. $3^{\mathrm{a}}$ ed. rev. e ampl. Rio de Janeiro: Forense, 2007, p. 95.

${ }^{439}$ Idem, p. 96.
} 
provocando um efeito positivo na proteção ambiental, eis que o álcool é sabidamente um combustível menos agressivo ao meio ambiente. ${ }^{440}$

Cite-se, ainda, o Imposto de Renda - IR, que pode ser utilizado com fins extrafiscais $^{441}$; o que, aliás, já ocorreu frente às disposições dos Decretos $n^{\circ}$ 5.106/1966, $n^{\circ}$ 93.607/1986 e no 96.233/1988. Embora não exatamente com objetivos ambientais, tais diplomas autorizavam a dedução de importâncias empregadas em projetos de reflorestamento. ${ }^{442}$

A par dessas intenções, vale apontar o já positivado Imposto sobre a Propriedade Predial e Territorial Urbana - IPTU progressivo no tempo, mediante o qual o tributo é elevado àqueles que não cumpram com a função social da propriedade, buscando, justamente, evitar a subutilização ou o subaproveitamento dos imóveis urbanos. ${ }^{443}$

Mister ainda mencionar a isenção do Imposto Territorial Rural - ITR nas áreas mantidas para a Reserva Legal. A respeito, Ana Maria de Oliveira Nusdeo destaca: “dentre os instrumentos já existentes, é interessante lembrar-se a isenção do Imposto Territorial Rural (ITR) sobre as áreas de reserva legal das propriedades rurais. A isenção representa uma articulação do instrumento de

\footnotetext{
${ }^{440}$ Acerca do IPI, é oportuno destacar o Projeto de Lei no 3.955/2004, que propõe, como medida extrafiscal, que o Imposto sobre Produtos Industrializados - IPI tenha redução de alíquota para máquinas, equipamentos e aparelhos antipoluidores, bem como suas partes, peças e acessórios, adquiridos pelas empresas industriais e agroindustriais, desde que destinados ao uso próprio do beneficiário e diretamente vinculados a suas unidades de produção. Esse Projeto de Lei encontra-se arquivado na Câmara dos Deputados, desde 31 de janeiro de 2011. O arquivamento se baseou no art. 105 do seu Regimento Interno. Disponível em: $<$ http://www.camara.gov.br/proposicoesWeb/fichadetramitacao?idProposicao=260546>. Acesso em: 2.12.2011.

${ }^{441}$ Mencione-se uma interessante iniciativa de criação de um Imposto de Renda Ecológico, cuja proposta está em trâmite no Congresso Nacional através do Projeto de Lei ${ }^{\circ}$ 5.974/2005. A exemplo da famosa Lei Rouanet, que dá incentivos fiscais àqueles que investem em cultura, esse PL sugere um abatimento substancial no imposto de renda das pessoas físicas e jurídicas que invistam em projetos ambientais. O projeto prevê que a dedução do tributo a pagar por pessoas físicas e jurídicas seja revertida na destinação de recursos a projetos ambientais de entidades não governamentais. Por evidente, serão projetos que deverão ser previamente aprovados pelo Ministério do Meio Ambiente, mediante a garantia do uso sustentável dos recursos naturais e a preservação do meio ambiente, enquadrando-se nas diretrizes, prioridades e normas do Fundo Nacional do Meio Ambiente. O último andamento desse Projeto perante a Câmara dos Deputados foi o apensamento do PL 7224/2010, em 12.5.2010. Esse último propõe a concessão de incentivo fiscal do Imposto sobre a Renda às pessoas físicas ou jurídicas que implantarem projetos de reflorestamento e florestamento e de preservação do meio ambiente. Disponível em: $<$ http://www.camara.gov.br/proposicoesWeb/fichadetramitacao?idProposicao=301799>. Acesso em: 2.12.2011.

${ }^{442}$ Segundo esses diplomas, as pessoas físicas e jurídicas podiam abater de suas declarações de rendimento as importâncias empregadas em florestamento e reflorestamento.

${ }^{443}$ Lei n ${ }^{\circ} 10.257 / 2001$ (Estatuto da Cidade), art. $7^{\circ}$.
} 
controle consistente na obrigação de manutenção da reserva legal, com a atribuição de uma recompensa a propriedade pela externalidade positiva”. ${ }^{444}$

Da mesma maneira, não se deve esquecer o Imposto Sobre os Serviços ISS, que pode vir a ser utilizado pela autoridade pública mediante a concessão de incentivos àqueles que prestem serviços que protejam o meio ambiente, como, por exemplo, o ecoturismo.

O Estado de São Paulo, por meio da Lei $n^{0}$ 6.606, de 20.12.1989, com a redação das Leis $n^{0}$ 7.644/1991 e $n^{0}$ 9.459/1996, de igual modo prevê tributação diferenciada para o Imposto sobre Veículos Automotores - IPVA: 3\% para automóveis e camionetas de uso misto, movidos a álcool, gás natural ou eletricidade; $4 \%$ para automóveis de passeio e camionetas de uso misto em geral; e 6\% para automóveis de passeio movidos a óleo diesel. ${ }^{445}$

Por fim, mas não menos importante, cite-se o ICMS Ecológico ${ }^{446}$ como outro exemplo de extrafiscalidade que - muito embora não tenha repercussões diretas no comportamento do produtor e/ou do contribuinte, eis que não se aplica diretamente sobre a produção e/ou a aquisição de bens, mas, sim, sobre a destinação da arrecadação - vem sendo muito evidenciado pela doutrina como um meio tributário eficiente para a proteção do meio ambiente. Com efeito, ele leva uma maior destinação de parcela desse tributo pelos estados aos municípios em razão de sua adequação a níveis legalmente estabelecidos de preservação ambiental e de melhoria da qualidade de vida. ${ }^{447}$

\footnotetext{
${ }^{444}$ NUSDEO, Ana Maria de Oliveira. O uso dos instrumentos econômicos nas normas de proteção ambiental. Revista da Faculdade de Direito da Universidade de São Paulo. v. 101. jan/dez, 2006, p. 373.

${ }_{445}$ OLIVEIRA, José Marcos Domingues de. Direito tributário e meio ambiente. $3^{\mathrm{a}}$ ed. rev. e ampl. Rio de Janeiro: Forense, 2007, p. 76. Esse autor cita inúmeros outros exemplos de normas federais e estaduais que impõe incentivos por meio de tributos.

${ }^{446}$ Conforme se verá na nota de rodapé 455, o governo brasileiro vem compreendendo o ICMS Ecológico como uma forma de Pagamento por Serviços Ambientais. No nosso modo de ver, é uma maneira de induzir a implementação de programas ambientais por parte dos municípios beneficiados por esse tributo, e não um meio de pagar pelos serviços oferecidos pela natureza (como é o caso de atividades extrativistas, em que se paga um determinado valor àquele que pratica o extrativismo para manter a qualidade ambiental como forma de permitir a perpetuidade da prestação dos serviços ambientais pela natureza).

${ }^{447} \mathrm{O}$ Estado do Paraná foi pioneiro na concepção do instituto e, como tal, o primeiro a experimentar resultados externamente positivos da adoção do ICMS Ecológico. O número de municípios beneficiados eleva-se a cada ano. Em 1992, foram 112; em 1998, o número chegou a 192. Consequentemente, os dados da preservação ambiental do Estado mantêm-se em constante crescimento. Estima-se que desde a aprovação da Lei do ICMS Ecológico, em 1991, as áreas protegidas no Paraná aumentaram 950\%.
} 


\subsubsection{Pagamento por Serviços Ambientais - PSA}

Os recursos naturais, além de propiciar matéria-prima para o processo produtivo, e condições capazes de degradar os resíduos e bens de consumo não mais necessários ou desejados, também oferecem importantes serviços ambientais, podendo ser exemplificados como a polinização natural, a ciclagem de nutrientes do solo, o fluxo de genes, a manutenção do volume e qualidade dos recursos hídricos, o sequestro de carbono que permite a estabilização climática, entre outros ${ }^{448}$.

Diante disso, em respeito à essa segunda categoria de serviços propiciados pelos recursos naturais, raramente valorada, e da síntese entre a necessidade premente de salvar da natureza o que restava e restaurar o que fora destruído, a dificuldade de estabelecer preços para os bens ambientais, e a constatação da relativa ineficácia dos mecanismos de comando e controle meramente coercitivos, surgiu o conceito de PSA - Pagamento por Serviços Ambientais $^{449}$.

Para Ana Maria de Oliveira Nusdeo, “entende-se como pagamento por serviços ambientais (florestais) a remuneração, em espécie monetária ou por outros meios, para agentes determinados, responsáveis pela conservação ou reflorestamento de áreas específicas a fim de propiciar à natureza a prestação por um determinado serviço ambiental.” Esse pagamento, ainda de acordo com essa autora, “pode ser efetuado tanto por agentes privados usuários do serviço quanto pelo poder público enquanto representante da coletividade beneficiada pelo mesmo". 450

A bem ver, a ideia de Pagamento por Serviços Ambientais - PSA surge como um instrumento econômico para corrigir, parcialmente, a 'falha de

\footnotetext{
${ }^{448}$ NUSDEO, Ana Maria de Oliveira. Pagamento por serviços ambientais no Brasil: elementos para uma regulamentação ambientalmente íntegra e socialmente justa. Tese apresentada à Faculdade de Direito da Universidade de São Paulo para obtenção do título de Livre-Docente. São Paulo/2010, p. 81.

${ }^{449}$ MILARÉ, Édis. Direito do ambiente. $7^{\mathrm{a}}$ ed. São Paulo: RT, 2011, p. 382. O mesmo autor esclarece que a primeira iniciativa do PSA ocorreu na Costa Rica, na década de 80. Segundo a WWF, o estímulo remunerado a quem protege as florestas nesse país contribuiu para o aumento da cobertura florestal de $32 \%$ para $45 \%$ do território nacional, entre 1990 e 2002.

${ }^{450}$ NUSDEO, Ana Maria de Oliveira. Ob. cit., p. 83-84
} 
mercado' decorrente dos bens públicos ${ }^{451}$, significando a necessidade de os beneficiários dos serviços prestados pelos recursos naturais pagarem por ele. Sendo assim, realiza-se por transferências financeiras de beneficiados de serviços ambientais para os que, devido a práticas que conservam a natureza, fornecem esses serviços. ${ }^{452}$ No entanto, conforme pontua Ana Maria de Oliveira Nusdeo, “a lógica econômica por trás dos pagamentos não significa uma lógica de mercado”. ${ }^{453}$ De fato, a lógica do Pagamento por Serviços Ambientais - PSA é outra e se subsume a um novo princípio do Direito Ambiental, considerado como o princípio do conservador credor ou princípio do protetor recebedor. Acerca desse princípio, novamente nos socorremos do ensinamento de Ana Maria de Oliveira Nusdeo, para quem:

A proposta de pagamento ao protetor, assim, trata de retirar da esfera daquele que preserva, total ou parcialmente, os custos da preservação, podendo chegar mesmo a permitir que aufira algum ganho com a proteção. Coloca-se então como o oposto do poluidor-pagador e do usuário-pagador. ${ }^{454}$

Há inúmeros exemplos nacionais ${ }^{455}$ e internacionais ${ }^{456}$ de iniciativas de Pagamento por Serviços Ambientais. No Brasil, o Acre foi o primeiro estado

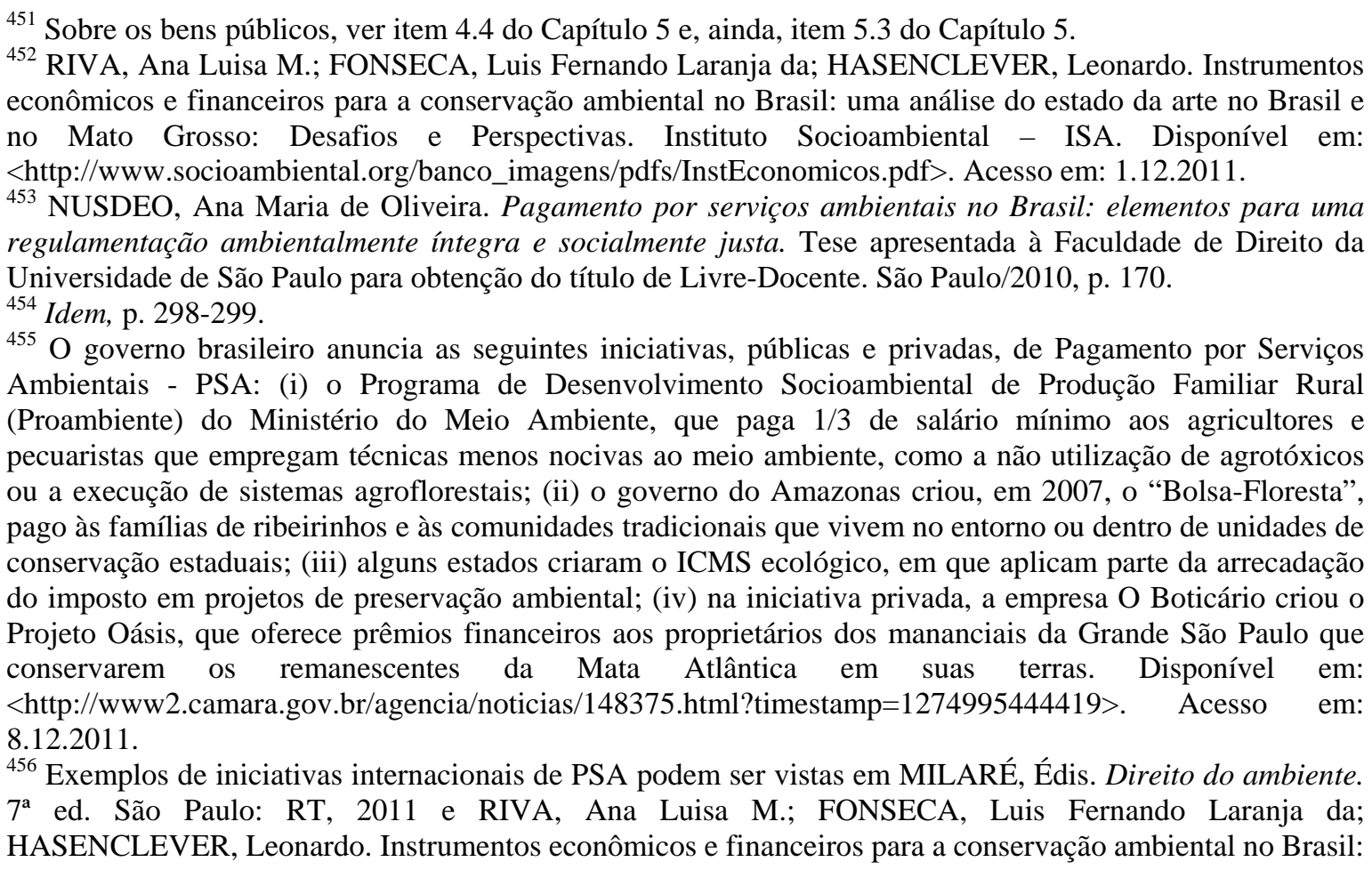


que avançou nas discussões sobre esse instrumento, prestados por áreas de floresta. Nesse estado permite-se que o executivo subsidie o quilo de borracha natural produzida por seringueiro, de forma a agregar valor ao seringal nativo. Esse mecanismo - tido como mecanismo ou instrumento híbrido, pois contempla tanto o subsídio quanto o PSA - foi criado para contornar a falta de estrutura legal de modo a permitir ao Poder Público transferir fundos públicos, ou captar recursos do setor privado nacional e internacional, para o pagamento direto por serviços ambientais. ${ }^{457}$

À derradeira, é oportuno destacar serem bastante embrionárias as normas que tratam do PSA, não impondo uma obrigação cogente, mas apenas possibilidade de adesão voluntárias a projetos específicos. Em outros termos, louvando-nos novamente das lições de Édis Milaré, “vincula-se assim, sua viabilidade à vontade dos particulares de firmarem contratos para gerir relações dessa natureza, ou de aderirem aos programas a serem instituídos pelo Estado ou pelos Municípios conveniados”. E, ainda, “o mesmo se diga quanto aos projetos em trâmite na esfera federal, cujo conteúdo não permite antever - salvo, é claro, a apresentação de emendas específicas nesse sentido - a adoção da obrigatoriedade de pagamento por serviços ambientais diretamente dos beneficiários aos prestadores”. ${ }^{458}$

\subsubsection{Subsídios}

"Subsidies are the mirror image of taxes and, in theory, can provide incentives to address environmental problems. 459

uma análise do estado da arte no Brasil e no Mato Grosso: Desafios e Perspectivas. Instituto Socioambiental - ISA. Disponível em: <http://www.socioambiental.org/banco_imagens/pdfs/InstEconomicos.pdf>. Acesso em: $1^{\circ} .12 .2011$.

${ }^{457}$ RIVA, Ana Luisa M.; FONSECA, Luis Fernando Laranja da; HASENCLEVER, Leonardo. Instrumentos econômicos e financeiros para a conservação ambiental no Brasil: uma análise do estado da arte no Brasil e no Mato Grosso: Desafios e Perspectivas. Instituto Socioambiental - ISA. Disponível em: $<$ http://www.socioambiental.org/banco_imagens/pdfs/InstEconomicos.pdf>. Acesso em: 1º.12.2011.

${ }^{458}$ MILARÉ, Édis. Ob. cit., p. 393.

${ }^{459}$ REVESZ, Richard L. STAVINS, Robert N. Environmental Law and Policy. NYU Public Law Research Paper 82; NYU Law \& Econ Research Paper 04-015; Harvard Public Law Working Paper No. 102; KSG Working Paper No. RWP04-023, September, 2004. Disponível em: <http://ssrn.com/abstract=552043>. Acesso em: 3.10.2011. Os autores salientam que "Although subsidies can advance environmental quality 
A respeito dos subsídios, Ronaldo Seroa da Motta et al. informam que “é comum também se propor que, ao invés de tributos sobre usuários e poluidores, que acabam por onerar as atividades econômicas, dever-se-iam oferecer subsídios”. 460

Sabe-se que os subsídios são apoios monetários estatais a certas atividades ou setores econômicos, e objetivam impulsionar a produção de um determinado bem. Exemplificativamente, cite-se estudo da OCDE, de 2007. Nele se divulgou que o Brasil era um dos países que mais fornece subsídios para seus agricultores. A mesma organização revelou que dois terços dos subsídios aos produtores eram concedidos na forma de crédito subsidiado, e um terço por meio de políticas de garantia de preço mínimo. ${ }^{461}$

Ainda ilustrativamente, vale citar recente subsídio criado pelo Estado de São Paulo, cuja Assembleia Legislativa aprovou, em 8 de dezembro de 2011, um Projeto de Lei que cria o programa Pró-Conexão, de autoria do executivo estadual. O programa oferecerá subsídio financeiro à população de baixa renda para realizar obras necessárias à implantação de ligações domiciliares de esgoto. Segundo notícias divulgadas na mídia ${ }^{462}$, o Estado realizou um diagnóstico, no qual se constatou que parte considerável da sua população carente residia em áreas onde havia sistema de esgoto, mas não dispunha de recursos para solicitar a ligação de seu domicílio à rede pública. Dessa forma, o Estado de São Paulo subsidiará esse programa cujo custo médio da ligação foi avaliado em R\$ 1.820,00 (hum mil oitocentos e vinte reais).

Outrossim, dentro da categoria dos subsídios a produtos e tecnologias menos lesivas ao meio ambiente, recorde-se o Programa de Incentivo às Fontes

(see, for example, Jaffe and Stavins 1995), it is also true that subsidies, in general, have important disadvantages relatives to taxes (Dewees and Sims 1976; Baumol and Oates 1988). Because subsidies increase profits in an industry, they encourage entry, and can thereby increase industry size and pollution output (Mestelman 1982, Kohn 1985).”

460 SEROA DA MOTTA, Ronaldo; OLIVEIRA, José Marcos Domingues de; MARGULIS, Sergio. proposta de tributação ambiental na atual reforma tributária brasileira. IPEA. Texto para discussão n ${ }^{\circ}$ 738, 2000. Disponível em: < http://www.ipea.gov.br/pub/td/td_2000/td0738.pdf>. Acesso em: 3.12.2011.

${ }^{461}$ No período 2003-2005, os subsídios aos produtores rurais brasileiros representaram 5\% do valor bruto das receitas agrícolas, sendo bem abaixo da média de 30\% exibida pelos países membros da OCDE (como França, Itália, EUA e Inglaterra). Disponível em: < http://www.bbc.co.uk/portuguese/reporterbbc/ story/2007/03/070315_ocdesubsidios.shtml>. Acesso em: 10.12.2011.

${ }^{462}$ Vide jornal Valor Econômico, de 9, 10 e 11.12.2011. 
Alternativas de Energia Elétrica - PROINFRA, criado pelo Decreto $\mathrm{n}^{\mathrm{o}}$ 5.025/2004. A sistemática do programa consiste no estabelecimento de dois tipos de quotas, uma para custeio do programa (quotas de custeio) e outra para a garantia da comercialização da energia gerada por fontes alternativas nas usinas (quotas de energia). A quota de custeio é recolhida pelos agentes distribuidores na venda aos consumidores cativos ou transmissores com base na energia consumida pelos consumidores finais (residenciais ou industriais), exceto aqueles classificados na subclasse residencial de baixa renda. A quota de energia, por sua vez, é proveniente das fontes alternativas, obrigatoriamente adquirida pelos que compram energia elétrica: distribuidores, comercializadores, autoprodutores e consumidores livres. ${ }^{463}$

Os subsídios, no entanto, não deixam de ser criticados. A esse respeito, Seroa et al. alertam que:

na verdade, a curto prazo tanto os subsídios como os tributos induzem o alcance do mesmo objetivo ambiental. No entanto, existem dois problemas com os subsídios, a saber: a) seu financiamento é formado de saques da arrecadação tributária total e, portanto, ou terminaria por impor aumentos na carga fiscal ou por reduzir gastos governamentais em outros setores. Dessa forma, seriam os contribuintes de outros tributos que pagariam a conta ambiental, independentemente de quanto contribuíram para o problema ambiental; e b) se no curto prazo a consecução de metas ambientais é indiferente quanto ao tributo ou subsídio, no longo prazo o subsídio, ao reduzir o custo privado de degradar, estimula justamente as atividades intensivas em uso de recursos ambientais (seja como insumo, ou consumo direto, seja para lançamento de poluentes) e retarda o avanço tecnológico. 464

\footnotetext{
${ }^{463}$ NUSDEO, Ana Maria de Oliveira. O uso dos instrumentos econômicos nas normas de proteção ambiental. Revista da Faculdade de Direito da Universidade de São Paulo. v. 101. jan/dez, 2006, p. 374. A autora observa que o PROINFRA deve ser planejado através de um plano anual elaborado pela Eletrobrás, e deve conter o demonstrativo dos benefícios financeiros provenientes do Mecanismo de Desenvolvimento Limpo, criado pelo Protocolo de Quioto, numa demonstração de que se espera valer-se da possibilidade de transacionar redução de emissão de gases de efeito estufa, a partir da produção de energia elétrica por fontes alternativas. Ao final, Nusdeo frisa que, tratando-se de importante questão ambiental, seria importante que essa medida, criada no âmbito da política de energia elétrica do país, fosse mais bem articulada com a política ambiental.

${ }^{464}$ SEROA DA MOTTA, Ronaldo; OLIVEIRA, José Marcos Domingues de; MARGULIS, Sergio. Proposta de tributação ambiental na atual reforma tributária brasileira. IPEA. Texto para discussão $n^{\circ}$ 738, 2000. Disponível em: < http://www.ipea.gov.br/pub/td/td_2000/td0738.pdf>. Acesso em: 3.12.2011.
} 
A bem ver, os subsídios não parecem aplicar-se como instrumento econômico duradouro, embora por questões estratégicas possam ser bem utilizados ocasional e temporariamente. ${ }^{465}$

\subsubsection{Instrumentos de criação de mercado}

Os mais conhecidos instrumentos de criação de mercado são mecanismos que alocam direitos de uso aos agentes econômicos. Esses direitos, que no agregado não excedem o total de uso socialmente desejado, podem, todavia, ser transacionados entre os agentes econômicos. As suas características principais são: (i) alteram, via alocação e comercialização, os direitos de uso de bens e serviços; (ii) essa alocação de direitos está relacionada com o objetivo da política; (iii) são economicamente equivalentes ao instrumento precificado, só que ajustam por quantidade e não pelo preço dos bens e serviços; (iv) não requerem, entretanto, o conhecimento a priori da reação do agente ao preço dado, pois são os próprios agentes que irão criar um mercado para realocar esses direitos, definindo preços de transação; (v) a regra de comercialização e o nível inicial de alocação dependem também do objetivo da política; e (vi) para a maximização de bem-estar requerem o conhecimento prévio da quantidade social ótima e da quantidade de direitos. ${ }^{466}$

Nesse entendimento, mencione-se novamente o conhecido "Mecanismo de Desenvolvimento Limpo" - MDL, que torna eficaz o Protocolo de Kyoto mediante a instituição de um mercado de venda de créditos de carbono. A bem ver, o MDL é um dos mais importantes instrumentos econômicos de flexibilização estabelecidos pelo referido Protocolo com a tarefa de facilitar o atingimento das metas de redução de emissão de gases de efeito estufa, metas essas definidas para os países que ratificaram tal documento. A proposta do MDL (descrita no art. 12 do Protocolo) consiste, em síntese, em que cada tonelada de $\mathrm{CO}_{2}$ que deixar de ser emitida ou for retirada da atmosfera por um

\footnotetext{
${ }^{465}$ SEROA DA MOTTA, Ronaldo; OLIVEIRA, José Marcos Domingues de; MARGULIS, Sergio. Ob. cit. 466 SEROA DA MOTTA, Ronaldo. Instrumentos econômicos e política ambiental. Revista de Direito Ambiental, n. 20, out/dez, 2000.
} 
país em desenvolvimento, poderá ser negociada no mercado mundial, criando novo atrativo para a redução das emissões globais.

Porém, os instrumentos de criação de mercado não se limitam à comercialização do direito de uso por agentes econômicos; há, de fato, inúmeras opções que vêm sendo aplicadas - algumas passando, inclusive, a ser positivadas -, como é o caso dos sistemas de depósito e reembolso e as chamadas 'iniciativas de intervenção na demanda final' através da educação e informação aos consumidores. ${ }^{467}$

Nesse sentido, cite-se a conhecida Certificação ISO 14000 e outros "selos verdes”, pelos quais uma determinada empresa ou atividade (inclusive prestação de serviços) tem condições de cumprir uma série de normas ${ }^{468}$ que mostram a sua boa gestão ambiental e responsabilidade para com a sociedade e com o meio ambiente. Muitas empresas usam a certificação ou o “selo verde” juntamente com a sua logomarca, como uma espécie de marketing para atrair clientes preocupados com a proteção da natureza e, assim, vender seus produtos. É, certamente, uma espécie de instrumento que, se bem implementado, faz com que ganhe a empresa, ganhe o meio ambiente e ganhe o consumidor.

Vale ainda considerar os instrumentos de informação, como a rotulagem de produtos poluidores ou ofensivos à saúde, como ainda a informação que incentiva o consumo, como a mensagem sobre a eficiência energética ou utilização de produtos 'limpos' ou 'ambientalmente corretos, ${ }^{469}$.

\footnotetext{
${ }^{467}$ NUSDEO, Ana Maria de Oliveira. O uso dos instrumentos econômicos nas normas de proteção ambiental. Revista da Faculdade de Direito da Universidade de São Paulo. v. 101. jan/dez, 2006, p. 369.

${ }^{468}$ As normas da ISO 14000 são desenvolvidas pela International Organization for Standardization - ISO. Trata-se, em suma, de uma série de normas que estabelecem diretrizes sobre a área de gestão ambiental dentro de uma empresa. Sobre a Certificação ISO 14000, ver D’ISEP, Clarissa Ferreira Macedo. Direito ambiental econômico e a ISO 14000: Análise jurídica do modelo de gestão ambiental e certificação ISO 14001. $2^{\mathrm{a}}$ ed. rev. atual. e ampl. São Paulo: RT, 2009.

${ }^{469}$ For example, the U.S. Energy Policy and Conservation Act of 1975 specifies that certain appliances and equipment carry labels with information on products' energy efficiency and estimated energy costs (U.S. Congress, Office of Technology Assessment 1992). More recently, EPA and the U.S. Department of Energy developed the Energy Star program, in which energy efficient products can display an EnergyStar label. And since 1976, the Department of Energy has provided no-cost energy assessments to small and medium-sized manufacturers through its university-based Industrial Assessment Centers (IAC) program. There has been relatively little analysis of the efficacy of such programs, but limited empirical (econometric) evidence suggests that energy-efficiency product labeling has had significant impacts on efficiency improvements, essentially by making consumers and therefore producers more sensitive to energy price changes (Newell, Jaffe, and Stavins 1999). Also, about half of the projects recommended by assessment teams in the IAC program were subsequently adopted, with firms applying a one to two-year payback period (or about a 50 to 100 percent hurdle rate) to the decisions (Anderson and Newell 2004). REVESZ, Richard L. STAVINS,
} 
Na mesma direção dos “selos verdes”, da Certificação pela ISO 14000, dos mecanismos de informação, como a rotulagem, e de medidas correlatas usualmente utilizadas pelas empresas privadas, saliente-se a licitação sustentável, que, se bem implementada, servirá também para um bom marketing para os governos municipais, estaduais e federais, demonstrando o seu cuidado para com o meio ambiente. A licitação sustentável é uma intenção de vários organismos públicos e privados, que vem sendo muito discutida no âmbito das Nações Unidas, através de seu Programa das Nações Unidas para o Meio Ambiente (PNUMA). Nesse âmbito, definiu-se que a licitação sustentável é processo pelo qual as organizações adquirem suprimentos ou contratam serviços, levando em consideração aspectos como: (i) o melhor valor para considerações monetárias que incluam a análise de preço, qualidade, disponibilidade, funcionalidade, dentre outras; (ii) aspectos ambientais ("licitação verde"), que constituem os efeitos sobre o meio ambiente que o produto e/ou serviço provocam em todo o seu ciclo de vida, ou seja, do berço ao túmulo; (iii) o ciclo de vida integral dos produtos; e (iv) aspectos sociais: efeitos sobre questões sociais, tais como a erradicação da pobreza, equidade internacional na distribuição de recursos, direitos trabalhistas, direitos humanos. ${ }^{470}$

Ademais, também vêm sendo instituídos instrumentos econômicos que visam a incentivar atitudes “mais verdes” ou ambientalmente responsáveis, inclusive para as instituições financeiras. Nesse sentido, vale citar os "Princípios do Equador”, um mecanismo de análise de financiamento de projetos que priorizam padrões de políticas de sustentabilidade e desempenho com base nas diretrizes do International Finance Corporation - IFC, braço financeiro do Banco Mundial, e são mundialmente aplicados na implementação de projetos de todos os setores de atividades com valores de US\$ 10 milhões de dólares ou mais. Esses princípios vêm tendo a adesão também dos bancos particulares.

Robert N. Environmental Law and Policy. NYU Public Law Research Paper 82; NYU Law \& Econ Research Paper 04-015; Harvard Public Law Working Paper No. 102; KSG Working Paper No. RWP04-023, September, 2004. Disponível em: <http://ssrn.com/abstract=552043>. Acesso em: 3.10.2011.

${ }^{470}$ A inclusão de princípios de desenvolvimento sustentável nas práticas licitatórias já é uma realidade em vários países como o Canadá, Japão, Áustria, Itália, Países Baixos, Noruega, Estados Unidos e África do Sul. As experiências nesses países indicam que incluir considerações sobre consumo e produção sustentável nas opções de compra pelo poder público não só é viável, como ainda têm o importante papel de incentivar um mercado sustentável. 
Nesse mesmo compasso, mencione-se a carta de princípios denominada “Protocolo Verde”, criada em 1995 pelos bancos oficiais brasileiros. Seu objetivo é incorporar a variável ambiental no crédito e, desse modo, evitar o uso de recursos públicos em atividades lesivas ao meio ambiente. Os compromissos previstos no Protocolo, firmado, como dito, em 1995, foram ratificados e intensificados, em 2009, em um Protocolo de Intenções - vulgarmente chamado de “Protocolo Verde II" - firmado pelo Ministério do Meio Ambiente - MMA e pela Federação Brasileira de Bancos - Febraban. A esse pacto já aderiram vários bancos privados. Fundamentando-se no artigo 12 da Lei n ${ }^{\circ} 6.938 / 1981,{ }^{471}$ o “Protocolo Verde” estabelece a perda ou restrições sobre benefícios fiscais concedidos pelo Poder Público ou sobre linhas de crédito em bancos oficiais para quem descumpri-lo.

Aponte-se, outrossim, o “Índice Carbono Eficiente” - ICO2. Trata-se de outro indicador de mercado, visando a estimular práticas sustentáveis, mais especificamente voltadas para o combate às mudanças climáticas. Criado em conjunto entre a BM\&F Bovespa e o Banco Nacional de Desenvolvimento Econômico e Social - BNDES, o ICO2 busca incentivar as empresas emissoras das ações mais negociadas a aferir, divulgar e monitorar suas emissões de gases causadores do efeito estufa (GEE), ingressando assim no chamado "mercado de baixo carbono". 472

Mencione-se, também, o “Índice de Sustentabilidade Empresarial”, criado a partir de uma iniciativa da Bolsa de Valores de São Paulo - Bovespa, ${ }^{473}$ para avaliar ações de determinadas empresas comprometidas com políticas

\footnotetext{
471 "As entidades e órgãos de financiamento e incentivos governamentais condicionarão a aprovação de projetos habilitados a esses benefícios ao licenciamento, na forma desta Lei, e ao cumprimento das normas, dos critérios e dos padrões expedidos pelo CONAMA."

${ }^{472}$ MILARÉ, Édis. Direito do ambiente. $7^{\mathrm{a}}$ ed. São Paulo: RT, 2011, p. 399-400. Esse autor explica, ainda, que "esse indicador, composto pelas ações das companhias participantes do índice IBrX-505 que aceitaram participar dessa iniciativa, leva em consideração, para ponderação das ações das empresas componentes, seu grau de eficiência de emissões de GEE, além do free float (total de ações em circulação) de cada uma delas. Em 2010, as trinta e cinco empresas participantes não foram obrigadas a apresentar inventário de emissões para fazer parte da carteira. A partir de 2011, passou a ser obrigatória a realização desse balanço pelas empresas, incluindo-se emissões diretas e emissões geradas pelo consumo de energia elétrica”.

${ }^{473}$ No ano de 2010, trinta e oito grandes companhias preencheram os requisitos para fazer parte deste índice, mostrando possuírem compromisso com o desenvolvimento sustentável formalmente inserido em suas estratégias, em especial com os temas: respeito ao meio ambiente, práticas éticas de negócio e relações com clientes e consumidores.
} 
socioambientais corretas. Essa iniciativa permite que os investidores privilegiem as empresas que atuam de forma sustentável, ou por razões éticas ou porque elas têm mais chances de permanecer produtivas pelas próximas décadas, pois sofrerão menos com passivos ambientais. De fato, esse Índice é composto por empresas que se destacam em responsabilidade socioambiental e em sustentabilidade a longo prazo, o que estimula boas práticas por parte das demais empresas que visam a integrá-lo. Afinal, empresas irresponsáveis podem causar enormes passivos em termos ambientais, os quais têm o condão de ensejar indenizações milionárias para a devida recuperação do meio ambiente e reparar os terceiros afetados, circunstância que, evidentemente, implica a desvalorização das suas ações no mercado.

\subsection{Conclusões preliminares}

Consoante aludido no início deste capítulo, a intenção era aqui demonstrar o porquê e como o Estado regula práticas visando à preservação ambiental.

Na busca do porquê, verificou-se como o Estado enfrenta os conflitos ou as “falhas de mercado" que são inerentes ao sistema econômico vigente. E o faz impondo-se como uma destacada estrutura da sociedade civil e do mercado para, assim, regular condutas que permitam reproduzir e manter o sistema econômico vigente e, ao mesmo tempo, atender os interesses que são contrários ao poderio do mercado, como os sociais, ambientais, trabalhistas etc. Segundo sustentamos, ao conformar tais conflitos, atendendo ora aos interesses de um lado, ora aos interesses do outro, o Estado acaba por manter equilíbrio ou o marco de elasticidade do sistema econômico vigente.

Mesmo porque, se não forem contidas as forças do mercado, elas buscarão a máxima utilização dos recursos naturais, com o menor custo possível, o que significará, a um só tempo, a destruição do meio ambiente e do próprio sistema econômico. Daí surgirem as regras e limites para a utilização dos recursos naturais. 
O Estado, ao instituir e implementar políticas públicas ambientais, utiliza-se, como visto, de inúmeros instrumentos capazes de alcançar os seus objetivos e metas, quais sejam resguardar o meio ambiente e estabelecer critérios para a utilização racional dos seus recursos.

Antes, porém, procurou-se demarcar as dificuldades para a valoração dos bens ambientais, sendo elas decorrentes, a uma, da própria lógica do mercado, segundo a qual não se podem incluir plenamente os custos dos bens ambientais nos custos da produção e consumo, sob pena de impedir o lucro e a competitividade e, então, o próprio mercado; e, a duas, os empecilhos inerentes aos próprios bens da natureza, seja porque bens públicos, seja porque essa dificuldade de valoração é uma característica própria dos recursos naturais (basta perguntar: quanto vale uma árvore, uma espécie da fauna, o ar puro?).

Tendo claras essas dificuldades, mostrou-se que elas fazem parte do sistema econômico em que vivemos, que impõe, por conseguinte, um déficit necessário em relação à possibilidade de internalização dos custos pela utilização dos recursos naturais na cadeia produtiva. Bem por isso, com a tarefa de edificar e implementar mecanismos e instrumentos buscando a proteção ambiental, em todos os seus aspectos, não cabe a ilusão ou a ingenuidade de propor uma efetiva valoração dos bens ambientais, significando uma internalização plena dos custos pela sua utilização dos seus recursos. Ao contrário, deve-se buscar o melhor ou melhores instrumentos para alcançar esse objetivo, com base em critérios econômicos, que viabilizem o melhor custobenefício, ou o grau ótimo que se quer alcançar com tal utilização.

Por conseguinte, para equacionar a crise ambiental, no contexto do desenvolvimento econômico, o Estado, procura ou deve procurar, estruturar políticas ambientais, fundamentadas em uma análise econômica, e destinadas a mostrar os mecanismos e instrumentos viáveis para o alcance dos seus objetivos, evitando que se criem outras falhas de mercado, como monopólios, desemprego etc. Essas políticas de caráter público servem-se de inúmeros modelos de processos, como administrativos, econômicos, bancários, mercadológicos, judiciais, tributários etc.

Daí que os instrumentos e mecanismos, como se viu, são de diversas naturezas, podendo ser classificados como de intervenção, de comando $e$ 
controle, repressivos, e econômicos. Embora todos tenham, em última instância, uma repercussão econômica, pois refletem nos custos da produção e do consumo, deu-se foco neste estudo aos mecanismos de comando e controle e aos econômicos propriamente ditos, por se acreditar que, nas políticas ambientais, são eles que ganham o papel central na busca e alcance dos seus objetivos e metas.

Foi possível arrolar exemplos de mecanismos de comando e controle e de instrumentos econômicos; tudo, para demonstrar as suas características e como podem ser numerosos e complexos.

Ao final, foi ainda possível verificar que criar e implementar mecanismos e instrumentos na política de proteção ambiental é tarefa árdua. Há inúmeras dificuldades em encontrar um instrumento, em delimitar a sua equação e, por fim, em perceber seus resultados. Nesse sentido, é sempre mais importante buscar os instrumentos mais viáveis, do que os melhores ou mais desejáveis.

Como exemplo dessa complexidade, cite-se o Projeto de $\mathrm{Lei}^{474}$ do novo Código Florestal, que, no início de dezembro, foi aprovado pelo Senado Federal, e no qual se prevê um programa de apoio e incentivo à preservação e recuperação do meio ambiente. Esse programa estabelece que o Poder Executivo Federal ficará autorizado a instituir, no prazo de 180 dias, contados da data da publicação da lei, programa de apoio e incentivo à conservação do meio ambiente.

Esse apoio e incentivo se centrarão na adoção de tecnologias e boas práticas agropecuárias que conciliem a produtividade com a redução de impactos, no âmbito do que poderão ser concedidos benefícios creditícios, financeiros e tributários aplicáveis à recuperação de áreas desmatadas antes de 22 de julho de 2008. Tal diretriz abrange as seguintes categorias e linhas de ação: (i) pagamento ou incentivo a serviços ambientais como retribuição ou não, às atividades de conservação e melhoria dos ecossistemas e que geram serviços ambientais, (ii) compensação pelas medidas de conservação ambiental, necessárias para atingir os objetivos da eventual futura lei, (iii) utilização de créditos agrícolas com juros menores que os praticados pelo mercado, (iv)

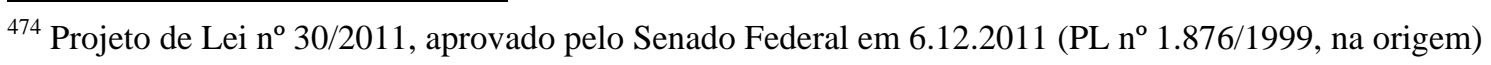


contratação de seguro agrícola em melhores condições, (v) dedução das áreas de preservação permanente - APPs, reservas florestais legais - RFLs e áreas de uso restrito da base de cálculo do Imposto Territorial Rural - ITR, e (vi) linhas de financiamento para atender a iniciativas de preservação voluntária de vegetação nativa.

Outrossim, para financiar as atividades necessárias à regularização ambiental das propriedades rurais, o programa poderá prever, dentre outras medidas, (i) a utilização de fundos públicos para concessão de créditos reembolsáveis e não reembolsáveis destinados à compensação, (ii) recuperação ou recomposição de áreas de preservação permanente e reservas florestais legais, e (iii) dedução da base de cálculo do Imposto sobre a Renda do proprietário de imóvel com os gastos efetuados com a recuperação dessas Áreas de Preservação Permanente - APPs e Reservas Florestais Legais - RFLs.

Daí se vê o quão complexa pode ser a elaboração de uma determinada política ambiental, que combina e entrelaça diversos mecanismos de comando e controle e instrumentos econômicos.

“O fato concreto é que sem a aplicação de um todo coerente e orgânico de medidas, o mal não regridirá. Pelo contrário, a sua tendência será a de se expandir contínua e cumulativamente, como, aliás, o demonstram os dados disponíveis, tanto os referentes ao país quanto ao exterior. Como ocorre com todos os fenômenos de saturação, o tempo somente trabalha contra; nunca a favor." 475

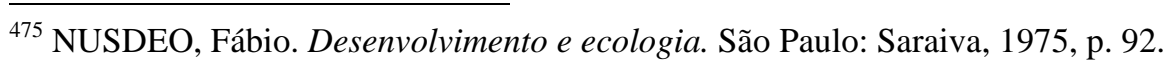




\section{AS MEDIDAS COMPENSATÓRIAS}

\subsection{Escopo do capítulo}

Conforme visto tantas vezes durante esta tese, as medidas compensatórias são um instituto cada vez mais presente no licenciamento ambiental e, por decorrência, na iniciativa daqueles que procuram empreender projetos ou atividades que causam impactos negativos no meio ambiente. São novas obrigações no campo do direito, que, de forma cada vez mais constante, impõem-se através de condicionantes nas licenças ambientais, devendo ser cumpridas para permitir a implantação e a operação de um empreendimento.

Sendo assim, por meio do presente capítulo, pretende-se demonstrar a funcionalidade das medidas compensatórias como forma de buscar a proteção do meio ambiente ao permitir a internalização dos custos pela utilização dos recursos naturais; funcionalidade essa que, nos limites impostos pelo sistema econômico vigente - e pela estrutura do direito -, auxiliará na tarefa de manter a qualidade de vida para as presentes e futuras gerações.

A análise funcional do instituto implicará em defender ser desnecessário enquadrá-lo em uma determinada categoria ou 'natureza jurídica'. De fato, percorrendo os debates já travados sobre a natureza jurídica da compensação ambiental da Lei do SNUC (Lei nº 9.985/2000) - que vem sendo considerada, quer como uma forma de reparação civil por danos futuros, quer como um tributo, quer como um meio de compartilhamento de despesas - será possível demonstrar a não subsunção das medidas compensatórias a esse ou àquele ramo do direito, podendo emergir em várias tipologias.

Não obstante, não se deixará de avaliar os elementos para a estruturação da regulamentação jurídica das medidas compensatórias. Nesse sentido, serão avaliados os critérios - se objetivos ou subjetivos - de aplicação das obrigações e, ainda, se elas devem ou não ser previstas em lei em sentido estrito. Em relação a este último ponto, o princípio da legalidade será revisitado; na verdade, não há dúvidas quanto à presença cada vez mais constante de leis 
genéricas e abstratas no ordenamento jurídico e, por consequência, com atribuições mais amplas ao poder regulamentar, ao poder normativo e à atuação da Administração Pública. Essa análise é essencial ao se constatar que os órgãos ambientais licenciadores, de forma bastante usual, impõem medidas compensatórias nas licenças ambientais de atividades ou empreendimentos impactantes, sem baseá-las em previsão legal, no sentido estrito.

Ainda nessa linha estrutural, será necessário, ademais, perscrutar a correta competência legislativa para tratar de medidas compensatórias, sobretudo porque se tem verificado que alguns estados da Federação vêm editando normas impositivas de medidas compensatórias, o que, por vezes, transparece como mero intuito arrecadatório e absolutamente dissociado do escopo de proteção ambiental.

A bem ver, as medidas compensatórias são obrigações novas para o direito, sendo, pois, recentes os debates sobre a sua natureza jurídica, sua forma de instituição e os mecanismos pelos quais devem ser implementadas. Na razão em que aumenta a escassez dos recursos naturais, as medidas compensatórias surgem como um meio de racionalizar a sua utilização; mas, como são obrigações que interferem no patrimônio daqueles que pretendem empreender, é preciso uma avaliação criteriosa quanto à maneira de serem instituídas e implementadas. Portanto, o presente capítulo serve à análise tanto funcional quanto estrutural do instituto.

Tudo, como se verá, para evitar que as medidas compensatórias sejam desvirtuadas e deixem de auxiliar no alcance dos objetivos e das metas fixados por políticas públicas ambientais.

\subsection{Conclusões acerca do debate em torno da natureza jurídica das medidas compensatórias}

Como se viu no Capítulo 2 deste estudo, há um amplo debate sobre a natureza jurídica da obrigação chamada compensação ambiental - que é, conforme já aludimos diversas vezes, uma espécie do gênero medidas compensatórias - instituída pela Lei $n^{\circ}$ 9.985/2000 (SNUC). Desse debate, 
surgiram três principais correntes, quais sejam: (i) alguns autores compreendem que esse instituto enquadra-se em uma espécie de reparação por dano futuro ou ex ante, (ii) outros doutrinadores defendem ser um tipo de tributo ambiental e, (iii) o Poder Judiciário (STF) decidiu tratar-se, na verdade, de um compartilhamento de despesas entre o Poder Público e a iniciativa privada em decorrência da obrigação compartilhada pela proteção ambiental, imposta pelo art. 225 da Constituição Federal.

Neste momento, passa-se, portanto, a analisar se a compensação ambiental - e, por decorrência, as demais medidas compensatórias - enquadrase, ou não, nas concepções de reparação por dano ambiental futuro, de tributo ou de compartilhamento de despesas. Pois bem.

Em primeiro lugar, na linha do exposto no item 2.4 do Capítulo 2 e no item 3.3.1 do Capítulo 3, pode-se já concluir que as medidas compensatórias não servem para indenizar danos futuros. Em breve síntese, é o que se passa a demonstrar:

A uma, dado não ser possível imputar, frente às disposições do ordenamento jurídico nacional, uma forma de reparação por 'dano futuro', pois não há como afastar o pressuposto da concretização do dano para emergir o dever de reparar; a duas, porquanto já existem meios processuais aptos a lidar com riscos concretos de danos ambientais, isto é, com aqueles riscos cujas ocorrências e cujos efeitos são previsíveis e estimáveis; a três, pois o direito encontra seus limites frente ao dano futuro, considerado aquele risco abstrato ou incerto da 'sociedade de risco' ou das 'incertezas', ou seja, um risco cuja ocorrência não é possível prever e, bem por isso, tampouco estimar os seus efeitos; a quatro, por não haver vantagem em construir uma teoria de reparação por danos futuros, bastando considerar que qualquer tentativa nesse sentido seria inoperante.

Sobre o quarto ponto, vale considerar, na esteira da análise introduzida no item 5.3 do Capítulo 5, se já é difícil valorar os danos concretos e, por consequência, repará-los devidamente, debatendo-se o Poder Judiciário para aplicar condenações aos seus responsáveis, imagine-se o que será frente a danos futuros, cujas consequências são de impossível previsão e estimativa (basta questionar: Quanto valerá a mudança climática que implique a mortandade de 
inúmeras espécies? Quem será condenado por esse fato?). Ademais, nesse campo das desvantagens, frise-se que, caso se concluísse ser reparatória a natureza jurídica das medidas compensatórias - ou indenização por 'danos futuros', como querem alguns doutrinadores -, verificar-se-ia a necessidade de celebrar inúmeros 'acordos' no decorrer do processo de licenciamento visando a reparar/indenizar os referidos 'danos futuros' que podem ser causados ao meio ambiente. Essa situação, no entanto, criaria uma 'condição' nem sempre segura no processo de licenciamento ambiental, na medida em que tais 'acordos' poderiam desvirtuar o verdadeiro intuito de proteção ambiental e, ainda, condicionar a emissão das licenças ambientais; em suma, resultariam em uma espécie de "negociação" com o órgão licenciador que, ao fim e ao cabo, é o que detém o poder de emitir ou não a licença.

Ademais, a cinco, dado serem absolutamente diversos os conceitos jurídicos de dano ambiental e de impacto negativo no meio ambiente, não se pode falar em dano quando à frente de processos de licenciamento de empreendimento lícitos e desejados, em que se gerenciam, na verdade, impactos negativos necessários para a sua implantação. Então, para o dano ambiental emerge as responsabilidades civil, administrativa e criminal; para o impacto negativo no meio ambiente, por sua vez, decorrem as medidas compensatórias impostas por meio do licenciamento ambiental. Em uma palavra, quando do gerenciamento do impacto, por meio do licenciamento ambiental, não se pode equipará-lo a um dano.

Sendo assim, fica claro que as medidas compensatórias não incidem como meio de reparação por danos futuros, mas, sim, como uma forma de compensar o meio ambiente pelos impactos negativos causados por atividades lícitas e aceitas pelo homem.

Em segundo lugar, as medidas compensatórias não são necessariamente tributos, embora possam vir à tona, por meio de uma Contribuição (à semelhança da Contribuição de Melhoria), incidente em empreendimentos que causem perdas ao Estado e a terceiros, os quais, assim, recebem uma retribuição pela desvalorização da sua propriedade. Podem, ainda, emergir na forma de uma Contribuição de Intervenção no Domínio Econômico - CIDE, cujo intuito seja aplicar uma exação a um determinado segmento econômico que cause impactos 
negativos ao meio ambiente. Seria o caso, por exemplo, de uma CIDE a incidir em empreendimentos de geração de energia elétrica com potência de geração acima de 500MW, independentemente de serem usinas hidrelétricas, termelétricas ou eólicas. Afinal, cada um à sua maneira, todas essas espécies de geração de energia provocam impactos negativos e não mitigáveis no meio ambiente, muitos deles, aliás, significativos ${ }^{476}$.

Não cremos na instituição de um tributo ambiental, na forma de imposto, cujo fato gerador seja o impacto negativo e não mitigável no meio ambiente. Isto é, não verificamos a possibilidade de um 'imposto verde' como modo de compensar o meio ambiente pelos impactos negativos e não mitigáveis a ele causados; na verdade, isso desvirtuaria a figura do imposto, que tem natureza preponderantemente fiscal. Outrossim, não há dúvidas de que a incidir no subjetivo conceito de impacto ambiental, inúmeras discussões surgiriam acerca da concretização ou não do seu fato gerador, levando a um acúmulo de ações judiciais.

E nem se fale em uma taxa ambiental com intuito compensatório, pois, como se sabe, as taxas são cobradas pela prestação de serviços públicos, situação essa em que certamente não se subsumem os impactos negativos e não mitigáveis causados no meio ambiente.

Em terceiro lugar, poder-se-ia seguir a linha proposta pelo STF que, conforme vimos, ao julgar a ADI 3.378/DF, compreendeu ser a compensação ambiental da Lei $n^{\circ}$ 9.985/2000 (Lei do SNUC) uma forma de compartilhamento de despesas com as medidas oficiais de específica prevenção em face de empreendimentos de significativo impacto ambiental, baseando-se na Lei Maior, que impôs ao “ao Poder Público e à coletividade o dever de defender e preservar o meio ambiente para as presentes e futuras gerações” (art. 225, caput). Segundo o Ministro Relator da ADI, Carlos Ayres Britto, a Constituição Federal criou a obrigação de compartilhamento de despesas, densificada no "princípio

\footnotetext{
${ }^{476}$ As hidrelétricas causam modificações irreversíveis à ictiofauna; as termelétricas emitem poluentes absolutamente prejudiciais à atmosfera e, muitas vezes, resíduos perigosos (quando queima óleo diesel ou carvão); as eólicas, por sua vez, provocam inúmeros incômodos visuais e prejudicam sobremaneira a avifauna, modificando as rotas dos pássaros, inclusive dos morcegos, que, conforme dizem, ficam atordoados pelo funcionamento das suas pás.
} 
usuário-pagador, este a significar um mecanismo de assunção da responsabilidade social (partilhada, insista-se) pelos custos ambientais derivados da atividade econômica”. Consoante já transcrevemos no Capítulo 2 deste estudo, ao final do seu voto, o referido Relator ainda sustentou que "nessa ampla moldura, é de se inferir que o fato de, aqui e ali, inexistir efetivo dano ambiental não significa isenção do empreendedor de partilhar os custos de medidas preventivas. Isto porque uma das vertentes do princípio usuáriopagador é a que impõe ao empreendedor o dever de também responder pelas medidas de prevenção de impactos ambientais que possam decorrer, significativamente, da implementação de sua empírica empreitada econômica”.

Ora, conforme temos exposto nesta tese, ao buscar internalizar os custos da utilização dos recursos naturais, notadamente os decorrentes dos impactos negativos e não mitigáveis causados por empreendimentos ou atividades lícitos e licenciados, as medidas compensatórias densificam o princípio do poluidorpagador. ${ }^{477}$ Ademais, como nunca será possível que essa internalização seja plena (por dificuldades de valoração dos custos dos bens ambientais e por obstáculos do próprio mercado), haverá um déficit necessário de externalidades negativas que serão inevitavelmente assumidas pelo Poder Público e, em última instância, por toda a coletividade. Outrossim, a Constituição Federal realmente introduziu uma obrigação compartilhada pelo Poder Público e pelos empreendedores em relação aos custos pela utilização dos recursos naturais no processo produtivo. Dessa forma, saiu bem o STF ao compreender a compensação ambiental (frise-se: que é uma de tantas medidas compensatórias existentes) como uma forma de compartilhamento de despesas, pois, ao fim e ao cabo, essas despesas (ou custos pela utilização dos recursos naturais na cadeia produtiva) são realmente divididas entre aqueles que produzem os bens de consumo e toda a coletividade.

Todavia, ao chamar a compensação ambiental de compartilhamento de despesas, o STF acabou por não estabelecer uma natureza jurídica para essa

\footnotetext{
${ }^{477}$ Conforme já pontuado antes (vide item 4.4 do Capítulo 4), consideramos que o princípio do poluidorpagador não se distingue do princípio do usuário-pagador e nem o complementa, ou vice-versa. A bem ver, o usuário-pagador está subsumido ao princípio do poluidor-pagador.
} 
obrigação - e para todas as medidas compensatórias -, mas, sim, por apontar justamente o seu objetivo ou funcionalidade.

Por conseguinte, embora logicamente construídas, vê-se que ficam superadas as teorias que pretenderam enquadrar a compensação ambiental - e, por consequência, todas as medidas compensatórias - em uma categoria jurídica estanque, vinculada a um determinado ramo do direito. Isso ocorre, como se verá logo a seguir, pois, ao tratar de regras protetoras do meio ambiente, é preciso, de um lado, focar na sua funcionalidade e não sua natureza jurídica, e, por outro lado, não se pode mais conceber a sua fixação neste ou naquele ramo do direito. $\mathrm{Na}$ verdade, as normas ambientais, buscando alcançar os seus objetivos, ou meramente a sua funcionalidade, atravessam, como uma linha diagonal, praticamente todos os ramos do direito e, daí, a sua característica de transversalidade.

\subsection{Funcionalidade e transversalidade das medidas compensatórias}

Como vem sendo exposto nesta tese, a crescente crise ambiental exige a edição de normas ambientais e a adequação do Estado a tais normas no sentido de edificar políticas ambientais, procurando, a um só tempo, proteger o meio ambiente e manter o sistema econômico em que vivemos. Essa é, portanto, e em breve síntese, a função a ser perseguida pelo direito frente à escassez dos recursos naturais.

Sendo assim, na imposição de regras e limites para utilizar os recursos naturais no processo produtivo, e consequentes consumo e descarte, acabam sendo muito oportunas as medidas compensatórias; com efeito, elas permitem, o quanto possível, internalizar os custos decorrentes desse processo, desestimulando o uso irracional dos bens ambientais. Essa é, assim, a funcionalidade das medidas compensatórias.

Com esse entendimento, portanto, no trato das medidas compensatórias será sempre importante atentar mais para a sua funcionalidade ${ }^{478}$ do que para sua

\footnotetext{
478 Sobre a análise funcional do direito, como uma evolução da sua análise meramente estrutural (ou kelsiana), vide BOBBIO, Norberto. Da estrutura à função: novos estudos de teoria do direito. Trad. Daniela Beccaccia Versiani. Barueri: Manole, 2007.
} 
estrutura. Porém, desde já, observe-se: nessa busca, não cabe desconsiderar a análise estrutural do direito, mas, sim, incorporar na avaliação do sistema jurídico a dita análise funcional, dando-lhe preponderância à mera análise estrutural.

De fato, quando se depara com questões envolvendo direitos difusos e coletivos - como é o caso do direito a um meio ambiente saudável -, é preciso redobrar o cuidado quanto a um pensamento unicamente estruturador do direito, como fez Kelsen. E, ao se deparar com a escassez dos recursos naturais, com a crescente crise ambiental e, bem por isso, com a absoluta necessidade de proteger o meio ambiente, o jurista deve procurar uma aplicação funcionalista para o direito, preocupando-se menos com a estrutura e mais com teleologia ou o objetivo que se quer alcançar. Assim, ao lado de suas missões tradicionais, o direito assume um papel, conforme já dissemos, chamado por Norberto Bobbio de “promocional". 479

Nessa linha, Fábio Nusdeo ensina que há uma outra visão, além da formalista e dogmática do direito, “mais funcional e realista, segundo a qual o direito seria o estudo das relações sociais enquanto objeto de regramento por (...) normas legais.” Quer o autor dizer que, “ao invés de enfocar predominantemente a norma, enfoca-se a realidade enquanto objeto da norma”. 480

Também nesse sentido, Cristiane Derani afirma: “a norma jurídica, inclusive a norma constitucional, não é simplesmente a positivação, o estabelecimento de uma prescrição; ela é ao mesmo tempo hipótese e tentativa de solucionar um problema.” E aduz a autora: “a norma é mais que um instrumento mediador das atividades sociais; ela é um meio para o alcance das finalidades sociais". 481

Com relação à finalidade social, é sempre oportuna a lição de Carlos Maximiliano que, ao tratar da interpretação teleológica, esclarece a dinâmica do

\footnotetext{
${ }^{479}$ BOBBIO, Norberto. Da estrutura à função: novos estudos de teoria do direito. Trad. Daniela Beccaccia Versiani. Barueri: Manole, 2007.

${ }^{480}$ NUSDEO, Fábio. A contribuição de melhoria revisitada: uma revisão e uma proposta. In: SCHOUERI, Luís Eduardo (org.). Direito tributário: homenagem a Alcides Jorge Costa. São Paulo: Quartier Latin, 2003.

${ }^{481}$ DERANI, Cristiane. Direito ambiental econômico. $3^{\text {a }}$ ed. São Paulo: Saraiva, 2008, p. 198.
} 
processo de hermenêutica jurídica e as exigências (fins) que impõem a sua constante evolução. Confira-se:

não se deve ficar aquém, nem passar além do escopo referido; o espírito da norma há de ser entendido de modo que o preceito atinja completamente o objetivo para o qual a mesma foi feita, porém dentro da letra dos dispositivos. Respeita-se esta, e concilia-se com o fim. Isolado, o elemento verbal talvez imobilizasse o Direito Positivo, por lhe tirar todo o elastério. Enquadra, de fato, o último em uma fórmula abstrata, que encerra o escopo social; porém este, como elemento móvel, conduzirá o jurista às aplicações diversas e sucessivas de que a fórmula é suscetível. Deste modo a lei adquire o máximo de ductilidade. ${ }^{482}$

De fato, a funcionalidade do direito ou a teleologia jurídica procura o fim, a ratio do preceito normativo, para, a partir dele, determinar o seu sentido, ou seja, o resultado que ela precisa alcançar com sua aplicação. O sentido normativo requer a captação dos fins para os quais se elaborou a norma, exigindo, para tanto, a concepção do direito como sistema, o apelo às regras da técnica lógica válidas para séries definidas de casos, e a presença de certos princípios que se aplicam para séries indefinidas de casos, como o da boa-fé, o da exigência de justiça, o do respeito aos direitos da personalidade, o da igualdade perante a lei ${ }^{483}$, a defesa do meio ambiente para a manutenção da qualidade de vida para as presentes e futuras gerações, dentre outros.

Nessa direção, Michel Van de Kerchove e François Ost, ao apresentarem o direito como meio para o alcance de suas funções, ensinam

Dans ce but, le droit promeut la santé publique et la qualité de l'environnement, il protégé la vie privée et établit la famille, il maintient l'ordre dans le groupe et garantit les libertés publiques, il réduit les inégalités de chances, assure la sécurité des transactions et le redressement des griefs, il reconnaît et ordonne la propriété privée. Pour realizer ces divers objectifs, le droit use indifféremment et parfois concurremment de diverses techniques: tantôt il prévoit des dispositifs de compensation de dommages, tantôt il applique des

${ }^{482}$ MAXIMILIANO, Carlos. Hermenêutica e aplicação do Direito. $9^{\mathrm{a}}$ ed. Rio de Janeiro: Forense, 1979, p. 152 e 153.

483 DINIZ, Maria Helena. Lei de introdução ao código civil - interpretada. 9a ed. São Paulo: Saraiva, 2002, p. 160. 
peines répressives ou des mesure equivalents, tantôt il encadre les activités en recourant à la régulation administrative, tantôt il met en place des services publics, tantôt enfin il reconnaît et garantit l'efficacité des transactions privées. ${ }^{484}$

Para a boa funcionalidade das normas, é preciso valorizar situações, o que também implica a avaliação axiológica de institutos jurídicos. Afinal, as normas têm sua letra e seu espírito; se a letra prevalecer exclusiva sobre o espírito, corre-se o risco de ingressar-se na estreiteza de visão e partir para atitudes unilaterais e reducionistas. Bem por isso, e mais do que nunca, quando se lida com o meio ambiente, é preciso buscar uma interpretação baseada em princípios. Daí, inclusive, a importância dos princípios mencionados neste estudo, dentre eles o princípio do poluidor-pagador, base das medidas compensatórias.

Sabe-se, no entanto, da possibilidade de haver uma contraposição de princípios - razão, inclusive, do conceito de desenvolvimento sustentável ${ }^{485}$, tentando conciliar a exigência de proteção ambiental com a necessidade de exploração dos recursos naturais para o êxito do desenvolvimento econômico quando, então, evidenciam-se conflitos dos interesses em jogo. Nessa situação, é preciso dar preponderância àquele interesse que melhor se amolde às finalidades sociais e ambientais da regra, de acordo com cada caso concreto. ${ }^{486}$

Nessa linha, a lição de Gustavo Zagrebelsky é bastante oportuna:

\footnotetext{
${ }^{484}$ KERCHOVE, Michel Van de; OST, François. Le système juridique: entre ordre et désordre. Paris: Presses Universitaires de France, 1988, p. 162.

${ }^{485}$ Sobre o conceito de desenvolvimento sustentável e suas funções, ver item 4.2.1 do Capítulo 4.

${ }^{486}$ Nesse sentido, vale a transcrita de excerto de decisão proferida pelo Ministro Celso de Mello, na Ação Direta de Inconstitucionalidade 3540-1, em trâmite no Supremo Tribunal Federal: "Concluo o meu voto: atento à circunstância de que existe um permanente estado de tensão entre o imperativo de desenvolvimento nacional (CF, art. $3^{\circ}$, II), de um lado, e a necessidade de preservação da integridade do meio ambiente (CF, art. 225), de outro, torna-se essencial reconhecer que a superação desse antagonismo, que opõe valores constitucionais relevantes, dependerá da ponderação concreta, em cada caso ocorrente, dos interesses e direitos postos em situação de conflito, em ordem a harmonizá-los e a impedir que se aniquilem reciprocamente. Isso significa, portanto, (...) que a superação dos antagonismos existentes entre princípios e valores constitucionais há de resultar da utilização de critérios que permitam, ao Poder Público (e, portanto, aos magistrados e Tribunais), ponderar e avaliar, "hic et nunc", em função de determinado contexto e sob uma perspectiva axiológica concreta, qual deva ser o direito a preponderar no caso, considerada a situação de conflito ocorrente, desde que, no entanto - tal como adverte o magistério da doutrina na análise da delicadíssima questão pertinente ao tema da colisão de direitos (...) a utilização do método da ponderação de bens e interesses não importe em esvaziamento do conteúdo essencial dos direitos fundamentais, dentre os quais avulta, por sua significativa importância, o direito à preservação do meio ambiente.” Tribunal Pleno, DJ 03.02.2006, p. 14.
} 
Creo, por tanto, que la condición espiritual del tempo em que vivimos podría describirse como la aspiración no a uno, sino a los muchos principios o valores que conforman la convivencia colectiva; la libertad de la sociedad, pero también las reformas sociales; la igualdad ante la ley, y por tanto la generalidad de trato jurídico, pero también la igualdad respecto a las situaciones, y por tanto la especialidad de las reglas jurídicas; el reconocimiento de los derechos de los individuos, pero también de los derechos de la sociedad; la valoración de las capacidades materiales y espirituales de los individuos, pero también la protección de los bienes colectivos frente a la fuerza destructora de aquéllos; el rigor em la aplicación de la ley, pero también la piedad ante sus consecuencias más rígidas; la responsabilidad individual em la determinación de la propia existencia, pero también la intervención colectiva para el apoyo a los más débiles, etc.

Si cada principio y cada valor se entendiesen como conceptos absolutos sería imposible admitir otros junto a ellos. Es el tema del conflicto de valores, que querríamos resolver dando la victoria a todos, aun cuando no ignoremos su tendencial inconciliabilidad. Em el tempo presente parece dominar la aspiración a algo que es conceptualmente imposible, pero altamente deseable en la práctica: no la prevalência de un sólo valor y de un sólo principio, sino la salvaguardia de vários simultáneamente. El imperativo teórico de no contradicción válido para la 'scientia juris' - no debería obstaculizar la labor, propia de la 'jurisprudentia', de intentar realizar 'positivamente' la 'concordancia práctica' de las diversidades e incluso de las contradicciones que, aun siendo tales em teoria, no por ello dejan de ser deseables em la práctica. 'Positivamente': no, por tanto, mediante la simple amputatión de potencialidades constitucionales, sino principalmente mediante prudentes soluciones acumulativas, combinatórias, compensatórias, que conduzcan a los princípios constitucionales a um desarrollo conjunto y no a um declive conjunto. $^{487}$

Ademais, face à complexidade das questões jurídicas suscitadas no mundo moderno, a exegese literal, isolada e excessivamente positivista, deve ser substituída por uma interpretação sistemática que não deixe de considerar a intervisão, a inter-relação, a interdependência, a organicidade do todo, ${ }^{488}$ além do somatório com os demais princípios e direitos fundamentais previstos no ordenamento jurídico. Por conseguinte, quando se trata de questões econômicas,

${ }^{487}$ ZAGREBELSKY, Gustavo. El derecho dúctil: ley, derechos, justicia. Trad. Marina Gascón. Madrid: Editorial Trotta, 2009.

${ }_{488}$ ALVES, Alaôr Caffé. Fundamentos do Direito e Meio Ambiente. In: PHILIPPI JR., Arlindo; CAFFÉ ALVES, Alaôr (eds). Curso Interdisciplinar de Direito Ambiental. Barueri: Manole, 2005, p. 309. 
incluindo a variável ambiental como elemento decisório, não deve haver dúvidas quanto à necessária verificação da funcionalidade e, ainda, sistematização da análise jurídica. De fato, a economia e, por decorrência, o meio ambiente perpassam por, praticamente, todos os ramos do direito, o que fazem, sobretudo, para equacionar o problema da escassez dos bens, notadamente dos recursos naturais.

Nessa linha, não há dúvidas, o Direito Ambiental, por derivar do Direito Econômico, permeia vários - senão todos - os ramos do direito, o que implica que os seus mecanismos e instrumentos também o fazem.

Conforme a imagem de Finzi, o Direito Econômico pode ser visualizado como um 'taglio transversale', ou seja, um corte transversal a seccionar a árvore do direito. ${ }^{489}$ Sendo assim, pode-se dizer, inclusive por decorrer da economia, que a positivação de normas protetoras do meio ambiente, com o pano de fundo de sua funcionalidade, atravessa todo o ordenamento jurídico pátrio, adentrando outros campos do direito (como o civil, o tributário, o comercial, o constitucional, o administrativo etc.).

Isso evidencia a marca da transversalidade das normas do Direito Ambiental que, incluindo a interdisciplinaridade, ${ }^{490}$ é uma típica característica dos direitos de terceira geração. Com efeito, diante de sua natureza coletiva e difusa, aliada ao intento promocional dos seus institutos, são marcas que não mais permitem uma separação estanque do direito público e do direito privado e, tampouco, a aplicação isolada de vários conceitos e princípios jurídicos dos inúmeros campos do direito. Vale dizer que a transversalidade significa que o

\footnotetext{
${ }^{489}$ Apud: NUSDEO, Fábio. Fundamentos para uma codificação do direito econômico. São Paulo: RT, 1995, p. 38.

${ }^{490}$ Perseu Abramo há muito já ensinava que interdisciplinares são "pesquisas sobre assuntos que estão na fronteira de dois ou mais campos de conhecimento, como, por exemplo, sobre o grau de ajustamento de mão de obra qualificada oriunda do meio rural aos padrões de trabalho e vida urbanos; não se trata, propriamente, nem de sociologia, nem de economia, nem de psicologia social, nem de educação, nem de antropologia cultural; evidentemente, na prática nem sempre é possível distinguir entre pesquisas multidisciplinares e pesquisas interdisciplinares (por multidisciplinares o autor entende ser os estudos que envolvem duas ou mais áreas do conhecimento, como aqueles de natureza sócioeconômica, histórico-social, jurídico-filosófica, psico-sócio-antropológica etc.)." ABRAMO, Perseu. Pesquisa social. In: HIRANO, Sedi (org.). Pesquisa em ciências sociais. São Paulo: T.A. Queiroz Editor, 1979, p. 34. Em doutrina mais atual, Édis Milaré ensina a interdisciplinaridade como a "característica que se atribui à abordagem das questões ambientais para cuja exposição ou concretização intervêm duas ou mais disciplinas que, intencionalmente, estabelecem nexos e vínculos entre si, a fim de analisarem, teórica e praticamente, uma realidade ou um dado problema". MILARÉ, Édis. Direito do Ambiente. 7ª ed. São Paulo: RT, 2011, p. 1622.
} 
Direito Ambiental ${ }^{491}$ acaba perpassando todas as áreas do direito, ou, melhor dizendo, “é uma área jurídica que penetra horizontalmente vários ramos de disciplinas tradicionais”. 492

Paulo de Bessa Antunes explica o fenômeno da seguinte forma:

a relação do DA [Direito Ambiental] com os demais ramos do Direito é transversal, isto é, as normas ambientais tendem a se incrustar em cada uma das demais normas jurídicas, obrigando que se leve em conta a proteção ambiental em cada um dos demais 'ramos' do Direito. Uma norma de direito público que determine a administração, a realização de estudos de impacto ambiental para a implementação de determinadas atividades está situada no Direito Administrativo ou no DA? Uma norma que tipifica crimes contra o meio ambiente é uma norma criminal ou ambiental? ${ }^{493}$

Acerca da transversalidade das normas ambientais, observe-se, a título de exemplo, que, atualmente, quando se fala no direito constitucional e civil da propriedade, não há como deixar de pensar na função social e ambiental que ela, propriedade, deve cumprir. Ademais, o Direito Econômico, consoante o art. 170 da Constituição Federal, exige a observância do princípio da defesa do meio ambiente. Ainda, mencione-se a inserção do meio ambiente no Direito Tributário, bastando ver quão recorrentes são os estudos que sustentam a necessidade de criar um tributo ambiental para equacionar o problema das externalidades negativas decorrentes da utilização dos recursos naturais sem o cômputo do seu custo no processo produtivo, de consumo e de descarte. ${ }^{494}$ Outrossim, não há dúvidas de que o direito administrativo está em um processo contínuo de adaptação para fazer face à situações envolvendo interesses complexos, como os difusos, até agora não devidamente tratados. Igualmente,

\footnotetext{
491 Para Paulo Affonso Leme Machado, “o Direito Ambiental é um Direito sistematizador, que faz a articulação da legislação, da doutrina e da jurisprudência concernentes aos elementos que integram o ambiente. Procura evitar o isolamento dos temas ambientais e sua abordagem antagônica”. MACHADO, Paulo Affonso Leme. Direito ambiental brasileiro. 19ª ed. São Paulo: Malheiros, 2011, p. 58.

${ }^{492}$ MORATO LEITE, José Rubens; AYALA, Patryck de Araújo. Direito ambiental na sociedade de risco. Rio de Janeiro: Forense Universitária, 2002, p. 54.

${ }^{493}$ ANTUNES, Paulo de Bessa. Direito ambiental. 11 ${ }^{\text {a }}$ ed. amplamente reformulada. Rio de Janeiro: Lumen Juris, 2008, p. 20.

${ }^{494}$ MILARÉ, Édis. Direito do ambiente. $7^{\text {a }}$ ed. São Paulo: RT, 2011, p. 1087.
} 
observam-se normas relacionadas com a proteção do meio ambiente no Direito Sanitário, no Direito Agrário e no Direito do Consumidor. 495

Sendo assim, com o intuito de alcançar seus objetivos de proteção dos recursos naturais - ou, simplesmente, a sua funcionalidade - os institutos do Direito Ambiental, ao serem transversais, podem emergir com diversas características dos vários ramos do direito e, bem por isso, acabam por ser institutos de difícil enquadramento.

Por conseguinte, as medidas compensatórias, como típico instituto do direito ambiental, procurando equacionar as externalidades negativas - e daí, como dito, a sua funcionalidade -, acabam por emergir em diversos ramos do direito, não podendo, por essa razão, ser conceituadas como subsumindo-se a uma determinada categoria ou a uma específica 'natureza jurídica'.

\subsection{As medidas compensatórias como instrumento híbrido}

Em relação à natureza jurídica, temos que as medidas compensatórias são, como aludido logo acima, um instituto de difícil definição. De fato, elas não estão inseridas em uma determinada categoria jurídica. Ao serem impostas a empreendimentos causadores de significativos impactos negativos no meio ambiente, podem, por vezes, apresentar características preponderantes de mecanismos administrativos de comando e controle e, por outras, de instrumentos econômicos, havendo características de ambos em muitas situações. Diante disso, compreendemos serem as medidas compensatórias mecanismos ou instrumentos híbridos ${ }^{496}$, sem uma natureza jurídica específica.

Claramente, as medidas compensatórias acabam sendo instituídas sob diversas formas - inclusive, como já se pontuou, como tributos -, bastando que

\footnotetext{
495 PHILIPPI JR., Arlindo; RODRIGUES, José Eduardo Ramos. Uma introdução ao Direito Ambiental: conceitos e princípios. In: PHILIPPI JR., Arlindo; CAFFÉ ALVES, Alaôr (eds.). Curso interdisciplinar de Direito Ambiental. Barueri: Manole, 2005, p. 12.

${ }^{496}$ Conforme já citado por Goulder e Parry, "it's sometimes desirable to design hybrid instruments that combine features of various instruments in their 'pure' form." GOULDER, Lawrence H. PARRY, Ian W. H. Instrument Choice in Environmental Policy. Resources for the future - RFF Discussion Paper No. 08-07. April/2008. Disponível em: <http://ssrn.com/abstract=1117566>. Acesso em: 3.10.2011.
} 
se considerem, sempre, como incidentes em situações, específicas ou não, nas quais o meio ambiente sofre com impactos negativos. Tudo, é claro, permitindo internalizar, o quanto possível, os custos pela utilização dos recursos naturais. Senão, vejamos.

\subsubsection{Medidas compensatórias como mecanismo de comando e controle}

Consoante ventilado logo acima, as medidas compensatórias podem expressar-se com características predominantes de mecanismos de comando e controle, ocorrendo quando incidem em impactos específicos, avaliados por meio do processo de licenciamento ambiental. São medidas que se impõem, caso a caso, na hipótese de não ser possível prevenir ou mitigar os impactos negativos de um determinado empreendimento ou de uma determinada atividade.

Consoante já exposto nesta tese, o licenciamento ambiental é um típico mecanismo de comando e controle, sendo usualmente incluído em inúmeras políticas ambientais. Ademais, é um procedimento capaz de conduzir a imposição de vários outros instrumentos, como os econômicos, e sobretudo os mecanismos de comando e controle, como medidas preventivas e mitigadoras, tidas, por exemplo, na fixação de limitações para a implantação de empreendimentos ou atividades, na determinação de padrões de emissão de efluentes líquidos e gasosos etc. E, quando não é possível prevenir ou mitigar, de forma técnica, um determinado impacto, emergem as medidas compensatórias. ${ }^{497}$

\footnotetext{
497 Observe-se que as medidas compensatórias não têm relação direta com os aspectos técnicos do empreendimento ou da atividade, o que ocorre com as medidas preventivas e mitigadoras. Bem por isso é que se vem defendendo que o não cumprimento de uma medida compensatória não implica a suspensão ou revogação da licença ambiental, pois, via de regra, desse eventual inadimplemento não há qualquer efeito deletério ao meio ambiente. Ao contrário, para as medidas preventivas e mitigadoras, diretamente relacionados com os aspectos de controle técnico do empreendimento ou da atividade, caso haja violação dos termos correspondentes da licença, corre-se o risco de prejudicar a natureza e, bem por isso, ter esse ato administrativo suspenso ou revogado, à luz do art. 19 da Resolução CONAMA n 237/1997, in verbis: "Art. 19 - O órgão ambiental competente, mediante decisão motivada, poderá modificar os condicionantes e as medidas de controle e adequação, suspender ou cancelar uma licença expedida, quando ocorrer: I - Violação ou inadequação de quaisquer condicionantes ou normas legais. II - Omissão ou falsa descrição de informações relevantes que subsidiaram a expedição da licença. III - superveniência de graves riscos ambientais e de saúde."
} 
Para ilustrar as medidas compensatórias com características predominantes de mecanismos de comando e controle, citamos as estabelecidas no Código Florestal e na Lei da Mata Atlântica.

O atual ${ }^{498}$ Código Florestal (Lei n $4.771 / 1965$ ) impõe a compensação por supressão de vegetação de área de preservação permanente - $\mathrm{APP}^{499}$. Essa compensação é estabelecida no caput do seu art. $4^{0500}$, determinando que a supressão de vegetação em APP somente poderá ser autorizada em caso de utilidade pública ou de interesse social $^{501}$, devidamente caracterizados e motivados em procedimento administrativo de licenciamento próprio. O $\S 4^{\circ}$ desse art. $4^{\circ}$ impõe que “O órgão ambiental competente indicará, previamente à emissão da autorização para a supressão de vegetação em área de preservação permanente, as medidas mitigadoras e compensatórias que deverão ser adotadas pelo empreendedor”. (destaquei)

\footnotetext{
${ }^{498}$ Diz-se atual Código Florestal, pois em 6.12.2011 foi aprovado pelo Senado Federal o Projeto de Lei no 30/2011 (nº 1.876, de 1999, na origem) que contempla o novo Código Florestal.

${ }^{499}$ Esse Código Florestal - Lei no ${ }^{4} .771 / 1965$ - define área de preservação permanente - APP como sendo aquela "protegida nos termos dos arts. $2 .^{\circ}$ e $3 .^{\circ}$ desta Lei, coberta ou não por vegetação nativa, com a função ambiental de preservar os recursos hídricos, a paisagem, a estabilidade geológica, a biodiversidade, o fluxo gênico de fauna e flora, proteger o solo e assegurar o bem-estar das populações humanas".

500 “Art. $4^{\circ} \mathrm{A}$ supressão de vegetação em área de preservação permanente somente poderá ser autorizada em caso de utilidade pública ou de interesse social, devidamente caracterizados e motivados em procedimento administrativo próprio, quando inexistir alternativa técnica e locacional ao empreendimento proposto.”

${ }^{501}$ As atividades consideradas de utilidade pública e interesse social foram arroladas na Resolução CONAMA n 369/2006, quais sejam: “Art. $2^{\circ} \mathrm{O}$ órgão ambiental competente somente poderá autorizar a intervenção ou supressão de vegetação em APP, devidamente caracterizada e motivada mediante procedimento administrativo autônomo e prévio, e atendidos os requisitos previstos nesta Resolução e noutras normas federais, estaduais e municipais aplicáveis, bem como no Plano Diretor, Zoneamento Ecológico-Econômico e Plano de Manejo das Unidades de Conservação, se existentes, nos seguintes casos: I - utilidade pública: a) as atividades de segurança nacional e proteção sanitária; b) as obras essenciais de infraestrutura destinadas aos serviços públicos de transporte, saneamento e energia; c) as atividades de pesquisa e extração de substâncias minerais, outorgadas pela autoridade competente, exceto areia, argila, saibro e cascalho; d) a implantação de área verde pública em área urbana; e) pesquisa arqueológica; f) obras públicas para implantação de instalações necessárias à captação e condução de água e de efluentes tratados; e g) implantação de instalações necessárias à captação e condução de água e de efluentes tratados para projetos privados de aqüicultura, obedecidos os critérios e requisitos previstos nos $\S \S 1^{\circ}$ e $2^{\circ}$ do art. 11 , desta Resolução. II - interesse social: a) as atividades imprescindíveis à proteção da integridade da vegetação nativa, tais como prevenção, combate e controle do fogo, controle da erosão, erradicação de invasoras e proteção de plantios com espécies nativas, de acordo com o estabelecido pelo órgão ambiental competente; b) o manejo agroflorestal, ambientalmente sustentável, praticado na pequena propriedade ou posse rural familiar, que não descaracterize a cobertura vegetal nativa, ou impeça sua recuperação, e não prejudique a função ecológica da área; c) a regularização fundiária sustentável de área urbana; d) as atividades de pesquisa e extração de areia, argila, saibro e cascalho, outorgadas pela autoridade competente; III - intervenção ou supressão de vegetação eventual e de baixo impacto ambiental, observados os parâmetros desta Resolução.”
} 
Também se afiguram como um mecanismo de comando e controle as obrigações de compensação por supressão de vegetação de Mata Atlântica, impostas pelos arts. 17 e 32 da Lei no 11.428/2006 (Lei da Mata Atlântica) ${ }^{502}$. São dois tipos de compensação; a primeira, para a genérica supressão de vegetação primária ou secundária nos estágios médio ou avançado de regeneração; a segunda, para essas mesmas situações, mas aplicadas às atividades minerárias.

No primeiro caso, tem-se que a compensação reside na forma da destinação de área equivalente à extensão da área desmatada, com as mesmas características ecológicas, na mesma bacia hidrográfica, sempre que possível na mesma microbacia hidrográfica, e, ainda, nos casos previstos nos arts. 30 e $31^{503}$ dessa lei, em áreas localizadas no mesmo Município ou região metropolitana.

Para as mineradoras, a medida compensatória inclui a recuperação de área equivalente à área do empreendimento, com as iguais características ecológicas, na mesma bacia hidrográfica e, sempre que possível, na mesma microbacia hidrográfica. É oportuno notar que o diploma legal, em relação às atividades minerárias, destaca que a medida compensatória é aplicada “independentemente do disposto no art. 36 da Lei n 9.985, de 18 de julho de 2000”. Ou seja, a (i) compensação pela supressão de vegetação de Mata Atlântica, por atividades minerárias, pode sobrepor-se à (ii) compensação ambiental instituída pela Lei $n^{\circ}$

\footnotetext{
502 “Art. 17. O corte ou a supressão de vegetação primária ou secundária nos estágios médio ou avançado de regeneração do Bioma Mata Atlântica, autorizados por esta Lei, ficam condicionados à compensação ambiental, na forma da destinação de área equivalente à extensão da área desmatada, com as mesmas características ecológicas, na mesma bacia hidrográfica, sempre que possível na mesma microbacia hidrográfica, e, nos casos previstos nos arts. 30 e 31, ambos desta Lei, em áreas localizadas no mesmo Município ou região metropolitana. (...) Art. 32. A supressão de vegetação secundária em estágio avançado e médio de regeneração para fins de atividades minerárias somente será admitida mediante: I - licenciamento ambiental, condicionado à apresentação de Estudo Prévio de Impacto Ambiental/Relatório de Impacto Ambiental - EIA/RIMA, pelo empreendedor, e desde que demonstrada a inexistência de alternativa técnica e locacional ao empreendimento proposto; II - adoção de medida compensatória que inclua a recuperação de área equivalente à área do empreendimento, com as mesmas características ecológicas, na mesma bacia hidrográfica e sempre que possível na mesma microbacia hidrográfica, independentemente do disposto no art. 36 da Lei $n^{\circ} 9.985$, de 18 de julho de 2000.”

${ }^{503}$ Em suma, o art. 30 trata da supressão de vegetação secundária em estágio avançado de regeneração primária do Bioma Mata Atlântica, para fins de loteamento ou edificação, nas regiões metropolitanas e áreas urbanas. Já o art. 31 se refere ao parcelamento do solo nas regiões metropolitanas e áreas urbanas para fins de loteamento ou qualquer edificação em área de vegetação secundária, em estágio médio de regeneração, do Bioma Mata Atlântica.
} 
9.985/2000, que se impõe a empreendimentos que causam significativos impactos no meio ambiente.

Como se vê, as medidas compensatórias citadas acima, instituídas no Código Florestal e na Lei da Mata Atlântica têm nítido caráter de mecanismos de comando e controle, dado serem impostas em situações de específicos impactos negativos e não mitigáveis, gerenciados no decorrer do licenciamento ambiental de atividades ou empreendimentos líticos e desejados. Exemplificativamente, é o que ocorre na implantação de empreendimentos de infraestrutura - como hidrelétricas, rodovias, portos etc. -, que usualmente implicam a supressão de áreas de preservação permanente e vegetação de Mata Atlântica, impactos estes, como visto, que devem ser devidamente compensados, consoante previsto nas leis específicas.

\subsubsection{Medidas compensatórias como instrumento econômico}

Conforme já aludido, as medidas compensatórias podem ser determinadas também no quadro de instrumento ou instrumentos econômicos, dispostos em uma política ambiental. Nesse enfoque, elas não incidem em específicos impactos, como é o caso da supressão de área de preservação permanente ou vegetação de Mata Atlântica; incidem, sim, em condições impostas a empreendimentos que tenham as mesmas características ou, de igual modo, a um determinado segmento econômico, estimulando ou não condutas afeiçoadas à proteção ambiental, e podendo ou não visar a arrecadação de recursos para esse mesmo objetivo. É claro que, em muitas situações, o campo de tal imposição, ainda quando com características de instrumento econômico, também pode ser o licenciamento ambiental, pois, como se disse logo acima, o próprio processo de licenciamento é uma medida de comando e controle capaz de suportar outros meios, mecanismos e instrumentos em condições de internalizar os custos com a utilização dos recursos naturais no processo produtivo.

É o que foi feito, por exemplo, pela conhecida 'compensação ambiental', instituída pelo Sistema Nacional de Unidades de Conservação (SNUC) - Lei n⿳0 9.985/2000, analisada no Capítulo 2 desta tese. Nesse diploma legal, a exação 
visa, a bem ver, a arrecadar recursos para permitir o apoio à implantação e à manutenção de unidades de conservação. Ela se aplica a todos os empreendimentos causadores de significativos impactos negativos e não mitigáveis no meio ambiente, apreciáveis com base em EIA/RIMA e geridos pelo licenciamento ambiental. Não importa quais sejam tais impactos; basta a sua significância e que o licenciamento ambiental esteja em curso e baseado em EIA/RIMA. Assim, todos os empreendimentos enquadrados nessas características pagarão a exação pecuniária, calculada consoante metodologia fixada pelo Decreto $\mathrm{n}^{\circ} 6.848 / 2009$, a qual determina não poder o resultado ser superior a $0,5 \%$ sobre determinados custos do empreendimento. Observe-se o fato de a compensação ambiental dever constar como condicionante da licença ambiental de instalação ${ }^{504}$ e, ainda, o seu descumprimento poder ensejar penalidades administrativas ${ }^{505}$.

Aliás, como dito em linhas anteriores, é possível haver sobreposição ambiental com outras medidas compensatórias, como as já citadas compensação por supressão de área de preservação permanente - APP e de Mata Atlântica.

Da mesma forma, pode ser considerada uma medida compensatória com características típicas dos instrumentos econômicos, porquanto não vinculada a específicos impactos, a imposição do Estatuto da Cidade (Lei n ${ }^{\circ}$ 10.257, de 10 de julho de $2001^{506}$ ), exigindo de empreendimentos ou atividades com significativo impacto ambiental de âmbito regional ou nacional o aporte de recursos técnicos e financeiros para a elaboração do plano diretor dos municípios afetados. A propósito, vale ressaltar a determinação, nesse diploma,

\footnotetext{
${ }^{504}$ É o que dispõe o art. $5^{\circ}, \S \S 1^{\circ}$ e $2^{\circ}$, da Resolução CONAMA n ${ }^{\circ} 371 / 2006$, verbis: “Art. $5^{\circ}$ O percentual estabelecido para a compensação ambiental de novos empreendimentos deverá ser definido no processo de licenciamento, quando da emissão da Licença Prévia, ou quando esta não for exigível, da Licença de Instalação. $\S 1^{\circ}$ Não será exigido o desembolso da compensação ambiental antes da emissão da Licença de Instalação. § $2^{\circ} \mathrm{A}$ fixação do montante da compensação ambiental e a celebração do termo de compromisso correspondente deverão ocorrer no momento da emissão da Licença de Instalação.”

${ }^{505}$ Conforme determina o Decreto federal $\mathrm{n}^{\circ}$ 6.514/2008. Confira-se: “Art. 83. Deixar de cumprir compensação ambiental determinada por lei, na forma e no prazo exigidos pela autoridade ambiental: Multa de $\mathrm{R} \$ 10.000,00$ (dez mil reais) a $\mathrm{R} \$ 1.000 .000,00$ (um milhão de reais)."

506 "Art. 41. O plano diretor é obrigatório para cidades: (...) V - inseridas na área de influência de empreendimentos ou atividades com significativo impacto ambiental de âmbito regional ou nacional. $\S 1^{\circ}$ No caso da realização de empreendimentos ou atividades enquadrados no inciso $\mathrm{V}$ do caput, os recursos técnicos e financeiros para a elaboração do plano diretor estarão inseridos entre as medidas de compensação adotadas."
} 
de que tal obrigação esteja incluída entre as medidas de compensação adotadas no licenciamento ambiental.

Por fim, aponte-se como uma medida compensatória, com características de instrumento econômico tributário, a Contribuição de Intervenção no Domínio Econômico - CIDE introduzida no art. 177, da Lei Maior, mediante a Emenda Constitucional $n^{\circ} 33$, de 11 de dezembro de 2001, cujo $\S 4^{\circ}$ dispõe: “A lei que instituir contribuição de intervenção no domínio econômico relativa às atividades de importação ou comercialização de petróleo e seus derivados, gás natural e seus derivados e álcool combustível deverá atender aos seguintes requisitos: (...) II - os recursos arrecadados serão destinados: (...) b) ao financiamento de projetos ambientais relacionados com a indústria do petróleo e do gás.”

Aliás, não deve haver dúvidas, a intervenção na atividade econômica dáse justamente para equacionar os impactos de atividades ou empreendimentos, compensando o meio ambiente e a sociedade pelas perdas por elas geradas. A esse respeito, note-se o fato de a Emenda Constitucional $\mathrm{n}^{\circ} 42$, de 19 de dezembro de 2003, ter incluído na ordem econômica o princípio de “defesa do meio ambiente, inclusive mediante tratamento diferenciado conforme o impacto ambiental dos produtos e serviços e de seus processos de elaboração e prestação” (art.170, IV, CF).

Vê-se, assim, que a CIDE pode, de forma bastante efetiva e eficaz, incidir como uma medida compensatória em impactantes empreendimentos, que envolvam a importação ou comercialização de combustíveis poluentes -, não sendo relevante os específicos prejuízos causados ao meio ambiente. Observese: nessa situação, diferentemente das outras, a exigibilidade da exação não será no decorrer do licenciamento ambiental.

Uma última observação é necessária: mais uma vez, não há que se falar, por serem obrigações pecuniárias, incidentes em hipóteses lícitas, que esses instrumentos econômicos se enquadrariam apenas em uma espécie tributária, diante do que dispõe o art. $3^{\circ}$, do Código Tributário Nacional. De fato, há prestações financeiras compulsórias impostas pelo Estado tendo em vista o interesse público e que não são tributárias, como o DPVAT - Danos Pessoais Causados por Veículos Automotores de Via Terrestre e outros seguros 
obrigatórios (de condomínios), como também a indenização ao proprietário do solo objeto de lavra mineral (Constituição, art. 176, §2º , e Lei do Petróleo, art. 52). ${ }^{507}$ Ou seja, o Estado pode impor obrigações compulsórias financeiras, incidentes em atividades lícitas, sem que sejam consideradas necessariamente tributos.

Por qualquer prisma, as medidas compensatórias com características de instrumentos econômicos, têm como objetivo compensar a sociedade pelas atividades impactantes em geral, o que usualmente fazem mediante a arrecadação de recursos que podem ser destinados a projetos ambientais a elas relacionados.

\subsection{Elementos para a estruturação da regulamentação jurídica das medidas compensatórias}

Como visto logo acima, a análise funcional das medidas compensatórias permitiu evidenciar a sua importância para a internalização dos custos pela utilização dos recursos naturais. Isso, no entanto, não descarta a necessidade de avaliar, na estrutura do ordenamento jurídico, qual a melhor forma para a sua regulamentação, buscando sua eficácia e efetividade.

Em outros termos, não obstante a absoluta importância da funcionalidade das medidas compensatórias, razão pela qual, inclusive, verificou-se ser de menor relevância o seu enquadramento em uma natureza jurídica estanque, é necessário terem elas um enquadramento na estrutura do ordenamento jurídico. Afinal, mesmo com o avanço da análise funcionalista do direito, a análise estrutural não perdeu sua importância. Nas palavras de Bobbio: “a análise estrutural do ordenamento jurídico está em condições de absorver sem demasiada perturbação as mudanças introduzidas pela análise funcional”. ${ }^{508}$

\footnotetext{
${ }^{507}$ OLIVEIRA, José Marcos Domingues de. Direito tributário e meio ambiente. $3^{\mathrm{a}}$ ed. rev. e ampl. Rio de Janeiro: Forense, 2007, p. 242.

${ }^{508}$ BOBBIO, Norberto. Da estrutura à função: novos estudos da teoria do direito. Trad. Daniela Beccacia Versiani. Barueri: Manole, 2007, p. 77.
} 
De efeito, a análise funcional de um instituto, não afasta a consideração instrumental do direito, própria da teoria kelseniana. Ainda nas palavras de Bobbio:

\begin{abstract}
o uso de sanções positivas, ou, de qualquer forma de incentivos econômicos, nada mais é que uma técnica específica de organização social. Mesmo depois de termos percebido que o direito não se limita a reprimir, mas estimula ou promove, podemos continuar a afirmar, como faz Kelsen, que o direito é um meio, e não um fim. Quando chegamos, ainda, a sustentar que o direito é a organização não apenas do poder coativo, mas também do poder econômico, não escapamos de um determinado modo de entender a especificidade do direito, que consiste precisamente em considerá-lo uma forma de 'organização social'. ${ }^{509}$
\end{abstract}

Destarte, embora se mantenha a preponderância à funcionalidade das medidas compensatórias, torna-se necessário, então, avaliar como devem ser regulamentadas, buscando serem eficazes e efetivas na busca pela proteção ambiental. Em outro dizer, em que pese não importar em qual categoria ou 'natureza jurídica' se enquadram as medidas compensatórias, preponderando a busca pela sua funcionalidade, há certas circunstâncias instrumentais a serem respeitadas a fim de que o instituto não seja desvirtuado. Para isso, vai de muito auxílio a estrutura do direito.

Nesse sentido, buscar-se-á distinguir os limites legais para a sua instituição, ou, com base no princípio da legalidade, ver qual a extensão do poder regulamentar, do poder normativo ou da atuação da Administração Pública, mormente porque hoje se percebe a imposição de inúmeras medidas compensatórias, sem haver qualquer base legal. A par dessas questões, será preciso apreciar a competência legislativa para instituir medidas compensatórias, sobretudo ao se constatar que diversos Estados da Federação vêm editando inúmeras leis para instituir medidas compensatórias, sendo muitas, no entanto, se apresentando com aparente intuito meramente arrecadatório. Nesse caminho, será necessário avaliar, ainda, o conteúdo da regulamentação, significando questionar se devem ser fundadas em critérios

${ }^{509}$ Idem, p. 77. 
objetivos de cálculo, ou basear-se na difícil valoração do impacto negativo a ser causado ao meio ambiente. Pois bem.

6.5.1 Medidas compensatórias impostas, sem base legal, no processo de licenciamento ambiental

Já expusemos algumas vezes neste estudo que os órgãos ambientais, no decorrer dos processos de licenciamento se deparam com impactos negativos e não mitigáveis. Quando isso acontece, costumam, além das medidas compensatórias já previstas em lei, impor várias outras obrigações com essa finalidade, mas que não tem base legal ou, quando muito, fundam-se em normas editadas pela própria Administração Pública. Nesse passo, faz-se necessário avaliar a legalidade dessas medidas, o que exigirá, antes, revisitar o princípio da legalidade. Pois bem.

\subsubsection{Revisitando o princípio da legalidade}

Neste ponto, é preciso inicialmente relembrar que há uma concepção rígida do princípio da legalidade, segundo a qual a Administração Pública não pode impor restrição alguma à liberdade ou à propriedade se não estiver previamente delineada, configurada e estabelecida em alguma lei em sentido estrito.

A razão dessa concepção é que o princípio da legalidade, ao lado de um Estado baseado na tripartição dos Poderes, defende os indivíduos contra atos de desmando de seus governantes; com isso, evita limitações maiores à liberdade e à propriedade, como também restrições aos demais direitos fundamentais. Em outras palavras, para defender os cidadãos contra os achaques estatais, além do princípio da legalidade, o liberalismo cunhou a tripartição do exercício do Poder, negando ao Executivo qualquer força jurídica para estabelecer as regras que implicassem limitações à liberdade e à propriedade das pessoas. 
Essa concepção rígida ${ }^{510}$ foi adotada no Brasil, evidenciando-se na Constituição Federal de 1988, quando positivou o princípio da legalidade como balizador da atuação administrativa (art. $5^{\circ}$ e art. 37, CF). Em suma, ao lado do considerado como instransponível princípio da separação dos poderes, o direito nacional deve seguir a máxima de que "ninguém será obrigado a fazer ou deixar de fazer alguma coisa senão em virtude de lei".

A forma inflexível do princípio da legalidade evidentemente implica uma limitação também rígida ao poder regulamentar ou ao poder normativo do Executivo $^{511}$. De fato, nessa acepção, qualquer obrigação ou restrição de direitos e garantias fundamentais pode decorrer apenas da lei em sentido estrito, não podendo o regulamento ou o poder normativo da Administração Pública, jamais, invadir esse âmbito, sob pena de se deflagrarem ilicitudes e inconstitucionalidades. Nessa linha, seguiu-se Geraldo Ataliba ${ }^{512}$, Seabra Fagundes $^{513}$, Pontes de Miranda ${ }^{514}$, dentre tantos outros.

\footnotetext{
${ }^{510}$ A respeito dessa posição rígida do princípio da legalidade, pontifica Celso Antonio Bandeira de Mello, assim discorrendo: "No Brasil, o princípio da legalidade, além de assentar-se na própria estrutura do Estado de Direito e, pois, do sistema constitucional como um todo, está radicado especificamente nos arts. $5^{\circ}$, II, 37 e 84, IV, da Constituição Federal. Estes dispositivos atribuem ao princípio em causa uma compostura muito estrita e rigorosa, não deixando válvula para que o Executivo se evada de seus grilhões. É, aliás, o que convém a um país, de tão acentuada tradição autocrática, despótica, na qual o Poder Executivo, abertamente ou através de expedientes pueris - cuja pretensa juridicidade não iludiria sequer a um principiante -, viola de modo sistemático direitos e liberdades públicas e tripudia à vontade sobre repartição de poderes (...). Logo, a Administração não poderá proibir ou impor comportamento algum a terceiro, salvo se estiver previamente embasada em determinada lei que lhe faculte proibir ou impor algo. Vale dizer, não lhe é possível expedir regulamento, instrução, resolução, portaria ou seja lá que ato for para coactar a liberdade dos administrados, salvo se estiver previamente embasada em determinada lei que lhe faculte proibir ou impor algo a quem quer que seja." MELlO, Celso Antonio Bandeira de. Curso de Direito Administrativo. 28 ${ }^{\mathrm{a}}$ ed. São Paulo: Malheiros, 2011, p. 102.

${ }^{511}$ Observe-se aqui que adotamos os conceitos de poder regulamentar e poder normativo atribuídos pela Profa. Odete Medauar, para quem "o poder regulamentar configura um dos modos de exercício do poder normativo no âmbito do Poder Executivo. Do ponto de vista lógico, é melhor dizer que há um poder normativo geral, do qual o poder regulamentar apresenta-se como espécie". E ainda: "Além do poder regulamentar, a Administração detém a faculdade de emitir normas para disciplinar matérias não privativas de lei. Tais normas podem ter repercussão mais imediata sobre pessoas físicas, jurídicas, grupos, a população em geral ou mais imediata sobre a própria Administração, podendo ter ou não reflexos externos." MEDAUAR, Odete. Direito administrativo moderno. 14a ed. São Paulo: RT, 2010, p. 119/121.

512 ATALIBA, ATALIBA, Geraldo. Decreto Regulamentar no Sistema Brasileiro. Revista de Direito Administrativo. $\mathrm{n}^{\circ}$ 97. Rio de Janeiro.

${ }^{513}$ FAGUNDES, Seabra. O Controle dos Atos Administrativos pelo Poder Judiciário. $5^{\mathrm{a}}$ ed. Rio de Janeiro: Forense, 1979.

${ }^{514}$ MIRANDA, Pontes de. Comentários à Constituição de 1967, com a Emenda $n^{\circ} 1$ de 1969. Tomo III. $2^{\mathrm{a}}$ ed. São Paulo: RT, 1970, p. 314.
} 
Em outro dizer, denota-se que essa postura rígida adota o sentido estritamente positivo $^{515}$ da lei à Administração Pública ou o princípio da conformidade, segundo os quais o administrador, na prática de seus atos, se vincula à lei porque a totalidade das ações administrativas deve estar submetida, ou ser conforme, a uma norma legal prévia. ${ }^{516}$

Todavia, o princípio da legalidade ${ }^{517}$ concebido com tal rigidez vem sendo muito criticado. Em suma, entende-se não ser a legalidade estrita factível nos dias atuais ${ }^{518}$, em que, à evidência, o Poder Legislativo não está apto a acompanhar a dinâmica das relações sociais e a adaptar-se às novas técnicas decorrentes das revoluções tecnológicas.

Nessa linha crítica, Eros Grau defende existirem momentos nos quais “a instabilidade de determinadas situações e estados econômicos, sujeitos a permanentes flutuações que definem seu caráter conjuntural -, impõem sejam extremamente flexíveis e dinâmicos os instrumentos normativos de que deve lançar mão o Estado para dar correção a desvios ocorridos no desenrolar do processo econômico e no curso das políticas que estejam a implementar”. O autor expõe o motivo pelo qual entende existir, mesmo em nosso ordenamento, um amplo poder normativo da Administração Pública: “a existência de uma capacidade normativa de conjuntura”. Firmado seu ponto de vista, Eros Grau brada contra o entendimento doutrinário contrário à existência dos regulamentos autônomos (nos quais inclui as normas editadas pela Administração Pública), afirmando:

\footnotetext{
515 Diferenciando-se do sentido negativo ou do "princípio da compatibilidade", que sugerem que o administrador pode fazer tudo o que a lei não proíbe. Observe-se que a conceituação amplamente adotada pela doutrina moderna acerca do princípio da conformidade e do princípio da compatibilidade nos é dada por Charles Eisenmann. EISENMANN, Charles. O direito administrativo e o princípio da legalidade. Revista de Direito Administrativo, p. 45/58.

516 SESIN, Domingo. Administración pública. Actividad reglada, discrecional y técnica - nuevos mecanismos de control judicial. Buenos Aires: Depalma, 1994, p. 3-6.

${ }^{517}$ Conforme lembra-me o Prof. Fábio Nusdeo, a concepção rígida do princípio da legalidade também é conhecida com "garantista".

${ }^{518}$ Para Odete Medauar nunca houve, de fato, uma conotação rígida do princípio da legalidade, discorrendo que "a função administrativa talvez nunca tenha se limitado a executar a lei ou a executar a lei de ofício. Embora norteada pelo princípio da legalidade, a função administrativa não tem o fim único de executar a lei, desempenhando amplo rol de atividades que propiciam serviços, bens, utilidades, dificilmente 'enquadráveis' na rubrica 'execução da lei'”. MEDAUAR, Odete. A processualidade no direito administrativo. São Paulo: RT, 1993, p. 53.
} 
a doutrina tradicional do direito administrativo, isolando-se da realidade, olimpicamente ignora que um conjunto de elementos de índole técnica, aliado a motivações de premência e celeridade na conformação do regime a que se subordinam a atividade de intermediação financeira, tornam o procedimento legislativo, com seus prazos e debates prolongados, inadequado à ordenação de matérias essencialmente conjunturais. ${ }^{519}$

Vale dizer, diante das novas relações sociais e surpreendentes inovações tecnológicas, o processo legislativo, ao ser baseado na democracia representativa, não é mais capaz de dar conta de uma rápida adequação da legislação às circunstâncias verificadas no âmbito dos fatos, sobretudo às questões de ordem técnica. Ou, melhor falando, a rapidez da evolução do ser não é mais compatível com o ritmo da produção de regras sobre o dever ser, havendo um absoluto descompasso do que se passa na realidade com o processo legislativo parlamentar.

Tal evolução social implica, na prática, a edição de leis genéricas e abstratas, abrindo a possibilidade para os regulamentos, as normas editadas ou os próprios atos administrativos emitidos pela Administração Pública inovarem diariamente na ordem jurídica, impondo muitas vezes obrigações que a lei não criou, indo de encontro à regra que exige a conformidade à letra da lei.

A par da evolução das relações sociais, é válido considerar, ainda, o fato de a edição de normas com cunho de proteção ambiental gerarem benefícios para muitos e, ao mesmo tempo, custos para poucos. Esses poucos, todavia, são os que usualmente detêm o poderio econômico, razão pela qual, logicamente, não pretenderão incentivar a normatização de regras a lhes impor a majoração de custos. Nessas condições, evidencia-se com muita clareza o conflito entre aqueles que objetivam obter os benefícios da proteção ambiental e os que pagam com os custos para tanto. Esse conflito resultará no tramitar extremamente tumultuado dos projetos de lei, podendo ser bastante procrastinados pelo poderio econômico. Foi efetivamente o que ocorreu - e vem ocorrendo - com o novo Código Florestal, onde se constata uma verdadeira luta entre os latifundiários e os ambientalistas para o atendimento dos antagônicos interesses.

\footnotetext{
${ }^{519}$ GRAU, Eros Roberto. O direito posto e o direito pressuposto. 5. ed. rev., atual. e ampl. São Paulo: Malheiros, 2003, p. 232-242.
} 
O resultado desse conflito, conforme Fábio Nusdeo, é que “a lei provavelmente terá expressões vagas e dúbias, e haverá um papel muito grande da jurisprudência para balizar realmente o sentido que se quis dar à norma, ou, mais sério ainda, o sentido mais consentâneo com o bem comum independentemente da mens legislatoris”. ${ }^{20}$

Em suma, a complexidade das normas ambientais, ao gerarem custos para poucos e benefícios para muitos, implicam um tumultuado trâmite legislativo, resultando, não raro, em leis genéricas e abstratas. Afinal, apesar desses poucos, são eles detêm o poder econômico, sendo-lhes, via de regra, imputados os custos pela utilização dos recursos naturais.

A esse respeito, aliás, não se pode desconsiderar o mecanismo pelo qual o poder econômico costuma atuar, mormente no exercício do lobby. Mas não o lobby no sentido pejorativo, e, sim, nas evidentes possibilidades de os grupos de interesses serem capazes de intervir fortemente na confecção de leis - ou mais comumente mantê-las no estado em que se encontram - com vistas ao atendimento dos seus exclusivos interesses. ${ }^{521}$

Quando os grupos de pressão, os grupos de interesses, ou, simplesmente, os lobbies se envolvem no processo legislativo, ou regulamentar, isso implica a necessidade de investir tudo o que for possível para atingir seu objetivo, ou seja, gastos elevados com viagens, com produção de estudos e contratando pessoas para fazerem contatos com os legisladores a fim de negociar ${ }^{522}$, gastos esses com os quais a comunidade ou a cidadania, em geral, não terá condições de arcar.

Diante dessa realidade, poder-se-ia defender ser melhor que as leis tratassem de assuntos de forma ampla e genérica, deixando ao Poder Executivo, ao regulador ou simplesmente à Administração Pública o preenchimento das lacunas deixadas propositadamente pelo legislador. No entanto, se o poder

\footnotetext{
${ }^{520}$ NUSDEO, Fabio. Primeiro encontro: poder econômico - o jogo e as regras. In: FERRAZ JR., Tércio Sampaio; SALOMÃO FILHO, Calixto; NUSDEO, Fábio (orgs.). Poder econômico: direito, pobreza, violência, corrupção. Barueri: Manole, 2009, p. 9.

${ }^{521}$ Idem, p. 4.

${ }^{522}$ NUSDEO, Fabio. Primeiro encontro: poder econômico - o jogo e as regras. In: FERRAZ JR., Tércio Sampaio; SALOMÃO FILHO, Calixto; NUSDEO, Fábio (orgs.). Poder econômico: direito, pobreza, violência, corrupção. Barueri: Manole, 2009, p. 4.
} 
econômico pode influir na confecção das leis, é correto dizer também poder fazê-lo no processo regulamentador, normativo ou regulador. A isso se chama captura do regulador ou captura das agências, administradores públicos etc. Conforme ensina Fábio Nusdeo:

Muitas vezes, quando se cria uma agência reguladora ou um órgão regulador, se estabelece um intercâmbio entre reguladores e regulados e, nesse convívio, com frequência, dáse aquilo a que se chama captura das agências. Isto é, os interesses regulados cooptam os reguladores para que essa regulação os favoreça. ${ }^{523}$

Nessas bases, sem dúvida, não importa se pelo trâmite do processo legislativo, se pela regulamentação, regulação ou pelo simples poder normativo da Administração Pública; é certo que, em qualquer circunstância, as regras a serem editadas, em sentido estrito ou não, sofrerão bastante influência do poder econômico no atendimento dos seus interesses.

Em todo o cenário acima delineado, não restam dúvidas de que a mudança que tem sido vista na concepção rígida do princípio da legalidade, decorre, de um lado, da já propalada evolução da sociedade e complexidade das relações modernas; de outro lado, diante de as normas ambientais representarem custos assumidos por poucos e benefícios usufruídos por muitos, implicando conflitos no processo de sua elaboração. E, daí, a edição de leis bastante genéricas e abstratas.

Isso significa deparar-se com uma nova concepção do princípio da legalidade, mais factível, implicando, como vem sendo propalado, uma fase póspositivista do direito. Também é considerado um fenômeno chamado por alguns autores como a "crise da lei". 524

\footnotetext{
${ }^{523}$ Idem, p. 5.

${ }^{524}$ A respeito, Glauco Martins Guerra discorre: “a crise da lei na modernidade é fruto das transformações da vida contemporânea, dentre elas as mudanças estruturais de classe e, fundamentalmente, de uma nova relação entre Estado e sociedade, provocadas por demandas sócio-econômicas e políticas no seio do Estado Social, em consolidação ao processo capitalista. De outra sorte, há causas externas ao ordenamento que repercutem nas causas internas de abalo da identidade da lei. A quebra do suporte cultural que sustenta a racionalidade legislativa comprova que as fontes formais do direito se descaracterizam e perdem relevância. Com isso, tornam-se obsoletos pressupostos instrumentais da ação legislativa, na medida em que a lei deixa de ser uma ferramenta básica de regulação. A lei acaba sendo mimetizada, provocando desordem no aparelho estatal, como o enfraquecimento do princípio da legalidade e da força executiva (e sancionatória do direito).”
} 
A consequência dessa concepção gera, de igual modo, uma mudança em relação às limitações rígidas ao poder regulamentar do Poder Executivo, do poder normativo e da própria atuação da Administração Pública. Sim, pois, ao se editar leis genéricas e abstratas, é certo estender-se uma maior possibilidade de atuação ao regulador ou ao agente administrativo. Sendo assim, vem-se vivenciando uma ampla delegação ou 'carta em branco' para a edição de normas, ou meros atos administrativos com força normativa - como a portaria, a resolução, a instrução normativa etc. - que, não raro, inovam a ordem jurídica.

Embora as normas genéricas e abstratas permitam um certo dinamismo para o regulador ou para a atuação da própria administração pública, não há dúvidas de que também podem ensejar abusos, arbítrios e, sobretudo, desvios de finalidade. De fato, ao se deixar um campo muito amplo para a atuação do poder regulamentar ou do poder normativo, tem-se a possibilidade, inclusive de se desvirtuar a função dos institutos ou dos próprios reguladores.

Portanto, a evolução do princípio da legalidade tem evidentemente limites. Com efeito, ainda que se admita a ele uma nova e inevitável concepção mais flexível, não se pode afastar o princípio da segurança jurídica e o necessário respeito ao Estado Democrático de Direito, para garantir a estabilidade e a inviolabilidade dos direitos fundamentais. De fato, não se pode deixar ao alvedrio do Poder Executivo, e, menos ainda, aos órgãos administrativos, a atribuição ampla e irrestrita de regulamentar ou normatizar as mais diversas matérias, inovando no ordenamento jurídico ao impor obrigações que a lei não previu, sob pena de transgressão da ordem jurídica. ${ }^{525}$

Por conseguinte, ao mesmo tempo em que não se pode negar a tendência de editar leis mais genéricas e abstratas, a questão é: até que ponto a lei pode ser genérica e abstrata e, com isso, quais os limites do poder regulamentar ou do poder normativo e regulador? Ou, até que ponto a lei deve pré-estabelecer os conteúdos dos atos a serem expedidos infralegalmente pela Administração

GUERRA, Glauco Martins. Princípio da legalidade e poder normativo: dilemas da autonomia regulamentar. Revista do Tribunal Regional do Trabalho da $15^{a}$ Região. Campinas, n. 24, 2004. Disponível em: $<$ http://www.trt15.jus.br/escola_da_magistratura/Rev24Art15.pdf>. Acesso em: 1\%/6/2010.

${ }^{525}$ Bem por isso, aliás, é que se constata um controle cada vez mais rígido do Poder Judiciário sobre os atos administrativos. 
Pública; até que ponto pode conferir liberdade à Administração Pública para definir direitos e obrigações. ${ }^{526}$

Note-se que, mesmo os administrativistas ${ }^{527}$ que concebem a evolução do direito administrativo de modo a minimizar a importância do princípio da legalidade ou permitir que o poder regulamentar ou o poder normativo da Administração Pública seja mais amplo, vêm defendendo a imposição de limites à edição de leis vagas, abstratas e muito genéricas, que remetem ao Poder Executivo ou aos órgãos da administração pública a atribuição para 'legislar' sobre determinadas matérias, ainda quando meramente técnicas. Nesse sentido, vem se ponderando ser necessário que a lei estabeleça princípios, finalidades, critérios mínimos, padrões ou standards que propiciem o controle do regulamento. ${ }^{528}$

Ao enfrentar questões ambientais, é necessário cuidar para não serem editadas normas muito genéricas ou abstratas, pois isso pode levar, inclusive, a oportunismos, repercutindo na própria degradação ambiental. Como visto, o mercado tem uma característica tipicamente hedonista, aproveitando-se ao máximo das situações na obtenção dos seus interesses de lucro e de apropriação de riqueza. E, assim, o poder econômico não terá receio em aproveitar-se de brechas da lei para evitar o acréscimo de custos na cadeia produtiva. Por conseguinte, tem-se, por certo, ser necessário que a lei em sentido estrito contemple os critérios e padrões mínimos para a proteção ambiental, sendo possível e necessária a normatização de determinados assuntos por normas de cunho administrativo, os quais, porém, devem apenas desonerar as leis formais de detalhes técnico-específicos, sem jamais substituí-las ${ }^{529}$.

Significa dizer, por exemplo, que, para restringir a liberdade e a propriedade, o regulamento ou o ato administrativo devem ser conformes à lei, aumentando o grau de densificação. Caso, no entanto, refira-se a regras

\footnotetext{
${ }^{526}$ ARAGÃO, Alexandre Santos de. A concepção pós-positivista do princípio da legalidade. Revista de Direito Constitucional e Internacional. n 65. Ano 16. São Paulo: RT, 2008.

${ }^{527}$ Nessa linha, cite-se Luís Roberto Barroso e Alexandre Santos de Aragão.

${ }^{528}$ ARAGÃO, Alexandre Santos de. Ob. cit.

${ }^{529}$ KRELL, Andreas. 'Licença ou autorização ambiental? Muita discussão em torno de um falso dilema'. Revista de Direito Ambiental, vol. 49, ano 13. São Paulo: RT, 2008, p. 65.
} 
procedimentais ou técnicas, é possível uma inovação maior por parte do poder regulamentar ou do poder normativo.

Ao se tratar de normas limitadoras da utilização dos recursos naturais, como sói acontecer com as medidas compensatórias, a sua imposição, não há dúvidas, incide no direito da propriedade, pois cria ônus a se refletir no patrimônio daqueles que empreendem. Ao mesmo tempo, essas normas servem, sobretudo, para compensar o meio ambiente e a sociedade pela perda de qualidade ambiental, que é um direito fundamental também previsto na Constituição Federal. Essa perda é traduzida em termos técnicos, de modo que não há como a lei em sentido estrito prescrever todas as situações de incidência das medidas compensatórias e tampouco o conteúdo operacional imprescindível à sua implementação.

Nessa linha, pode-se dizer que as medidas compensatórias, por se tratarem de obrigações incidentes sobre o patrimônio, acabam por exigir, necessariamente, a reserva da lei, devendo estar delineadas na norma primária, editada para prescrever o seus critérios e padrões mínimos. Por outro lado, esses critérios e padrões podem e devem ser preenchidos por parâmetros técnicos definidos pelo poder regulamentador e, por vezes, pela própria Administração Pública $^{530}$. Para as regras de proteção ambiental, no caso brasileiro ${ }^{531}$, o estofo

\footnotetext{
${ }^{530}$ Ricardo Lobo Torres, discorrendo sobre o julgado pertinente à Contribuição do SAT, expõe: “Indaga-se: a definição de atividades preponderantes para efeito de determinação de grau de risco por ato do Poder Executivo contraria o princípio da legalidade? Parece-nos que não. Os riscos de acidente do trabalho devem ser cobertos pelas empresas que expõem os seus empregados a atividades que os provoquem. Não há por que repassar o financiamento à sociedade como um todo. Assim sendo, é legítima a lei que transfere ao regulamento a competência para preencher o conceito indeterminado nela previsto. Ninguém conhece previamente e a lei formal não poderia determinar o conceito de risco leve, médio ou grave, tanto mais que tal conceito é cambiante, estando ao sabor do crescimento das atividades econômicas e do desenvolvimento tecnológico. (...) Após intensa e demorada discussão perante os Tribunais Regionais Federais, o Supremo Tribunal Federal deu pela constitucionalidade do exercício do poder regulamentar, fundando a sua argumentação, entretanto, na figura da delegação, consubstanciada, na palavra do Ministro Relator Carlos Velloso, no 'regulamento delegado, intra legem, condizente com a ordem jurídico-constitucional'que teria autorizado o Executivo a aferir dados para a concreta aplicação da lei. Não se preocupou o STF especificamente com a problemática da tipificação, por certo diante da ausência de contribuições doutrinárias que lhe pudessem embasar a decisão e da circunstância de que o Judiciário vem se utilizando das delegações atípicas para contornar o princípio da legalidade.” TORRES, Ricardo Lobo. Valores e princípio no Direito Tributário Ambiental. In: TÔRRES. Heleno Taveira (org.). Direito tributário ambiental. São Paulo: Malheiros, 2005, p. 42-44.

${ }^{531}$ Muito embora fuja ao escopo central deste trabalho, não pode ser olvidados os esforços normativos que vêm sendo envidados em vários países no sentido de aperfeiçoar o próprio mecanismo de feitura das normas, tanto as legais, quanto as regulamentares, no sentido de elas passarem a lidar com a inescapável realidade da ação dos 'lobbies' e da captura das agências e, em alguns casos, do próprio parlamento e até mesmo dos
} 
técnico deve ser, de preferência, preenchido pelo Conselho Nacional do Meio Ambiente - CONAMA ${ }^{532}$.

No entanto, ao tratar das medidas compensatórias, não há como estabelecer uma regra a priori acerca do grau de densificação do ato regulamentar ou normativo da Administração Pública com relação à lei. De fato, isso vai depender das características da medida compensatória. Caso seja um mecanismo de comando e controle, basta ver que eles podem ter critérios ou padrões mais vagos ou genéricos estabelecidos em lei, os quais devem, portanto, ser preenchidos tecnicamente pelo regulamento ou, ainda, pela própria Administração Pública. A esse respeito, veja-se o Código Florestal (Lei $\mathrm{n}^{\circ}$ 4.771/1965), a exigir que o órgão licenciador imponha uma compensação pela supressão de vegetação em área de preservação permanente. Logicamente essa compensação deve ser proporcional à área em que houve a supressão de vegetação.

Já para as medidas compensatórias com características de instrumentos econômicos, algumas terão um alto grau de densificação com a lei - como no caso da CIDE -, em que, é certo dizer, exige-se a reserva total da lei.

Em qualquer hipótese, sugerimos que os critérios ou padrões mínimos precisam ser prescritos pela norma primária, com o pano de fundo das suas finalidades, devendo o regulamento e, ainda, preferencialmente as resoluções do CONAMA (ou dos Conselhos Estaduais) preencherem com estofo técnico os parâmetros necessários para a eficaz aplicação da lei. É evidente que, a depender das características da medida compensatória, a densificação dos

órgãos julgadores. Não basta, pois, para a legitimação do direito haver um due process of law, mas também um due process of law making. Cf. NUSDEO, Fábio. Fundamentos para uma codificação do Direito Econômico. São Paulo: RT, 1995.

${ }^{532}$ A competência normativa do CONAMA está prevista no art. 6º inciso II, da Lei n ${ }^{\circ}$ 6.938/1981. Em suma, o CONAMA é órgão consultivo para assessorar, estudar e propor ao Conselho de Governo diretrizes de políticas governamentais para o meio ambiente, cabendo-lhe deliberar, no âmbito de sua competência, sobre normas e padrões compatíveis com o meio ambiente ecologicamente equilibrado e essencial à sadia qualidade de vida. Embora órgão consultivo e normativo, ainda de acordo com o art. $8^{\circ}$ da Lei n ${ }^{\circ} 6.938 / 81$, a competência do CONAMA se restringe a editar normas, critérios e padrões técnicos. É oportuno observar que o CONAMA não tem amplo poder normativo, estando restrito a expedir disposições de índole técnica. Isso significa que não pode inovar onde a lei não fez, vez que isso é vedado pela Constituição Federal (vide art. 25 do ADCT). Nesse sentido, Luis Carlos Silva de Moraes averba que “a competência do CONAMA não pode inovar, originalmente, no campo das proibições do direito de uso de propriedade; é-lhe permitido assumir matriz legal e adequá-la aos casos específicos, nada mais”. MORAES, Luis Carlos Silva de. Código Florestal Comentado. $2^{a}$ ed. São Paulo: Atlas, 2000, p. 44. 
complementos técnicos com a lei pode ser maior ou menor. Mas, isso apenas pode ser avaliado caso a caso.

6.5.1.2 Análise da legalidade das medidas compensatórias exigidas sob critério exclusivo do órgão licenciador

Neste momento, faz-se necessário avaliar a legalidade das medidas compensatórias impostas, de forma bastante usual, pelos órgãos licenciadores sem estarem expressamente positivadas.

É o caso, por exemplo, do processo de dragagem de um rio, que inevitavelmente gera, mesmo que temporária, a turbidez da água, quando não, a mortandade de peixes. Nessa circunstância, e frente aos impactos inevitáveis e não mitigáveis, o órgão licenciador acaba por impor, por exemplo, que a empresa responsável pela dragagem faça o plantio de uma área de preservação permanente, ou realize um curso de educação ambiental com alguma comunidade próxima ao local, com vistas a evitar a poluição do rio e outros problemas ambientais.

Como se vê, e sem adentrar no mérito da pertinência ou não dessas exigências, tratam-se de típicas medidas compensatórias impostas pelo administrador público sem qualquer base legal a fundamentá-las.

Há situações, ainda, nas quais os órgãos ambientais editam normas ou atos administrativos, criando medidas compensatórias a serem impostas em processos de licenciamento por eles conduzidos. É o caso da medida compensatória que, sem ter fulcro em lei em sentido estrito, vem há muito sendo exigida de mineradoras, localizadas em florestas nacionais ${ }^{533}$, em decorrência da supressão de vegetação necessária à atividade. Atualmente, a exação é cobrada

\footnotetext{
${ }^{533}$ A floresta nacional é uma unidade de conservação de uso sustentável. Por ser de uso sustentável, permitese a exploração de atividades econômicas no seu interior. Conforme a Lei no 9.985/2000, "é uma área com cobertura florestal de espécies predominantemente nativas e tem como objetivo básico o uso múltiplo sustentável dos recursos florestais e a pesquisa científica, com ênfase em métodos para exploração sustentável de florestas nativas” (art.17).
} 
pelo ICMBio, ${ }^{534}$ por força da Instrução Normativa ICMBio 09, de 28 de abril de $2010 .^{535}$ Ao que importa para o momento, basta considerar que essa norma administrativa exige que a madeira a ser suprimida para permitir a atividade de mineração deva ser indenizada à Autarquia. ${ }^{536}$ A valoração dessa indenização é calculada por uma metodologia prevista na Portaria ICMBio 15, de 5 de março de $2010 .^{537}$ Tal obrigação pode gerar uma enorme dificuldade para determinadas mineradoras, que já pagam (i) pela recuperação da área degradada, conforme prescrito na Constituição Federal (art. 225, §2º), (ii) pela compensação ambiental, estabelecida pela Lei 9.985/2000 (SNUC) e, ainda, (iii) pela compensação financeira - CFEM decorrente do quanto disposto no art. $20, \S 1^{\circ}$, da Lei Maior. Assim, o novo ônus, sem estar devidamente contemplado ou baseado em uma lei em sentido estrito, pode determinar a inviabilidade econômica de mineração em florestas nacionais. A respeito, observe-se que o Brasil detém importantes reservas minerárias em florestas nacionais, como é o caso do ferro na floresta nacional de Carajás e da bauxita na floresta nacional Saracá-Taquera, ambas no Estado do Pará. Aliás, são justamente as atividades minerárias que vêm possibilitando a preservação das florestas nacionais ${ }^{538}$.

Tudo isso significa imposições obrigacionais, sem qualquer base legal, as quais podem ser em muito desarrazoadas e desproporcionadas. Também por isso, aliás, é que, no final de outubro de 2011, o Governo Federal editou um

\footnotetext{
${ }^{534}$ Com a edição da Lei n ${ }^{\circ}$ 11.516, de 28 de agosto de 2007, o Instituto Chico Mendes de Conservação da Biodiversidade - ICMBio passou a ser a Autarquia federal responsável por gerenciar as unidades de conservação federais, categoria em que se enquadram as Florestas Nacionais. Antes dessa norma, a atribuição cabia ao IBAMA.

${ }^{535}$ Essa Instrução Normativa do ICMBio sucedeu e revogou a Instrução Normativa IBAMA 152, de 17.1.2007, que, por sua vez, revogou a Instrução Normativa IBAMA 31, de 27.5.2004.

${ }^{536}$ Após a indenização, a madeira passa a 'pertencer’ à mineradora, que pode comercializá-la da maneira que considerar mais condizente.

${ }^{537}$ O ICMBio editou a Portaria 15/2010 a fim de "estabelecer critério de valoração financeira para a cobrança pelo uso de recursos florestais, madeireiros ou não madeireiros, do interior das Florestas Nacionais, quando da supressão de vegetação autorizada para fins de pesquisa e lavra mineral”. A mesma norma dispõe que "para a valoração financeira mencionada, adotar-se-á o método apresentado no Manual de Valoração Econômica de Florestas Nacionais, elaborado pelo Instituto Brasileiro do Meio Ambiente e dos Recursos Naturais Renováveis - IBAMA, em 2007, que é anexo à Portaria.”

${ }^{538}$ De fato, há análises concluindo serem as atividades minerárias no interior das florestas nacionais que permitem a sua conservação e a preservação dos seus atributos. Essas constatações baseiam-se, em muito, na verificação do avanço da degradação - sobretudo por atividades agropecuárias - do entorno dessas unidades de conservação.
} 
“pacote ambiental” composto de várias Portarias Interministeriais, ${ }^{539}$ destinadas a padronizar o procedimento de licenciamento ambiental de obras de infraestrutura. Conforme notícia divulgada pela imprensa, uma das intenções era deixar de incluir nos processos de licenciamento medidas compensatórias sem relação com os impactos causados pelas correspondentes obras. O exemplo citado pela ministra de Meio Ambiente Izabela Teixeira foi uma exigência da Fundação Cultural Palmares, ${ }^{540}$ que cuida dos interesses dos remanescentes de quilombolas, que chegou a impor a uma construtora de rodovia o pagamento de tratamento dentário à população quilombola afetada. Como asseverou a ministra, “o potencial impacto de uma rodovia não gera dano para a arcada dentária da população”. 541

Novamente sem entrar no mérito da pertinência ou não das medidas compensatórias impostas sem base legal, pode-se constatar, de um lado, a criação de uma obrigação totalmente dissociada de uma política ambiental e desviada do intuito de proteção ambiental e, de outro lado, a exigibilidade da exação sem critérios, padrões ou standards mínimos definidos em lei, podendo tornar inoperacional a obrigação.

539 O referido 'pacote ambiental' foi composto pelas seguintes Portarias: (i) Portaria Interministerial MMA/MJ/MC/MS 419, de 26.10.2011 - Regulamenta a atuação dos órgãos e entidades da Administração Pública Federal envolvidos no licenciamento ambiental, de que trata o art. 14 da Lei no 11.516, de 28.08.2007; (ii) Portaria Interministerial MMA/MT 423, de 26.10.2011 - Institui o Programa de Rodovias Federais Ambientalmente Sustentáveis para a regularização ambiental das rodovias federais; (iii) Portaria Interministerial MMA/SEP/PR 425, de 26.10.2011 - Institui o Programa Federal de Apoio à Regularização e Gestão Ambiental Portuária - PRGAP de portos e terminais portuários marítimos, inclusive os outorgados às Companhias Docas, vinculadas à SEP/PR; (iv) Portaria MMA 420, de 26.10.2011 - Dispõe sobre procedimentos a serem aplicados pelo Instituto Brasileiro do Meio Ambiente e dos Recursos Naturais Renováveis - IBAMA na regularização e no licenciamento ambiental das rodovias federais; (v) Portaria MMA 421, de 26.10.2011 - Dispõe sobre o licenciamento e a regularização ambiental federal de sistemas de transmissão de energia elétrica e dá outras providências; (vi) Portaria MMA 422, de 26.10.2011 - Dispõe sobre procedimentos para o licenciamento ambiental federal de atividades e empreendimentos de exploração e produção de petróleo e gás natural no ambiente marinho e em zona de transição terra-mar; (vii) Portaria MMA 424, de 26.10.2011 - Dispõe sobre procedimentos específicos a serem aplicados pelo IBAMA na regularização ambiental de portos e terminais portuários, bem como os outorgados às Companhias Docas, previstos no art. 24-Ada Lei $n^{\circ} 10.683$, de 28.05.2003.

${ }_{540}$ Consoante divulgado na internet, a Fundação Cultural Palmares, criada em 1988, é uma instituição pública vinculada ao Ministério da Cultura que tem a finalidade de promover e preservar a cultura afrobrasileira. Preocupada com a igualdade racial e com a valorização das manifestações de matriz africana, a Palmares formula e implanta políticas públicas que potencializam a participação da população negra brasileira nos processos de desenvolvimento do País. Disponível em: <www.palmares.gov.br>. Acesso em: 15.12.2011.

${ }^{541}$ Folha de S. Paulo, 29 de outubro de 2011. 
No primeiro caso, prescinde-se da avaliação econômica em relação ao 'grau ótimo' a se alcançar com a utilização dos recursos da natureza no processo produtivo, de consumo e de descarte. Essa situação, conforme explorada no item 5.3 do Capítulo 5 desta tese, pode gerar inúmeras dificuldades, inclusive criar falhas de mercado ou outros efeitos indesejados (como o monopólio, desemprego, entre outras). Além do mais, não há dúvidas de que, ao abrir ampla possibilidade de o administrador público exigir medidas compensatórias, a seu exclusivo critério, pode ocorrer abuso de poder e desvio de finalidade. Isso quando não forem utilizadas as medidas compensatórias como meros instrumentos arrecadatórios, sem qualquer vínculo com a proteção ambiental.

De fato, para atender ao 'grau ótimo' de utilização dos recursos naturais - internalizando, o quão possível, o decorrente custo na cadeia produtiva, sem gerar outras falhas de mercado -, todos os mecanismos de comando e controle e os instrumentos econômicos devem passar por uma avaliação econômica e serem implementados por meio de uma política ambiental devidamente estruturada e positivada. Tudo voltado para permitir a utilização racional dos recursos da natureza, protegendo ao máximo o meio ambiente sem impedir que o sistema econômico se funcione e se mantenha.

O segundo caso, constatado na exigência de obrigações sem qualquer base legal, demonstra a infringência frontal ao princípio da legalidade, ainda quando considerado na sua acepção mais flexível. Afinal, mesmo entendendo que a Administração Pública detém um poder normativo mais amplo, em razão, sobretudo, da atual dinâmica das relações sociais e das inúmeras revoluções tecnológicas, é preciso estabelecer um limite aos órgãos administrativos quanto à imposição de medidas compensatórias.

Em outros termos, muito embora a definição dos diferentes graus de impacto ambiental seja de índole eminentemente técnica, o seu regramento geral é obrigatoriamente da norma primária, que, num momento posterior, pode vir a ser regulamentada, desde que já existam os critérios e padrões mínimos a serem observados pela prática da atividade delegada. 


\subsubsection{Definição de critérios objetivos}

Conforme aludido, para tornar eficazes e efetivas as medidas compensatórias, apoiando-nos no quanto deduzido no item 6.5.1 acima, o poder normativo da Administração Pública encontra seu limite na definição técnica de conceitos estabelecidos na lei. Ou seja, tendo a lei imposto seus critérios e padrões mínimos, cabe ao Poder Executivo, inclusive à Administração Pública, preenchê-los com o conteúdo técnico necessário à aplicação da norma.

Assim, verificando os elementos de estruturação do instituto das medidas compensatórias, agora, porém, adentrando no seu conteúdo, é interessante aqui incluir a necessidade de as normas, ao tratarem seus dos critérios e padrões mínimos, vincularem a sua aplicação a critérios objetivos de valoração da obrigação.

Afinal, consoante já aduzido no item 5.3 do Capítulo 5, a valoração dos impactos ambientais é de difícil cálculo. Basta constatar, por exemplo, que as atividades de uma indústria têm reflexos inevitáveis no ar, na água, no solo e, ainda, na população do seu entorno, nas estradas utilizadas para o escoamento dos seus produtos, nos rios e mares que fazem, por transporte aquaviário, a sua circulação. Aliás, os impactos dessa indústria se acumularão com os impactos das demais indústrias que a circundam.

Sendo assim, ao pretender vincular uma regra compensatória com a valoração do impacto em si, será bastante provável a sua inoperância. E, para evitar a inoperância das medidas compensatórias, essas obrigações devem basear-se em critérios objetivos de aplicação, capazes de alcançar, ao máximo, a internalização dos custos externos resultantes da utilização dos recursos naturais.

Significa dizer que, independentemente das preponderantes características apresentadas pela medida compensatória - se de mecanismo de comando e controle, se de instrumento econômico, se de ambos -, sua imposição deve ser baseada em um critério objetivo de valoração, podendo apresentar-se em parâmetros definidos em lei ou em uma equação clara e cujos fatores sejam facilmente preenchidos. Isto é, podem ser critérios ou parâmetros de diversas 
ordens, desde uma metodologia de cálculo (consoante o disposto no Decreto $\mathrm{n}^{\mathrm{o}}$ 6.848/2009), até uma pertinência com o impacto causado (como os parâmetros estabelecidos pelas citadas normas do Código Florestal e da Lei da Mata Atlântica) e, ainda, ter uma base correlata com o impacto, como as que foram estabelecidas para a aplicação de multas ambientais (o Decreto $n^{0}$ 6.514/2008 determinou, em seu art. $8^{\circ}$, critérios como a unidade, hectare, metro cúbico, quilograma, metro de carvão-mdc, estéreo, metro quadrado, dúzia, estipe, cento, milheiros ou outra medida pertinente, de acordo com o objeto jurídico lesado). ${ }^{542}$

De fato, justamente por ser de dificílima a valoração, o legislador, ao criar a medida compensatória, e visando a sua operacionalidade, não deve relacioná-la ou densificá-la com o impacto negativo causado ao meio ambiente; deve, sim, escolher um determinado grau objetivo para que as medidas compensatórias sejam efetivas e eficazes, sem causar efeitos colaterais indesejados.

Afinal, não basta querer; é preciso encontrar uma forma de alcançar o resultado pretendido.

\subsubsection{Competência legislativa para tratar das medidas compensatórias}

Consoante já comentando no item 2.1 do Capítulo 2 deste estudo, alguns estados da Federação, à semelhança da compensação ambiental instituída pela Lei do SNUC, vêm editando normas específicas para impor medidas compensatórias.

A respeito, cite-se a legislação do Estado de Goiás ${ }^{543}$, exigindo duas formas de medida compensatória. A primeira delas, bastante parecida com a obrigação já exigida pela Lei federal n ${ }^{\circ}$ 9.985/2000, visa à imposição de pagamento de no mínimo $0,5 \%$ (meio por cento) sobre os custos totais previstos

\footnotetext{
${ }^{542}$ Qualquer alteração adversa do meio ambiente tem difícil quantificação, assim como ocorre com a valoração da vida, da saúde etc. Bem por isso é que, para os danos morais, os tribunais pátrios definiram uma forma objetiva para a sua indenização (muitas vezes centrada em determinada quantidade de saláriosmínimos).

${ }^{543}$ Lei no 14.241 , de 29.07.2002, e o Decreto no 5.899, de 9.2.2004, ambos do Estado de Goiás.
} 
para desenvolver o projeto, cujo montante serve para apoiar a implantação e a manutenção de Unidade de Conservação do grupo de proteção integral. A segunda, instituída exclusivamente pelo Estado de Goiás, determina que os mesmos empreendimentos cominados pela primeira exação, também arquem com o pagamento de, no mínimo, $1 \%$ do valor total do empreendimento para 'para implementação de medidas mitigadoras e compensatórias das espécies afetadas, conforme determinado pelo órgão ambiental competente'”, ${ }^{544}$

Ainda a título ilustrativo, citem-se as regras editadas pelo Estado do Rio Grande do Norte, impondo medidas compensatórias específicas naquele ente da Federação, ${ }^{545}$ definidas a critério do órgão ambiental, em todos os empreendimentos que causem impactos ao meio ambiente. ${ }^{546} \mathrm{~A}$ primeira delas é de, no mínimo, 0,5\% destinada à implantação e à manutenção de Unidades de Conservação e, a segunda, até o limite de 5\% para apoiar ou executar outras medidas ambientais de compensação à comunidade atingida. ${ }^{547}$

Vale verificar, ademais, o Estado do Mato Grosso do Sul, que também dispõe de duas medidas compensatórias, uma delas bastante parecida com a Lei do SNUC, incidindo em processos de empreendimentos causadores de significativo impacto negativo e, a outra, impondo-se em todos os outros processos de licenciamento de empreendimentos causados de impactos ambientais (não significativos). Mas, o que chama a atenção no caso do Estado do Mato Grosso do Sul é a destinação dos recursos dessa segunda medida compensatória, os quais cabem servir “integralmente ao custeio de atividades de gestão ambiental”548 à cargo do órgão ambiental estadual, incluindo-se “a

\footnotetext{
${ }^{544}$ Art. 10 da Lei no 14.241/2002, do Estado de Goiás.

545 O Rio Grande do Norte promulgou a Lei Complementar estadual n ${ }^{\circ} 272$, de 3.3.2004 (alterada pela Lei Complementar estadual $n^{\circ}$ 336, de 12.12..2006), dispondo sobre a Política e o Sistema Estadual do Meio Ambiente, as infrações e sanções administrativas ambientais, as unidades estaduais de conservação da natureza e institui medidas compensatórias ambientais.

546 “Art. 22. Nos casos de licenciamento de empreendimentos de impacto para o meio ambiente, assim considerado pela autoridade ambiental competente, com base em estudos ambientais, o empreendedor é obrigado a adotar compensação ambiental.”

547 “Art. 23. Para os fins da compensação ambiental de que trata o art. 22, o empreendedor deverá destinar uma parcela dos custos totais para a implantação do empreendimento, às seguintes finalidades: I - no mínimo, meio por cento, para apoiar a implantação e manutenção de unidade de conservação; II - garantido o disposto no inciso anterior, e até o limite máximo de cinco por cento, para apoiar ou executar outras medidas ambientais de compensação à comunidade atingida, na forma a ser disciplinada em regulamento.(...)”.

548 Sobre medidas de 'gestão ambiental', note-se ter o Superior Tribunal de Justiça, em voto do Ministro Luiz Fux, anulado um Termo de Ajustamento de Conduta por prever a destinação de 'entrega de bem móvel para
} 
aquisição de bens, a execução de obras e serviços, os dispêndios com pessoal e outras exigências necessárias à execução da política ambiental do Estado do Mato Grosso do Sul”. ${ }^{549}$

Conforme se vê, a “moda pegou”, como se diz popularmente. Então, por todo o lado proliferam a edição de normas estaduais para impor medidas compensatórias a incidir no processo de licenciamento ambiental. Não deixa de chamar a atenção a subjetividade das regras e, com isso, transparece o intuito meramente arrecadatório das obrigações, absolutamente desvinculado da intenção de proteção ambiental.

Nessa linha, ainda que não se adentre na pertinência ou não das obrigações, vale a pergunta: os estados podem legislar livremente sobre medidas compensatórias que visam compensar o meio ambiente por impactos negativos causados por atividades lícitas e licenciadas? Não parece estarem os estados acima exemplificados 'aproveitando' a aparente 'brecha' da legislação com intuito meramente arrecadatório?

Para tanto responder, é necessário, novamente, e em que pese à crescente importância da análise funcional do direito, lembrar que um Estado de Direito, como o brasileiro, funda-se em prescrições e princípios positivados no ordenamento jurídico, cuja estrutura é estabelecida de forma hierárquica; nela, a norma inferior tem sua validade fulcrada em uma superior, e assim por diante, até que se alcance a norma fundamental - “a última e mais elevada do sistema jurídico". 550

Procurando, assim, subsumir as citadas normas estaduais com as normas hierarquicamente superiores, a fim de que estas lhe emprestem validade, deparase com o fato de a Constituição Federal ter estabelecido competência comum para proteger o meio ambiente e combater a poluição em qualquer de suas

\footnotetext{
uso de órgão da Administração Pública’, especificamente ‘a obrigação de dar equipamento de informática’ à uma agência florestal estadual, por desvirtuar a obrigação de reparação de um dano (STJ, REsp $n^{\circ}$ 802.060/RS). Analogamente, vislumbra-se que a destinação de recursos para a 'gestão ambiental', a fim de permitir a aquisição de equipamentos para a administração pública, desvirtua o objetivo ou a funcionalidade das medidas compensatórias, cujas ações ou recursos devem ser destinados para medidas capazes de compensar efetivamente o meio ambiente impactado.

${ }^{549}$ Lei n ${ }^{\circ}$ 3.709, de 16.7.2009 e Decreto nº 12.909, de 29.12.2009, ambos do Estado do Mato Grosso do Sul.

${ }^{550}$ KELSEN, Hans. Teoria pura do direito. São Paulo: Martins Fontes, 2000, p. 217.
} 
formas e preservar as florestas, a fauna e a flora (art. 23, incisos VI e VII ${ }^{551}$ ), e competência legislativa concorrente para a União, os Estados e o Distrito

Federal tratarem das florestas, caça, pesca, fauna, conservação da natureza, defesa do solo e dos recursos naturais, proteção do meio ambiente e controle da poluição (art. 24, inciso VI, e parágrafos ${ }^{552}$ ). ${ }^{553}$

\footnotetext{
${ }^{551}$ Art. 23. É competência comum da União, dos Estados, do Distrito Federal e dos Municípios: (...) VI proteger o meio ambiente e combater a poluição em qualquer de suas formas; VII - preservar as florestas, a fauna e a flora."

552 “Art. 24. Compete à União, aos Estados e ao Distrito Federal legislar concorrentemente sobre: "VI florestas, caça, pesca, fauna, conservação da natureza, defesa do solo e dos recursos naturais, proteção do meio ambiente e controle da poluição; (...) $\S 1^{\circ}$ No âmbito da legislação concorrente, a competência da União limitar-se-á a estabelecer normas gerais. $\S 2^{\circ}$ A competência da União para legislar sobre normas gerais não exclui a competência suplementar dos Estados. $\S 3^{\circ}$ Inexistindo lei federal sobre normas gerais, os Estados exercerão a competência legislativa plena, para atender a suas peculiaridades. $\S 4^{\circ}$ A superveniência de lei federal sobre normas gerais suspende a eficácia da lei estadual, no que lhe for contrário.”

553 Observe-se que, em relação ao regramento ambiental, o STF já julgou impondo limites à atividade legiferante dos Estados: “AÇÃO DIRETA DE INCONSTITUCIONALIDADE. ARTIGOS $2^{\circ}, 4^{\circ} \mathrm{E} 5^{\circ} \mathrm{DA}$ LEI N. 10.164/94, DO ESTADO DO RIO GRANDE DO SUL. PESCA ARTESANAL. INCONSTITUCIONALIDADE FORMAL. 1. A Constituição do Brasil contemplou a técnica da competência legislativa concorrente entre a União, os Estados-membros e o Distrito Federal, cabendo à União estabelecer normas gerais e aos Estados-membros especificá-las. 2. É inconstitucional lei estadual que amplia definição estabelecida por texto federal, em matéria de competência concorrente. 3. Pedido de declaração de inconstitucionalidade julgado procedente” STF - ADI 1245/RS - Relator(a): Min. EROS GRAU - DJ 26-08-2005 PP-00005 - EMENT VOL-02202-01 PP-00064 - LEXSTF v. 27, n. 321, 2005, p. 38-45 - RTJ VOL-00194-03 PP-00776. Também a esse respeito, vale citar decisão do STF que tratou de norma do Estado do Paraná que, em absoluta dissonância com a norma geral, criou obrigação a respeito da presença de organismos geneticamente modificados em alimentos e ingredientes alimentares destinados ao consumo humano e animal. Confira-se: "AÇÃO DIRETA DE INCONSTITUCIONALIDADE. LEI 14.861/05, DO ESTADO DO PARANÁ. INFORMAÇÃO QUANTO À PRESENÇA DE ORGANISMOS GENETICAMENTE MODIFICADOS EM ALIMENTOS E INGREDIENTES ALIMENTARES DESTINADOS AO CONSUMO HUMANO E ANIMAL. LEI FEDERAL 11.105/05 E DECRETOS 4.680/03 E 5.591/05. COMPETÊNCIA LEGISLATIVA CONCORRENTE PARA DISPOR SOBRE PRODUÇÃO, CONSUMO E PROTEÇÃO E DEFESA DA SAÚDE. ART. 24, V E XII, DA CONSTITUIÇÃO FEDERAL. ESTABELECIMENTO DE NORMAS GERAIS PELA UNIÃO E COMPETÊNCIA SUPLEMENTAR DOS ESTADOS. 1. Preliminar de ofensa reflexa afastada, uma vez que a despeito da constatação, pelo Tribunal, da existência de normas federais tratando da mesma temática, está o exame na ação adstrito à eventual e direta ofensa, pela lei atacada, das regras constitucionais de repartição da competência legislativa. Precedente: ADI 2.535-MC, rel. Min. Sepúlveda Pertence, DJ 21.11.03. 2. Seja dispondo sobre consumo (CF, art. 24, V), seja sobre proteção e defesa da saúde (CF, art. 24, XII), busca o Diploma estadual impugnado inaugurar regulamentação paralela e explicitamente contraposta à legislação federal vigente. 3. Ocorrência de substituição - e não suplementação - das regras que cuidam das exigências, procedimentos e penalidades relativos à rotulagem informativa de produtos transgênicos por norma estadual que dispôs sobre o tema de maneira igualmente abrangente. Extrapolação, pelo legislador estadual, da autorização constitucional voltada para o preenchimento de lacunas acaso verificadas na legislação federal. Precedente: ADI 3.035, rel. Min. Gilmar Mendes, DJ 14.10.05. 4. Declaração de inconstitucionalidade conseqüencial ou por arrastamento de decreto regulamentar superveniente em razão da relação de dependência entre sua validade e a legitimidade constitucional da lei objeto da ação. Precedentes: ADI 437QO, rel. Min. Celso de Mello, DJ 19.02.93 e ADI 173-MC, rel. Min. Moreira Alves, DJ 27.04.90. 5. Ação direta cujo pedido formulado se julga procedente." STF - ADI 3645/PR - Relator(a): Min. ELLEN GRACIE Julgamento: 31.05.2006 - Órgão Julgador: Tribunal Pleno - Publ.: DJ 01.09.2006 PP-00016 - EMENT VOL02245-02 PP-00371 - LEXSTF v. 28, n. 334, 2006, p. 75-91.
} 
A competência comum, não há dúvidas, refere-se às atribuições licenciatórias e ao poder de polícia administrativa. De fato, todos os entes podem licenciar empreendimentos - cuja competência é definida com base na extensão dos impactos ${ }^{554}$ - como também cabe a eles fiscalizar as atividades poluentes e aplicar penalidades administrativas de acordo com os limites impostos pela legislação ${ }^{555}$.

Acerca da competência legislativa concorrente, ela compõe-se de dois elementos: (i) possibilidade de disposição sobre o mesmo assunto ou matéria por mais de uma entidade federativa e (ii) primazia da União no que tange à fixação de normas gerais. Lembre-se de que da competência concorrente decorre a suplementar, significando o poder dos estados de formular normas desdobrando o conteúdo de princípios ou normas gerais ou destinadas a suprir a ausência ou omissão destas (art. $24, \S \S 1^{\circ}$ a $\left.4^{\circ}\right){ }^{556}$

A descentralização de competências pela Constituição Federal - comum para proteção ambiental e concorrente para legislar sobre o mesmo assunto tem, ao que parece, quatro principais razões: (i) a necessidade de ampla fiscalização em relação a atos danosos ao meio ambiente; (ii) em um país de dimensões continentais, as diferentes regiões apresentarão diversas realidades sociais, ambientais e econômicas; (iii) os benefícios da proteção ambiental variam sobremaneira ao longo do país, bastando considerar que os limites para a emissão gasosa no Estado de São Paulo trará benefícios que não serão sentidos quando impostos ao Estado do Mato Grosso; e (iv) os custos para alcançar um

\footnotetext{
${ }^{554}$ A limitação da competência para o licenciamento ambiental já era definida pela Resolução CONAMA n ${ }^{\circ}$ 237/1997 e, hoje, pela Lei Complementar no 140/2011.

${ }^{555}$ A Lei Complementar $n^{\circ}$ 140/2011 estabelece que o poder fiscalizatório corresponde àquele que detém competência para licenciar ou autorizar. É o que dispõe seu art. 17, § 3º verbis: “Art. 17. Compete ao órgão responsável pelo licenciamento ou autorização, conforme o caso, de um empreendimento ou atividade, lavrar auto de infração ambiental e instaurar processo administrativo para a apuração de infrações à legislação ambiental cometidas pelo empreendimento ou atividade licenciada ou autorizada. (...) $\S 3^{\circ} \mathrm{O}$ disposto no caput deste artigo não impede o exercício pelos entes federativos da atribuição comum de fiscalização da conformidade de empreendimentos e atividades efetiva ou potencialmente poluidores ou utilizadores de recursos naturais com a legislação ambiental em vigor, prevalecendo o auto de infração ambiental lavrado por órgão que detenha a atribuição de licenciamento ou autorização a que se refere o caput.”

${ }^{556}$ SILVA. José Afonso da. Curso de Direito Constitucional Positivo. $28^{a}$ ed. São Paulo: Malheiros, 2007, p. 504.
} 
determinado parâmetro de proteção ambiental variam substancialmente de região para região. ${ }^{557}$

No entanto, também vem se destacando a importância da intervenção federal em normas protetoras do meio ambiente, evitando certas patologias evidenciadas nas normatizações estaduais. Uma dessas patologias reside no fato de os estados poderem estabelecer padrões inferiores de proteção ambiental, buscando incentivar a instalação de indústrias, aumentar a oferta de empregos e a arrecadação de tributos. Outra delas encontra-se nos exemplos acima citados, evidenciando-se as normas estaduais apenas com o objetivo de mera arrecadação de recursos, cuja destinação está dissociada dos efetivos objetivos de proteção ambiental.

Outrossim, a pulverização de normas, sejam federais, sejam estaduais, pode representar graves carências legislativas, inclusive levando à degradação e poluição desmesuradas. Ou, nas palavras de Édis Milaré:

No emaranhado de normas existentes, difícil mesmo é encontrar matérias nas quais não existam conflitos normativos, em que os dispositivos, nos vários níveis legislativos, falem a mesma língua. Nada mais proveitoso para o degradador ambiental do que a existência de normas que se antagonizam, com isso deixando o terreno livre para o exercício de atividades altamente lesivas ao meio ambiente. ${ }^{558}$

Bem por isso, aliás, vem se defendendo uma codificação ambiental. ${ }^{559}$ Aliás, sobre o tema, tem-se defendido a codificação não com apego ao formalismo, mas como forma de ordenar um processo decisório caótico, errático e de difícil controle pela sociedade. ${ }^{560}$

Temos, no entanto, que a edição de normas gerais pela União resolveria, em muito, as dificuldades impostas pela ampla pulverização de regras de proteção - ou não proteção - ambiental Brasil afora. Sobre a norma geral,

\footnotetext{
${ }^{557}$ REVESZ, Richard L. STAVINS, Robert N. Environmental Law and Policy. NYU Public Law Research Paper 82; NYU Law \& Econ Research Paper 04-015; Harvard Public Law Working Paper No. 102; KSG Working Paper No. RWP04-023. Setembro/2004. Disponível em: <http://ssrn.com/abstract=552043>. Acesso em: 03.10.2011.

${ }^{558}$ MILARÉ, Édis. Direito do ambiente. $7^{\text {a }}$ ed. São Paulo: RT, 2011, p. 1048.

${ }^{559}$ Sobre o assunto, vide MILARÉ, Édis. Ob. cit., p. 1049 e segs.

${ }^{560}$ NUSDEO, Fábio. Fundamentos para uma codificação do Direito Econômico. São Paulo: RT, 1995, p. 6.
} 
enfrentada pelo prisma do Direito Ambiental, Marcelo Abelha Rodrigues assim ensina:

\begin{abstract}
A norma geral é aquela que deve ser nacionalmente seguida, posto que sua importância transcende a esfera de um Estado da Federação apenas. Mesmo que não atenda aos interesses de todos os Estados (polígono das secas, por exemplo) ainda assim insere-se no contexto nacional, tendo em vista o fato de que não se poderia admitir que servisse para um Estado e não servisse para outro.

O critério da isonomia e paridade deve ser um importante elemento para a verificação in concreto da existência de interesse nacional. Ao fazer a norma geral, a União estabelece a raiz legislativa das normas ambientais, de forma que caberá aos Estados e Municípios, seguindo a direção indicada pela raiz, estabelecer o esgalhamento da proteção legislativa ambiental, atentando-se que essa ramificação deve ser feita de acordo e em respeito aos seus interesses. ${ }^{.61}$
\end{abstract}

Voltando ao tema tratado das medidas compensatórias, viu-se, ao longo dessa tese, que a União vem estabelecendo normas gerais sobre o licenciamento ambiental $^{562}$, como também vem tratando das medidas compensatórias incidentes em empreendimentos causadores de impactos negativos, a serem aplicadas no decorrer de tal processo. Trata-se, portanto, de normas gerais, significando estarem os estados e o Distrito Federal impossibilitados de ampliar, inovando na ordem jurídica, o que ali foi estabelecido. De fato, se a moldura federal estabeleceu as compensações a incidir em licenciamentos ambientais de empreendimentos causadores de significativos impactos, cujos recursos devem ser destinados às unidades de conservação - federais, estaduais e municipais certamente os estados e municípios não podem impor outras medidas compensatórias com esses mesmos pressupostos, ampliando o disposto na lei federal $^{563}$. Com efeito, esses entes ficam restritos ao preenchimento das lacunas, suplementando o regramento imposto pela moldura legislativa federal.

\footnotetext{
${ }^{561}$ RODRIGUES. Marcelo Abelha. Elementos de Direito Ambiental - Parte Geral. 2a ed. São Paulo: RT, 2005, p. 145.

${ }^{562}$ Vide Lei $n^{\circ}$ 6.938/1981, recentemente alterada pela Lei Complementar $n^{\circ} 140 / 2011$, que regulamentou o art. 23, incisos III, VI e VII, da Constituição Federal.

${ }^{563}$ A competência licenciatória ambiental era prescrita na Resolução CONAMA 237/1997, e, hoje, pela Lei Complementar $n^{\circ}$ 140, de 8.12.2011. Frise-se, ainda, que obrigação da compensação ambiental, como visto
} 
Não se quer, com isso, defender a impossibilidade de os estados tratarem dos assuntos do seu próprio interesse; trata-se, sim, de respeito à sua competência suplementar, significando que, conforme ensinamento de Paulo Affonso Leme Machado:

quando a competência da pessoa de Direito Público interno for somente suplementar a legislação de outro ente, se inexistirem normas, não existirá o poder supletório. Não se suplementa uma regra jurídica simplesmente pela vontade de os Estados inovarem diante da legislação federal. A capacidade suplementária está condicionada à necessidade de aperfeiçoar a legislação federal ou diante da constatação de lacunas ou de imperfeições da norma geral federal. ${ }^{564}$

A bem ver, o limite dos estados à edição de normas segue a racionalização do uso do princípio do poluidor-pagador, buscando a melhor internalização dos custos com a utilização dos recursos naturais, sem desviar do objetivo da proteção. Ou, nas palavras de Maria Alexandra de Sousa Aragão, não é apenas necessário compreender o princípio do poluidor-pagador, mas aplicá-lo devidamente, em conformidade com uma interpretação, sempre uniforme, evitando uma poluição normativa. Segundo a autora, essa poluição normativa ocorre quando as normas vigentes são, supostamente, conformes ao princípio do poluidor-pagador; na realidade, porém, pelo seu conteúdo ou forma de aplicação, mostram que tal princípio não é observado com todo rigor ou, então, fazem dele uma aplicação incorreta, redundando, substancialmente, em autênticas licenças gratuitas de poluição, que fazem prevalecer o interesse particular dos poluidores, de redução de custos, sobre o interesse público de proteção do ambiente. ${ }^{565}$

tantas vezes ao longo deste estudo, está hoje limitada ao julgado pelo STF, na ADI 3.378/DF, e à metodologia disposta no Decreto $\mathrm{n}^{\circ}$ 6.848/2009.

${ }_{564}$ MACHADO, Paulo Affonso Leme. Direito ambiental brasileiro. 19a ed. rev. atual. e ampl. São Paulo: Malheiros, 2011, p. 123.

565 ARAGÃO, Maria Alexandra de Sousa. O princípio do poluidor pagador: pedra angular da política comunitária do ambiente. Coimbra: Coimbra Editora, 1997, p. 55-56. 


\subsection{Conclusões preliminares}

O presente capítulo procurou demonstrar a funcionalidade das medidas compensatórias como instrumento de proteção do meio ambiente ao permitir, através delas, internalizar o mais possível os custos derivados da utilização dos recursos naturais.

Nessa linha, foi possível avaliar a correta (in)definição do instituto, ou melhor, o seu enquadramento ou não em uma determinada categoria ou natureza jurídica. Nesse sentido, e aproveitando o debate que girou em torno de uma das medidas compensatórias - a compensação ambiental da Lei do SNUC, analisada no Capítulo 2 desta tese -, iniciou-se demonstrando que as obrigações impostas por essas medidas não são, de fato, uma reparação por dano futuro, como querem alguns autores. Tampouco devem necessariamente ser enquadradas na natureza jurídica tributária, embora, como visto, possam, por vezes e a depender maneira como que instituídas, emergir na forma de um tributo. É possível, ainda, que sejam consideradas uma espécie de compartilhamento de despesas, como quis o STF no julgamento da ADI n ${ }^{0} 3.378 / \mathrm{DF}$, mas muito demonstrando o seu objetivo ou funcionalidade do que uma natureza jurídica.

A bem ver, pretendeu-se evidenciar que as medidas compensatórias não se subsumem a uma categoria estanque, ou em uma determinada "natureza jurídica”. De fato, é um instituto de difícil definição, que pode ser visto ora com características predominantes de um mecanismo de comando e controle, ora com as de um instrumento econômico, razão pela qual consideramos ser um instituto híbrido. E assim ocorre, pois, a par da preponderância à funcionalidade do instituto, do mesmo modo como acontece com as regras do Direito Ambiental, seus mecanismos e instrumentos também têm a característica da transversalidade, podendo manifestar-se em vários ramos do direito.

Como mecanismos de comando e controle, as medidas compensatórias aparecem ao incidir em impactos específicos, gerenciados por meio do processo de licenciamento ambiental. São medidas que se impõem, caso a caso, na hipótese de não ser possível prevenir ou mitigar os impactos negativos de determinadas atividades ou específicos empreendimentos. Já na forma de instrumentos econômicos, as medidas compensatórias não se impõem a impactos 
específicos; devem sim ser aplicadas a empreendimentos ou atividades com determinadas características ou, ainda, a um determinado segmento econômico.

Diante desse cenário, verificou-se, a bem ver, não importar tanto a categoria ou natureza jurídica do instituto - que, em verdade, é nenhuma; importa usar do direito para que seja funcional, permitindo eficazmente internalizar, o quão possível os custos derivados da utilização dos recursos naturais no processo produtivo.

No entanto, como é sempre necessário conjugar a análise funcional à análise estrutural do direito, inclusive para o bem da eficácia e efetividade das medidas compensatórias, foi preciso avaliar a melhor forma de serem racionalmente instituídas e implementadas. Sendo assim, foi possível verificar que (i) seus critérios ou padrões mínimos devem ser dispostos em lei em seu sentido estrito; (ii) faz-se necessário respeitar a competência legislativa concorrente disposta no art. 24 da Constituição Federal, deixando os Estadosmembros e o Distrito Federal apenas com poderes suplementares para tratar do tema; e (iii) é preciso que sejam obrigações fundadas em critérios objetivos de valoração. 


\section{CONCLUSÃO GERAL}

É óbvio e previsível que todo caminho encerra a expectativa da chegada. Nesta tese, essa expectativa deságua na conclusão, decorrência lógica do roteiro proposto inicialmente e, de certa forma, projeta-se para o futuro. No presente estudo, a conclusão comporta duas visões: uma, retrospectiva; outra, prospectiva.

A visão retrospectiva retoma as etapas percorridas e os elementos da ciência jurídica que foram trabalhados e acrescidos com novas considerações, elaboradas à luz da economia, do direito e da evolução da sociedade. Assim, é pertinente retomar os sucessivos passos dados nas normas, na doutrina e na argumentação - o que é feito à guisa de uma visão de conjunto sobre o tema desenvolvido.

A visão prospectiva, por sua vez, busca entrever, a partir da visão retrospectiva, novos rumos que o tema deverá comportar para progredir e enriquecer a ciência, a técnica e a prática. Parece-nos inerente a um trabalho que se pretende científico abrir-se para a continuidade, para o futuro. E, sem dúvida, o conhecimento e a prática do instituto jurídico das medidas compensatórias muito têm a ganhar com esse procedimento.

Vamos, pois, às conclusões a que chegamos.

\subsection{Visão retrospectiva}

A presente tese teve como tarefa axial discutir as medidas compensatórias, vistas como novo instituto jurídico que emerge como um dos meios disponibilizados pelo Direito Ambiental para equacionar a crescente crise ecológica, sendo mecanismo capaz de internalizar, já na implantação e início de operação de empreendimentos que causam impactos negativos ao meio ambiente, os custos pela utilização dos recursos naturais. 
O ponto de partida foi o debate travado em torno da compensação ambiental da Lei do Sistema Nacional de Unidades de Conservação - SNUC (Lei $n^{0}$ 9.985/2000). Tal introdução foi necessária, pois, em que pese a compensação ambiental ser espécie do gênero medidas compensatórias, foi ela por muito tempo considerada como a única medida compensatória capaz de equacionar os impactos negativos e não mitigáveis gerenciados no processo de licenciamento ambiental. Bem por isso, as discussões sobre a forma com que a compensação foi instituída, acerca do critério positivado para a sua aplicação e, ainda, no que se refere à sua natureza jurídica, necessariamente acabam por refletir no estudo das medidas compensatórias.

Considerado o cenário de onde se inferiram os questionamentos relacionados às medidas compensatórias, fez-se necessária, então, uma breve parada para avaliar a distinção dos conceitos jurídicos de dano ambiental e de impacto negativo ao meio ambiente. Afinal, as medidas compensatórias, impostas no decorrer do processo de licenciamento ambiental, são aplicadas para compensar o meio ambiente pelos impactos negativos resultantes de empreendimentos lícitos e aceitos, e não pelos danos ambientais decorrentes de eventos ilícitos e, portanto, não desejados.

Para tanto, acabamos por incursionar no estudo do risco, e dele foi possível extrair que os termos dano ambiental e impacto negativo no meio ambiente encontram-se no âmbito do risco concreto e, portanto, passível de ser gerenciado pelo direito e pela economia. Há, ainda, o risco abstrato ou incerto, condizente com o que se alude como dano futuro, e do qual trata Ulrich Beck em sua sociedade de risco. No risco abstrato ou no dano futuro, o direito encontra seus limites, significando que o respectivo gerenciamento deve ser vislumbrado em outra esfera, na qual se questiona, em última análise, o caminho que a humanidade está trilhando.

Ademais, verificou-se que o dano ambiental é uma lesão ilícita aos recursos ambientais, causando um indesejado prejuízo - ou poluição - ao meio ambiente e/ou a terceiros (conhecido esse último efeito como efeito ricochete ou reflexo), prejuízo a ser reparado pelos mecanismos da responsabilidade civil ambiental, inclusive utilizando-se dos meios processuais preventivos. Os danos ambientais podem, ainda, ser coibidos pela aplicação de penalidades administrativas 
e sanções criminais. Já o impacto negativo no meio ambiente é um fato previsto e aceito, exigindo, porém, o seu gerenciamento pelo processo administrativo de licenciamento ambiental. Em uma palavra, não se pode falar em dano quando se promove o gerenciamento dos impactos pelo licenciamento ambiental.

Após verificar as medidas compensatórias como instrumentos incidentes em situações onde ocorrem impactos negativos no meio ambiente - e não de danos ambientais - tornou-se possível volver para o tema central do estudo.

Nesse sentido, procuramos demonstrar como a economia e o direito, conciliando-se, enfrentam a crise ambiental e, sobretudo, equacionam a 'falha de mercado' chamada externalidade negativa. Nesse contexto, buscamos, antes, identificar o momento em que o ser humano tomou consciência da crise ambiental e, por decorrência, percebeu ter chegado ao estágio de escassez dos recursos naturais. Tal momento de conscientização conduziu a uma série de análises por parte da economia, e iniciativas por parte do direito, com vistas a procurar meios de internalização no processo produtivo dos custos decorrentes da sua utilização.

Constatou-se o sistema econômico de mercado exigindo velocidade na produção e no consumo - para dar conta da competitividade e ampliar o espaço para o lucro -, e, com isso, impor inevitavelmente rápidas inovações tecnológicas no processo industrial e, por consequência, induzir uma incalculável e contínua utilização dos recursos naturais. Nesse ritmo, foi possível defender que a economia e o direito, ao procurar equacionar a crise ambiental, e visando a proteger o meio ambiente, também o fazem com o intuito de renovar e manter o sistema econômico vigente, dentro, porém, de padrões de racionalidade, a que também se pode dar o nome de sustentabilidade.

Em tal conjuntura, com a evidencia da crise ambiental, surgiram progressivamente normas e princípios jurídicos nacionais e internacionais de proteção aos recursos naturais. Nesta tese, deu-se ênfase, sobretudo, ao princípio do poluidor-pagador cuja premissa, em síntese, é equacionar as externalidades negativas, a fim de internalizar os custos com a utilização dos recursos naturais na cadeia produtiva, por meio de mecanismos com diversas facetas, por vezes preventivas, por vezes reparatórias, por vezes compensatórias. 
Essa análise foi necessária, porquanto já se advogou que do princípio do poluidor-pagador derivariam apenas ações reparatórias, significando que qualquer medida destinada a internalizar os custos pela utilização dos recursos naturais serviria para reparar danos causados ao meio ambiente. Em tal contexto, ao explorar as demais dimensões do princípio do poluidor-pagador, verificou-se que ele também fundamenta alguns mecanismos preventivos e, daí, as próprias medidas compensatórias.

Em um terceiro momento, procuramos verificar por que e como o Estado regula práticas visando à preservação ambiental. Nesse sentido, foi possível demonstrar que o Estado acaba por harmonizar os conflitos ou as "falhas de mercado” inerentes ao sistema econômico vigente. Essa 'harmonização' é realizada atendendo-se ora aos interesses do poder econômico, ora aos interesses a eles contrapostos - como são os interesses sociais ou ambientais; sempre, porém, visando a um equilíbrio ou a manter incólume o marco de elasticidade do sistema, para que ele não se rompa. Afinal, dissemos que, se não forem contidas as forças do mercado, elas buscarão a máxima utilização dos recursos naturais, com o menor custo possível, o que significará, a um só tempo, a destruição do meio ambiente e do próprio sistema econômico.

Daí as políticas ambientais, emergindo como forma de impor regras e limites para a utilização dos recursos naturais, seja como meio de manter a maior possível a qualidade do meio ambiente, seja para permitir a perpetuação de bens necessários à manutenção e reprodução do sistema de mercado em que vivemos.

Essas políticas ambientais não são estruturadas para internalizar plenamente os custos da utilização dos recursos naturais. Isso porque, como visto, são inúmeras as dificuldades para a valoração dos bens ambientais, o que implica um inevitável déficit necessário que é assumido pelo Poder Público e, em última instância, pela própria sociedade. Sendo assim, as políticas são estruturadas para procurar o 'grau ótimo’ ou a melhor relação ‘custo benefício’ da utilização dos recursos naturais, o que passa por uma análise econômica que, por sua vez, permite identificar os melhores mecanismos e instrumentos para o alcance das metas e objetivos dessas políticas ambientais. 
Esses mecanismos e instrumentos apresentam-se de diversas formas, podendo ser classificados como de intervenção, de comando e controle, repressivos e econômicos. A presente tese, todavia, restringiu-se aos mecanismos de comando e controle e aos econômicos; isso, por acreditarmos terem esses o papel central na busca dos objetivos e metas das políticas ambientais. Nessa linha, vários mecanismos de comando e controle foram citados, como, também, foi possível apontar inúmeros instrumentos econômicos já aplicados, alguns já em utilização.

Os fundamentos jurídicos e econômicos das medidas compensatórias não se esgotam em si. Exigem a demonstração de sua funcionalidade ao permitirem internalizar o mais possível os custos derivados da utilização dos recursos naturais.

Para tanto, foi necessário avançar na discussão da sua natureza ou da sua categoria jurídica. Nesse sentido, e aproveitando o debate acerca da compensação ambiental da Lei do SNUC, verificou-se que as medidas compensatórias não são uma forma de reparação por dano futuro, muito menos se enquadram necessariamente como um tributo, mas podem ser vistas como instrumentos de compartilhamento de despesas.

A bem ver, considerando a transversalidade do Direito Ambiental e, por consequência, dos seus institutos, as medidas compensatórias ora manifestam-se com características predominantes de medidas de comando e controle, ora com as marcas de instrumentos econômicos, razão pela qual se concluiu tratar-se de instrumentos híbridos.

Como mecanismos de comando e controle, as medidas compensatórias incidem em impactos específicos, gerenciados por meio do processo de licenciamento ambiental. Impõem-se, caso a caso, na hipótese de não ser possível prevenir ou mitigar os impactos negativos de determinadas atividades ou empreendimentos específicos. Para exemplificar, apontaram-se as regras dispostas no Código Florestal e na Lei da Mata Atlântica, ambas impondo compensações pelas perdas decorrentes da supressão de vegetação em áreas de preservação permanente - APP ou na Mata Atlântica, respectivamente.

$\mathrm{Na}$ forma preponderante de instrumentos econômicos, as medidas compensatórias não se impõem a impactos específicos, embora possam ser 
exigidas também no decorrer do processo de licenciamento ambiental. Nesse formato, elas são impostas a priori, ao incidir em um determinado segmento econômico ou, por exemplo, em todos os empreendimentos que possam causar significativos impactos no meio ambiente. Nessas situações, é muito usual sirvam como forma de arrecadação de recursos para um determinado fim de proteção ambiental. É o que ocorre, a título ilustrativo, com a multirreferida 'compensação ambiental' da Lei do SNUC, com a medida compensatória do Estatuto da Cidade, e, ainda, com a CIDE imposta nas atividades de comercialização e importação de combustíveis.

Superada a questão do enquadramento das medidas compensatórias no ordenamento jurídico, e verificando-se não se subsumirem exatamente a uma categoria estanque, de modo a poderem emergir com diversas facetas, foi possível caminhar para a análise da sua funcionalidade. Nesse sentido, procuramos demonstrar como essas medidas são capazes de internalizar os custos dos recursos naturais, desestimulando seu uso no processo produtivo.

Demonstrada a sua funcionalidade - e os seus limites -, partiu-se para uma análise estrutural do instituto, ao avaliar os elementos para uma firme regulamentação jurídica das medidas compensatórias, de modo a torná-las eficazes e efetivas, e não serem desvirtuadas dos seus objetivos. Dessa forma, foi possível sugerir que as medidas compensatórias devem: (i) ter critérios ou padrões mínimos dispostos em lei em sentido estrito; (ii) ser instituídas em respeito à competência legislativa concorrente; e, ainda, (iii) em razão das dificuldades de valoração dos bens ambientais, ser fundadas em critérios objetivos de cálculo e aplicação. Isso, claramente, para permitir a funcionalidade do instrumento, sem desvirtuá-lo com intenções arrecadatórias ou desvinculadas com o objetivo de proteção ambiental.

\subsection{Visão prospectiva}

Por último e agora em uma visão prospectiva, é oportuno deixar aqui registrado que as conclusões obtidas com o presente estudo não pretendem ser simplesmente um ponto de chegada. Propõe-se sejam um ponto de partida em 
condições de colaborar com outras contribuições voltadas para o campo do Direito Ambiental como um saber que procura salvaguardar os bens da natureza sem criar obstáculos desnecessários ao desenvolvimento socioeconômico, conceito este, aliás, que está demandar uma definição mais elaborada e operacional para fins ambientais.

Desde logo, é necessário admitir, não obstante todo o caminho percorrido na sua análise e na reflexão, o princípio do poluidor-pagador ainda se encontra em fase inicial de aplicação no ordenamento jurídico nacional. Com efeito, não se pode dizer ter o direito brasileiro - salvo com algumas exceções -, sido capaz de criar mecanismos efetivamente capazes de internalizar os custos pela utilização dos recursos naturais, mormente quando esse uso se refira aos impactos negativos avaliados no decorrer do licenciamento ambiental de empreendimentos e atividades consideradas importantes para o desenvolvimento. Essa dificuldade talvez ocorra por restarem dúvidas, ambiguidades e resistências quanto à aplicação prática de tal princípio, afora a natural e espera resistência dos desenvolvimentistas “à outrance”, isto é, a qualquer custo.

Não há, pois, como desdenhar o papel das medidas compensatórias, fundadas no princípio do poluidor-pagador, como significativo instrumento capaz de equacionar - ainda que parcialmente - as falha de mercado conhecida como externalidade negativa, desestimulando o uso dos recursos naturais no processo produtivo e de consumo.

Sendo assim, imprescindível avançar-se na compreensão e aplicação do instituto, sobretudo por poderem as medidas compensatórias transparecer em diversas facetas jurídicas, aplicando-se ora como mecanismos de comando e controle ora como instrumentos econômicos. Com isso, temos esperança que tal instituto sirva para impulsionar atitudes “mais limpas”, visando a minimizar o irracional e predatório modo de produção, consumo e descarte hoje presente em tantas atividades e empreendimentos.

Para tanto, esperamos que o tema seja aprofundado mediante a análise do sistema jurídico como um todo - de forma holística -, respeitando as características da transversalidade e da interdisciplinaridade que permeiam a norma jurídica ambiental, para com isso evitar-se o impulso de estancar os 
institutos do Direito Ambiental em determinadas categorias fixas, obstando a sua aplicação com infindáveis questiúnculas. De fato, espera-se que se dê preponderância à análise funcional do instituto.

Assim, o conceito das medidas compensatórias deve ser sempre reforçado com o de compromisso compartilhado e de custo igualmente compartilhado. Isso, aliás, e é sempre oportuno lembrar, está contido embrionariamente no preceito do art. 225, em seu $\S 1^{\circ}$, da Lei Maior, determinando a obrigação compartilhada como meio a alcançar um "meio ambiente ecologicamente equilibrado, bem de uso comum do povo e essencial à sadia qualidade de vida”. 


\section{BIBLIOGRAFIA}

AMARAL, Paulo Henrique do. Tributação Ambiental: contributo à política de desenvolvimento sustentável no Brasil. Revista de Direito Ambiental. no 50. Ano 13.abr-jun. São Paulo: RT, 2008.

AMARAL, Paulo Henrique do; MOREIRA, José Edson Campos. Contribuição social ambiental: Um instrumento jurídico-econômico efetivo no combate à degradação ambiental e efetivo na proteção do meio ambiente ecologicamente equilibrado. In: BENJAMIN, Antonio Herman (org.). Anais do $5^{\circ}$ Congresso de Direito Ambiental, de 4 a 7 de junho de 2001. São Paulo: IMESP, 2001.

ANDRADE, Nelson Luis Sampaio de. A cobrança pelo uso dos recursos hídricos. In: Revista de Direito Ambiental. $n^{\circ}$ 4. Ano 1. out-dez. São Paulo: RT, 1996.

ANTUNES, Paulo de Bessa. Dano ambiental: uma abordagem conceitual. Rio de Janeiro: Lumen Juris, 2000.

. Direito ambiental. $11^{\text {a }}$ ed. ampl. ref. Rio de Janeiro: Lumen Juris, 2008,

AQUINO, Sandra Clice de. A compensação ambiental na legislação brasileira sob o foco do desenvolvimento sustentável das cidades. In: SILVA, Bruno Campos (org.). Direito ambiental: enfoques variados. São Paulo: Lemos \& Cruz, 2004.

ARAGÃO, Alexandre Santos de. A concepção pós-positivista do princípio da legalidade. Revista de Direito Constitucional e Internacional. $\mathrm{n}^{\circ} 65$. Ano 16. São Paulo: RT, 2008.

ARAGÃO, Maria Alexandra de Sousa. O princípio do poluidor-pagador: pedra angular da política comunitária do meio ambiente. Coimbra: Coimbra Editora, 1997. 
- O princípio do nível elevado de proteção e a renovação ecológica do direito do ambiente e dos resíduos. Coimbra: Almedina, 2006.

ARAÚJO, Claudia Campos de; FERREIRA, Maria Isabel Reis; RODRIGUES, Patricia Castilho; SANTOS, Simone Marques dos. Meio ambiente e sistema tributário. São Paulo: Senac, 2003.

ARRUDA, Domingos Sávio de Barros. A categoria acautelatória da responsabilidade ambiental. Revista de Direito Ambiental. vol. 42. p. 25. Abr / 2006.

ARTIGAS, Priscila Santos. O princípio do poluidor pagador e a busca pela eficácia de seus instrumentos após 25 anos da Política Nacional do Meio Ambiente. Direito, Política e Meio Ambiente: 25 anos da Lei Federal no. 6.938/81. Curitiba: Ordem dos Advogados do Brasil, Seção Paraná, 2006.

- Os limites da democracia participativa na defesa do meio ambiente. Dissertação de Mestrado, Departamento de Filosofia e Teoria Geral do Direito. Faculdade de Direito da Universidade de São Paulo - USP. Maio/2008.

ATALIBA, Geraldo. Decreto Regulamentar no Sistema Brasileiro. Revista de Direito Administrativo. $\mathrm{n}^{\circ}$ 97. Rio de Janeiro.

ATHIAS, Jorge Alex Nunes. Responsabilidade civil e meio ambiente - breve panorama do direito brasileiro. In BENJAMIN, Antonio Herman V. (coord.). Dano ambiental: prevenção, reparação e repressão. São Paulo: RT, 1993.

BANCO MUNDIAL. Licenciamento ambiental de empreendimentos hidrelétricos no Brasil: uma contribuição para o debate. Vol. I: Relatório Síntese. mar/2008.

BARBOSA, Rangel; OLIVEIRA, Patrícia. O princípio do poluidor pagador no Protocolo de Quioto. Revista de Direito Ambiental. n 44. Ano 11. out-dez. São Paulo: RT, 2006. 
BARROSO, Luís Roberto. Interpretação e Aplicação da Constituição. $6^{\mathrm{a}}$ ed. São Paulo: Saraiva, 2008.

BECHARA, Erika. Licenciamento e compensação ambiental - na lei do Sistema Nacional das Unidades de Conservação (SNUC). São Paulo: Atlas, 2009.

BECK, Ulrich. Sociedade de risco: rumo a uma outra modernidade. Trad. Sebastião Nascimento. São Paulo: Ed.34, 2010.

BECKER, Alfredo Augusto. Teoria geral do Direito Tributário. $4^{\mathrm{a}}$ ed. São Paulo: Noeses, 2007.

BENJAMIN, Antonio Herman de V. (coord.). Dano ambiental: prevenção, reparação e repressão. São Paulo: RT, 1993.

BENJAMIN, Antonio Herman de V. Função ambiental. In BENJAMIN, Antonio Herman V. (coord.). Dano ambiental: prevenção, reparação e repressão. São Paulo: RT, 1993.

- O princípio do poluidor pagador e a reparação do dano ambiental. In BENJAMIN, Antonio Herman V. (coord.). Dano ambiental: prevenção, reparação e repressão. São Paulo: RT, 1993.

- Responsabilidade civil pelo dano ambiental. Revista de Direito Ambiental, ano 3, n. 9, p. 12, jan/mar. 1998.

BOBBIO, Norberto. Teoria do ordenamento jurídico. Trad. Maria Celeste Cordeiro Leite dos Santos. $10^{\text {a }}$ ed. Brasília: Editora Universidade de Brasília, 1999.

As ideologias e o poder em crise. Trad. de João Ferreira; rev. téc. Gilson César Cardoso. 4ª ed. Brasília: UNB, 1999.

- Teoria da norma jurídica. Trad. Fernando Pavan Baptista e Ariani Bueno Sudatti. São Paulo: Edipro, 2001.

- O futuro da democracia. Trad. Marco Aurélio Nogueira. $8^{a}$ ed. São Paulo : Editora Paz e Terra, 2002. 
. Da estrutura à função, novos estudos de teoria do direito. Barueri: Manole, 2007.

BOBBIO, Norberto. MATTEUCCI, Nicola. PASQUINO, Gianfranco. Dicionário de Política. Vol. 2. $5^{\text {a }}$ ed. Brasília: Editora Universidade de Brasília. São Paulo: Imprensa Oficial do Estado, 2000.

BONAVIDES, Paulo. Curso de direito constitucional. $12^{\mathrm{a}}$ ed. São Paulo: Malheiros, 2002.

BOTTOMORE, Tom (ed.). Dicionário do pensamento marxista. Trad. Waltensir Dutra. Rio de Janeiro: Jorge Zahar Ed., 2001.

BUCCI, Maria Paula Dallari. Políticas públicas: reflexões sobre o conceito jurídico. São Paulo: Saraiva: 2006

BÜRGENMEIER, Beat. Politiques économiques du développement durable. Bruxelles: De Boeck, 2008.

CABRAL, Ligia Maria Martins (coord.). O meio ambiente e o setor de energia elétrica brasileiro. Rio de Janeiro: Centro de Memória da Eletricidade no Brasil, 2009.

CAFFÉ ALVES. Estado e ideologia - aparência e realidade. São Paulo: Brasiliense, 1987.

. Fundamentos dos direito e meio ambiente. In: PHILIPPI JR., Arlindo;

CAFFÉ ALVES, Alaôr (eds.). Curso interdisciplinar de Direito Ambiental. Barueri: Manole, 2005.

. Dialética e direito: linguagem, sentido e realidade: fundamentos a uma teoria crítica da interpretação do direito. Barueri: Manole, 2010.

CANOTILHO, José Joaquim Gomes. Direito Constitucional. $5^{\mathrm{a}}$ ed. Coimbra: Almedina, 1992.

. Estudos sobre direitos fundamentais. Coimbra: Coimbra Editora, 2004. 
CANOTILHO, José Joaquim Gomes; LEITE, José Rubens Morato. Direito constitucional ambiental brasileiro. São Paulo: Saraiva, 2007.

CARRAZA, Roque Antonio. Curso de direito constitucional tributário. $18^{\mathrm{a}}$ ed. São Paulo: Malheiros, 2002.

CARVALHO, Délton Winter de. Dano ambiental futuro - a responsabilização civil pelo risco ambiental. Rio de Janeiro: Forense Universitária, 2008.

CARVALHO, Paulo de Barros. Direito tributário: fundamentos jurídicos da incidência. 8 ${ }^{\mathrm{a}}$ ed. rev. São Paulo: Saraiva, 2010.

. Curso de direito tributário. 23 a ed. São Paulo: Saraiva, 2011.

CASTELlo, Melissa Guimarães. Contribuição de Intervenção no Domínio Econômico sobre os Combustíveis: um superfund brasileiro? Revista de Direito Ambiental. no 44. Ano 11. out-dez. São Paulo: RT, 2006.

CAVALIERI FILHO, Sérgio. Programa de Responsabilidade Civil. $4^{\mathrm{a}}$ ed. São Paulo: Malheiros, 2003.

CERRI NETO, Mauro. Impacto Ambiental, degradação ambiental, poluição, contaminação e dano ambiental: comparação entre conceitos legal e técnico. Dissertação de Mestrado, Universidade Estadual Paulista, Rio Claro, 2008.

COGGIOLA, Osvaldo. Neoliberalismo, futuro do capitalismo? In: KATZ, Claudio; COGGIOLA, Osvaldo. Neoliberalismo ou crise do capital? São Paulo: Xamã, 1996.

COIMBRA, José de Ávila Aguiar. O outro lado do meio ambiente. Campinas: Millenium, 2002.

COLE, Scott G. Environmental compensation using Resource Equivalency Analysis (REA) and Habitat Equivalency Analysis (HEA): Is it just for the birds? Licentiate Thesis. Swedish University of Agricultural Sciences.Umeå, 2010. 
CONFERÊNCIA DAS NAÇÕES UNIDAS SOBRE MEIO AMBIENTE E DESENVOLVIMENTO. Agenda 21. Ementa. Senado Federal, Brasília, 2001.

CORREIA, José Manuel Sérvulo. Legalidade e autonomia contratual nos contratos administrativos. Coimbra: Almeida, 1987.

COSTA, Regina Helena. Aspectos tributários do Estatuto da Cidade. In: Temas de Direito Urbanístico 3. CAOHURB - Centro Operacional das Promotorias de Justiça e Habitação e Urbanismo. São Paulo: Ministério Público/Imprensa Oficial, 2001.

Apontamentos sobre a tributação ambiental no Brasil. In: TÔRRES, Heleno Taveira (org.). Direito Tributário Ambiental. São Paulo: Malheiros, 2005.

DAHL, Robert. On democracy. New Haven: Yale University Press, 1998.

D’ISEP, Clarissa Ferreira Macedo. Direito ambiental econômico e a ISO 14000: Análise jurídica do modelo de gestão ambiental e certificação ISO 14001. $2^{\mathrm{a}}$ ed. rev. atual. e ampl. São Paulo: RT, 2009.

DERANI, Cristiane. Direito ambiental econômico. $3^{\mathrm{a}}$ ed. São Paulo: Saraiva, 2008.

DI PIETRO, Maria Sylvia Zanella Di Pietro. Direito administrativo. $12^{\mathrm{a}}$ ed. São Paulo: Atlas, 2000.

DINIZ, Maria Helena. Lei de introdução ao código civil - interpretada. 9a ed. São Paulo: Saraiva, 2002.

DUPUY, Jean-Pierre. Pour um catastrophisme éclairé: quand l'impossible est certain. Paris: Éditions du Seuil, 2002.

DWORKIN, Ronald. Por uma questão de princípio. Trad. Luís Carlos Borges. São Paulo: Martins Fontes, 2001. 
EISENMANN, Charles. O Direito Administrativo e o Princípio da Legalidade. Revista de Direito Administrativo, n ${ }^{\circ}$ 56. 1959.

FAGUNDES, Seabra. O Controle dos Atos Administrativos pelo Poder Judiciário. 5ª ed. Rio de Janeiro: Forense, 1979.

FARBER, Daniel A. Climate Justice (July 10, 2011). Available at SSRN: http://ssrn.com/abstract=1883186, extraído em 13.10.2011.

. From Here to Eternity: Environmental Law and Future Generations. University of Illinois Law Review, Forthcoming. 2002. Disponível em: $<$ http://ssrn.com/abstract=314464>. Acesso em: 13.10.2011.

. Uncertainty. The Georgetown Law Jornal. Vol. 99, p. 901, 2011; UC Berkeley Public Law Research Paper No. 1555343. Disponível em: $<$ http://ssrn.com/abstract=1555343>. Acesso em: 13.10.2011.

FAURE, Michael. L'analyse économique du droit de l'environnement. Bruxelles: Bruyllant Bruxelles, 2007.

FERRAZ JR., Tércio Sampaio. Introdução ao estudo do direito: técnica, decisão, dominação. $4^{\mathrm{a}}$ ed. São Paulo: Ed. Atlas, 2003.

. Poder econômico e gestão orgânica. In: FERRAZ JR., Tércio Sampaio; SALOMÃO FILHO, Calixto; NUSDEO, Fábio (orgs.). Poder econômico: direito, pobreza, violência, corrupção. Barueri: Manole, 2009.

FERRAZ JR., Tércio Sampaio; SALOMÃO FILHO, Calixto; NUSDEO, Fábio (orgs.). Poder econômico: direito, pobreza, violência, corrupção. Barueri: Manole, 2009.

FERRAZ, Roberto. Tributação e meio ambiente: O green tax no Brasil (a contribuição da Emenda 33/2001). Revista de Direito Ambiental. n 31 . Ano 8. jul-set. São Paulo: RT, 2003.

. Tributação ambientalmente orientada e as espécies tributárias no Brasil. In: TÔRRES, Heleno Taveira (org.). Direito Tributário Ambiental. São Paulo: Malheiros, 2005. 
FERREIRA, João S. Whitaker. O mito da cidade-global: o papel da ideologia na produção do espaço urbano. Petrópolis: Vozes, 2007.

FERREIRA, Manoel Gonçalves. Do processo legislativo. $3^{\mathrm{a}}$ ed. São Paulo: Saraiva, 1995.

FINK, Daniel; ALONSO JR., Hamilton; DAWALIBI, Marcelo. Aspectos jurídicos do licenciamento ambiental. $3^{\mathrm{a}}$ ed. rev. e atual. Rio de Janeiro: Forense Universitária, 2004.

FREITAS, Vladimir Passos de. A Constituição Federal e a efetividade das normas ambientais. $2^{\mathrm{a}}$ ed. São Paulo: RT, 2002.

GERENT, Juliana. Internalização das externalidades negativas ambientais - uma breve análise da relação jurídico-econômica. Revista de Direito Ambiental. $n^{0}$ 44. Ano 11. out-dez. São Paulo: RT, 2006.

GIORGI, Raffaele De. Direito, democracia e risco: vínculos com o futuro. Porto Alegre: Sergio Antonio Fabris Editor, 1998.

. O risco na sociedade contemporânea. Revista de Direito Sanitário. São Paulo, v. 9, n.1, p.37-49, mar/jun 2008.

GOULDER, Lawrence H. PARRY, Ian W. H. Instrument Choice in Environmental Policy. RFF Discussion Paper No. 08-07. Abril/2008. Disponível em: <http://ssrn.com/abstract=1117566>. Acesso em: 3.10.2011.

GRANZIERA, Maria Luiza Machado. Direito das águas: disciplina jurídica das águas doces. São Paulo: Atlas, 2001.

GRAU, Eros Roberto. A ordem econômica na Constituição de 1988 (interpretação e crítica). São Paulo: RT, 1990.

. O direito posto e o direito pressuposto. $5^{\mathrm{a}}$ ed. rev. atual. e ampl. São Paulo: Malheiros, 2003.

GRUPPI, Luciano. O conceito de hegemonia em Gramsci. Rio de Janeiro: Graal, 1978. 
GUERRA, Glauco Martins. Princípio da legalidade e poder normativo: dilemas da autonomia regulamentar. Revista do Tribunal Regional do Trabalho da 15 Região. Campinas, n. 24, 2004. Disponível em: $<$ http://www.trt15.jus.br/escola_da_magistratura/Rev24Art15.pdf>. Acesso em $1^{\circ} \cdot 6.2010$.

GUERRA, Sérgio. Compensação ambiental nos empreendimentos de significativo impacto. In: WERNECK, Mário et al. (coord.). Direito ambiental: visto por nós advogados. Belo Horizonte: Del Rey, 2005.

GUERRA, Sinclair Mallet-Guy; SUAREZ, Mirian Liliana Hinostroza. Questões econômicas e implicações ambientais: Visão introdutória. Revista de Direito Ambiental. no 8. Ano 2. out-dez. São Paulo: RT, 1997.

GUSMÃO, Omara Oliveira de. Proteção ambiental e tributação: o tributo como coadjuvante na concretização do valor constitucional "meio ambiente". Revista Tributária e de Finanças Públicas. vol. 66. Ano 14. jan-fev. São Paulo: RT, 2006.

HABERMAS, Jurgen. Direito e democracia: entre facticidade e validade, vol. II. Trad. Flávio Beno Siebeneichler. Rio de Janeiro: Tempo Brasileiro, 1997.

HAMMERSCHMIDT, Denise. O risco na sociedade contemporânea e o princípio da precaução no Direito Ambiental. Revista dos Tribunais. Ano 92. v. 808. Fev. 2003.

JONAS, Hans. O princípio da responsabilidade: ensaio de uma ética para a civilização tecnológica. Trad. Marijane Lisboa e Luiz Barros Montez. Rio de Janeiro: Contraponto, Ed. PUC-Rio, 2006.

KELSEN, Hans. Teoria pura do direito. 6ª ed. São Paulo: Martins Fontes, 1998.

KERCHOVE, Michel Van de; OST, François. Le système juridique: entre ordre et désordre. Paris: Presses Universitaires de France, 1988, p. 162. 
KRELL, Andreas. Licença ou autorização ambiental? Muita discussão em torno de um falso dilema. Revista de Direito Ambiental. nº 49. Ano 13. jan-mar. São Paulo: RT, 2008.

LEFF, Enrique. Saber Ambiental: sustentabilidade, racionalidade, complexidade, poder. Trad. de Lúcia Mathilde Endlich Orth. $5^{\mathrm{a}}$ ed. Petrópolis: Vozes, 2001.

. Racionalidade ambiental: a reapropriação social da natureza. Rio de Janeiro: Civilização Brasileira, 2006.

. Epistemologia ambiental. Trad. Sandra Valenzuela ; rev. Técnica de Paulo Freire Vieira. 4ª ed. São Paulo: Cortez, 2007.

LEITE, José Rubens Morato; AYALA, Patryck de Araújo. Direito ambiental na sociedade de risco. Rio de Janeiro: Forense Universitária, 2002.

; . Dano ambiental: do individual ao coletivo extrapatrimonial: teoria e prática. 4a ed. São Paulo: RT, 2011.

LEITE, José Rubens Morato; BELLO FILHO, Ney de Barros (orgs.). Direito ambiental contemporâneo. Barueri: Manole, 2004.

LEMOS, Patrícia Faga Iglecias. Direito ambiental - Responsabilidade civil e proteção ao meio ambiente. $3^{\mathrm{a}}$ ed. São Paulo: RT, 2010.

. Resíduos sólidos e responsabilidade civil pós-consumo. São Paulo: RT, 2011.

LIMA, Alvino Ferreira. Culpa e risco. Atual. Ovídio Rocha Barros Sandoval. São Paulo: RT, 1998.

MACHADO, Paulo Affonso Leme. Recursos hídricos. Direito brasileiro e internacional. São Paulo: Malheiros, 2002.

. Direito ambiental brasileiro. 19a ed. São Paulo: Malheiros, 2011.

MARSHALL, Alfred. Principles of economics. 8th ed. London: Macmillian, 1920. 
MAXIMILIANO, Carlos. Hermenêutica e aplicação do Direito. 9a ed. Rio de Janeiro: Forense, 1979.

MEDAUAR, Odete. Ato de Governo. Revista de Direito Administrativo. janmar. Rio de Janeiro: RT, 1993.

. A processualidade no direito administrativo. São Paulo: RT, 1993.

. Direito administrativo moderno. $14^{\text {a }}$ ed. São Paulo: RT, 2010.

MEDAUAR, Odete (org.). Coletânea de legislação de direito ambiental: Constituição Federal. São Paulo: RT, 2008.

MELLO, Celso Antonio Bandeira de. Curso de Direito Administrativo. $28^{\mathrm{a}}$ ed. São Paulo: Malheiros, 2011.

MILARÉ, Édis. Direito do ambiente. $7^{\mathrm{a}}$ ed. São Paulo: RT, 2011.

A ação civil pública por dano ao meio ambiente. In: MILARÉ, Édis (coord.). Ação Civil Pública - Lei 7.347/1985 - 15 anos. 2a ed. São Paulo: RT, 2002.

MILARÉ, Édis; ARTIGAS, Priscila Santos. Compensação Ambiental: questões controvertidas. Revista de Direito Ambiental. no 43. Ano 11. jul-set. São Paulo: RT, 2006.

MILARÉ, Édis; COIMBRA, José de Ávila Aguiar. Antropocentrismo x Ecocentrismo na ciência jurídica. Revista de Direito Ambiental. $n^{\circ}$ 36. Ano 9. out-dez. São Paulo: RT, 2004.

MILARÉ, Édis; MACHADO, Paulo Affonso Leme (orgs.). Doutrinas essenciais: Direito Ambiental. Vol. II. São Paulo: RT, 2011.

MIRANDA, Pontes de. Comentários à Constituição de 1967. tomo III. $2^{\mathrm{a}}$ ed. São Paulo: RT, 1970.

MIRANDA, Pontes. Comentários à Constituição de 1967, com a Emenda $n^{o} 1$ de 1969. Tomo III. $2^{a}$ ed. São Paulo: RT, 1970. 
MIRRA, Álvaro Luiz Valery. Princípios Fundamentais do Direito Ambiental. In: OLIVEIRA Jr., José Alcebíades; LEITE, José Rubens Morato (orgs.). Cidadania coletiva. Florianópolis: Paralelo, 27, 1996.

. Impacto ambiental - aspectos da legislação brasileira. $4^{\mathrm{a}}$ ed. São Paulo: Juarez de Oliveira, 2008.

MODÉ, Fernando Magalhães. Tributação ambiental - A função do tributo na proteção do meio ambiente. Curitiba: Juruá, 2004.

MORAIS, José Luiz Bolzan de. Novos direitos e tributação. Perspectivas necessárias para uma ecotributação. Anotações preliminares. In: TÔRRES, Heleno Taveira (org.). Direito Tributário Ambiental. São Paulo: Malheiros, 2005.

MORAIS, Roberta Jardim de. O princípio da precaução (re)visitado - um olhar jurídico-econômico sobre o comércio internacional dos organismos geneticamente modificados. Tese de Doutorado, Universidade de Coimbra, 2008.

NABAIS, José Casalta. Tributos com fins ambientais. Revista Tributária e de Finanças Públicas. vol. 80. São Paulo: Revista dos Tribunais, 2008.

NEVIN, Edward. The economics of Europe. Macmillan, 1990.

NUNES, Lilian Rose Lemos Soares. Política fiscal aplicada ao meio ambiente: Aspectos jurídicos do instrumento econômico/tributos. In: BENJAMIN, Antonio Hermann (org.). Anais do $6^{\circ}$ Congresso Internacional de Direito Ambiental, de 03 a 06 de junho 2002: 10 anos da Eco-92: O Direito e o Desenvolvimento Sustentável. São Paulo: IMESP, 2002.

NUSDEO, Ana Maria de Oliveira. O uso dos instrumentos econômicos nas normas de proteção ambiental. Revista da Faculdade de Direito da Universidade de São Paulo. v. 101, jan/dez 2006.

. Pagamento por serviços ambientais no Brasil: elementos para uma regulamentação ambientalmente íntegra e socialmente justa. Tese 
apresentada à Faculdade de Direito da Universidade de São Paulo para obtenção do título de Livre-Docente. São Paulo/2010.

NUSDEO, Fábio. Desenvolvimento e ecologia. São Paulo: Saraiva, 1975.

. Desenvolvimento e ecologia. Revista Justitia, São Paulo, 47(128):5259, jan/mar 1995.

. Fundamentos para uma codificação do direito econômico. São Paulo: RT, 1995.

. A contribuição de melhoria revisitada: uma revisão e uma proposta. In: SCHOUERI, Luís Eduardo (org.). Direito tributário: homenagem a Alcides Jorge Costa. São Paulo: Quartier Latin, 2003.

- Economia do Meio Ambiente. In: PHILIPPI JR., Arlindo; CAFFÉ ALVES, Alaôr (eds.). Curso interdisciplinar de Direito Ambiental. Barueri: Manole, 2005.

- Direito Econômico Ambiental. In: PHILIPPI JR., Arlindo; CAFFÉ ALVES, Alaôr (eds.). Curso interdisciplinar de Direito Ambiental. Barueri: Manole, 2005.

. Legislação econômica, grupos de pressão e regulação. In: FERRAZ JR., Tércio Sampaio; SALOMÃO FILHO, Calixto; NUSDEO, Fábio (orgs.). Poder econômico: direito, pobreza, violência, corrupção. Barueri: Manole, 2009.

. Curso de economia: Introdução ao direito econômico. $6^{\mathrm{a}}$ ed. São Paulo: RT, 2010.

OECD. The polluter pays principle: definition, analysis, implementation. Paris, 1975.

OECD. Environmental principes and concepts. Paris, 1975.

OLIVEIRA, Antônio Inagê de Assis Oliveira. O licenciamento ambiental. São Paulo: Iglu Editora, 1999. 
OLIVEIRA, José Marcos Domingues de. Direito tributário e meio ambiente. $3^{\mathrm{a}}$ ed. ver. e ampl. Rio de Janeiro: Forense, 2007.

. O Supremo Tribunal e a compensação SNUC. A ADI 3.378-DF. Revista Direito GV. São Paulo, vol. 5, nº 1, jan/jun-2009.

- A chamada compensação financeira do SNUC. Revista Dialética de Direito Tributário, $\mathrm{n}^{\circ}$ 133, out. 2006.

. Environmental fees and compensatory tax in Brazil. Law and Business Review of the Américas, v.13, Spring, 2007, p. 279-303.

OST, François. A natureza à margem da lei - A ecologia à prova do direito. Trad. Joana Chaves. Lisboa: Ed. Instituto Piaget, 1995.

PETRY, Rodrigo Caramori. Compensações financeiras, participações e outras cobranças estatais sobre empresas dos setores de mineração, energia, petróleo e gás. Revista Tributária e de Finanças Públicas. vol. 89. Nov/2009.

PHILIPPI JR., Arlindo; CAFFÉ ALVES, Alaôr (eds.). Curso interdisciplinar de Direito Ambiental. Barueri: Manole, 2005.

PINHO, Hortênsia Gomes. Prevenção e reparação de danos ambientais. As medidas de reposição natural, compensatórias e preventivas e a indenização pecuniária. Rio de Janeiro: GZ Editora, 2010.

POSNER, Eric. Agencies should ignore distant-future generations. The University of Chicago law review. 74:139, 2007.

POSNER, Richard A. Catastrophe: risk and response. New York: Oxford University Press, 2004

PRIEUR, Michel. Droit de l'environnement. 5ª ed. Paris: Dalloz, 2004.

REALI, Darci. Os municípios e a tributação ambiental. Caxias do Sul: Educs, 2006. 
REVESZ, Richard L. STAVINS, Robert N. Environmental Law and Policy. NYU Public Law Research Paper 82; NYU Law \& Econ Research Paper 04-015; Harvard Public Law Working Paper No. 102; KSG Working Paper No. RWP04-023. Setembro/2004. Disponível em: <http://ssrn.com/abstract= 552043>. Acesso em: 3.10.2011.

RIBAS, Lidia Maria L.R; CARVALHO, Valbério Nobre de. O tributo como instrumento de tutela do meio ambiente. Revista de Direito Ambiental. $\mathrm{n}^{\circ}$ 54. Ano 14. abr-jun. São Paulo: RT, 2009.

RODRIGUES, Marcelo Abelha. Aspectos jurídicos da compensação ambiental e do art. 36, $\S 1^{\circ}$ da Lei brasileira das Unidades de Conservação (Lei 9.985/00). Revista de Direito Ambiental. $n^{\circ}$ 46. Ano 12. abril-junho. São Paulo: RT, 2007.

RUARO, Regina Linden. CURVELO, Alexandre Schubert. O Poder Regulamentar (Autônomo) e o Conselho Nacional de Justiça - Algumas Anotações Sobre o Poder Regulamentar Autônomo no Brasil. Revista dos Tribunais. 858/103. São Paulo: RT, 2007.

SACHS, Ignacy. La troisième rive - À la recherche de l'écodéveloppement. Paris: Bourin Éditeur, 2007.

SÁNCHEZ, Luiz Enrique. Danos e passivo ambiental. In: PHILIPPI JR., Arlindo; CAFFÉ ALVES, Alaôr (eds.). Curso interdisciplinar de Direito Ambiental. Barueri: Manole, 2005.

Avaliação de impacto ambiental: conceitos e métodos. São Paulo: Oficina de Textos, 2008.

SANTILLI, Juliana. Socioambientalismo e novos direitos. São Paulo: Peirópolis, 2005.

SCAFF, Fernando Facury; TUPIASSU, Lise Vieira da Costa. Tributação e políticas públicas: O ICMS ecológico. Revista de Direito Ambiental. $\mathrm{n}^{\circ} 38$. Ano 10. abr-jun. São Paulo: RT, 2005. 
SCHOUERI, Luís Eduardo. Contribuição ao estudo das normas tributárias indutoras como instrumento de intervenção sobre o domínio econômico. São Paulo: USP, 2002.

- Normas Tributárias Indutoras em Matéria Ambiental. In: TÔRRES, Heleno Taveira (org.). Direito Tributário Ambiental. São Paulo: Malheiros Editores, 2005.

SEROA DA MOTTA, Ronaldo. Instrumentos econômicos e política ambiental. Revista de Direito ambiental. $\mathrm{n}^{\circ}$ 20. Ano 5. out-dez. São Paulo: RT, 2000. . Economia ambiental. Rio de Janeiro: Editora FGV, 2006.

SEROA DA MOTTA, Ronaldo; OLIVEIRA, José Marcos Domingues de; MARGULIS, Sergio. Proposta de tributação ambiental na atual reforma tributária brasileira. IPEA. Texto para discussão $n^{\circ}$ 738, 2000. Disponível em: <http://www.ipea.gov.br/pub/td/td_2000/td0738.pdf>. Acesso em: 3.12.2011.

SEROA DA MOTTA, Ronaldo; RUITENBEEK, Jack; HUBER, Richard. Uso de instrumentos econômicos de gestão ambiental da América Latina e Caribe: Lições e Recomendações. IPEA. Texto para discussão $n^{\circ}$ 440, 1996. Disponível em : < http://www.ipea.gov.br/pub/td/td0440.pdf>. Acesso em: 3.12.2011.

SESIN, Domingo. Administración pública. Actividad reglada, discrecional y técnica - nuevos mecanismos de control judicial. Buenos Aires: Depalma, 1994.

SETZER, Joana. Panorama do princípio da precaução: o direito do ambiente face aos novos riscos e incertezas. Dissertação (mestrado). Programa de Ciência Ambiental. Universidade de São Paulo-USP, São Paulo, 2007.

SILVA, José Afonso da. Direito ambiental constitucional. 9a ed. São Paulo: Malheiros, 2011. 
SOFFIATI, Arthur. A natureza no pensamento liberal clássico. Revista de Direito Ambiental. no 21. Ano 6. jan-mar. São Paulo: RT, 2001.

STAVINS, Robert N. Experience with market-based environmental policy instruments. Fondazione Eni Enrico Mattei - FEEM, Working Paper $n^{o}$ 52/2002; Kennedy School of Government - KSG/Harvard University, Working Paper $\quad n^{o} \quad 00 / 2004$ Disponível em $<$ http://ssrn.com/abstract=199848>. Acesso em: 3.10.2011.

STEIGLEDER, Annelise Monteiro. Responsabilidade civil ambiental: as dimensões do dano ambiental no direito brasileiro. $2^{\mathrm{a}}$ ed. Porto Alegre: Livraria do Advogado, 2011.

TOMASSI, Luiz Roberto Tommasi. Estudo de impacto ambiental. São Paulo: CETESB: Terragraph Artes e Informática, 1993.

TÔRRES, Heleno Taveira (org.). Direito Tributário Ambiental. São Paulo: Malheiros, 2005.

TÔRRES, Heleno Taveira. Da relação entre competências constitucionais tributária e ambiental - os limites dos chamados 'tributos ambientais'. In: TÔRRES, Heleno Taveira (org.). Direito Tributário Ambiental. São Paulo: Malheiros, 2005.

TORRES, Roberto Lobo. Valores e princípio no Direito Tributário Ambiental. In: TÔRRES. Heleno Taveira (org.). Direito tributário ambiental. São Paulo: Malheiros, 2005.

VARELLA, Marcelo Dias. BARROS-PLATIAU, Ana Flávia. SCHLEICHER, Rafael T. Meio ambiente e relações internacionais: perspectivas teóricas, respostas institucionais e novas dimensões de debate. Revista Brasileira de Política Internacional. 47 (2), 2004.

VEIGA, José Eli da. Desenvolvimento sustentável: o desafio do século XXI. $3^{\mathrm{a}}$ ed. Rio de Janeiro: Garamond, 2008. 
VIEIRA, Bruno Soeiro. Os impostos municipais e a proteção do meio ambiente. Porto Alegre: Núria Fabris Ed., 2011.

VIEIRA, Liszt. Os argonautas da cidadania: a sociedade civil na globalização. Rio de Janeiro: Record, 2001.

ZAGREBELSKY, Gustavo. El derecho dúctil: ley, derechos, justicia. Trad. Marina Gascón. Madrid: Editorial Trotta, 2009. 